SÉRGIO KINYA FUGIMOTO

\title{
A UNIVERSALIZAÇÃO DO SERVIÇO DE ENERGIA ELÉTRICA ACESSO E USO CONTÍNUO
}

Dissertação apresentada à Escola
Politécnica da Universidade de São
Paulo para a obtenção do título de
Mestre em Engenharia

São Paulo

2005 


\title{
A UNIVERSALIZAÇÃO DO SERVIÇO DE ENERGIA ELÉTRICA ACESSO E USO CONTÍNUO
}

\author{
Dissertação apresentada à Escola \\ Politécnica da Universidade de São \\ Paulo para a obtenção do título de \\ Mestre em Engenharia \\ Área de Concentração: \\ Sistemas de Potência \\ Orientador: \\ Prof. Dr. Carlos Márcio Vieira Tahan
}


Este exemplar foi revisado e alterado em relação à versão original, sob responsabilidade única do autor e com a anuência de seu orientador.

São Paulo, de maio de 2005.

Assinatura do autor

Assinatura do orientador

FICHA CATALOGRÁFICA

Fugimoto, Sérgio Kinya

A universalização do serviço de energia elétrica - acesso e uso contínuo / S.K. Fugimoto. - ed.rev. --São Paulo, 2005.

264 p.

Dissertação (Mestrado) - Escola Politécnica da Universidade de São Paulo. Departamento de Engenharia de Energia e Automação Elétricas.

1.Políticas públicas 2.Eletrificação rural 3.Tarifas públicas 4.Serviços públicos (Regulação) I.Universidade de São Paulo. Escola Politécnica. Departamento de Engenharia de Energia e Automação Elétricas II.t. 
Aos meus pais, Hideo (in memoriam) e Maria, pela minha vida e pela formação dos meus valores com base na observação dos seus incansáveis esforços.

A minha esposa Lílian, com amor e gratidão, por sua compreensão e apoio em todos os momentos da minha vida.

Aos meus filhos, Aline Yukari e Victor Yukio, felicidade maior da minha vida, que me ensinam o valor de prezar cada momento.

Ao meu mestre, Daisaku Ikeda, pelo direcionamento da minha vida e pelo exemplo de dedicação em prol da felicidade das pessoas.

A dedicação eterna do autor. 


\section{AGRADECIMENTOS}

Ao amigo, professor e orientador Carlos Márcio Vieira Tahan, por sua dedicação, paciência, bom senso e sabedoria - características ideais de um regulador, no direcionamento preciso deste trabalho.

Aos professores Fernando Selles Ribeiro, incansável defensor da eletrificação rural e coordenador do Programa Luz para Todos no Estado de São Paulo, Osvaldo Soliano Pereira, entusiasta da geração descentralizada para atendimento em regiões isoladas e coordenador do Comitê Técnico de Universalização do CNPE, Francisco Anuatti Neto, especialista em políticas publicas, pelas sugestões para o aprimoramento desta dissertação.

Ao ex-comissário-chefe da CSPE, Prof. Marcos Roberto Gouvêa, ao exsuperintendente da Aneel, Francisco Ivaldo Andrade Frota, ao ex-diretor de regulação da EDP Brasil, Eduardo Leite Hoffmann, e ao atual, José Simões Neto, por permitirem e apoiarem o desenvolvimento deste trabalho.

Ao ex-diretor geral da Aneel, José Mário Abdo, exemplo de espírito público, ao diretor do Programa Luz para Todos, João Ramis, e sua equipe, Rosana, André, Marcelo, ao colega Genésio Betiol, da Ceresp, por tornarem disponíveis dados imprescindíveis para esta pesquisa.

Aos amigos da equipe de fiscalização da CSPE, Plácido, Paulo Albuquerque, Dário, Paulo Katumi, Luis Roberto, com os quais aprendi os fundamentos da regulação do setor elétrico, e do grupo de universalização da Aneel, em especial, Marco Aurélio Castro, Marcos Bragatto, Breno Souza, Wougran Galvão, Cristiano Logrado, companheiros dos debates sobre a universalização dos serviços de energia elétrica.

Aos amigos da Academia, Marcelo Pelegrini, Luiz Henrique Pazzini, Nélson Minami e Zilmar Souza, pelas discussões e compartilhamento de idéias que enriqueceram este estudo.

Aos amigos, Odair, Jefer e Eiji, que me suportaram e me incentivaram nos momentos finais deste trabalho.

O agradecimento sincero do autor. 
The entire object of true education is to make people not merely do the right things, but enjoy the right things.

\section{John Ruskin}




\section{RESUMO}

Com base nos dados do IBGE, estima-se que aproximadamente 2,4 milhões de domicílios brasileiros não têm acesso ao serviço de energia elétrica. Ainda, projeções da Aneel indicam que, após a alteração dos critérios determinados pela Lei $\mathrm{n}^{\circ}$ 10.438/2002, o número de unidades consumidoras classificadas na subclasse residencial baixa renda passou de 8 para 14 milhões. Conforme estimativas atuais, são necessários recursos da ordem de $\mathrm{R} \$ 7,3$ bilhões para equacionar o acesso à energia elétrica daqueles domicílios, bem como de aproximadamente $\mathrm{R} \$ 1$ bilhão por ano para compensar as distribuidoras pela perda de receita decorrente do aumento do número de consumidores baixa renda. Os dois aspectos são complementares na conceituação da universalização, na visão do autor. Deste modo, este estudo apresenta uma visão sistêmica sobre ambos os aspectos da universalização: a garantia do acesso físico e do uso contínuo; ; sendo este último considerado como as condições para a manutenção do acesso ao serviço de eletricidade por meio de uma tarifa social ou de programas compensatórios. O objetivo principal dessa dissertação é, então, analisar e avaliar as normas legais e os regulamentos que norteiam as políticas públicas de universalização dos serviços de energia elétrica, como também dos que indiretamente interferem nessas ações, buscando identificar eventuais necessidades de sua complementação ou mesmo de sua alteração. Para isso, mostra-se a evolução recente das ações do Estado, da legislação pertinente e da regulamentação promovida pela Aneel para cada um das duas vertentes da universalização. Apresenta-se também a dimensão dos recursos financeiros envolvidos, identificando os possíveis impactos decorrente da nova regulamentação da subclasse residencial baixa renda e também do programa de universalização Luz para Todos. 


\begin{abstract}
IBGE data has shown that approximately 2.4 million Brazilian households do not have access to electricity service. Moreover, Aneel's projections indicate that, after the alteration of the criteria determined by Law 10,438/2002, the number of households classified as low income residential subclass has increased from 8 to 14 million. Further studies imply that $\mathrm{R} \$ 7.3$ billion would be necessary to enable those 2.4 million households to have access to electric energy, as well as $\mathrm{R} \$ 1$ billion per year to compensate the utilities for the loss resulting from the increase of low income consuming domiciles. The two aspects are complementary as for the universal electricity service, in the vision of the author. Hence, this work proposes to overview both aspects: to ensure physical access and the continuous use through social tariffs or compensating programs. The main objective of this dissertation is to analyze and to evaluate the regulations which guide the public policies of universal electricity service in order to identify whenever its complementation or its alteration is required. Thus, this study shows relevant government policies and Aneel regulation as well as necessary resources, possible and likely impacts to improve the current situation.
\end{abstract}




\section{SUMÁRIO}

LISTA DE TABELAS

LISTA DE QUADROS

LISTA DE FIGURAS

LISTA DE ABREVIATURAS

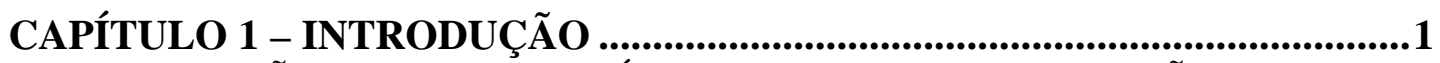

1.1 MOTIVAÇÃO - ENERGIA ELÉTRICA: DIREITO DO CIDADÃO ……...........1

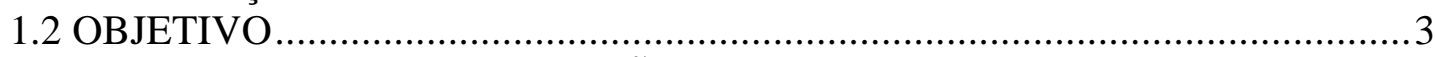

1.3 ESTRUTURA DA DISSERTAÇÃO..........................................................

CAPÍTULO 2 - CONCEITOS BÁSICOS ......................................................

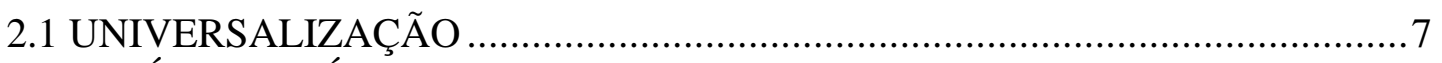

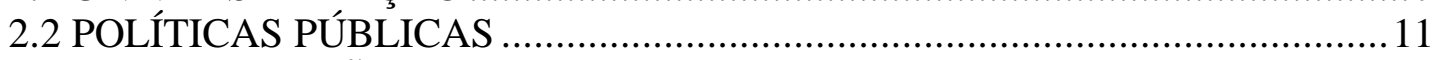

2.3 CONCEITUAÇÃO DE POBREZA ………………………………………....... 13

CAPÍTULO 3 - ANTECEDENTES DA UNIVERSALIZAÇÃO DO ACESSO 15

3.1 HISTÓRICO DA PARTICIPAÇÃO FINANCEIRA ………………………........16

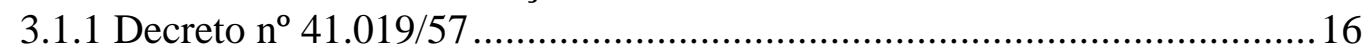

3.1.2 Nova redação dada pelo Decreto $\mathrm{n}^{\circ}$ 83.269/79 ……................................17

3.1.3 Nova redação dada pelo Decreto $\mathrm{n}^{\circ} 98.335 / 89$ ……................................ 18

3.1.4 Portarias Dnaee, referentes ao limite de investimento das distribuidoras. 20

3.2 PROGRAMAS DE ELETRIFICAÇÃO RURAL ………………………….....24

3.2.1 Cooperativas de Eletrificação Rural.....................................................2

3.2.2 Programas de Eletrificação Rural.............................................................. 30

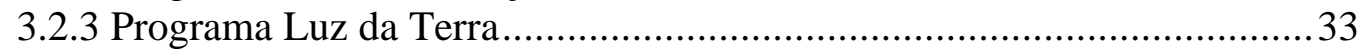

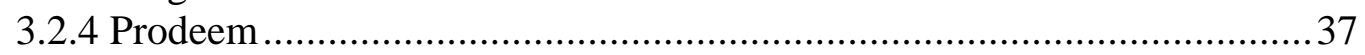

3.2.5 Programa Luz no Campo ...................................................................... 38

3.3 RESPONSABILIDADE PELA EXPANSÃO DO SERVIÇO DE ENERGIA

ELÉTRICA E REESTRUTURAÇÃO DO SETOR DA DÉCADA DE 90.41

3.3.1 Responsabilidade pela expansão do serviço na reestruturação do setor ...41

3.3.2 Proposta de regulamentação da Aneel em 2000 ………………………..... 43

3.4 ANÁLISE DOS ANTECEDENTES DA UNIVERSALIZAÇÃO DO ACESSO45

3.4.1 Análise da participação financeira ........................................................ 45

3.4.2 Resultados dos Programas de Eletrificação Rural ..................................... 48

3.4.3 Análise da responsabilidade pela expansão do serviço na reestruturação do

Setor Elétrico da década de 90 .................................................................51

3.4.4 Considerações .......................................................................................54

CAPÍTULO 4 - ANTECEDENTES DA UNIVERSALIZAÇÃO DO USO ........55

4.1 ESTUDO DO DNAEE - 1985 ...............................................................5

4.2 PROGRAMAS DESTINADOS AOS CONSUMIDORES BAIXA RENDA......58

4.2.1 Programas de financiamento dos padrões de entrada...............................59

4.2.2 Programas de atendimento das distribuidoras .........................................61

4.2.3 Programa Eletrificação de Favelas - Pró-Luz ................................................61

4.2.4 Programa de descontos para a população baixa renda ................................62

4.2.5 Programa Habitações Multi-familiares .....................................................62 
4.3 CRIAÇÃO DA TARIFA RESIDENCIAL BAIXA RENDA .62

4.4 TARIFA SOCIAL E REESTRUTURAÇÃO DO SETOR DA DÉCADA DE 90

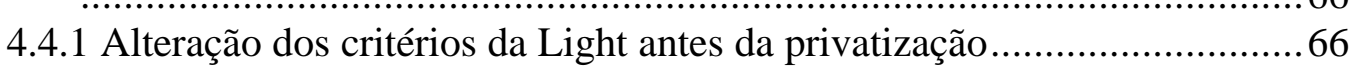

4.4.2 Aplicação integral dos critérios pela CPFL ...........................................67

4.4.3 Alteração dos critérios na Eletropaulo ................................................6 68

4.4.4 Proposta para definição de tarifas sociais - Metodologia FIPE ...............70

4.5 ANÁLISE DOS ANTECEDENTES DA UNIVERSALIZAÇÃO DO USO ......73

4.5.1 Análise do Estudo do Dnaee .............................................................. 73

4.5.2 Análise dos programas destinados especificamente aos consumidores

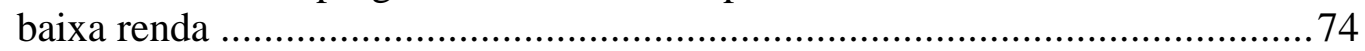

4.5.3 Análise da criação da tarifa social..................................................75

4.5.4 Análise da tarifa social na reestruturação do setor da década de 90 ........78

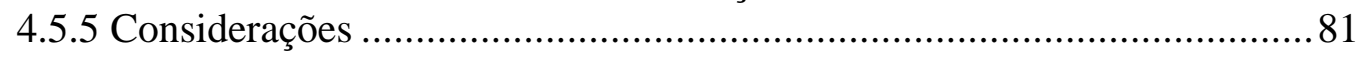

CAPÍTULO 5 - EXPERIÊNCIAS INTERNACIONAIS ....................................82

5.1 EXPERIÊNCIAS INTERNACIONAIS -UNIVERSALIZAÇÃO DO ACESSO 82

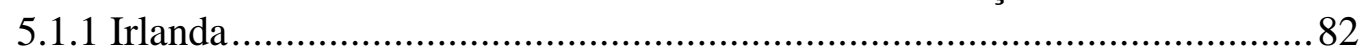

5.1.2 Canadá - Província de Ontario ...................................................... 83

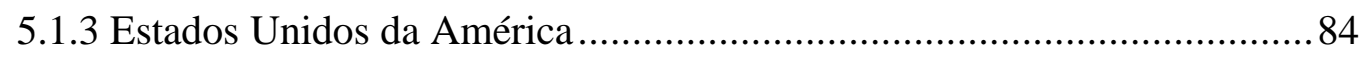

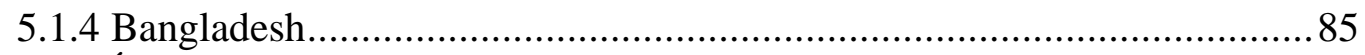

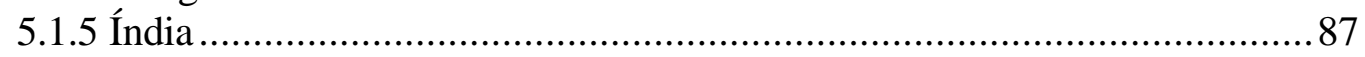

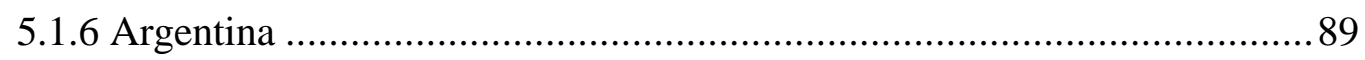

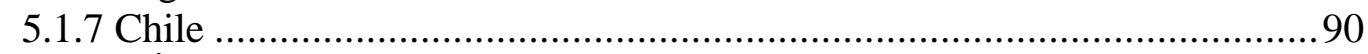

5.2 EXPERIÊNCIAS INTERNACIONAIS UNIVERSALIZAÇÃO DO USO ........91

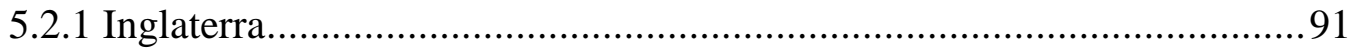

5.2.2 Estados Unidos da América - Estado da Pensilvânia .............................99

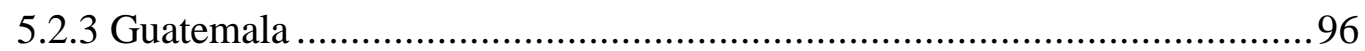

5.2.4 Argentina - Província de Buenos Aires .............................................. 97

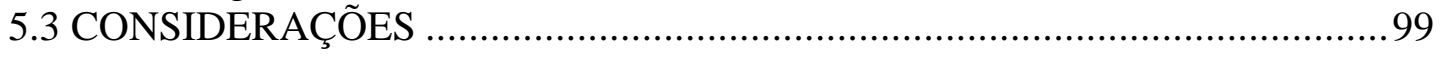

CAPÍTULO 6 - LEI No 10.438/2002 E REGULAMENTAÇÃO ATUAL ........101

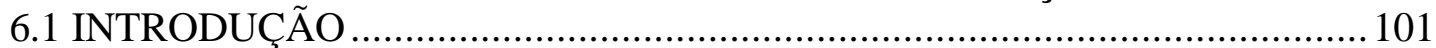

6.2 LEI N ${ }^{\circ}$ 10.438/2002 E UNIVERSALIZAÇÃO DO ACESSO .......................... 103

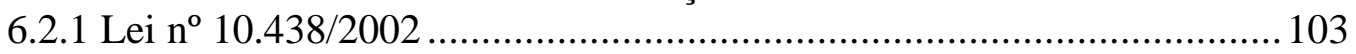

6.2.2 Processo de regulamentação da Lei no 10.438/2002 ............................ 105

6.2.3 Metas estabelecidas pela Aneel ....................................................... 108

6.2.4 Lei $n^{\circ}$ 10.762/2003 e adequação da Resolução no 223/2003 .................. 115

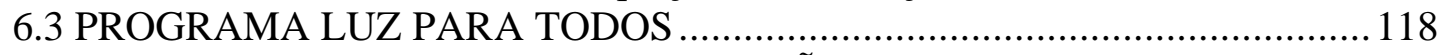

6.4 LEI No 10.438/2002 E UNIVERSALIZAÇÃO DO USO ............................... 122

6.4.1 Critérios definidos pela Lei $\mathrm{n}^{\circ} 10.438 / 2002$........................................ 122

6.4.2 Regulamentação da tarifa residencial baixa renda ............................... 123

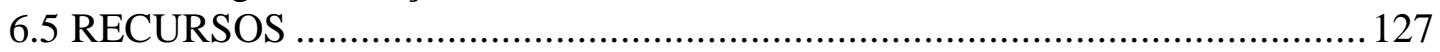

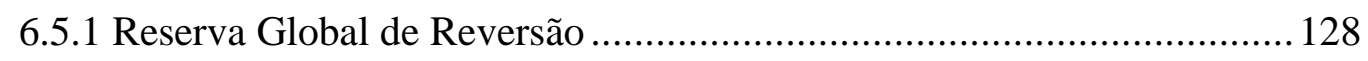

6.5.2 A Conta de Desenvolvimento Energético ............................................. 133

CAPÍTULO 7 - NÚMEROS DA UNIVERSALIZAÇÃO.......................................140

7.1 DOMICILIOS SEM ACESSO À ENERGIA ELÉTRICA..................................140

7.2 APLICAÇÃO DA TARIFA RESIDENCIAL BAIXA RENDA ........................145 


\section{CAPÍTULO 8 - ANÁLISE DO MARCO LEGAL E DA REGULAMENTAÇÃO}

DA UNIVERSALIZAÇÃO............................................................150

8.1 ANÁLISE DO MARCO LEGAL DA UNIVERSALIZAÇÃO .............................150

8.1.1 Conceito de universalização do acesso ................................................. 151

8.1.2 Conceito de universalização do uso …………………………............ 153

8.2 ANÁLISE DA REGULAMENTAÇÃO DA UNIVERSALIZAÇÃO DO

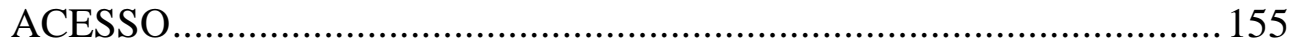

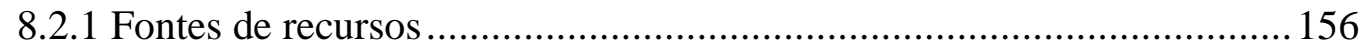

8.2.2 Responsabilidade da distribuidora: Grupo B até $50 \mathrm{~kW}$.........................158

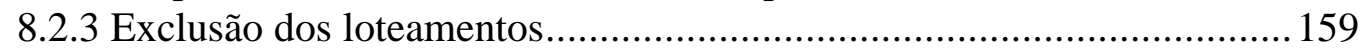

8.2.4 Identificação do ponto de entrega ....................................................... 160

8.2.5 Limite de investimento obrigatório das distribuidoras............................. 161

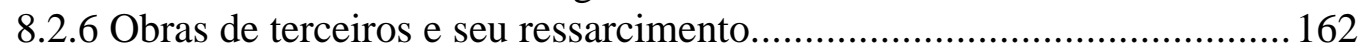

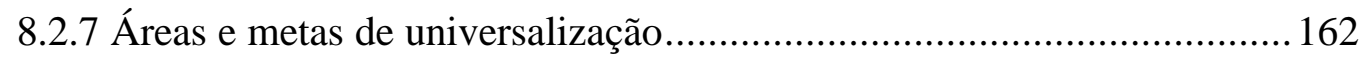

8.2.8 Programa Luz para Todos................................................................. 166

8.3 ANÁLISE DA REGULAMENTAÇÃO DA UNIVERSALIZAÇÃO DO USO 168

8.3.1 Critério: Programas sociais do Governo Federal .................................. 168

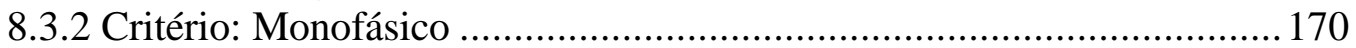

8.3.3 Limite de consumo regional .............................................................. 173

8.3.4 Faturamento mensal baixa renda.......................................................... 174

8.4 ANÁLISE DOS RECURSOS PARA UNIVERSALIZAÇÃO ............................174

8.4.1 Análise dos recursos para universalização do acesso................................174

8.4.2 Análise dos recursos para a universalização do uso.................................. 177

8.4.3 Alteração na metodologia de cálculo das perdas ..................................... 181

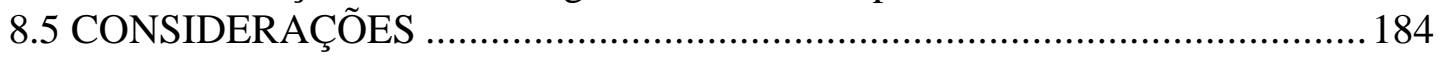

CAPÍTULO 9 - APRIMORAMENTOS DA REGULAMENTAÇÃo E

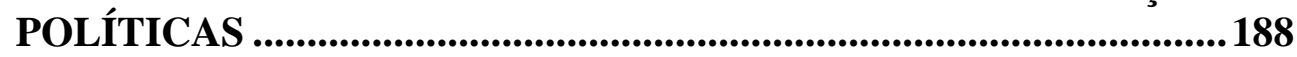

9.1 NECESSIDADES DE REGULAMENTAÇÃO ……………........................ 188

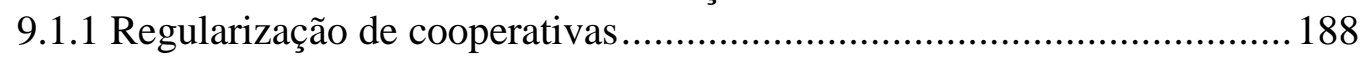

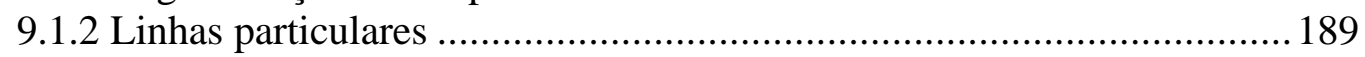

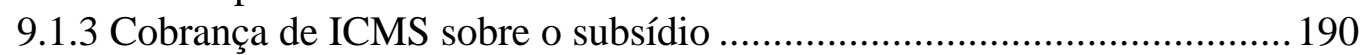

9.2 PROPOSTAS DE REGULAMENTAÇÃO .................................................... 193

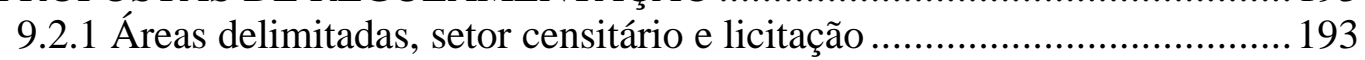

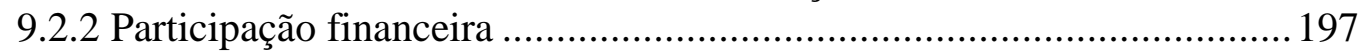

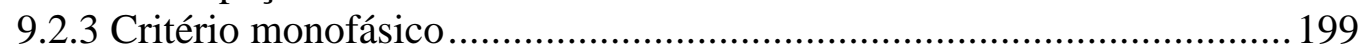

9.2.4 Metodologia de cálculo das perdas e dos ganhos de receitas ..................201

9.2.5 Fator X e investimentos em universalização ........................................2202

9.3 PROPOSIÇÃO DE NOVAS DIRETRIZES PARA APRIMORAR A POLÍTICA

DE UNIVERSALIZAÇÃO ..................................................................205

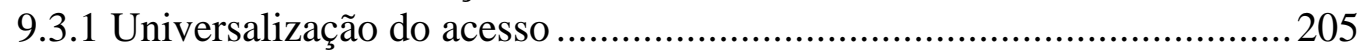

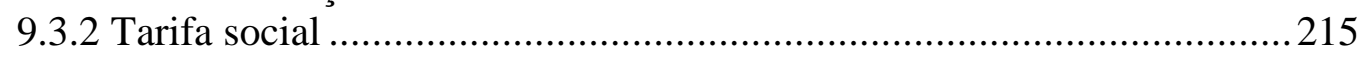

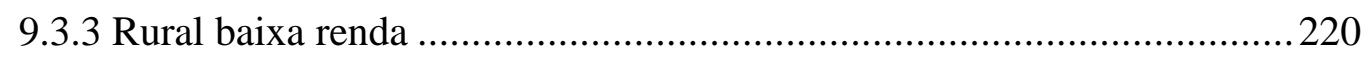

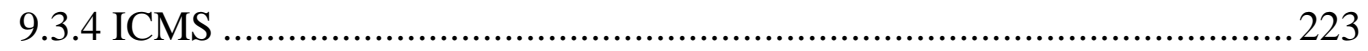

CAPITULO 10 - CONCLUSÕES E COMENTÁRIOS......................................227

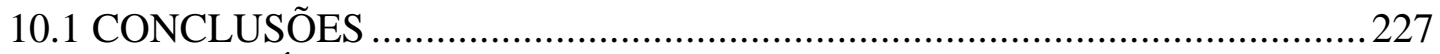

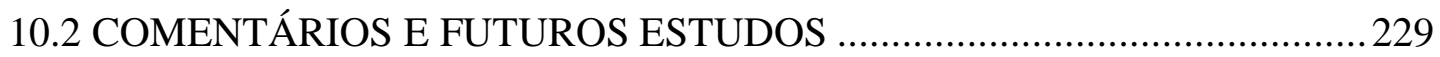




\section{ANEXOS}

Anexo A - Acesso à energia elétrica - Dados do Censo 2000...............................232

Anexo B - Estimativa de custos da universalização .............................................2233

Anexo C - Municípios - Índices máximos e mínimos por Estado .........................2234

Anexo D - Municípios e domicílios sem acesso à energia elétrica em função do índice de atendimento municipal .........................................................235

Anexo E - Resultados do Programa Luz no Campo - 2003 ..................................236

Anexo F - Estimativa da alocação dos recursos do Programa Luz para Todos ......237

Anexo $\mathrm{G}$ - Estimativa preliminar de impacto tarifário decorrente da universalização 238

Anexo H - Caracterização dos domicílios classificados na subclasse residencial

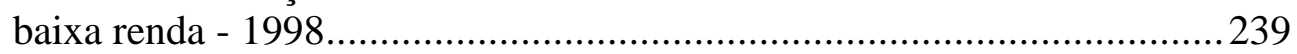

Anexo I - Cadastro único dos programas sociais - Estimativa de cadastramento ... 240

Anexo J - Evolução do número de consumidores baixa renda por distribuidora 1998 a 2002

Anexo K - Perdas de receita da distribuidora devido aos novos consumidores baixa renda - 2002

Anexo L - Perdas de receita das distribuidoras decorrentes dos novos consumidores baixa renda - 2003

Anexo M - Perdas de receita das distribuidoras decorrentes dos novos consumidores baixa renda $-1^{\circ}$ semestre 2004 ............................................................246

Anexo N - Leis e regulamentos relevantes .................................................247

REFERÊNCIAS BIBLIOGRÁFICAS..........................................................256

APÊNDICE A - CCC

APÊNDICE B - SETOR CENSITÁRIO 


\section{LISTA DE TABELAS}

Tabela 1 - Consumidores atendidos por cooperativas de eletrificação rural..............30

Tabela 2 - Beneficiados pelo Programa Luz da Terra .......................................... 36

Tabela 3 - Prodeem - Situação dos equipamentos amostrados - 2001......................38

Tabela 4 - Resultados do Programa Luz no Campo (jan/2004) ............................40

Tabela 5 - Limites de investimento da concessionária - atualizados (dez/2004) ......47

Tabela 6 - Programas de Eletrificação Rural......................................................49

Tabela 7 - Consumo de Referência (kWh/mês) ..................................................56

Tabela 8 - Tarifa Residencial Transitória Proposta .............................................58

Tabela 9 - Tarifa Residencial Definitiva Proposta............................................58

Tabela 10 - Evolução no desconto por faixa de consumo - Eletropaulo ..................63

Tabela 11 - Reajustes das tarifas de energia elétrica em novembro/1995 ...............64

Tabela 12 - Programas Baixa Renda (1986).................................................... 75

Tabela 13 - Efeito do término dos descontos para consumidores residenciais ..........76

Tabela 14 - Comparação domicílios pobres e consumidores baixa renda (1998) .....79

Tabela 15 - Índia - Sistemas de geração de energia por fontes renováveis............... 88

Tabela 16 - Linha de pobreza - Renda familiar bruta (US\$) ................................93

Tabela 17 - Valor da conta de energia em função da renda do consumidor .............94

Tabela 18 - Prazos Limites para a Universalização na Área de Concessão ............. 109

Tabela 19 - Prazo para Universalização nos Municípios ...................................... 110

Tabela 20 - Penalidade pelo não cumprimento das metas de universalização........ 113

Tabela 21 - Custo anual do Programa Luz para Todos....................................... 119

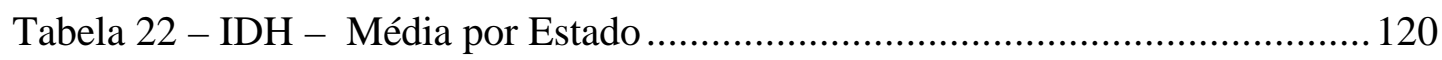

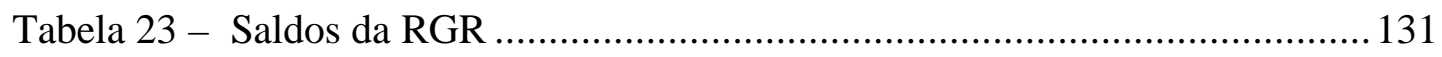

Tabela 24 - Aplicação da RGR por Região ................................................... 131 
Tabela 25 - Aplicação da RGR por projetos

Tabela 26 - Previsão de recolhimento de UBP - período 2004 a 2007

Tabela 27 - Previsão dos recursos da CDE em 2004

Tabela 28 - Domicílios sem acesso à energia elétrica - 2000

Tabela 29 - Domicílios não atendidos - índice do município - 2000

Tabela 30 - Domicílios sem energia elétrica - percentual por faixa de renda

Tabela 31 - Estimativa do Custo Universalização....

Tabela 32 - Descontos aplicados para a tarifa da subclasse residencial baixa renda

Tabela 33 - Municípios priorizados pelo Programa Luz para Todos. 167

Tabela 34 - Programa Luz para Todos - Dados dos contratos assinados (jul/2004) 168

Tabela 35 - Limite regional para aplicação da tarifa baixa renda. 173

Tabela 36 - Metas e alocação percentual dos recursos do Programa Luz para Todos

Tabela 37 - Alocação de recursos do Programa Luz para Todos 177

Tabela 38 - Perdas baixa renda - Valores homologados pela Aneel (R\$ milhares)

Tabela 39 - Arrecadação anual da CDE (em R\$ bilhões) 186

Tabela 40 - Destinação anual da CDE (em R \$ bilhões)

Tabela 41 - Impacto da incidência de ICMS sobre o subsídio baixa renda 192

Tabela 42 - Sigfi - Classificação e disponibilidade de atendimento 208

Tabela 43 - Impacto dos investimentos em universalização na tarifa

Tabela 44 - Peso da energia elétrica na renda das comunidades baixa renda do Rio de Janeiro 220 


\section{LISTA DE QUADROS}

Quadro 1 - Evolução da regulamentação da responsabilidade pelo atendimento ......19

Quadro 2 - Valores históricos dos limites de investimento da concessionária ..........23

Quadro 3 - Critérios dos programas de financiamento ......................................6 60

Quadro 4 - Elementos de caracterização - famílias pobres - RMSP .......................72

Quadro 5 - Comparação consumidores baixa renda versus famílias pobres........... 148

Quadro 6 - Ano máximo para universalização das distribuidoras .......................... 164

Quadro 7 - Comparação das tarifas residencial e rural .......................................221

Quadro 8 - Alíquotas de ICMS incidentes sobre o fornecimento de energia elétrica -

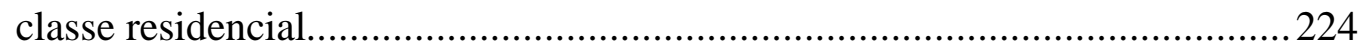

Quadro 9 - Alíquotas de ICMS incidentes sobre o fornecimento de energia elétrica -

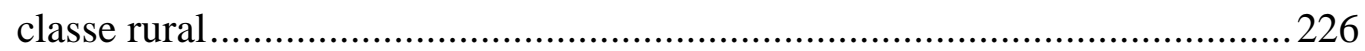




\section{LISTA DE FIGURAS}

Figura 1 - Metas do Programa Luz no Campo

Figura 2 - Percentual de consumidores baixa renda e população pobre distribuidoras selecionadas

Figura 3 - Domicílios pobres e consumidores baixa - resultados da aplicação da Metodologia FIPE. 80

Figura 4 - Índice de domicílios com energia elétrica. 140

Figura 5 - Número de Consumidores da Subclasse Residencial Baixa 145

Figura 6 - Percentual de consumidores baixa renda - 1998/2004. 147

Figura 7 - Quantidade de Municípios Envolvidos por Ano 165

Figura 8 - Evolução prevista da quantidade de domicílios a serem atendidos 165

Figura 9 - Exemplos de sistemas simplificados de distribuição. 172

Figura 10 - Quotas da CDE - Previsão de recolhimento 2004 175

Figura 11- Perdas das distribuidoras ( $1^{\circ}$ semestre de 2004$)$. 181

Figura 12 - Arrecadação da CDE e sua alocação por Região. 185 


\section{LISTA DE ABREVIATURAS}

ANEEL: Agência Nacional de Energia Elétrica

BID: Banco Interamericano de Desenvolvimento

BIRD: Banco Internacional para Reconstrução e Desenvolvimento

BNDES: Banco Nacional de Desenvolvimento Econômico e Social

BRRLi: Base de Remuneração Regulatória Líquida inicial

BRRLf: Base de Remuneração Regulatória Líquida final

CCC: Conta de Consumo de Combustíveis Fósseis

CCF: Custo de Capacidade do Fornecimento

CDE: Conta de Desenvolvimento Energético

CEER: Comissão de Eletrificação Rural

CERESP: Comissão de Eletrificação Rural do Estado de São Paulo

CRC: Contas de Resultados a Compensar

CSPE: Comissão de Serviços Públicos de Energia

DEER: Departamento de Eletrificação Rural da Eletrobrás

DNAEE: Departamento Nacional de Águas e Energia Elétrica

DIEESE: Departamento Intersindical de Estatística e Estudos Sócio-Econômicos

ELETROBRÁS: Centrais Elétricas Brasileiras

ERMIG: Eletrificação Rural de Minas Gerais

FAO: Food and Agriculture Organization of the United Nations

FC: Fluxo de Caixa

FEAP: Fundo de Expansão da Agropecuária e da Pesca

FIPE: Fundação Instituto de Pesquisas Econômicas

FUER: Fundo de Eletrificação Rural das Cooperativas

GCE: Câmara de Gestão da Crise de Energia Elétrica

GCOI: Grupo Coordenador para Operação Interligada

GEER: Grupo Executivo de Eletrificação Rural das Cooperativas

IASC: Índice Aneel de Satisfação do Consumidor

IBGE: Instituto Brasileiro de Geografia e Estatística

ICMS: Imposto sobre Circulação de Mercadorias e Serviços

IDH: Índice de Desenvolvimento Humano

IGP-M: Índice Geral de Preços do Mercado

IGP-DI: Índice Geral de Preços - Disponibilidade Interna 
IPCA: Índice de Preços ao Consumidor Ampliado

INCRA: Instituto Nacional de Colonização e Reforma Agrária

IUEE: Imposto Único sobre Energia Elétrica

LBR: Programa Luz para Baixa Renda

LIO: Limite de Investimento Obrigatório

LQO: Lei de Quantidade de Obras

MAE: Mercado Atacadista de Energia Elétrica

MDS: Ministério de Desenvolvimento Social e Combate à Fome

MME: Ministério de Minas e Energia

MPOG: Ministério de Planejamento, Orçamento e Gestão

MRT: Monofilar com Retorno por Terra

ONS: Operador Nacional do Sistema Elétrico

PCH: Pequena Central Hidrelétrica

PERCEE: Programa Emergencial de Redução de Consumo de Energia Elétrica

PIB: Produto Interno Bruto

PNAD: Pesquisa Nacional por Amostra de Domicílios

PNER: Plano Nacional de Eletrificação Rural

PPL: Padrão Popular de Ligação

PPV: Pesquisa sobre Padrões de Vida

PROCEL: Programa de Combate ao Desperdício de Energia Elétrica

PRODEEM: Programa de Desenvolvimento Energético de Estados e Municípios

PROINFA: Programa de Incentivo às Fontes Alternativas de Energia Elétrica

REA: Rural Electrification Administration

RENCOR: Reserva Nacional de Compensação de Remuneração

RGR: Reserva Global de Reversão

RMSP: Região Metropolitana de São Paulo

SEER: Serviço Especial de Eletrificação Rural

SRC: Superintendência de Regulação da Comercialização da Eletricidade

SRD: Superintendência de Regulação dos Serviços de Distribuição

SFE: Superintendência de Fiscalização dos Serviços de Eletricidade

SFF: Superintendência de Fiscalização Econômica e Financeira

SRE: Superintendência de Regulação Econômica

TCU: Tribunal de Contas da União

TUSD: Tarifa de Uso do Sistema de Distribuição 
UBP: Uso do Bem Público

VPA: Valor Presente da Anuidade

VPL: Valor Presente Líquido 


\section{CAPÍTULO 1 - INTRODUÇÃO}

\subsection{MOTIVAÇÃO - ENERGIA ELÉTRICA: DIREITO DO CIDADÃO}

Com base nos dados do Censo 2000 do Instituto Brasileiro de Geografia e Estatística (IBGE), estima-se que 2,4 milhões de domicílios não têm acesso aos serviços de energia elétrica ${ }^{1}$, correspondendo a aproximadamente 11 milhões de brasileiros, em que pese ser este o serviço público com maior índice de atendimento, atingindo a 42,3 milhões de domicílios.

Por outro lado, segundo Castro e Nunes (2003), projeções da Agência Nacional de Energia Elétrica (Aneel) indicam que, com a alteração dos critérios de classificação determinados pela Lei $\mathrm{n}^{\mathrm{o}} 10.438$, de 26 de abril de 2002, o número de unidades consumidoras classificadas na subclasse residencial baixa renda passou de 8 para 14 milhões. Apesar de ultrapassar as 11 milhões de famílias pobres estimadas pelo Ministério de Desenvolvimento Social e Combate à Fome (2004), a distribuição desses consumidores baixa renda por Estado da Federação não é coerente com o número de pobres estimados.

O acesso aos serviços públicos, entre os quais se inclui a energia elétrica, é imprescindível para o desenvolvimento individual e da sociedade. Segundo Amartya Sen (2000, p. 18), prêmio Nobel de Economia:

O desenvolvimento requer que se removam as principais fontes de privação de liberdade: pobreza e tirania, carência de oportunidades econômicas e destituição social sistemática, negligência dos serviços públicos e intolerância ou interferência excessiva de Estados repressivos. (grifo nosso).

Desse modo, as escolhas que são feitas pelo Estado não se restringem necessariamente entre as duas opções: mercado puro ou paternalismo. Deve-se levar em conta que a liberdade individual somente se concretiza com o acesso ao mesmo rol de oportunidades para todas as pessoas, conforme Sen (2000, p. 322):

A alternativa ao apoio exclusivo na responsabilidade individual não é, como se supõe, o chamado "Estado babá". Há uma diferença entre "pajear" as escolhas de um individuo e criar mais oportunidades de escolha e decisões substantivas para as pessoas que então poderão agir de modo responsável sustentando-se nessa base.

\footnotetext{
${ }^{1}$ O Censo 2000 informa se o domicílio tem iluminação elétrica, mas não detalha sua procedência: rede elétrica, gerador particular ou fonte alternativa.
} 
Lamounier (1998, p. 333), em seminário do Banco Nacional de Desenvolvimento Econômico e Social (Bndes), sobre a reestruturação dos setores de infra-estrutura, destacou a importância do provimento de serviços públicos, entre eles a energia elétrica a todos os cidadãos:

[...] naquela época (final do século XIX), eletricidade e telefone eram privilégios, coisas ao alcance de muitos poucos, ao passo que hoje são... Ia dizer apenas coisas ao alcance de muitos, mas na verdade quero dizer mais: coisas que, hoje, são direitos básicos. São claims, ou "títulos de direito", absolutamente básicos. Estranho, anormal, hoje, é não têlas. Mesmo quem aluga uma residência, e mesmo num bairro de baixa renda, espera, como direito seu, que tais serviços (água, eletricidade, esgoto, transporte público e, cada vez mais, telefone) lhe serão supridos. É normal que assim seja. O serviço só não será suprido a determinada família se não o puder ser (por razões técnicas ou econômicas de caráter geral) a toda uma coletividade. A todo o bairro, por exemplo. Se é um serviço disponível para alguns, terá de sê-lo a todos. Admitir o contrário equivaleria a negar a determinada pessoa algo que não está vinculado à propriedade ou a uma condição de status social, e sim à sua condição de cidadã. Um direito básico, portanto.

No Brasil, a reestruturação do setor elétrico, iniciada na década de 90 e marcada pela ênfase na atuação do Estado como ente regulador e não mais como empreendedor, trouxe também a necessidade de se discutir a questão do fornecimento de eletricidade a grandes parcelas da população que, em pleno século XXI, não têm acesso a esse bem.

Essa situação pode ser exemplificada pelo menino Leonardo, vencedor de um concurso de frases promovido pelo Ministério da Educação, que recebeu do Presidente Fernando Henrique um computador, embora sua residência localizada na zona rural de São João da Ponte, em Minas Gerais, não tivesse energia elétrica. Segundo Lancellotti (2002):

O encontro do presidente com o menino foi o encontro de dois brasis, de dois brasileiros, que sendo cidadãos e tendo os mesmos direitos vivem realidades tão distintas e contrastantes que não parecem morar no mesmo País. [...] a criança e o adolescente são prioridade absoluta, como diz o art. 227 [da Constituição Federal]. Prioridade absoluta significa que será atendido antes para que tenha a condições dignas de existência $[\ldots]$.

De acordo com França e Bermann (2000), anteriormente à privatização do setor elétrico, a implantação de programas sociais ocorria devido à sobreposição dos fins econômicos das concessionárias de distribuição de energia elétrica com os objetivos sociais e políticos dos governos que as controlavam, mesmo que essas metas estivessem à margem da regulamentação. 
No entanto, essa situação sofre modificação com a introdução das empresas privadas na atividade de distribuição de energia elétrica. Evidentemente, não faz parte dos objetivos da distribuidora de energia elétrica arcar com os custos de investimentos que não gerem o retorno esperado.

De acordo com Coutinho (2002, p. 71), os investimentos não rentáveis, utilizados para expandir as redes de infra-estrutura para localidades e populações não atendidas, “justificam-se tão-somente como política pública de conteúdo social”. Por essa lógica, caso não haja perspectivas de rentabilidade futura, as empresas somente investem em universalização "quando são obrigadas a isso pelas regras de regulação que tenham, entre seus escopos, objetivos redistributivos", respeitando a condição de equilíbrio econômico-financeiro do contrato de concessão.

Portanto, para haver acesso universal ao serviço de energia elétrica, o estabelecimento de políticas públicas é fundamental. Ou seja, é necessário definir claramente o limite de responsabilidade das distribuidoras em relação a programas de eletrificação de interesse social, assim como o papel do Governo Federal e dos Estaduais nesse processo.

Considerando a responsabilidade do Estado em prover acesso ao serviço público à população, garantindo as mesmas oportunidades para todos, é dever do Estado, como Poder Concedente, garantir as condições necessárias para que o serviço de energia elétrica possa ser acessível, por meio de políticas públicas e de sua regulação, inclusive com a definição da sua amplitude e das fontes de recursos alocadas.

\subsection{OBJETIVO}

Este estudo inicialmente conceitua a universalização dos serviços de energia elétrica no País que, na visão do autor, apresentada em conjunto com Pelegrini e Pazzini em 2001, pressupõe duas componentes distintas na sua forma, mas que estão interligadas no que se refere ao uso do serviço propriamente dito, sendo: a garantia do acesso físico e do uso contínuo. Este último é considerado como as condições para a 
manutenção do acesso ao serviço de eletricidade por meio de uma tarifa social ou de programas compensatórios.

Em seguida, discute-se o tratamento dado, ao longo do tempo, à responsabilidade pelos investimentos em obras necessárias para atender os novos consumidores e a aplicação da tarifa social no setor elétrico. Apresenta-se o histórico dos programas sociais com ênfase aos de eletrificação rural, que foram desenvolvidos para mitigar a falta de recursos que impedia o acesso de parcela da população ao serviço de energia elétrica.

O objetivo desta dissertação centra-se em analisar e avaliar as normas legais e os regulamentos que norteiam as políticas públicas de universalização dos serviços de energia elétrica, buscando identificar eventuais necessidades de sua complementação ou até mesmo de sua alteração. Com especial atenção discute-se a origem e a disponibilidade dos recursos para a universalização do acesso, considerando a finalidade política de levar o atendimento à população carente, dentro de um prazo exeqüível.

\subsection{ESTRUTURA DA DISSERTAÇÃO}

O Capítulo 2 apresenta os conceitos básicos, incluindo os diversos níveis de políticas públicas, as diferentes percepções de pobreza e o conceito de universalização no sentido amplo, englobando o acesso físico e o uso contínuo.

Os antecedentes da universalização do acesso ao serviço de energia elétrica são detalhados no Capítulo 3. Enfoca a evolução da participação financeira do consumidor, os programas de eletrificação rural conduzidos pelas cooperativas e pelas distribuidoras com o objetivo de mitigar a barreira para o atendimento representada pela participação financeira do consumidor e as propostas da Coopers \& Lybrand, consultora do processo de reestruturação do setor elétrico brasileiro, para a expansão do serviço de energia elétrica.

O Capítulo 4 trata dos antecedentes da universalização do uso contínuo do serviço de energia elétrica. Apresenta os estudos realizados pelo Dnaee visando a 
implementação de uma tarifa social para a energia elétrica; a criação da subclasse residencial baixa renda e os critérios estabelecidos naquela época pelas próprias distribuidoras. Também enfoca estudos da Fundação Instituto de Pesquisas Econômicas (FIPE), com o objetivo de aprimorar os critérios para a focalização no público-alvo adequado, e os programa sociais implementados pelas distribuidoras à margem da regulamentação.

O Capítulo 5 discorre sobre as experiências de alguns países desenvolvidos e outros em fase de desenvolvimento, para viabilizar o acesso aos serviços de energia elétrica bem como para garantir a continuidade do seu fornecimento à população carente.

A Lei $n^{\circ} 10.438 / 2002$ firmou-se como marco legal da universalização, tanto do acesso, estabelecendo a responsabilidade pela expansão do serviço de energia elétrica, como do uso contínuo, definindo novos critérios para classificação dos consumidores baixa renda. Dessa forma, o Capítulo 6 enfoca a referida Lei e sua regulamentação, bem como apresenta os recursos alocados para a universalização. Pode-se afirmar que o capítulo corresponde a cross section, dividindo o trabalho em duas partes: anterior e posterior a este marco legal.

O Capítulo 7 apresenta o contexto atual do não-atendimento, com base nos dados do Censo 2000, da Aneel e da estimativa feita pelo Ministério de Minas e Energia (MME) para a implementação do Programa Luz para Todos. Também estuda a evolução dos consumidores baixa renda no período de 1998 a 2004 e os impactos do subsídio concedido para as distribuidoras devido às perdas decorrentes da aplicação dos novos critérios para classificação, geradas com a publicação da Lei $\mathrm{n}^{\circ}$ $10.438 / 2002$.

O Capítulo 8 analisa a regulamentação da universalização do acesso físico e do uso contínuo apresentada no Capítulo 6. Enfoca os conceitos de universalização, identifica as necessidades adicionais de regulamentação, como por exemplo, a definição do limite de investimento obrigatório da distribuidora em obras para o atendimento de consumidores não abrangidos pela universalização e $\quad$ o aprimoramento dos critérios para a classificação dos consumidores baixa renda. 
Examina também a arrecadação e a aplicação dos recursos previstos para a universalização.

O Capítulo 9 identifica necessidades de regulamentação de outros assuntos relacionados com a universalização, como cooperativas de eletrificação rural, linhas particulares e incidência do Imposto sobre Circulação de Mercadorias e Serviços (ICMS) sobre o subsídio baixa renda concedido. Propõem-se aprimoramentos para determinadas regulamentações e diretrizes gerais para o aperfeiçoamento das políticas públicas de universalização. Essas propostas envolvem o acesso aos serviços de energia, inclusive para regiões isoladas; a necessidade de definição de uma política tarifária que englobe a tarifa residencial, a tarifa rural e a reavaliação das alíquotas de ICMS; a adequação das metas da Aneel e do Programa Luz para Todos; e a compatibilização dos recursos previstos para a universalização.

Finalizando o trabalho, o Capítulo 10 apresenta as conclusões sobre a regulamentação da universalização dos serviços de energia elétrica e identifica futuros estudos visando aprimorar a análise iniciada nesta dissertação. 


\section{CAPÍTULO 2 - CONCEITOS BÁSICOS}

\subsection{UNIVERSALIZAÇÃO}

Definir o significado de universalização é um passo essencial para o entendimento de ações planejadas pelos formuladores de políticas (Congresso Nacional e Poder Executivo, por meio do MME), regulamentadas pela Aneel e executadas por diversas distribuidoras. Isso porque, aparentemente, não existe o mesmo entendimento entre os diversos setores envolvidos nesse assunto e, possivelmente, o que realmente a sociedade deseja.

Segundo o dicionário Aurélio (2003), universalização significa o ato de tornar geral, comum a todos. Etimologicamente explica-se como:

universalização . [De universalizar + -ção.] S. f. 1. Ato ou efeito de universalizar(-se).

universalizar . [De universal + -izar.] V. t. d. 1. Tornar universal; generalizar: As gerações moças vêm universalizando novos hábitos e costumes. T. d. e i. 2. Tornar comum: Cumpre universalizar o ensino aos desfavorecidos. P. 3. Tornar-se universal; generalizar-se. [Pret. imperf. ind.: universalizava, .... universalizáveis, universalizavam. Cf. universalizáveis, pl. de universalizável.]

Dessa forma, com esse ponto de vista aplicado ao setor elétrico, universalizar corresponde ao ato de generalizar o serviço de energia elétrica, independentemente da classe de consumidor.

Até 2000 a universalização não era mencionada nos regulamentos do setor elétrico; por isso caracterizava-se como parte da prestação obrigatória do serviço concebido como adequado, mencionado no art. 175 da Constituição Federal, de 1988, e na Lei $\mathrm{n}^{\circ}$ 8.987, de 13 de fevereiro de 1995, e do atendimento abrangente ao mercado, sem exclusão das populações de baixa renda e das áreas de baixa densidade, estabelecida na Lei $\mathrm{n}^{\circ} 9.074$, de 7 de julho de 1995 .

\section{Constituição da República Federativa do Brasil de 1988}

Art. 175. Incumbe ao Poder Público, na forma da lei, diretamente ou sob regime de concessão ou permissão, sempre através de licitação, a prestação de serviços públicos.

Parágrafo Único. A lei disporá sobre:

IV - a obrigação de manter serviço adequado. 


\section{Lei $\mathbf{n}^{\circ} 8.987$, de 13 de fevereiro de 1995}

Art. $6^{\circ}$ Toda concessão ou permissão pressupõe a prestação do serviço adequado ao pleno atendimento dos usuários, conforme estabelecido nesta Lei, nas normas pertinentes e no respectivo contrato.

$\S 1^{\circ}$ Serviço adequado é o que satisfaz as condições de regularidade, continuidade, eficiência, segurança, atualidade, generalidade, cortesia na sua prestação e modicidade das tarifas.

\section{Lei $\mathbf{n}^{0}$ 9.074, de 7 de julho de 1995}

Art. $3^{\circ} \mathrm{Na}$ aplicação dos arts. 42, 43 e 44 da Lei $n^{\circ}$ 8.987, de 1995, serão observadas pelo poder concedente as seguintes determinações:

IV - atendimento abrangente ao mercado, sem exclusão das populações de baixa renda e das áreas de baixa densidade populacional inclusive as rurais;

[...]. (grifos nossos).

De acordo com Grotti (2000, p. 55) o princípio da generalidade ou universalidade, um dos fatores que balizam o serviço adequado, "é uma manifestação do princípio da igualdade, isto é, a possibilidade de que o serviço possa ser exigido e usado por todos". Segundo a autora, a necessidade de atendimento abrangente, sem exclusão das populações de baixa renda e das áreas de baixa densidade, determinada pela Lei $n^{\circ}$ 9.074/95, veda a criação de graus de cidadania: os que têm acesso e os excluídos. A prestação do serviço público deve possibilitar o acesso e o uso para todos, "independentemente das forças de mercado".

Em 2000, a Aneel propôs uma regulamentação, com base nesses conceitos e no entendimento de que a tarifa compreenderia toda a prestação do serviço, inclusive a necessidade de obras para a conexão do consumidor, apresentando pela primeira vez o termo "universalização", restrito, porém, ao acesso físico.

Nos Estados Unidos da América, onde o acesso à rede elétrica é praticamente pleno, seja por um grau de eletrificação em estágio avançado, seja por não se ter, praticamente, restrições econômicas ao acesso, o conceito de universalização corresponde à continuidade ou à manutenção do serviço a uma parcela da população que não tem condições de arcar com o pagamento das tarifas, segundo o documento "Universal Service Programs Manual"² da Pensylvania Public Utility Commission

${ }^{2}$ The Electricty Generation Customer Choice and Competition Act at $\$ 2803$ and the Natural Gás Choice Competition Act at $\$ 2202$ defines universal service and energy conservation as policies, protections and services that help low-income customers to maintains electric service. 
(2002), órgão regulador do Estado da Pensilvânia. Esse subsídio é fundamental, pois no inverno o consumo de energia para o sistema de aquecimento é maior, o que significa risco de morte na falta de energia elétrica ou de gás na residência, caso haja corte por não pagamento.

Para evitar esses possíveis casos, alguns governos estaduais americanos formularam programas para auxiliar as famílias carentes no sentido de não perderem o serviço de eletricidade ou gás canalizado.

Na Comunidade Européia, segundo Barros (2000, p. 142), com a reestruturação do setor elétrico nos diversos países, "criou-se um descompasso entre o novo "marco regulador' e os preceitos constitucionais e a doutrina dominante em cada um destes países". Após o avanço do poder “desregulamentador”, entre 1987 e 1993, a evolução da jurisprudência tende ao equilíbrio entre monopólio e concorrência e entre os interesses dos consumidores, das empresas de serviço público e do Estado. $\mathrm{O}$ surgimento da noção de serviço universalizado decorre dessa busca e é entendido como complemento indispensável à liberalização do setor.

No exemplo apresentado pela autora ao citar a área de telecomunicações, o serviço universal abrangeria uma dimensão suplementar ao acesso aos meios de comunicação: a exigência da criação e de tornar disponíveis as informações a todos, "coibindo-se a existência de duas classes de cidadãos", por um lado os que têm pleno acesso aos serviços públicos, por outro, os que não têm acesso.

De modo similar, Pelegrini (1998, p. 28) defende a necessidade de se "levar a energia elétrica à zona rural, com o fim primeiro de melhorar a qualidade de vida do homem do campo" ao analisar a implementação do Programa Luz da Terra, do governo paulista. De fato, o Decreto Estadual n ${ }^{\circ}$ 41.187, de 25 de setembro de 1996, define como um dos objetivos do programa "propiciar a maximização do atendimento de energia elétrica à população da zona rural do Estado, fazendo respeitar o direito igualitário de todos os cidadãos por tal benefício". Essa diretriz pode ser interpretada como a antecipação, em seis anos, do novo paradigma oficialmente estabelecido pela Lei $\mathrm{n}^{\circ}$ 10.438/2002, marco legal da universalização dos serviços de energia elétrica no Brasil. 
Com base nesses conceitos e no debate realizado sobre o assunto, no período que antecedeu a regulamentação, Pelegrini, Pazzini e Fugimoto (2001) conceituaram um enfoque mais abrangente sobre universalização: pressupõem-se duas componentes, distintas na sua forma e interligadas no que se refere ao uso do serviço propriamente dito, as quais atingem grupos de pessoas que se caracterizam pela mesma classe social.

A primeira vertente se refere ao acesso físico ao serviço de energia elétrica, ou seja, a possibilidade de se ter o serviço disponível para ser utilizado. Enquanto a segunda vertente diz respeito à manutenção desse acesso, ou seja, o uso contínuo do serviço de energia elétrica. Mesmo que as residências tenham acesso físico à rede de distribuição, uma parcela da população não possui renda para arcar com os custos do serviço. A conseqüência dessa dificuldade é a alocação desproporcional da renda familiar para esse serviço ou a suspensão do acesso que, via de regra, não é efetivo, levando, em alguns casos, a uma ligação clandestina. A existência de grupos de pessoas nessa condição também caracteriza um dos problemas constituintes da universalização dos serviços de energia, sob o ponto de vista de Pelegrini, Pazzini e Fugimoto (2001).

Nesse sentido, Prado (1999, p. 83) considera que o montante de ligações clandestinas, especialmente em regiões de proteção ambiental, alcança milhões de unidades consumidoras. No entanto, o problema não é a indisponibilidade de redes elétricas, mas sim

o fato de que essas pessoas não podem atender aos requisitos para disporem de uma ligação legalizada, ou por não terem os recursos necessários ao pedido de ligação, e finalmente porque quando esses obstáculos são vencidos, nem sempre conseguem fazer frente ao pagamento das contas.

Uma particularidade que liga os dois aspectos é a população envolvida. Tanto em relação à questão da conexão física, quanto à questão econômica da manutenção desse acesso, a população atingida é a mesma: os extratos sociais mais pobres da sociedade.

Este ponto de vista é reconhecido pelo Decreto n ${ }^{\circ} 4.541$, de 23 de dezembro de 2002, que regulamenta, dentre outros pontos, a Conta de Desenvolvimento Energético 
(CDE), um dos recursos previstos para a universalização. O regulamento define pela primeira vez no setor elétrico, o conceito de universalização do serviço de energia elétrica num sentido mais amplo, no art. $2^{\circ}$, inciso IX:

Universalização do Serviço Público de Energia Elétrica: busca do fornecimento generalizado de energia elétrica, alcançando, progressivamente, o atendimento de consumidores impossibilitados de ser atendidos em face da distância em que se encontram das redes existentes ou da dificuldade em arcar com tarifas normais de fornecimento.

Adicionalmente no documento preliminar para discussão do Programa Nacional de Universalização (MME, 2003a), o enfoque dado à universalização compreende esta acepção mais ampla do conceito de universalização, conforme pode ser observado nos trechos citados pelo MME de um documento preparado pela Aneel.

A universalização dos serviços de energia elétrica pressupõe duas componentes distintas na sua forma e interligadas no que se refere ao uso do serviço propriamente dito [...]. Uma primeira vertente se refere ao acesso físico ao serviço de energia elétrica, ou seja, a possibilidade de se ter o serviço disponível para ser utilizado. A segunda vertente é o acesso contínuo ao serviço de eletricidade. Mesmo que conectadas fisicamente à rede (ou a uma outra forma descentralizada de atendimento), parcelas da população não possuem renda para arcar com os custos do serviço [...]. (ANEEL, 2003, apud MME, 2003a).

Dessa forma, o conceito de universalização utilizado neste estudo envolve as suas duas componentes: o acesso e o uso contínuo, e pressupõe também um direito igualitário de todos os cidadãos ao serviço de energia elétrica, como antecipado pelo Decreto Estadual $\mathrm{n}^{\mathrm{o}}$ 41.187/96, não é responsabilidade do solicitante, em consonância com a Lei $n^{\circ} 10.438 / 2002$, arcar com os custos das obras necessárias para o seu atendimento.

\subsection{POLÍTICAS PÚBLICAS}

O desenvolvimento de Políticas Públicas ${ }^{3}$, entendido como o conjunto de Políticas de Estado e de Governo, é um meio efetivo para garantir o direito de cada cidadão, que consiste em ter acesso aos serviços públicos, inclusive energia elétrica.

\footnotetext{
${ }^{3}$ Segundo Marques (2003), as Políticas de Estado são aquelas definidas, por Lei, no processo que envolve o Executivo e o Legislativo; e as Políticas de Governo são os objetivos concretos que um governante pretende imprimir a um setor, limitadas a Políticas de Estado.
} 
De acordo com Pelegrini (1998, p. 4), as agências internacionais de financiamento e fomento de projetos de infra-estrutura nos países em desenvolvimento

entendem que eletrificação rural é uma questão social que deve ser resolvida por uma agência de desenvolvimento, de preferência nacional, externa e independente à concessionária, cujos objetivos não se coadunam com o atendimento de populações rurais pobres.

Segundo Anuatti (2000), as experiências internacionais obtidas em programas de atendimento das necessidades de energia de populações carentes podem ser divididas em três filosofias:

- realismo tarifário com reconhecimento das carências energéticas através de programas compensatórios;

- universalização das necessidades básicas;

- descontos tarifários aplicados aos domicílios pobres.

Na política denominada de realismo tarifário, a distribuidora não é responsável pelo suprimento das necessidades dos consumidores pobres, e não há descontos tarifários para essa parcela da população. Entretanto, o Estado reconhece a sua responsabilidade de garantir que os mais pobres tenham acesso aos serviços públicos, por meio de programas sociais, a exemplo do "renda mínima". Para o sucesso dessa política é imprescindível o apoio de uma rede de seguridade social bem organizada.

A universalização das necessidades básicas baseia-se no direito de acesso a uma quantidade de energia considerada como essencial, independentemente da classe social. Isso é garantido através de um escalonamento tarifário, ou seja, pela concessão de descontos para as faixas de menor de consumo. A eficácia dessa política depende da existência do subsídio cruzado e da diferenciação do consumo de energia elétrica entre pobres e ricos.

Os descontos tarifários aplicados aos domicílios pobres visam focalizar o benefício de uma tarifa menor para os consumidores que necessitam. O ponto crítico dessa política é a definição dos critérios para a inclusão no programa. Esta filosofia é empregada no setor elétrico desde 1995, necessitando, porém, de ajustes nos critérios para focalizar eficientemente o público-alvo. 


\subsection{CONCEITUAÇÃO DE POBREZA}

De acordo com Barros, Henriques e Mendonça (2001), em 1999, cerca de 22 milhões de brasileiros (14\% da população) viviam em famílias com renda inferior à linha de indigência e 53 milhões (34\%) em famílias com renda inferior à linha de pobreza ${ }^{4}$.

Embora não possa ser definida de forma única e universal, pode-se afirmar que a pobreza refere-se a situações de carência em que os indivíduos não conseguem manter um padrão mínimo de vida, condizente com as referências socialmente estabelecidas em cada contexto histórico (BARROS; HENRIQUES; MENDONÇA, 2001). Os conceitos de linha de pobreza e de indigência equivalem a essa medida.

Para Rocha (2000a), a fonte mais adequada para o estabelecimento dos parâmetros para mensuração da pobreza é a estrutura de consumo das famílias. Dessa forma, a linha de indigência refere-se somente à estrutura de custos de uma cesta alimentar, regionalmente definida, que contemple as necessidades de consumo calórico mínimo dos indivíduos. Nessa ótica, a linha de pobreza é calculada como múltiplo da linha de indigência, considerando os gastos com alimentação como uma parte dos gastos totais mínimos, referentes, entre outros, a vestuário, habitação e transportes (BARROS; HENRIQUES; MENDONÇA, 2001).

O valor da linha de pobreza que, como visto, contempla a alimentação e outras necessidades básicas, é diferente em cada região do País. Segundo Rocha (2000b), em 1997, o seu valor per capita variava de $\mathrm{R} \$ 41,66$ na área rural da Região Nordeste a R\$ 144,96 na região metropolitana de São Paulo.

Adicionalmente, a concentração de renda no País é elevada, uma das maiores do mundo. De acordo com Rocha (2000b, p. 3), “com renda anual per capita de R\$ 5.500 - portanto, bem acima de qualquer valor que possa ser realisticamente associado à linha de pobreza - a incidência de pobreza absoluta no Brasil decorre da forte desigualdade na distribuição de rendimentos". Ou seja, “o Brasil não é um País

\footnotetext{
${ }^{4}$ De acordo com os autores, as linhas de indigência e de pobreza utilizadas foram as da região metropolitana de São Paulo de 1999: R\$76,36 e R\$152,73, respectivamente.
} 
pobre, mas um País com muitos pobres", de acordo com raciocínio sustentado por Barros, Henriques e Mendonça (2001, p. 1).

Se forem comparados países com renda per capita similar à brasileira, reportados no Relatório de Desenvolvimento Humano de 1999, pode-se construir uma "norma internacional" que imputaria um valor previsto de somente $8 \%$ de pobres nesses países $^{5}$, valor muito inferior ao índice brasileiro de 34\% (BARROS; HENRIQUES; MENDONÇA, 2001).

Da mesma forma, de acordo com dados apresentados por Bermann (2002), com base nos dados do IBGE, o Índice de Gini ${ }^{6}$, o mais aceito instrumento de aferição da distribuição de renda, permaneceu em torno de 0,6, no período de 1981 a 1999, demonstrando que o grau de desigualdade praticamente não se alterou mesmo após o Plano Real e a estabilização da moeda.

Apesar dos estudos que almejam a mensuração da linha de pobreza, no Brasil é comum a utilização de múltiplos de salário mínimo como parâmetro. O Governo Federal, por exemplo, adotava até 2003 a renda familiar per capita de meio salário mínimo como valor determinante para a inclusão nos programas sociais. Atualmente, o Programa Bolsa Família, instituído pela Lei no 10.836, de 9 de janeiro de 2004, considera como famílias em situação de extrema pobreza e de pobreza aquelas com renda mensal per capita de $\mathrm{R} \$ 50,00$ e $\mathrm{R} \$ 100,00$, respectivamente, cujos valores foram calculados com base no salário mínimo.

\footnotetext{
${ }^{5}$ Para maiores detalhes dessa relação entre nível de pobreza e renda per capita ver Barros, Henriques e Mendonça (2001, p. 7).

6 Índice de Gini. Medida de concentração mais freqüentemente aplicada à renda, variando entre 1 e 0 . Quanto mais próximo de 1 for o índice de Gini, maior será a concentração na distribuição da renda, acontecendo o contrário à medida que esse coeficiente se aproxima de 0 .
} 


\section{CAPÍTULO 3 - ANTECEDENTES DA UNIVERSALIZAÇÃO DO ACESSO}

Este capítulo avalia a responsabilidade pelo atendimento de novas ligações no setor elétrico, até a publicação da Lei $\mathrm{n}^{\circ}$ 10.438/2002. O contexto da responsabilidade abrange os recursos necessários para as obras de extensão da rede de distribuição de energia elétrica: do próprio solicitante, da distribuidora ou ainda do Poder Público. Nos dois últimos casos, em última instância, os responsáveis seriam todos os consumidores da área de concessão da distribuidora ou os contribuintes do País, respectivamente.

Inicialmente, a responsabilidade da distribuidora de energia elétrica pelo atendimento ao consumidor era definida em plantas, que em geral cobriam núcleos urbanos, com o aval do Poder Público. O atendimento aos potenciais consumidores excluídos dessas áreas e, portanto, distantes da rede de distribuição era feito até um determinado valor, conhecido como limite de investimento obrigatório da concessionária $^{7}$. Caso o valor das obras necessárias para o atendimento fosse maior, o solicitante deveria arcar com a diferença denominada de participação financeira do consumidor.

O limite de investimento obrigatório da concessionária buscava vincular a expansão da empresa a um valor que não provocasse impacto tarifário significativo para os demais consumidores. Porém, por força da regulamentação, este limite reduziu-se ao longo do tempo, ao passo que a participação financeira do consumidor, em conseqüência, aumentou.

Dessa forma, para se compreender a importância desse processo na falta de acesso ao serviço de energia elétrica, este capítulo discorre sobre o histórico dos normativos que deram sustentação para esse conceito enfocando a evolução do limite de investimento das distribuidoras e seu complemento, a participação financeira do consumidor, como forma de desonerar o custo do serviço. Em seguida são

\footnotetext{
${ }^{7} \mathrm{O}$ limite de investimento da concessionária era também denominado encargo de responsabilidade da concessionária.
} 
apresentados os programas de universalização do acesso e a discussão sobre a sua amplitude (público-alvo), prazos e recursos.

\subsection{HISTÓRICO DA PARTICIPAÇÃO FINANCEIRA}

\subsubsection{Decreto $n^{0} 41.019 / 57$}

O Decreto $\mathrm{n}^{\circ}$ 41.019, de 26 de fevereiro de 1957 - considerado como "Regulamento dos serviços de eletricidade" - estabelecia originalmente a obrigatoriedade e a responsabilidade da distribuidora quanto ao fornecimento de energia elétrica a uma região, configurada em plantas organizadas de comum acordo com as Prefeituras Municipais e aprovadas pelo Departamento Nacional de Águas e Energia Elétrica (Dnaee). As ampliações para o atendimento nesse perímetro também seriam executadas sob responsabilidade das empresas.

Essas áreas poderiam ser revistas a fim de atender ao crescimento das concentrações de população, porém observado o princípio econômico de que as extensões em baixa tensão não compreendidas nas áreas "demarcadas" seriam custeadas até o limite de três vezes a receita anual estimada do novo consumo. O regulamento facultava ao consumidor contribuir, sendo que as extensões poderiam ser executadas por terceiros e cedidas às empresas.

As linhas de transmissão, subtransmissão e de distribuição em tensão primária ${ }^{8}$ e as respectivas subestações seriam implementadas sob a responsabilidade das distribuidoras, para o atendimento da área delimitada, de acordo com o projeto aprovado pelo Poder Concedente.

As extensões dessas linhas e respectivas subestações, para o atendimento fora das áreas definidas e as destinadas a consumidores em média e alta tensão, seriam implementadas até o limite de três vezes e meia a receita anual estimada do novo

\footnotetext{
${ }^{8}$ Tensão Primária de Distribuição: tensão disponibilizada no sistema elétrico, com valores iguais ou superiores a $2,3 \mathrm{kV}$.
} 
consumo, diferentemente do limite estabelecido para a rede em tensão secundária ${ }^{9}$. Porém, no caso de previsão de aumento de receita que, dentro do prazo de cinco anos, atingisse os limites apresentados anteriormente, as contribuições dos consumidores seriam recebidas a título de adiantamento e restituídas a partir do terceiro exercício em que fossem verificadas as condições econômicas já referidas.

Em resumo, para as áreas onde havia concentração populacional, as quais poderiam ser entendidas como urbanas, o atendimento era sempre responsabilidade da concessionária. Além dessas áreas, o investimento estava limitado ao valor correspondente a três vezes a receita anual estimada para consumidores atendidos em baixa tensão; para ligações em média e alta tensão o limite era três vezes e meia a receita anual estimada.

Nas áreas rurais, o atendimento, conforme já exposto, não era responsabilidade da distribuidora. De fato, o Decreto $\mathrm{n}^{\circ}$ 62.655, de 3 de maio de 1968, que regulamenta a execução de serviços de eletrificação rural mediante autorização para uso privativo, conceitua a eletrificação rural, como sendo:

[...] a execução de serviços de transmissão e distribuição de energia elétrica destinada a consumidores localizados em áreas fora dos perímetros urbanos e suburbanos das sedes municipais e aglomerados populacionais com mais de 2.500 habitantes, e que se dediquem a atividades ligadas diretamente à exploração agropecuária, ou a consumidores localizados naquelas áreas, dedicando-se a quaisquer tipos de atividades, porém com carga ligada de até $45 \mathrm{kVA}$.

\subsubsection{Nova redação dada pelo Decreto $\mathrm{n}^{0}$ 83.269/79}

O Decreto $\mathrm{n}^{\circ} 83.269$, de 12 de março de 1979 , alterou a redação do Decreto $\mathrm{n}^{\circ}$ 41.019/57 estabelecendo que os limites de investimentos seriam calculados pelo Dnaee segundo condições estipuladas nesse regulamento e em atos do MME.

Um desses procedimentos previa que no cálculo seria considerada somente a extensão no segmento do sistema que atendesse à unidade de consumo, exceção feita ao atendimento em tensão secundária, no qual seria incluída também a extensão primária, se necessária.

\footnotetext{
${ }^{9}$ Rede em tensão secundária: rede de distribuição de energia elétrica em tensão inferior a 2,3kV cujo fornecimento é feito por um transformador de distribuição.
} 
O regulamento previa que o Dnaee deveria elaborar suas normas considerando o sistema elétrico como um todo, para garantir que os investimentos não acarretassem acréscimos ao custo total de serviço, superior ao acréscimo da receita proveniente dos consumidores atendidos por esses investimentos, ou seja, não poderiam acarretar aumento nas tarifas dos consumidores.

A execução de extensões ou obras ficaria condicionada à contribuição no valor correspondente à diferença entre o custo da obra e o limite de investimento de responsabilidade da concessionária de distribuição de energia elétrica.

Seria responsabilidade total da distribuidora o acréscimo de fases em redes existentes, reforço ou acréscimo de novo circuito em tensão inferior a $34,5 \mathrm{kV}$ (exceção feita à eletrificação rural); reforma em redes existentes e atendimento aos níveis de continuidade e qualidade.

Por outro lado, seriam de responsabilidade total do consumidor: extensão de linha exclusiva ou de reserva; melhoria a qualidade ou continuidade superior ao exigido pela regulamentação e melhoria de aspectos estéticos.

\subsubsection{Nova redação dada pelo Decreto $\mathrm{n}^{0}$ 98.335/89}

O Decreto $\mathrm{n}^{\circ}$ 98.335, de 26 de outubro de 1989, novamente alterou a redação do Decreto $\mathrm{n}^{\circ}$ 41.019/57. A responsabilidade total da concessionária foi diminuída, englobando somente as obras não vinculadas diretamente ao atendimento de novas cargas e obras para o atendimento aos níveis de continuidade e qualidade.

A responsabilidade financeira exclusiva do consumidor, assim como no regulamento anterior, era: extensão de linha exclusiva ou de reserva; melhoria da qualidade ou continuidade superior ao exigido pela regulamentação e melhoria de aspectos estéticos.

O regulamento determinava ainda que os encargos de responsabilidade seriam definidos pelo Dnaee com base nos investimentos na expansão, considerando o País como um todo, de modo que não acarretassem acréscimo ao custo total do serviço, superior ao acréscimo à receita, decorrentes dos demais investimentos. 
$\mathrm{O}$ atendimento ficaria condicionado ao pagamento da participação financeira do consumidor que poderia, para compatibilizar o prazo, aportar a totalidade dos recursos, devendo a concessionária efetuar a restituição da parcela de sua responsabilidade.

O Quadro 1 a seguir, apresenta um resumo da evolução da regulamentação comparando o conteúdo dos artigos do Decreto $n^{\circ} 41.019 / 57$ e as novas redações implementadas em 1979 e 1989.

\section{Quadro 1 - Evolução da regulamentação da responsabilidade pelo atendimento}

\begin{tabular}{|c|c|c|c|}
\hline Artigo & Decreto $n^{\circ} 41.019 / 57$ & Decreto $\mathrm{n}^{\circ} 83.269 / 79$ & Decreto $\mathrm{n}^{\circ} \mathbf{9 8 . 3 3 5 / 8 9}$ \\
\hline 136 & $\begin{array}{c}\text { Obrigação de fornecimento dentro da área } \\
\text { definida pelo art. } 138\end{array}$ & $\begin{array}{c}\begin{array}{c}\text { Obrigação de fornecimento nas condições } \\
\text { estipuladas neste capítulo e em atos do } \\
\text { MME e DNAEE }\end{array} \\
\end{array}$ & $\begin{array}{c}\text { Obrigação de fornecimento nas } \\
\text { condições estipuladas neste capítulo e } \\
\text { em atos do MME e DNAEE }\end{array}$ \\
\hline \multirow{4}{*}{138} & \multirow{2}{*}{$\begin{array}{c}\text { Responsabilidade de atendimento à } \\
\text { concentração de população, configurados } \\
\text { em plantas organizadas de comum acordo } \\
\text { com as Prefeituras Municipais e aprovadas } \\
\text { pela Fiscalização }\end{array}$} & $\begin{array}{c}\text { Custeio é de responsabilidade do } \\
\text { concessionário até limites por ele } \\
\text { calculados, conforme normas do DNAEE }\end{array}$ & \multirow{4}{*}{$\begin{array}{l}\text { Os encargos de responsabilidade serão } \\
\text { definidos pelo DNAEE }\end{array}$} \\
\hline & & $\begin{array}{c}\text { No cálculo considerar somente o } \\
\text { montante relativo ao segmento do sistema } \\
\text { que atender à unidade de consumo }\end{array}$ & \\
\hline & \multirow{2}{*}{$\begin{array}{l}\text { Poderão ser revistas atendendo ao } \\
\text { crescimento das concentrações de } \\
\text { população e observadas as condiçoes } \\
\text { econômicas definidas no artigo seguinte }\end{array}$} & $\begin{array}{l}\text { Atendimento em tensão secundária - } \\
\text { considerar extensão secundária e } \\
\text { primária, se necessária }\end{array}$ & \\
\hline & & $\begin{array}{c}\text { Atendimento em tensão primária, } \\
\text { subtransmissão ou transmissão - } \\
\text { considerar a extensão na tensão de } \\
\text { fornecimento } \\
\end{array}$ & \\
\hline \multirow{3}{*}{139} & $\begin{array}{c}\text { As extensões não compreendidas no art. } \\
138 \text { serão estabelecidas à custa do } \\
\text { concessionário até o limite de três vezes a } \\
\text { receita anual estimada do novo consumo }\end{array}$ & \multirow{3}{*}{\begin{tabular}{|c|} 
O DNAEE deve elaborar as normas \\
considerando o sistema elétrico como um \\
todo e de forma a garantir que os \\
investimentos não acarretem acréscimo \\
ao custo total de serviço superior ao \\
acréscimo à receita, acréscimos esses \\
previstos e decorrentes dos mesmos \\
investimentos
\end{tabular}} & \multirow{3}{*}{$\begin{array}{l}\text { O DNAEE levará em conta os } \\
\text { investimentos na expansão, } \\
\text { considerando o país como um todo, de } \\
\text { modo que não acarretem acréscimo ao } \\
\text { custo total do serviço, superior ao } \\
\text { acréscimo à receita, decorrentes dos } \\
\text { demais investimentos }\end{array}$} \\
\hline & É facultado ao consumidor contribuir & & \\
\hline & $\begin{array}{l}\text { As extensões poderão ser executadas por } \\
\text { terceiros e cedidas aos concessionários }\end{array}$ & & \\
\hline \multirow{3}{*}{140} & $\begin{array}{c}\text { As linhas de transmissão, subtransmissão e } \\
\text { de distribuição primária e respectivas } \\
\text { subestações serão estabelecidas à custa dos } \\
\text { concessionários }\end{array}$ & \multirow{3}{*}{\begin{tabular}{|} 
A execução de extensões ou obras a que \\
se refere o art. 138 fica condicionada \\
contribuição no valor correspondente à \\
diferença entre o custo da obra e o limite \\
de investimento de responsabilidade do \\
concessionário
\end{tabular}} & $\begin{array}{l}\mathrm{O} \text { atendimento fica condicionado ao } \\
\text { pagamento da participação financeira do } \\
\text { consumidor. }\end{array}$ \\
\hline & \begin{tabular}{|c|} 
As ampliações para o atendimento do \\
perímetro referido no art. 138 serão à custa \\
dos concessionários
\end{tabular} & & \multirow{2}{*}{$\begin{array}{c}\text { Para conpatibilizar o prazo, o } \\
\text { consumidor poderá aportar a totalidade } \\
\text { dos recursos. A concessionária efetuará } \\
\text { a restituição da parcela de sua } \\
\text { responsabilidade. }\end{array}$} \\
\hline & $\begin{array}{c}\text { As extensões das linhas tratadas por esse } \\
\text { artigo para o atendimento, nos termos do } \\
\text { art. 139, serão estabelecidas até o limite de } \\
3,5 \text { a receita anual estimada do novo } \\
\text { consumo }\end{array}$ & & \\
\hline \multirow[t]{2}{*}{141} & \multirow{2}{*}{$\begin{array}{c}\text { Quando for previsto aumento de receita } \\
\text { que, dentro do prazo de cinco anos, venha } \\
\text { a satisfazer os limites estabelecidos nos } \\
\text { arts. } 139 \text { e } 140 \text {, as contribuições dos } \\
\text { consumidores serão recebidas a título de } \\
\text { adiantamento, que será restituído a partir } \\
\text { do terceiro exercício em que forem } \\
\text { verificadas as condições econômicas já } \\
\text { referidas. }\end{array}$} & $\begin{array}{c}\text { Responsabilidade total do } \\
\text { concessionário: acréscimo de fases em } \\
\text { redes existenstes; reforço ou acréscimo de } \\
\text { novo circuito em tensão inferior a } \\
34,5 \mathrm{kV} ; \text { reforma em redes existentes e } \\
\text { atendimento aos níveis de continuidade e } \\
\text { qualidade. }\end{array}$ & \multirow[t]{2}{*}{$\begin{array}{l}\text { Responsabilidade total do } \\
\text { concessionário: obras não vinculadas } \\
\text { diretamente ao atendimento de novas } \\
\text { cargas e obras para o atendimento aos } \\
\text { níveis de continuidade e qualidade. }\end{array}$} \\
\hline & & $\begin{array}{c}\text { Não é responsabilidade no caso de } \\
\text { eletrificação rural, os dois primeiros } \\
\text { casos (acréscimo de fase, reforço ou } \\
\text { acréscimo de novo circuito em tensão } \\
\text { inferior a } 34,5 \mathrm{kV} \\
\end{array}$ & \\
\hline 142 & $\begin{array}{c}\text { Modificações nos circuitos de distribuição } \\
\text { determinadas pelo Poder Público serão } \\
\text { realizadas à custa dos concessionários, até } \\
\text { o limite de } 2,5 \text { vezes a receita anual do } \\
\text { consumo }\end{array}$ & $\begin{array}{c}\text { Responsabilidade total do consumidor: } \\
\text { extensão de linha exclusiva ou de reserva; } \\
\text { melhoria a qualidade ou continuidade } \\
\text { superior ao exigido pela regulamentação } \\
\text { e melhoria de aspectos estéticos. }\end{array}$ & $\begin{array}{c}\text { Responsabilidade total do } \\
\text { consumidor: extensão de linha } \\
\text { exclusiva ou de reserva; melhoria a } \\
\text { qualidade ou continuidade superior ao } \\
\text { exigido pela regulamentação e melhoria } \\
\text { de aspectos estéticos. }\end{array}$ \\
\hline
\end{tabular}

Fonte: Elaborado pelo autor. 
Observa-se que o detalhamento contido no regulamento foi gradativamente diminuído, ao mesmo tempo em que foi delegada sua regulamentação ao Dnaee. Por essa razão, os normativos, que tratam da participação financeira do consumidor e do limite de investimento obrigatório da distribuidora, também são detalhados sob uma perspectiva cronológica, no próximo item.

\subsubsection{Portarias Dnaee, referentes ao limite de investimento das distribuidoras}

O Decreto no 41.019/57, primeiramente com a redação dada pelo Decreto $\mathrm{n}^{\circ} 83.269 / 79$ e posteriormente pelo Decreto $\mathrm{n}^{\circ} 98.335 / 89$, determinou ao Dnaee a definição dos encargos de responsabilidade da concessionária de distribuição de energia elétrica e da participação financeira do consumidor, decorrentes do atendimento de novas ligações ou acréscimos de carga.

A seguir são detalhados os valores históricos dos limites de investimentos da distribuidora, resumidos na Figura 4, em razão da sua importância na revisão da literatura. No fechamento deste capítulo analisa-se a influência desse mecanismo na falta de acesso, sendo então apresentados valores atualizados, para garantir a eficácia da comparação.

Com o intuito de estabelecer normas para a determinação dos limites de investimento da concessionária foram publicadas diversas portarias do Dnaee. A primeira delas, a Portaria $\mathrm{n}^{\circ}$ 57, de 15 de maio de 1979, estabeleceu os valores em Cr\$3.500,00 $(\mathrm{R} \$ 957,51)^{10}$ por $\mathrm{kW}$ para os consumidores do Grupo $\mathrm{A}^{11} \mathrm{e}$ o mesmo valor por consumidor residencial, conforme pode ser observado no Quadro 2.

A Portaria $\mathrm{n}^{\circ}$ 10, de 21 de janeiro de 1980, ajustou esses valores para Cr $\$ 7.0000,00$ para consumidores residenciais (B1) ${ }^{12}$ e para o primeiro bloco de $200 \mathrm{kWh}$ dos

\footnotetext{
${ }^{10}$ Correção pela variação do IGP-DI até dez/2004.

${ }^{11}$ Grupo "A": composto de unidades consumidoras com fornecimento em tensão igual ou superior a $2,3 \mathrm{kV}$. Em geral consumidores com carga instalada acima de $50 \mathrm{~kW}$ ou $75 \mathrm{~kW}$, dependendo da regulamentação vigente na época da ligação.

${ }^{12}$ Grupo B: composto de unidades consumidoras com fornecimento em tensão inferior a 2,3 kV ou atendida em tensão superior à mencionada e caracterizada pela estruturação tarifária monômia (somente a tarifa de energia). Constituída dos seguintes subgrupos:

- B1 - residencial e residencial caracterizada como baixa renda;
} 
consumidores B2 (rurais) e B3 (demais classes, exceto residenciais), permanecendo Cr\$ 3.500,00 para os demais blocos ou fração.

Esta regulamentação foi inovadora ao vincular o nível de consumo estimado do consumidor B2 ou B3 ao limite de investimento da distribuidora. Por exemplo, para um consumidor rural (B2) com estimativa de consumo de $400 \mathrm{kWh}$, o cálculo do limite de investimento da distribuidora seria feito desta forma: $\mathrm{Cr} \$ 7.000,00$, valor referente ao primeiro bloco de consumo de $200 \mathrm{kWh}$, somado com $\mathrm{Cr} \$ 3.500,00$ correspondente ao bloco (ou fração) seguinte, totalizando $\mathrm{Cr} \$ 10.500,00$. Se a estimativa de consumo fosse de $500 \mathrm{kWh}$, o cálculo do limite seria: o somatório de Cr\$ 7.000,00, referente ao primeiro bloco; Cr\$ 3.500,00, que corresponde ao segundo bloco; Cr\$ 3.500,00 para a fração seguinte de consumo, totalizando Cr\$ $14.000,00$.

A Portaria $n^{\circ} 10 / 80$ incluiu a obrigação da aplicação do limite de investimento da concessionária, não podendo ser maior nem menor ao calculado, salvo quando o custo da obra fosse inferior. Estabeleceu também que, para o desenvolvimento de programas especiais de eletrificação, a concessionária poderia investir além dos limites estabelecidos, devendo contabilizar os valores adicionais de investimento como Imobilizações com Remuneração em Suspenso, de acordo com o regulamento do Plano de Contas.

A Portaria $\mathrm{n}^{\circ}$ 116, de 3 de dezembro de 1980, reajustou os valor de responsabilidade da distribuidora. Para o atendimento dos consumidores residenciais o limite passou a ser $\operatorname{Cr} \$ 12.0000,00(\mathrm{R} \$ 1.101,24)^{13}$, mantendo a mesma proporção relativa dos valores da regulamentação anterior para as demais classes de consumidores.

O limite de investimento para os consumidores do Grupo A permaneceu inalterado desde maio de 1979. Esse valor somente foi atualizado com a Portaria $\mathrm{n}^{\circ}$ 93, de 13 de novembro de 1981, que vinculou os encargos da concessionária à denominada tarifa

- B2 - rural, cooperativa de eletrificação rural e serviço público de irrigação;

- B3 - demais classes (comercial, industrial);

- B4 - iluminação pública.

${ }^{13}$ Correção pela variação do IGP-DI até dez/2004. A utilização do IGP-DI, ao invés do IGP-M, devese ao fato de que o histórico de apurações deste último índice se inicia em junho de 1989. 
fiscal $^{14}$. A nova regulamentação definiu o valor de 1,15 vezes a tarifa fiscal por $\mathrm{kW}$ para os consumidores do Grupo A; para os consumidores residenciais, seis vezes a tarifa fiscal; para os consumidores B2 e B3, o mesmo valor para o primeiro bloco de 200 kWh, e três vezes a tarifa fiscal para os demais blocos ou fração.

O valor da tarifa fiscal em $1^{\circ}$ de janeiro de 1982 (data a partir da qual a Portaria $n^{\circ} 93 / 81$ entrou em vigor) era $\mathrm{Cr} \$ 4.610,00(\mathrm{R} \$ 204,68)^{15}$, de acordo com a Portaria $n^{\circ} 78$, de 24 de setembro de 1981.

A Portaria $\mathrm{n}^{\mathrm{o}}$ 5, de 11 de janeiro de 1990, com base no Decreto $\mathrm{n}^{\circ}$ 98.335/89, estabeleceu inicialmente um encargo correspondente ao Custo de Capacidade do Fornecimento (CCF) para consumidores do Grupo A, mesmo que não fossem necessárias obras para o atendimento ao consumidor. Os encargos da concessionária correspondentes aos limites de investimento foram segregados por subgrupo tarifário no Grupo A, conforme detalhado no Quadro 2.

Para o Grupo B, o referido normativo, vigente a partir de 14 de fevereiro de 1990, sustentou os valores previstos no regulamento anterior e estabeleceu o limite de duas vezes a tarifa fiscal por blocos ou fração de $200 \mathrm{kWh}$ para os consumidores B4 (iluminação pública) ${ }^{16}$.

A Portaria $\mathrm{n}^{\circ} 347$, de 20 de dezembro de 1991, alterou a Portaria $\mathrm{n}^{\circ}$ 5/90 diminuindo os limites do Grupo B: quatro vezes a tarifa fiscal para residenciais (B1) e para o primeiro bloco de 200kWh dos consumidores B2 e B3; e duas vezes a tarifa fiscal referentes aos demais blocos ou fração de $200 \mathrm{kWh}$.

O encargo de Custo de Capacidade de Fornecimento (CCF) para consumidores do Grupo A foi extinto pela Portaria $\mathrm{n}^{\circ}$ 39, de 21 de fevereiro de 1997, possivelmente devido à melhoria das condições econômico-financeiras das distribuidoras, conforme

\footnotetext{
${ }^{14}$ A Lei $n^{\circ} 4.156$, de 28 de novembro de 1962, que alterou a legislação sobre o Fundo Federal de Eletrificação, define a tarifa fiscal como o "quociente do valor em cruzeiros da energia vendida a medidor no País, em determinado mês, pelo correspondente volume físico (número de quilowattshora) de energia consumida durante o mês", ou seja, uma tarifa média de fornecimento.

15 Corrigido pela variação do IGP-DI até dez/2004.

16 De acordo com a Portaria $\mathrm{n}^{\mathrm{o}} 23$, de 8 de fevereiro 1990, o valor da tarifa fiscal vigente a partir de 10/02/1990 era NCz\$ 892,22 (R\$ 205,05 atualizado pela variação do IGP-M até dez/2004).
} 
consta nas considerações do referido regulamento. $\mathrm{Na}$ realidade, a participação financeira do consumidor, também cobrada do consumidor quando da realização de obras, já seria suficiente para remunerar esses investimentos da distribuidora.

\section{Quadro 2 - Valores históricos dos limites de investimento da concessionária}

\begin{tabular}{|c|c|c|c|c|}
\hline \multirow{2}{*}{$\begin{array}{c}\text { Limite de } \\
\text { Investimento da } \\
\text { Concessionária }\end{array}$} & \multicolumn{4}{|c|}{ Grupo Tarifário } \\
\hline & $\mathbf{A}$ & B1 & B2 & B3 \\
\hline $\begin{array}{c}\text { Portaria DNAEE } 57 \\
\text { de } 15 / 05 / 79\end{array}$ & $\mathrm{Cr} \$ 3.500,00$ por $\mathrm{kW}$ & $\begin{array}{l}\mathrm{Cr} \$ 3.500,00 \text { por } \\
\quad \text { consumidor }\end{array}$ & $\begin{array}{l}\text { Cr } \$ 3.500,00 \text { por } \\
\quad \text { consumidor }\end{array}$ & $\begin{array}{c}\text { Cr\$3.500,00 por bloco de } \\
200 \mathrm{kWh}\end{array}$ \\
\hline $\begin{array}{c}\text { Portaria DNAEE } 10 \\
\text { de } 21 / 01 / 80\end{array}$ & $\mathrm{Cr} \$ 3.500,00$ por $\mathrm{kW}$ & $\begin{array}{l}\mathrm{Cr} \$ 7.000,00 \text { por } \\
\quad \text { consumidor }\end{array}$ & $\begin{array}{l}\text { Cr\$ 7.000,00 primeiro } \\
\text { bloco de } 200 \mathrm{kWh} \text { e Cr\$ } \\
3.500,00 \text { para os demais }\end{array}$ & $\begin{array}{l}\text { Cr\$ } 7.000,00 \text { primeiro } \\
\text { bloco de } 200 \mathrm{kWh} \text { e Cr\$ } \\
3.500,00 \text { para os demais }\end{array}$ \\
\hline $\begin{array}{c}\text { Portaria DNAEE } 116 \\
\text { de } 03 / 12 / 80\end{array}$ & $\mathrm{Cr} \$ 3.500,00$ por $\mathrm{kW}$ & $\begin{array}{l}\text { Cr\$ } 12.000,00 \text { por } \\
\quad \text { consumidor }\end{array}$ & $\begin{array}{l}\text { Cr\$ } 12.000,00 \text { primeiro } \\
\text { bloco de } 200 \mathrm{kWh} \text { e } \mathrm{Cr} \$ \\
6.000,00 \text { para os demais }\end{array}$ & $\begin{array}{l}\text { Cr\$ } 12.000,00 \text { primeiro } \\
\text { bloco de } 200 \mathrm{kWh} \text { e } \mathrm{Cr} \$ \\
6.000,00 \text { para os demais }\end{array}$ \\
\hline $\begin{array}{c}\text { Portaria DNAEE } 93 \\
\text { de } 13 / 11 / 81\end{array}$ & $1,15 \mathrm{x}$ tarifa fiscal por $\mathrm{kW}$ & $\begin{array}{l}6 \times \text { tarifa fiscal por } \\
\text { consumidor }\end{array}$ & $\begin{array}{c}6 \mathrm{x} \text { tarifa fiscal primeiro } \\
\text { bloco de } 200 \mathrm{kWh} \text { e } 3 \times \\
\text { tarifa fiscal para os } \\
\text { demais }\end{array}$ & $\begin{array}{c}6 \mathrm{x} \text { tarifa fiscal primeiro } \\
\text { bloco de } 200 \mathrm{kWh} \text { e } 3 \mathrm{x} \\
\text { tarifa fiscal para os } \\
\text { demais }\end{array}$ \\
\hline $\begin{array}{c}\text { Portaria DNAEE } 5 \text { de } \\
\text { 03/12/80 }\end{array}$ & $\begin{array}{c}\text { A1, A2 e A3 - 0,60 x Tarifa } \\
\text { Fiscal por kW; A3a e A4 - } \\
1,00 \times \text { Tarifa Fiscal por kW; } \\
\text { AS - } 0,80 \times \text { Tarifa Fiscal por } \\
\text { kW }\end{array}$ & $\begin{array}{l}4 \times \text { Tarifa Fiscal por } \\
\text { consumidor }\end{array}$ & $\begin{array}{c}4 \text { x Tarifa Fiscal } \\
\text { (primeiro bloco de } 200 \\
\text { kWh); } 2 \text { x Tarifa Fiscal } \\
\text { para os demais blocos ou } \\
\text { fração }\end{array}$ & $\begin{array}{l}4 \text { x Tarifa Fiscal por } \\
\text { bloco de } 200 \mathrm{kWh}\end{array}$ \\
\hline $\begin{array}{c}\text { PORTARIA } 5 \\
\text { Custo de Capacidade do } \\
\text { Fornecimento (1990- } \\
\text { 1997)* }\end{array}$ & $\begin{array}{c}\text { A1, A2 e A3 - 0,30 x Tarifa } \\
\text { Fiscal por kW; A3a e A4 - } \\
0,35 \times \text { Tarifa Fiscal por kW; } \\
\text { AS - 0,50 x Tarifa Fiscal por } \\
\text { kW }\end{array}$ & & & \\
\hline
\end{tabular}

* (em vigor de 14/02/90, estabelecido pela Portaria DNAEE 5/90 até 24/02/1997 quando foi revogado pela Portaria DNAEE 39/97))

Fonte: Elaborado pelo autor.

Ressalta-se que a tarifa fiscal permaneceu, por sete anos ${ }^{17}$, no valor de $\mathrm{R} \$ 64,48$, definido na Portaria $n^{\circ}$ 2, de 4 de janeiro de 1996, o que implicou o congelamento do limite de investimento da concessionária, desconsiderando, dentre outros efeitos, o inflacionário. Caso fosse corrigida pela variação do IGP-M até dezembro de 2004, a tarifa fiscal seria de $\mathrm{R} \$ 172,30$.

${ }^{17}$ A vinculação do limite de investimento à tarifa fiscal era determinada pela Portaria $\mathrm{n}^{\mathrm{o}} 5 / 90$ que foi revogada pela Resolução n 223/2003. 


\subsection{PROGRAMAS DE ELETRIFICAÇÃO RURAL}

A energia elétrica foi introduzida no Brasil no mesmo ano que ocorreu a primeira demonstração pública da lâmpada elétrica de Edison em 1879: acionadas a partir da energia gerada por dois dínamos, seis lâmpadas de arco, do tipo Jablockhov, iluminaram a estação central da Estrada de Ferro D. Pedro (atual Central do Brasil) (MEMÓRIA DA ELETRICIDADE, 1988).

Em 1883 o primeiro aproveitamento hidrelétrico, localizado em Diamantina - MG, foi instalado no Brasil. Uma linha de transmissão de $2 \mathrm{~km}$ de extensão transportava energia até as minas de diamantes onde era utilizada para movimentar bombas de desmonte hidráulico, que por sua vez revolviam o terreno.

Nesse mesmo ano foi inaugurada a primeira linha de bondes movidos por energia elétrica no País, na cidade de Niterói - Rio de Janeiro.

Nos anos de 1883 e 1885, respectivamente, foram inaugurados o primeiro serviço de iluminação pública municipal do Brasil em Campos, Rio de Janeiro, e o serviço de iluminação pública na cidade de Rio Claro, São Paulo.

Em 1887, novamente em Minas Gerais (Nova Lima), outra usina hidrelétrica começou a ser utilizada para auxiliar os trabalhos de mineração. Adicionalmente, uma pequena linha de transmissão possibilitava o uso da energia para a iluminação elétrica nas casas dos funcionários da empresa.

Portanto, o surgimento de pequenas usinas geradoras decorreu da necessidade de fornecimento para serviços públicos de iluminação, tração elétrica e para atividades econômicas como mineração e posteriormente beneficiamento de produtos agrícolas, fábricas de tecido, entre outras.

O fornecimento de energia elétrica nas cidades era feito por meio de concessão municipal assim como ocorria para os serviços públicos de transporte, telegrafia e telefonia. Em 1899, a São Paulo Tramway, Light and Power Company Limited (conhecida como Light), detinha a concessão do serviço de transporte urbano de 
passageiros e cargas em bondes elétricos, geração e distribuição de energia elétrica na cidade de São Paulo.

Nas primeiras décadas do século XX verificou-se o aumento de indústrias e também a substituição gradual do vapor pela energia elétrica. A participação da energia elétrica que em 1907 correspondia a 4\% da força motriz utilizada pela indústria passou para aproximadamente $47 \%$ em 1920, percentual dez vezes superior (MEMÓRIA DA ELETRICIDADE, 1998).

Portanto, no início do seu desenvolvimento, o serviço público de distribuição de energia elétrica era restrito às áreas urbanas visando a iluminação pública, bondes elétricos e para o nascente parque fabril.

\subsubsection{Cooperativas de Eletrificação Rural}

O primeiro registro de utilização de energia rural data de 1923, quando João Nogueira de Carvalho instalou eletricidade em sua propriedade no município de Batatais - São Paulo (DNAEE, 1985).

As primeiras cooperativas surgiram no Rio Grande do Sul, no início da década de 1940, primeiramente por iniciativa de pequenos núcleos urbanos, que pretendiam eletrificar suas residências; posteriormente as cooperativas foram expandindo suas áreas de atuação englobando ou atingindo também as áreas rurais.

Segundo Souto e Loureiro (1999), o movimento cooperativo foi criado pelos pequenos agricultores e operários para "contrapor" ou mitigar os efeitos negativos que a mecanização impôs ao mercado de trabalho dessas classes. Nesse sentido, o objetivo da cooperativa era o auxílio mútuo entre pessoas que possuíssem uma atividade comum.

De fato, a Lei $\mathrm{n}^{\circ} 5.764$, de 16 de dezembro de 1971 , em seu artigo $4^{\circ}$, define as cooperativas como sociedade de pessoas, com forma e natureza jurídica próprias, de natureza civil, não sujeitas à falência, constituídas para prestar serviços aos associados, distinguindo-se pelas seguintes características: adesão voluntária, limitação do número de quotas-parte do capital para cada associado, singularidade de 
voto, quorum e deliberação da assembléia geral baseado no número de associados e não no capital, entre outras.

A Lei $n^{\circ} 4.504$, de 30 de novembro de 1964, que dispõe sobre o Estatuto da Terra, já incentivava a eletrificação rural por meio de cooperativas. Os projetos de eletrificação teriam prioridade nos financiamentos e poderiam receber auxílio do Governo Federal, Estadual e Municipal.

Para Pelegrini (2003, p. 17), a eletrificação rural nos Estados Unidos da América foi implementada pelas cooperativas, uma vez que não houve interesse das distribuidoras locais em explorar um mercado caracterizado como pouco rentável:

A saída encontrada foi, através de um órgão federal, a REA (Rural Electrification Administration), incentivar a formação de cooperativas que construíssem, operassem e mantivessem o sistema de distribuição de energia elétrica para grupos de agricultores interessados.

Em 1953, a REA havia emprestado aproximadamente US\$ 3 bilhões para mais de mil organizações rurais servindo a quase 4 milhões de propriedades rurais. $\mathrm{O}$ índice de eletrificação rural americano era de $97 \%$ em 1960, segundo documento Rural Eletrictification - United Nations, New York (ÁLVARES, 1978).

De acordo com Pelegrini (2003), o surgimento das cooperativas no Brasil é fruto das experiências bem sucedidas americanas e européias. Segundo Ribeiro (1993 apud PELEGRINI, 2003), as comunidades de imigrantes europeus, no Sul do Brasil, tentaram organizar as primeiras cooperativas de eletrificação rural na década de 20 do século passado.

Conforme discutido anteriormente, era responsabilidade das distribuidoras o fornecimento de energia apenas a uma região com concentração de população, configurada em plantas organizadas de comum acordo com as Prefeituras. O Decreto n $41.019 / 57$ estabelece no artigo 145 os incentivos econômicos aos agentes que executassem a eletrificação rural.

Decreto 41.019, de 26 de fevereiro de 1957

Art 145. Para fomento da eletrificação rural, o Poder Público competente poderá estabelecer facilidades para a construção de linhas necessárias mediante subvenções, financiamentos, isenções de tributos e outras vantagens. 
O Decreto $\mathrm{n}^{\circ} 1.033$, de 22 de maio de 1962, permitiu que as cooperativas de âmbito rural requeressem o reconhecimento como permissionárias e concessionárias de "uso exclusivo de energia elétrica". Criou, então, a cooperativa rural como classe de consumidor, para o efeito de aplicação das tarifas.

Segundo Souto e Loureiro (1999), a partir dessa regulamentação a eletrificação rural passou a ser realizada sob a ótica de serviço público, quando prestada pelas distribuidoras, e de "uso exclusivo", quando realizada pelo consumidor ou cooperativa, em seu próprio interesse.

No entanto, o Decreto $\mathrm{n}^{\circ}$ 62.655, de 3 de maio de 1968, revogou o regulamento anteriormente citado, definindo eletrificação rural como sendo a execução de serviços de transmissão e distribuição destinada a consumidores localizados fora dos perímetros urbanos e suburbanos das sedes municipais e dos aglomerados populacionais com mais de 2.500 habitantes, com carga ligada de até $45 \mathrm{kVA}$.

Essa determinação também estabeleceu a obrigatoriedade de permissão federal para a execução de obras de transmissão e distribuição de energia elétrica destinada para o uso privativo de consumidores rurais, não conferindo, no entanto, delegação do Poder Público ${ }^{18}$.

Segundo o regulamento, para se obter a autorização do Governo Federal deveria constar no requerimento da cooperativa, dentre outros requisitos, a concordância da distribuidora local em realizar o suprimento de energia elétrica e uma declaração de responsabilidade técnica pela manutenção e operação do sistema elétrico pela distribuidora local, caso a cooperativa não tivesse condições técnicas. Exigiam-se também as fichas cadastrais de cada um dos consumidores rurais a serem beneficiados, além de projetos e plantas, para comprovar que o atendimento seria restrito aos cooperados.

\footnotetext{
${ }^{18}$ Segundo Álvares (1978, p. 158), o Decreto $\mathrm{n}^{\circ} 62.655 / 68$ cometeria um deslize técnico quando utiliza o termo serviços de eletrificação rural para uso privativo: "[...] se é para privativo a noção de serviço público está necessariamente ausente, e substituída pela adequada figura da autorização ou permissão".
} 
Na concepção de Pelegrini (2003), o regulamento restringia a atuação das cooperativas aos consumidores rurais, não permitindo o estabelecimento da abrangência de serviço público, o que limitava a expansão e exigia a comunicação prévia de cada nova ligação.

De acordo com Álvares (1978, p. 160) os sucessivos decretos oferecem a “[...] impressão de provisoriedade, pois, se antes era omissão, de 1962 a 1977 vagou-se demais, para tantos anos de procura de uma diretriz adequada".

O incentivo à atuação das cooperativas, segundo Pelegrini (2003), é reforçado pela criação do Fundo de Eletrificação Rural das Cooperativas (FUER) e do Grupo Executivo de Eletrificação Rural das Cooperativas (GEER), em 1970, que serão discutidos no próximo item.

No entanto, a ausência de uma política adequada para o tratamento de eletrificação rural, a falta de controle sobre as cooperativas e a omissão das concessionárias de distribuição quanto à universalização dos serviços incentivaram o crescimento das cooperativas, não só à margem das distribuidoras, mas também em paralelo, "criando uma situação de competição absolutamente incompatível" (SOUTO; LOUREIRO, 1999, p. 80). Algumas cooperativas atendiam um público indistinto, cooperados que não constavam no ato de permissão e consumidores não cooperados, atuando fora da zona rural, segundo estes autores.

Para normalizar essa situação, a Lei $n^{\circ}$ 9.074/95 estabeleceu a regulamentação dos serviços prestados pelas cooperativas, visando adequá-las ao ambiente do setor elétrico em implementação a partir da década de 90.

A Resolução n ${ }^{\circ}$ 54, de 7 de abril de 1999, da Aneel, considerando a necessidade de prevenir a ocorrência de conflitos no atendimento do mercado e de resguardar a segurança de pessoas e bens, determinou que nas áreas onde coincidissem serviços e instalações de energia elétrica, de concessionária e cooperativa de eletrificação rural, a sua expansão ficaria condicionada ao estabelecimento de prévio acordo formal, entre os dois agentes. Enquanto não fosse estabelecido o acordo referido nesse 
regulamento, a expansão dos respectivos serviços e instalações ficaria condicionada ao consentimento prévio da Aneel.

Em 1999 iniciou-se um processo de regularização das cooperativas de eletrificação rural. O arcabouço legal previa a possibilidade de duas formas de regulamentação: uma como permissionária de serviço público de distribuição de energia atendendo a público indistinto, e outra como autorizada, para uso privativo de seus associados, classificada como consumidor de energia elétrica (ANEEL, 2004b).

Dessa forma, a Resolução no 333 , de 2 de dezembro de 1999, estabelecia um prazo de até noventa dias ${ }^{19}$, a ser contado a partir da publicação do regulamento, para as cooperativas que, em 7 de julho de 1995 exploravam serviços e instalações de energia elétrica, em situação de fato ou com base em autorização ou permissão anteriormente outorgadas, solicitassem a instauração de processo administrativo, para fins de regularização.

Essa regulamentação foi revogada pela Resolução $n^{\circ}$ 12, de 11 de janeiro de 2002, pois, de acordo com Pelegrini e Fugimoto (2003), a regulamentação anterior possibilitava a autorização na área urbana. Assim, o novo normativo trata somente do processo de regularização de cooperativas de eletrificação rural, remetendo-se para outra ocasião a regulamentação dos instrumentos da permissão e autorização; estabeleceu novo prazo para a solicitação de instauração de processo administrativo e a necessidade de compatibilização das áreas concedidas às empresas distribuidoras com as de atuação de cooperativas de eletrificação rural, visando a racionalização de atuação e redução de custos para o consumidor, bem como o delineamento claro de obrigações do serviço a ser prestado.

Segundo dados da Aneel, em 2002 cerca de 490 mil associados eram atendidos por 116 cooperativas, das quais 44 se concentravam na Região Sul do Brasil, conforme demonstrado a seguir.

${ }^{19}$ A Resolução $\mathrm{n}^{\circ} 57$, de $1^{\circ}$ de março de 2000, prorrogou, até 7 de abril de 2000, o prazo estabelecido pela Resolução n $333 / 99$. 
Tabela 1 - Consumidores atendidos por cooperativas de eletrificação rural

\begin{tabular}{|c|c|c|c|c|}
\hline \multirow[t]{2}{*}{ Estados } & \multirow{2}{*}{ Cooperativas } & \multicolumn{3}{|c|}{ Número de consumidores } \\
\hline & & Rural & Urbano & Total \\
\hline Rondônia & 1 & $(*)$ & $(*)$ & $(*)$ \\
\hline Pará & 1 & 4.062 & - & 4.062 \\
\hline NORTE & 2 & 4.062 & - & 4.062 \\
\hline Piauí & 1 & 2.653 & - & 2.653 \\
\hline Ceará & 1 & 11.473 & - & 11.473 \\
\hline Rio Grande do Norte & 7 & 28.719 & 83 & 28.802 \\
\hline Paraíba & 7 & 6.509 & 2 & 6.511 \\
\hline Pernambuco & 11 & 50.055 & - & 50.055 \\
\hline Sergipe & 1 & 3.126 & - & 3.126 \\
\hline NORDESTE & 28 & 102.535 & 85 & 102.620 \\
\hline Minas Gerais & 4 & $(*)$ & $(*)$ & $(*)$ \\
\hline Rio de Janeiro & 5 & 13.105 & 11.102 & 24.207 \\
\hline São Paulo & 17 & 35.353 & 6.125 & 41.478 \\
\hline SUDESTE & 26 & 48.458 & 17.227 & 65.685 \\
\hline Paraná & 7 & 7.817 & 350 & 8.167 \\
\hline Santa Catarina & 21 & 55.209 & 59.122 & 114.331 \\
\hline Rio Grande do Sul & 16 & 139.999 & 39.640 & 179.639 \\
\hline SUL & 44 & 203.025 & 99.112 & 302.137 \\
\hline Mato Grosso do Sul & 4 & 4.533 & - & 4.533 \\
\hline Mato Grosso & 1 & 823 & - & 823 \\
\hline Goiás & 11 & 10.174 & - & 10.174 \\
\hline CENTRO-OESTE & 16 & 15.530 & - & 15.530 \\
\hline BRASIL & 116 & 373.610 & 116.424 & 490.034 \\
\hline
\end{tabular}

(*) Não fornecido

Fonte: Comitê de Revitalização (2002).

\subsubsection{Programas de Eletrificação Rural}

Segundo Tendrih (1990, apud PELEGRINI, 2003, p. 19), "as primeiras iniciativas de discussão para solucionar o problema da eletrificação rural no País aconteceram na segunda metade da década de 50”. Em 1959 surgiu no Estado de São Paulo o Serviço Especial de Eletrificação Rural (SEER) e em 1962 a Eletrificação Rural de Minas Gerais (Ermig), subsidiária da Cemig. Ambas as iniciativas se inspiraram no modelo 
norte-americano, com preocupações de redução de custos e organização dos consumidores em forma de cooperativas (RIBEIRO, 1993 apud PELEGRINI, 2003).

O Decreto $\mathrm{n}^{\circ}$ 67.052, de 13 de agosto de 1970, criou o Grupo Executivo de Eletrificação Rural (GEER), órgão subordinado ao Ministério da Agricultura, e instituiu o Fundo de Eletrificação Rural (FUER), objetivando gerir e movimentar os recursos destinados às cooperativas e aqueles oriundos do Banco Interamericano de Desenvolvimento (BID).

Esse regulamento originou o I Programa Nacional de Eletrificação Rural de Cooperativas (I PNER), que incentivou o surgimento da maioria das cooperativas atuais. No período entre 1970 e 1976 esse programa atendeu a 28.056 propriedades rurais, em nove Estados da Federação, o que possibilitou a implantação de 16.446 km de redes de distribuição rural (DNAEE, 1985).

Foram investidos aproximadamente US\$ 61,6 milhões nesse programa, executado pelo Ministério da Agricultura através de concessionárias e cooperativas de eletrificação rural. De acordo com o Dnaee (1985), os percentuais de aplicação foram: 47,4\% oriundos do BID, 18,1\% dos usuários e 34,5\% do Ministério da Agricultura (OLIVEIRA, 2001).

O programa determinava que os empréstimos fossem destinados às cooperativas de eletrificação rural, de maneira direta ou indireta, por meio de repasse das concessionárias (DNAEE, 1985). Os financiamentos tinham três anos de carência, prazos de 12 anos e juros a 12\% a.a. (PAGLIARDI; GEMIGNANI; JULIANI, 2000).

Em 1976 foi criado o Departamento de Eletrificação Rural (DEER) da Eletrobrás, com o intuito de garantir o suprimento de energia elétrica no setor rural, atuando em conjunto com as concessionárias de distribuição, por meio do Programa de Eletrificação Rural. Essa iniciativa complementaria os programas de eletrificação do GEER, direcionados especificamente para as cooperativas (PAGLIARDI; GEMIGNANI; JULIANI, 2000).

No período de 1976 a 1980 foram eletrificadas 117.100 propriedades por meio da extensão de $64.500 \mathrm{~km}$ de redes de distribuição rural em 16 Estados, um território e o 
DF (DNAEE, 1985). Os recursos (52,3\% da Eletrobrás e 47,7\% das distribuidoras e usuários) totalizavam US\$ 300 milhões ${ }^{20}$. As condições de financiamento eram: prazo de 20 anos, com sete anos de carência e juros a $12 \%$ a.a., sem correção monetária (PAGLIARDI; GEMIGNANI; JULIANI, 2000).

O Decreto $\mathrm{n}^{\mathrm{o}}$ 79.897, de 30 de junho de 1977, reformulou e alterou a denominação do GEER e do FUER para Grupo Executivo de Eletrificação Rural de Cooperativas, Fundo de Eletrificação Rural de Cooperativas. No entanto foram preservadas as siglas originais, o GEER permaneceu como responsável pela execução da política de eletrificação rural do Ministério da Agricultura e o FUER caracterizava-se como fonte de recursos para financiar a extensão das redes de distribuição de energia elétrica.

O II Programa Nacional de Eletrificação Rural de Cooperativas (II PNER) foi implementado no período de 1979 a 1982 eletrificando 59.667 propriedades com a construção de $31.428 \mathrm{~km}$ de redes de distribuição rural, envolvendo investimentos da ordem de US\$ 113 milhões (PAGLIARDI, GEMIGNANI; JULIANI, 2000). De acordo com o Dnaee (1985), o programa foi implementado em 18 Estados e no DF, com 32\% dos recursos oriundos do BID e $68 \%$ do Ministério da Agricultura, Governos Estaduais e cooperados.

Em dezembro de 1983 a Eletrobrás firmou com o Banco Internacional para Reconstrução e Desenvolvimento (BIRD), denominado de Banco Mundial, um financiamento para a implantação da eletrificação rural na Copel e Cemig envolvendo investimentos da ordem de US\$ 704 milhões, sendo US\$ 223 milhões provenientes de empréstimo do BIRD. De acordo com Oliveira (2001) foram eletrificadas, no período de 1984 a 1988, 225 mil propriedades rurais graças a esses recursos.

O acordo previa o investimento de US\$ 700 mil para uma consultoria desenvolver os seguintes assuntos (DNAEE, 1985):

${ }^{20}$ Dados obtidos de Oliveira (2001). Segundo Pagliardi, Gemignani e Juliani (2000) teriam sido investidos US\$ 458 milhões. 
1. Plano Nacional de Eletrificação Rural.

- Revisão dos planos e programas existentes.

- Identificar fatores limitantes: recursos financeiros, capacidade de execução e suprimento de energia.

- Estabelecer critérios de prioridade.

- Contemplar horizonte de cinco anos e indicações para 15 anos.

2. Metodologia para avaliação econômica dos programas.

- Previsão de demanda, principalmente para os primeiros dez anos.

- Procedimentos para determinação de menor custo.

- Cálculo da taxa de retorno.

- Teste de sensibilidade.

3. Metodologia para avaliação econômica dos programas.

4. Organização da eletrificação rural.

5. Revisão de padrões técnicos.

6. Financiamento para eletrificação rural.

7. Tarifa para eletrificação rural.

Estava previsto o III PNER, com o objetivo de eletrificar 34.500 propriedades mediante a construção de $25.000 \mathrm{~km}$ de linhas, abrangendo 14 Estados e o DF, envolvendo recursos da ordem de US\$ 138 milhões (DNAEE, 1985). Porém, foram eletrificadas neste programa apenas 4.402 propriedades rurais com recursos oriundos do retorno dos I e II PNER, pois os recursos externos previstos não foram aportados (PAGLIARDI; GEMIGNANI; JULIANI, 2000).

\subsubsection{Programa Luz da Terra}

A Comissão Especial de Eletrificação Rural (CEER), instituída em 1995 pelo governo do Estado de São Paulo para avaliar a situação da eletrificação rural, 
recomendou a definição de uma estratégia estadual única, que estabelecesse um programa de ações pertinentes a todas as distribuidoras.

Segundo Ribeiro et al. (2000), a partir dessa conclusão foi instituída, em 1996, a Comissão de Eletrificação Rural do Estado de São Paulo (Ceresp), com a tarefa de coordenar a implantação de um programa de eletrificação rural com o objetivo de atender a população mais pobre e eliminar o déficit de energia elétrica existente na zona rural paulista.

Os trabalhos da Ceresp levaram à criação do Programa de Eletrificação Rural Luz da Terra, baseado em um modelo aplicado com grande sucesso no Rio Grande do Sul que recebeu recursos do Fundo de Amparo ao Trabalhador (FAT), gerenciado pelo Bndes (RIBEIRO et al., 2000).

As recomendações do Bndes foram aceitas pelo Governo Estadual na composição dessa política de eletrificação rural: projeto com viés social, voltado para a inclusão de família baixa-renda e equacionamento da cobertura ao risco bancário pelo governo de São Paulo (RIBEIRO; PELEGRINI; UDAETA, 2000). Dessa forma, de acordo com Ribeiro et al. (2000), os interessados baixa renda teriam suas ligações efetivadas sem a necessidade de aporte de recursos próprios ${ }^{21}$.

Para Pelegrini, Pazzini e Fugimoto (2001), o modelo pode ser dividido em duas componentes:

- uma financeira, na qual se busca formar as condições para a população carente ter acesso a uma linha de crédito;

- outra técnica, visando a solução para o atendimento da demanda reprimida da forma mais econômica possível.

Direcionado a famílias com renda bruta anual inferior a $\mathrm{R} \$ 7.500,00$, teria como condições de financiamento o prazo de seis anos, um ano de carência e juros de 3,5\% a.a., acrescidos da taxa de juros de longo prazo (TJLP) (PAGLIARDI; GEMIGNANI; JULIANI, 2000). 
$\mathrm{O}$ atendimento mais econômico, com a meta de $\mathrm{R} \$ 1.500,00$ por ligação (como referencial de custo do projeto), recomendava a adoção de padrões elétricos simplificados, com preferência ao sistema Monofilar com Retorno por Terra (MRT), condutor de aço zincado, poste de madeira, transformador de pequeno porte, além da construção pelo sistema de mutirão.

Segundo Ribeiro, Pelegrini e Udaeta (2000), o Governo de São Paulo assumiu compromissos nesse programa:

- constituição de fundo de equivalência do produto no âmbito do Fundo de Expansão da Agropecuária e da Pesca (FEAP);

- garantias bancárias dadas pela Nossa Caixa (Banco estadual paulista) e FEAP;

- aportar recursos para as obras de ligação das famílias de baixa renda e para a construção de linhas troncos necessárias;

- incentivar e orientar a participação das prefeituras e instituições comunitárias municipais.

O objetivo inicial previa o atendimento de $80 \%{ }^{22}$ das propriedades rurais, mas passou a visar $100 \%$ de eletrificação no Estado de São Paulo, envolvendo recursos iniciais da ordem de R\$ 225 milhões para as primeiras 150 mil ligações, das 200 mil estimadas como demanda reprimida. Desse total, o Bndes aportaria 80\%, os beneficiários $15 \%$ e o Governo do Estado 5\% (RIBEIRO; PELEGRINI; UDAETA, 2000).

A participação dos beneficiários poderia ser paga por meio de trabalho em mutirões, enquanto a parcela do Governo Estadual seria paga pelas distribuidoras, na época estatais, com a elaboração de projetos, fiscalização e aceite das obras em doação.

\footnotetext{
${ }^{21}$ Considerados baixa renda aqueles com renda familiar bruta até um salário mínimo (CESP e CPFL) ou até três salários mínimos (Eletropaulo), de acordo com Ribeiro et al. (2000).

22 A meta de elevar de $60 \%$ para $80 \%$ o índice de propriedades rurais atendidas fazia parte do Plano de Governo, segundo Ribeiro; Pelegrini; Udaeta (2000).
} 
Porém, até março de 1998, no encerramento da primeira etapa do contrato com o Bndes, somente 2.074 contratos estavam assinados dentre os 30 mil previstos na proposta inicial.

Em outubro de 1998 o programa foi retomado com uma nova metodologia de trabalho, que se fundamentava nos Serviços Municipais de Eletrificação Rural (SMER), privilegiando a participação dos órgãos locais. Essas organizações seriam responsáveis pela coordenação das ações do programa, como a sua divulgação, o cadastramento dos interessados, o assessoramento e o acompanhamento da comunidade na formalização dos processos de crédito e técnico. Em alguns municípios, a implantação do SMER possibilitou melhoria significativa no desempenho do programa (PAZZINI et al., 2000).

A Tabela 2 apresenta o desempenho do programa entre 1997 a 2003, conforme dados da Ceresp (informação pessoal) ${ }^{23}$. Nesse período foram realizadas aproximadamente 20 mil novas ligações, o que corresponde a $10 \%$ do total previsto inicialmente. $\mathrm{O}$ aporte de recursos a cargo do Bndes gira em torno de $\mathrm{R} \$ 33$ milhões, correspondendo a um financiamento médio de $\mathrm{R} \$ 1,7$ mil por consumidor.

Tabela 2 - Beneficiados pelo Programa Luz da Terra

\begin{tabular}{|c|r|r|r|r|r|r|}
\hline Fases & $\begin{array}{c}\text { Total de } \\
\text { beneficiados }\end{array}$ & $\begin{array}{c}\text { Financiados } \\
\text { pelo Bndes }\end{array}$ & $\begin{array}{c}\text { Recursos } \\
\text { próprios e de } \\
\text { empresas }\end{array}$ & Desistentes & $\begin{array}{c}\text { Total do } \\
\text { financiamento } \\
\text { (R\$) }\end{array}$ & $\begin{array}{c}\text { Valor médio } \\
\text { do } \\
\text { financiamento } \\
\text { (R\$) }\end{array}$ \\
\hline 1 & 2.255 & 2.085 & 163 & 7 & $2.384 .232,91$ & $1.143,52$ \\
\hline 2 & 4.172 & 3.916 & 85 & 171 & $6.185 .945,87$ & $1.579,66$ \\
\hline 3 & 4.517 & 4.055 & 274 & 188 & $7.442 .324,19$ & $1.835,35$ \\
\hline 4 & 6.527 & 5.901 & 309 & 317 & $10.584 .527,75$ & $1.793,68$ \\
\hline 5 & 1.968 & 1.847 & 5 & 116 & $3.480 .076,13$ & $1.884,18$ \\
\hline 6 & 1.531 & 1.447 & 1 & 83 & $2.777 .606,84$ & $1.919,56$ \\
\hline TOTAIS & $\mathbf{2 0 . 9 7 0}$ & $\mathbf{1 9 . 2 5 1}$ & $\mathbf{8 3 7}$ & $\mathbf{8 8 2}$ & $\mathbf{3 2 . 8 5 4 . 7 1 3 , 6 9}$ & $\mathbf{1 . 7 0 6 , 6 5}$ \\
\hline
\end{tabular}

Fonte: Ceresp (informação pessoal).

${ }^{23}$ CERESP. Resultados do Programa Luz da Terra. [mensagem pessoal]. Mensagem recebida por <sergiokf@uol.com.br>em 17 mai. 2004. 


\subsubsection{Prodeem}

O Programa de Desenvolvimento Energético de Estados e Municípios (Prodeem), instituído por Decreto Presidencial em 27 de Dezembro de 1994, direciona-se ao atendimento das populações rurais dispersas, não supridas de energia elétrica pela rede convencional. Para isso, esse programa utiliza-se de fontes locais renováveis e auto-sustentáveis, com o intuito de promover o desenvolvimento sócio-econômico dessas localidades.

O Prodeem desenvolveu diversos projetos. Inicialmente, estabeleceu parceria com a Petrobrás. Posteriormente, associou-se com o Centro de Pesquisas de Energia Elétrica (Cepel) e a Eletrobrás, disponibilizando equipamentos para uso comunitários, como sistemas de bombeamento de água. De acordo com o MME (2003b), no período de 1996 a 2002 foram implantadas as fases I a IV, correspondendo a aproximadamente 6.000 sistemas fotovoltaicos; nesse montante inclui uma ação de emergência, devido ao período de seca prolongado na Região Nordeste, na qual foram adquiridos 800 sistemas de bombeamento. A partir de 2002 foi implantada a fase V, com a aquisição de 3.000 sistemas. Sob o ponto de vista de Ribeiro (2004) foram investidos mais de US\$ 20 milhões na aquisição desses 9.000 sistemas.

O programa era parte integrante do Programa Avança Brasil, programa plurianual de investimentos do Governo Federal. O Decreto $n^{\circ}$ 3.746, de 6 de fevereiro de 2001, selecionou o Prodeem como alternativa estratégica, constituindo um dos 15 programas do Projeto Alvorada. Esses programas teriam acompanhamento especial pelo Ministério de Planejamento, Orçamento e Gestão (MPOG), estariam isentos de contingenciamento de orçamento e teriam o controle do fluxo de recursos financeiros para cumprimento dos resultados esperados (MME, 2003b).

No entanto, o processo de desenvolvimento do Prodeem foi marcado por vários problemas, dentre eles, muitos foram detectados internamente e outros pela auditoria operacional do TCU, que recomendou uma reestruturação completa do programa e determinou a implantação de um controle patrimonial adequado (MME, 2004a). 
De acordo com os dados apresentados pelo TCU (POPPE, 2003), as principais constatações negativas foram:

- problemas na concepção do programa e execução centralizada;

- falta de levantamento das demandas energéticas e das ofertas locais;

- falta de integração com outras ações: eletrificação rural, programas do Ministério da Educação, programas estaduais;

- não há definição sobre a responsabilidade e a forma de manutenção dos sistemas instalados.

O TCU apresentou dados de um levantamento realizado em 2001, pela Secretaria Federal de Controle Interno, a partir de uma amostra aleatória entre municípios beneficiados, conforme Tabela 4. Dos 1.029 sistemas energéticos inspecionados, somente $23,4 \%$ estavam instalados e funcionando adequadamente e $45,7 \%$ eram classificados como inexistentes. Esta informação demonstra a existência de problemas inclusive no controle patrimonial dos equipamentos, pois parte dos classificados como inexistentes podem ter sido extraviados e parte instalados, funcionando ou não, em outros locais não identificados no controle do programa (POPPE, 2003).

Tabela 3 - Prodeem - Situação dos equipamentos amostrados - 2001

\begin{tabular}{l|c|c}
\multicolumn{1}{c|}{ Situação dos equipamentos } & Quantidade & Percentual \\
\hline Instalados e funcionando & 241 & $23,4 \%$ \\
\hline Instalados e não funcionando & 135 & $13,1 \%$ \\
\hline Estocados & 138 & $13,4 \%$ \\
\hline Inexistentes & 470 & $45,7 \%$ \\
\hline Em outras condições & 45 & $4,4 \%$ \\
\hline
\end{tabular}

Fonte: Adaptado de: Poppe (2003).

\subsubsection{Programa Luz no Campo}

O Programa Nacional de Eletrificação Rural Luz no Campo foi criado pelo Decreto Presidencial, de 2 de dezembro de 1999, com o objetivo de eletrificar um milhão de propriedades rurais até 2002. 
Segundo dados oficiais, extraídos de Pertusier (2000), esse programa possuía a meta de elevar o índice de eletrificação rural do Brasil, de $33 \%$ para $55 \%$ e atingir $100 \%$ em nove Estados, conforme se exemplifica na Figura 1 abaixo.

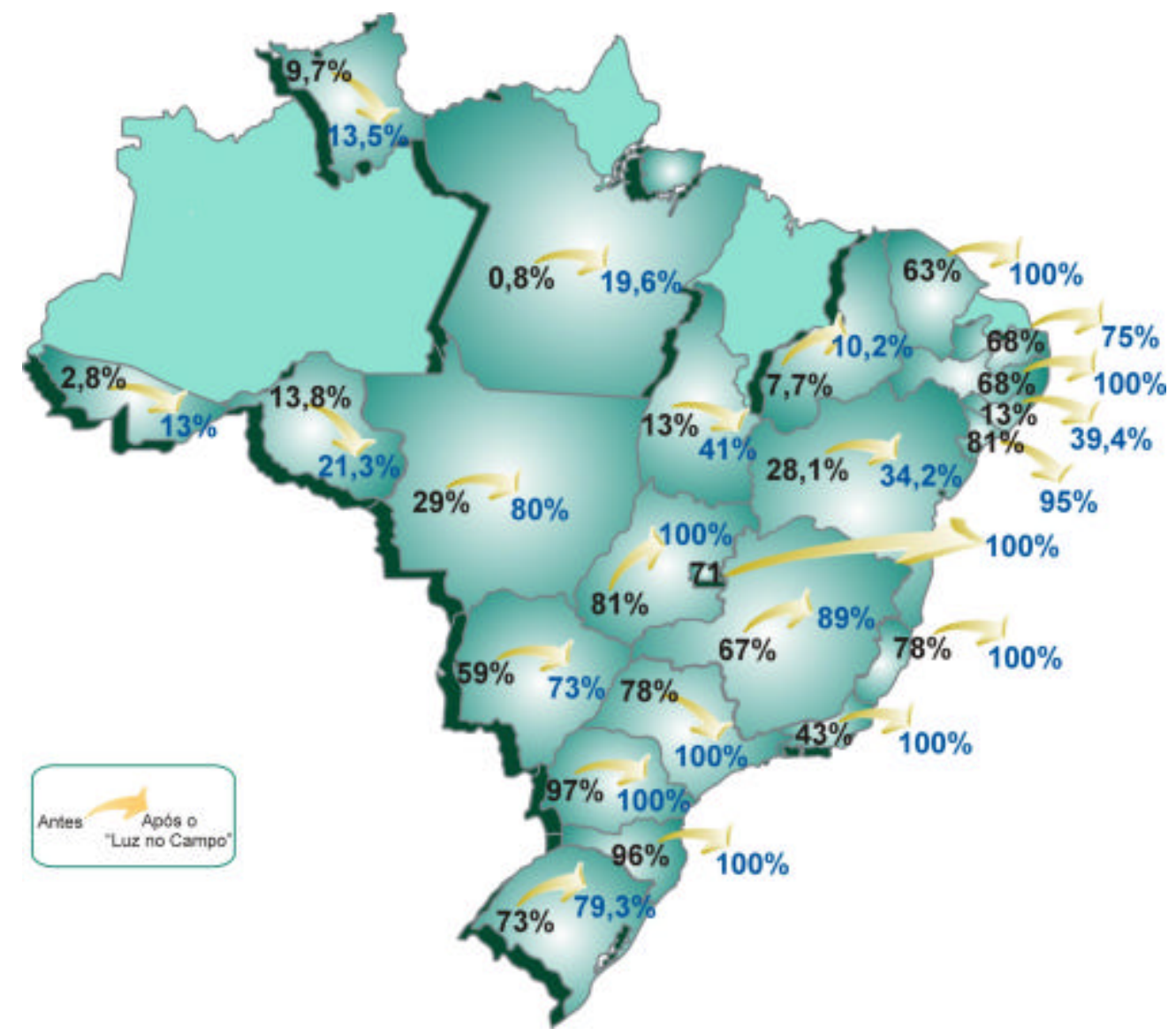

Fonte: Pertusier (2000).

\section{Figura 1 - Metas do Programa Luz no Campo}

A fonte primária de recursos era a Reserva Global de Reversão (RGR), e o financiamento realizava-se diretamente com as concessionárias de distribuição de energia elétrica. Portanto, a formatação de programas de comercialização adequados aos interessados, incluindo o percentual de repasse e a sua forma, estava sob a responsabilidade da própria distribuidora.

Os recursos cobriam o financiamento de $75 \%$ dos projetos apresentados, com custo estimado de $\mathrm{R} \$ 3.200,00$ por ligação (preço de 31 de dezembro de 1998). Podiam ser financiados os custos diretos do projeto: aquisição de material, equipamentos e prestação de serviços vinculados ao empreendimento. No entanto, não era possível a 
realização do financiamento de custos próprios da distribuidora, como os utilizados para o pagamento de mão-de-obra, transporte, administração.

O prazo de carência de pagamento era de 24 meses e a amortização deveria ocorrer em parcelas mensais durante cinco anos nas regiões Sul e Sudeste e em dez anos nas demais regiões. Em todas as regiões havia padrão na taxa de juros, correspondendo a $5 \%$ a.a. e taxa de administração de $1 \%$ ao ano.

O programa estabelecia o cumprimento dos seguintes itens para a aprovação técnica dos projetos:

- otimização dos traçados de redes e linhas, encurtando distâncias;

- utilização, em larga escala, de sistemas elétricos monofásicos, notadamente monofásicos com retorno por terra (MRT);

- escolha de materiais e equipamentos alternativos, de menor custo;

- atendimento prioritário às cargas típicas rurais;

- incentivo a participação dos interessados no fornecimento de mão-de-obra não especializada, em áreas de menor poder aquisitivo.

De acordo com os dados divulgados pela Eletrobrás (2004), até janeiro de 2004 cerca de 570 mil famílias foram beneficiadas com esse programa. Portanto, apesar de não ter atingido a meta inicial, o resultado é significativo, caracterizando-se como o maior programa de eletrificação rural executado no País, o que pode ser observado na Tabela 3 , a seguir.

Tabela 4 - Resultados do Programa Luz no Campo (jan/2004)

\begin{tabular}{|c|c|c|c|c|c|c|c|c|}
\hline \multirow[b]{2}{*}{ Estado } & \multicolumn{4}{|c|}{ Metas físicas } & \multicolumn{4}{|c|}{ Realizado } \\
\hline & $\begin{array}{l}\text { Famílias a } \\
\text { serem } \\
\text { Atendidas }\end{array}$ & $\begin{array}{l}\text { Investimento } \\
\text { Total } \\
\text { (R\$ milhões) }\end{array}$ & $\begin{array}{c}\text { Valor } \\
\text { Financiado } \\
\text { pela Eletrobrás } \\
\text { (R\$ milhões) }\end{array}$ & $\begin{array}{l}\text { km de } \\
\text { rede a } \\
\text { instalar }\end{array}$ & $\begin{array}{c}\text { Famílias } \\
\text { Atendidas }\end{array}$ & $\begin{array}{l}\text { \% Famílias } \\
\text { Atendidas }\end{array}$ & $\begin{array}{c}\mathbf{k m} \text { de } \\
\text { rede } \\
\text { instalada }\end{array}$ & $\begin{array}{c}\% \text { rede } \\
\text { instalada }\end{array}$ \\
\hline Norte & 93.282 & 390,2 & 206,4 & 63.593 & 49.957 & $53,6 \%$ & 24.790 & $39,0 \%$ \\
\hline Nordeste & 404.643 & 801,2 & 599,8 & 93.941 & 263.328 & $65,1 \%$ & 38.823 & $41,3 \%$ \\
\hline Sudeste & 179.595 & 513,3 & 314,1 & 68.698 & 153.337 & $85,4 \%$ & 40.252 & $58,6 \%$ \\
\hline Sul & 82.413 & 310,7 & 208,8 & 30.318 & 41.379 & $50,2 \%$ & 11.617 & $38,3 \%$ \\
\hline Centro-Oeste & 76.872 & 376,7 & 263,5 & 45.140 & 62.828 & $81,7 \%$ & 27.042 & $59,9 \%$ \\
\hline BRASIL & 836.805 & $2.392,1$ & $1.592,6$ & 301.691 & 570.829 & $68,2 \%$ & 142.523 & $47,2 \%$ \\
\hline
\end{tabular}

Fonte: Adaptado de: Eletrobrás (2004). 


\subsection{RESPONSABILIDADE PELA EXPANSÃO DO SERVIÇO DE ENERGIA ELÉTRICA E REESTRUTURAÇÃO DO SETOR DA DÉCADA DE 90}

Pode-se afirmar que a reestruturação do setor elétrico não tratou adequadamente a responsabilidade pela expansão do serviço de energia elétrica, nem definiu os critérios para a classificação dos consumidores baixa renda no marco legal. Isso pode ser evidenciado pela análise das obrigações contidas no contrato de concessão, no caso da universalização do acesso, e pelas alterações de critérios para classificar os consumidores baixa renda efetuadas em algumas empresas.

\subsubsection{Responsabilidade pela expansão do serviço na reestruturação do setor}

No processo de reestruturação do setor elétrico brasileiro, a discussão sobre a responsabilidade pela expansão da eletrificação rural ou, em última análise, a universalização do acesso físico, entrou tardiamente, muitas vezes como forma de compensar eventuais resistências à privatização das empresas.

O Consórcio Coopers \& Lybrand (1997a) tratou do assunto no documento redigido sobre as Cooperativas de Eletrificação Rural, em um curto capítulo. As sugestões apresentadas para a "expansão da energia no meio rural" eram:

- mobilizar concessionárias, permissionárias e outros agentes para expandir a eletrificação rural;

- reforçar sinais econômicos para incentivar as distribuidoras a investir neste mercado. Subsídios cruzados de outras classes consumidoras (via descontos no fornecimento), aporte de recursos governamentais e revisão das tarifas rurais (via elevação para refletir os custos do serviço) formariam um tripé essencial para garantir o equilíbrio econômico dos agentes responsáveis;

- considerar outros meios que não extensão de rede para garantir o acesso;

- criar obrigações de serviço para as concessionárias e permissionárias, e assegurar que, com incentivos e metas acordadas, os agentes tivessem 
estímulos para a expansão da eletrificação rural. Em alguns casos, poderia até ser necessário relicitar áreas mal atendidas;

- alavancar a gama de recursos disponíveis, por meio da busca de várias fontes de financiamento.

Estas recomendações não garantem efetivamente a universalização do serviço, tampouco foram seguidas pelo Poder Concedente. Em geral, a maioria dos contratos de concessão não estabelece metas de universalização. Oliveira (2001, p. 85-86) analisa os instrumentos disponíveis para a expansão da eletrificação rural, com a pesquisa de 52 contratos assinados entre a Aneel e as distribuidoras:

Somente os contratos da CEEE - Centro Oeste e da CEEE - Norte-Nordeste, ambas operando no Rio Grande do Sul, contêm metas específicas para indicadores de universalização dos serviços. Em outros casos, há cláusulas que determinam o tratamento não-excludente a populações de baixa renda e de baixa densidade populacional, inclusive em áreas rurais. Outros contratos prevêem a realização de obras, estabelecendo que a participação da concessionária se dará dentro de limites de viabilidade econômica do projeto, sem a complementação financeira do governo, que tem interesse no resultado social do projeto. Algumas concessionárias têm o compromisso contratual de participar de programas federais ou estaduais de eletrificação rural. $\mathrm{O}$ caso da CERJ é o mais grave de todos: o instrumento contratual não faz nenhuma menção à obrigatoriedade de atendimento de consumidores de baixa renda e de áreas rurais ${ }^{24}$.

Com base nesse estudo observa-se que não houve a padronização dos contratos de concessão e nem se buscou o seu aperfeiçoamento ao longo do tempo. Dessa forma, a eletrificação rural não foi adequadamente contemplada naquele momento de reestruturação do setor elétrico no qual poderiam ter sido criadas metas e incentivos para a expansão do serviço de energia elétrica. Oliveira (2001, p. 86-87), conclui que:

A escassez de metas específicas torna praticamente voluntária a adesão efetiva da concessionária ao esforço de universalização. De forma geral, pode-se dizer que todos os contratos são bastante negligentes, sendo que, no caso da CERJ, a questão rural foi completamente omitida. [...] Esta negligencia provavelmente esteve associada a uma sensibilização reprimida, no âmbito da reforma, em relação à necessidade de expandir o atendimento rural, em função da lógica subjacente às privatizações brasileiras, cujo objetivo foi a maximização das receitas de venda de ativos. Dessa forma, na via expressa das privatizações, a alternativa contratual foi desperdiçada, não tendo sido firmada a necessidade de engajamento efetivo do agente privado no esforço de universalização do atendimento rural.

${ }^{24}$ As concessionárias de distribuição CEEE - Centro Oeste e CEEE - Norte-Nordeste são as atuais AES Sul e RGE, respectivamente. A distribuidora CERJ alterou sua razão social para Ampla. 


\subsubsection{Proposta de regulamentação da Aneel em 2000}

Após o processo de privatização, quando se percebeu a necessidade de se resolver o problema da responsabilidade pela expansão do serviço, a Aneel tinha poucos instrumentos legais para esse fim. Por isso, tornou-se necessário um estudo jurídico, como estratégia para se encontrar mecanismos que pudessem implementar efetivamente o processo de universalização.

Segundo Correia, Valente e Pereira (2002), com base em estudos da Universidade Salvador (Unifacs), feitos para a Aneel, a participação financeira do consumidor seria ilegal, pois o artigo 14, inciso I, da Lei $\mathrm{n}^{\circ}$ 9.427/96, estabelece que:

o regime econômico e financeiro da concessão de serviço público de energia elétrica, conforme estabelecido no respectivo contrato, compreende a contraprestação pela execução do serviço paga pelo consumidor final com tarifas baseadas no serviço pelo preço, nos termos da Lei $\mathrm{n}^{\circ}$ 8.987, de 13 de fevereiro de 1995.

Dessa forma, os estudos concluíam que a construção, a ampliação e a modificação das instalações são atividades inerentes à exploração dos recursos físicos e tecnológicos, como fator de produção para prestar o serviço público, não compondo, portanto, a relação entre consumidor e concessionária. A expansão do sistema estaria configurada na relação jurídica entre o Poder Concedente (União) e a distribuidora, evidentemente garantida pelo equilíbrio econômico-financeiro dos contratos, não devendo o consumidor individualmente ter responsabilidade direta pelas obras (CORREIA; VALENTE; PEREIRA, 2002). Assim, ou a totalidade dos consumidores arcariam com as obras necessárias para o atendimento de um solicitante, por meio da tarifa, ou os contribuintes via recursos do poder público.

Em 2000, com base nesses estudos a Aneel elaborou uma minuta de resolução contemplando metas de universalização para as distribuidoras, utilizando pela primeira vez, o termo universalização como acesso físico. Em síntese, a proposta eliminava a participação financeira do consumidor em obras de extensão e reforço de rede. Nas áreas urbanas as ligações seriam realizadas sem nenhum ônus a partir da emissão da norma. Já para as áreas rurais, as distribuidoras seriam obrigadas a apresentar um "Plano de Universalização do Atendimento Rural", prevendo o atendimento de todo o mercado rural em cinco anos, à razão de $20 \%$ por ano. 
Na Audiência Pública, ocorrida em 26 de outubro de 2000, foram apresentadas 39 contribuições dos agentes setoriais, das universidades, do poder público e da sociedade civil.

Os principais questionamentos das distribuidoras referiam-se à legalidade da extinção da participação financeira por meio de resolução, pois o Decreto $\mathrm{n}^{\mathrm{o}} 41.019 / 57$ regulamentava os investimentos da concessionária, e a um possível desequilíbrio econômico-financeiro da concessão, motivado pela carga adicional de investimentos necessários à universalização. As empresas sugeriam também uma "universalização qualificada", excluindo alguns setores do plano.

Outra questão apresentada referia-se à necessidade de serem diferenciados os prazos de atendimento por região, levando em conta as disparidades regionais brasileiras. A participação da sociedade local e o envolvimento das Prefeituras Municipais na formulação e implantação dos Planos de Universalização, de modo similar ao implementado com sucesso no Programa Luz da Terra, foram recomendadas pelos pesquisadores do Grupo de Eletrificação Rural da Escola Politécnica da USP.

A Aneel, na nessa Audiência Pública, argumentou que era "essencial a compreensão quanto à mudança de conceito introduzida pelas Leis $\mathrm{n}^{\circ} 8.987 / 95$ e $\mathrm{n}^{\circ} 9.427 / 96$, de tarifa baseada em custo contábil por tarifa pelo preço". Afonso Henriques Moreira Santos, diretor da agência, expôs que:

[...] considerava haver uma mistura conceitual quanto às contas especiais. Um concessionário dizer que não há remuneração do capital que está nessa conta, é condizente com o modelo antigo quanto ao custo contábil. À luz do regime de tarifa pelo preço, isso não fazia sentido. Adicionalmente lembrou que o programa Luz no Campo possui a mesma função de um fundo de universalização de serviço de eletricidade, conforme pleiteado pelos concessionários (ANEEL, 2000b).

Em paralelo à regulamentação proposta pela Aneel, estava em debates na Câmara dos Deputados um substitutivo ao Projeto de Lei $n^{\circ}$ 2.905/00 do Governo Federal. Nessa proposta foi incluído um artigo prevendo que a Aneel fixaria áreas crescentes, em torno das redes de distribuição existentes, nas quais a ligação seria realizada sem ônus ao consumidor. Outra inovação do projeto era a autorização para a licitação de permissões em áreas já concedidas onde a concessionária não atendesse o mercado. 
Porém, o processo de regulamentação da universalização foi postergado pelo racionamento de energia elétrica, que em 2001 tomou as atenções do regulador e do Governo. Na Câmara de Gestão da Crise de Energia Elétrica (GCE), formada então, a universalização passou a fazer parte dos estudos do processo de revitalização do setor elétrico. A GCE apresentou, no Relatório de Progresso nº 2, do Comitê de Revitalização, as seguintes propostas para o problema (GCE, 2002):

- suprimir a participação financeira apenas para cargas até $15 \mathrm{kVA}$;

- consumidores acima desse limite poderiam ser financiados, com direito à restituição dos valores pagos, de acordo com o Plano de Universalização de cada concessionária, a ser apresentado à Aneel.

A discussão não avançou, pois, em 29 de abril de 2002, foi publicada a Lei $\mathrm{n}^{\text {o }}$ 10.438/2002 que, derivada da Medida Provisória $n^{\circ} 14 / 2001^{25}$, incorporou pontos do Projeto de Lei $n^{\circ}$ 2.905/2000 estabelecendo novas diretrizes para universalização, que serão discutidas no Capítulo 6.

\subsection{ANÁLISE DOS ANTECEDENTES DA UNIVERSALIZAÇÃO DO ACESSO}

\subsubsection{Análise da participação financeira}

Segundo o Decreto $\mathrm{n}^{\circ} 41.019 / 57$, inicialmente a responsabilidade pela expansão da rede de distribuição de energia elétrica era da concessionária no interior das áreas acordadas com o Poder Público. Externamente a essas regiões, a distribuidora investiria até o teto de três vezes a receita anual estimada da nova ligação.

O Decreto $n^{\circ} 83.269 / 79$ alterou essa sistemática. A partir de então, a concessionária de distribuição passou a ser responsável pelo atendimento em qualquer região da concessão até um determinado limite de investimento, calculado de acordo com normas do Dnaee.

\footnotetext{
25 A Medida Provisória n ${ }^{\circ}$ 14/2001 tratava do acordo do setor elétrico para equacionar as perdas
} decorrentes do racionamento. 
O limite para o investimento consistia em vincular a expansão da empresa a um valor que não provocasse impacto tarifário significativo para os demais consumidores: "garantir que os investimentos não acarretem acréscimo ao custo total de serviço superior ao acréscimo à receita”.

A Portaria $n^{\circ} 57 / 79$, do Dnaee, estabeleceu como limite para os investimentos no atendimento de um consumidor residencial o valor que corresponderia atualmente a $\mathrm{R} \$ 957,51^{26}$. Regulamentações posteriores do órgão vincularam o limite de investimentos à tarifa fiscal para facilitar a correção da parcela de responsabilidade da empresa.

Porém, a última atualização da tarifa fiscal foi realizada pela Portaria $n^{\circ} 2$, de 4 de janeiro de 1996, permanecendo então constante no valor de $\mathrm{R} \$ 64,48$. Ao longo do tempo, e com o congelamento da tarifa fiscal, o valor do limite de investimento obrigatório da distribuidora para atendimento da expansão se reduziu, aumentando, conseqüentemente, a participação financeira do consumidor.

A definição da tarifa fiscal, dada pela Lei $\mathrm{n}^{\circ}$ 4.156, de 28 de novembro de 1962, é "quociente do valor em cruzeiros da energia vendida a medidor no País, em determinado mês, pelo correspondente volume físico (número de quilowatts-hora) de energia consumida durante o mês", ou seja, uma tarifa média de fornecimento. Dessa maneira, o valor deveria corresponder a $\mathrm{R} \$ 194,75$, pois esta é a tarifa média de fornecimento do Brasil em outubro de 2004, de acordo com os dados da Aneel, próximo do valor da tarifa fiscal de $\mathrm{R}$ \$172,30 corrigida pela variação do IGP-M até dezembro de 2004, conforme já apresentado anteriormente.

Assim, os limites de investimento da distribuidora para o atendimento de um consumidor residencial previstos na Portaria Dnaee $n^{\circ}$ 5/90 (quatro vezes a tarifa fiscal) corresponderia à cerca de $\mathrm{R} \$ 779,00$ ou $\mathrm{R} \$ 689,20$, atualizando a tarifa fiscal pela tarifa média de fornecimento ou pelo IGP-M, respectivamente.

Adicionalmente, é possível comparar os valores definidos nas primeiras regulamentações do Dnaee, conforme exemplifica a Tabela 5, que atualiza os

\footnotetext{
${ }^{26}$ Valor atualizado pela variação do IGP-DI até dezembro de 2004.
} 
diferentes limites de investimento ao longo do tempo (Portarias $n^{\circ}$ 57/79, $n^{\circ}$ 93/81 e $n^{\circ}$ 5/90). A título de comparação, essa tabela também expõe os limites da última regulamentação (Portaria $n^{\circ}$ 5/90) considerando a atualização da tarifa fiscal pelo IGP-M e os valores nominais com a tarifa fiscal "congelada".

Tabela 5 - Limites de investimento da concessionária - atualizados (dez/2004)

\begin{tabular}{|c|c|c|c|c|}
\hline \multirow[b]{2}{*}{$\begin{array}{l}\text { Limite de Investimento } \\
\text { da Concessionária }\end{array}$} & \multicolumn{4}{|c|}{ Grupo Tarifário } \\
\hline & $\mathrm{A} 4(\mathrm{R} \$ / \mathrm{kW})$ & $\begin{array}{c}\text { B1 - Residencial } \\
\text { (R\$ por } \\
\text { consumidor) }\end{array}$ & $\begin{array}{c}\text { B2 - Rural (por } \\
\text { consumidor até } \\
200 \mathrm{kWh)}\end{array}$ & $\begin{array}{c}\text { B3 - } \\
\text { Comercial/Industrial } \\
\text { (por consumidor até } \\
600 \mathbf{k W h} \text { ) } \\
\end{array}$ \\
\hline $\begin{array}{c}\text { Portaria Dnaee no } 57 \\
\text { de } 15 / 05 / 79^{1}\end{array}$ & 957,51 & 957,51 & 957,51 & $2.872,53$ \\
\hline $\begin{array}{c}\text { Portaria Dnaee } n^{0} 93 \\
\text { de } 13 / 11 / 81^{2}\end{array}$ & 204,68 & $1.205,40$ & $1.205,40$ & $2.009,00$ \\
\hline $\begin{array}{c}\text { Portaria Dnaee n } \\
\text { de } 11 / 01 / 90^{3}\end{array}$ & 205,05 & 820,20 & 820,20 & $2.460,60$ \\
\hline $\begin{array}{c}\text { Portaria Dnaee } n^{0} 5 \\
\text { atualização tarifa fiscal }\end{array}$ & 172,30 & 689,20 & 689,20 & $2.067,60$ \\
\hline $\begin{array}{c}\text { Portaria Dnaee no } 5 \\
\text { tarifa fiscal "congelada" } \\
\text { ÚLTIMA } \\
\text { REGULAMENTAÇÃo }\end{array}$ & 64,48 & 257,92 & 257,92 & 773,76 \\
\hline
\end{tabular}

1. Correção pelo IGP-DI até dez/2004.

2. Vigente a partir de jan/1982; correção pelo IGP-DI até dez/2004.

3. Vigente a partir de fev/1990; correção pelo IGP-M até dez/2004.

4. Tarifa fiscal de jan/96, atualizada pelo IGP-M até dez/2004.

Fonte: Elaborado pelo autor.

Conforme se depreende dos dados apresentados, o limite de investimento da distribuidora para o atendimento ao consumidor residencial, vigente até a edição da Resolução $n^{\circ}$ 223/2003, era aproximadamente $31 \%$ do valor de janeiro de 1982 , atualizado pela variação do IGP-DI, e 37\% do valor de fevereiro de 1990, atualizando-se a tarifa fiscal.

Até a publicação da Resolução ${ }^{\circ}$ 223/2003, se o valor das obras necessárias para o atendimento de um consumidor residencial ultrapassasse $\mathrm{R} \$ 257,92$, a diferença entre esse valor e o limite de investimento da distribuidora seria arcada pelo próprio solicitante, o que constituía uma barreira econômica crescente para o acesso aos serviços de energia elétrica, caracterizado como um direito universal. De acordo com 
a Associação Brasileira dos Distribuidores de Energia Elétrica (ABRADEE, 2002), o custo médio de uma ligação na área urbana era de aproximadamente $\mathrm{R} \$ 1.500,00$. Mas, caso um pedido fosse feito separadamente ${ }^{27}$, o consumidor residencial arcaria com a diferença, que em média era de $\mathrm{R} \$ 1.242,08$. Isso também se aplicava ao consumidor rural que pagaria, o custeio de $\mathrm{R} \$ 2.742,08$, considerando um custo médio por ligação na área rural de $\mathrm{R} \$ 3.000,00$, divulgado pela Abradee (2002).

Ao longo do período apresentado há evidências de que o acréscimo da participação financeira do consumidor contribuiu para as crescentes dificuldades de acesso à energia elétrica no Brasil.

\subsubsection{Resultados dos Programas de Eletrificação Rural}

As cooperativas de eletrificação rural passaram a ocupar espaço das concessionárias de distribuição, pois até 1979 a legislação contemplava somente a área delimitada em conjunto com o Poder Público. Ao mesmo tempo em que outro regulamento de 1968 definia eletrificação rural como o atendimento prestado a consumidores localizados em áreas fora dos perímetros urbanos e suburbanos das sedes municipais e dos aglomerados populacionais que possuíssem mais de 2.500 habitantes.

O interesse pela expansão da energia elétrica na área rural era do Ministério de Agricultura. Desde a Lei no 4.504/64, com o Estatuto da Terra, já havia o incentivo à eletrificação rural por meio de cooperativas. Segundo a norma legal, os projetos de eletrificação rural, feitos pelas cooperativas rurais, teriam prioridade nos financiamentos e poderiam receber auxílio do Governo Federal, Estadual e Municipal.

Os diversos programas de eletrificação implementados impulsionaram a ligação de mais de 1 milhão de propriedades, destacando-se o êxito do Programa Luz no Campo, que atingiu mais da metade desses esforços, conforme pode ser observado na Tabela 6.

\footnotetext{
${ }^{27}$ A expansão da rede de distribuição de energia que beneficia vários consumidores aumenta a participação da concessionária, pois o limite de investimento da distribuidora dependia diretamente do número de solicitantes para uma mesma obra.
} 
É interessante ressaltar que os PNER's eram gerenciados pelo Ministério de Agricultura e incentivavam a expansão do setor elétrico por meio das cooperativas de eletrificação rural, enquanto a Eletrobrás apoiava fortemente os programas implementados pelas concessionárias de distribuição.

Os PNER's estimularam o surgimento de grande parte das cooperativas de eletrificação rural do País. De acordo com Oliveira (2001), ao contrário do movimento cooperativista do Sul originado pelos próprios produtores rurais, no Nordeste esse surgimento foi conseqüência do processo de direcionamento dos empréstimos às cooperativas, sendo que algumas eram subsidiárias das próprias distribuidoras. Segundo dados do Dnaee (1985), 90\% dos contratos foram executados pelas distribuidoras, demonstrando que algumas cooperativas foram utilizadas como artifício para a obtenção de recursos.

Tabela 6 - Programas de Eletrificação Rural

\begin{tabular}{c|c|c|c}
\hline \multirow{2}{*}{ Programa } & Período & $\begin{array}{c}\text { Propriedades } \\
\text { eletrificadas }\end{array}$ & $\begin{array}{c}\text { Custo (US\$ } \\
\text { milhões) }\end{array}$ \\
\cline { 3 - 4 } & 1970 a 1976 & 28.056 & 61,6 \\
\hline I PNER & 1976 a 1980 & 117.100 & 300 \\
\hline ELETROBRAS & 1979 a 1982 & 59.667 & 113 \\
\hline II PNER & 1984 a 1988 & 225.000 & 704 \\
\hline CEMIG/COPEL & 1984 & 4.402 & $* 1$ \\
\hline III PNER & 1996 a 2004 & 9.000 & 20 \\
\hline PRODEEM & 1997 a 2003 & 20.088 & 11,3 \\
\hline LUZ DA TERRA $^{2}$ & 2000 a 2004 & 570.829 & 841 \\
\hline
\end{tabular}

1. Dado não disponível: foram ligadas com recursos oriundos do retorno dos I e II PNER's.

2. Dados da Tabela 2 convertido pela cotação do dólar de 31/12/2003.

3. Dados da Tabela 3 convertido pela cotação do dólar de 23/01/2004.

Fonte: Elaborado pelo autor com base em dados de Dnaee (1985), Pagliardi, Gemignani e Juliani (2000), Oliveira (2001), Poppe (2003), Ceresp (informação pessoal), Eletrobrás (2004) e Ribeiro (2003).

Apesar da publicidade feita pelos organizadores, o desenho dos programas não representou uma quebra de paradigma, pois apenas financiou parte da responsabilidade da distribuidora, mas com base na legislação referente à participação financeira, repassou parte dos custos ao consumidor. A maior parte dos 
excluídos do acesso aos serviços de energia não tinha e ainda não tem condições de arcar com esse empréstimo.

De acordo com dados da Eletrobrás apresentados por Pertusier (2000), o investimento total previsto para o Programa Luz no Campo era de R \$ 2,255 bilhões, enquanto o valor financiado com recursos da RGR correspondia a $\mathrm{R} \$ 1,525$ bilhão (aproximadamente $68 \%$ do total). O restante dos investimentos era complementado com recursos próprios das distribuidoras, dos Governos Estaduais e dos solicitantes.

O financiamento com recursos da RGR poderia ser repassado para os consumidores dependendo do limite de investimento da empresa; porém, o pagamento dos consumidores para a distribuidora não contemplava necessariamente as mesmas condições obtidas pela empresa, pois o programa não previa empréstimos diretamente para os consumidores.

No edital de privatização das empresas paulistas, exceto no da Companhia Paulista de Força e Luz (CPFL), constou a obrigatoriedade da participação nos programas de eletrificação rural e respectivas metas de ligação. As metas eram de 600, 12.500 e 22.970 consumidores rurais, no período de 1998 e 1999, para as empresas Eletropaulo, Bandeirante e Elektro, respectivamente. Como não havia obrigação contratual, a CPFL praticamente se afastou do Programa Luz da Terra (RIBEIRO; PELEGRINI; UDAETA, 2000).

Os programas de eletrificação mitigaram a situação, mas a falta de um comando legal capaz de estabelecer a responsabilidade "de fato" e a escassez de recursos necessários para a expansão da distribuição impediam a plena universalização dos serviços de energia.

Um novo ambiente institucional para a universalização do acesso à energia no País foi criado com a Lei 10.438/2002. Os programas Prodeem e Luz no Campo tornaram-se, então, instrumentos do Programa Nacional de Universalização Luz para Todos, que visa integrar e coordenar todas as ações governamentais (MME, 2003b). 
A integração dos esforços de universalização é muito importante, pois deverá diminuir problemas que ocorriam, a exemplo daquele identificado pelo TCU: implantação da rede de distribuição de energia elétrica pelo Programa Luz no Campo poucos meses após a instalação do sistema fotovoltaico individual na localidade.

\subsubsection{Análise da responsabilidade pela expansão do serviço na reestruturação do Setor Elétrico da década de 90}

A Lei $n^{\circ}$ 9.074/95 (art. $3^{\circ}$, inciso IV) determinou que o Poder Concedente observasse, para outorga e prorrogações das concessões e permissões de serviços públicos, a necessidade de "[...] atendimento abrangente ao mercado, sem exclusão das populações de baixa renda e das áreas de baixa densidade populacional inclusive as rurais".

Da mesma maneira, no conjunto de diretrizes da Aneel, está prevista a “[...] adoção de medidas efetivas que assegurem a oferta de energia elétrica a áreas de renda e densidade de carga baixas, urbanas e rurais [...]" (art. $3^{\circ}$, inciso IV, do Anexo I do Decreto $\mathrm{n}^{\circ} 2.335$, de 6 de outubro de 1997).

Apesar da determinação legal, em alguns contratos de concessão de serviço público de energia elétrica, a exemplo daqueles redigidos para a Light e para a Ampla, não contemplam a cláusula de atendimento abrangente ao mercado. Em outros contratos, a obrigatoriedade está condicionada aos regulamentos do Poder Concedente e da Aneel.

\section{Contrato de Concessão no $162 / 98$}

\section{CLÁUSULA QUINTA - ENCARGOS DA CONCESSIONÁRIA}

Além de outras obrigações decorrentes da Lei e das normas regulamentares específicas, constituem encargos da CONCESSIONÁRIA inerentes à prestação dos serviços públicos concedidos:

[...]

II - dar atendimento abrangente ao mercado, sem exclusão das populações de baixa renda e das áreas de baixa densidade populacional, inclusive as rurais, atendidas as normas do PODER CONCEDENTE e da Aneel;

[...]. (grifo nosso). 
Os contratos de concessão das empresas AES - Sul e RGE, ambas situadas no Rio Grande do Sul, incluíam indicadores de universalização dos serviços que demonstrariam o nível de atendimento na área urbana e rural (OLIVEIRA, 2001).

Porém, tais indicadores, semelhantes aos estabelecidos na Resolução no 223/2003, não foram coletados ou acompanhados pelo regulador, conforme se evidenciou em consulta feita à AGERGS ${ }^{28}$ (informação pessoal).

Segundo Correia, Valente e Pereira (2002), as normas legais que reestruturaram o setor elétrico na década de 90 imputaram às distribuidoras a responsabilidade integral pelas obras necessárias para o atendimento dos consumidores, tornando ilegal a cobrança da participação financeira do consumidor.

O regime econômico-financeiro da concessão compreenderia, na avaliação dos autores, a contraprestação pela execução do serviço paga pelo consumidor final somente com tarifas baseadas no serviço pelo preço; apesar da Lei no 9.427/95 (art. 14, inciso III) também abranger a "[...] participação do consumidor no capital da concessionária, mediante contribuição financeira para execução de obras de interesse mútuo, conforme definido em regulamento".

Contudo, segundo o estudo realizado pela Unifacs, esta última determinação legal indicaria que o investimento do consumidor deveria ser ressarcido em participação no capital da concessionária, evidenciando que o legislador quis eliminar o procedimento corrente no setor, no qual o consumidor contribuía a fundo perdido para investimentos que deveriam correr por conta e risco da concessionária (CORREIA; VALENTE; PEREIRA, 2002).

O consórcio Coopers \& Lybrand, no relatório do Projeto de Reestruturação do Setor Elétrico Brasileiro, sugeriu a criação de obrigações de serviço para as distribuidoras e assegurar que, com incentivos e metas acordadas, os agentes teriam estímulos para a expansão da eletrificação rural. Em alguns casos, segundo o estudo, poderia até ser necessário relicitar áreas mal atendidas (COOPERS \& LYBRAND, 1997a).

\footnotetext{
${ }^{28}$ AGERGS. Fiscalização dos indicadores de universalização. [mensagem pessoal]. Mensagem recebida por<sfugimoto@ibest.com.br>em 28 out. 2003.
} 
A consultoria também analisou os encargos, que naquela época baseavam-se no conceito de conexão "profunda", a partir da qual os consumidores contribuem de acordo com o custo dos reforços ao sistema principal para acomodar a nova conexão.

O primeiro usuário de uma nova linha era o único a pagar as contribuições e, em teoria, as distribuidoras deveriam construir a linha apenas para fornecer a capacidade necessária para este usuário. No entanto, de acordo com informações apresentadas no citado relatório, a prática demonstrava o contrário, uma vez que a linha era normalmente dimensionada para atrair outros usuários.

O consórcio Coopers \& Lybrand recomendou a distinção entre os encargos de conexão e os encargos para uso do sistema de distribuição. Com base na conexão "rasa", um consumidor pagaria apenas pelo equipamento imediatamente necessário para a conexão, e não pelo conseqüente reforço ao sistema principal, que seria recuperado pelos encargos de Uso do Sistema de Distribuição, pagos por todos os usuários.

Preferimos incluir todos os custos de reforço ao sistema principal nos encargos do USD, a serem pagos por todos os usuários no nível de tensão correspondente ou abaixo, a fim de evitar tais distorções. Reconhecemos que sem dúvida haverá ocasiões em que um único usuário novo será imediatamente responsável pelo reforço ao sistema principal. No entanto, mesmo nestes casos, propomos os encargos de conexão rasa, pois entendemos que qualquer diferenciação poderia impedir o livre acesso e a consistência, neste aspecto, é importante. (COOPERS \& LYBRAND, 1997b, p. 6).

Essa visão, embora apresentada no contexto de livre acesso ao sistema de distribuição e de transmissão, pode ser estendida para o consumidor cativo da distribuidora, considerando a isonomia de tratamento.

Dessa forma, percebe-se que na reestruturação do setor elétrico, a universalização foi tratada parcialmente, sem contemplar, de forma abrangente, a obrigatoriedade da expansão e metas, apesar das recomendações indicadas pela consultoria contratada.

O contrário ocorria com a privatização do setor de telecomunicações, que abrangia a universalização como um dos seus objetivos, embora o conceito fosse diferente 
daquele visado pelo setor elétrico ${ }^{29}$. De acordo com a Lei $n^{\circ} 9.472$, de 16 de julho de 1997 (Lei Geral de Telecomunicações), a Anatel deve regular as obrigações de universalização para possibilitar o acesso de qualquer pessoa a esse serviço, independentemente de sua localização e condição sócio-econômica.

\subsubsection{Considerações}

Este capítulo demonstrou que a sistemática de limitar os investimentos da distribuidora para não onerar demasiadamente a tarifa dos demais consumidores se tornou uma barreira para o acesso à energia elétrica no Brasil.

Apesar dos programas de eletrificação rural terem atendido milhares de propriedades, os consumidores pagavam parte do valor das obras necessárias para o seu atendimento por meio de financiamento repassado pelas concessionárias. Faltava um marco legal que estabelecesse a responsabilidade da distribuidora e do Poder Concedente, bem como os recursos necessários para a expansão da distribuição, possibilitando assim o acesso aos serviços de energia para a parcela da população que não pode arcar com a participação financeira do consumidor.

As distintas interpretações da Lei nº 9.427/96, quanto à responsabilidade pelas obras necessárias para o atendimento dos consumidores, levaram, em 2000, à formulação de uma proposta de regulamentação de metas de universalização pela Aneel e o questionamento da legalidade dessa medida pelas distribuidoras. Essa discussão foi superada com a publicação da Lei $n^{\circ} 10.438 / 2002$, que estabeleceu concretamente as diretrizes para universalização do acesso e do uso.

\footnotetext{
${ }^{29}$ Universalização na área de telecomunicações corresponde a metas de acordo com o número de habitantes da localidade. Por exemplo, segundo a Anatel, todas as localidades com mais de 300 habitantes deverão estar atendidas com pelo menos um telefone público e todas com mais de 600 deverão estar atendidas com telefones individuais, em dezembro de 2003. Até dezembro de 2005, as localidades, a serem atendidas com pelo menos um telefone público e com telefones individuais, são aquelas com mais de 100 e mais de 300 habitantes, respectivamente.
} 


\section{CAPÍTULO 4 - ANTECEDENTES DA UNIVERSALIZAÇÃO DO USO}

Neste capítulo são apresentadas as discussões sobre a necessidade da criação de uma tarifa social para a energia elétrica, iniciada pelo estudo do Dnaee, desenvolvido em 1985. Posteriormente, são expostos os normativos que deram surgimento à "tarifa social", destinada aos consumidores baixa renda, bem como seus critérios de classificação.

\subsection{ESTUDO DO DNAEE - 1985}

A Portaria MME $n^{\circ}$ 817, de 28 de junho de 1985, compôs uma comissão responsável por estudar a criação de uma tarifa residencial de cunho social e suas condições de aplicação, incluindo o perfil de consumidores baixa renda a serem beneficiados. Segundo o normativo, era necessária a uniformização dos critérios e procedimentos, visando integrar à sociedade as famílias marginalizadas e carentes.

O "Plano de Trabalho da Tarifa Social" da comissão entendia que a energia elétrica era "componente imprescindível ao acesso da população a níveis de higiene e saúde, informação e cultura, segurança e lazer, próprias a sua subsistência” (DNAEE, 1986, p. 49). Nesse plano reconhecia-se a energia elétrica residencial como necessidade humana básica e, portanto como direito humano do cidadão da sociedade moderna. A esse direito do cidadão correspondia o dever do Estado, que seria assegurar a cada pessoa a possibilidade de acesso à energia elétrica, como a um serviço público qualquer. Dessa forma, o objetivo do programa de trabalho da comissão era permitir que:

- a população desprovida de serviços residenciais de energia elétrica passasse a ser atendida;

- todos os usuários atuais e potenciais de eletricidade residencial pudessem ter acesso a um consumo de energia elétrica adequado às suas necessidades básicas, a um preço compatível com seu orçamento familiar. 
De acordo com o Dnaee (1986, p. 18):

a criação de uma tarifa de cunho social, com base num consumo mínimo essencial, [...] através da identificação das reais necessidades básicas da população, parece ser o caminho mais justo para consecução dos objetivos sociais pretendidos nesse campo.

A Comissão classificou quatro níveis de utilização de equipamentos, para o cálculo do consumo mínimo essencial de referência ${ }^{30}$, com base no uso de lâmpadas, ferro de passar roupa, televisão, geladeira e chuveiro. A estimativa máxima de $105 \mathrm{kWh} / \mathrm{mês}$, conforme demonstrado na Tabela 7, poderia ser diminuída em $20 \%$ em razão dos incentivos decorrentes da implementação do Programa Nacional de Conservação de Energia Elétrica. Adicionalmente seria importante considerar as diferenças regionais de consumo bem como seu caráter dinâmico, em estudos futuros (DNAEE, 1986).

Tabela 7 - Consumo de Referência (kWh/mês)

\begin{tabular}{c|c|c|c|c|c|c|c}
\hline Nível & Ilum. & Ferro & TV & Gelad. & Chuv. & Total & $\begin{array}{c}\text { Total } \\
\text { considerando } \\
\text { Eficiência } \\
\text { Energética }\end{array}$ \\
\hline $1^{\circ}$ & 14 & 4 & & & & 16 & 15 \\
\hline $2^{\circ}$ & 14 & 4 & 18 & & & 36 & 30 \\
\hline $3^{\text {o }}$ & 14 & 4 & 18 & 37 & & 73 & 60 \\
\hline $4^{\circ}$ & 14 & 4 & 18 & 37 & 32 & 105 & 80 \\
\hline
\end{tabular}

Fonte: Dnaee (1986).

O documento concluía que a adoção de uma tarifa social deveria beneficiar a todos os consumidores residenciais, até o limite de suas necessidades básicas, calculado em $80 \mathrm{kWh} / \mathrm{mês}$. Para o Dnaee (1986), a proposta fundamentava-se no princípio de que essa necessidade básica significava um direito igual para todo cidadão, sendo inaceitável qualquer política discriminatória.

\footnotetext{
${ }^{30}$ Dados utilizados na estimativa (DNAEE, 1986). Iluminação: quatro lâmpadas $60 \mathrm{~W}$ - 50\% ligada 4h por dia; ferro elétrico: $1.000 \mathrm{~W}-4 \mathrm{~h}$ por mês; televisor: $100 \mathrm{~W}-6 \mathrm{~h}$ por dia; geladeira: $200 \mathrm{ou}$ $150 \mathrm{~W}-7 \mathrm{~h}$ por dia; chuveiro: $3.200 \mathrm{~W}-12,5 \mathrm{~h}$ por mês.
} 
Identificado o consumo mínimo essencial, a proposta da comissão era aplicar um desconto na tarifa referente a essa faixa de consumo, que atingisse, no máximo, o comprometimento de $4 \%$ do salário mínimo da época. Para compensar, esse desconto tarifário seria subsidiado com recursos da própria classe residencial.

Foram feitas simulações utilizando três patamares de consumo de referência: 80, 100 e $120 \mathrm{kWh} / \mathrm{mês}$. Esta última hipótese atenderia às necessidades básicas da Região Metropolitana de São Paulo, mas, devido ao baixo consumo médio nas demais regiões, a adoção deste nível implicaria sensível elevação da tarifa para o consumo que excedesse esse patamar. Por isso, a hipótese de $80 \mathrm{kWh} / \mathrm{mês}$ seria a mais recomendável, considerando a manutenção do nível de receita das distribuidoras. De todo modo, nas três alternativas simuladas considera-se a isenção do Imposto Único sobre Energia Elétrica (IUEE), para o primeiro bloco de consumo (80 ou 100 ou $120 \mathrm{kWh} / \mathrm{mês})^{31}$.

A proposta apresentada para uma fase transitória, em vez de um único bloco para os descontos, sugeria quatro faixas de consumo com descontos escalonados, conforme ilustrado na Tabela 8 , e a correção em $27,6 \%$ da tarifa residencial que correspondia, em janeiro de 1986, a Cr\$586,00/kWh equivalente a $\mathrm{R} \$ 0,39 / \mathrm{kWh}$, atualizado com base na variação do IGP-DI até dezembro de 2004. Nessa transição, as alíquotas do IUEE permaneceriam nos mesmos níveis praticados $^{32}$.

A proposta da tarifa residencial definitiva alterava os níveis dos primeiros blocos de consumo; aumentava a tarifa residencial em 37,4\% sobre a base de janeiro de 1986; além de alterar a aplicação do IUEE (Tabela 9).

\footnotetext{
${ }^{31}$ Imposto Único sobre Energia Elétrica (IUEE). Criado pela Lei no 2.308 , de 31 de agosto de 1954, e extinto pela Constituição Federal de 1988, incidia sobre a energia elétrica consumida de cada classe de consumidor, a saber: $50 \%$ da tarifa fiscal no caso de residencial; $60 \%$, comercial; e $2 . \%$, industrial (abaixo de $2 \mathrm{MWh} / \mathrm{mês}$ ).

32 De acordo com a Portaria $n^{\circ}$ 279, de 27 de dezembro de 1985, o IUEE correspondia a CR\$ 150.505,00/MWh para os consumidores residenciais.
} 
Tabela 8 - Tarifa Residencial Transitória Proposta

\begin{tabular}{|c|c|c|c|c|c|}
\hline $\begin{array}{c}\text { Faixa de } \\
\text { consumo } \\
(\mathrm{kWh})\end{array}$ & $\begin{array}{c}\text { Tarifa } \\
\text { (Cr } \$ / \mathbf{k W h}) \\
\text { base jan/86 }\end{array}$ & $\begin{array}{c}\text { Tarifa } \\
(\mathbf{R} \$ / \mathbf{k W h})^{*}\end{array}$ & Desconto & $\begin{array}{c}\text { IUEE } \\
(\mathrm{Cr} \$ / \mathbf{k} W h)\end{array}$ & $\begin{array}{c}\text { IUEE } \\
(\mathbf{R} \$ / \mathbf{k W h}) *\end{array}$ \\
\hline 0 a 80 & 175 & 0,12 & $77 \%$ & 150,505 & 0,10 \\
\hline 81 a 120 & 367 & 0,24 & $51 \%$ & 150,505 & 0,10 \\
\hline 121 a 200 & 545 & 0,36 & $27 \%$ & 150,505 & 0,10 \\
\hline acima de 200 & 748 & 0,52 & $0 \%$ & 150,505 & 0,10 \\
\hline
\end{tabular}

* atualizado pela variação do IGP-DI de jan/86 a dez/2004

Fonte: Dnaee (1986).

Tabela 9 - Tarifa Residencial Definitiva Proposta

\begin{tabular}{|c|c|c|c|c|c|c|}
\hline $\begin{array}{c}\text { Faixa de } \\
\text { consumo } \\
(\mathrm{kWh})\end{array}$ & $\begin{array}{c}\text { Tarifa } \\
(\mathrm{Cr} \$ / \mathbf{k} W h) \\
\text { base jan/86 }\end{array}$ & $\begin{array}{c}\text { Tarifa } \\
(\mathbf{R} \$ / \mathbf{k W h}) \\
*\end{array}$ & Desconto & $\begin{array}{c}\text { IUEE } \\
(\mathbf{C r} \$ / \mathbf{k} W h)\end{array}$ & $\begin{array}{c}\text { IUEE } \\
(\mathbf{R} \$ / \mathbf{k W h})^{*}\end{array}$ & Desconto \\
\hline 0 a 30 & 175 & 0,12 & $78 \%$ & isento & isento & $100 \%$ \\
\hline 31 a 120 & 205 & 0,14 & $75 \%$ & 60,202 & 0,04 & $60 \%$ \\
\hline 121 a 200 & 610 & 0,40 & $24 \%$ & 150,505 & 0,10 & $0 \%$ \\
\hline acima de 200 & 805 & 0,53 & $0 \%$ & $150,505 * *$ & 0,10 & $0 \%$ \\
\hline
\end{tabular}

Fonte: Dnaee (1986).

Contudo, este estudo não foi aplicado. Para Tavares (2003), isso ocorreu, possivelmente, por causa da implementação do Plano Cruzado em 1986 e dos desequilíbrios macro-econômicos dessa época.

\subsection{PROGRAMAS DESTINADOS AOS CONSUMIDORES BAIXA RENDA}

O fluxo migratório das áreas rurais para as urbanas contribui para um processo acelerado e caótico, principalmente nas grandes metrópoles. Segundo Ramalho (2001), esse crescimento desordenado impossibilita, na maioria das vezes, o fornecimento de energia elétrica a essas comunidades, que passaram a se valer de ligações clandestinas, quer seja através da ligação à rede de distribuição ou de iluminação pública.

Para mitigar essa situação as distribuidoras implementaram programas à margem da regulamentação. É importante ressaltar que os programas destinados a atender 
consumidores baixa renda apresentados a seguir abrangem além dos descontos na tarifa de energia elétrica e do faturamento por meio de uma taxa mínima, também o financiamento do padrão de entrada de energia elétrica e a assunção de parte da participação financeira do consumidor baixa renda pela distribuidora, embora estas duas últimas sejam mais bem identificadas com a universalização do acesso do que com a universalização do uso, objeto de estudo deste capítulo.

\subsubsection{Programas de financiamento dos padrões de entrada}

De acordo com as normas do setor elétrico, para a regularização das ligações clandestinas e o atendimento aos novos pedidos de ligação, o consumidor deve dispor de um ponto de entrada para a conexão das suas instalações com o ramal da concessionária e para abrigar os equipamentos de medição e proteção. Porém, parte dessa população não tinha recursos para arcar com o denominado padrão de entrada de energia elétrica, inviabilizando os esforços para regularização e atendimento.

Levantamento do Dnaee (1986), no âmbito do estudo para a proposição de tarifas sociais, apresentou também programas implantados por diversas distribuidoras do País para o financiamento ou, em alguns casos, a doação dos padrões de entrada de energia elétrica para populações carentes.

No início dos anos 80, o governo de São Paulo, por meio de suas empresas de distribuição de energia, implantou programas de atendimento denominado na CESP de Luz para Baixa Renda (LBR), na CPFL de Padrão Popular de Ligação (PPL) e na Eletropaulo, Pró Luz.

Nesses programas, as distribuidoras adquiriam o padrão de entrada, enquanto a comunidade e as prefeituras, geralmente em regime de mutirão, os instalavam com a assessoria técnica das empresas. O padrão de entrada implantado pelas distribuidoras normalmente era constituído de poste de madeira compartilhado por até seis medidores de energia com suas respectivas caixas e proteção. Existiam também situações com apenas um medidor para várias casas, nesse caso, o faturamento era dividido pelo número de casas, em contas individuais. 
Este levantamento do Dnaee (1986) apresentou dados de 17 distribuidoras, que possuíam programas para financiamento, e de quatro empresas, que doavam os padrões de entrada. A maior parte das empresas concedia o prazo de até 60 meses para o pagamento dos padrões financiados.

O principal critério de seleção dos beneficiados era priorizar as residências localizadas na periferia das cidades, em áreas de expansão urbana ou em bairros de pouca densidade populacional. Somente três empresas (Cemig, Celesc e CEEE) informaram que o programa também se estendia para a área rural.

No quadro seguinte são apresentados os diversos critérios utilizados pelas empresas pesquisadas pelo Dnaee, com o propósito de identificar os consumidores beneficiários dos programas. Além da localização, algumas empresas avaliavam a característica da construção, em geral de padrão popular ${ }^{33}$, a área construída, exigiam limitação de carga e verificavam a renda do interessado. A maioria das distribuidoras (62\%) também incluía as instalações internas da residência no programa.

\section{Quadro 3 - Critérios dos programas de financiamento}

\begin{tabular}{|c|c|c|c|c|c|c|c|c|c|c|c|c|c|}
\hline \multirow[b]{2}{*}{ EMPRESA } & \multicolumn{4}{|c|}{ Localização $^{1}$} & \multicolumn{4}{|c|}{$\begin{array}{c}\text { Renda } \\
\text { (sal. mín.) }\end{array}$} & \multirow{2}{*}{$\begin{array}{c}\text { Área } \\
\text { construida } \\
\left(\mathrm{m}^{2}\right)\end{array}$} & \multirow{2}{*}{$\begin{array}{c}\text { Carga } \\
\text { (W) }\end{array}$} & \multirow{2}{*}{$\begin{array}{c}\text { Instalação } \\
\text { interna }^{2}\end{array}$} & \multirow{2}{*}{$\begin{array}{c}\text { Prazo do } \\
\text { Financiamento } \\
\text { (meses) }\end{array}$} & \multirow[b]{2}{*}{ Tipo de construção } \\
\hline & favelas & rural & conj. hab. & cortiços & 1 & 1,5 & 2 & 3 & & & & & \\
\hline CEMIG & $\operatorname{sim}$ & $\operatorname{sim}$ & $\operatorname{sim}$ & & & $\mathrm{x}$ & & & & 850 & & 12 & Tijolo sem reboco e pau a pique \\
\hline CEMAT & & & $\operatorname{sim}$ & & & & & $\mathrm{x}$ & & 3800 & $\operatorname{sim}$ & 24 & \\
\hline ESCELSA & $\operatorname{sim}$ & & sim & & & & & & & 1300 & & 24 & \\
\hline CELESC & & $\operatorname{sim}$ & $\operatorname{sim}$ & & & & & $\mathrm{x}$ & & 6000 & $\operatorname{sim}$ & 36 & alvenaria, madeira, pau a pique, estuque \\
\hline CERJ & sim & & & & & & & $\mathrm{x}$ & 60 & 3500 & & 60 & humilde \\
\hline ELETROPAULO & & & & & & & & $\mathrm{x}$ & 72 & 6000 & & & rudimentar \\
\hline \begin{tabular}{|l} 
CELPE \\
\end{tabular} & $\operatorname{sim}$ & & & & $\mathrm{x}$ & & & & 80 & 635 & $\operatorname{sim}$ & 60 & predominantemente madeira \\
\hline CELG & & & & & & & & $\mathrm{x}$ & 20 & 1100 & & 12 & barracoes e edificações de concreto premoldado \\
\hline CELPA & & & & & $\mathrm{x}$ & & & & 3 cômodos & 635 & $\operatorname{sim}$ & 36 & madeira, taipa, alvenaria, mista \\
\hline COELCE & & & & & $\mathrm{x}$ & & & & & 635 & $\operatorname{sim}$ & 60 & alvenaria, madeira \\
\hline CEEE & & $\operatorname{sim}$ & & & & & & $\mathrm{x}$ & 30 & 600 & $\operatorname{sim}$ & 60 & madeira, estuque, adobe \\
\hline ENERSUL & & & & & & & & $\mathrm{x}$ & 60 & 3000 & $\operatorname{sim}$ & 56 & barracoes \\
\hline CEAM & & & & & $\mathrm{x}$ & & & & & 600 & sim & 10 & madeira \\
\hline
\end{tabular}

1 Todas as empresas consideram: periferias/áreas de expansão urbanas/bairros de pouca densidade populacional

2. Algumas concessionárias providenciavam também as instalações internas das residências

Fonte: Elaborado pelo autor com base em dados do Dnaee (1986).

${ }^{33}$ Interessante notar alguns critérios subjetivos das avaliações utilizadas pelas distribuidoras para identificar um padrão popular de construção: humilde, rudimentar. Fonte: Dnaee, 1986. 


\subsubsection{Programas de atendimento das distribuidoras}

As empresas CPFL e Eletropaulo arcavam com o padrão de entrada da população carente, mesmo sendo de responsabilidade do consumidor, por regulamentação. Além disso, respectivamente por meio dos programas Eletricidade para Periferia e Programa de Baixa Renda, assumiam, até um dado limite de extensão da rede, o encargo que naquela época era atribuível ao consumidor.

\subsubsection{Programa Eletrificação de Favelas - Pró-Luz}

Em geral, eram instalados medidores de energia elétrica nas unidades consumidoras beneficiárias dos programas de financiamento dos padrões de entrada. Porém, devido à quantidade insuficiente destes equipamentos, a Eletropaulo faturava os consumidores atendidos pelo programa, por meio de uma taxa mínima, equivalente a um consumo de $50 \mathrm{kWh} / \mathrm{mês}$.

Com a compra de novos medidores, a Eletropaulo tentou alterar essa política a partir dos novos projetos. No entanto, uma parte da população sentiu-se prejudicada em pagar pelo consumo real, enquanto em outros locais já implantados os consumidores pagavam pelo mínimo. Esse fato levou o governo paulista, na época controlador da empresa, a adotar a solução paliativa de estender o faturamento pela taxa mínima a todos os consumidores localizados em áreas de favelas (FRANÇA, 1999).

Essa sistemática de pagamento pela taxa mínima, sem considerar o consumo real ${ }^{34}$, aumentava as perdas comerciais e não induzia nenhum incentivo para o uso eficiente da energia. Por meio de pesquisas domiciliares, sem caráter científico, a empresa verificou casos de consumo de energia que excede a taxa mínima (50 kWh/mês), evidenciada pela utilização de geladeiras sem porta em algumas residências e de equipamentos específicos de uso não residencial.

\footnotetext{
34 No início da última década, a Eletropaulo estimava um consumo médio de $150 \mathrm{kWh} / \mathrm{mês}$ para os beneficiários desse programa.
} 


\subsubsection{Programa de descontos para a população baixa renda}

Algumas empresas, além dos descontos concedidos na época para a classe residencial, aplicavam um valor diferenciado para o faturamento de energia elétrica da população baixa renda. De acordo com o Dnaee (1985), a CESP possuía o programa "Bônus Social" que permitia desconto de 50\% sobre o consumo, limitado até $120 \mathrm{kWh} / \mathrm{mês}$. A CPFL, por sua vez, fornecia gratuitamente os primeiros $60 \mathrm{kWh} / \mathrm{mês}$ para consumidores residentes em favelas, com o consumo mensal de até $120 \mathrm{kWh}$.

\subsubsection{Programa Habitações Multi-familiares}

O Programa Habitações Multi-familiares da Eletropaulo atendia as famílias que residiam em cortiços. A empresa emitia a Fatura Residencial Múltipla (FRM) em nome de um único responsável, porém aplicava os descontos tarifários em função do número de famílias residentes, como se fossem contas individuais. A redução correspondia a aproximadamente $35 \%$ do valor da conta de energia elétrica do faturamento normal.

\subsection{CRIAÇÃO DA TARIFA RESIDENCIAL BAIXA RENDA}

De 1974 a 1993 a política tarifária consistiu na adoção de um valor único para todo o território brasileiro. Havia a Conta de Resultados a Compensar (CRC), com o objetivo de contabilizar as insuficiências e excedentes de receita, de forma a garantir uma remuneração mínima de 10\% sobre os ativos das empresas (DIEESE, 1998).

A Lei $n^{\circ}$ 8.631, de 4 de março de 1993, estabeleceu a denominada desequalização tarifária na qual os níveis tarifários deveriam corresponder aos valores necessários para a cobertura do custo do serviço de cada distribuidora, segundo suas características específicas e de modo a garantir a prestação de serviços adequados à população. Também extinguiu o regime de remuneração garantida e, em 
conseqüência, a Conta de Resultados a Compensar $\left(\right.$ CRC) ${ }^{35}$ e a Reserva Nacional de Compensação de Remuneração (RENCOR) ${ }^{36}$.

Essa norma legal permite à distribuidora promover alterações compensatórias entre os níveis de tarifa de fornecimento relativos a cada classe de consumidor final, respeitado o valor médio das tarifas de fornecimento. Com base nesse dispositivo, a Portaria Dnaee $n^{\circ}$ 922, de 28 de julho de 1993, determinou que as distribuidoras elaborassem, estudos, com o propósito de definir suas "políticas tarifárias" para o atendimento de consumidores baixa renda.

A classe residencial possuía, desde 1974, uma estrutura tarifária que concedia descontos para as primeiras faixas de consumo, independentemente do consumo total de energia elétrica. Dessa forma, um cliente residencial que consumisse, por exemplo, $400 \mathrm{kWh} / \mathrm{mês}$, teria, para as primeiras faixas de consumo, os mesmos descontos que um outro que consumisse apenas $100 \mathrm{kWh} / \mathrm{mês}$.

No entanto, os percentuais de desconto foram gradativamente diminuídos desde 1989, conforme pode ser observado na Tabela 10, que apresenta os descontos praticados pela Eletropaulo.

Tabela 10 - Evolução no desconto por faixa de consumo - Eletropaulo

\begin{tabular}{c|c|c|c|c|c}
$\begin{array}{c}\text { Consumo } \\
\text { (kWh) }\end{array}$ & $\begin{array}{c}\text { A partir de } \\
\mathbf{1 4 / 0 1 / 8 9}\end{array}$ & $\begin{array}{c}\text { A partir de } \\
\mathbf{0 8 / 1 1 / 9 0}\end{array}$ & $\begin{array}{c}\text { A partir de } \\
\mathbf{0 1 / 0 2 / 9 1}\end{array}$ & $\begin{array}{c}\text { A partir de } \\
\mathbf{0 4 / 0 2 / 9 3}\end{array}$ & $\begin{array}{c}\text { A partir de } \\
\mathbf{0 5 / 1 1 / 9 5}\end{array}$ \\
\hline $\mathbf{0 ~ a ~ 3 0}$ & $89 \%$ & $70 \%$ & $60 \%$ & $81 \%$ & $65 \%$ \\
\hline $\mathbf{3 1}$ a 100 & $72 \%$ & $52 \%$ & $40 \%$ & $55 \%$ & $40 \%$ \\
\hline $\mathbf{1 0 1}$ a 200 & $65 \%$ & $45 \%$ & $35 \%$ & $24 \%$ & $10 \%$ \\
\hline $\mathbf{2 0 1}$ a 300 & $17 \%$ & $0 \%$ & $0 \%$ & $0 \%$ & $0 \%$ \\
\hline Acima de 300 & $0 \%$ & $0 \%$ & $0 \%$ & $0 \%$ & $0 \%$ \\
\hline
\end{tabular}

Fonte: Aneel, apud França (1999).

\footnotetext{
35 Conta de Resultados a Compensar (CRC). Conta contábil na qual as concessionárias registravam eventuais insuficiências ou excessos de remuneração decorrente da taxa interno de retorno permitida pela legislação (mínima de $10 \%$ e máxima de $12 \%$ ).

36 Reserva Nacional de Compensação de Remuneração (Rencor). Instituída pelo Decreto-Lei $n^{\circ}$ 2.432, de 17 de maio de 1988, com a finalidade de compensar as insuficiências de remuneração do investimento das concessionárias de serviços públicos de energia elétrica. Era constituída por recursos provenientes: do recolhimento das quotas anuais de compensação, constituídas pelas parcelas de receita excedente das concessionárias, atendida a taxa de remuneração legal máxima do investimento; dos saldos credores registrados na Conta de Resultados a Compensar das concessionárias; de receitas de outras origens, inclusive de eventuais dotações consignadas no Orçamento Geral da União.
} 
Após o Plano Real (1994), o primeiro reajuste ocorreu em novembro de 1995. Nessa ocasião, de acordo com o Dieese (1998), as tarifas de energia elétrica foram corrigidas por classe de consumidor, de modo diferenciado, variando desde $0 \%$ para o residencial até $20,5 \%$ para o consumidor do Grupo A, conforme se demonstra na Tabela 11, a seguir.

Tabela 11 - Reajustes das tarifas de energia elétrica em novembro/1995

\begin{tabular}{c|c|c|c}
\hline \multirow{2}{*}{ Empresas } & Grupo A & Residencial & Rural \\
Celesc & $13,5 \%$ & $0,0 \%$ & $13,5 \%$ \\
\hline Cemig & $11,8 \%$ & $0,0 \%$ & $11,8 \%$ \\
\hline Ampla & $9,8 \%$ & $0,0 \%$ & $9,8 \%$ \\
\hline CESP & $20,5 \%$ & $3,0 \%$ & $20,5 \%$ \\
\hline Coelba & $19,5 \%$ & $0,0 \%$ & $19,5 \%$ \\
\hline Copel & $12,0 \%$ & $0,0 \%$ & $12,0 \%$ \\
\hline CPFL & $11,1 \%$ & $3,0 \%$ & $11,1 \%$ \\
\hline Eletropaulo & $12,3 \%$ & $3,0 \%$ & $12,3 \%$ \\
\hline Escelsa & $6,0 \%$ & $0,0 \%$ & $6,0 \%$ \\
\hline Light & $8,0 \%$ & $0,0 \%$ & $8,0 \%$ \\
\hline
\end{tabular}

Fonte: Adaptado de: Dieese (1998).

Porém, o impacto para a classe residencial não foi nulo, pois as diminuições dos descontos para as primeiras faixas de consumo, conforme demonstrado na Tabela 10 (Evolução no desconto por faixa de consumo - Eletropaulo) implicaram um aumento real da conta do consumidor. Ao mesmo tempo, determinou-se que esse benefício, antes aplicado a todos os consumidores residenciais, fosse restrito aos integrantes da recém criada subclasse residencial baixa renda.

Assim, em 3 de novembro de 1995, o Dnaee emitiu a Portaria $n^{\circ} 437$, que alterou o artigo 19 da Portaria $\mathrm{n}^{\mathrm{o}}$ 222, de 22 de dezembro de 1987, e criou a subclasse residencial baixa renda visando identificar, “[...] entre os consumidores residenciais, aqueles de baixo poder aquisitivo, para que se possa praticar política tarifária mais adequada". O Dnaee estabeleceu patamares de consumo regionais que deveriam balizar a classificação e os níveis de tarifa a serem aplicados. Atribuiu às distribuidoras a responsabilidade pela caracterização das unidades beneficiárias, 
concedendo prazo para que as empresas submetessem os critérios e o cadastro das residências classificadas como de baixa renda para aprovação do órgão.

Em 1996 foram aprovadas as primeiras propostas das distribuidoras para classificação das unidades consumidoras ${ }^{37}$. Além dos limites regionais de consumo, que variavam de 140 a $220 \mathrm{kWh} / \mathrm{mês,} \mathrm{foram} \mathrm{aprovados} \mathrm{critérios} \mathrm{diversos} \mathrm{e}$ heterogêneos, que envolviam limitação de carga (de 1,8 a 7 kW), características da moradia e aspectos sócio-econômicos.

As características propostas para classificação das moradias como baixa renda envolviam:

- limite de construção variando de 30 até $70 \mathrm{~m}^{2}$, para algumas distribuidoras, embora outras não o exigissem;

- padrão popular de construção, ou padrão simples, ou ainda com "características de baixa renda" (termo utilizado por algumas distribuidoras);

- em geral localizadas em favelas, loteamentos "irregulares", núcleos populares baixa renda e construídas em regime de mutirão.

Quanto aos aspectos sócio-econômicos utilizados para classificação como baixa renda, algumas empresas estabeleciam limite de renda que variava de um a três salários mínimos, enquanto duas distribuidoras exigiam que a residência não dispusesse de linha telefônica.

Segundo a Aneel (1998), os percentuais de consumidores classificados como baixa renda, em relação aos consumidores residenciais, variavam de $0,13 \%$ na Cepisa a 80,59\% na Cemig, conforme pode ser observado no Anexo J - Evolução do número de consumidores baixa renda por distribuidora - 1998 a 2002.

De acordo com o documento, os critérios da Cepisa para classificação dos consumidores na subclasse residencial baixa renda eram: carga limitada a 2,5 kW,

${ }^{37}$ Vide Anexo H - Caracterização das moradias baixa renda - 1998. 
residência de baixo padrão localizada em bolsões de pobreza, com área construída até $27 \mathrm{~m}^{2}$, além do enquadramento no limite de consumo regional de $140 \mathrm{kWh} / \mathrm{mês}$. Por outro lado, o critério da Cemig correspondia a um consumo de $180 \mathrm{kWh} / \mathrm{mês,}$ limitação de carga por disjuntor de 40 A e moradia de baixo padrão, em favelas e aglomerados urbanos.

\subsection{TARIFA SOCIAL E REESTRUTURAÇÃO DO SETOR DA DÉCADA DE 90}

A exemplo do acesso físico, a tarifa para os consumidores residenciais baixa renda também não foi tratada no processo de privatização do setor elétrico brasileiro. Os critérios propostos pelas distribuidoras e aprovados pelo Dnaee permaneceram inalterados. Nessa situação, durante a avaliação das empresas que seriam privatizadas, alguns consórcios interessados, possivelmente consideraram um eventual ganho adicional com a mudança dos critérios de classificação dos consumidores residenciais baixa renda.

\subsubsection{Alteração dos critérios da Light antes da privatização}

A Light, uma das distribuidoras do Estado do Rio de Janeiro, não obteve inicialmente a aprovação dos critérios propostos para classificação das unidades consumidoras na subclasse residencial baixa renda. Dessa forma, o critério estabelecido para classificação foi o consumo regional, no caso $140 \mathrm{kWh} / \mathrm{mês}$.

$\mathrm{Na}$ mesma época, a empresa passava pelo processo de privatização que se arrastou por vários meses, em decorrência de liminares que postergaram a data do leilão.

Porém, duas semanas antes do leilão, o Dnaee aprovou a caracterização das unidades consumidoras classificadas na subclasse residencial baixa renda, por meio da Portaria $\mathrm{n}^{\mathrm{0}}$ 145, de 7 de maio de 1996. Esses consumidores constavam dos programas especiais de atendimento para a população de baixo poder aquisitivo, mantidos pela Light na sua área de concessão.

Os critérios aprovados foram: ligação monofásica, carga instalada de até $3,3 \mathrm{~kW}$; consumo médio de até $140 \mathrm{kWh} / \mathrm{mês}$ nos últimos doze meses e características de 
construção e localização, objeto de norma específica da concessionária. De acordo com a Aneel (1998), os critérios de avaliação do padrão de moradia correspondiam a residências simples, barracos, cortiços, ou seja, conjuntos habitacionais de baixa renda.

O leilão ocorreu em 21 de maio de 1996 e o Contrato de Concessão nº 001/96, para geração, transmissão e distribuição de energia elétrica, foi assinado em 4 de junho de 1996.

\subsubsection{Aplicação integral dos critérios pela CPFL}

A Portaria Dnaee n 261/96 aprovou, para a classificação na subclasse residencial baixa renda, os seguintes quesitos necessários dos consumidores da CPFL: atendimento monofásico, consumo de $220 \mathrm{kWh} / \mathrm{mês}$ e capacidade instalada até 4 kW. Naquela época a distribuidora não utilizou o critério de carga instalada na implantação do benefício, considerando apenas o tipo de ligação e a limitação de consumo, embora o regulamento permitisse.

Esta situação perdurou até dezembro de 1998, quando a distribuidora, já privatizada, decidiu reclassificar os consumidores, seguindo integralmente os critérios anteriormente aprovados. Nessa ocasião, o total de consumidores residenciais da empresa aproximava-se de 2,169 milhões, dos quais cerca de 1,228 milhão (56\%) usufruíam o benefício (RAMALHO, 2001).

Admitindo que um consumo inferior a $120 \mathrm{kWh} / \mathrm{mês}$ corresponderia a uma potência instalada de $4 \mathrm{~kW}$, a empresa preservou cerca de 500 mil consumidores de uma campanha de recadastramento, e manteve para esses consumidores a classificação de residenciais baixa renda.

Para os demais consumidores, classificados como baixa renda e com consumo superior a $120 \mathrm{kWh} / \mathrm{mês}$, a CPFL informou o critério de carga instalada até $4 \mathrm{~kW}$ para a continuidade do benefício dos descontos e estabeleceu um prazo para resposta ao formulário de recadastramento dos aparelhos instalados nas residências. 
O valor da potência utilizado como critério acarretou dificuldades na obtenção do benefício, pois a maioria dos chuveiros fabricados tem potência nominal em torno de $4 \mathrm{~kW}$, o que comprometia o limite estabelecido pelo regulamento do Dnaee.

Acordo entre a Comissão de Serviços Públicos de Energia (CSPE) e a CPFL levou ao aprimoramento do processo de comunicação e a adoção do valor de $2,5 \mathrm{~kW}$ para o chuveiro elétrico, qualquer que fosse a sua potência nominal, proporcionando a continuidade do benefício para um maior número de consumidores (RAMALHO, 2001).

Em 7 de junho de 2000 a Aneel emitiu a Resolução no 196 que estabeleceu um novo limite de carga instalada, passando de 4 para $6,2 \mathrm{~kW}$, para classificação na subclasse residencial baixa renda. Com essa nova diretriz, o valor de potência dos chuveiros voltou a ser considerado com base em dados reais, ao invés do valor fixo de $2,5 \mathrm{~kW}$ adotado no acordo.

\subsubsection{Alteração dos critérios na Eletropaulo}

Assim como a Light, a Eletropaulo não obteve a aprovação dos seus critérios, resultando somente o limite de consumo regional de $220 \mathrm{kWh} / \mathrm{mês}$, como condição para que os consumidores residenciais fossem beneficiados com os descontos proporcionados pela tarifa baixa renda.

No entanto, após a privatização da Eletropaulo, o consórcio vencedor, Lightgás Ltda, não aceitava assinar o contrato de concessão sem a revisão dos critérios dos consumidores baixa renda, que correspondiam a $52 \%$ dos residenciais. A imprensa publicou na época que:

\footnotetext{
a falta de acordo entre as partes quase inviabilizou a concretização da transferência da concessão e chegou a acarretar uma situação extremamente desconfortável ao governo, que viu transformado em um fiasco a solenidade que marcaria a concretização de uma das maiores operações de privatização do setor elétrico brasileiro (PAUL, 1998 apud FRANÇA, 1999, p. 103).
}

As exigências da concessionária, para a revisão dos critérios de classificação na subclasse residencial baixa renda, eram as seguintes:

- área construída até $72 \mathrm{~m}^{2}$;

- carga total até $6 \mathrm{~kW}$; 
- ser autoconstruída ou pertencer a conjunto habitacional construído sob a forma de mutirão;

- renda familiar de até três salários mínimos, comprovados por meio da carteira profissional atualizada ou de comprovante de pagamento ou ainda pela declaração do empregador ou do próprio interessado.

Segundo dados da imprensa, com essa proposta cerca de um milhão de consumidores perderiam o subsídio, representando um excedente equivalente à cerca de $3 \%$ da receita anual, aproximadamente R\$ 80 milhões (CORRÊA, 1998 apud FRANÇA, 1999, p. 103).

A primeira solenidade para assinatura do contrato estava marcada para o dia 29 de maio de 1998, mas o consórcio vencedor não enviou representante. De acordo com o jornal Folha de São Paulo, de 16 de junho de 1998, a empresa "havia solicitado a revisão da tarifa social no dia 27 (de maio) e condicionado a assinatura do contrato ao atendimento de seu pedido". A empresa negou esse entendimento, alegando "um mal-entendido em torno das datas", para justificar o não comparecimento ao evento.

Finalmente, em 15 de junho de 1998, no prazo final estabelecido pela Aneel, foi assinado o contrato de concessão da Eletropaulo, incondicionalmente, segundo a agência. Porém, de acordo com a imprensa ${ }^{38}$, a Aneel iria rever os critérios de classificação dos consumidores beneficiados com a tarifa baixa renda no segundo semestre daquele ano; no entanto, os ganhos de receita obtidos com esses novos critérios seriam descontados na revisão tarifária periódica da empresa.

Posteriormente, a Aneel negou novo pedido feito pela Eletropaulo para a reclassificação de cerca de dois milhões de consumidores baixa renda da concessionária. Para a agência, a reclassificação deveria ser, necessariamente, acompanhada da reavaliação da situação econômico-financeira da empresa, para a divisão, com todos os seus consumidores, do crescimento estimado, na época, de cerca de R\$ 120 milhões por ano (ANEEL, 1999).

\footnotetext{
${ }^{38}$ Folha de São Paulo; O Estado de São Paulo; Jornal do Brasil; O Globo; Gazeta Mercantil, de 16 de junho de 1998.
} 
Em 2000, a Eletropaulo conseguiu liminar contra a Aneel possibilitando a alteração dos critérios, de acordo com a proposta inicialmente apresentada ao regulador. Porém, a agência determinou a contabilização em separado dos ganhos de receita para, na época da revisão, serem compartilhados com o consumidor.

Em 19 de setembro de 2001 foi julgada favorável a decisão judicial, possibilitando, em definitivo, a reclassificação dos consumidores baixa renda. Segundo a Eletropaulo (2002), o critério anterior baseado apenas no limite de consumo de até $220 \mathrm{kWh}$, beneficiava 2,7 milhões de consumidores residenciais (65\%). Com a alteração, o número estimado seria de 500 mil beneficiados, ocasionando uma receita anual adicional de aproximadamente $\mathrm{R}$ \$ 230 milhões.

\subsubsection{Proposta para definição de tarifas sociais - Metodologia FIPE}

Devido às distorções existentes nos critérios de classificação para os consumidores baixa renda, a Aneel, em 1999, contratou a Fundação Instituto de Pesquisas Econômicas (FIPE) para elaborar um estudo sobre tarifas sociais, visando a proposição de critérios mais adequados para a inclusão da população necessitada.

Os resultados do trabalho foram apresentados, em 10 de fevereiro de 2000, no Seminário Metodologia para Definição de Domicílios Baixa Renda e discorriam sobre vários assuntos: critérios para avaliação dos programas, domicílios baixa renda e linha de pobreza, critérios de focalização (targeting), possibilidades de variações das estruturas tarifárias e seus efeitos, além de experiência de alguns países na implementação de tarifas sociais.

A metodologia adotada por Rocha (2000a) para definir pobreza, utilizada no estudo da FIPE, considera a família como unidade básica de consumo e rendimento, e a linha de pobreza baseada em um valor per capita familiar que leva em conta todos os rendimentos dos membros da família, o seu tamanho e o seu papel como unidade redistributiva da renda. 


\subsubsection{Critérios de Focalização}

Uma vez definida a população alvo, por meio do conceito de linha de pobreza, é necessário, para a caracterização dessas pessoas, utilizar mecanismos que avaliam o conjunto de atributos necessários, denominados critérios de focalização (targeting) que, segundo Fernandes (2000), podem ser classificados nos seguintes tipos: categorical ou geographic target, means-tested; proxy-means testing e self-selecting.

O primeiro critério de focalização, categorical ou geographic target, depende do conhecimento da distribuição geográfica da incidência, profundidade e severidade da pobreza. Dessa forma, este critério será mais eficiente se a pobreza for concentrada numa determinada área, como por exemplo, um bairro ou uma região carente. Os custos administrativos de implementação são relativamente baixos comparativamente com outros critérios que necessitam identificar individualmente as famílias pobres.

O segundo mecanismo, means-tested, define como beneficiários de um programa as famílias com renda inferior a um determinado valor pré-estabelecido.

O proxy-means testing utiliza características observáveis das famílias ao invés de um valor de renda pré-estabelecida. No entanto, as variáveis escolhidas devem funcionar como indicadores do bem-estar da família e, portanto, correlacionadas com a renda.

O último mecanismo, self-selecting, não representa propriamente um critério de focalização, pois todas as pessoas, a princípio, teriam direito ao benefício. A atração ficaria somente para as pessoas mais carentes, devido ao tempo de espera ou menor qualidade do produto oferecido (como exemplo, assistência médica pública).

\subsubsection{Aplicação da metodologia}

O critério de focalização mais simples a ser utilizado seria o mecanismo meanstested, se a distribuidora tivesse acesso a informações confiáveis sobre a renda familiar per capita dos seus consumidores.

Dessa forma, o projeto piloto apresentado pela FIPE, para a Região Metropolitana de São Paulo (RMSP), utilizou outro mecanismo de focalização: proxy-means testing, 
que correlaciona características observáveis com a renda. Os dados da Pesquisa Nacional de Amostragem de Domicílios (PNAD), de 1997, trazem informações das residências, que foram utilizadas como variáveis para estimar a probabilidade de uma determinada família ser considerada como pobre.

Para essa região estudada, algumas das variáveis constantes da PNAD não auxiliam na discriminação entre pobres e não-pobres, como por exemplo, o acesso à energia, água e coleta de lixo, pois estão presentes em mais de 96\% dos domicílios. Por essa razão, a FIPE optou por empregar uma "stepwise regression anlysis", com todas as possíveis variáveis, na qual um sistema calcula aquelas correlacionadas com a pobreza da região. O Quadro 4 a seguir, apresenta as variáveis mais significativas e seus valores relativos calculados pelo sistema. Com base nessas características e nos respectivos valores relativos, o valor de corte do modelo será aquele que separa o mesmo percentual de famílias pobres estimado da região em estudo.

Quadro 4 - Elementos de caracterização - famílias pobres - RMSP

\begin{tabular}{l|c}
\hline \multicolumn{1}{c|}{ Características } & coeficiente \\
\hline Gênero do chefe da família & $-0,4171$ \\
\hline Anos de estudo & $-0,07368$ \\
\hline Densidade morador/cômodo & $+1,01120$ \\
\hline Televisão a cores & $-0,52601$ \\
\hline Geladeira-freezer & $-0,25112$ \\
\hline Máquina de lavar & $-0,65306$ \\
\hline Telefone & $-0,60879$ \\
\hline Esgoto & $-0,32678$ \\
\hline Lixo & $-0,80316$ \\
\hline Consumo familiar per capita de energia & $-0,00375$ \\
\hline
\end{tabular}

Fonte: FIPE (2000).

Para a aplicação dessa sistemática, inicialmente seria enviado ao consumidor alvo do programa um questionário contendo as variáveis identificadas no estudo. Após a coleta dos dados, o sistema calcularia se o consumidor seria pobre ou não, utilizando os coeficientes calculados pelo modelo. 


\subsection{ANÁLISE DOS ANTECEDENTES DA UNIVERSALIZAÇÃO DO USO}

\subsubsection{Análise do Estudo do Dnaee}

O estudo do Dnaee (1986) avaliou o consumo mínimo essencial de energia elétrica em quatro níveis de referência, de acordo com a utilização de iluminação e equipamentos $^{39}$. A estimativa mensal máxima foi de $105 \mathrm{kWh}$ que poderia ser reduzido para $80 \mathrm{kWh}$, considerando os incentivos do programa de conservação de energia elétrica.

Há contestações nessas proposições; por exemplo, para Bermann (2003), as necessidades para assegurar um padrão mínimo de qualidade de vida, caracterizado em uma cesta básica de energia elétrica, podem ser estimadas em $220 \mathrm{kWh} / \mathrm{mês,}$ considerando as seguintes cargas: duas lâmpadas de $100 \mathrm{~W}$, três lâmpadas de $60 \mathrm{~W}$, ferro elétrico $(1.000 \mathrm{~W})$, televisor $(60 \mathrm{~W})$, geladeira $(200 \mathrm{~W})$, chuveiro $(3.200 \mathrm{~W})$, lavadora de roupa $(1.500 \mathrm{~W})$ e aparelho de som $(20 \mathrm{~W})$.

A proposta de tarifa apresentada pelo grupo de trabalho do Dnaee fixava os descontos para as faixas iniciais de consumo de modo a resultar no comprometimento máximo de $4 \%$ do salário mínimo da época, para a quantidade de energia elétrica considerada como essencial. O subsídio seria compensado pela própria classe residencial por meio da tarifa maior para o consumo mensal superior a $200 \mathrm{kWh}$.

Segundo a classificação apresentada por Anuatti (2000), essa proposta do Dnaee corresponderia à política denominada de universalização das necessidades básicas que pressupõe o direito de acesso a uma quantidade de energia considerada como básica, independentemente da classe social.

\footnotetext{
${ }^{39}$ Foram utilizadas no estudo, as seguintes cargas: quatro lâmpadas de $60 \mathrm{~W}$, ferro elétrico $(1.000 \mathrm{~W})$, televisor $(100 \mathrm{~W})$, geladeira $(200 \mathrm{~W})$ e chuveiro $(3.200 \mathrm{~W})$.
} 


\subsubsection{Análise dos programas destinados especificamente aos consumidores baixa renda}

Segundo dados do Dnaee (1986) havia cerca de 1,6 milhão de consumidores que, embora próximos às redes de distribuição de energia elétrica, não apresentavam condições econômicas de arcar com os investimentos necessários a sua ligação. Para atender esses consumidores, o estudo feito pelo órgão recomendava a criação de um Programa Nacional de Ligação para Consumidores Baixa Renda, com base nas soluções implementadas por 21 distribuidoras, à margem da regulamentação existente. Observa-se, portanto, que os programas direcionados para os consumidores baixa renda não se restringiam aos descontos adicionais nas tarifas residenciais das pessoas pobres, mas também incluíam facilidades para o acesso ao serviço de energia elétrica.

Pela proposta do Dnaee, os beneficiados pelo programa de ligação pagariam durante 60 meses, além do consumo de energia elétrica, um valor correspondente à "Taxa Mínima para Consumidor Residencial Monofásico", que na época era de Cr\$ 4.709,00, e que atualmente corresponderia cerca de $\mathrm{R} \$ 8,00^{40}$. Para aqueles cuja ligação necessitasse de extensão da rede, o valor cobrado seria duas vezes a taxa mínima ${ }^{41}$.

Em relação aos programas que proporcionavam descontos adicionais para consumidores classificados como baixa renda, o Dnaee (1986) avaliou que não possuíam base nos regulamentos da época. A falta de instalação de medição de energia elétrica e o fornecimento gratuitamente para os primeiros $60 \mathrm{kWh} / \mathrm{mês}$, não observando os mínimos de faturamento, podiam estimular o desperdício de energia elétrica. O programa da Eletropaulo concedia um percentual de $64 \%$ de descontos,

\footnotetext{
40 Atualização feita considerando a tarifa média residencial do Brasil, em junho de 2004, de R\$ 263,23/MWh (Aneel on line) aplicada ao consumo mínimo mensal, para efeitos de faturamento, da classe residencial atendida em sistema monofásico $(30 \mathrm{kWh})$.

41 Segundo levantamentos do Dnaee (1986), cerca de 670 mil ligações necessitariam de extensão da rede de distribuição, enquanto que as demais 930 mil, não.
} 
em média, que somavam o montante atualizado de $\mathrm{R} \$ 2,7$ milhões, conforme demonstrado na Tabela 12 a seguir ${ }^{42}$.

Tabela 12 - Programas Baixa Renda (1986)

\begin{tabular}{|c|c|c|c|c|c|c|}
\hline Empresa & \begin{tabular}{|c|} 
Número de \\
consumidores
\end{tabular} & $\begin{array}{l}\text { Faturamento } \\
\text { Normal } \\
\text { (Cr\$) }\end{array}$ & $\begin{array}{l}\text { Faturamento } \\
\text { Programa } \\
\text { (Cr\$) }\end{array}$ & $\begin{array}{l}\text { Diferença } \\
(\mathrm{Cr} \$)\end{array}$ & $\begin{array}{c}\% \\
\text { subsídio }\end{array}$ & $\begin{array}{l}\text { Diferença } \\
\text { atualizada } \\
\text { (R\$) }\end{array}$ \\
\hline Eletropaulo & 121.092 & 3.377 .696 .700 & 1.207 .151 .600 & 2.170 .545 .100 & $64 \%$ & $2.698 .638,72$ \\
\hline CESP & 3.285 & 46.272 .734 & 22.972 .937 & 23.299 .797 & $50 \%$ & $31.238,04$ \\
\hline$\overline{\text { CPFL }}$ & 5.153 & 113.665 .827 & 67.917 .299 & 45.748 .528 & $40 \%$ & $61.335,05$ \\
\hline
\end{tabular}

Base dos dados - Eletropaulo: julho/85; CESP e CPFL: junho/85.

Fonte: Adaptado de: Dnaee (1986).

De maneira semelhante, o Programa Habitações Multi-familiares da Eletropaulo, apesar da autorização do Dnaee para o funcionamento provisório, não possuía respaldo na legislação em vigor, tanto no aspecto medição como no faturamento.

Para França e Bermann (2000), estes programas, além de atender à população pobre por meio de sua inclusão no universo de consumidores regulares, sob outro ponto de vista, proporcionavam vantagens para as distribuidoras evitando o furto de energia elétrica e aumentando a sua receita. Independentemente das vantagens, observa-se que esses programas foram baseados em estrutura de subsídios cruzados, na qual os demais consumidores arcavam com o custo dos benefícios para essa população.

\subsubsection{Análise da criação da tarifa social}

A partir de 1995 os descontos escalonados que beneficiavam todos os consumidores residências foram restritos aos consumidores classificados na subclasse residencial baixa renda.

A alteração ocorreu, portanto, antes do processo de privatização das distribuidoras de energia elétrica. Os órgãos de defesa do consumidor creditam ao processo de privatização o aumento das tarifas para a classe residencial, o que na visão temporal dos fatos não é verdadeira. No entanto, é preciso reconhecer que essas

\footnotetext{
42 Valores atualizados pela variação do IGP-DI do período.
} 
transformações não ocorreram de forma isolada, mas visando a recuperação de tarifas para aumentar a atratividade das empresas.

Apesar do primeiro reajuste após o Plano Real não ter incidido sobre as tarifas da classe residencial, a perda dos descontos escalonados para os consumidores não classificados na nova subclasse correspondeu, na prática, a um aumento tarifário na faixa de $70 \%$ a $110 \%$, para aqueles imediatamente acima do limite de consumo regional, como demonstra a Tabela 13.

Tabela 13 - Efeito do término dos descontos para consumidores residenciais

\begin{tabular}{c|c|c|c}
\hline Empresas & $\begin{array}{c}\text { Limite de consumo } \\
\text { mensal com } \\
\text { desconto } \mathbf{( k W h})\end{array}$ & $\begin{array}{c}\text { Aumento para } \\
\text { consumo abaixo do } \\
\text { limite }\end{array}$ & $\begin{array}{c}\text { Aumento para o } \\
\text { consumo superior } \\
\text { ao limite }\end{array}$ \\
\hline Celesc & 160 & $28,2 \%$ & $93,8 \%$ \\
\hline Cemig & 180 & $26,6 \%$ & $84,0 \%$ \\
\hline Ampla & 140 & $30,6 \%$ & $108,0 \%$ \\
\hline CESP & 220 & $25,2 \%$ & $70,3 \%$ \\
\hline Coelba & 140 & $30,6 \%$ & $108,3 \%$ \\
\hline CPFL & 220 & $25,2 \%$ & $70,3 \%$ \\
\hline Eletropaulo & 220 & $25,2 \%$ & $70,3 \%$ \\
\hline Escelsa & 180 & $26,6 \%$ & $84,0 \%$ \\
\hline Light & 200 & $25,4 \%$ & $76,8 \%$ \\
\hline
\end{tabular}

Fonte: Adaptado de: Dieese (1998).

Conforme citado, os consumidores classificados como baixa renda não foram afetados pelo efeito do corte dos descontos. Porém, a aprovação de características heterogêneas apresentadas pelas empresas refletiu, em parte, na quantidade de consumidores classificados como baixa renda, ocasionando situações contraditórias.

Com base no levantamento feito pela Aneel (1998), observa-se que várias distribuidoras localizadas em regiões pobres possuíam, contraditoriamente, percentual pequeno de consumidores baixa renda, como por exemplo, Cepisa $(0,13 \%)$, CEAL $(1,95 \%)$, Coelba $(9,28 \%)$.

Outras empresas também apresentavam baixo percentual, embora em regiões menos pobres, como nas Regiões Sudeste e Sul: Escelsa (4,97\%), Light (6,05\%) e Ampla (6,43\%); RGE (0,80\%), Celesc (2,09\%) e CEEE (7,77\%), respectivamente.

De fato, o TCU (2003b, p.13) também constatou distorções no programa, particularmente em relação ao público-alvo que deveria ser beneficiado: 
Uma das mais significativas constatações foi que a Região Sudeste, a mais rica do Brasil, apresenta o maior índice de consumidores de baixa renda, chegando a 46,77\% dos consumidores da classe residencial em dezembro/97 e 42,34\% em março/99 e a Região Nordeste apresenta índices de $14,67 \%$ e $11,80 \%$ no mesmo período.

Dentre os Estados do Sudeste o que melhor representa essa distorção é Minas Gerais, com o índice de $80,59 \%$ dos consumidores residenciais classificados na subclasse de baixa renda em dezembro/97, o maior do Brasil e 80,30\% em março/99.

Inexplicavelmente, o Estado do Piauí, apresentou um dos menores índices de consumidores residenciais classificados na subclasse de baixa renda: $0,13 \% \mathrm{em}$ dezembro/97 e $0,11 \%$ em março/99.

Os critérios diferenciados poderiam esclarecer, parcialmente, o pequeno número de consumidores baixa renda. Os da Cepisa correspondem a um dos mais restritivos do Brasil: carga limitada a $2,5 \mathrm{~kW}$, residência de baixo padrão localizada em bolsões de pobreza, com área construída até $27 \mathrm{~m}^{2}$, além do limite de consumo regional de 140 kWh. Porém, empresas como a Coelce e a Saelpa, também localizadas na Região Nordeste, apresentavam maior quantidade de consumidores baixa renda, apesar dos critérios semelhantes ao da Cepisa, diferença essa possivelmente decorrente dos procedimentos de cadastramento.

Na Região Nordeste também havia empresas com percentual significativo de consumidores baixa renda, como a Cemar $(55,74 \%)$, Celpe $(58,64 \%)$ e Coelce $(76,45 \%)$. Paradoxalmente, as principais distribuidoras da Região Sudeste, a mais rica do Brasil, apresentava alto índice de consumidores baixa renda, CPFL (53,87\%), Bandeirante (55,17\%), Eletropaulo (70,64\%), Cemig (80,59\%).

É possível comparar estimativa da população pobre por Estado realizada FIPE (2000) com o percentual de consumidores baixa renda das distribuidoras levantado pela Aneel (1998), apesar dos anos de referência distintos dessas pesquisas. A Figura 2 apresenta essa avaliação para algumas empresas selecionadas. 


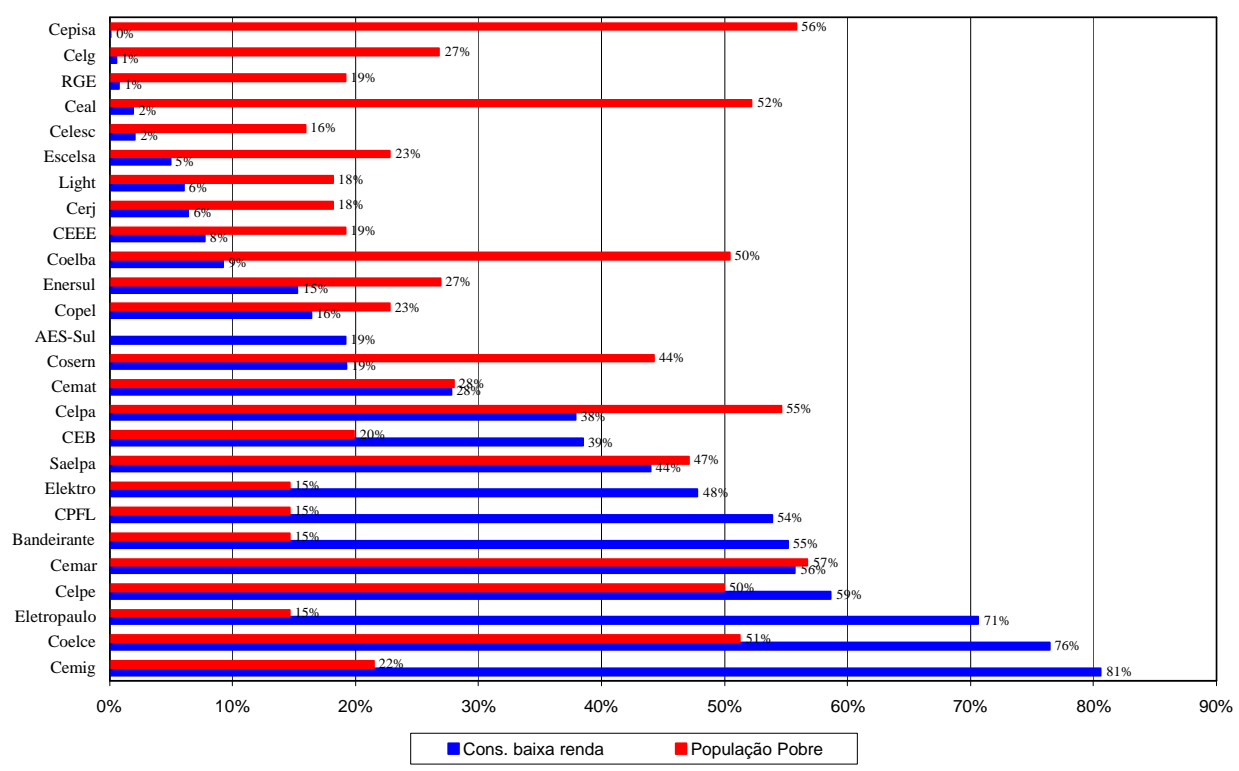

Fonte: Elaborado pelo autor com base em dados da Aneel (1998) e FIPE (2000).

\section{Figura 2 - Percentual de consumidores baixa renda e população pobre - distribuidoras selecionadas}

Essa era a situação anterior ao estabelecimento de novos critérios pela Lei $\mathrm{n}^{\circ}$ 10.438/2002, na qual cerca de $33 \%$ dos consumidores do Brasil eram classificados como baixa renda. Apesar desse percentual total ultrapassar os $28 \%$ da população pobre estimada, a análise dos dados por Estado apresentou variações contraditórias: Piauí com menos de $1 \%$ de consumidores baixa renda para 56\% de pobres e Minas Gerais com $81 \%$ de baixa renda para $22 \%$ de pobres. Dessa forma, os critérios estabelecidos pelas distribuidoras e aprovados pelo Dnaee não foram eficientes para a focalização necessária para o programa.

\subsubsection{Análise da tarifa social na reestruturação do setor da década de 90}

A proposta da FIPE para a identificação dos domicílios baixa renda tem baixos custos administrativos e de implementação, segundo Fernandes (2000). Apesar desse fato e do embasamento teórico, a sua regulamentação seria complexa e possivelmente sujeita a questionamentos legais.

O preenchimento de formulários sem haver transparência para o consumidor dos critérios que objetivamente seriam considerados na avaliação é legalmente frágil. 
Impor que uma determinada característica será considerada como ponderação não é um critério objetivo.

Uma adaptação possível seria utilizar o estudo como base para a identificação das variáveis comuns à população carente e, conseqüentemente, defini-las como critérios objetivos (existência ou ausência) para a caracterização do público-alvo do programa.

A Tabela 14 apresenta informações dos domicílios considerados pobres e de unidades consumidoras classificadas como baixa renda extraídos da Aneel (2000a) comparando-os com os dados do modelo proposto pela FIPE (2000) para a identificação dos consumidores baixa renda.

Tabela 14 - Comparação domicílios pobres e consumidores baixa renda (1998)

\begin{tabular}{|c|c|c|c|}
\hline ESTADO & $\begin{array}{c}\text { Domicílios } \\
\text { Pobres* }\end{array}$ & $\begin{array}{l}\text { Consumidores } \\
\text { Baixa Renda*** }\end{array}$ & $\begin{array}{l}\text { Modelo } \\
\text { Proposto }\end{array}$ \\
\hline ACRE & $42,56 \%$ & $78,45 \%$ & $21,02 \%$ \\
\hline ALAGOAS & $52,21 \%$ & $7,75 \%$ & $36,64 \%$ \\
\hline AMAPÁ & $36,78 \%$ & $52,94 \%$ & \\
\hline AMAZONAS & $44,75 \%$ & $40,77 \%$ & \\
\hline BAHIA & $50,40 \%$ & $2,40 \%$ & $41,54 \%$ \\
\hline CEARÁ & $51,26 \%$ & $11,96 \%$ & $33,34 \%$ \\
\hline DISTRITO FEDERAL & $19,91 \%$ & $38,86 \%$ & $27,17 \%$ \\
\hline ESPÍRITO SANTO & $22,82 \%$ & $5,27 \%$ & $19,13 \%$ \\
\hline GOIÁS & $26,81 \%$ & $0,51 \%$ & $29,08 \%$ \\
\hline MARANHÃO & $56,76 \%$ & $48,59 \%$ & $47,55 \%$ \\
\hline MATO GROSSO & $27,99 \%$ & $14,32 \%$ & $28,05 \%$ \\
\hline MATO GROSSO DO SUL & $26,92 \%$ & $13,02 \%$ & $27,90 \%$ \\
\hline MINAS GERAIS & $21,51 \%$ & $75,92 \%$ & $24,50 \%$ \\
\hline PARÁ & $54,64 \%$ & $25,66 \%$ & \\
\hline PARAIIBA & $47,09 \%$ & $32,42 \%$ & $31,10 \%$ \\
\hline PARANÁ & $22,78 \%$ & $8,25 \%$ & $18,35 \%$ \\
\hline PERNAMBUCO & $49,93 \%$ & $41,13 \%$ & $43,40 \%$ \\
\hline PIAUÍ & $55,83 \%$ & $0,11 \%$ & $46,31 \%$ \\
\hline RIO DE JANEIRO & $18,16 \%$ & $4,85 \%$ & $22,44 \%$ \\
\hline RIO GRANDE DO NORTE & $44,28 \%$ & $21,28 \%$ & $33,83 \%$ \\
\hline RIO GRANDE DO SUL & $19,19 \%$ & $7,88 \%$ & $11,95 \%$ \\
\hline RONDÔNIA & $39,25 \%$ & $39,59 \%$ & \\
\hline RORAIMA & $18,93 \%$ & $40,77 \%$ & \\
\hline SANTA CATARINA & $15,92 \%$ & $1,56 \%$ & $8,78 \%$ \\
\hline SÃO PAULO & $14,66 \%$ & $46,56 \%$ & $33,09 \%$ \\
\hline SERGIPE & $47,85 \%$ & $8,52 \%$ & $33,41 \%$ \\
\hline TOCANTINS & $58,49 \%$ & $1,28 \%$ & $48,87 \%$ \\
\hline TOTAL & $28,58 \%$ & $29,10 \%$ & \\
\hline
\end{tabular}

* Dados de 1996 do IPEA

** Dados de 1999 da Aneel

Fonte: Adaptado de: Aneel (2000a) e FIPE (2000). 
$\mathrm{Na}$ análise desses dados, observa-se que em vinte Estados brasileiros havia mais domicílios pobres do que consumidores baixa renda, podendo resultar na redução de receita da distribuidora local, caso fosse adotada a metodologia proposta pela FIPE; para outros seis estados, com mais consumidores baixa renda do que domicílios pobres, aumentaria a receita. Somente o Estado de Rondônia possuía aproximadamente o mesmo percentual de consumidores baixa renda e de domicílios pobres, de acordo com a FIPE (2000).

A Figura 3, a seguir, ilustra a situação já apresentada na tabela anterior enfocando alguns estados mais representativos do Brasil.

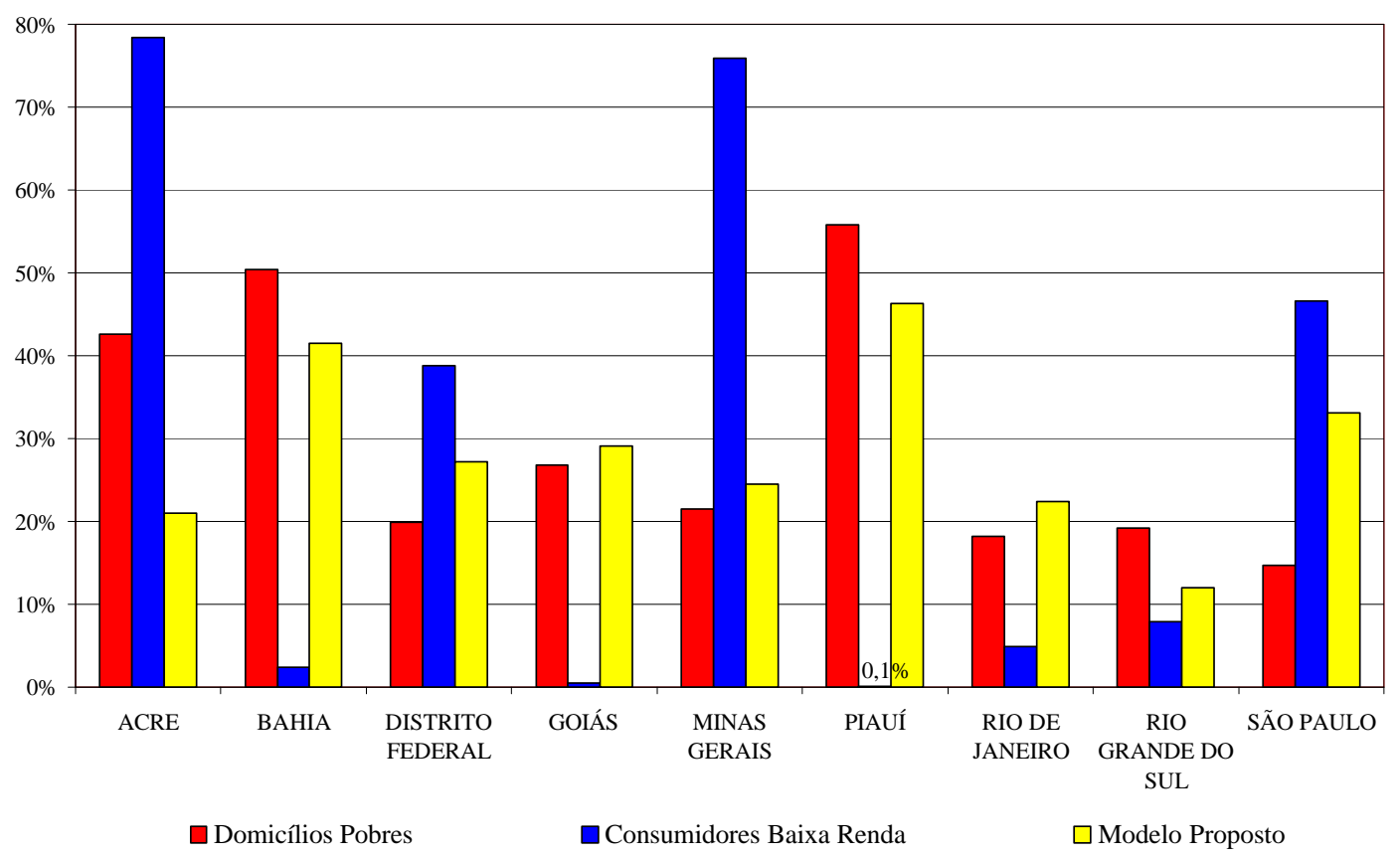

Fonte: Elaborado pelo autor com base em dados da Aneel (2000a) e FIPE (2000).

\section{Figura 3 - Domicílios pobres e consumidores baixa - resultados da aplicação da Metodologia FIPE}

Para completar a análise é necessário citar que a reclassificação dos consumidores da Eletropaulo foi determinada pela Justiça em setembro de 2001, antes da publicação da Lei $n^{\circ} 10.438 / 2002$. Findou uma situação na qual consumidores não-pobres com baixo consumo mensal de energia elétrica tinham direito ao benefício do desconto escalonado destinado essencialmente aos consumidores baixa renda. 


\subsubsection{Considerações}

A proposta de tarifa apresentada pelo Dnaee em 1986 baseava-se no princípio da universalização das necessidades básicas de energia que corresponde ao direito igualitário de todo o cidadão, independentemente da sua condição sócio-econômica, de acesso ao serviço. Os descontos previstos para a quantidade de energia elétrica considerada como essencial deveriam resultar no comprometimento máximo de $4 \%$ do salário mínimo da época. O subsídio seria compensado pela própria classe residencial por meio da tarifa maior para o consumo superior $200 \mathrm{kWh} / \mathrm{mês}$.

Os programas destinados a consumidores baixa renda, que proporcionavam descontos adicionais ou cobrança pela taxa mínima e que possibilitavam a doação dos padrões de entrada, não possuíam base na legislação, além de poderem estimular o desperdício de energia elétrica, pela falta de medição.

A tarifa residencial baixa renda, criada em 1995, empregava a filosofia dos descontos tarifários aplicados aos domicílios pobres. A focalização do programa, no entanto, não foi eficiente, pois os critérios para inclusão da população pobre, definidos pelas próprias distribuidoras, resultaram situações contraditórias, como mencionado anteriormente: Piauí com menos de $1 \%$ de consumidores baixa renda para 56\% de pobres e Minas Gerais com $81 \%$ de baixa renda para $22 \%$ de pobres.

Assim, caracterizam-se como um grande desafio a concepção e a aplicação de uma tarifa social homogênea decorrente de critérios de focalização adequados. A definição desses parâmetros deveria estar centrada no Governo Federal e não nas próprias concessionárias de distribuição, pois se trata de política pública. A publicação da Lei no 10.438/2002 modificou essa situação, impondo parte dessa responsabilidade para a agência reguladora. 


\section{CAPÍTULO 5 - EXPERIÊNCIAS INTERNACIONAIS}

\subsection{EXPERIÊNCIAS INTERNACIONAIS - UNIVERSALIZAÇÃO DO ACESSO}

\subsubsection{Irlanda}

De acordo com Zomers (2001), em meados da década de 1940, a Irlanda criou uma organização independente, a ESB (Electricity Supply Board), com o objetivo de implementar a política de eletrificação com autonomia de operação.

Naquela época cerca de 58\% da população da Irlanda não tinha acesso aos serviços de energia elétrica. $\mathrm{Na}$ área rural havia um potencial de 400 mil ligações das quais somente 12 mil estavam em vilas com mais de 20 domicílios; as demais ficavam em regiões isoladas.

O planejamento e a administração foram centralizados na ESB devido aos altos investimentos por consumidor e à necessidade de especialização no gerenciamento do processo.

O plano de eletrificação rural envolvia a participação das comunidades locais além de ações para integração rural. A estratégia do programa era baseada nos denominados distritos rurais que, em geral, eram áreas, com aproximadamente $65 \mathrm{~km}^{2}$, delimitadas em função da distância entre as redes de distribuição de energia elétrica e dos potenciais beneficiários da eletrificação.

A ESB criou organizações descentralizadas com sede em cada um dos distritos rurais, visando o planejamento, a construção e a implementação da eletrificação rural nas localidades. O objetivo do plano de eletrificação rural era conectar 280 mil consumidores, construindo 125 mil km de linhas de distribuição e de subtransmissão e instalando 100 mil transformadores. O esquema não incluía as vilas com mais de 250 residências, e consumidores isolados com mais de $100 \mathrm{~kW}$ de carga instalada (ZOMERS, 2001). 
A avaliação dos projetos de eletrificação, feito por um comitê local com representantes das diferentes áreas do distrito rural, considerava o número de consumidores envolvidos, a densidade de carga e a receita estimada decorrente dessas ligações. Um importante aspecto foi o estabelecimento de uma taxa fixa para cada consumidor calculada em função da área e do número de cômodos do domicílio.

O princípio utilizado na eletrificação rural era de que a soma anual das taxas fixas pagas pelos consumidores deveria, pelo menos, cobrir os custos anuais estimados em $12 \%$ do capital investido para a infra-estrutura daquela área ${ }^{43}$.

Foi necessária a criação de um fundo de eletrificação rural, pois a maioria dos consumidores rurais possuía renda baixa. Dessa forma, a ESB recebia 50\% de subsídio do governo para expansão da rural. Na maioria dos paises industrializados, a média entre a população rural e urbana permite subsídios cruzados na estrutura tarifária da distribuidora. Na Irlanda, contudo, esse procedimento causaria distorções, devido à expressiva quantidade de consumidores rurais (400 mil), comparados com os urbanos (250 mil).

A ESB adotou tarifas uniformes para toda a Irlanda, embora alguns estudiosos entendam que o princípio de que cada área deva suportar seus próprios custos de suprimento seja o mais adequado.

Segundo Zomers (2001), para suprir mais de 400 mil consumidores foram construídas 15 mil km de linhas trifásicas e 45 mil km de linhas monofásicas, instalados 100 mil transformadores monofásicos e estendidas 45 mil km de linhas de distribuição em tensão secundária.

\subsubsection{Canadá - Província de Ontario}

Na Província de Ontário, Canadá, similarmente ao plano de eletrificação rural desenvolvido na Irlanda, foram definidos distritos rurais, com dimensões em torno de

\footnotetext{
43 De acordo com Zomers (2001), esse percentual considerava taxa de retorno de 5\% a.a., depreciação de $2,5 \%, 0,5 \%$ relativo a um fundo para amortização do investimento feito pelo governo, e custos operacionais estimados em $4 \%$.
} 
$250 \mathrm{~km}^{2}$, determinados pela distância, economicamente viável, para o consumidor ser conectado à rede de distribuição.

Cada distrito rural pagava pelos custos da operação e da manutenção do sistema de distribuição, referentes à sua área, além de contribuir para um fundo de reposição e amortização dos investimentos feitos pelo governo. O critério de avaliação das extensões do sistema de distribuição era muito simples, pois exigia unicamente que o projeto de eletrificação contemplasse, no mínimo, três ligações de propriedades rurais por 1,6 km de linha. A tarifa era constituída pela soma de uma taxa de serviço (função da demanda individual) e de uma taxa de consumo.

\subsubsection{Estados Unidos da América}

Nos Estados Unidos da América, a eletrificação rural iniciou sua expansão a partir da criação da Rural Electrification Administration (REA), um dos programas integrantes do New Deal, desenvolvido nos anos 30 pelo governo americano.

Dessa forma, os primórdios da formação da REA podem ser remetidos à situação socioeconômica vivida pela população rural durante a depressão, e também pela insatisfação com a eletrificação lenta, que era conduzida pelas concessionárias de distribuição existentes.

A principal tarefa da REA é financiar a eletrificação rural tornando disponível recursos para cooperativas e para autoridades locais, bem como para empresas privadas. $\mathrm{O}$ organismo, além de prover empréstimo com taxa de juros de $2 \%$ a.a., também auxilia as empresas nas áreas técnicas administrativa, legal e contábil.

A REA pretendia alocar empréstimos para as concessionárias de distribuição de energia elétrica existentes. Em 1935, um comitê, representante das empresas privadas, produziu uma proposta de eletrificação avaliada pela REA como descontextualizada e complexa, bem como extremamente vaga quanto às tarifas para os consumidores finais. Além disso, considerando o histórico do não atendimento das concessionárias de distribuição, a REA resolveu financiar as organizações sem fins lucrativos, a exemplo das cooperativas de eletrificação rural (ZOMERS, 2001). 
A condição de viabilidade dos projetos era avaliada pela REA com base no atendimento de no mínimo de três propriedades rurais por $1,6 \mathrm{~km}$ de linha de distribuição de energia elétrica.

De acordo com Zomers (2001), em 1938, cerca de 400 projetos de eletrificação rural estavam em implementação, evolvendo cerca de 400 mil propriedades e 2 milhões de pessoas, no âmbito de 45 estados. Em 1961, aproximadamente 98\% das propriedades tinham acesso à energia elétrica, das quais $51 \%$ eram atendidas por cooperativas de eletrificação rural, $43 \%$ por empresas privadas e $6 \%$ por outros órgãos. Atualmente, o índice de eletrificação é de 99\%, o que indica o sucesso do plano de eletrificação rural desenvolvido nos Estados Unidos da América, atribuído à REA, com o auxilio das cooperativas e empresas de eletrificação rural.

Segundo Zomers (2001), no período de 1936 a 1940 houve cerca de duzentos conflitos de interesse entre as concessionárias de distribuição e as cooperativas de eletrificação, como, por exemplo, a obrigação das empresas privadas de fornecer energia elétrica para as cooperativas a preço de atacado, por força de atos das agências estaduais (State Public Service Commission).

Muitas vezes as concessionárias demonstravam mais empenho para eliminar as cooperativas do que para expandir o serviço de energia elétrica na área rural. A distribuidora tentava obter o controle da cooperativa por meio da compra da participação dos seus membros, para então desligar as linhas menos lucrativas e aumentar o preço de energia para os cooperados. Outra ação comum era a construção de linhas de distribuição de energia que cortavam as áreas buscando alcançar os consumidores mais lucrativos (NYE, 1990 apud ZOMERS, 2001).

\subsubsection{Bangladesh}

Em Bangladesh, 74\% da população reside na área rural, o que corresponde a 99 milhões de pessoas, de acordo com dados de Nexant (2004). Dos 15 milhões domicílios rurais somente $15 \%$ estão conectados na rede de distribuição de energia elétrica. 
A responsabilidade pelo suprimento rural é de competência da Bangladesh Rural Electrification Board (BREB), criada pelo governo para implementar especificamente a eletrificação rural por meio da extensão da rede.

O objetivo do programa de eletrificação rural é fornecer energia para $70 \%$ dos domicílios rurais até 2020, utilizando geração distribuída e sistemas individuais de geração de energia por células fotovoltaicas, home solar system, como complementação à expansão da rede de distribuição de energia elétrica.

A BREB é totalmente responsável pela eletrificação rural em todos os seus aspectos, identificando as áreas que serão eletrificadas, organizando as cooperativas de eletrificação rural e iniciando o desenvolvimento rural da região.

As cooperativas são concessões sem fins lucrativos, de propriedades de seus cooperados, consumidores de energia elétrica, e funcionam como um apêndice da BREB. De acordo com Zomers (2001), a rede de distribuição é projetada diferentemente das usuais práticas da expansão com base no crescimento econômico. Do universo de aproximadamente 70 cooperativas planejadas, 67 foram implementas e 57 estão em operação.

A área de cobertura de eletrificação rural varia, em geral, de 100 a $1.500 \mathrm{~km}^{2}$, atendendo de 15 a 30 mil consumidores por meio de 800 a $1500 \mathrm{~km}$ de rede de distribuição de energia.

O desempenho das cooperativas é avaliado anualmente pela BREB por meio de indicadores, com base em dados dos anos anteriores, que visam medir itens como perdas técnicas, receita por $\mathrm{km}$ de rede, crescimento de consumo, aumento de consumidores, dentre outros. Cada objetivo tem um fator de ponderação que pode variar de acordo com os ativos e a tempo de existência da cooperativa.

Há vários mecanismos de subsídio destinados para as cooperativas, os quais compreendem taxas de financiamento, inferiores às praticadas no mercado; compra de energia e subsídios cruzados, conforme apresentado a seguir: 
- compra de energia elétrica diretamente das geradoras com preço subsidiado, em geral com tarifa significativamente menor do que a paga por um consumidor industrial;

- financiamento com taxas de $2 \%$ a.a. com prazos de amortização e carência compatíveis com o fluxo de receita do serviço de eletrificação rural;

- participação de recursos de governo de até $80 \%$ no início da operação da cooperativa;

- taxa de financiamento de $0,75 \%$ para os primeiros anos de operação das cooperativas;

- subsídio cruzado entre consumidores residencial, industrial e comercial;

- subsídio entre cooperativas.

De acordo com Karlson (2002), a BREB já estendeu o serviço de energia elétrica para 2,9 milhões de consumidores. Atualmente são conectados por ano cerca de 390 mil novos consumidores, correspondendo a uma média diária de mais de mil ligações.

\subsection{5 Índia}

De acordo com Nexant (2004), cerca de $70 \%$ da população da Índia se fixa na área rural, correspondendo a 743 milhões de pessoas. Apesar de $85 \%$ das localidades estarem conectadas à rede de distribuição de energia elétrica, somente $37 \%$ dos domicílios rurais tem acesso ao serviço.

O objetivo do programa de eletrificação volta-se para o fornecimento de energia para todas as localidades até 2007, e para todos os domicílios até 2012. O slogan adotado é Electricity for all by 2012, semelhante àquele utilizado pelo programa brasileiro de universalização de "Luz para Todos".

O esquema de eletrificação, análogo ao desenvolvido em Bangladesh, organiza cooperativas de eletrificação rural como estratégia para o desenvolvimento da região. Porém, de um total de 41 cooperativas, somente 20 delas ainda estão em operação. 
Ao contrário de Bangladesh, a base legal na Índia não possibilita às cooperativas prioridades e nem mesmo descontos na compra de energia das geradoras.

Em vários países do Sul da Ásia, a população rural está dispersa em áreas isoladas, nas quais a eletrificação por meio de extensão de rede não é uma solução factível devido ao seu alto custo. As opções para o acesso ao serviço de energia são, nesses casos, geração local com mini-rede de distribuição ou sistemas individuais de geração com base em fontes eólica ou solar fotovoltaica.

Na Índia foi criada, dentro do governo com status de ministério, uma instituição responsável pela pesquisa, desenvolvimento e implementação de planos de eletrificação, com foco em energias renováveis (Ministry of Non-Conventional Energy Sources - MNES).

Esse organismo associado a agências de desenvolvimento de energias renováveis implementou um dos maiores programas de fornecimento de energias renováveis do mundo (KARLSON, 2002). A Tabela 15 a seguir apresenta a amplitude do programa implementado na Índia pelo MNES.

Tabela 15 - Índia - Sistemas de geração de energia por fontes renováveis

\begin{tabular}{l|r|r}
\hline \multicolumn{1}{c|}{ Sistemas de fornecimento de energia } & \multicolumn{1}{|c}{$\begin{array}{c}\text { Número de } \\
\text { sistemas } \\
\text { operando }\end{array}$} & $\begin{array}{c}\text { Capacidade } \\
\text { instalada total } \\
\text { estimada (MW) }\end{array}$ \\
\hline Individual Fotovoltaico & 137.212 & 4,80 \\
\hline Bomba de água (rural) fotovoltaico & 3.575 & 6,40 \\
\hline Micro rede com geração fotovoltaico & 13 & 0,20 \\
\hline Gaseificação de biomassa com rede isolada & 1.719 & 35,50 \\
\hline Micro Central Hidrelétrica & & 226,00 \\
\hline Pequena Central Hidrelétrica & 387 & $1.341,00$ \\
\hline Micro moinho de vento & 45 & 0,090 \\
\hline Geração Eólica & 2507 & $1.267,00$ \\
\hline TOTAL & $\mathbf{1 4 5 . 4 5 8}$ & $\mathbf{2 . 8 8 1 , 0 0}$ \\
\hline
\end{tabular}

Fonte: MNES Annual Report 2000-2001 apud Karlson (2002). 


\subsubsection{Argentina}

Em 1995, em paralelo com a reestruturação do setor elétrico, a Argentina implementou o "Programa de Abastecimento Elétrico para atender a População Rural”, com o intuito de atingir 1,4 milhões de usuários, aproximadamente 300 mil domicílios dispersos e 6 mil serviços públicos como escola e hospitais no período de seis anos (GOUVELLO; MAIGNE, 2003).

O programa contempla duas áreas, dependendo do sistema de atendimento: expansão da rede e geração distribuída. Na primeira área, o governo subsidia totalmente a instalação da rede de distribuição, por meio de fundo proveniente de recursos nacionais e internacionais; o consumidor arca com os custos de fornecimento de energia e da manutenção da rede de distribuição por meio das tarifas pagas à operadora do sistema.

Nas áreas mais isoladas utiliza-se a geração distribuída com base em tecnologia solar, eólica, PCH ou gerador de energia elétrica movido a diesel. O governo outorga a concessão elegendo o menor custo dentre os apresentados pela empresas interessadas em eletrificar uma determinada região.

A concessionária deve atender todos os solicitantes na área exclusiva e subsidiar totalmente os custos iniciais da instalação equipamentos de geração. Esse subsídio será provido pelas receitas futuras dos consumidores, recursos da província e fundo nacional, financiados, em alguns casos, por capital estrangeiro e por organizações multinacionais.

Nesse sistema, os usuários são responsáveis pelos equipamentos instalados em suas casas e devem contribuir com pelo menos $10 \%$ dos custos, o que depende da capacidade que a população local tem de pagar e do porte do sistema de fornecimento de energia elétrica. Assim, os gastos com outras formas de energia, como querosene, velas, lanternas, pilhas, que foram substituídos pela eletricidade, corresponde ao valor dessa contribuição, que é a "propensão a pagar" dos consumidores. 
O governo argentino complementa o subsídio, pagando para a concessionária a diferença entre o custo real do fornecimento de energia elétrica e a capacidade de pagamento do consumidor (GOUVELLO; MAIGNE, 2003).

Por exemplo, na Província de Jujuy o custo mensal de fornecimento é de aproximadamente US\$ 27 para um sistema residencial de energia solar com capacidade de $100 \mathrm{Wp}$, fornecendo $7,5 \mathrm{kWh} / \mathrm{mês}^{44}$. Como a estimativa dos gastos com outras formas de energia é de US\$15/mês para uma necessidade equivalente, o governo arca com um subsídio de aproximadamente US\$ 12 mensais (GOUVELLO; MAIGNE, 2003).

Apesar do sucesso do programa, para Gouvello e Maigne (2003) foram identificados alguns problemas quando os usuários não seguem as normas, e utilizam carga acima da capacidade do equipamento individual de geração de energia elétrica.

\subsubsection{Chile}

Em 1994, mais da metade da população rural do Chile não tinha acesso à energia elétrica. Para mitigar essa situação foi lançado um plano de eletrificação rural com o objetivo de alcançar, em 2000 , o índice de $75 \%$ da população rural com acesso à energia elétrica e até 2004 a totalidade.

O plano concede subsídio, durante o período previsto de 10 anos, para o operador local que ofertar menor custo para prover o serviço de energia elétrica. Apesar de utilizar a competição para outorgar, a sistemática empregada não oferece uma concessão com área exclusiva.

O operador local, trabalhando com a comunidade, se compromete em realizar um número determinado de novas conexões. Para receber o subsídio, esta empresa submete seus projetos para a avaliação da comunidade que, por sua vez, os enviam para o governo regional. Os recursos são alocados para os melhores projetos,

\footnotetext{
${ }^{44}$ Segundo Christophe e Maigne (2003) para esse custo de fornecimento foram considerados um retorno do investimento de $14 \%$, o tempo de vida útil de 15 anos para sistemas solares, com substituição da bateria a cada três anos, operação, manutenção e substituição do controlador a cada sete anos.
} 
avaliados com base na análise de custo e benefício, no compromisso de investimentos do operador e no impacto social.

O percentual do subsídio depende do número de beneficiários, do custo unitário e da necessidade de financiamento. Doações de organismos internacionais também são utilizadas, especialmente para aqueles projetos que envolvem tecnologia experimental, geração individual e outras fontes alternativas.

Os usuários devem arcar com os custos de instalações internas, dos medidores e da conexão à rede. Esses custos correspondem à cerca de $10 \%$ do total do projeto, inicialmente é financiado pela empresa e pago pelos consumidores juntamente às suas contas mensais.

O programa de eletrificação rural no Chile atingiu, em 1999, o índice de $76 \%$ dos domicílios, ultrapassando a meta que previa 75\% (NEXANT, 2004).

\subsection{EXPERIÊNCIAS INTERNACIONAIS - UNIVERSALIZAÇÃO DO USO}

\subsubsection{Inglaterra}

Segundo Moita (2000), a introdução de competição no setor elétrico e de gás canalizado na Inglaterra, tornou inviável o subsídio cruzado para o financiamento do atendimento a consumidores baixa renda. Os consumidores mais rentáveis, que financiariam esse subsídio, são disputados pelas empresas em um mercado competitivo, diferentemente do que ocorre com os consumidores mais pobres.

Nas empresas que atendem consumidores mais pobres, o preço da energia para os demais consumidores seria maior, se houvesse subsídio cruzado. Por isso, essas empresas correriam o risco de perder os usuários rentáveis, que financiariam o subsídio, para outras que não tivessem uma parcela significativa de consumidores pobres.

Dessa forma, a agência reguladora britânica, a pedido do governo, elaborou o Plano de Ação Social para auxiliar os consumidores baixa renda, os fuel poor, definidos como aqueles que gastam mais de $10 \%$ da renda líquida com eletricidade ou gás. 
Segundo Moita (2000), estima-se a existência de 4,3 milhões de pessoas nessa condição, dos quais 400 mil gastariam mais do que $20 \%$ da renda com o consumo de energia.

Uma das propostas estudadas pela agência é a adoção de tarifas especiais para pequena quantidade de consumo de energia, admitindo-se que os fuel poor consumiriam, em geral, abaixo da média. Outro estudo indicou que cerca de metade dos usuários de medidores pré-pago seria baixa renda, o que permitiria à agência direcionar o foco de um programa para essa opção de medição, apesar de incluir indevidamente a outra parcela que não é fuel poor. Uma terceira proposta é o aumento do seguro social que incluiria também os gastos com energia. Contudo, essa solução não garante que o beneficiário utilize esse valor adicional no pagamento do fornecimento energia (MOITA, 2000).

\subsubsection{Estados Unidos da América - Estado da Pensilvânia}

No mesmo marco legal que estabeleceu, em 1996, a competição no setor de energia elétrica no Estado da Pensilvânia, o governo também procurou assegurar o serviço universal para todos os consumidores.

A norma legal, Act $\$ 2803$, define a conservação de energia e a universalização do serviço como políticas, proteções e serviços que auxiliam os consumidores baixa renda a manterem seu fornecimento de energia elétrica em razão da possibilidade de corte por falta de pagamento.

Estabelece que a agência reguladora estadual, Pennsylvania Public Utility Commission (PPUC), assegure fundos apropriados para a implementação da política de conservação de energia e universalização do serviço em todo Estado.

Os programas de universalização implementados no estado da Pensilvânia prestam assistência técnica, visando a redução do consumo de energia, com o Low Income Usage Reduction Programs (LIURP); auxiliam pessoas com necessidades especiais, com o Customer Assistance and Referral Evaluation Services (CARES); e subsidiam parte da energia com o Customer Assistance Programs (CAP) e o Utility Hardship Fund Programs. 
A regulamentação americana define por cliente residencial baixa renda aquele que possui renda familiar bruta igual ou menor do que $150 \%$ do valor da linha de pobreza estimada pelo Governo Federal. Esta linha considera também o número de moradores num mesmo domicílio, conforme se observa na Tabela 16 a seguir.

Tabela 16 - Linha de pobreza - Renda familiar bruta (US\$)

\begin{tabular}{c|c|c|c|c}
\hline \multirow{2}{*}{$\begin{array}{c}\text { Número de } \\
\text { moradores }\end{array}$} & $\begin{array}{c}100 \% \text { Linha de } \\
\text { Pobreza }\end{array}$ & $\begin{array}{c}110 \% \text { Linha de } \\
\text { Pobreza }\end{array}$ & $\begin{array}{c}150 \% \text { Linha de } \\
\text { Pobreza }\end{array}$ & $\begin{array}{c}\text { 200\% Linha de } \\
\text { Pobreza }\end{array}$ \\
& 8.860 & 9.746 & 13.290 & 17.720 \\
\hline 2 & 11.940 & 13.134 & 17.910 & 23.880 \\
\hline 3 & 15.020 & 16.522 & 22.530 & 30.040 \\
\hline 4 & 18.100 & 19.910 & 27.150 & 36.200 \\
\hline 5 & 21.180 & 23.298 & 31.770 & 42.360 \\
\hline 6 & 24.260 & 26.686 & 36.390 & 48.520 \\
\hline 7 & 27.340 & 30.074 & 41.010 & 54.680 \\
\hline 8 & 30.420 & 33.462 & 45.630 & 60.840 \\
\hline cada pessoa adicional & 3.080 & 3.388 & 4.620 & 6.160 \\
\hline
\end{tabular}

Fonte: Pennsylvania Public Utility Commission (2002).

Geralmente, no Estado da Pensilvânia, a renda média anual dos beneficiários dos programas é menor que US\$13.000. Os domicílios têm em média três moradores dos quais dois são menores de 18 anos. Portanto, a renda média dos participantes do programa de conservação de energia e universalização do serviço é inferior ao estabelecido: $150 \%$ da linha de pobreza que corresponde, considerando três pessoas por domicílio, a US\$22.536 (Pennsylvania Public Utility Commission, 2002).

\section{LIURP}

O LIURP é um programa estadual cujo objetivo principal é auxiliar os consumidores residenciais baixa renda a reduzir o uso da energia. O programa identifica problemas e realiza a manutenção no sistema de aquecimento e na isolação do domicílio, incentiva a utilização de lâmpadas fluorescentes compactas e promove instrução sobre a conservação de energia.

O LIURP tem como público-alvo consumidores que apresentam renda anual igual ou inferior a $150 \%$ da linha de pobreza estabelecida pelo governo federal. Porém, a partir 1998, o regulamento permite alocar até $20 \%$ do orçamento do programa em 
consumidores com renda entre $150 \%$ e $200 \%$ da linha de pobreza. O LIURP prioriza os usuários com consumo de energia mais elevado, em geral acima de $6.000 \mathrm{kWh}$ anuais, e que, portanto, oferecem maiores oportunidades para a redução do valor da conta de energia.

Os recursos para o programa estão incluídos nas tarifas dos consumidores residenciais como parte do custo de distribuição. Os níveis de financiamento do LIURP e das necessidades de atendimento para cada concessionária são ajustados nos planos de universalização do serviço (Universal Service Plans) a cada três anos.

\section{CAP}

O programa CAP fornece uma alternativa aos métodos tradicionais de arrecadação para os consumidores baixa renda com dificuldades para o pagamento das contas de energia. Com isso os consumidores pagam valores mensais fixos, que são menores do que aqueles normalmente cobrados na conta.

O valor desses pagamentos é calculado por um dos três critérios: percentual de renda do consumidor (na maioria dos casos); ou desconto na tarifa de energia; ou ainda pelo histórico dos pagamentos do consumidor sobre o qual incide um percentual de desconto.

No caso de pagamentos baseados na renda do consumidor, o número de moradores e a renda familiar determinam o nível de desconto, como demonstrado na Tabela 17 a seguir.

Tabela 17 - Valor da conta de energia em função da renda do consumidor

$$
\begin{array}{c|c}
\begin{array}{c}
\text { Renda do consumidor - Percentual } \\
\text { da linha de pobreza }
\end{array} & \begin{array}{c}
\text { Valor da conta de energia - percentual } \\
\text { da renda do consumidor }
\end{array}
\end{array}
$$

\begin{tabular}{c|c}
$0-50 \%$ & $7 \%-13 \%$ \\
\hline $51 \%-100 \%$ & $11 \%-16 \%$ \\
\hline $101 \%-150 \%$ & $15 \%-17 \%$ \\
\hline
\end{tabular}

Fonte: Pennsylvania Public Utility Commission, 2002. 
Para permanecer no programa CAP, além de efetuar os pagamentos mensais, o consumidor deve informar as eventuais alterações na renda, receber serviço de orientação para a conservação de energia, reduzir o consumo para um nível préestabelecido e também solicitar sua inclusão no programa federal de auxílio LIHEAP.

\section{CARES}

O programa CARES é direcionado às pessoas com necessidades especiais, como por exemplo, com doenças graves, inválidos, idosos. Esse programa fornece três serviços principais: consultoria para o gerenciamento do consumo de energia, relacionamento ou comunicação com empresas de serviços públicos visando a continuidade do fornecimento do serviço e o encaminhamento dos beneficiários para programas específicos de assistência social e saúde.

Com a expansão do programa CAP pelas concessionárias, o CARES transformou-se em um dos seus componentes. A maioria dos consumidores recebe os serviços do CARES durante seis meses. Se a incapacidade de pagamento do consumidor não for resolvida nesse período, a empresa o transferirá do CARES para o CAP.

\section{Hardship Funds}

Os fundos da concessionária Hardship Funds fornecem auxílio financeiro aos consumidores não incluídos em outros programas ou àqueles que ainda têm a necessidade de auxílio, depois que os recursos recebidos de outros programas se esgotarem.

Este programa efetua pagamentos diretamente às companhias de energia, em nome dos clientes selecionados. A principal fonte de recursos dos Hardship Funds provém de contribuições dos acionistas, dos empregados e dos consumidores das concessionárias.

\section{LIHEAP}

O Low Income Home Energy Assistance Program (LIHEAP) é um programa do governo federal americano, que destina parte dos seus recursos para o pagamento de 
contas de energia dos consumidores baixa renda.

O regulamento do programa estabelece, como critério para inclusão do consumidor, o nível máximo de renda até $150 \%$ da linha de pobreza definida pelo governo federal ou $60 \%$ da renda média do Estado que, no entanto, não pode ser inferior a $110 \%$ da linha de pobreza.

\subsubsection{Guatemala}

O acordo assinado pelo governo da Guatemala com o Fundo Monetário Internacional (FMI) em 2002, dentre outros pontos, incentiva o aprimoramento do foco dos subsídios sobre a energia elétrica (PINOT, 2004).

Com esse fim, o governo propôs a alteração no limite de consumo de $300 \mathrm{kWh} / \mathrm{mês}$, utilizado como critério anterior para subsidiar o consumo de energia elétrica. O novo valor é de $100 \mathrm{kWh} / \mathrm{mês}$, estimado com base no consumo associado a linha de pobreza.

De acordo com dados do governo apresentados por Pinot (2004) a linha de indigência e de pobreza corresponderiam a uma renda mensal de US\$ 65 e de US\$ 215 , respectivamente ${ }^{45}$. Os consumos médios de energia associados a situações de indigência e de pobreza estimados no estudo correspondem a $24 \mathrm{kWh} / \mathrm{mês}$ e $53 \mathrm{kWh} / \mathrm{mês}$.

Dessa forma, o subsídio até $300 \mathrm{kWh} / \mathrm{mês}$ estaria beneficiando indevidamente consumidores com renda maior do que a estipulada pela linha de pobreza, constituindo, portanto, uma justificativa para a revisão do valor atribuído ao limite de consumo de energia para a obtenção do subsídio.

De acordo com Pinot (2004), a alteração do limite possibilitará a redução da tarifa de energia elétrica para os demais consumidores residenciais, de US\$ 176 para US\$ 162 por MWh. A tarifa de energia para consumidores baixa renda é de aproximadamente US\$ 81 por MWh, correspondendo a um desconto superior a 50\%. Em dezembro de

\footnotetext{
45 Taxa de câmbio de dez/2003, utilizada para conversão: 1 US\$ = Q 8,01 (Quetzal). Fonte: Banco Central da Guatemala.
} 
2003, 1,625 milhão dos consumidores da Guatemala (87,8\%) eram beneficiados com o desconto tarifário; o novo limite previsto de $100 \mathrm{kWh}$ para a aplicação do subsídio reduzirá esse conjunto para aproximadamente 1,170 milhões $(63,2 \%)$.

\subsubsection{Argentina - Província de Buenos Aires}

O marco regulatório argentino estabelece que os custos dos serviços, em nenhum caso, podem ser recuperados através da cobrança de tarifas de outros usuários, não permitindo, portanto, subsídio cruzado entre classes de consumidores, segundo Moita (2000).

Porém, o agravamento da situação econômica na Argentina e a conseqüente dificuldade de pagamento de parcela da população levaram à desconexão de muitos consumidores. Segundo Sanchez (2003), a mobilização da sociedade organizada na cidade de Mar del Plata (Província de Buenos Aires) resultou alguns acordos com a distribuidora:

- facilitar a religação dos consumidores diminuindo a taxa cobrada pelo serviço;

- financiamento das dividas;

- tarifa mínima de $\$ 20$ (peso argentino) ${ }^{46}$, equivalente ao consumo de $150 \mathrm{kWh}$ para consumidores de bairros carentes.

Este conflito incentivou outras exigências, no âmbito nacional, como a definição legal de uma tarifa social, a garantia do fornecimento com tarifas especiais para os desempregados, a diminuição da carga tributária e a universalidade do serviço de energia elétrica.

Em complemento, o autor ressalta que em junho de 2000 o Poder Executivo da Província de Buenos Aires estabeleceu o Decreto 1.522, que determina o livre acesso, não discriminatório e generalizado ao serviço público de energia elétrica. $\mathrm{O}$ regulamento cria a Tarifa de Interesse Social (TIS), assegurando uma redução de

\footnotetext{
${ }^{46} \mathrm{Na}$ época desses acordos, inicio de 2000, um peso argentino correspondia a um dólar americano.
} 
40\% para todos os consumidores residenciais que não pudessem pagar a tarifa vigente.

Em 2001, a Ley provincial 12.698 estabeleceu que as distribuidoras da província de Buenos Aires poderiam conceder aos consumidores residenciais com recursos escassos, impossibilitados de acessar ou manter o serviço mínimo de energia elétrica, tarifas $40 \%$ inferiores às reguladas para consumo até $150 \mathrm{kWh} / \mathrm{mês}$. As distribuidoras podem também, nesse caso, instalar limitador de corrente, com reposição automática, com capacidade de no mínimo 6 A.

Para os consumidores baixa renda, a norma legal reduz as alíquotas de impostos de competência da província e incentiva os municípios a aderir ao programa, sancionando leis para reduzir as alíquotas de impostos municipais, como beneficio.

Um ponto a ser destacado é que a Lei não prevê a obrigatoriedade da distribuidora aderir ao programa. Para Sanchez (2003), considerando o benefício, o valor pago pelo consumidor corresponde somente aos custos de geração de energia. Dessa forma, o restante, denominado de valor agregado de distribuição, que engloba os custos de operação e manutenção da rede de distribuição e a remuneração dos investimentos, não é recuperado pela distribuidora. Não há subsídio cruzado que auxilie a empresa a recuperar esses custos; assim sendo, devem ser arcados com uma porcentagem dos ganhos da distribuidora. Porém, algumas empresas não aplicam a TIS, pois entendem que o subsídio deveria ser coberto pelo Estado para manter a equação econômico-financeira vigente na assinatura do contrato de concessão.

Para o referido autor, a aplicação da TIS é, basicamente, um programa para regularizar os consumidores clandestinos, com o intuito de reduzir as perdas por furto de energia e os riscos decorrentes de ligações inadequadas.

A avaliação dos potenciais beneficiários da TIS é feita diretamente pela distribuidora, auxiliada, em geral, pela associação de moradores de bairros carentes. Eventualmente a seleção conta com o apoio de profissionais ligados à assistência social do governo municipal e da província. 
A mobilização da sociedade e a criação da TIS, na Província de Buenos Aires, incentivaram discussões sobre o assunto com a realização de simpósios com o tema Universalidad de los servicios essenciales y tarifa social, em 2000 e em 2001.

\subsection{CONSIDERAÇÕES}

Em relação à universalização do acesso, as pesquisas incluíram tanto países em desenvolvimento como países desenvolvidos. Observa-se que as cooperativas foram parte importante dos programas de eletrificação rural que em várias regiões eram conduzidos pelo governo central.

Vários planos de eletrificação utilizavam a estratégia de focalizar a eletrificação em distritos rurais, determinados pela distância, economicamente viável, da conexão à rede de distribuição. Esses distritos eram direcionados para o atendimento por cooperativas, planejadas pelo órgão responsável pela eletrificação.

Como a maioria dos consumidores rurais era de baixa renda, a criação de um fundo de eletrificação rural adquiriu fundamental importância para subsidiar a expansão da eletrificação rural. Além disso, em alguns casos havia mecanismos de subsídio para as cooperativas, que compreendiam taxas de financiamento inferiores àquelas praticadas no mercado; compra de energia diretamente das geradoras com preço diferenciado e subsídios cruzados entre consumidores e cooperativas.

$\mathrm{Na}$ Índia, o ministério responsável por fontes de energia, associado a agências de desenvolvimento, implementou um dos maiores programas de fornecimento de energia renováveis do mundo, totalizando 145 mil sistemas, com a capacidade instalada de $2.881 \mathrm{MW}$.

No Chile, a concessão de áreas isoladas é feita pelo menor custo apresentado pelas empresas interessadas em eletrificar uma determinada região, porém não implica o direito de atendimento exclusivo na área de concessão. O consumidor deve contribuir com pelo menos $10 \%$ dos custos, de acordo com a capacidade de pagar da população local, calculada com base nos gastos com outras formas de energia anteriormente utilizadas. 
Quanto aos programas de atendimento para a população de baixa renda, observa-se que, em geral, nos países que implementaram a competição na comercialização de energia para consumidores residenciais a filosofia empregada é do realismo tarifário, auxiliado por programas compensatórios.

Embora possa ocorrer transferência de receita tarifária entre classes de consumidores decorrente da estrutura da tarifa dos serviços de distribuição de energia elétrica, não é possível aplicar esse subsídio cruzado na parcela competitiva do fornecimento de energia. Além do mais, em alguns países, o próprio marco regulatório não permite subsídio cruzado entre classes de consumidores (MOITA, 2000).

O público-alvo, tanto nos programas compensatórios como nos programas de descontos tarifários, é a população pobre definida, em geral, por uma linha de pobreza oficial, como ocorre, por exemplo, na Guatemala e nos Estados Unidos. No caso da Inglaterra, diferentemente, o critério que define os consumidores baixa renda é o comprometimento de $10 \%$ da renda familiar com energia. Nota-se que no programa CAP, no Estado da Pensilvânia, há também um valor máximo de comprometimento da renda com gastos com energia, não para classificar os beneficiários, mas para calcular o subsídio do programa.

Na Província de Buenos Aires, a distribuidora pode conceder aos consumidores baixa renda descontos de $40 \%$ nas tarifas de energia elétrica para consumo de até $150 \mathrm{kWh} / \mathrm{mês}$. É importante destacar que a norma legal reduz, adicionalmente, as alíquotas de impostos de competência da província, bem como incentiva os municípios a aderir ao programa diminuindo também as alíquotas de impostos municipais incidentes na conta de energia elétrica dos consumidores baixa renda.

A distribuidora não é obrigada a aderir ao programa, pois não há fonte de recursos ou subsídio cruzado para a empresa recuperar esses custos devendo, portanto, ser arcado com uma porcentagem dos seus ganhos. 


\section{CAPÍTULO 6 - LEI N 10.438/2002 E REGULAMENTAÇÃO ATUAL}

\subsection{INTRODUÇÃO}

A falta de investimentos em geração de energia elétrica, agravada pela hidrologia desfavorável no início de 2001, obrigou a implantação de racionamento denominado de Programa Emergencial de Redução de Consumo de Energia Elétrica (Percee), na tentativa de diminuir em cerca de $20 \%$ o consumo, considerando a necessidade manter os níveis de segurança dos reservatórios dos sistemas Sudeste/Centro-Oeste e Nordeste.

O sucesso do plano, em grande parte devido à adesão maciça da população, causou uma redução na receita das distribuidoras de energia maior do que os $20 \%$ de energia racionada. Ao mesmo tempo, as geradoras ficaram expostas ao Preço MAE ${ }^{47}$ pela não geração de energia elétrica.

Essa intervenção do governo no mercado acarretou desequilíbrio nas contas das empresas que, num contexto de indefinições regulatórias, apresentaram reivindicações que podem ser resumidas nas denominadas controvérsias do setor elétrico: a aplicação do Anexo $\mathrm{V}^{48}$ ou Acordo de Recompra ${ }^{49}$, o reajuste da Parcela $\mathrm{A}^{50}$ e a exposição à denominada Energia Livre ${ }^{51}$.

${ }^{47}$ Preço MAE (PMAE). Valor da energia elétrica negociada no Mercado de Curto Prazo (Mercado Spot), ambiente no qual se negocia a energia não contratada bilateralmente ou as sobras dos contratos bilaterais. O preço do MAE varia conforme a relação de oferta e demanda de energia. Com o novo modelo do setor implementado pela Lei $\mathrm{n}^{\circ} 10.848 / 2004$, este preço passa a ser denominado de PLD (Preço de Liquidação de Diferenças).

48 Anexo V. Documento que integra os contratos de compra e venda de energia, firmados entre geradoras e distribuidoras com preços fixados pela Aneel. (contratos iniciais). Esse anexo determina a compra compulsória, pelas geradoras, de parte da energia economizada durante períodos de racionamento. $\mathrm{O}$ valor de compra dessa energia é maior que o estabelecido nos contratos iniciais.

49 Acordo de Recompra. Acordo entre geradores e distribuidores de energia comprometidos com contratos iniciais que estabelece que as distribuidoras de energia acumulam créditos em energia para utilização futura quando a carga do sistema foi menor do que a energia contratada. Esses créditos, quando contraídos, contribuem para reduzir a exposição dos geradores no momento da transação e, uma vez acumulados para os meses seguintes, contribuem para reduzir também a exposição dos distribuidores em momentos futuros.

${ }^{50}$ Parcela A. Também chamada de custos não gerenciáveis, são custos que independem de decisões das concessionárias, como a CCC, RGR, CDE, taxa de fiscalização, Compensação Financeira pela Utilização de Recursos Hídricos (CFURH); energia adquirida de Itaipu para revenda convencional; 
É necessário ressaltar que os contratos assinados pelas empresas distribuidoras de energia elétrica garantem a manutenção do equilíbrio econômico e financeiro das concessões, assim como os contratos iniciais garantem aos geradores equilíbrio econômico-financeiro e proteção no caso de hidrologia desfavorável. O Governo Federal propôs, então, no âmbito de um processo que ficou conhecido como Acordo Geral do Setor, a compensação dessas perdas por meio de um empréstimo do Bndes a cada distribuidora, a ser pago com um aumento adicional na tarifa denominado de recomposição tarifária extraordinária ${ }^{52}$.

O acordo foi implementado pela Medida Provisória $n^{\circ} 14 / 2001$. No processo de conversão, o Congresso Nacional incorporou três pontos do Projeto de Lei $n^{\circ} 2.905$ que já tramitava na Casa:

- a criação de um programa de incentivo às fontes alternativas de energia (Proinfa);

- uma nova definição de critérios para o enquadramento na subclasse residencial baixa renda;

- a proposta de universalização do acesso, a ser implementada por meio de uma sistemática de metas e áreas crescentes de universalização.

O Projeto de Lei foi aprovado rapidamente, em razão da urgência das empresas pelos recursos do Bndes, resultando na Lei $\mathrm{n}^{\circ}$ 10.438/2002, que é o marco legal do processo de universalização.

encargos pelo uso da Rede Básica; transporte da energia gerada por Itaipu, e encargos de conexão do sistema e compra de energia; esta última determinada pela Lei ${ }^{\circ}$ 10.848/2004.

${ }^{51}$ Energia Livre - Energia não contratada e comercializada no mercado de curto prazo (spot).

52 A recomposição tarifária extraordinária corresponde à aplicação de $2,9 \%$ para os consumidores integrantes das Classes Residencial, Rural e iluminação pública e de até 7,9\% para os demais consumidores. 


\subsection{LEI N 10.438/2002 E UNIVERSALIZAÇÃO DO ACESSO}

\subsubsection{Lei no 10.438/2002}

A Lei $n^{\circ} 10.438 / 2002$ foi um importante passo na definição das responsabilidades pela universalização. Atribuiu à Aneel a tarefa de estabelecer metas de universalização do acesso ao serviço público de energia elétrica, utilizando uma sistemática de áreas crescentes nas quais o atendimento de novas ligações deverá ser realizado sem ônus de qualquer espécie para o solicitante, conforme transcrição, a seguir, da redação original:

Art. 14. No estabelecimento das metas de universalização do uso da energia elétrica, a Aneel fixará, para cada concessionária e permissionária de serviço público de distribuição de energia elétrica:

I - áreas, progressivamente crescentes, em torno das redes de distribuição, no interior das quais a ligação ou aumento de carga de consumidores deverá ser atendida sem ônus de qualquer espécie para o solicitante;

II - áreas, progressivamente decrescentes, no interior das quais a ligação de novos consumidores poderá ser diferida pela concessionária ou permissionária para horizontes temporais pré-estabelecidos pela Aneel, quando os solicitantes do serviço serão então atendidos sem ônus de qualquer espécie. (grifos nossos).

Para fixação das áreas, segundo a redação original, deveriam ser levadas em conta taxas de atendimento da distribuidora, de forma global e desagregada por município, bem como a capacidade técnica e econômica para o atendimento das metas de universalização. A agência deveria estabelecer mecanismos que possibilitassem ao futuro cliente, localizados em áreas não imediatamente atendidas, a antecipação de sua ligação, mediante restituição posterior do valor investido.

A norma legal, em seu art. 14, $\S 7^{\circ}$, determinou que a partir de 31 de julho de 2002 novos pedidos de ligação, cujo fornecimento pudesse ser realizado mediante a extensão de rede em tensão secundária de distribuição, ainda que fosse necessário realizar reforço ou melhoramento na rede primária, deveriam ser atendidos sem ônus para o consumidor. Este procedimento transitório vigoraria até que a agência reguladora definisse a sistemática das áreas para atendimento sem ônus. 
Estabeleceu também que a não fixação das áreas de universalização no prazo de um ano de sua publicação implicaria a obrigação de atendimento dos pedidos de ligação sem qualquer espécie ou tipo de ônus para o solicitante em toda a área concedida ou permitida $\left(\operatorname{art} .14, \S 6^{\circ}\right)$.

$\mathrm{O}$ art. 13 criou a Conta de Desenvolvimento Energético (CDE), com duração de 25 anos, visando o desenvolvimento dos Estados, a competitividade de fontes eólicas, pequenas centrais hidrelétricas, biomassa e gás natural, e carvão mineral nacional no sistema interligado e a promoção da universalização do serviço de energia elétrica em todo o território nacional.

$\mathrm{O}$ art. 15 estabeleceu, complementarmente, um possível instrumento para o processo de universalização: a licitação para outorga de permissões de serviço público de energia elétrica, em áreas já concedidas.

A Lei $n^{\circ} 10.438 / 2002$ introduziu a obrigação da universalização do acesso ao setor elétrico. Com isso rompeu-se um paradigma que perdurava desde a constituição do setor: a responsabilidade financeira do consumidor solicitante, geralmente "pioneiro", pela extensão da rede, posteriormente na qual se conectariam novos consumidores a custos mais baixos.

Entretanto, é necessário compatibilizar a nova responsabilidade da distribuidora pelo custo integral das obras necessárias para o atendimento aos consumidores com a garantia legal do direito ao equilíbrio econômico financeiro do contrato de concessão. Dessa forma, a origem dos recursos só pode decorrer da tarifa cobrada dos consumidores já conectados, ou do Governo, por meio dos impostos pagos pelos contribuintes.

Esta alocação dos recursos e outras questões permearam o processo de regulamentação da universalização, que ainda não está totalmente completado, conduzido pela Aneel e pelo Governo Federal em um período de transição de administrações. 


\subsubsection{Processo de regulamentação da Lei $n^{0}$ 10.438/2002}

Após a publicação da Lei n ${ }^{\circ} 10.438 / 2002$, iniciaram-se estudos para regulamentá-la. No âmbito federal dois grupos discutiam a questão: a Aneel, que detinha a obrigação legal de elaborar as regras para as distribuidoras, e o Comitê Técnico 7 Universalização no Fornecimento de Eletricidade (CT-7), formado no âmbito do Conselho Nacional de Política Energética (CNPE) ${ }^{53}$, com integrantes dos ministérios, universidades, agentes setoriais, organizações não governamentais e da própria Aneel.

O CT-7 objetivava apresentar propostas ao CNPE, que poderiam ser encaminhadas, e eventualmente incorporadas pela Aneel, na regulamentação da Lei nº 10.438/2002 e outras recomendações, nas áreas de desenvolvimento regional e combate à pobreza, de responsabilidade do Poder Executivo (PEREIRA; MACHADO, 2004).

As principais questões discutidas eram estas: a amplitude da universalização, a utilização de sistemas descentralizados onde não fosse possível a extensão de rede, a fonte dos recursos para cobrir possíveis desequilíbrios no contrato de concessão das distribuidoras e o prazo adequado para o atendimento pleno.

Essas questões remetiam-se à definição de universalização: abrangeria todas as classes de consumidores em todos os níveis de tensão ou deveria se restringir aos consumidores baixa renda, rurais e urbanos.

Os recursos da CDE estavam, na época, direcionados para a energia produzida a partir de fontes eólica, pequenas centrais hidrelétricas, biomassa, gás natural e carvão mineral nacional, além da universalização. O Decreto $n^{\circ} 4.541 / 2002$ permitia que somente parte dos recursos da CDE, aqueles oriundos das multas da Aneel e do Uso do Bem Público (UBP), fosse destinada para a universalização, o que não seria

\footnotetext{
53 Conselho Nacional de Política Energética (CNPE). Órgão de assessoramento do Presidente da República, tem como finalidade formular políticas e diretrizes para o setor de energia. Criado em agosto de 1997, o CNPE é presidido pelo ministro de Minas e Energia e conta com a participação de vários ministros, representantes da sociedade, da universidade e dos Estados. Em junho de 2002, o CNPE passou a abrigar a Câmara de Gestão do Setor Elétrico (CGSE), substituta da Câmara de Gestão da Crise do Setor Elétrico (GCE), criada para gerir o racionamento de energia e os problemas do setor elétrico.
} 
suficiente para atender a todos em um prazo adequado. Dessa forma, naquela época, era necessário viabilizar recursos adicionais para a universalização.

Segundo Pereira e Machado (2004), analisando cenários que envolviam, dentre outros fatores, prazos diferenciados (2010, 2012 e 2015) e recursos disponíveis, o CT-7 concluiu seus trabalhos com as seguintes recomendações, quanto à abrangência e prazos:

- a universalização deveria alcançar todos os potenciais consumidores que pudessem ser atendidos em baixa tensão;

- a meta de universalização poderia ser 2010, para todas as regiões, embora com impacto tarifário, variando muito entre as diversas áreas de concessão $^{54}$.

A Aneel, devido ao prazo de um ano, determinado pela Lei para sua regulamentação, realizava estudos mais aprofundados, contratando consultores para estudar os possíveis impactos tarifários, o uso de fontes alternativas e metodologias para definição das áreas de universalização (ANEEL, 2002a).

A estratégia inicial do regulador era emitir uma resolução que, além dos prazos para as distribuidoras, fornecesse diretrizes mais detalhadas para os Planos de Universalização a serem apresentados pelas distribuidoras, quanto a estratégias de identificação de mercado, opções tecnológicas e padrões aceitáveis.

Desde a publicação da Lei $\mathrm{n}^{\circ}$ 10.438/2002, a Aneel expôs a necessidade das definições governamentais de política pública, formuladas pelo Ministério de Minas e Energia, para poder exercer a incumbência legal de definir, tecnicamente, as metas de universalização para as distribuidoras. Conforme apresentado no III Workshop do Programa Luz no Campo (ANEEL, 2002a), a agência solicitou posicionamento do MME em relação a três pontos, considerados como definição de Política de Governo:

\footnotetext{
${ }^{54} \mathrm{Na}$ determinação desse prazo foram consideradas, pelo CT-7, as seguintes premissas quanto aos recursos disponíveis: $\mathrm{R} \$ 500$ milhões anuais da RGR; quotas da CDE, além dos recursos provenientes de UBP e multas da Aneel, direcionadas para universalização; a CDE não cobriria o subsídio para os consumidores baixa renda.
} 
a amplitude da universalização, a definição dos recursos e os impactos tarifários admitidos.

Provavelmente o processo eleitoral em curso na época tenha contribuído para o adiamento dessas definições, como o alcance da universalização. No fim do governo Fernando Henrique Cardoso, em 23 de dezembro de 2002, foi promulgado o Decreto $\mathrm{n}^{\circ} 4.541$, regulamentando alguns pontos da Lei $\mathrm{n}^{\circ} 10.438 / 2002$, dentre eles o art. 13 que trata da CDE e o art. $3^{\circ}$ que se refere ao Proinfa.

Em 2003 Luiz Inácio Lula da Silva assumiu a presidência da República, demonstrando posição crítica a respeito das políticas adotadas por seu antecessor no setor elétrico, inclusive sobre o papel das agências reguladoras. Iniciou-se um debate sobre os limites de ação das agências, pois o Poder Executivo entendia que as agências atuavam como formuladoras ativas de políticas, responsabilidade que seria exclusivamente do Governo.

Sem se aprofundar no mérito dessa discussão, observa-se que não há uma fronteira bem definida sobre as políticas públicas e a regulamentação ${ }^{55}$. Na prática, o MME não formulava políticas, e a Aneel, em razão de suas obrigações constantes na Lei n ${ }^{\circ} 10.438 / 2002$, assumia o papel de definição dos critérios da universalização.

Em meio às indefinições da política de universalização, esse debate levou a agência a recuar na intenção de realizar uma regulamentação mais detalhada sobre o processo de universalização.

Em abril de 2003, perto do prazo final imposto pela Lei ${ }^{\circ} 10.438 / 2002$ para a regulamentação ${ }^{56}$, a Aneel apresentou em audiência pública uma proposta de resolução que definia prazos para a universalização do acesso. O processo foi rápido e no dia 29 de abril de 2003 foi publicada a Resolução no 223/2003, regulamentando, no mínimo necessário, os pontos da Lei $\mathrm{n}^{\circ}$ 10.438/2002, referentes à universalização.

\footnotetext{
${ }^{55}$ Sobre o assunto ver Marques (2003).

${ }^{56}$ A Lei ${ }^{\circ}$ 10.438/2002 determinava o prazo de um ano, contado a partir de sua publicação, para que a Aneel fixasse as áreas de universalização. No caso de não cumprimento do prazo e até que fossem definidas as áreas, a obrigação das distribuidoras de atendimento, sem qualquer espécie ou tipo de ônus para os solicitantes, aplicar-se-ia a toda a área de concessão.
} 


\subsubsection{Metas estabelecidas pela Aneel}

A Resolução $n^{\circ}$ 223/2003 originalmente determinava que consumidores de todas as classes não mais seriam obrigados a arcar com despesas para sua ligação à rede elétrica, que passavam a ser de responsabilidade exclusiva das distribuidoras.

Até essa data, o atendimento ao consumidor que exigisse a execução de obras era realizado a partir do cálculo do limite de investimento de responsabilidade da distribuidora. A diferença entre tal limite e o custo total das obras necessárias ao atendimento, se positiva, deveria ser integralmente paga pelo interessado, conforme discutido no Capítulo 3.

Este regulamento determina o atendimento gratuito a novos pedidos de ligação que possam ser ligados por meio da extensão da rede secundária, mantendo a sistemática adotada pela Lei $\mathrm{n}^{\circ} 10.438 / 2002$ para o período até a sua regulamentação pela agência $^{57}$. Assim, segundo a Aneel (2003a), o limite de expansão da rede secundária representa as áreas sobre as quais se refere o Art. 14, inciso I, da Lei n ${ }^{\circ}$ 10.438/2002.

Quando a solicitação do consumidor demandar investimentos na expansão da rede primária de distribuição, as distribuidoras cumprem os prazos previstos em seus respectivos planos de universalização. Assim, além das metas iniciais para 2003 (atendimento de extensão da rede secundária), a Aneel também estabelece o horizonte em que deverá ser atingida a universalização para cada distribuidora, de modo que o consumidor possa ter o conhecimento do ano a partir do qual será atendido gratuitamente, nesse caso de necessidade de obras de extensão da rede primária.

A resolução conceituava, originalmente ${ }^{58}$, a universalização como o atendimento a $\underline{\text { todos }}$ os pedidos de ligação ou de aumento de carga de consumidores nos prazos

\footnotetext{
57 A Lei no 10.438/2002 determinava que, a partir de 31 de julho de 2002 e até que a Aneel regulamentasse a sistemática de atendimento por área, as distribuidoras deveriam atender, obrigatoriamente e sem qualquer ônus para o consumidor, ao pedido de ligação cujo fornecimento pudesse ser realizado mediante a extensão de rede em tensão secundária de distribuição, ainda que fosse necessário realizar reforço ou melhoramento na rede primária.

58 Com a alteração promovida pela Lei no 10.762/2003, a Aneel revisou a abrangência da universalização, conforme será discutido no próximo item.
} 
previstos nas Condições Gerais de Fornecimento.

Dessa forma, se for conveniente, o consumidor pode efetuar a antecipação da ligação, arcando inicialmente com os custos. Nesse caso, os interessados serão ressarcidos pela distribuidora a partir do ano previsto para a extensão do serviço àquele consumidor. Os valores antecipados deverão ser corrigidos com base no IGPM, mais juros de $0,5 \%$ ao mês.

A estratégia empregada na regulamentação foi a de dividir as distribuidoras em 5 grupos com anos diferenciados para se atingir a universalização, calculados em função do índice de atendimento da distribuidora e da sua capacidade técnica e econômica, conforme Tabela 18 a seguir. Quanto maior o índice de atendimento diferença entre o número de domicílios com energia e o total de domicílios estimados pelo Censo 2000 - menor será o prazo para a universalização.

Tabela 18 - Prazos Limites para a Universalização na Área de Concessão

\begin{tabular}{c|c}
\hline $\begin{array}{c}\text { Índice de Atendimento } \\
\text { da Concessionária }\end{array}$ & $\begin{array}{c}\text { Prazo Máximo para Universalização na } \\
\text { Área de Concessão }\end{array}$ \\
\hline $\mathrm{Ia}>99,50 \%$ & 2006 \\
\hline $98,00 \%<\mathrm{Ia}<99,50 \%$ & 2008 \\
\hline $96,00 \%<\mathrm{Ia}<98,00 \%$ & 2010 \\
\hline $80,00 \%<\mathrm{Ia}<96,00 \%$ & 2013 \\
\hline $\mathrm{Ia}<80,00 \%$ & 2015 \\
\hline
\end{tabular}

Fonte: Resolução no 223/2003.

Além dessa meta para a distribuidora, a resolução da Aneel fixa também outras específicas para cada um dos municípios atendidos pelas empresas, em função do índice de atendimento da localidade. Quanto menor for o indicador, maior será o tempo para que a distribuidora possa universalizar o município, conforme exemplifica Tabela 19 a seguir. 
Tabela 19 - Prazo para Universalização nos Municípios

\begin{tabular}{c|c}
\hline $\begin{array}{c}\text { Índice de Atendimento } \\
\text { Do Município (Ia) }\end{array}$ & $\begin{array}{c}\text { Prazo Máximo para Universalização no } \\
\text { Município }\end{array}$ \\
\hline $\mathrm{Ia}>96,00 \%$ & 2004 \\
\hline $90,00 \%<\mathrm{Ia} \leq 96,00 \%$ & 2006 \\
\hline $83,00 \%<\mathrm{Ia} \leq 90,00 \%$ & 2008 \\
\hline $75,00 \%<\mathrm{Ia} \leq 83,00 \%$ & 2010 \\
\hline $65,00 \%<\mathrm{Ia} \leq 75,00 \%$ & 2012 \\
\hline $53,00 \%<\mathrm{Ia} \leq 65,00 \%$ & 2014 \\
\hline $\mathrm{Ia} \leq 53,00 \%$ & 2015 \\
\hline
\end{tabular}

Fonte: Resolução nº 223/2003.

A distribuidora pode adotar um ano diferente do estabelecido no quadro anterior, desde que justifique técnica e economicamente e não ultrapasse o ano para vigência da universalização de sua área de concessão. Esta sistemática também é válida para o caso do município tiver um horizonte maior para atingir a universalização do que a empresa: o ano previsto para universalização da distribuidora prevalece.

O Plano de Universalização, elaborado pela distribuidora e aprovado pela Aneel, para o atendimento de todas as solicitações de novas ligações, no período de $1^{\circ}$ de janeiro de 2004 até o término do ano previsto para o alcance da universalização é constituído por um conjunto de Programas Anuais de Expansão do Atendimento até o limite definido para a universalização.

Os Programas Anuais devem contemplar, para cada município, metas para a extensão de redes de distribuição primária e secundária e para a ligação de novas unidades consumidoras sem ônus de qualquer espécie.

Além das ligações decorrentes da extensão da rede secundária de distribuição, as empresas definem para cada município, ou conjunto de municípios, o número de consumidores que serão atendidos e respectivos percentuais demonstrando a evolução anual até o alcance da universalização.

Os Programas Anuais de Expansão do Atendimento contém, no mínimo, as seguintes informações, por município:

- metas de expansão da rede de distribuição primária e secundária; 
- metas de unidades a serem atendidas por município e separadas em atendimento por meio de reforço ou melhoramento e atendimento por meio de extensão de redes;

- custo médio por atendimento de unidade urbana e rural, via extensão de redes;

- formas de divulgação do plano de universalização para as populações a serem atingidas;

- padrões de qualidade de atendimento a vigorarem na expansão do atendimento.

O ano máximo para o alcance da universalização pode ser antecipado pela Aneel sempre que houver alocação de recursos a fundo perdido, oriundos de programas especiais implementados por órgão da Administração Pública Federal, do Distrito Federal, dos Estados ou dos Municípios, inclusive de administração indireta.

Por força do ato expedido pela Aneel, os Planos de Universalização estão sendo implementados desde janeiro de 2004. As distribuidoras apresentaram ao regulador, em setembro de 2004, suas metas para o período entre 2005 e 2008 e deverão enviar, até 31 de março de 2005, os Programas Anuais para o restante do período previsto de Universalização, que varia de acordo com a distribuidora.

Se a distribuidora não enviar os Programas Anuais, a obrigação de atendimento, sem qualquer tipo de ônus para o solicitante, passará a ser aplicada em toda a área concedida ou permitida, mecanismo idêntico ao previsto para o caso de não regulamentação da sistemática de área pela Aneel.

Visando acompanhar a evolução dos Planos de Universalização, a distribuidora deverá enviar anualmente, para cada município e para toda a sua área de atuação, à Aneel os seguintes indicadores relativos à universalização dos serviços de energia elétrica: 
I - Nível Urbano de Universalização (NUU):

$$
N U U=\frac{T U C(u)}{T D(u)} \times 100
$$

II - Nível Rural de Universalização (NRU):

$$
N R U=\frac{T U C(r)}{T D(r)} \times 100
$$

III - Nível Global de Universalização (NGU), mediante a seguinte fórmula:

$$
N G U=\frac{T U C}{T D} \times 100(\%)
$$

Onde:

$\mathrm{TUC}(\mathrm{u})=$ Total de unidades consumidoras residenciais urbanas;

$\mathrm{TD}(\mathrm{u})=$ Total de domicílios urbanos, estimados a partir de dados do IBGE;

TUC $(r)=$ Total de unidades consumidoras residenciais localizadas na área rural e de unidades consumidoras da classe rural, subclasse agropecuária;

$\mathrm{TD}(\mathrm{r})=$ Total de domicílios rurais, estimados a partir de dados do IBGE;

$\mathrm{TUC}=\mathrm{TUC}(\mathrm{u})+\mathrm{TUC}(\mathrm{r}) ; \mathrm{e}$

$\mathrm{TD}=$ Total de domicílios urbanos e rurais, estimados a partir de dados do IBGE.

Estes indicadores que expressam, em percentual, a relação entre o número de unidades consumidoras eletrificadas e o total de domicílios, serão utilizados para verificar o cumprimento das metas anuais das empresas.

Complementando esta informação as distribuidoras deverão encaminhar relatório, por município, informando o número de unidades consumidoras atendidas pelo Plano 
de Universalização e as atendidas com financiamento pelos consumidores e pelos órgãos públicos.

As empresas que não cumprirem as metas poderão ter seus níveis tarifários reduzidos durante as revisões periódicas. O valor da penalidade será obtido por meio da multiplicação de um coeficiente - que varia entre 0,90 e 0,97 de acordo com o total de municípios não-atendidos e constante da Tabela 20 pelos itens referentes aos custos gerenciáveis ${ }^{59}$. As reduções serão aplicadas durante período equivalente ao número de anos em que as metas deixaram de ser cumpridas. Assim, se uma distribuidora não cumprir as metas por dois anos, a redução será efetivada pelo mesmo período.

Tabela 20 - Penalidade pelo não cumprimento das metas de universalização

\begin{tabular}{c|c} 
Não-Atendimento & Coeficiente Redutor \\
\hline Em até $10 \%$ dos Municípios & 0,97 \\
\hline Em até $20 \%$ dos Municípios & 0,95 \\
\hline Em até 30\% dos Municípios & 0,94 \\
\hline Em até 40\% dos Municípios & 0,92 \\
\hline Em até 50\% dos Municípios & 0,91 \\
\hline Acima de 50\% dos Municípios & 0,90 \\
\hline
\end{tabular}

Fonte: Resolução no 223/2003.

O art. 15 da Lei $n^{\circ}$ 10.438/2002 prevê a possibilidade de licitações para a outorga de permissões, com a finalidade de alcançar a universalização nas áreas não concedidas ou concedidas em contratos que não contenham cláusula de exclusividade. Possibilita, para a permissionária originária deste processo, a utilização de sistema alternativo descentralizado e a prestação do serviço em associação ou pela contratação de agentes detentores de tecnologia ou de autorização para geração de energia elétrica com base em fontes solar, eólica, biomassa e pequenas centrais hidrelétricas.

${ }^{59}$ Custos gerenciáveis. Custos que dependem essencialmente da eficácia da gestão empresarial, como os gastos com pessoal, compra de materiais, pagamento de serviços de terceiros, outras despesas e remuneração. São indexados pela variação do IGPM para cálculo do reajuste tarifário anual previsto nos contratos de concessão. 
A resolução prevê que na formação das tarifas da permissionária serão levados em consideração os eventuais incentivos existentes na legislação para a energia a ser gerada por ela própria ou adquirida de terceiros. Este mecanismo visa incentivos para pequenas centrais hidrelétricas ( $\left.\mathrm{PCH}^{\prime} \mathrm{s}\right)$ e a sub-rogação da $\mathrm{CCC}^{60}$.

A permissionária poderá realizar o fornecimento a qualquer unidade consumidora ligada ou não na área de permissão, independentemente da magnitude da carga e do nível de tensão e dos prazos fixados nos arts. 15 e 16 da Lei ${ }^{\circ}$ 9.074/95, que tratam da possibilidade dos consumidores optaram por outro fornecedor de energia elétrica.

A regulamentação da Aneel determina a exclusão das condições de atendimento estabelecidas nesta resolução dos seguintes casos: ligações provisórias, iluminação pública, lotes urbanos em loteamentos e áreas em processo de regularização (cooperativas) segundo a Resolução no 12/2002. Nos dois últimos casos a resolução previa a publicação de regulamentação específica posteriormente.

Dessa forma, a Resolução Normativa $\mathrm{n}^{\circ}$ 82, de 13 de setembro de 2004, estabelece que a distribuidora não é responsável pelos investimentos necessários à construção das obras de infra-estrutura básica destinadas ao atendimento com energia elétrica nos lotes situados em loteamentos urbanos.

Porém, a concessionária ou permissionária de distribuição é responsável pela construção das redes e instalações de distribuição para o atendimento das unidades consumidoras situadas em parcelamentos de interesse social, em parcelamentos populares e em áreas objeto de desmembramento que atendam à legislação aplicável.

A regulamentação determina que o atendimento a solicitações em loteamentos aprovados antes da publicação da Resolução nº 223/2003 seja de responsabilidade da concessionária.

Visando adotar um mecanismo para acompanhar o processo de universalização, essa regulamentação inclui na Resolução ${ }^{\circ}$ 456/2000 a obrigatoriedade de fornecer por

\footnotetext{
${ }^{60}$ Sub-rogação da CCC é o direcionamento desse benefício para os empreendimentos de geração, transmissão ou distribuição de energia elétrica em sistemas elétricos isolados que substituam a geração termelétrica à base de derivados de petróleo ou que atendam a novas cargas, devido à expansão do mercado, reduzindo o dispêndio atual ou futuro da CCC.
} 
escrito o prazo previsto no Plano de Universalização para o atendimento sem ônus, e de manter cadastro específico para efeito de fiscalização.

Revoga também o inciso III do art. $7^{\circ}$ do citado regulamento que permitia o atendimento de unidades rurais com carga instalada igual ou inferior a $75 \mathrm{~kW}$ em tensão primária de distribuição, impondo o custo do transformador de distribuição para os consumidores rurais, que à luz do novo marco legal não se justifica.

A resolução revoga a Portaria $n^{\circ}$ 5/90 considerando a extinção da participação financeira de qualquer consumidor pela redação original da Lei $n^{\circ} 10.438 / 002$. No entanto, com a restrição feita pela Lei $\mathrm{n}^{\mathrm{o}}$ 10.762/2003 será necessária a regulamentação para os consumidores com carga instalada acima de $50 \mathrm{~kW}$, não contemplados na nova definição de universalização.

Em resumo, nas áreas próximas da rede secundária de distribuição e para os consumidores contemplados no Plano de Universalização da distribuidora o atendimento é imediato. Para os demais consumidores, as ligações podem ser antecipadas, desde que com o aporte de recursos, dos eventuais interessados, que serão devolvidos a partir dos anos previstos para a universalização de cada localidade.

\subsubsection{Lei $n^{0}$ 10.762/2003 e adequação da Resolução no 223/2003}

A Medida Provisória n ${ }^{\circ}$ 127, de 4 de agosto de 2003, criou o programa de apoio emergencial às concessionárias de distribuição devido o adiamento da compensação do saldo da Conta de Compensação de Variação de Valores de Itens da "Parcela A" (CVA) determinado pela Portaria Interministerial no 116, de 4 de abril de 2003.

No projeto de conversão da referida MP foram incluídas, pelo Congresso Nacional, alterações na Lei $\mathrm{n}^{\circ}$ 10.438/2002 que regulamenta, dentre outros temas, a universalização dos serviços de energia elétrica.

A principal alteração refere-se à restrição da responsabilidade das distribuidoras para o atendimento, sem ônus, somente para consumidores do Grupo B com carga 
instalada de até $50 \mathrm{~kW}$. Em linhas gerais, no que se refere à universalização, as seguintes alterações foram introduzidas na Lei $n^{\circ} 10.438 / 2002$ :

1. Restringe a responsabilidade das distribuidoras pelo atendimento sem ônus nas áreas de universalização para consumidores do Grupo B (tensão secundária de distribuição) com carga abaixo de $50 \mathrm{~kW}$ (Art. 14, incisos I e II). Anteriormente essa determinação abrangia todos os consumidores independentemente da classe ou tensão de fornecimento.

Art. 14. [...]

I - áreas, progressivamente crescentes, em torno das redes de distribuição, no interior das quais o atendimento em tensão inferior a $2,3 \mathrm{kV}$, ainda que necessária a extensão de rede primária de tensão inferior ou igual a $138 \mathrm{kV}$, e carga instalada na unidade consumidora de até $50 \mathrm{~kW}$, será sem ônus de qualquer espécie para o solicitante que possuir característica de enquadramento no Grupo B, excetuado o subgrupo iluminação pública, e que ainda não for atendido com energia elétrica pela distribuidora local;

II - áreas, progressivamente decrescentes, no interior das quais o atendimento em tensão inferior a $2,3 \mathrm{kV}$, ainda que necessária a extensão de rede primária de tensão inferior ou igual a $138 \mathrm{kV}$, e carga instalada na unidade consumidora de até $50 \mathrm{~kW}$, poderá ser diferido pela concessionária ou permissionária para horizontes temporais preestabelecidos pela Aneel, quando o solicitante do serviço, que possuir característica de enquadramento no Grupo B, excetuado o subgrupo iluminação pública, e que ainda não for atendido com energia elétrica pela distribuidora local, será atendido sem ônus de qualquer espécie. (grifos nossos).

2. Atribui a regulamento da Aneel o investimento de responsabilidade da distribuidora relativo aos consumidores não contemplados na universalização. A diferença entre o valor das obras e o limite da distribuidora poderá ser custeada pelo consumidor ou por órgãos públicos, conforme regulamentação a ser definida pela Aneel.

Art. 14. [...]

$[\ldots]$

$\S 1^{\circ} \mathrm{O}$ atendimento dos pedidos de nova ligação ou aumento de carga dos consumidores que não se enquadram nos termos dos incisos I e II deste artigo, será realizado à custa da concessionária ou permissionária, conforme regulamento específico a ser estabelecido pela Aneel, que deverá ser submetido a Audiência Pública.

$\S 2^{\circ}$ É facultado ao consumidor de qualquer classe contribuir para o seu atendimento, com vistas em compensar a diferença verificada entre o custo total do atendimento e o limite a ser estabelecido no $\S 1^{\circ}$. 
3. Determina que as áreas atendidas por cooperativa de eletrificação rural terão as mesmas metas estabelecidas para a distribuidora, onde esteja localizada a respectiva cooperativa, conforme regulamentação da Aneel (Art. 14, § $6^{\circ}$ ).
Art. 14. [...]
$[\ldots]$
$\S 6^{\circ}$ Para as áreas atendidas por cooperativas de eletrificação rural serão consideradas as mesmas metas estabelecidas, quando for o caso, para as concessionárias ou permissionárias de serviço público de energia elétrica, onde esteja localizada a respectiva cooperativa de eletrificação rural, conforme regulamentação da Aneel (grifo nosso).

4. Esclarece que os aportes de recursos, aplicado a fundo perdido por órgãos públicos, não serão restituídos pelas concessionárias ${ }^{61}$.
Art. 14. [...]
[...]
$\S 7^{\circ} \mathrm{O}$ financiamento de que trata $\mathrm{o} \S 5^{\circ}$ deste artigo, quando realizado por órgãos públicos, inclusive da administração indireta, a exceção dos aportes a fundo perdido, visando a universalização do serviço, serão igualmente restituídos pela concessionária ou permissionária, ou se for o caso, cooperativa de eletrificação rural, devendo a Aneel disciplinar o prazo de carência quando o fornecimento for em áreas com prazos de diferimento distintos.

5. Prioriza o atendimento dos municípios com índice de eletrificação inferior a $85 \%$, calculados com base nos dados do Censo 2000, podendo ser subvencionada parcela dos investimentos com recursos da RGR e da CDE.
Art. 14. [...]
[...]
$\S 12$ No processo de universalização dos serviços públicos de energia elétrica no meio rural, serão priorizados os municípios com índice de atendimento aos domicílios inferior a oitenta e cinco por cento, calculados com base nos dados do Censo 2000 do IBGE, podendo ser subvencionada parcela dos investimentos com recurso da Reserva Global de Reversão, instituída pela Lei n ${ }^{\circ}$ 5.655, de 20 de maio de 1971 e da Conta de Desenvolvimento Energético - CDE, de que trata o art. 13 desta Lei, nos termos da regulamentação.

6. Determina que o Poder Executivo estabeleça procedimentos para a atribuição da subvenção econômica às concessionárias e para a fiscalização da sua aplicação nos municípios beneficiados, proporcionando base legal para o Programa de Luz para Todos do Governo Federal.

\section{Art. 14. [...]}

$[\ldots]$

\footnotetext{
${ }^{61}$ A Lei $n^{\circ} 10.438 / 2002$ era ambígua, pois também determinava que os financiamentos feitos pelo poder público seriam restituídos posteriormente em função do cronograma de atendimento das áreas de universalização.
} 
§ 13 O Poder Executivo estabelecerá diretrizes específicas que criem as condições, os critérios e os procedimentos para a atribuição da subvenção econômica às concessionárias e permissionárias de serviço público de energia elétrica e, se for o caso, cooperativas de eletrificação rural e para a fiscalização da sua aplicação nos municípios beneficiados.

Devido à nova redação da Lei, foi necessária a adequação da Resolução nº 223/2003. A Resolução $n^{\circ}$ 52/2004 restringiu a abrangência da universalização para consumidores com carga instalada até $50 \mathrm{~kW}$ e retirou a possibilidade de atendimento, sem ônus, para o aumento de carga. Dessa forma, o conceito de universalização, segundo a regulamentação da Aneel é:

Universalização: atendimento a todos os pedidos de nova ligação para fornecimento de energia elétrica a unidades consumidoras com carga instalada menor ou igual a $50 \mathrm{~kW}$, em tensão inferior a $2,3 \mathrm{kV}$, ainda que necessária a extensão de rede de tensão inferior ou igual a $138 \mathrm{kV}$, sem ônus para o solicitante, observados os prazos fixados nas 'Condições Gerais de Fornecimento de Energia Elétrica'.

\subsection{PROGRAMA LUZ PARA TODOS}

Conforme discutido anteriormente, no início de 2003 estava pendente a definição da Política Governamental de universalização, envolvendo principalmente a alocação de recursos da CDE e da RGR. Apesar estabelecida, em Lei, a destinação da CDE e RGR, a distribuição dos recursos para as diferentes necessidades regionais somente foi possível com a definição do programa de universalização do Governo Federal.

O Programa Luz para Todos foi lançado em cerimônia no Palácio do Planalto pelo presidente Luis Ignácio Lula da Silva, no dia 11 de novembro de 2003. Na solenidade, que foi prestigiada por senadores, deputados, ministros, presidentes e representantes das empresas, o presidente brasileiro fez um apelo especial aos 21 governadores presentes para que as várias esferas governamentais não deixassem o projeto ser prejudicado por disputas políticas: "não temos o direito de sermos pequenos diante da magnitude desse projeto".

Esse programa visa reduzir a pobreza e a fome utilizando a energia como vetor de desenvolvimento focando o atendimento na área rural para pequenos consumidores, considerando que, segundo estimativas do MME, 90\% dos dois milhões de 
domicílios sem energia elétrica na área rural têm renda familiar de até três salários mínimos.

O objetivo é atender, até 2008 , todos os domicílios rurais sem energia elétrica, com custo total estimado em cerca de $\mathrm{R} \$ 7$ bilhões, conforme cronograma original a seguir:

Tabela 21 - Custo anual do Programa Luz para Todos

\begin{tabular}{|c|c|c}
\hline Ano & $\begin{array}{c}\text { Número de domicílios } \\
\text { rurais }\end{array}$ & Custo (R\$ bilhões) \\
\hline 2004 & $400 \mathrm{mil}$ & 1,320 \\
\hline 2005 & $500 \mathrm{mil}$ & 1,700 \\
\hline 2006 & $500 \mathrm{mil}$ & 1,750 \\
\hline 2007 & $300 \mathrm{mil}$ & 1,080 \\
\hline 2008 & $300 \mathrm{mil}$ & 1,100 \\
\hline
\end{tabular}

Fonte: MME (2003c)

Esses recursos são aportados pelos Estados da Federação (10\%), pelas distribuidoras e cooperativas (15\%) e o restante pelo Governo Federal por meio de uma composição de recursos a fundo perdido (a princípio, CDE) e financiamento (RGR).

Segundo o MME, a distribuição desses recursos leva em conta a mitigação do impacto tarifário decorrente da universalização; ou seja, para algumas áreas é necessário o aporte de recursos a fundo perdido numa proporção maior do que o financiamento de modo que o processo de universalização não resulte em aumento tarifário excessivo para a população local.

Em que pese o investimento da distribuidora ser de apenas $15 \%$ aparentemente, é importante ressaltar que os $75 \%$ de recursos oriundos do Governo Federal são compostos por fundo perdido e financiamento. Esta última parte, mesmo com juros baixos, será paga pela distribuidora, elevando a sua participação na prática.

A sinalização do MME é que, para as distribuidoras com alto índice de eletrificação e localizadas em regiões com Índice de Desenvolvimento Humano (IDH) maior, os recursos a fundo perdido serão menores; as condições de financiamento são similares às do Programa Luz no Campo da Eletrobrás, porém sem o repasse de parte dos 
custos para os consumidores em razão do atendimento sem ônus determinado pela Lei $n^{\circ} 10.438 / 2002$.

A adesão ao programa ocorre mediante a assinatura de um convênio entre a distribuidora, o estado e o Governo Federal devendo também a Aneel e a Eletrobrás participar como intervenientes.

\section{Critérios para priorização das obras}

Tendo o programa uma vertente social, de acordo com o MME (2003c), serão priorizadas obras nos municípios com Índice de Atendimento a domicílios inferior a $85 \%$, calculado com base no Censo 2000, ou com IDH inferior à média estadual apresentado a seguir.

Tabela 22 - IDH - Média por Estado

\begin{tabular}{l|c}
\multicolumn{1}{c|}{ ESTADO } & IDH \\
\hline Acre & 0,692 \\
\hline Alagoas & 0,633 \\
\hline Amapá & 0,751 \\
\hline Amazonas & 0,717 \\
\hline Bahia & 0,693 \\
\hline Ceará & 0,699 \\
\hline Distrito Federal & 0,844 \\
\hline Espírito Santo & 0,767 \\
\hline Goiás & 0,770 \\
\hline Maranhão & 0,647 \\
\hline Mato Grosso & 0,767 \\
\hline Mato Grosso do Sul & 0,769 \\
\hline Minas Gerais & 0,766 \\
\hline Pará & 0,720 \\
\hline Paraíba & 0,678 \\
\hline Paraná & 0,786 \\
\hline Pernambuco & 0,692 \\
\hline Piauí & 0,673 \\
\hline Rio de Janeiro & 0,802 \\
\hline Rio Grande do Norte & 0,702 \\
\hline Rio Grande do Sul & 0,809 \\
\hline Rondônia & 0,729 \\
\hline Roraima & 0,749 \\
\hline Santa Catarina & 0,806 \\
\hline São Paulo & 0,814 \\
\hline Sergipe & 0,687 \\
\hline Tocantins & 0,721 \\
\hline
\end{tabular}

Fonte: MME (2003c) 
Os projetos de eletrificação rural a serem priorizados devem contemplar, pelo menos, um destes critérios, segundo o MME (2003c):

- atendimento às comunidades atingidas por barragens de usinas hidrelétricas ou por obras do Sistema Elétrico, cuja responsabilidade não esteja definida para o executor do empreendimento;

- projetos que enfoquem o uso produtivo da energia elétrica e que fomente o desenvolvimento local integrado;

- atendimento a escolas públicas, postos de saúde e poços de abastecimento d'água;

- localizados em assentamentos rurais;

- desenvolvimento da agricultura familiar, de subsistência ou de atividades de artesanato de base familiar.

- atendimento de pequenos e médios agricultores rurais - territórios definidos pelo MDA;

- projetos de eletrificação rural, já iniciados e paralisados por falta de recursos, que atendam às comunidades e povoados rurais;

- projetos de eletrificação rural das populações do entorno de Unidades de Conservação da Natureza e áreas de uso restrito de comunidades indígenas.

\section{Critérios técnicos}

Este programa possibilita o atendimento no meio rural por meio de alternativas, além de efetuar a tradicional extensão de redes: sistemas de geração descentralizada com redes isoladas ou sistemas individuais. Nesses casos, serão comparados com o custo de um projeto com rede convencional. É importante ressaltar que essa opção tecnológica deve obedecer à regulamentação específica da Aneel.

No caso de extensão de redes rurais, similarmente ao Programa Luz no Campo, a orientação do MME é priorizar tecnologia, materiais e equipamentos de rede que resultem em redução do custo das redes, utilizando, por exemplo, condutores tipo aço zincado (CAZ), molas desligadoras com elos fusíveis, chaves fusíveis religadoras.

As instalações do Programa Luz para Todos, segundo o MME (2003c), devem observar: 
- rede trifásica primária, em extensão não superior a $30 \%$ do comprimento total;

- rede trifásica primária e rede bifásica a três fios, em extensão não superior a $40 \%$ do comprimento total;

- sistemas elétricos monofásicos multiaterrados (fase-neutro), bifásico a dois fios (fase-fase) ou monofilares com retorno por terra (sistema MRT), em extensão não inferior a $60 \%$ do comprimento total;

- as obras de reforço (subestações, ampliação de pequenas centrais geradoras em sistemas isolados, recondutoramento, recapacitação, compensação reativa e regulação de tensão), deverão representar, no máximo, $10 \%$ do valor total do programa de obras;

- utilização de transformador com potência instalada de transformação, por unidade consumidora, até $15 \mathrm{kVA}$;

- utilização de redes de distribuição rural em tensões até $34,5 \mathrm{kV}$;

- inclusão de entradas de serviço ou padrões (poste auxiliar, caixa de medição, medidor, disjuntor, aterramento etc); e

- o ponto de medição, para ligações monofásicas ou bifásicas a dois fios, não poderá distar mais de $30 \mathrm{~m}$ do local de consumo.

O programa prevê que, em residências de famílias cadastradas no Programa BolsaFamília, cujo atendimento seja feito em sistema monofásico ou bifásico a dois fios, o agente executor (distribuidora ou cooperativa), além da obrigação regulamentar de atendimento, estenderá a rede de energia elétrica no interior da moradia instalando três pontos de luz e uma tomada.

\subsection{LEI No 10.438/2002 E UNIVERSALIZAÇÃO DO USO}

\subsubsection{Critérios definidos pela Lei $\mathrm{n}^{0} \mathbf{1 0 . 4 3 8 / 2 0 0 2}$}

A Lei $\mathrm{n}^{\circ}$ 10.438/2002 definiu os critérios para a inclusão de unidades consumidoras na subclasse residencial baixa renda, que anteriormente eram determinados pelas distribuidoras e homologados pelo Dnaee. 
$\mathrm{O}$ art. $1^{\circ}, \S 1^{\circ}$, da norma legal estabelece que a residência atendida por circuito monofásico e que tenha consumo mensal inferior a $80 \mathrm{kWh}$ seja considerada, para efeitos de classificação, como baixa renda, sem a necessidade de nenhuma outra comprovação.

Para consumos na faixa entre 80 a $220 \mathrm{kWh} / \mathrm{mês,} \mathrm{mantido} \mathrm{o} \mathrm{tipo} \mathrm{de} \mathrm{atendimento}$ monofásico, a Lei determinou que a Aneel estabelecesse outros critérios para a classificação. $\mathrm{O}$ art. $1^{\circ}, \S 5^{\circ}$, determinou que, após o prazo de 180 dias sem regulamentação, o critério exclusivo de consumo mensal seria estendido para esses consumidores.

Art. $1^{\circ}[\ldots]$

Lei $\mathbf{n}^{0} \mathbf{1 0 . 4 3 8}$, de 26 de abril de 2002

$\S 1^{\circ} \mathrm{O}$ rateio dos custos relativos à contratação de capacidade de geração ou potência $(\mathrm{kW})$ referidos no caput não se aplica ao consumidor integrante da subclasse residencial baixa renda, assim considerado aquele que, atendido por circuito monofásico, tenha consumo mensal inferior a $80 \mathrm{kWh} / \mathrm{mês}$ ou cujo consumo situe-se entre 80 e 220 $\mathrm{kWh} / \mathrm{mês}$, neste caso desde que observe o máximo regional compreendido na faixa e não seja excluído da subclasse por outros critérios de enquadramento a serem definidos pela Aneel.

$[\ldots]$

$\S 5^{\circ} \mathrm{A}$ regulamentação da Aneel de que trata o $\S 1^{\circ}$, referente aos consumidores com faixa de consumo mensal entre 80 e $220 \mathrm{kWh}$, será publicada no prazo de até 180 (cento e oitenta) dias e, ultrapassado este prazo sem regulamentação, será estendido a eles também o critério de enquadramento baseado exclusivamente no consumo mensal.

\subsubsection{Regulamentação da tarifa residencial baixa renda}

A Aneel, por meio da Resolução $n^{\circ}$ 246, de 30 de abril de 2002, estabelece que as unidades consumidoras atendidas por circuito monofásico ou bifásico equivalente e com média de consumo mensal dos últimos 12 meses inferior a $80 \mathrm{kWh}$, sejam classificadas na subclasse residencial baixa renda, com direito ao desconto previsto. Adicionalmente, para mitigar a inclusão de residência de veraneio, conforme determinado pelo art. $1^{\circ}, \S 7^{\circ}$, da Lei $n^{\circ} 10.438 / 2002$, a regulamentação determina a exclusão da unidade com dois consumos registrados acima de $120 \mathrm{kWh} / \mathrm{mês}$ no período de um ano, mesmo que tenha média mensal inferior a $80 \mathrm{kWh}$ nesse intervalo.

Para aquelas com consumo na faixa entre 80 e $220 \mathrm{kWh}$, o Decreto $\mathrm{n}^{\circ} 4.336$, de 15 de agosto de 2002, determinava que a Aneel observasse os mesmos critérios sócio- 
econômicos estabelecidos no art. $3^{\circ}$ do Decreto $n^{\circ} 4.102$, de 24 de janeiro de 2002 que regulamenta o Programa "Auxílio-Gás", destinado a subsidiar o preço do gás liquefeito de petróleo para famílias baixa renda.

Esse programa identifica as famílias alvo como aquelas com renda mensal per capita máxima equivalente a meio salário mínimo e integrantes do Cadastramento Único ${ }^{62}$ para Programas Sociais do Governo Federal ou dos programas Bolsa Escola ${ }^{63}$ ou Bolsa Alimentação ${ }^{64}$.

A Resolução $n^{\circ}$ 485, de 29 de agosto de 2002, fixa as regras de classificação com base nos critérios sócio-econômicos definidos pelo Decreto $n^{\circ} 4.336 / 2002$, para as unidades com consumo médio mensal entre 80 e $220 \mathrm{kWh}$ atendidas por circuito monofásico. Para obter o benefício da tarifa social, inicialmente, o responsável pela unidade consumidora deveria estar inscrito no Cadastro Único dos Programas Sociais do Governo Federal ou em um dos programas Bolsa Escola ou Bolsa Alimentação.

A agência determina que, para efeito de classificação, sejam considerados esquemas de fornecimento de energia: monofásico a dois condutores (fase e neutro), monofásico a três condutores (monofásico com neutro intermediário) e o fase-fase em sistemas com secundário sem neutro.

\section{Resolução no 485, de 29 de agosto de 2002}

Art. $1^{\circ}$ Estabelecer, na forma desta Resolução, as condições para a classificação na subclasse residencial baixa renda de unidade consumidora com consumo mensal entre 80 e $220 \mathrm{kWh}$, que seja atendida por circuito monofásico.

62 O Cadastro Único é um banco de dados, centralizado na Caixa Econômica Federal, com o cadastro de todas as famílias com renda mensal de até meio salário mínimo por pessoa que tem por objetivo mecanismo para focalizar as políticas públicas nas famílias em situação de extrema pobreza.

63 O Programa Bolsa Escola, criado em 2001 pelo Ministério da Educação, visa promover a educação das crianças de 6 a 15 anos de famílias com renda per capita mensal inferior a R\$90,00, assegurando sua permanência na escola, por meio de incentivo financeiro de $\mathrm{R} \$ 15,00$, por aluno, limitado a 3 beneficiários por família.

64 O Programa Bolsa Alimentação, criado pelo Ministério da Saúde, consiste na promoção das condições de saúde e nutrição de gestantes, mães amamentando seus filhos menores de seis meses (nutrizes) e crianças de 6 meses a 6 anos e 11 meses de idade, em risco nutricional, pertencentes a famílias sem renda ou que possuam renda mensal de até $\mathrm{R} \$ 90,00$ per capita, mediante a complementação da renda familiar ( $\mathrm{R} \$ 15,00$ por beneficiário até o limite de $\mathrm{R} \$ 45,00)$ e o fomento à realização de ações básicas de saúde com enfoque predominantemente preventivo. 
$\S 1^{\circ}$ Consideram-se como circuito monofásico, para efeito de classificação na subclasse residencial baixa renda, os seguintes esquemas de fornecimento de energia elétrica:

I - monofásico a dois condutores (fase e neutro); e

II - monofásico a três condutores (monofásico com neutro intermediário).

$\S 2^{\circ}$ Considera-se como equivalente a circuito monofásico o fornecimento fase-fase em sistemas com secundário sem neutro.

A Lei $n^{\circ}$ 10.836, de 9 de janeiro de 2004, originária da conversão da Medida Provisória $n^{\circ} 132 / 2003$, criou o Programa Bolsa Família ${ }^{65}$, unificando os programas de transferência de renda (Bolsa Escola, Bolsa Alimentação, Programa Nacional de Acesso à Alimentação também conhecido como "Fome Zero" e Auxílio-Gás) e mantendo como base o Cadastro Único.

Dessa forma, a Aneel, por meio das Resoluções $n^{\circ}$ 694/2003 e $n^{\circ} 44 / 2004$, alterou a Resolução no 485/2002 estabelecendo a diretriz de que as famílias cadastradas pelo Governo Federal com renda per capita até $\mathrm{R} \$ 100,00$ sejam as beneficiárias dos descontos dados na tarifa de energia elétrica da subclasse baixa renda. Durante o processo de unificação dos programas sociais, os consumidores ainda não atendidos pelo Programa Bolsa Família, devem comprovar a inscrição no Cadastro Único dos Programas Sociais ou em um dos programas de transferência de renda do Governo Federal.

Resolução no 485 , de 29 de agosto de 2002 , com redação dada pela Resolução no 44/2004

Art. $2^{\circ}$ Deverá ser classificada na subclasse residencial baixa renda, sem prejuízo do que determina a Resolução $\mathrm{n}^{\mathrm{o}} 246$, de 2002, a unidade consumidora que tenha consumo mensal entre 80 e $220 \mathrm{kWh}$, calculado com base na média dos últimos 12 (doze) meses, e seja habitada por unidade familiar cujo responsável esteja apto a receber os benefícios financeiros do Programa Bolsa Família, do Governo Federal.

$\S 1^{\circ}$ Para receber o benefício da subvenção econômica destinada à subclasse residencial baixa renda, o responsável pela unidade consumidora deverá estar inscrito no Cadastro Único do Governo Federal e enquadrar-se nas condições que o habilitem a ser beneficiário do Programa Bolsa Família, observando-se o respectivo período de transição e unificação a que se refere o $\S 2^{\circ}$ deste artigo.

$\S 2^{\circ}$ Até que seja concluída a unificação dos procedimentos de gestão e execução das ações de transferência de renda do Governo Federal e alcançado o objetivo de

65 O Programa Bolsa Família prevê dois tipos de benefícios financeiros. O benefício básico corresponde a $\mathrm{R} \$ 50,00$ e destina-se às famílias em situação de extrema pobreza $(\mathrm{R} \$ 50,00$ de renda mensal per capita). O benefício variável corresponde a $\mathrm{R} \$ 15,00$ por pessoa, limitado a três benefícios, e destina-se às famílias em situação de extrema pobreza e de pobreza (até R \$100,00 de renda mensal per capita) que tenham em sua composição gestantes, nutrizes (mulher que amamenta) ou crianças até doze anos ou adolescentes até quinze. 
concessão de um único benefício por meio do Programa Bolsa Família, o responsável pela unidade consumidora deverá comprovar:

I - sua inscrição no Cadastramento Único para Programas Sociais do Governo Federal, criado pelo Decreto $\mathrm{n}^{\mathrm{o}} 3.877$, de 24 de julho de 2001; ou

II - ser beneficiário do Programa Bolsa Escola, instituído pela Lei no 10.219, de 11 de abril de 2001; ou

III - ser beneficiário do Programa Bolsa Alimentação, instituído pela Medida Provisória $\mathrm{n}^{\circ}$ 2.206-1, de 6 de setembro de 2001; ou

IV - ser beneficiário do Programa Auxílio-Gás, instituído pelo Decreto no 4.102, de 24 de janeiro de 2002; ou

V - ser beneficiário do Programa Cartão Alimentação, instituído pela Medida Provisória n ${ }^{\circ}$ 108, de 27 de fevereiro de 2003.

A Resolução n ${ }^{\circ}$ 485/2002 estabeleceu que, durante o prazo de 90 dias $^{66}$, contados a partir da sua publicação, ficaria preservado o benefício dos descontos da tarifa baixa renda para os consumidores que atendessem somente aos critérios de classificação anteriores à Lei $\mathrm{n}^{\circ} 10.438 / 2002$.

No entanto, em virtude das dificuldades das Prefeituras realizarem o cadastramento dos consumidores nos programas sociais do Governo Federal ${ }^{67}$, tais como infraestrutura, recursos financeiros e disponibilidade de pessoal, e atendendo às solicitações das entidades de defesa do consumidor, esse prazo para vigência simultânea dos critérios foi sucessivamente prorrogado pela Aneel: inicialmente até 31 de março de 2003 (Resolução n 609/2002), até 30 de junho de 2003 (Resolução $n^{\circ}$ 136/2003), novamente até 31 de dezembro de 2003 (Resolução $n^{\circ}$ 308/2003) e finalmente até 29 de fevereiro de 2004, pela Resolução no 694/2003.

Esta última regulamentação, com nova redação dada pela Resolução no 44/2004, prevê que o consumidor que, embora não esteja inscrito nos programas sociais, se considere apto a ser beneficiário das ações de transferência de renda previstas na política social do Governo Federal, deve enviar à distribuidora declaração de que a renda da respectiva unidade familiar (até $\mathrm{R} \$ 100,00$ per capita) o habilita a continuar a receber o benefício da tarifa para consumidores baixa renda.

Nesse caso, o potencial beneficiário teria que, até 31 de julho de 2004, comprovar sua inscrição no Programa Bolsa Família, pois do contrário seria excluído desta

\footnotetext{
${ }^{66}$ Até 27 de novembro de 2002.

${ }^{67}$ Segundo a Aneel (2003c), até junho de 2003, somente cerca de 800 mil consumidores tinham comprovado inscrição.
} 
classificação. Esse prazo foi prorrogado para 28 de fevereiro de 2005, pela Resolução no 76, de 30 de julho de 2004.

Nos critérios anteriores à Lei $\mathrm{n}^{\circ} 10.438 / 2002$, o consumidor classificado na subclasse residencial baixa renda poderia consumir sem perder o benefício até o denominado limite regional. Caso o consumo mensal fosse maior, independentemente da inclusão por outros critérios previstos, tais como as condições de moradia ou a renda familiar, o consumidor perdia o benefício dos descontos tarifários.

A nova regulamentação da Aneel altera esse conceito admitindo, para a inclusão na subclasse, um valor máximo único para todo o País $(220 \mathrm{kWh} / \mathrm{mês})$, mantendo, porém, o limite regional para aplicação da tarifa diferenciada.

Dessa forma, o consumidor cadastrado nos programas sociais do Governo Federal (ou o potencial beneficiário, respeitando o prazo até 28 de fevereiro de 2005) poderá, mantendo a média anual de $220 \mathrm{kWh} /$ mês, consumir acima do limite regional tendo ainda direito aos descontos tarifários. Somente a parcela do consumo mensal que ultrapassar o máximo regional será valorada pela tarifa do Subgrupo B1 Residencial $^{68}$, ou seja, sem descontos.

Em resumo, a regulamentação atual prevê que são classificadas na subclasse residencial baixa renda: as unidades atendidas por sistema monofásico com consumo até $80 \mathrm{kWh}$ e, aquelas, com consumo entre 80 e $220 \mathrm{kWh} / \mathrm{mês,} \mathrm{cujos} \mathrm{responsáveis}$ sejam beneficiários do Programa Bolsa Família.

\subsection{RECURSOS}

Embora a Lei $n^{\circ} 10.438 / 2002$, que criou a CDE, tenha direcionado recursos para a universalização do acesso, a aplicação dessa fonte para as várias destinações previstas na Lei não estava regulamentada no momento da definição, pela Resolução $n^{\circ} 223 / 2003$, das metas de universalização, ocasionando uma incerteza no montante de recursos disponíveis devido a uma possível competição pela divisão dos recursos.

\footnotetext{
${ }^{68}$ Excluído o percentual correspondente à recomposição tarifária extraordinária (RTE), enquanto esta for aplicada.
} 
Adicionalmente no caso da universalização do uso, com base no princípio de que a estipulação de novos benefícios tarifários deve estar condicionada à previsão da origem dos recursos, a Lei $\mathrm{n}^{\mathrm{o}}$ 10.604/2002, regulamentada pelo Decreto $\mathrm{n}^{\mathrm{0}} 4.538 / 2002$, determinou que as perdas decorrentes de novos critérios para a classificação dos consumidores baixa renda fossem custeadas por meio de subvenção. Os recursos previstos proveriam do adicional de dividendos devidos à União pela Eletrobrás, associado às receitas adicionais auferidas com a comercialização de energia elétrica nos leilões públicos ou, na sua insuficiência, com recursos a fundo perdido da Reserva Global de Reversão (RGR), nos exercícios 2002 $-2003$.

Posteriormente, a Lei $n^{\circ} 10.762 / 2003$ alterou a redação do art. 13 da Lei $n^{\text {o }}$ 10.438/2002 possibilitando, por meio da CDE, a cobertura das perdas das distribuidoras, decorrentes dos novos critérios para a classificação dos consumidores baixa renda, a partir de 2004. Por outro lado, estabeleceu que os recursos da RGR poderão ser utilizados como subvenção no processo de universalização no meio rural, além da destinação já prevista para investimentos em expansão do sistema de distribuição.

\subsubsection{Reserva Global de Reversão}

De acordo com a Lei $n^{\circ} 5.655$, de 20 de maio de 1971, com redação dada pela Lei $n^{\circ}$ 8.631/93, a Reserva Global de Reversão (RGR), originalmente prevista pelo Decreto $\mathrm{n}^{\mathrm{o}} 41.019 / 57$, tornou-se um fundo com a finalidade de prover recursos, para a expansão e melhoria dos serviços de energia elétrica, além dos recursos necessários para a reversão e encampação das concessões.

A extinção da RGR estava prevista para 2002, mas a Lei $n^{\circ} 10.438 / 2002$ alterou o art. $8^{\circ}$ da Lei $n^{\circ} 9.648 / 98$ prorrogando a sua vigência até 2010 .

A Lei $n^{\circ}$ 9.427/96 fixou a quota anual de reversão em até 2,5\% sobre os investimentos das concessionárias e permissionárias, observado o limite de $3 \%$ da receita anual. Estabeleceu, ainda, que o valor da taxa de fiscalização fosse deduzido do valor global das quotas da Reserva Global de Reversão. 
De acordo com a Lei ${ }^{\circ}$ 9.427/96, no mínimo 50\% dos recursos da RGR devem ser aplicados em investimentos no setor elétrico das Regiões Norte, Nordeste e CentroOeste do Brasil. Desse montante, a metade em programas de eletrificação rural, conservação e uso racional de energia e atendimento de comunidades de baixa renda.

Segundo a Lei $\mathrm{n}^{\mathrm{o}} 10.438 / 2002$, os recursos podem ser destinados, mediante projetos específicos de investimentos:

- às concessionárias, permissionárias e cooperativas de eletrificação rural, para expansão dos serviços de distribuição de energia elétrica especialmente em áreas de baixa renda e para o programa de combate ao desperdício de energia elétrica;

- para instalações de produção a partir de fontes eólica, solar, biomassa e pequenas centrais hidrelétricas, assim como termelétrica associada a pequenas centrais hidrelétricas e conclusão de obras já iniciadas de geração termonuclear, limitado, neste último caso, a 10\% dos recursos disponíveis;

- para estudos de inventário e viabilidade de aproveitamento de potenciais hidráulicos;

- para implantação de centrais geradoras de potência até $5.000 \mathrm{~kW}$, destinadas exclusivamente ao serviço público em comunidades populacionais atendidas por sistema elétrico isolado; e

- para o desenvolvimento e implantação de programas e projetos destinados ao combate ao desperdício e uso eficiente da energia elétrica, de acordo com as políticas e diretrizes estabelecidas para o Programa Nacional de Conservação de Energia Elétrica - Procel.

A Lei também determina que a Eletrobrás organize programa para a utilização de equipamentos, de uso individual e coletivo, destinados à transformação de energia solar em energia elétrica, empregando recursos da RGR e contratados diretamente com as concessionárias e permissionárias. 
Adicionalmente, a Lei $\mathrm{n}^{\circ}$ 10.604/2002, autorizou a concessão de subvenção econômica com a finalidade de contribuir para a modicidade da tarifa de fornecimento de energia elétrica aos consumidores finais integrantes da subclasse residencial baixa renda.

Esta subvenção seria custeada com recursos financeiros oriundos do adicional de dividendos devidos à União pela Eletrobrás, associado às receitas adicionais auferidas pelas concessionárias geradoras de serviço público, sob controle federal, com a comercialização de energia elétrica nos leilões públicos ou, na sua insuficiência, nos exercícios de 2002 e 2003, com recursos da RGR.

Posteriormente, a Lei $\mathrm{n}^{\mathrm{o}} 10.762 / 2003$ altera a redação da Lei $\mathrm{n}^{\mathrm{o}} 10.438 / 2002$, possibilitando a utilização dos recursos da RGR a fundo perdido para a universalização do acesso físico.

Art. 14

Lei $\mathbf{n}^{0} 10.438$, de 26 de abril de 2002

$[\ldots]$

$\S 12$. No processo de universalização dos serviços públicos de energia elétrica no meio rural, serão priorizados os municípios com índice de atendimento aos domicílios inferior a oitenta e cinco por cento, calculados com base nos dados do Censo 2000 do IBGE, podendo ser subvencionada parcela dos investimentos com recurso da Reserva Global de Reversão, instituída pela Lei n ${ }^{\circ}$ 5.655, de 20 de maio de 1971 e da Conta de Desenvolvimento Energético - CDE, de que trata o art. 13 desta Lei, nos termos da regulamentação. (Incluído pela Lei no 10.762, de 11.11.2003).

A Eletrobrás, gestora dos recursos oriundos da Reserva Global de Reversão, apresenta no seu Relatório de Administração os valores recolhidos e as aplicações em diversas linhas de crédito e programas de obras de empresas do setor elétrico brasileiro, inclusive suas controladas, conforme estabelecido na Lei $\mathrm{n}^{\circ}$ 8.631/93.

Os dados referentes ao período de 2000 a 2002 estão detalhados na Tabela 23. É interessante observar que o financiamento das empresas coligadas e controladas da própria Eletrobrás corresponde a maior parte das aplicações da RGR, atingindo o patamar máximo de $98 \%$ em 2002. No entanto, esse fato não reflete adequadamente a realidade, pois o Programa Luz no Campo está inserido nessas aplicações e corresponde a empréstimos para as diversas distribuidoras e não somente às coligadas. 
Tabela 23 - Saldos da RGR

\begin{tabular}{c|r|r|r|}
\hline Movimentação & $\mathbf{2 0 0 0}$ & $\mathbf{2 0 0 1}$ & $\mathbf{2 0 0 2}$ \\
\hline SALDO INICIAL (1) & 198,6 & 362,1 & 994,5 \\
\hline INGRESSOS (2)=(3) +(4) & $1.102,7$ & $1.151,5$ & $1.231,8$ \\
\hline Arrecadação de quotas (3) & 951,5 & $1.030,3$ & 990,1 \\
\hline Outros (4) & 151,2 & 121,2 & 241,7 \\
\hline APLICAÇÕES (5) = (6)+(7)+(8)+(9) & 939,2 & 608,6 & $1.384,7$ \\
\hline Financiamento Controladas/Coligadas(6) & 586,7 & 552,0 & $1.360,8$ \\
\hline Aquisição de ações(7) & 216,6 & 31,2 & \\
\hline Verba Aneel(8) & 19,8 & 25,4 & 20,0 \\
\hline Outras (9) & 116,1 & $*$ & 3,9 \\
\hline SALDO TOTAL DISPONÍVEL (1)+(2)-(5) & 362,1 & 905,0 & 841,6 \\
\hline
\end{tabular}

* Em 2001 o item "Outras" está incluído no item "Verba Aneel".

Fonte: Elaborado pelo autor com base nos Relatórios de Administração - Eletrobrás.

A conta da RGR, a partir de 1999, vem obtendo uma arrecadação da ordem de $\mathrm{R}$ \$ 1 bilhão ao ano, valores estes que ao longo do tempo vêm sendo utilizados pelas distribuidoras para investimentos previstos na Legislação. De acordo com os Relatórios de Administração, a Eletrobrás investiu nos últimos anos, em observância ao que estabelece a Lei $n^{\circ}$ 9.427/96, grande parte dos recursos da RGR, nas Regiões Norte, Nordeste e Centro-Oeste, conforme especificado na Tabela 24, apresentada a seguir.

Tabela 24 - Aplicação da RGR por Região

\begin{tabular}{|c|c|c|c|c|c|c|c|c|}
\hline \multirow{2}{*}{$\begin{array}{l}\text { Aplicação por } \\
\text { Região }\end{array}$} & \multicolumn{2}{|c|}{2000} & \multicolumn{2}{|c|}{2001} & \multicolumn{2}{|c|}{2002} & \multicolumn{2}{|c|}{2003} \\
\hline & \begin{tabular}{|c|} 
R\$ \\
milhões
\end{tabular} & $\%$ & $\begin{array}{c}\text { R\$ } \\
\text { milhões }\end{array}$ & $\%$ & $\begin{array}{c}\text { R\$ } \\
\text { milhões }\end{array}$ & $\%$ & $\begin{array}{c}\text { R\$ } \\
\text { milhões }\end{array}$ & $\%$ \\
\hline NORTE & 281,3 & 35,0 & 335,2 & 57,4 & 721,2 & 53,0 & 344,7 & 74,5 \\
\hline NORDESTE & 320,0 & 39,8 & 121,1 & 20,8 & 267,1 & 19,6 & 465,4 & 6,9 \\
\hline CENTRO-OESTE & 32,0 & 4,0 & 59,2 & 10,1 & 45,7 & 3,4 & 63,3 & 0,5 \\
\hline SUL & 87,0 & 10,8 & 40,8 & 7,0 & 116,1 & 8,5 & 262,2 & 1,7 \\
\hline SUDESTE & 83,0 & 10,3 & 27,3 & 4,7 & 210,7 & 15,5 & 188,0 & 16,4 \\
\hline BRASIL & 803,3 & 100,0 & 583,6 & 100,0 & $1.360,8$ & 100,0 & $1.323,5$ & 100,0 \\
\hline
\end{tabular}

Fonte: Elaborado pelo autor com base nos Relatórios de Administração - Eletrobrás. 
A Tabela 25 a seguir apresenta as aplicações da RGR nos diversos projetos. Destacase o nível de aplicações na Linha de Eletrificação Rural referente ao Programa Luz no Campo, para o qual foram destinados, até 2003, R\$ 735,6 milhões atendendo a todas as Regiões do Brasil.

O subsídio anual para as perdas das distribuidoras com os novos consumidores baixa renda foi estimado inicialmente pela Aneel em R $\$ 709$ milhões (CASTRO; NUNES, 2003). De acordo com os relatórios da Eletrobrás, em 2002 e 2003 foram liberados, respectivamente, $\mathrm{R} \$ 173,0$ milhões e $\mathrm{R} \$ 922,5$ milhões ${ }^{69}$. Essa diferença decorre do período menor (maio a dezembro) para cobertura das perdas menor em 2002 e dos prazos para liberação dos recursos. Destaca-se que, em 2003, o subsídio para as distribuidoras, relativo aos consumidores baixa renda, correspondeu a $67 \%$ do total de R \$ 1,3 bilhão das aplicações da RGR naquele ano.

Tabela 25 - Aplicação da RGR por projetos

\begin{tabular}{|c|c|c|c|c|c|c|c|c|}
\hline \multirow[b]{2}{*}{ PROJETOS } & \multicolumn{2}{|c|}{2000} & \multicolumn{2}{|c|}{2001} & \multicolumn{2}{|c|}{2002} & \multicolumn{2}{|c|}{2003} \\
\hline & \begin{tabular}{|l}
$\mathbf{R} \$$ \\
millõ̃es
\end{tabular} & $\%$ & $\begin{array}{c}\mathbf{R} \$ \\
\text { milhões }\end{array}$ & $\%$ & $\begin{array}{l}\mathbf{R} \$ \\
\text { milhões }\end{array}$ & $\%$ & $\begin{array}{c}\mathbf{R} \$ \\
\text { milhões }\end{array}$ & $\%$ \\
\hline $\begin{array}{c}\text { Eletrificação Rural - } \\
\text { Luz no Campo }\end{array}$ & 215,0 & 26,8 & 197,8 & 33,9 & 297,0 & 21,8 & 25,8 & 1,9 \\
\hline $\begin{array}{c}\text { Conservação de Energia - } \\
\text { ReLuz } \\
\end{array}$ & 25,3 & 3,1 & 25,1 & 4,3 & 36,0 & 2,6 & 13,6 & 1,0 \\
\hline FINEL/RGR & 94,0 & 11,7 & & & & & & \\
\hline Projetos/Ações Prioritárias & 173,3 & 21,6 & & & 609,9 & 44,8 & & \\
\hline Projetos Emergenciais & 43,1 & 5,4 & & & 68,9 & 5,1 & & \\
\hline Compra de Ações & 216,6 & 27,0 & 31,2 & 5,3 & & & & \\
\hline PCHS's & & & 16,0 & 2,7 & 17,7 & 1,3 & & \\
\hline $\begin{array}{c}\text { UHE Tucuruí } \\
\left(2^{\mathrm{a}} \text { Etapa - Parte }\right)\end{array}$ & & & 240,0 & 41,2 & & & & \\
\hline Geração & & & & & & & 200,1 & 15,1 \\
\hline $\begin{array}{c}\text { Revitalização - Parques } \\
\text { Térmicos }\end{array}$ & & & & & & & 29,8 & 2,3 \\
\hline $\begin{array}{c}\text { Transm., Distrib., Prog. } \\
\text { Emergenciais e Sist. Isolados }\end{array}$ & & & 73,1 & 12,5 & & & 121,7 & 9,2 \\
\hline Baixa Renda & & & & & 173,0 & 12,7 & 922,5 & 69,7 \\
\hline Outros & 36,0 & 4,5 & & & 158,3 & 11,6 & 10,0 & 0,8 \\
\hline TOTAL & 803,3 & 100,0 & 583,2 & 100,0 & $1.360,8$ & 100,0 & $1.325,5$ & 100,0 \\
\hline
\end{tabular}

Fonte: Elaborado pelo autor com base nos Relatórios de Administração - Eletrobrás.

${ }^{69}$ No capitulo 7 são apresentados e analisados os valores homologados pela Aneel. 


\subsubsection{A Conta de Desenvolvimento Energético}

A Conta de Desenvolvimento Energético (CDE) foi criada pela Lei $n^{\circ} 10.438 / 2002$, com a duração de 25 anos, visando o desenvolvimento energético dos Estados e a competitividade da energia produzida a partir de fontes alternativas, gás natural e carvão mineral nacional, no sistema interligado, e promover a universalização do serviço de energia elétrica. A Lei ${ }^{\circ} 10.762 / 2003$ incluiu, dentre as destinações da $\mathrm{CDE}$, a subvenção econômica destinada à modicidade da tarifa de fornecimento de energia elétrica aos consumidores finais integrantes da subclasse residencial baixa renda.

Os recursos da CDE são constituídos por três parcelas: pagamentos anuais realizados a título de uso de bem público (UBP), multas aplicadas pela Aneel e quotas anuais pagas por todos os agentes que comercializem energia com o consumidor final. Este último componente foi alterado pela Lei $\mathrm{n}^{\circ} 10.848$, de 15 de março de 2004, com a determinação de que as quotas sejam rateadas entre todos os consumidores finais, mediante encargo tarifário a ser incluído, exclusivamente, nas tarifas de uso dos sistemas de transmissão ou de distribuição. As Resoluções Normativas $n^{\circ}$ 71/2004 e n $74 / 2004$ definiram os critérios e procedimentos para que as concessionárias de transmissão que atendam consumidor livre e/ou autoprodutor, com unidade de consumo conectada às respectivas instalações de transmissão integrantes da rede básica, passem a recolher quotas da CDE, a partir de julho de 2004.

Segundo a Lei $\mathrm{n}^{\circ}$ 10.438/2002, as quotas teriam "valor idêntico àquelas estipuladas para o ano de 2001, mediante aplicação do mecanismo estabelecido no $\S 1^{\circ}$ do art. 11 da Lei n ${ }^{\circ}$ 9.648, de 27 de maio de 1998", ou seja, o mesmo valor da Conta Consumo de Combustíveis (CCC) de 2001, “deduzidas em 2003, 2004 e 2005, dos valores a serem recolhidos a título da sistemática de rateio de ônus e vantagens para as usinas termelétricas, situadas nas Regiões atendidas pelos sistemas elétricos interligados".

Portanto, o legislador criou as quotas, que constitui um item da CDE, com base no valor, em reais, da CCC de 2001, pois a partir de 2003 estava prevista a diminuição da CCC do sistema interligado, conforme prescrevia a Lei $\mathrm{n}^{\circ} 9.648 / 98$, e a 
regulamentação da Aneel $^{70}$. Dessa forma, as quotas devem ser deduzidas, à razão de 25\% ao ano, em 2003, 2004 e 2005 dos valores previstos da CCC do sistema interligado, a denominada sistemática de rateio de ônus e vantagens para as usinas termelétricas mencionada na Lei $n^{\circ} 10.438 / 2002^{71}$.

\subsubsection{Recursos da CDE}

O Despacho $\mathrm{n}^{\circ}$ 921, de 28 de novembro de 2003, publicado em cumprimento ao estabelecido no art. 42 do Decreto $\mathrm{n}^{\circ} 4.541 / 2002$, indica que majoritariamente os recursos da CDE provêm das quotas "originadas" da CCC do sistema interligado que corresponderá, em 2004, a R\$1,782 bilhão ${ }^{72}$.

Desse montante, denominado didaticamente neste estudo como quotas "brutas", devem ser descontados os valores previstos para a CCC do sistema interligado que diminuem à razão de $25 \%$ ao ano até sua extinção prevista para o ano de 2006, conforme previsto pela Resolução $n^{\circ}$ 261/98. Assim, em 2003, a Resolução $n^{\circ}$ 42/2003 estabeleceu as quotas "brutas" em R\$ 1,592 bilhão e as "líquidas" em $\mathrm{R} \$ 1,076$ bilhão, pois o montante previsto para CCC do sistema interligado era de $\mathrm{R} \$ 516$ milhões.

Para 2004, a Aneel definiu, por meio da Resolução Homologatória no 12/2004, o valor das quotas "liquidas" (deduzidas do montante destinado à CCC do sistema interligado) da CDE de 2004 em R \$ 1,449 bilhão, representando um incremento de $34,73 \%$ em relação ao ano anterior, $\mathrm{R} \$ 1,076$ bilhão. O impacto da CDE na tarifa, segundo a Aneel, seria, em média, de $0,79 \%$.

Para 2005, a Resolução Normativa $n^{\circ}$ 144/2004 determinou o valor das quotas “brutas” em R \$ 2,044 bilhões; a CCC do sistema interligado em R \$ 176 milhões; e

\footnotetext{
${ }^{70}$ A Lei $n^{\circ} 9.648 / 1998$, em seu art. $11 \S 1^{\circ}$, alínea b, estabelece que no período entre 2003 e 2005 , o reembolso do custo do consumo dos combustíveis utilizados pelas usinas termelétricas participantes da CCC será reduzido até sua extinção, conforme percentuais fixados pela Aneel.

${ }^{71}$ Tendo em vista as destinações comuns entre a CCC e CDE, vide o Apêndice I que versa sobre a Conta de Consumo de Combustíveis.

72 A Resolução Homologatória $\mathrm{n}^{\mathrm{o}}$ 12, de 2 de fevereiro de 2004, alterou os valores "brutos" das quotas da CDE de 2004, inicialmente estimados pelo Despacho n $\mathrm{n}^{\circ}$ 921/2003 em R $\$ 1.630 .469 .506,69$, para $\mathrm{R} \$ 1.782 .103 .170,83$.
} 
as quotas "líquidas" da CDE em R $\$ 1,868$ bilhão, representando um incremento de $29,01 \%$ em relação ao ano de 2004.

O Despacho $n^{\circ}$ 921/2003 e a Resolução Normativa n 144/2004 também apresentam a previsão da arrecadação do pagamento pelo Uso do Bem Público (UBP), que passará a recolher valores maiores a partir de 2007, conforme demonstrado na Tabela 26 abaixo.

Tabela 26 - Previsão de recolhimento de UBP - período 2004 a 2007

\begin{tabular}{c|c}
\hline Ano & Valores $(\mathbf{R} \mathbf{)}$ \\
\hline 2004 & $40.395 .894,00$ \\
\hline 2005 & $16.794 .876,04$ \\
\hline 2006 & $37.936 .913,19$ \\
\hline 2007 & $147.284 .509,26$ \\
\hline 2008 & $307.727 .428,58$ \\
\hline
\end{tabular}

Fonte: Resolução Normativa no 144/2004.

Portanto, com base nos dados divulgados pela Aneel pode-se estimar o valor previsto de arrecadação da CDE para 2004, conforme Tabela 27 a seguir. Observa-se que as quotas representam $96,3 \%$ da CDE.

Tabela 27 - Previsão dos recursos da CDE em 2004

\begin{tabular}{|c|c|c|}
\hline Parcelas da CDE & Valores (R\$) & Percentual \\
\hline Multas recolhidas em 2004 & $15.058 .559,05$ & $1,0 \%$ \\
\hline UBP & $40.395 .894,00$ & $2,7 \%$ \\
\hline Quotas "líquidas" & $1.449 .608 .645,89$ & $96,3 \%$ \\
\hline TOTAL & $\mathbf{1 . 5 0 5 . 0 6 3 . 0 9 8 , 9 4}$ & $\mathbf{1 0 0 , 0 \%}$ \\
\hline
\end{tabular}

Fonte: Resolução Homologatória n o 12/2004.

O legislador criou as quotas da CDE a partir da CCC buscando, inicialmente, não causar aumento na tarifa de fornecimento de energia elétrica, como se pode inferir do disposto no art. $13, \S 3^{\circ}$, da Lei $\mathrm{n}^{\mathrm{o}} 10.438 / 2002$ que estabelece que o reajuste anual 
dessas quotas fosse "na proporção do crescimento do mercado de cada agente, até o limite que não cause incremento tarifário para o consumidor",73.

No ano de 2001, em razão do Programa Emergencial de Redução do Consumo de Energia Elétrica (Percee), a CCC do sistema interligado definida pela Aneel foi de R\$ 1,570 bilhão, segundo a Resolução n 467/2001. Porém, em 2002 o gasto de combustíveis nas termelétricas no sistema interligado foi substancialmente menor: $\mathrm{R}$ \$ 688 mil, conforme registra a Resolução n ${ }^{0}$ 325/2002.

Dessa forma, a criação da CDE com o valor "idêntico àquelas estipuladas para o ano de 2001 mediante aplicação do mecanismo estabelecido no $\S 1^{\circ}$ do art. 11 da Lei $n^{\circ}$ 9.648, de 27 de maio de 1998" (Art. $2^{\circ}$, § $2^{\circ}$, da Lei $n^{\circ} 10.438 / 2002$ ), causou um impacto tarifário que se manterá, pelo menos até $2027^{74}$. Portanto, o máximo valor pago pelos consumidores para subsidiar o combustível das termelétricas do sistema interligado na época do racionamento permanecerá, apesar da extinção da CCC ao final de 2005, prevista pela Lei $n^{\circ} 9.648 / 98$, direcionado agora para outros fins.

Adicionalmente, a Lei $\mathrm{n}^{\mathrm{o}} 10.762 / 2003$ alterou a redação da Lei $\mathrm{n}^{\circ}$ 10.438/2002, possibilitando também a atualização monetária das quotas da CDE, diferentemente do reajuste proporcional ao mercado, previsto inicialmente. Dessa forma, o Decreto $n^{\circ} 4.970$, de 30 de janeiro de 2004, determina que o índice de atualização monetária das quotas será o Índice Nacional de Preços ao Consumidor Amplo - IPCA, calculado pelo IBGE e acumulado no período anterior.

Para apuração das quotas anuais de 2005, a Aneel utilizou a tarifa deste encargo em $\mathrm{R} \$ \mathrm{MWh}$ por região, referente ao exercício de 2004 , e a corrigiu monetariamente pela variação do IPCA acumulado no período de setembro de 2003 a agosto de 2004, no percentual de $7,18 \%$.

\footnotetext{
$73 \mathrm{O}$ aumento das quotas da CDE, que é proporcional ao mercado, não causaria acréscimo tarifário uma vez que o valor reajustado seria dividido por um mercado também maior, mantendo a mesma relação.

${ }^{74}$ A Lei n ${ }^{\circ} 10.438 / 2002$, em seu art. $13 \S 6^{\circ}$, estabelece que a CDE terá a duração de 25 anos.
} 
Em seguida foram subtraídos os valores referentes aos custos de geração da CCC para o exercício de 2005 dos Sistemas Interligados Sul/Sudeste/Centro-Oeste e Norte/Nordeste, obtendo-se assim, como resultado, os valores líquidos das quotas da CDE para o exercício de 2005. Observa-se que a sistemática empregada aplica a correção sobre o valor do encargo em $\mathrm{R} \$ / \mathrm{MWh}$ e não sobre o montante total em reais, incorporando ao valor final a correção monetária e o aumento decorrente do crescimento do mercado de energia elétrica.

\subsubsection{Destinação dos recursos da CDE}

A Lei $\mathrm{n}^{\circ}$ 10.438/2002 estabeleceu as seguintes destinações para a CDE: cobertura do custo de combustível de termelétricas, cobertura do custo das instalações de transporte de gás natural, cobertura da diferença entre o valor econômico da geração a partir de fonte eólica, gás natural biomassa e pequenas centrais hidrelétricas (PCH`s) e o valor correspondente à energia competitiva, promoção da universalização do serviço de energia elétrica e subvenção para a subclasse baixa renda.

A cobertura do custo de combustível das termelétricas é destinada para a geração em operação até 06/02/1998 que utilizem carvão mineral nacional e para aquelas classificadas no $\S 2^{\circ}$, do art. 11 da Lei $n^{\circ}$ 9.648/98. Este dispositivo permitiu que, excepcionalmente, o Poder Executivo aplicasse a CCC, sob os mesmos critérios de prazo e redução fixados, para as usinas termelétricas situadas nas regiões abrangidas pelos sistemas elétricos interligados, desde que as respectivas concessões ou autorizações estivessem em vigor na data de publicação desta norma legal.

A Lei $n^{\circ} 10.438 / 2002$, com redação dada pela Lei $n^{\circ} 10.762 / 2003$, garante até $100 \%$ do valor do combustível às usinas termelétricas a carvão mineral nacional, desde que estas participem da otimização dos sistemas elétricos interligados, compensando-se, os valores a serem recebidos a título da sistemática de rateio de ônus e vantagens para as usinas termelétricas. Na prática, para essas usinas manteve-se, até 2027 o benefício da CCC previsto para terminar em 2006. 
Adicionalmente, até $15 \%$ do montante das quotas da CDE, pode ser destinada para pagamento da diferença entre o valor econômico correspondente à geração termelétrica a carvão mineral nacional que utilize tecnologia limpa, de instalações que entrarem em operação a partir de 2003, e o valor econômico correspondente a energia competitiva.

A CDE pode ser utilizada também para a cobertura do custo das instalações de transporte de gás natural a serem implantados para os Estados onde, até o final de 2002, não exista o fornecimento de gás natural canalizado. No pagamento do custo das instalações de transporte de gás natural, devem ser deduzidos os valores que forem pagos em substituição aos investimentos em transmissão necessários para transportar a energia de uma termelétrica ao centro de carga, por meio da incorporação nas tarifas de uso dos sistemas de transmissão e distribuição de energia elétrica, de acordo com art. $13, \S 7^{\mathrm{o}}$, da Lei $\mathrm{n}^{\mathrm{o}} 10.438 / 2002^{75}$.

A nova redação dada pela Lei $\mathrm{n}^{\mathrm{o}}$ 10.762/2003 assegura, nos anos de 2004, 2005, 2006, 2007 e 2008 percentuais mínimos da receita anual da CDE de 15\%, 17\%, 20\%, $25 \%$ e $30 \%$, respectivamente, para utilização na instalação de transporte de gás natural. Determina que o saldo dos recursos eventualmente não utilizados em cada ano no custo das instalações de transporte de gás natural será destinado à mesma utilização no ano seguinte, somando-se à receita anual do exercício.

A CDE pode ser destinada também para o para pagamento ao produtor de energia elétrica a partir de fontes eólica, térmicas a gás natural, biomassa e pequenas centrais hidrelétricas, cujos empreendimentos entrem em operação a partir de 29 de abril de 2002 (data da publicação da Lei $n^{\circ}$ 10.7438/2002), da diferença entre o valor econômico correspondente à tecnologia específica da fonte e o valor da energia competitiva. Esse benefício é aplicável para a geradora somente quando a

$75 \S 7^{\circ}$ Para fins de definição das tarifas de uso dos sistemas de transmissão e distribuição de energia elétrica, considerar-se-á integrante da rede básica de que trata o art. 17 da Lei ${ }^{\circ} 9.074$, de 7 de julho de 1995, as instalações de transporte de gás natural necessárias ao suprimento de centrais termelétricas nos Estados onde, até o final de 2002, não exista fornecimento de gás natural canalizado, até o limite do investimento em subestações e linhas de transmissão equivalentes que seria necessário construir para transportar, do campo de produção de gás ou da fronteira internacional até a localização da central, a mesma energia que ela é capaz de produzir no centro de carga, na forma da regulamentação da Aneel. 
comercialização de energia for realizada com o consumidor final e não com a distribuidora ou a comercializadora.

Segundo a Lei $\mathrm{n}^{\circ}$ 10.438/2002 a CDE também se presta para pagamento, ao produtor de energia alternativa integrante de $2^{\mathrm{a}}$ fase do Proinfa, do crédito complementar, calculado pela diferença entre o valor econômico correspondente à tecnologia específica de cada fonte e o valor recebido da Eletrobrás, apesar das incertezas decorrentes da implantação das novas diretrizes para o setor elétrico decorrente da Lei $n^{\circ} 10.848 / 2004$, que determina a realização de leilões para a compra de energia pelas distribuidoras.

De acordo com a referida Lei, a nenhuma das fontes eólica, biomassa, pequenas centrais hidrelétricas, gás natural e carvão mineral nacional, poderão ser destinados anualmente recursos cujo valor total ultrapasse a 30\% do recolhimento anual da CDE, condicionando-se o enquadramento de projetos e contratos à prévia verificação, junto à Eletrobrás, de disponibilidade de recursos.

Finalmente, a CDE também poderá ser destinada para a promoção da universalização do serviço de energia elétrica em todo o território nacional e também para garantir recursos à subvenção econômica destinada à modicidade tarifária para a subclasse baixa renda, objeto de estudo desta dissertação.

É oportuno observar que o marco legal da universalização foi instituído com a previsão do uso da CDE como fonte de recursos para a universalização. Porém, a falta de regulamentação e as demais destinações da CDE criaram certa disputa pelos recursos desse fundo que poderia inviabilizar os programas de universalização. Essa discussão é focalizada no Capítulo 8, que também analisa a Lei no 10.438/2002 e sua regulamentação. 


\section{CAPÍTULO 7 - NÚMEROS DA UNIVERSALIZAÇÃO}

\subsection{DOMICILIOS SEM ACESSO À ENERGIA ELÉTRICA}

Dados do Censo-2000 registram que até aquele ano cerca de 11 milhões de brasileiros ainda não tinham acesso aos serviços de energia elétrica, em que pese ser esse o serviço público com maior índice de atendimento, atingindo em 2000 cerca de 42,3 milhões de domicílios.

O esforço empreendido em esfera nacional nas últimas décadas permitiu que o índice de atendimento evoluísse de 24,6\% nos anos 50 para 94,5\% em 2000, como se observa na Figura 4. Nesse âmbito, vale destacar que em cinco décadas o número de domicílios cresceu cerca de 34,7 milhões, enquanto o número de domicílios atendidos com energia elétrica cresceu em torno de 40 milhões, o que representa um incremento médio de 1 milhão de ligações acima do crescimento vegetativo ${ }^{76}$, a cada 10 anos.

Isso demonstra a necessidade de ainda haver grande esforço para a universalização do acesso ao serviço de energia elétrica nos próximos anos, pois, se for mantido o mesmo ritmo de ampliação, o horizonte para o atendimento pleno seria somente em 2028.

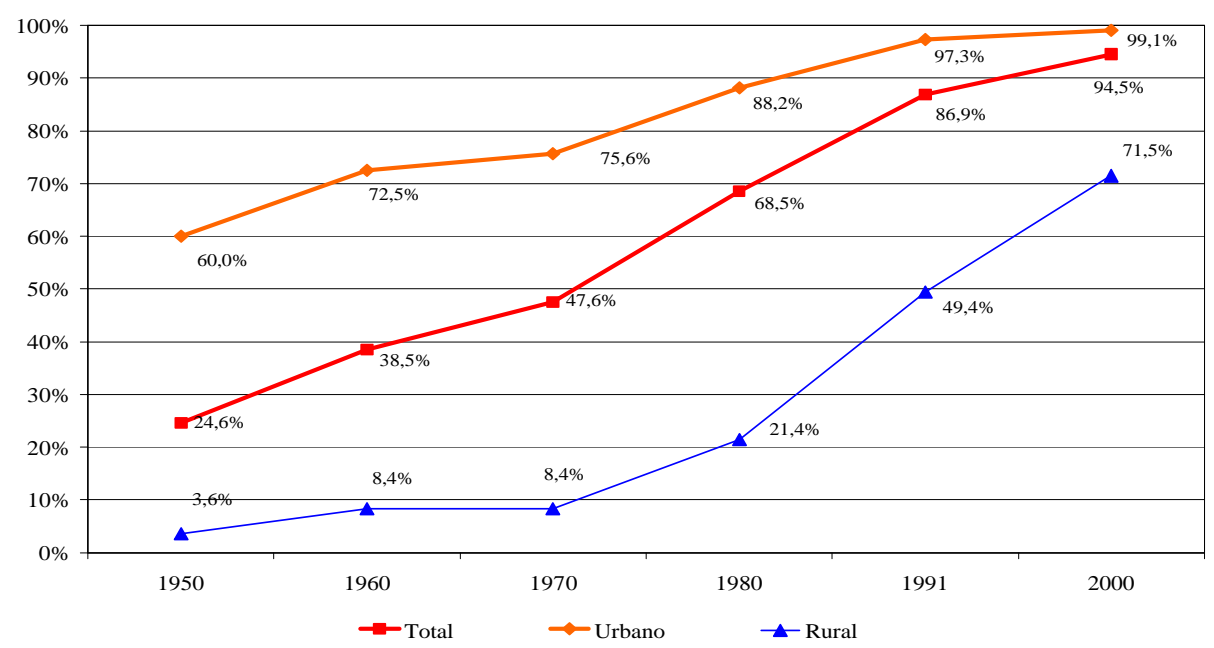

Fonte: Elaborado pelo autor com base em dados do IBGE.

Figura 4 - Índice de domicílios com energia elétrica

${ }^{76}$ Crescimento vegetativo ou natural é a diferença entre as taxas de natalidade e as de mortalidade. 
Segundo a Associação Brasileira dos Distribuidores de Energia Elétrica (ABRADEE, 2002), estatísticas demonstram que no período de 1991 a 2000, as distribuidoras atenderam a mais de dois milhões de novos consumidores por ano. Nesse período, a redução média da demanda reprimida na área rural foi de 174 mil unidades por ano. Na avaliação da associação, apresentada no III Workshop Luz no Campo, realizado em novembro de 2002 no Rio de Janeiro, permanecendo esse ritmo de atendimento, a universalização ocorreria em 2014.

A maioria dos 2,4 milhões de domicílios que não tem acesso à iluminação elétrica está localizada na área rural do País, e geograficamente nas Regiões Norte $(21,2 \%)$ e Nordeste $(57,3 \%)$, conforme se observa na Tabela 28 , a seguir.

Tabela 28 - Domicílios sem acesso à energia elétrica - 2000

\begin{tabular}{c|r|r|r|r|r|r|r|r|r|}
\hline \multirow{2}{*}{ Regiōes } & \multicolumn{3}{|c|}{ TOTAL } & \multicolumn{3}{c|}{ ÁREA URBANA } & \multicolumn{2}{c|}{ ÁREA RURAL } \\
\cline { 2 - 10 } & $\begin{array}{c}\text { Número } \\
\text { domicílios }\end{array}$ & $\begin{array}{c}\text { Sem } \\
\text { Iluminação } \\
\text { Elétrica }\end{array}$ & $\begin{array}{c}\text { \% do } \\
\text { Brasil }\end{array}$ & $\begin{array}{c}\text { Número } \\
\text { domicílios }\end{array}$ & $\begin{array}{c}\text { Sem } \\
\text { Iluminação } \\
\text { Elétrica }\end{array}$ & $\begin{array}{c}\text { \% do } \\
\text { Brasil }\end{array}$ & $\begin{array}{c}\text { Número } \\
\text { domicílios }\end{array}$ & $\begin{array}{c}\text { Sem } \\
\text { Iluminação } \\
\text { Elétrica }\end{array}$ & $\begin{array}{c}\text { \% do } \\
\text { Brasil }\end{array}$ \\
\hline Norte & 2.808 .804 & 518.129 & $21,2 \%$ & 2.041 .485 & 50.870 & $15,3 \%$ & 767.320 & 467.259 & $22,1 \%$ \\
\hline Nordeste & 11.398 .077 & 1.401 .840 & $57,3 \%$ & 8.160 .897 & 159.917 & $48,2 \%$ & 3.237 .182 & 1.241 .928 & $58,8 \%$ \\
\hline Sudeste & 20.215 .396 & 248.064 & $10,1 \%$ & 18.490 .460 & 58.518 & $17,6 \%$ & 1.724 .938 & 189.548 & $9,0 \%$ \\
\hline Sul & 7.201 .178 & 143.979 & $5,9 \%$ & 5.927 .755 & 37.651 & $11,4 \%$ & 1.273 .423 & 106.328 & $5,0 \%$ \\
\hline Centro-oeste & 3.153 .281 & 132.907 & $5,4 \%$ & 2.749 .356 & 24.693 & $7,4 \%$ & 403.925 & 108.215 & $5,1 \%$ \\
\hline BRASIL & $\mathbf{4 4 . 7 7 6 . 7 3 6}$ & $\mathbf{2 . 4 4 4 . 9 1 9}$ & $\mathbf{1 0 0 , 0 \%}$ & $\mathbf{3 7 . 3 6 9 . 9 5 3}$ & $\mathbf{3 3 1 . 6 4 9}$ & $\mathbf{1 0 0 , 0 \%}$ & $\mathbf{7 . 4 0 6 . 7 8 8}$ & $\mathbf{2 . 1 1 3 . 2 7 8}$ & $\mathbf{1 0 0 , 0 \%}$ \\
\hline
\end{tabular}

Fonte: Elaborado pelo autor com base em dados do IBGE - Censo 2000.

Apesar do acréscimo de cerca de 3,7 milhões de novos domicílios com acesso a energia elétrica nos últimos 20 anos, é justamente na área rural onde se concentra atualmente a maior parte da população sem acesso a este serviço, com cerca de 9,7 milhões de pessoas. Portanto, segundo dados do $\operatorname{IBGE}^{77}$, a universalização na área rural compreenderá a um esforço para o atendimento de 2,1 milhões de novos domicílios rurais.

$\mathrm{O}$ atendimento às áreas urbanas, por sua vez, está praticamente equacionado, haja vista que somente cerca de 330 mil domicílios não têm acesso ao serviço; segundo dados do Censo-2000, o índice de atendimento nas áreas urbanas é de 99,1\%.

${ }^{77} \mathrm{O}$ atual Índice de Atendimento Rural no País é de 71,5\%. 
Do ponto de vista regional é oportuno destacar a Região Nordeste, na qual existem cerca de 6,4 milhões de pessoas sem acesso a energia elétrica, representando 57,3\% da população sem energia elétrica no País. Apenas o Estado da Bahia possuía, em 2000, cerca de 550 mil domicílios sem energia elétrica; em termos absolutos corresponde ao valor mais significativo do Brasil.

O esforço de universalização do acesso físico aos serviços deverá ser igualmente grande em Estados como o Piauí (24,1\% dos domicílios sem atendimento) ${ }^{78}$, Tocantins (22,9\%), Pará (21,0\%) e Maranhão (20,3\%), conforme exposto no Anexo A - Acesso à energia elétrica - Dados do Censo 2000. Por outro lado, a diversidade observada, inclusive em uma mesma região, é um ponto importante a ser considerado no estabelecimento de metas para a universalização do acesso físico: enquanto o Estado do Piauí possui um índice de 24,1\% dos domicílios sem atendimento, no Estado de Pernambuco este índice é de apenas 3,9\%.

Os dados divididos por município indicam grande dispersão para o Estado da Bahia, uma vez que as taxas de atendimento em termos municipais variam desde $28 \%$ até 99\% (vide Anexo D - Municípios e domicílios sem acesso à energia elétrica em função do índice de atendimento municipal).

No Brasil, o município com o pior índice de atendimento é Novo Santo Antônio, no Piauí, com $8 \%$ dos domicílios com energia elétrica. Porém, a grande maioria dos municípios, que integram o território nacional, tem índice acima de $90 \%$, segundo Censo 2000, conforme Tabela 29 abaixo. É interessante notar que existem 224 municípios com 100\% de atendimento, sendo dois em Pernambuco, cinco em Goiás, 12 em Minas Gerais, 25 no Paraná, 37 em Santa Catarina e 36 no Rio Grande do Sul. Em São Paulo, além dos 107 municípios com 100\% de atendimento, 465 municípios, dentre os 645 do Estado, possuem índices superiores a 99\%, segundo dados do Censo 2000.

\footnotetext{
${ }^{78}$ No Estado do Piauí está localizado o município brasileiro com menor Índice de Atendimento, Novo Santo Antônio, com um Índice de 8,1 \%. Dos 706 domicílios do município, apenas 57 possuem energia elétrica, segundo dados do Censo-2000.
} 
Tabela 29 - Domicílios não atendidos - índice do município - 2000

\begin{tabular}{c|r|r|r}
\hline \multicolumn{4}{|c}{ BRASIL } \\
$\begin{array}{c}\text { Faixas de } \\
\text { atendimento }\end{array}$ & $\begin{array}{c}\text { Quantidade de } \\
\text { Municípios }\end{array}$ & $\begin{array}{c}\text { Domicílios não } \\
\text { atendidos }\end{array}$ & $\begin{array}{c}\text { Percentual do } \\
\text { País }\end{array}$ \\
\hline $0-10 \%$ & 1 & 649 & $0,03 \%$ \\
\hline $10-20 \%$ & 15 & 15.148 & $0,62 \%$ \\
\hline $20-30 \%$ & 24 & 35.084 & $1,43 \%$ \\
\hline $30-40 \%$ & 72 & 115.151 & $4,71 \%$ \\
\hline $40-50 \%$ & 152 & 217.859 & $8,91 \%$ \\
\hline $50-60 \%$ & 262 & 379.434 & $15,52 \%$ \\
\hline $60-70 \%$ & 329 & 352.051 & $14,40 \%$ \\
\hline $70-80 \%$ & 452 & 416.104 & $17,02 \%$ \\
\hline $80-90 \%$ & 820 & 434.762 & $17,78 \%$ \\
\hline $90-100 \%$ & 3.380 & 478.720 & $19,58 \%$ \\
\hline Total & $\mathbf{5 . 5 0 7}$ & $\mathbf{2 . 4 4 4 . 9 6 2}$ & $\mathbf{1 0 0 , 0 0 \%}$ \\
\hline
\end{tabular}

Fonte: Elaborado pelo autor com base em dados do IBGE - Censo 2000.

Esse fato revela que as metas devem ser diferenciadas em função da região e da taxa de atendimento, não sendo possível existir apenas uma meta em um País tão heterogêneo como o Brasil.

Adicionalmente, com base na Pesquisa Nacional de Amostra de Domicílios - PNAD - 2001, realizada pelo IBGE, o TCU (2003b, p. 23) apresenta dados que comprovam que "para domicílios com renda per capita mais elevada, maior é a probabilidade de que seja atendido pela rede de distribuição de energia elétrica”. Dessa forma, observa-se na Tabela 30 que 92,9\% da população sem acesso aos serviços de energia elétrica têm renda até $\mathrm{R} \$ 300,00$, o que demonstra que a exclusão no acesso à energia elétrica, além de estar focada na área rural e nas Regiões Norte e Nordeste, também se concentra entre a população mais pobre do País ${ }^{79}$.

\footnotetext{
79 É considerada pobre, pelos programas sociais do Governo Federal, a família com renda média per capita de meio salário mínimo. Admitindo-se quatro pessoas por família e o salário mínimo vigente em janeiro de 2001 ( $\mathrm{R} \$ 151,00)$, pode-se considerar que 92,9\% dos domicílios sem energia elétrica são habitados por famílias pobres.
} 
Tabela 30 - Domicílios sem energia elétrica - percentual por faixa de renda

\begin{tabular}{c|c}
\hline $\begin{array}{c}\text { Faixa de renda } \\
\text { (R\$) }\end{array}$ & Percentual \\
\hline zero & $2,8 \%$ \\
\hline 0 a 50 & $33,7 \%$ \\
\hline 50 a 100 & $26,6 \%$ \\
\hline 100 a 150 & $12,5 \%$ \\
\hline 150 a 200 & $11,5 \%$ \\
\hline 200 a 300 & $5,8 \%$ \\
\hline 300 a 400 & $2,3 \%$ \\
\hline 400 a 500 & $0,6 \%$ \\
\hline 500 a 750 & $0,7 \%$ \\
\hline 750 a 1000 & $0,2 \%$ \\
\hline mais de 1000 & $0,2 \%$ \\
\hline ignorada & $2,9 \%$ \\
\hline
\end{tabular}

Fonte: TCU (2003b)

Estimativas preliminares indicam que seriam necessários recursos da ordem de $\mathrm{R} \$ 7,3$ bilhões para levar o acesso da energia elétrica a esses 11 milhões de brasileiros, conforme apresentado na Tabela $31^{80}$.

Tabela 31 - Estimativa do Custo Universalização

\begin{tabular}{c|r|r|r|r|r}
\hline \multirow{2}{*}{ Região } & \multicolumn{5}{|c|}{ Domicílios Sem Iluminação Elétrica } \\
\cline { 2 - 6 } & Total & Urbanos & \multicolumn{1}{c|}{ Rurais } & $\begin{array}{c}\text { Custo } \\
\text { Estimado (R\$\$ } \\
\text { mil) }\end{array}$ & $\begin{array}{c}\text { \% do } \\
\text { custo } \\
\text { total }\end{array}$ \\
\hline Norte & 518.129 & 50.870 & 467.259 & 1.813 .107 & $24,7 \%$ \\
\hline Nordeste & 1.401 .840 & 159.917 & 1.241 .928 & 3.965 .660 & $54,0 \%$ \\
\hline Sudeste & 248.064 & 58.518 & 189.548 & 656.421 & $8,9 \%$ \\
\hline Sul & 143.979 & 37.651 & 106.328 & 375.461 & $5,1 \%$ \\
\hline Centro-oeste & 132.907 & 24.693 & 108.215 & 537.967 & $7,3 \%$ \\
\hline BRASIL & $\mathbf{2 . 4 4 4 . 9 1 9}$ & $\mathbf{3 3 1 . 6 4 9}$ & $\mathbf{2 . 1 1 3 . 2 7 8}$ & $\mathbf{7 . 3 4 8 . 6 1 4}$ & $\mathbf{1 0 0 , 0 \%}$ \\
\hline
\end{tabular}

Fonte: Elaborado pelo autor com base em dados do IBGE - Censo 2000 e Programa Luz no Campo.

Esses investimentos poderão provocar, no caso de ser custeado pelas tarifas dos consumidores já conectados, um aumento significativo nas tarifas de energia elétrica da população, atingindo inclusive as mais carentes, em especial nas Regiões Norte e

\footnotetext{
${ }^{80}$ Custos médios por unidade adotados: Rural: NE, SE e S - R\$ 3.000,00; CO - R \$ 4.629,00 (Luz no Campo); N - R\$3.717,00 (Luz no Campo). Urbano - R\$ 1.500,00. Dados do Programa Luz no Campo extraídos de Pertusier (2000).
} 
Nordeste, onde se concentra a maioria dos domicílios não atendidos e as distribuidoras com menor poder econômico ${ }^{81}$.

\subsection{APLICAÇÃO DA TARIFA RESIDENCIAL BAIXA RENDA}

Segundo dados da Aneel apresentados por Castro e Nunes (2003), imediatamente após aplicação da Lei $\mathrm{n}^{\mathrm{o}} 10.438 / 2002$, houve um aumento significativo de consumidores classificados na subclasse residencial baixa renda no País, cerca de 6,7 milhões, destacando-se a Região Nordeste, com aumento de 4,6 milhões.

Após o período de transição entre os novos critérios e aqueles anteriores à Lei $\mathrm{n}^{\circ}$ 10.438/2002, a Aneel estimava um total de cerca de 14 milhões de consumidores baixa renda no Brasil, correspondendo a $34 \%$ dos consumidores residenciais. A Figura 5 apresenta a estimativa do número de unidades consumidoras baixa renda nesse período.

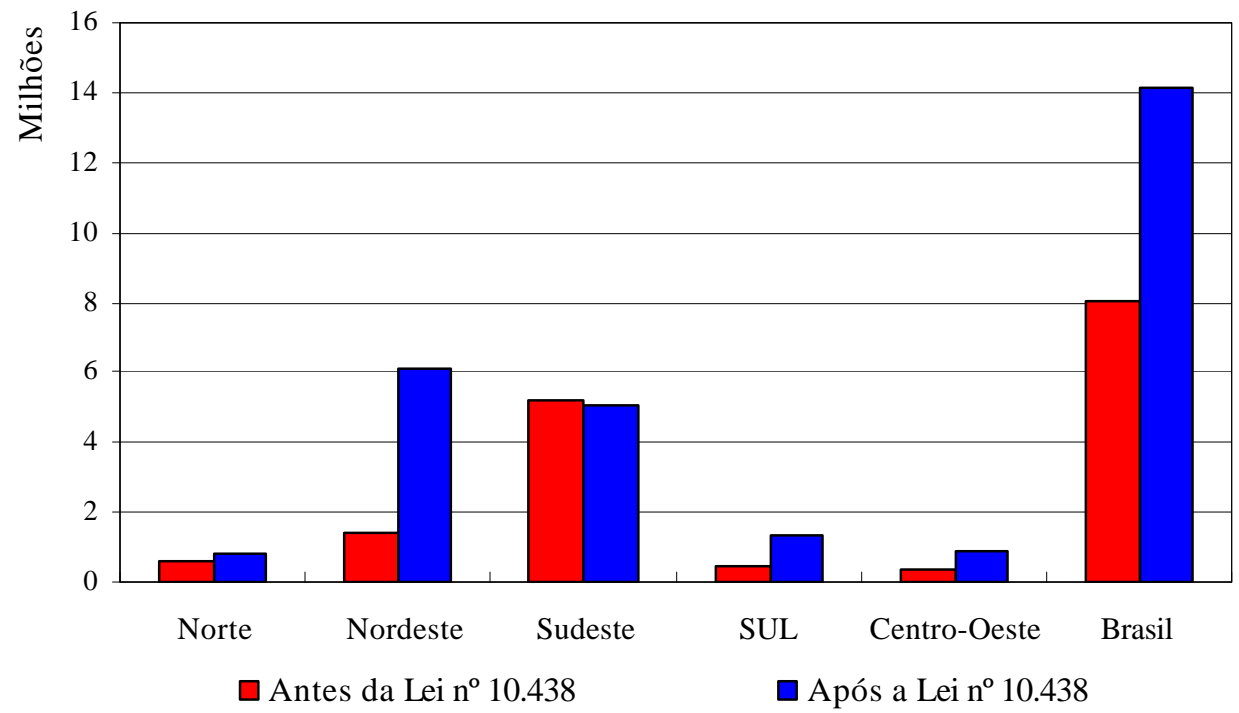

Fonte: Castro e Nunes (2003).

Figura 5 - Número de Consumidores da Subclasse Residencial Baixa

${ }^{81}$ Dos custos estimados, 72,3\% são relativos às Regiões Norte e Nordeste do Brasil, implicando uma política regional diferenciada a ser adotada pelo MME na alocação dos recursos necessários para o processo, não sendo possível o financiamento por meio de recursos da própria área de concessão. 
De acordo com dados fornecidos pelo Ministério do Desenvolvimento Social e Combate a Fome (2004), o número de famílias pobres no Brasil corresponde a 11 milhões, portanto menor do que a estimativa de domicílios classificados como baixa renda para a aplicação da tarifa com descontos.

A Figura 6 apresenta, por Região, os percentuais de consumidores baixa renda em relação ao total dos residenciais, desde 1998 até 2004, enfatizando dois momentos, anterior e posterior aos novos critérios estabelecidos pela Lei $n^{\circ} 10.438 / 2002$, elaborados com dados informados pelas distribuidoras para a Aneel (informação pessoal) ${ }^{82}$.

Em análise comparativa entre os dados da Aneel, observa-se uma melhor distribuição dos consumidores baixa renda após a Lei $n^{\circ}$ 10.438/2002, evidenciada pelo aumento na Região Nordeste e diminuição na Região Sudeste, em consonância com a distribuição das famílias pobres no País ${ }^{83}$.

No entanto, a diminuição dos consumidores baixa renda no início do ano de 2002 identificado na Figura como "2002 antes da Lei” - em relação ao ano de 1998 em todas as regiões brasileiras, não é facilmente explicável. Os percentuais deveriam ser semelhantes, pois os critérios seriam, em tese, os mesmos; exceto pelo crescimento diferenciado do mercado de consumidores residenciais e baixa renda, além da origem distinta dos dados. Dessa forma, feita essas considerações, a diminuição poderia ser creditada a um rigor maior na aplicação dos critérios anteriormente aprovados, a partir de 1998.

\footnotetext{
${ }^{82}$ ANEEL. Dados mensais - consumidores baixa renda por concessionária. [mensagem pessoal]. Mensagem recebida por<sergiokf@uol.com.br>em 21 out. 2004.

${ }^{83}$ Vide Anexo J - Evolução do número de consumidores baixa renda e número de domicílios pobres.
} 


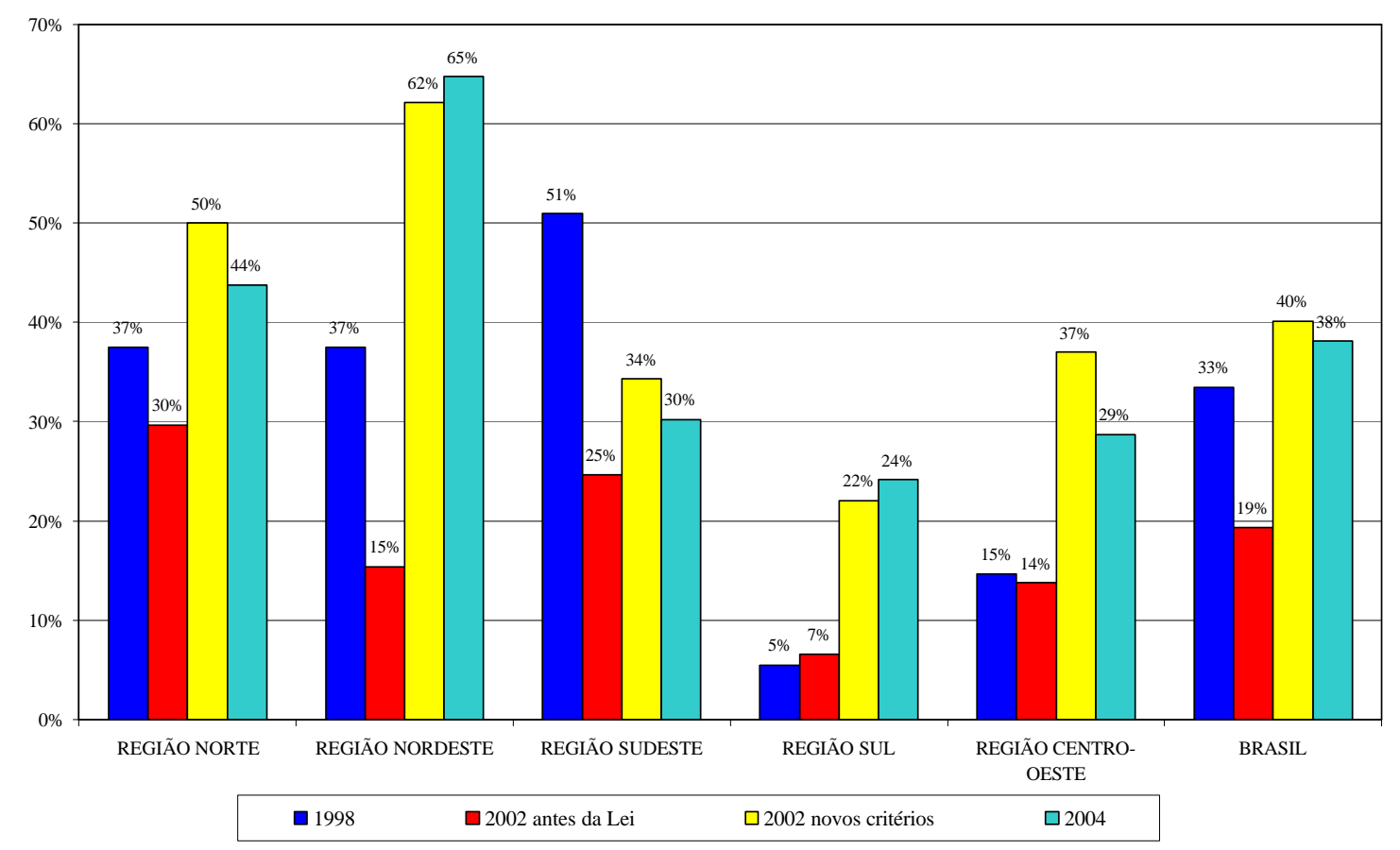

Fonte: Elaborado pelo autor com base em dados da Aneel (1998, informação pessoal).

Figura 6 - Percentual de consumidores baixa renda - 1998/2004

$\mathrm{O}$ aumento dos consumidores baixa renda representou perdas de receita para a grande maioria das concessionárias de distribuição. Em 2002, 2003 e no primeiro semestre de 2004, essas perdas foram da ordem de R \$ 473 milhões, R 937 milhões e R\$ 521 milhões respectivamente ${ }^{84}$, sendo as empresas da Região Nordeste as mais afetadas, em decorrência da adoção dos novos critérios.

Por outro lado, após 29 de fevereiro de 2004, em algumas empresas, principalmente da Região Sudeste, ocorreu uma redução do universo de consumidores beneficiados com a tarifa baixa renda, com o conseqüente aumento de receita da distribuidora ${ }^{85}$. Conforme estabelecido no Decreto ${ }^{\circ} 4.336 / 2002$, esses aumentos de receita deverão ser utilizados para modicidade tarifária de cada empresa, não sendo possível utilizálos para compensar as perdas de receita das demais distribuidoras.

\footnotetext{
${ }^{84}$ Este é o somatório dos valores homologados pela Aneel, até julho de 2004, de acordo com a metodologia estabelecida no art. $2^{-}, \S 2^{\circ}$, do Decreto $n^{-0} 4.538 / 2002$. Vide Anexos K, L e M - Perdas de receita da distribuidora devido aos novos consumidores baixa renda.

${ }^{85}$ Esta redução do número de consumidores baixa renda decorre dos critérios específicos de algumas distribuidoras mais restritivos que os definidos pela regulamentação atual.
} 
O Quadro 5 compara os percentuais de domicílios baixa renda, referente ao mês de julho de 2004, das distribuidoras com uma estimativa da população pobre realizada pelo Governo Federal.

Quadro 5 - Comparação consumidores baixa renda versus famílias pobres

\begin{tabular}{|c|c|c|c|c|c|c|}
\hline Região & Distribuidora & $\begin{array}{l}\text { Consumidores } \\
\text { Baixa Renda }\end{array}$ & $\begin{array}{c}\text { Famílias } \\
\text { pobres }\end{array}$ & Distribuidora & $\begin{array}{c}\text { Consumidores } \\
\text { Baixa Renda }\end{array}$ & $\begin{array}{c}\text { Famílias } \\
\text { pobres }\end{array}$ \\
\hline \multirow{5}{*}{ NORTE } & CEA & $27 \%$ & $17 \%$ & CELPA & $51 \%$ & $39 \%$ \\
\hline & CER & $81 \%$ & $37 \%$ & CELTINS & $51 \%$ & $37 \%$ \\
\hline & CERON & $29 \%$ & $37 \%$ & CEAM & $50 \%$ & $37 \%$ \\
\hline & ELETROACRE & $36 \%$ & $37 \%$ & MANAUS & $34 \%$ & $37 \%$ \\
\hline & BOA VISTA & $17 \%$ & $37 \%$ & & & \\
\hline \multirow{6}{*}{ NORDESTE } & CEMAR & $70 \%$ & $47 \%$ & CELPE & $60 \%$ & $45 \%$ \\
\hline & CEPISA & $68 \%$ & $48 \%$ & CEAL & $61 \%$ & $51 \%$ \\
\hline & COELCE & $70 \%$ & $47 \%$ & ENERGIPE & $61 \%$ & $44 \%$ \\
\hline & COSERN & $57 \%$ & $41 \%$ & SULGIPE & $75 \%$ & $44 \%$ \\
\hline & SAELPA & $69 \%$ & $47 \%$ & COELBA & $64 \%$ & $47 \%$ \\
\hline & CELB & $62 \%$ & $47 \%$ & & & \\
\hline \multirow{11}{*}{ SUDESTE } & CEMIG & $41 \%$ & $26 \%$ & CAIUÁ & $20 \%$ & $13 \%$ \\
\hline & CAT-LEO & $42 \%$ & $26 \%$ & JAGUARI & $6 \%$ & $13 \%$ \\
\hline & POÇOS DE CALDAS & $20 \%$ & $26 \%$ & MOCOCA & $15 \%$ & $13 \%$ \\
\hline & ESCELSA & $36 \%$ & $31 \%$ & CPEE & $11 \%$ & $13 \%$ \\
\hline & SANTA MARIA & $32 \%$ & $31 \%$ & SANTA CRUZ & $25 \%$ & $13 \%$ \\
\hline & LIGHT & $29 \%$ & $16 \%$ & CSPE & $18 \%$ & $13 \%$ \\
\hline & AMPLA & $48 \%$ & $16 \%$ & V. PARANAPANEMA & $22 \%$ & $13 \%$ \\
\hline & CENF & $26 \%$ & $16 \%$ & NACIONAL & $8 \%$ & $13 \%$ \\
\hline & ELEKTRO & $47 \%$ & $13 \%$ & ELETROPAULO & $15 \%$ & $13 \%$ \\
\hline & CPFL & $29 \%$ & $13 \%$ & BANDEIRANTE & $8 \%$ & $13 \%$ \\
\hline & BRAGANTINA & $12 \%$ & $13 \%$ & PIRATININGA & $20 \%$ & $13 \%$ \\
\hline \multirow{9}{*}{ SUL } & COPEL & $28 \%$ & $22 \%$ & CEEE & $24 \%$ & $18 \%$ \\
\hline & COCEL & $32 \%$ & $22 \%$ & AES-SUL & $22 \%$ & $18 \%$ \\
\hline & CORONEL VIVIDA & $36 \%$ & $22 \%$ & RGE & $27 \%$ & $18 \%$ \\
\hline & CFLO & $28 \%$ & $22 \%$ & ELETROCAR & $27 \%$ & $18 \%$ \\
\hline & CELESC & $16 \%$ & $12 \%$ & PANAMBI & $20 \%$ & $18 \%$ \\
\hline & URUSSANGA & $21 \%$ & $12 \%$ & NOVA PALMA & $37 \%$ & $18 \%$ \\
\hline & IGUAÇU ENERGIA & $21 \%$ & $12 \%$ & DEMEI & $24 \%$ & $18 \%$ \\
\hline & JOÃO CESA & $20 \%$ & $12 \%$ & MUXFELDT & $71 \%$ & $18 \%$ \\
\hline & COOPERALIANÇA & $50 \%$ & $12 \%$ & & & \\
\hline \multirow{3}{*}{$\begin{array}{l}\text { CENTRO- } \\
\text { OESTE }\end{array}$} & ENERSUL & $30 \%$ & $24 \%$ & CHESP & $49 \%$ & $26 \%$ \\
\hline & CEMAT & $21 \%$ & $25 \%$ & CEB & $19 \%$ & $18 \%$ \\
\hline & CELG & $35 \%$ & $26 \%$ & & & \\
\hline & BRASIL & $38 \%$ & $28 \%$ & & & \\
\hline
\end{tabular}

Fonte: Elaborado pelo autor com base em dados da Aneel (informação pessoal) e MDS (2004).

Observa-se que, em geral, o número de consumidores baixa renda é maior do que o de famílias pobres, o que evidencia que os critérios de focalização utilizados para a classificação dos consumidores baixa renda não são ideais. Contudo, é importante 
notar que o número de consumidores baixa renda deveria ser menor do que o apresentado, pois os critérios anteriores à Lei $n^{\circ}$ 10.438/2002 não são válidos desde 29 de fevereiro de 2004. O fato de que algumas distribuidoras não descadastraram esses consumidores pode ser parcialmente explicado pelas liminares conseguidas pelos órgãos de defesa do consumidor. 


\section{CAPÍTULO 8 - ANÁLISE DO MARCO LEGAL E DA REGULAMENTAÇÃO DA UNIVERSALIZAÇÃO}

\subsection{ANÁLISE DO MARCO LEGAL DA UNIVERSALIZAÇÃO}

Além das pessoas sem acesso ao serviço de energia elétrica no Brasil, parcelas significativas da população não possuem renda suficiente para arcar com os custos do serviço, ainda que suas residências tenham acesso físico à rede de distribuição.

Pode-se estimar o comprometimento médio na renda desses consumidores, decorrente dos gastos com energia elétrica. Aplicando-se a tarifa de fornecimento residencial de $\mathrm{R} \$ 311,51 / \mathrm{MWh}$ a um consumo de aproximadamente $140 \mathrm{kWh}$ ao mês, então se obtém o valor de $\mathrm{R} \$ 27,57^{86}$.

Segundo Bermann (2003), com base na PNAD de 1999, verifica-se que cerca de 4,2 milhões de domicílios ( $10 \%$ do total) possuem rendimento mensal de até um salário mínimo. Dessa forma, esse consumo comprometeria, no mínimo, $11 \%$ da renda das famílias moradoras desses domicílios. A aplicação de uma alíquota de 25\% de ICMS aumentaria o percentual para $14 \%$.

Importante destacar que as áreas com maior contingente de pessoas sem acesso à energia são aquelas com menores IDH (Piauí, Maranhão, Bahia, Amazonas, por exemplo). Se o financiamento do processo de universalização desse serviço se baseasse apenas em recursos extraídos da própria concessão certamente ocorreria um agravamento da dificuldade social em determinadas Unidades da Federação, tendo em vista que poderia ocorrer, como reflexo, um aumento tarifário justamente nas regiões menos desenvolvidas e mais pobres do País.

Da mesma maneira, as perdas de receita, devido ao aumento do número de baixa renda com os novos critérios definidos pela Lei $n^{\circ}$ 10.438/2002 ocorre, principalmente, nos Estados do Piauí, Sergipe, Bahia, Paraíba e Alagoas nos quais o incremento foi superior a 50 pontos percentuais.

\footnotetext{
86 Tarifa residencial referente à Eletropaulo. Adotou-se o consumo médio divulgado pelo Comitê Técnico para Estudos de Mercado (2003).
} 
O conceito de universalização, sob um ponto de vista mais amplo, que não compreende somente o acesso físico ao sistema de distribuição de energia elétrica, é fortalecido, considerando o foco dos programas de atendimento universal norteamericanos, definido como políticas, proteção e serviços que ajudam os consumidores baixa renda a manter o serviço de energia elétrica.

Da mesma forma, o Decreto $\mathrm{n}^{\circ} 4.541 / 2002$ e a versão inicial do documento do programa nacional de universalização (MME, 2003a) definem a universalização do serviço de energia elétrica neste sentido amplo, englobando as duas vertentes estudadas nesta dissertação.

Adicionalmente, o Tribunal de Contas da União (TCU, 2003a) afirma ser necessário criar condições econômicas (capacidade de pagamento) para viabilizar o acesso à rede de distribuição de energia elétrica, considerando que a maioria das pessoas excluídas do serviço é de baixa renda.

Portanto, consolida-se a tese da universalização dos serviços de energia elétrica com essas duas vertentes. Fica configurada a necessidade de tratamento desses dois assuntos em conjunto, principalmente em relação aos recursos necessários para a conexão e a garantia da continuidade do acesso aos consumidores baixa renda, tanto urbanos quanto rurais. O próprio TCU ressalta que a solução desse problema é essencial para assegurar o bem-estar que a energia elétrica propicia aos consumidores, como também "para conferir sustentabilidade econômico-financeira ao processo de expansão da rede de distribuição no País” (TCU, 2003a, p. 27).

\subsubsection{Conceito de universalização do acesso}

O conceito de universalização do acesso físico ao sistema de distribuição de energia elétrica foi estabelecido pela redação inicial da Lei $\mathrm{n}^{\circ} 10.438 / 2002$, definindo a distribuidora como responsável pelo ônus da conexão, independentemente do tipo de consumidor. A Lei permitia, no entanto, uma transição configurada no estabelecimento das denominadas áreas crescentes de universalização que seriam definidas pela Aneel. 
Isto significou mudança de paradigma, pois a regulamentação vigente até então estabelecia que o solicitante deveria arcar com a diferença entre o valor das obras necessárias para o seu atendimento e o limite de investimento obrigatório da distribuidora. Essa obrigação da concessionária deveria ser calculada pelo regulador em função do retorno econômico da nova ligação. Ultimamente esse valor não refletia adequadamente esse princípio, pois estava vinculado à denominada tarifa fiscal, mantida no mesmo patamar por sete $\operatorname{anos}^{87}$.

Dessa forma, com o limite de investimento da distribuidora atenuado, a participação financeira do consumidor aumentou desproporcionalmente nesse período. Esse fato é relevante uma vez que a situação de não-atendimento existente, principalmente na área rural é, em grande parte, decorrente da obrigatoriedade da participação financeira do consumidor.

O legislador estabeleceu o prazo de um ano, a partir da publicação do marco legal, para que o regulador fixasse as áreas de universalização. Se não fosse regulamentado nesse prazo, a obrigação de atendimento dos pedidos de ligação sem qualquer ônus para o solicitante se estenderia para toda a área concedida ou permitida. Essa imposição confirma o entendimento de que, após o período de transição, o objetivo do legislador era configurar a conexão como responsabilidade irrestrita da distribuidora, em toda a área de concessão ou permissão.

Posteriormente, essa amplitude de responsabilidade financeira das distribuidoras definida em 2002, independentemente do tipo de consumidor, carga instalada ou classe de tensão de fornecimento, foi diminuída pelo Congresso Nacional em 2003. No projeto de conversão da Medida Provisória $n^{\circ} 127 / 2003^{88}$, que originalmente tratava do financiamento para as distribuidoras, foram incluídas importantes alterações na Lei $\mathrm{n}^{\mathrm{o}}$ 10.438/2002.

${ }^{87}$ O limite de investimento da concessionária até a revogação da Portaria Dnaee $\mathrm{n}^{\mathbf{0}}$ 5/90 pela Resolução Aneel n 223/2003 era de R \$ 257,98 (4 vezes a tarifa fiscal) por consumidor residencial, sendo o restante arcado pelo solicitante independente do custo das obras necessárias para a ligação.

${ }^{88}$ A Medida Provisória $n^{\circ} 127$, de 4 de agosto de 2003, criou o programa de apoio emergencial e excepcional às concessionárias de distribuição destinado a suprir a insuficiência de recursos decorrentes do adiamento da compensação do saldo da Conta de Compensação de Variação de Valores de Itens da "Parcela A" - CVA. 
No que se refere à universalização, a Lei $\mathrm{n}^{\circ} 10.762$, de 11 de novembro de 2003, decorrente do projeto de conversão da Medida Provisória n ${ }^{\circ}$ 127/2003, restringe a responsabilidade das distribuidoras pelo atendimento, sem ônus para consumidores do Grupo B, com carga abaixo de $50 \mathrm{~kW}$, nas áreas de universalização, definindo deste modo o conceito de universalização do acesso físico.

Embora o conceito inicialmente definido pela Lei $\mathrm{n}^{\circ}$ 10.438/2002 fosse coerente com o princípio de atendimento universal, a atual redação corresponde a uma forma mais adequada considerando a coerência com os recursos disponíveis. Por outro lado, a inclusão de metas de universalização para as cooperativas, inseridas pela nova redação dada pela Lei $\mathrm{n}^{\circ} 10.762 / 2003$, não está coerente com o processo de regularização em andamento, pois essas passarão a atuar como autorizadas ou permissionárias. No primeiro caso seriam consumidoras e dessa forma não poderiam expandir a sua atuação. No segundo, a Lei $\mathrm{n}^{\circ} 10.438 / 2002$ e a Resolução $\mathrm{n}^{\circ}$ 223/2003, já prevêem o tratamento das permissionárias, não precisando então utilizar o termo metas para as cooperativas, conforme detalhado no Capítulo 9.

\subsubsection{Conceito de universalização do uso}

A política de descontos tarifários, aplicados às famílias carentes, é a filosofia empregada pelo setor elétrico a partir da Portaria Dnaee no $437 / 95$ e ratificada pela Lei $\mathrm{n}^{\circ} 10.438 / 2002$ e demais regulamentações. Os descontos previstos para esses consumidores incidem de forma escalonada sobre a tarifa plena da classe residencial com os seguintes percentuais ${ }^{89}$ :

Tabela 32 - Descontos aplicados para a tarifa da subclasse residencial baixa renda

\begin{tabular}{c|c|}
\hline Faixa de consumo (kWh) & Desconto \\
\hline 0 a 30 & $65 \%$ \\
\hline 31 a 100 & $40 \%$ \\
\hline 101 até limite regional & $10 \%$ \\
\hline
\end{tabular}

Fonte: Castro e Nunes (2003)

${ }^{89}$ Os descontos são aplicados sobre a tarifa residencial excluída do percentual correspondente à recomposição tarifária extraordinária (RTE). 
Porém, desde o estabelecimento da subclasse residencial baixa renda pelo Dnaee, os critérios utilizados para a classificação das famílias pobres são objeto de discussão.

A estratégia, empregada em 1995, de possibilitar que cada distribuidora definisse seus critérios e apresentasse o cadastro das famílias para aprovação do Dnaee não foi adequada, pois resultou em critérios heterogêneos: somente limitação de carga instalada para algumas distribuidoras; localização da residência (favelas, cortiços, conjuntos habitacionais vinculados a programas sociais de habitação) e construções modestas com área construída até $70 \mathrm{~m}^{2}$, para outras; e somente o nível de consumo (limite regional) para pequena parcela de distribuidoras que não apresentou os critérios e o cadastro das famílias no prazo determinado.

Estes critérios heterogêneos resultaram na focalização inadequada: famílias pobres não incluídas e famílias não pertencentes ao público-alvo inseridas no programa, bem como regiões mais pobres do País, com menores índices de consumidores cadastrados como baixa renda.

Porém, a Lei no 10.438/2002 estabeleceu os novos critérios para inclusão de unidades consumidoras na subclasse residencial baixa renda. A Aneel, de acordo com o comando legal, estabeleceu que as unidades consumidoras atendidas por circuito monofásico e com média anual de consumo inferior a $80 \mathrm{kWh} / \mathrm{mês}$ são automaticamente classificadas como subclasse residencial baixa renda. Para aquelas residências com consumo médio anual entre 80 e $220 \mathrm{kWh} / \mathrm{mês}$ é necessário que os consumidores estejam aptos a receber os benefícios do Programa Bolsa Família ${ }^{90}$.

No entanto, esse parâmetro de consumo não é adequado para a focalização do programa. O relatório "Características sócio-econômicas dos potenciais beneficiários da universalização dos serviços de energia elétrica e subsídios a domicílios de baixa renda" (TCU, 2003b) analisou, a partir dos dados da Pesquisa sobre Padrões de Vida (PPV), realizada pelo IBGE ao longo dos anos de 1996 e 1997, a correlação entre as variáveis "consumo residencial de energia" e "renda per capita". 
De acordo com o estudo, o valor do coeficiente de correlação de Pearson ${ }^{91}$ obtido, 0,015, "além de praticamente igual a zero é estatisticamente significativo apenas com 49\% de confiabilidade, o que indica que não há qualquer correlação entre as variáveis" TCU (2003b, p. 28-29).

Dessa forma, os resultados obtidos são conclusivos: "como não há correlação entre as variáveis, utilizar exclusivamente consumo domiciliar de energia elétrica como critério para selecionar consumidores de baixa renda não é adequado" TCU (2003b, p. 30).

Destaca-se que esses critérios de classificação são homogêneos para todo o País, embora o limite regional ainda seja utilizado para a aplicação dos descontos e pode ser considerado um ponto para o aprimoramento dos regulamentos.

\subsection{ANÁLISE DA REGULAMENTAÇÃO DA UNIVERSALIZAÇÃO DO ACESSO}

As alterações promovidas pela Lei $n^{\circ} 10.762 / 2003$ na Lei $n^{\circ} 10.438 / 2002$, de modo geral, foram benéficas para as distribuidoras e, em consequiência, preservando os consumidores já conectados de aumento tarifário maiores, em relação à obrigação original. Assim, no ambiente anterior, criado pela redação original da Lei $\mathrm{n}^{\circ}$ $10.438 / 2002$, as distribuidoras arcariam com todo o custo das obras, eventualmente necessárias, para conectar, por exemplo, um grande consumidor industrial; esses custos se refletiriam, no momento da revisão tarifária, sobre os demais consumidores das distribuidoras.

O pleito original das distribuidoras era restringir a obrigação de atendimento sem ônus (universalização) somente para os consumidores residenciais e rurais, conforme proposta da Abradee (2003a), apresentada durante a Audiência Pública nº 15/2003.

\footnotetext{
90 Até que seja concluída a unificação dos programas de transferência de renda do Governo Federal o responsável pela unidade consumidora deverá comprovar ser beneficiário de um dos programas Bolsa Escola, Bolsa Alimentação, Cartão Alimentação ou inscrição no Cadastro Único dos Programas Sociais do Governo Federal.

91 Coeficiente de Pearson. Coeficiente que determina a correlação entre duas variáveis. O valor 1 corresponde a correlação perfeita e valores próximos de zero indicam fraca correlação.
} 
Observa-se que o conceito de universalização do acesso ainda é foco de controvérsias embora a redação atual do marco legal seja considerada satisfatória pelo autor. Os principais assuntos em discussão tratam dos recursos para a universalização: a falta de previsão na regulamentação da Aneel e o direcionamento da CDE e da RGR por meio do Programa Luz para Todos do Governo Federal; a participação financeira do consumidor não alcançado pela universalização; a definição precisa do ponto de entrega na área rural que define a fronteira física da responsabilidade da distribuidora e do consumidor.

\subsubsection{Fontes de recursos}

A Resolução $n^{\circ}$ 223/2003, que define as metas de universalização, não trata dos recursos financeiros necessários às distribuidoras para que possam promover esse atendimento, como prevê a Lei $\mathrm{n}^{\circ} 10.438 / 2002$, que instituiu a CDE para este e outros fins. A omissão da Aneel é por ela justificada com base no entendimento de que compete ao Ministério de Minas e Energia, como representante do Poder Executivo, a definição de políticas e, conseqüentemente, a alocação de recursos para a universalização (ANEEL, 2003b).

Os principais questionamentos realizados pelas distribuidoras no processo de audiência pública, que tratava da regulamentação das metas de universalização, referiam-se, principalmente, a dois pontos: os prazos para universalização - alguns agentes sugeriram o ano de 2025; a origem e a alocação dos recursos.

A Abradee defendeu a manutenção da sistemática de se calcular a diferença, entre o valor das obras e o limite de investimento da distribuidora, só que neste caso, seria coberta com recursos da CDE ao invés do solicitante. Desse modo, para a distribuidora não haveria alteração no fluxo de investimentos e a implementação dos Planos ficaria condicionada à existência de recursos da CDE. Na audiência pública, a associação das distribuidoras apresentou as seguintes considerações:

- a implementação dos Planos de Universalização somente deveria ocorrer após a liberação dos recursos da CDE para cada empresa; 
- os valores previstos para as penalidades aplicáveis no caso de descumprimento das metas de universalização seriam excessivamente elevados e, portanto, careceriam de razoabilidade;

- para aplicação de penalidades, o cumprimento das metas deve ser avaliado considerando-se o número de domicílios que deixaram de ser atendidos por responsabilidade exclusiva da distribuidora e não pelo número de municípios nos quais a meta não foi atingida;

- a regulamentação ou os Planos de Universalização contemplariam proposta para o tratamento da incorporação de redes particulares, facilitando assim a resolução dos conflitos entre empresas e consumidores;

- os Planos de Universalização deveriam ser implementados somente a partir de $01 / 01 / 2005$.

Embora a Aneel tivesse solicitado posicionamento do MME quanto às diretrizes de política de universalização, como a alocação dos recursos disponíveis, o horizonte de universalização e o nível de possível impacto tarifário suportável, o Governo Federal não se manifestou formalmente.

A agência buscava em dispositivos governamentais bases para a proposição de sua regulamentação. Sem esse fundamento, a Resolução no 223/2003 estabeleceu metas possíveis naquele contexto, considerando que eventuais impactos no equilíbrio econômico-financeiro dos contratos de concessão seriam repassados na revisão tarifária, bem como indicou a possibilidade de reavaliação das metas de universalização, no caso de aporte de recursos a fundo perdido.

É importante ressaltar que se a Aneel não tivesse regulamentado o assunto até 29 de abril de 2003, a gratuidade no atendimento seria aplicada a todos os pedidos de ligação e em todo o território nacional, pois a Lei $\mathrm{n}^{\circ}$ 10.438/2002 assim determinava. 


\subsubsection{Responsabilidade da distribuidora: Grupo B até 50 kW}

Embora não considere a alocação dos recursos, entendida como política de universalização de competência do Governo Federal, a publicação da Resolução $n^{\circ}$ 223/2003 é um marco significativo, com avanços muito importantes.

Definiu-se universalização como o atendimento sem ônus para o consumidor com carga até $50 \mathrm{~kW}$, transferindo a responsabilidade pelo atendimento do mercado para a distribuidora, constituindo uma mudança de paradigma no setor elétrico brasileiro.

O não-atendimento do pleito das distribuidoras, de uso automático dos recursos da CDE imprime um sinal econômico importante. A responsabilidade pelas extensões da rede induz as distribuidoras a pesquisarem padrões de atendimento mais econômicos e a realizarem ações junto aos consumidores visando extrair informações reais sobre a capacidade do atendimento.

Ressalta-se que a regulamentação da Aneel, com base na nova redação da Lei $n^{\circ} 10.438 / 2002$ pela Lei ${ }^{\circ} 10.792 / 2003$, não possibilita o atendimento sem ônus para os casos de aumento de carga. Dessa forma, um aumento de carga, por exemplo, de $10 \mathrm{~kW}$ para $20 \mathrm{~kW}$, não é uma obrigação contida na universalização, acarretando, com isso, que o consumidor arque com eventuais custos das obras necessárias; o que não ocorre com uma nova ligação com a mesma carga de $20 \mathrm{~kW}$.

Considerar a adição de fases na rede de distribuição como extensão de rede também não é adequada, pois corresponde a um aumento da sua capacidade, ou seja, reforço da rede de distribuição. Essa definição da Resolução $n^{\circ}$ 223/2003 implica o atendimento no meio rural de um pedido de ligação que necessite de adição de fases conforme constar no cronograma definido nos Planos de Universalização, e não imediatamente como seria se a obra necessária fosse classificada como reforço da rede primária. Com o término dos prazos de universalização, porém, essa definição não terá implicação, pois a partir desse momento qualquer atendimento (Grupo B, $50 \mathrm{~kW}$ ) será realizado sem ônus para o solicitante. 
A Resolução $n^{\circ}$ 223/2003 também excluiu os loteamentos das condições de atendimento ali estabelecidas, conferindo tal regulamentação para ato específico posterior.

\subsubsection{Exclusão dos loteamentos}

A Resolução Normativa $n^{\circ}$ 82, de 13 de setembro de 2004, define que a responsabilidade pelos investimentos necessários para a construção da rede de distribuição de energia elétrica será do próprio loteador do empreendimento. Esse normativo se baseia no art. $2^{\circ}, \S 5^{\circ}$, da Lei $n^{\circ} 6.766 / 79$, com redação dada pela Lei n ${ }^{\circ}$ 9.785/99, que define a infra-estrutura básica dos lotes urbanos.

A regulamentação também estabelece que as obras construídas pelos loteadores deverão ser incorporadas ao patrimônio da concessionária no momento da sua conexão ao sistema de distribuição. Essa incorporação não implica qualquer forma de indenização ao loteador ou aos adquirentes dos lotes situados em loteamentos, segundo a minuta de resolução.

Porém, a referida norma legal estabelece que nos parcelamentos situados nas zonas habitacionais declaradas por Lei como de interesse social (ZHIS), a infra-estrutura básica consistiria de "soluções" para os esgotos sanitários e para a energia elétrica domiciliar (art. $2^{\circ}, \S 6^{\circ}$, da Lei $n^{\circ} 6.766 / 79$ ), embora não defina o significa desse termo.

Adicionalmente, a Nota Técnica $n^{\circ}$ 070/2003-SRC/ANEEL, ressalta a existência de uma terceira espécie de parcelamento: os parcelamentos populares, instituídos pelo $\S 4^{\circ}$, art. 18 , destinados

às classes de menor renda, em imóvel declarado de utilidade pública, com processo de desapropriação judicial em curso e imissão provisória na posse, desde que promovidos pela União, Estados, Distrito Federal, Municípios ou suas entidades delegadas, autorizadas por lei a implantar projetos de habitação.

Para estes dois últimos tipos de loteamentos, aqueles situados em áreas de interesse social (ZHIS) e os populares, a regulamentação da Aneel impõe a responsabilidade 
pela construção das redes à distribuidora local, diferentemente dos loteamentos promovidos por empresas privadas.

Essa regulamentação poderá gerar conflitos, pois as empresas que promovem os loteamentos entendem que os investimentos na infra-estrutura elétrica deveriam ser ressarcidos pela distribuidora no momento da incorporação dessas redes. Adicionalmente, na visão do autor, a Aneel, ao mesmo tempo em que impõe aos loteadores a responsabilidade pela infra-estrutura, com base na legislação que versa sobre parcelamento do solo, transfere a responsabilidade da infra-estrutura de distribuição de energia elétrica dos loteamentos populares do Poder Público para a distribuidora, sem haver suporte na Lei $n^{\circ}$ 6.766/79.

\subsubsection{Identificação do ponto de entrega}

A Resolução $n^{\circ} 456 / 2000$ define ponto de entrega como a conexão do sistema elétrico da distribuidora com as instalações elétricas da unidade consumidora. Essa definição determina o limite de responsabilidade do fornecimento de energia elétrica pela distribuidora.

Em geral, na área urbana, o ponto de entrega situa-se no limite da via pública com o imóvel em que se localiza a unidade consumidora, exceto alguns casos citados pela regulamentação.

Por exemplo, existindo uma ou mais propriedades entre a via pública e o imóvel em que se localizar a unidade consumidora, o ponto de entrega situa-se no limite da via pública com a primeira propriedade. No caso de linha de propriedade do consumidor, o ponto de entrega situa-se na estrutura inicial desta linha, de acordo com a regulamentação da Aneel.

$\mathrm{Na}$ área rural o ponto de entrega não é definido com precisão na Resolução $n^{\circ} 456 / 2000$, que trata das condições de fornecimento. O exemplo citado no caso de existência de outras propriedades entre a via pública e a unidade consumidora não se aplicaria a áreas rurais, segundo o entendimento da CSPE e da Aneel. A definição do ponto de entrega na estrutura inicial seria válida somente para 
linha particular, entendida como aquela utilizada para o fim exclusivo de prover energia elétrica para unidades de consumo de seus proprietários.

Adicionalmente, a Resolução $\mathrm{n}^{\mathrm{o}}$ 223/2003 revogou o inciso III, art. $7^{\circ}$, da Resolução $n^{\circ} 456 / 2000$, que possibilitava o atendimento na área rural em tensão

primária de distribuição, independentemente da carga instalada. Dessa forma, a distribuidora construía a rede de distribuição primária até o limite da propriedade, sendo que a responsabilidade pelo transformador seria do consumidor. Com a alteração promovida, a distribuidora é responsável pela instalação do transformador e deve respeitar uma distância máxima entre o equipamento e a unidade consumidora, para manter os padrões de qualidade da tensão de fornecimento. Portanto, é necessário regulamentar claramente o ponto de entrega na área rural.

\subsubsection{Limite de investimento obrigatório das distribuidoras}

A Resolução $n^{\circ}$ 223/2003, com base na redação original da Lei $n^{\circ} 10.438 / 2002$, revogou a Portaria $\mathrm{n}^{\circ} 5 / 90$, que tratava da participação financeira do consumidor e do limite de investimento obrigatório da distribuidora.

Com a alteração promovida pela Lei $\mathrm{n}^{\mathrm{o}}$ 10.762/2003, o atendimento aos consumidores não contemplados pela universalização será realizado à custa da distribuidora, conforme regulamento específico a ser estabelecido pela Aneel, que deverá ser submetido à Audiência Pública.

A norma legal também estabelece que é facultado ao consumidor contribuir para o seu atendimento, para compensar a diferença verificada entre o custo total do atendimento e o limite de investimento da distribuidora a ser estabelecido no regulamento. No entanto, esse procedimento definido em novembro de 2003 ainda não foi tratado pela agência, por isso a distribuidora pode atribuir ao solicitante todo o custo das obras necessárias para o seu atendimento.

Dessa forma, é necessário que a Aneel regulamente o limite de investimento da distribuidora, tanto para os novos pedidos de ligação solicitados por consumidores com carga superior a $50 \mathrm{~kW}$ como para os pedidos de aumento de carga solicitados por qualquer consumidor. 


\subsubsection{Obras de terceiros e seu ressarcimento}

A Resolução Normativa $n^{\circ} 58 / 2004$, que ajusta parcialmente a Resolução $n^{\circ}$ 223/2003 à Lei no 10.762/2003, também altera o art. 11 da Resolução nº 456/2000, que possibilitava ao solicitante executar obras de extensão de rede necessárias ao seu atendimento, mediante a contratação de uma empresa (terceira) legalmente habilitada. Nesse caso, a distribuidora deveria ressarcir ao interessado o limite de investimento obrigatório, calculado segundo regulamentação específica.

Com a revogação da Portaria $n^{\circ}$ 5/90, esse artigo se aplicava somente à antecipação do atendimento no caso do interessado optar pela execução da obras. Com isso, a restituição do valor pela distribuidora deveria ser regulamentada pela agência.

\section{Resolução no 456/2000}

Art. 11. A antecipação de atendimento de que trata o art. $14, \S 5^{\circ}$, da Lei $\mathrm{n}^{\circ} 10.438$, de 26 de abril de 2002, com redação dada pela Lei $n^{\circ} 10.762$, de 11 de novembro de 2003, poderá ser feita mediante execução da obra pelo interessado, observados os termos da Resolução n ${ }^{\circ} 223$, de 29 de abril de 2003, e as seguintes condições:

$[\ldots]$

II - o valor a ser restituído, quando o interessado optar pela execução da obra, será o constante do orçamento entregue pela concessionária, mediante pagamento em parcela única e independente de qualquer comprovação, acrescido de atualização e juros, conforme art. 11, § $2^{\circ}$, da Resolução ${ }^{\circ} 223$, de 2003;

$[\ldots]$

A alteração promovida pela Aneel, ao mesmo tempo em que inclui o mecanismo de antecipação do atendimento, exclui dessa sistemática de ressarcimento os futuros consumidores não abrangidos pela universalização.

Dessa forma, a regulamentação do procedimento de ressarcimento é necessária e deveria ser elaborada em conjunto com as regras de participação financeira para as novas ligações de unidades com carga acima de $50 \mathrm{~kW}$.

\subsection{7 Áreas e metas de universalização}

A Aneel estabeleceu o horizonte de universalização de acordo com cada área de concessão, de modo que o consumidor possa ter o conhecimento do ano a partir do qual será atendido sem ônus, possibilitando-o efetuar a antecipação, se lhe for conveniente. 
A sistemática de área foi estabelecida pela Lei $n^{\circ} 10.438 / 2002$ para permitir a transição entre os dois momentos distinguidos pela sua publicação: a expansão do sistema restrita ao limite de investimento obrigatório e a transferência da responsabilidade integral pelos investimentos para as distribuidoras.

Destaca-se, ainda, que a referida norma legal estabeleceu que, a partir de 31 de julho de 2002 e até que entrasse em vigor a sistemática de atendimento de área, as distribuidoras deveriam atender "obrigatoriamente e sem qualquer ônus para o consumidor ao pedido de ligação cujo fornecimento possa ser realizado mediante a extensão de rede em tensão secundária de distribuição”. Ou seja, o legislador entendia que a expansão da rede de distribuição secundária seria sempre responsabilidade da concessionária, desde que não fosse necessária a extensão da rede primária.

Os art. $3^{\circ}$ e $4^{\circ}$ da Resolução ${ }^{\circ}$ 223/2003, estão associados às áreas crescentes, nas quais o atendimento é feito sem ônus para um novo consumidor com carga até $50 \mathrm{~kW}$ (art. 14, inciso I, da Lei ${ }^{\circ}$ 10.438/2002). Observa-se que a Lei determinava que as referidas áreas deveriam se iniciar "em torno das redes de distribuição", mas não estabelecia um critério para a extensão destas.

$\mathrm{O}$ art. $4^{\circ}$ do regulamento cria o mecanismo de expansão das áreas ao exigir o estabelecimento de metas para a expansão de rede em tensão primária. Importante ressaltar que o ritmo de expansão das áreas é determinado pela distribuidora no Plano de Universalização, observado o ano máximo da área de concessão e de cada município indicados pela Aneel.

Adicionalmente, o art. $3^{\circ}$ da resolução da Aneel vincula essas áreas ao alcance das redes de distribuição em tensão secundária, utilizando-se do mesmo mecanismo já previsto na referida Lei para o período de transição entre 31 de julho de 2002, até o estabelecimento das regras pela agência.

Desse modo, ao término da implementação do Plano de Universalização de Energia Elétrica toda a concessão estaria "coberta" pelas "áreas crescentes" tratadas pelo inciso I, art. 14 da Lei no 10.438/2002. Em conseqüência, “as áreas decrescentes” nas 
quais o atendimento pode ser adiado para "horizontes temporais pré-estabelecidos pela Aneel", de acordo com art. 14, inciso II, do referido marco legal, ficam subtendidas como complementares às áreas crescentes.

A Aneel fixa, dessa forma, os prazos para alcance da universalização. Embora sejam, em alguns casos extensos, até 2015, há a possibilidade de antecipá-los, por meio de maior aporte de recursos a fundo perdido.

As definições da responsabilidade da distribuidora e das metas de universalização implicam a aceitação de que, no horizonte posterior aos prazos previstos para cada município, qualquer solicitação de ligação, feita por consumidores com carga de até 50 kW deverá ser atendida sem acarretar ônus para o solicitante e sem a possibilidade de adiamento de prazo.

Considerando os índices de atendimento, estimados com base nos dados dos municípios do Censo 2000, observa-se que mais da metade das empresas (33 distribuidoras) devem atingir a universalização até 2008, em conformidade com a regulamentação da Aneel, demonstrada o Quadro 6 a seguir.

\section{Quadro 6 - Ano máximo para universalização das distribuidoras}

\begin{tabular}{|c|c|c|}
\hline $\begin{array}{c}\text { Ano Máximo } \\
\text { para } \\
\text { Universalização }\end{array}$ & $\begin{array}{c}\text { Quantidade de } \\
\text { distribuidoras }\end{array}$ & Concessionárias \\
\hline $\mathbf{2 0 0 6}$ & 14 & $\begin{array}{c}\text { ELETROPAULO, LIGHT, CEB, CPFL, PIRATININGA, } \\
\text { BANDEIRANTE, JAGUARI, JOÃO CESA, POÇOS DE } \\
\text { CALDAS, COOPERALIANÇA, NACIONAL, } \\
\text { URUSSANGA, CPE, MOCOCA }\end{array}$ \\
\hline $\mathbf{2 0 0 8}$ & 19 & $\begin{array}{c}\text { ESCELSA, CEEE, ELEKTRO, AMPLA, CELESC, } \\
\text { ELETROCAR, V. PARANAPANEMA, MUXFELDT, } \\
\text { CENF, CAIUÁ, SANTA CRUZ, CELB, NOVA PALMA, } \\
\text { BOA VISTA, MANAUS, CSPE, DEMEI, SANTA MARIA, } \\
\text { BRAGANTINA }\end{array}$ \\
\hline $\mathbf{2 0 1 0}$ & 13 & $\begin{array}{c}\text { CEMIG, COPEL, AES SUL, RGE, CELG, CELPE, } \\
\text { COCEL, PANAMBI, CAT-LEO, CHESP, CFLO, } \\
\text { CORONEL VIVIDA, IGUAÇU ENERGIA }\end{array}$ \\
\hline $\mathbf{2 0 1 3}$ & 11 & $\begin{array}{c}\text { COELBA, ENERSUL, CEMAT, CEA, COSERN, SAELPA, } \\
\text { ENERGIPE, CEAL, COELCE, CERON, SULGIPE }\end{array}$ \\
\hline $\mathbf{2 0 1 5}$ & 7 & $\begin{array}{c}\text { CEMAR, CELPA, ELETROACRE, CELTINS, CEPISA, } \\
\text { CEAM, CER }\end{array}$ \\
\hline
\end{tabular}

Fonte: Aneel (2003a) 
Nas figuras seguintes são apresentadas estimativas da quantidade de municípios e domicílios que seriam contemplados com a universalização ao longo do tempo necessário para a implantação dos planos das distribuidoras, conforme dados da Aneel (2003a).

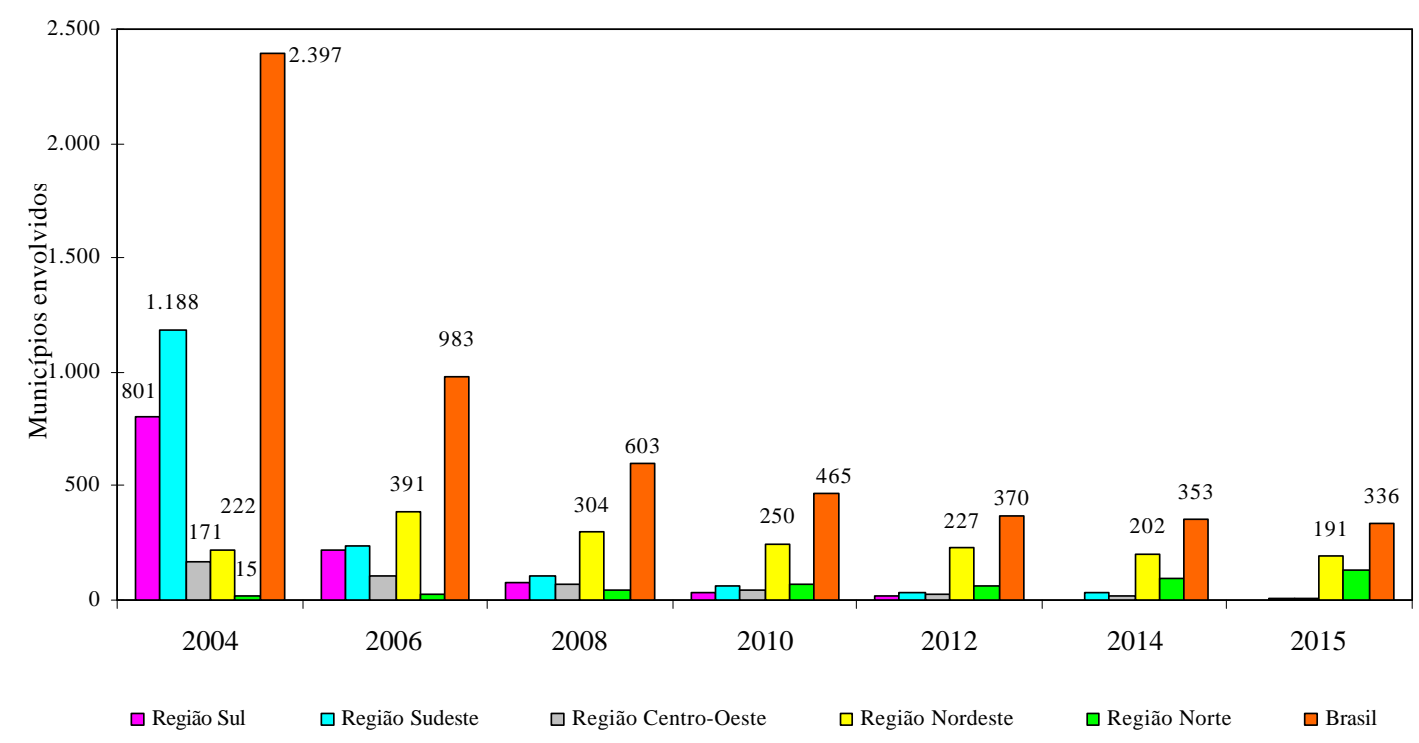

Fonte: Aneel (2003a)

Figura 7 - Quantidade de Municípios Envolvidos por Ano

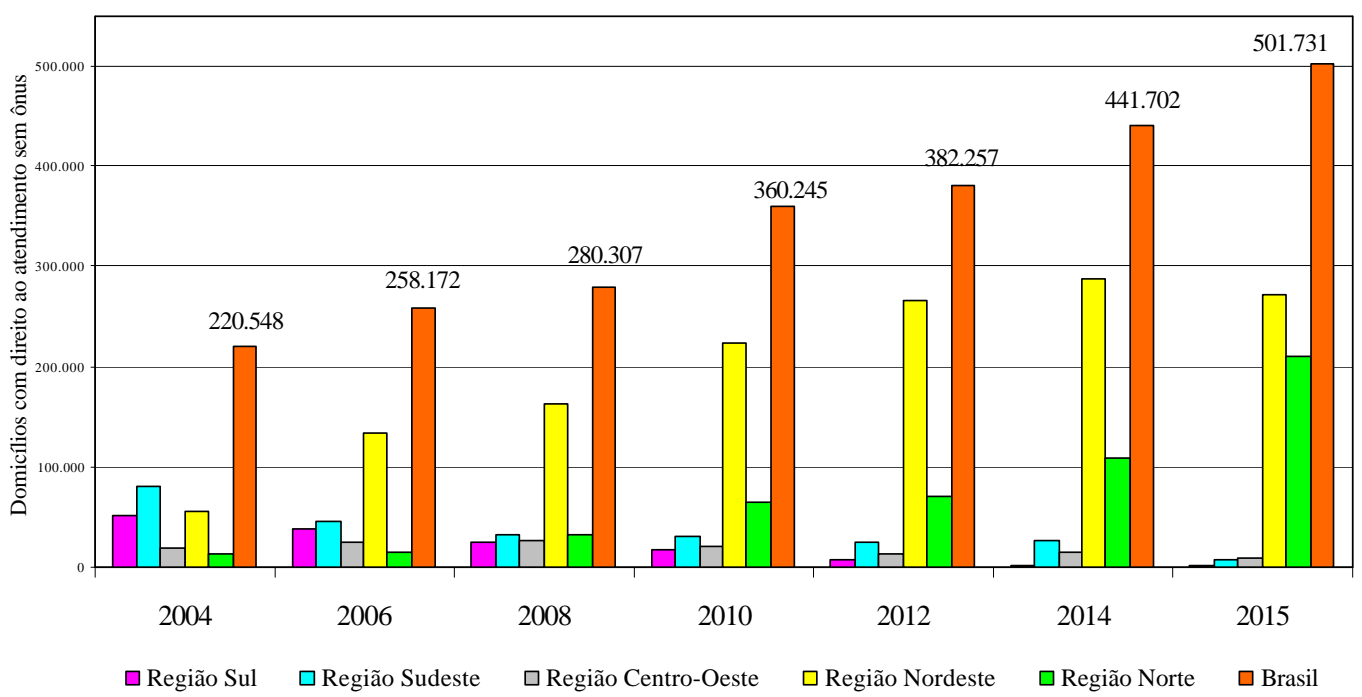

Fonte: Aneel (2003a)

Figura 8 - Evolução prevista da quantidade de domicílios a serem atendidos 
Observa-se que na Figura 8, o fato dos 501.731 domicílios estarem associados ao ano 2015 não significa que serão atendidos somente nessa época. Na elaboração dos Programas Anuais de Expansão do Atendimento, que constituem o Plano de Universalização, a distribuidora deve apresentar a evolução prevista para se atingir a universalização em cada município.

Ressalta-se que, até final de 2004, pelo menos 220.548 domicílios em 2397 municípios (cerca de 43\%) deveriam estar "universalizados" pelas distribuidoras, ou seja, sem a possibilidade de adiamento de prazo, exceto nos casos em que a empresa apresentar justificativas técnicas e econômicas nos respectivos Planos de Universalização.

A Resolução nº 223/2003 criou uma sistemática de apresentação e acompanhamento das metas de universalização das distribuidoras e de cadastramento dos pedidos de ligação. Porém, a fiscalização das metas é complexa e de difícil comprovação. Com o final dos prazos de universalização o controle do processo pela agência será mais efetivo. Por exemplo, a partir de 2005 qualquer solicitação de ligação com carga acima de $50 \mathrm{~kW}$, nos municípios cujo prazo de universalização era 2004 e não foi modificado pela homologação da Aneel do Plano de Universalização, deve ser atendido sem possibilidade de adiamento ${ }^{92}$.

Por ser uma informação pouco conhecida, esse fato deve ser divulgado amplamente para que as pessoas que ainda não possuem o acesso ao serviço possam se beneficiar da universalização. Para isso, a regulamentação prevê que a distribuidora defina, no próprio plano de universalização, formas de divulgação dessas metas para as populações a serem atendidas.

\subsubsection{Programa Luz para Todos}

Um dos critérios definidos pelo MME para priorização das obras do programa corresponde a Municípios com Índice de Atendimento inferior a 85\%. Analisando os

\footnotetext{
92 De acordo com a Aneel (2003a), 2.397 municípios devem observar o prazo de universalização até 2004. A distribuidora poderia propor a modificação desse prazo (até o limite de universalização da sua área de concessão) para homologação da agência. Porém de acordo com as diversas notas técnicas que homologam os planos das distribuidoras, em geral, a Aneel não aceitou as alterações das propostas.
} 
dados do Censo 2000 do IBGE observa-se que no Brasil existem 1.670 municípios (30\% do total) com percentual inferior, sendo que a maioria desses municípios se concentra nas Regiões Norte e Nordeste, conforme demonstra a Tabela 33 a seguir.

Ao contrário, o critério de Municípios com Índice de Desenvolvimento Humano (IDH) inferior à média estadual, apesar de socialmente parecer justo, é abrangente em demasia, pois praticamente todos os Municípios do País, 84,9\%, atendem esse critério. Dessa forma, não é efetivo para ser aplicado como critério para priorização do programa, diferentemente do critério que considera o Índice de Atendimento, como demonstra a Tabela 33 seguinte: na Região Sudeste, região mais rica do Brasil, pelo critério de IDH, 82,0\% dos Municípios poderiam ser priorizados, enquanto que, pelo critério de Índice de Atendimento seriam 9,8\%.

Tabela 33 - Municípios priorizados pelo Programa Luz para Todos

\begin{tabular}{|c|c|c|c|c|c|c|c|}
\hline \multirow[b]{2}{*}{ Região } & \multirow[b]{2}{*}{ Total } & \multicolumn{3}{|c|}{ Critério Índice Atendimento $<\mathbf{8 5 \%}$} & \multicolumn{3}{|c|}{ Critério IDH < IDH Estado } \\
\hline & & Eletivos & $\begin{array}{c}\text { Percentual } \\
\text { Eletivos }\end{array}$ & $\begin{array}{c}\text { Distribuição } \\
\text { em relação } \\
\text { ao Brasil }\end{array}$ & Eletivos & $\begin{array}{l}\text { Percentual } \\
\text { Eletivos }\end{array}$ & $\begin{array}{c}\text { Distribuição } \\
\text { em relação } \\
\text { ao Brasil }\end{array}$ \\
\hline Norte & 449 & 378 & $84,2 \%$ & $22,6 \%$ & 400 & $89,1 \%$ & $8,6 \%$ \\
\hline Nordeste & 1.787 & 943 & $52,8 \%$ & $56,5 \%$ & 1.662 & $93,0 \%$ & $35,6 \%$ \\
\hline Sudeste & 1.666 & 164 & $9,8 \%$ & $9,8 \%$ & 1.366 & $82,0 \%$ & $29,2 \%$ \\
\hline Sul & 1.159 & 77 & $6,6 \%$ & $4,6 \%$ & 888 & $76,6 \%$ & $19,0 \%$ \\
\hline Centro-oeste & 446 & 108 & $24,2 \%$ & $6,5 \%$ & 359 & $80,5 \%$ & $7,7 \%$ \\
\hline Brasil & 5.507 & 1.670 & $30,3 \%$ & $100,0 \%$ & 4.675 & $84,9 \%$ & $100,0 \%$ \\
\hline
\end{tabular}

Fonte: Elaborado pelo autor.

Em junho de 2004, o Governo Federal assinou contratos no valor de R 2,5 bilhões, dos quais R $\$ 1,7$ bilhão são recursos da CDE e RGR, para execução de obras do programa nos próximos 18 meses. Os contratos assinados com 35 concessionárias de distribuição e uma cooperativa resultarão em 567 mil novas ligações, conforme dados apresentados na Tabela 34. 
Tabela 34 - Programa Luz para Todos - Dados dos contratos assinados (jul/2004)

\begin{tabular}{|c|c|c|c|c|c|c|c|}
\hline REGIÃO & $\begin{array}{l}\text { Recursos } \\
\text { próprios } \\
\text { (R\$ milhôes) }\end{array}$ & $\underset{\text { (RS milhōes) }}{\mathbf{C D E}}$ & $\underset{\text { (R\$ milhốes) }}{\mathbf{R G R}}$ & $\begin{array}{l}\text { Governo } \\
\text { Estadual } \\
\text { (R\$ milhôes) }\end{array}$ & $\begin{array}{c}\text { Total } \\
\text { (RS milhōes) }\end{array}$ & $\begin{array}{c}\mathbf{N}^{\mathbf{0}} \\
\text { Ligações } \\
\text { (mil) }\end{array}$ & $\begin{array}{c}\text { População } \\
\text { beneficiada } \\
\text { (mil) }\end{array}$ \\
\hline NORTE & 89 & 424 & 50 & 74 & 637 & 109 & 529 \\
\hline NORDESTE & 165 & 600 & 129 & 178 & 1.071 & 269 & 1.300 \\
\hline SUDESTE & 64 & 133 & 164 & 46 & 407 & 114 & 550 \\
\hline SUL & 33 & 89 & 73 & 27 & 222 & 39 & 187 \\
\hline CENTRO-OESTE & 21 & 51 & 31 & 24 & 127 & 37 & 177 \\
\hline BRASIL & 372 & 1.297 & 447 & 348 & 2.464 & 567 & 2.743 \\
\hline
\end{tabular}

Fonte: Adaptado de: MME (2004b).

Não é possível inferir, a partir dos dados divulgados pelo MME, o número de ligações previstas em 2004 que foi efetivamente contratado. Por outro lado, conforme as metas de universalização da Aneel, ao menos 220 mil domicílios deveriam ser atendidos pelas distribuidoras no mesmo ano. Embora as metas do programa e aquelas definidas pela agência, com base na Lei $\mathrm{n}^{\circ} 10.438 / 2002$, não precisam ser necessariamente idênticas, as distribuidoras contam com os recursos do Programa Luz para Todos para atender às metas de universalização.

Dessa forma, um atraso do programa federal pode acarretar o não atendimento de meta da Aneel. Portanto, deve ser estudada a concatenação dessas metas e do cronograma do Programa Luz para Todos, visando o pleno desenvolvimento do processo de universalização.

\subsection{ANÁLISE DA REGULAMENTAÇÃO DA UNIVERSALIZAÇÃO DO USO}

\subsubsection{Critério: Programas sociais do Governo Federal}

O Governo Federal, por meio dos programas sociais e do Cadastro Único, busca focalizar as políticas públicas compensatórias nas famílias com renda mensal de até meio salário mínimo por pessoa. O Programa Bolsa Família, criado em 2003, unificou os demais programas de transferência de renda e estabelecendo os valores mensais de $\mathrm{R}$ \$ 50,00 e R \$100,00 per capita para incluir as famílias em situação de extrema pobreza e de pobreza, respectivamente. 
No Brasil ainda não há um critério oficial estabelecido para medir a pobreza, o que dificulta a aplicação de políticas sociais com metas claras e parâmetros definidos. Rocha (2000a) desenvolveu estudos para mensurar regionalmente a pobreza no Brasil, que foram utilizados pela FIPE na proposta de metodologia para identificar os beneficiários da tarifa para consumidores baixa renda.

Em março de 2003 o Governo Federal assinou acordo com o IBGE para definir um conceito oficial de linha de pobreza, previsto no Decreto $\mathrm{n}^{\circ} 4.564$, de $1^{\circ}$ de janeiro de 2003, para nortear as ações dos programas sociais. Os estudos serão fundamentados na renda, gastos, situação dos domicílios, emprego e nutrição das populações urbanas e rurais do País em estado de insegurança alimentar, de acordo com a Agência Brasil (2003).

De acordo com a Aneel (2003d), o MME solicitou à agência sucessivas prorrogações dos critérios vigentes anteriores à Lei $\mathrm{n}^{\mathrm{o}}$ 10.438/2002, devido à redefinição de critérios e condições de utilização do cadastro único para todos os programas sociais do Governo Federal e às dificuldades encontradas por algumas prefeituras para efetuar o cadastramento das famílias.

De acordo com o Ministério do Desenvolvimento Social e Combate à Fome (2004), em julho de 2004, cerca de 40 municípios ainda não haviam iniciado o cadastramento dos moradores nos programas sociais do Governo Federal. Segundo o documento, cerca de 9,5 milhões de famílias, das 11,2 milhões estimadas como pobres, estavam cadastradas até essa data. Em que pese o percentual de $85 \%$ de cadastramento ser uma sinalização positiva, o percentual ultrapassa $100 \%$, em oito Estados da Federação, indicando procedimentos inadequados para a comprovação das condições ou então uma subavaliação inicial do número de famílias pobres; neste caso, seria uma indicação de que o número de famílias a cadastrar, 1,7 milhões, é maior do que o estimado ${ }^{93}$. Esse fato pode prejudicar os consumidores que precisam comprovar vínculo com um desses programas, para receber o benefício da tarifa social baixa renda.

${ }^{93}$ Vide Anexo I - Cadastro único dos programas sociais - Estimativa de cadastramento. 
Adicionalmente, o TCU (2003a) identificou várias irregularidades no Cadastro Único dos programas sociais do Governo Federal: critério de unicidade de identificação e de cadastramento não totalmente cumprido; inclusão de famílias que não fazem parte do público-alvo; inexistência de sistemática para atualização e manutenção do cadastro; atraso no cadastramento causado por insuficiência de recursos humanos; falta de capacitação dos cadastradores; dificuldades de acesso às famílias; entre outros.

O critério definido pelo Governo Federal, para classificação dos consumidores (entre 80 e $220 \mathrm{kWh} / \mathrm{mês}$ ) na subclasse residencial baixa renda, focaliza o benefício para aqueles que apresentam renda familiar per capita inferior a $\mathrm{R} \$ 100,00$ ao mês. Independentemente da metodologia para mensurar a pobreza, atribuição do Poder Executivo, a definição da política governamental para os descontos tarifários vigente atualmente é mais justa do que os critérios distintos definidos pelas próprias distribuidoras.

\subsubsection{Critério: Monofásico}

A Lei $n^{\circ}$ 10.438/2002 definiu como condição básica para o consumidor ter direito à classificação na subclasse residencial baixa renda, ser atendido por circuito monofásico.

A Resolução $n^{\circ}$ 485/2002 considera, para efeito de classificação na subclasse residencial baixa renda, como circuito monofásico os seguintes esquemas de fornecimento:

- monofásico a dois condutores (fase e neutro) e;

- monofásico a três condutores (monofásico com neutro intermediário).

Adicionalmente, considera-se como equivalente a circuito monofásico o fornecimento fase-fase em sistemas com secundário sem neutro. Esses conceitos também se aplicam para as unidades classificadas somente pelo critério de consumo estabelecido na Resolução n 246/2002. 
Nos municípios da área de concessão da Eletropaulo, exceto em Vargem Grande Paulista, o atendimento é feito nas tensões $115 / 230 \mathrm{~V}$, conceituadas como redes monofásicas a três fios pelo Decreto $\mathrm{n}^{\mathrm{o}} 73.080$, de 5 de novembro de $1973^{94}$.

Nesse tipo de sistema, a rede de distribuição primária é implantada inicialmente com dois fios, fase e neutro. O centro do enrolamento secundário do transformador monofásico possui uma derivação (center tap) que é conectada ao neutro comum à rede primária e secundária. Dessa forma, as tensões entre cada extremidade desse enrolamento e o center tap são simétricas e correspondem à metade da tensão entre as pontas.

A Eletropaulo (2000) normaliza o atendimento monofásico a dois fios (115V) para unidade consumidora cuja carga instalada seja de até $5 \mathrm{~kW}$, com potência para cada equipamento limitada a $1,5 \mathrm{~kW}$. Portanto, o atendimento é feito, em geral, com três fios disponibilizando $115 / 230 \mathrm{~V}$ para os consumidores.

Dessa forma, o entendimento restrito desse sistema como bifásico impediria que os consumidores fossem classificados como baixa renda, mesmo aqueles que comprovassem a inscrição nos programas sociais do Governo Federal.

A Figura 9 a seguir ilustra esses diferentes padrões de sistemas de distribuição: 94 Atualmente essas tensões $115 / 230 \mathrm{~V}$ não são mais regulamentadas. O Decreto no 97.280 , de 16 de
dezembro de 1998 , normaliza a tensão $127 / 254 \mathrm{~V}$ para redes monofásicas. 


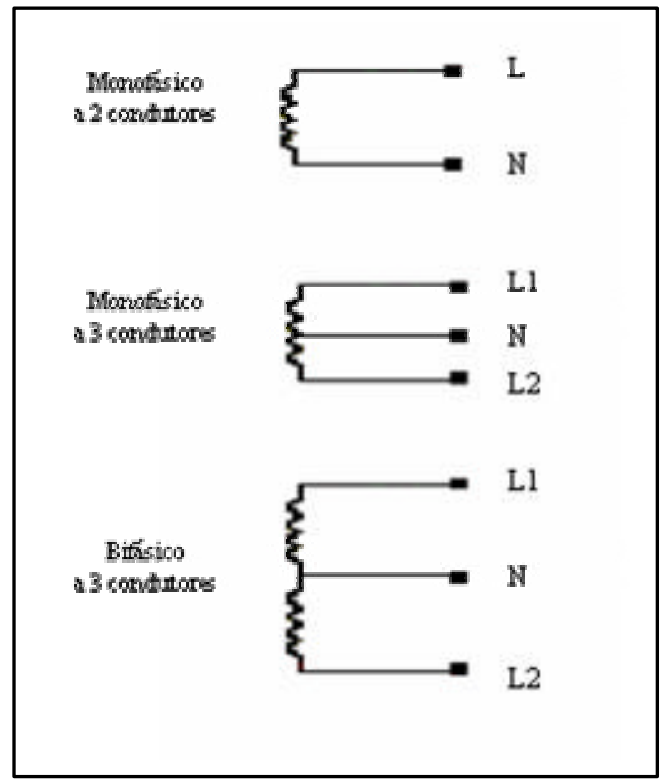

Fonte: Hayt e Kemmerly (1973).

\section{Figura 9 - Exemplos de sistemas simplificados de distribuição}

O atendimento por circuito monofásico, critério básico para classificação da unidade consumidora como baixa renda, resulta em situações distintas, pois é fundamentado em normas da distribuidora.

Nas áreas em que o sistema de distribuição disponibiliza as tensões de $127 \mathrm{~V}$ entre fases e neutro e $220 \mathrm{~V}$ entre fases (127/220V), o circuito monofásico é utilizado para cargas até $12 \mathrm{~kW}$, de acordo com as distribuidoras CPFL (2004) e Elektro (2004). Para uma unidade consumidora com carga instalada acima de $12 \mathrm{~kW}$ até $25 \mathrm{~kW}$ para tensão de fornecimento $127 / 220 \mathrm{~V}$, o tipo de atendimento seria com circuito bifásico a três fios.

Já para as áreas com tensão de fornecimento 220/380V, o limite de carga para atendimento em sistema monofásico é de $15 \mathrm{~kW}$ para as mesmas empresas. Porém, na Companhia Energética de Brasília (CEB), com sistema de distribuição em 220/380 V , o atendimento monofásico é possível para carga instalada de até $11 \mathrm{~kW}$ (CEB, 2004).

Essas situações demonstram que a aplicação do critério de atendimento monofásico para as diferentes regiões não inclui, necessariamente, a mesma parcela da população 
que necessita desse beneficio para permanecer conectada à rede de distribuição de energia elétrica.

\subsubsection{Limite de consumo regional}

Os limites de consumo variam, por região, de 140 a $220 \mathrm{kWh}$, conforme apresentado na Tabela 35. Esses valores foram estabelecidos em 1995, na definição dos critérios específicos das distribuidoras, e mantidos pelas regulamentações da Aneel posteriores à Lei no $10.438 / 2002$.

Tabela 35 - Limite regional para aplicação da tarifa baixa renda

\begin{tabular}{c|c} 
Estados & $\begin{array}{c}\text { Limite Regional } \\
(\mathbf{k W h} / \mathbf{m e ̂ s})\end{array}$ \\
\hline $\begin{array}{c}\text { Rondônia, Roraima, Pará e Amapá, Região Nordeste, Mato } \\
\text { Grosso, Mato Grosso do Sul e Rio de Janeiro }\end{array}$ & 140 \\
\hline Rio de Janeiro (Ampla) & 150 \\
\hline Região Sul & 160 \\
\hline Tocantins, Goiás e Brasília, Minas Gerais e Espírito Santo & 180 \\
\hline Acre e Amazonas & 200 \\
\hline São Paulo & 220 \\
\hline
\end{tabular}

Fonte: Elaborado pelo autor com base na Resolução nº 485/2002.

A Aneel, porém, como já apresentado anteriormente, alterou a aplicação desses limites. Na regulamentação de 1995, os valores correspondiam ao máximo de consumo para a inclusão na subclasse residencial baixa renda. $\mathrm{Na}$ regulamentação atual, o limite de consumo permitido, para inclusão, é único para todo o território nacional: $220 \mathrm{kWh} / \mathrm{mês}$. O limite regional é aplicado, então, somente para os descontos tarifários da subclasse residencial baixa renda.

Essa mudança abranda os efeitos da aplicação de valores diferenciados do consumo regional e possivelmente não coerentes. Observa-se, por exemplo, que o Estado do Acre possui um limite de consumo maior do que regiões mais desenvolvidas como a Região Sul e parte do Sudeste (exceto São Paulo). Da mesma forma, para o Estado 
do Rio de Janeiro o limite regional estabelecido corresponde ao das regiões mais pobres.

Mesmo atenuado seus efeitos, julga-se necessário avaliar os valores limites regionais definidos em 1995 em relação tanto às diferenças regionais de hábitos de consumo quanto a atualizar as necessidades básicas da sociedade brasileira.

\subsubsection{Faturamento mensal baixa renda}

O art. 45 da Resolução n ${ }^{\circ}$ 456/2000 determina que, para as unidades consumidoras classificadas como baixa renda, o faturamento seja calculado considerando o número de dias do mês anterior. Este procedimento impedia que o consumidor fosse prejudicado no caso do intervalo entre leituras do medidor de energia maior do que $30 \operatorname{dias}^{95}$.

Com a nova regulamentação para as unidades baixa renda, o consumo, para efeitos de classificação, é calculado como média mensal do período de um ano. Dessa forma, a sistemática prevista no art. 45 torna-se redundante para classificação como baixa renda, pois o consumidor não perde os descontos, desde que a média mensal calculada no período permaneça abaixo do limite de classificação. Porém, é necessário ressaltar que esse procedimento pode ser fundamental para pagamento de ICMS, dependendo das faixas de consumo para a incidência das alíquotas do imposto.

\subsection{ANÁLISE DOS RECURSOS PARA UNIVERSALIZAÇÃO}

\subsubsection{Análise dos recursos para universalização do acesso}

A previsão de recolhimento das quotas da CDE para 2004 - principal fonte de recurso para universalização do acesso e do uso - corresponde a R \$ 1,4 bilhão apresentada na Figura 10 a seguir. Ressalta-se a participação da Região Sudeste com

\footnotetext{
95 A Resolução n ${ }^{\circ} 456 / 2000$, da Aneel, regulamenta o intervalo entre leituras: no máximo 33 dias e no mínimo 27.
} 
a arrecadação de $69 \%$ do total e da Região Sul com $18 \%$, representando praticamente a totalidade dos recursos desse fundo.

(em R\$ mil)
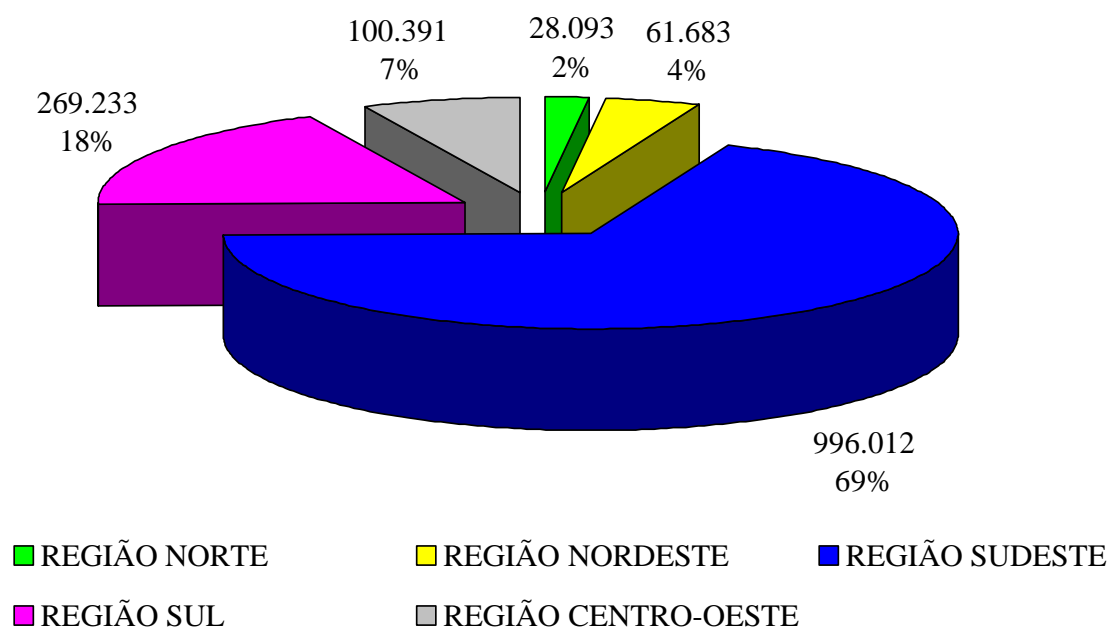

Fonte: Elaborado pelo autor com base na Resolução Homologatória n 12/2004.

Figura 10 - Quotas da CDE - Previsão de recolhimento 2004

O Programa Luz para Todos, que visa atender até 2008 todos os domicílios rurais sem energia elétrica, tem custo total estimado em cerca de $\mathrm{R} \$ 7$ bilhões. Esses recursos são aportados pelos Estados da Federação, pelas distribuidoras e cooperativas e o restante pelo governo federal por meio de uma composição de recursos a fundo perdido (CDE) e financiamento (RGR).

A Tabela 36 apresenta a previsão inicial de alocação dos recursos a fundo perdido (CDE) e financiamento (RGR) por estado, de acordo com dados fornecidos pelo MME (informação pessoal) ${ }^{96}$.

\footnotetext{
${ }^{96}$ MME. Alocação de recursos do Programa Luz para Todos. [mensagem pessoal]. Mensagem recebida por<sergiokf@uol.com.br> em 15 jul. 2004.
} 
Tabela 36 - Metas e alocação percentual dos recursos do Programa Luz para Todos

\begin{tabular}{l|c|c|c|c|c|c}
\hline \multirow{2}{*}{ Estado } & \multirow{2}{*}{ Meta Aneel } & Meta & \multicolumn{3}{c}{ Luz } & \multicolumn{3}{c}{ Participação Financeira } \\
\cline { 4 - 6 } & & 2008 & $80 \%$ & $10 \%$ & $0 \%$ & $10 \%$ \\
\hline Acre & 2015 & 2008 & $80 \%$ & $10 \%$ & $0 \%$ & $10 \%$ \\
\hline Amazonas & 2015 & 2008 & $80 \%$ & $10 \%$ & $0 \%$ & $10 \%$ \\
\hline Roraima & 2015 & 2008 & $65 \%$ & $10 \%$ & $10 \%$ & $15 \%$ \\
\hline Amapá & 2013 & 2008 & $65 \%$ & $10 \%$ & $10 \%$ & $15 \%$ \\
\hline Pará & 2015 & 2008 & $65 \%$ & $10 \%$ & $10 \%$ & $15 \%$ \\
\hline Rondônia & 2013 & 2008 & $55 \%$ & $20 \%$ & $10 \%$ & $15 \%$ \\
\hline Tocantins & 2015 & 2008 & $65 \%$ & $10 \%$ & $10 \%$ & $15 \%$ \\
\hline Maranhão & 2015 & 2008 & $65 \%$ & $10 \%$ & $10 \%$ & $15 \%$ \\
\hline Plauí & 2015 & 2008 & $60 \%$ & $10 \%$ & $15 \%$ & $15 \%$ \\
\hline Ceará & 2013 & 2008 & $50 \%$ & $25 \%$ & $10 \%$ & $15 \%$ \\
\hline Bahia & 2013 & 2008 & $50 \%$ & $30 \%$ & $5 \%$ & $15 \%$ \\
\hline Paraíba & 2013 & 2007 & $55 \%$ & $20 \%$ & $10 \%$ & $15 \%$ \\
\hline Pernambuco & 2013 & 2007 & $50 \%$ & $0 \%$ & $35 \%$ & $15 \%$ \\
\hline Rio Grande do Norte & 2013 & 2008 & $50 \%$ & $20 \%$ & $15 \%$ & $15 \%$ \\
\hline Sergipe & 2013 & 2006 & $50 \%$ & $30 \%$ & $5 \%$ & $15 \%$ \\
\hline Minas Gerais & 2010 & 2006 & $40 \%$ & $9,8 \%$ & $34 \%$ & $16,2 \%$ \\
\hline Espírito Santo & 2006 & 2006 & $10 \%$ & $10 \%$ & $65 \%$ & $15 \%$ \\
\hline Rio de Janeiro & 2008 & 2004 & $10 \%$ & $33 \%$ & $42 \%$ & $15 \%$ \\
\hline São Paulo & 2008 & 2005 & $10 \%$ & $10 \%$ & $65 \%$ & $15 \%$ \\
\hline Elektro & 2008 & 2005 & $30 \%$ & $10 \%$ & $45 \%$ & $15 \%$ \\
\hline Rio Grande do Sul & 2010 & 2006 & $50 \%$ & $20 \%$ & $15 \%$ & $15 \%$ \\
\hline Paraná & 2010 & 2006 & $30 \%$ & $10 \%$ & $40 \%$ & $20 \%$ \\
\hline Santa Catarina & 2010 & 2005 & $35 \%$ & $30 \%$ & $20 \%$ & $15 \%$ \\
\hline Goiás & 2010 & 2006 & $40 \%$ & $20 \%$ & $25 \%$ & $15 \%$ \\
\hline Mato Grosso & 2013 & 2008 & $40 \%$ & $10 \%$ & $35 \%$ & $15 \%$ \\
\hline Mato Grosso do Sul & 2013 & 2007 & $40 \%$ & $10 \%$ & $35 \%$ & $15 \%$ \\
\hline Distrito Federal & 2004 & 2004 & $0 \%$ & $0 \%$ & $0 \%$ & $100 \%$ \\
\hline
\end{tabular}

Fonte: MME (informação pessoal).

Com base nos custos estimados pela Aneel e a alocação informada pelo MME é possível valorizar a divisão dos recursos entre CDE, RGR, Estado e distribuidora, para cada unidade da federação. Dessa forma, a Tabela 37 apresenta o resumo por região desta alocação de recursos. 
Tabela 37 - Alocação de recursos do Programa Luz para Todos

\begin{tabular}{|l|r|r|r|r|r|r|r|r|r|r|}
\hline \multirow{2}{*}{ Regióes } & \multicolumn{2}{|c|}{ Domicilios rurais } & \multicolumn{2}{c|}{ Custos Elet. Rural } & \multicolumn{2}{c|}{ Alocação de recursos (milhares R\$) } & \multicolumn{2}{c|}{ Percentual } \\
\cline { 2 - 12 } & $\begin{array}{c}\text { Sem } \\
\text { Iluminação } \\
\text { Elétrica }\end{array}$ & $\begin{array}{c}\text { Perc. sobre } \\
\text { total de } \\
\text { domicilios } \\
\text { da região }\end{array}$ & $\begin{array}{c}\text { Estimado } \\
\text { (milhares } \\
\text { R\$) }\end{array}$ & $\begin{array}{c}\text { Perc. do } \\
\text { custo } \\
\text { Brasil }\end{array}$ & CDE & Estado & RGR & $\begin{array}{c}\text { Capital } \\
\text { próprio }\end{array}$ & CDE & RGR \\
\hline Norte & 467.259 & $60,9 \%$ & 1.736 .802 & $25,4 \%$ & 1.173 .903 & 192.470 & 131.165 & 239.263 & $31,2 \%$ & $14,0 \%$ \\
\hline Nordeste & 1.241 .928 & $38,4 \%$ & 3.725 .784 & $54,4 \%$ & 2.052 .372 & 756.761 & 357.783 & 558.868 & $54,6 \%$ & $38,1 \%$ \\
\hline Sudeste & 189.548 & $11,0 \%$ & 568.644 & $8,3 \%$ & 204.594 & 63.766 & 209.553 & 90.731 & $5,4 \%$ & $22,3 \%$ \\
\hline Sul & 106.328 & $8,3 \%$ & 318.984 & $4,7 \%$ & 127.462 & 54.891 & 82.300 & 54.332 & $3,4 \%$ & $8,8 \%$ \\
\hline Centro-0este & 108.215 & $26,8 \%$ & 500.927 & $7,3 \%$ & 199.071 & 64.985 & 158.970 & 77.901 & $5,3 \%$ & $16,9 \%$ \\
\hline Brasil & $\mathbf{2 . 1 1 3 . 2 7 8}$ & $\mathbf{2 8 , 5 \%}$ & $\mathbf{6 . 8 5 1 . 1 4 1}$ & $\mathbf{1 0 0 , 0} \%$ & $\mathbf{3 . 7 5 7 . 4 0 2}$ & $\mathbf{1 . 1 3 2 . 8 7 3}$ & $\mathbf{9 3 9 . 7 7 1}$ & $\mathbf{1 . 0 2 1 . 0 9 5}$ & $\mathbf{1 0 0 , 0 \%}$ & $\mathbf{1 0 0 , 0 \%}$ \\
\hline
\end{tabular}

Obs.: Custos adotados; NE, SE e S - R \$ 3.000,00; CO - R \$ 4.629,00 (Luz no campo); N - R\$ 3.717,00 (Luz no campo).

Fonte: Elaborado pelo autor.

Estima-se que os recursos oriundos da CDE, no período de 2004 a 2008, corresponderão a aproximadamente $\mathrm{R} \$ 3,8$ bilhões; os oriundos do Governo do Estado, os investimentos do agente executor (distribuidora ou cooperativa) e o financiamento da RGR correspondem a aproximadamente R \$ 1 bilhão, cada parcela.

Portanto, em média, o montante anual de recursos da CDE para o Programa Luz para Todos corresponderia cerca de R \$ 800 milhões, caso o atendimento for concretizado segundo o cronograma do programa (até 2008).

Desta análise depreende-se também que grande parte dos recursos desses dois fundos setoriais está destinada às Regiões Norte e Nordeste para mitigar eventuais impactos tarifários, evitando assim que as distribuidoras dessas regiões tivessem que arcar com investimentos maiores.

\subsubsection{Análise dos recursos para a universalização do uso}

Inicialmente a Lei $n^{\circ}$ 10.438/2002 não definiu a origem dos recursos necessários para cobrir as perdas de algumas distribuidoras devido aos novos consumidores baixa renda. Para mitigar essa situação, o Decreto $n^{\circ}$ 4.336/2002 determinou que recursos da RGR fossem emprestados às empresas, embora essa alternativa foi considerada inadequada pelas distribuidoras.

Este financiamento corresponderia à redução de receita da distribuidora decorrente da aplicação dos novos critérios de classificação, não cobrindo a parcela referente 
aos consumidores baixa renda classificados segundo os critérios específicos das concessionárias.

Dessa forma, para cada distribuidora, a Aneel calcula a diferença mensal entre o faturamento que decorreria da aplicação dos critérios vigentes na data imediatamente anterior à publicação da Lei $n^{\circ} 10.438 / 2002$ e aquele verificado em conformidade com os novos critérios.

O financiamento teria carência correspondente ao prazo necessário para a definição das fontes de recursos ou revisão da estrutura tarifária (mecanismos referidos no art. 35 da Lei $n^{\circ}$ 9.074/95), limitado à data da revisão tarifária de cada empresa. Esses mecanismos deveriam, segundo o regulamento, serem definidos até 16 de dezembro de 2002 e contemplar recursos para o pagamento do financiamento da RGR.

Por outro lado, o regulamento previa que o eventual aumento de receita, decorrente da aplicação dos novos critérios de classificação, fosse utilizado para modicidade tarifária, segundo mecanismo a ser estabelecido pela Aneel.

A Resolução n ${ }^{\circ}$ 514/2002 estabelece os procedimentos e os critérios de compensação nas tarifas. A compensação ocorreria durante o cálculo do Índice de Reajuste Tarifário Anual (IRT) e até a próxima revisão tarifária periódica, quando as tarifas seriam ajustadas para o nível compatível com a cobertura de custos operacionais eficientes e de remuneração adequada de investimentos prudentes.

Para ilustrar a "incerteza" regulatória desse período, a Medida Provisória n ${ }^{\circ}$ 64, de 26 de agosto de 2002, possibilitava o direcionamento da $\mathrm{CDE}^{97}$ para subsidiar as perdas das distribuidoras decorrentes dos novos critérios para classificação dos consumidores baixa renda.

Essa diretriz foi alterada, pois a Lei $\mathrm{n}^{\mathrm{o}} 10.604 / 2002$, resultante justamente do processo de conversão da MP $n^{\circ} 64$, estabeleceu que a subvenção dos consumidores baixa renda fosse custeada com recursos oriundos do adicional de dividendos

\footnotetext{
${ }^{97}$ MP n ${ }^{\text {o } 64 / 2002 . ~ A r t . ~} 9^{\circ}$ Os recursos da Conta de Desenvolvimento Energético - CDE, instituída pela Lei $\mathrm{n}^{\circ} 10.438$, de 2002, poderão ser destinados ao atendimento de consumidores integrantes da subclasse residencial baixa renda, decorrente dos critérios estabelecidos no art. $1^{\circ}$ da citada Lei.
} 
devidos à União pela Eletrobrás associado às receitas adicionais auferidas com a comercialização de energia elétrica nos leilões públicos e, na insuficiência desse adicional, com recursos da RGR nos exercícios de 2002 e 2003.

Posteriormente, a Lei $\mathrm{n}^{\circ}$ 10.762/2003 alterou a redação do art. 13 da Lei $n^{\circ}$ 10.438/2002 permitindo, por meio da CDE, a subvenção econômica destinada à modicidade da tarifa aos consumidores da subclasse residencial baixa renda, a partir de 2004. Por outro lado, estabelece que os recursos da RGR poderão ser utilizados como subvenção no processo de universalização do acesso no meio rural, nas regiões com menores índices de atendimento.

Com a definição das fontes de recursos, o Decreto $\mathrm{n}^{\mathrm{o}}$ 4.538/2002 determinou que os valores liberados a título de financiamento fossem ser totalmente liquidados com a utilização dos recursos da subvenção econômica a fundo perdido e, em decorrência, cancelados os correspondentes contratos de financiamento. O financiamento com recursos da RGR, determinado pelo Decreto $\mathrm{n}^{\circ} 4.336 / 2002$, foi substituído nos anos de 2002 e 2003 com os mesmos recursos (RGR), transformando-se em fundo perdido para essa finalidade.

No momento, devido aos preços baixos (sobras de energia no sistema) a constituição dessas receitas adicionais da Eletrobrás não está ocorrendo; em adição, para os próximos anos o Novo Modelo do Setor Elétrico, implementado em 2004, sinaliza que as receitas das geradoras federais permanecerão em nível abaixo do custo marginal de expansão impedindo, também, a formação desse "fundo" para subsidiar as perdas das distribuidoras com os novos consumidores baixa renda.

De acordo com os dados da Aneel, o montante de recursos necessários para cobrir essas perdas, nos anos de $2002^{98}, 2003$ e no primeiro semestre de 2004 totalizaram R\$ 1,9 bilhão, conforme demonstrado na Tabela 38. Esses valores foram cobertos como subvenção econômica por recursos da RGR nos anos de 2002 e 2003 e da CDE em 2004.

98 O subsídio em 2002 corresponde ao período de maio a dezembro. 
Tabela 38 - Perdas baixa renda - Valores homologados pela Aneel (R\$ milhares)

\begin{tabular}{c|r|r|r|r|r|r|}
\hline \multirow{2}{*}{ REGIÃo } & \multicolumn{2}{|c|}{$\mathbf{2 0 0 2}$} & \multicolumn{2}{c|}{$\mathbf{2 0 0 3}$} & \multicolumn{2}{|c|}{$\mathbf{2 0 0 4}$} \\
\cline { 2 - 8 } & \multicolumn{1}{|c|}{ anual } & \multicolumn{1}{c|}{$\begin{array}{c}\text { média } \\
\text { mensal }\end{array}$} & \multicolumn{1}{c|}{ anual } & \multicolumn{1}{c|}{$\begin{array}{c}\text { média } \\
\text { mensal }\end{array}$} & \multicolumn{1}{c|}{ anual } & $\begin{array}{c}\text { média } \\
\text { mensal }\end{array}$ \\
\hline NORTE & 20.262 & 2.533 & 46.168 & 3.847 & 25.474 & 4.246 \\
\hline NORDESTE & 231.578 & 28.947 & 435.023 & 36.252 & 261.499 & 43.583 \\
\hline SUDESTE & 141.109 & 17.639 & 274.149 & 22.846 & 131.912 & 21.985 \\
\hline SUL & 54.570 & 6.821 & 125.513 & 10.459 & 69.573 & 11.595 \\
\hline CENTRO-OESTE & 25.345 & 3.168 & 55.951 & 4.663 & 32.403 & 5.400 \\
\hline BRASIL & $\mathbf{4 7 2 . 8 6 4}$ & $\mathbf{5 9 . 1 0 8}$ & $\mathbf{9 3 6 . 8 0 4}$ & $\mathbf{7 8 . 0 6 7}$ & $\mathbf{5 2 0 . 8 6 0}$ & $\mathbf{8 6 . 8 1 0}$ \\
\hline
\end{tabular}

Fonte: Elaborado pelo autor com base em dados homologados pela Aneel.

Apesar da regulamentação ter determinado o prazo até 28 de fevereiro de 2004 para a manutenção simultânea dos critérios anteriores e posteriores à Lei $n^{\circ} 10.438 / 2002$, o subsídio mensal não sofreu uma redução significativa. Assim, o valor homologado referente a março de 2004 foi de $\mathrm{R} \$ 84$ milhões correspondendo a uma diminuição de somente $\mathrm{R} \$ 7$ milhões em relação ao subsídio concedido em fevereiro de 2004. O valor homologado de junho de 2004 correspondeu a $\mathrm{R} \$ 89$ milhões, mantendo o crescimento verificado mesmo após o fim da vigência simultânea dos critérios para classificação dos consumidores baixa renda.

Em 2004, o subsídio acumulado do primeiro semestre correspondeu a R\$ 520 milhões, dos quais mais da metade foi direcionado à Região Nordeste, conforme demonstrado na Figura 11. 


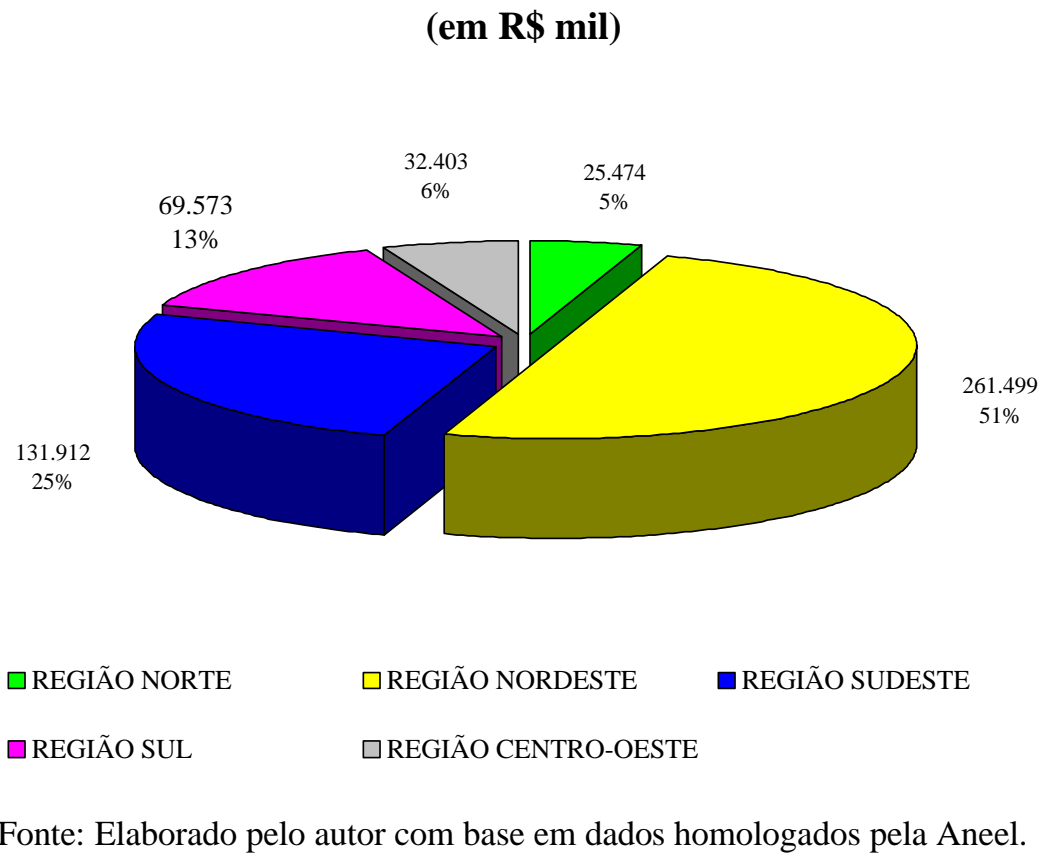

Figura 11 - Perdas das distribuidoras ( $\left(^{\circ}\right.$ semestre de 2004)

Essas perdas são cobertas, a partir de 2004, com recursos da CDE, conforme determina a Lei $\mathrm{n}^{\circ} 10.762 / 2003^{99}$. Em 2004, a projeção do subsídio para as distribuidoras, decorrente dos novos critérios estabelecidos pela Lei ${ }^{\circ} 10.438 / 2002$, alcança aproximadamente $\mathrm{R} \$ 1$ bilhão, o que corresponde cerca de $67 \%$ da arrecadação da CDE de 2004.

\subsubsection{Alteração na metodologia de cálculo das perdas}

A regulamentação determinou que a Aneel homologasse, mensalmente, os montantes referentes às reduções de receita das concessionárias provocadas pela aplicação dos novos critérios de classificação dos consumidores residenciais na subclasse baixa renda.

${ }^{99}$ As quotas da CDE, deduzidos os valores a serem recolhidos a título da sistemática de rateio de ônus e vantagens para as usinas termelétricas situadas nas Regiões atendidas pelos Sistemas Elétricos Interligados, correspondem para o ano de 2004 a R \$ 1.075.957.826,13, segundo a Resolução ANEEL $n^{\circ} 42$, de 31/01/2003. 
Por meio das Resoluções $n^{\circ}$ 41, de 31 de janeiro de 2003, e $n^{\circ}$ 116, de 19 de março de 2003, a agência estabeleceu inicialmente uma metodologia homologação dos recursos para subvenção econômica dessas perdas das distribuidoras.

Nessa metodologia, o cálculo era feito identificando, inicialmente, a diferença dos percentuais da receita associada aos consumidores baixa renda no mês de abril de $2002^{100}$ e no mês de processamento do cálculo. A receita total da classe residencial multiplicada por esse fator resultava nas perdas ou ganhos da distribuidora, dependendo do sinal, negativo ou positivo, da diferença calculada.

A Aneel, porém, apresentou proposta para a revisão dessa metodologia, objeto da Audiência Pública nº 028/2004 encerrada em 30 de julho de 2004. Segundo a agência, na metodologia inicial, o aumento de receita decorrente da recuperação do nível de consumo pós-racionamento era tratado indevidamente, como resultado da perda de descontos tarifários pelos consumidores, derivado da aplicação dos critérios para a concessão da subvenção econômica. Observou-se também, que as variações referentes aos consumidores que já recebiam o benefício da tarifa de baixa renda antes da nova Lei, produziam resultados não esperados e não desejados.

A Resolução nº 89/2004, resultante desse processo de audiência pública, estabeleceu a metodologia na qual, identifica-se inicialmente, com base nos critérios anteriores e posteriores à Lei $\mathrm{n}^{\mathrm{o}} 10.438 / 2002^{101}$, os seguintes consumidores:

a. classificados, em abril de 2002, como baixa renda, segundo os critérios anteriores (aprovados por Portaria do Dnaee específica para cada empresa);

b. dentre os anteriormente classificados (item a), os que deixaram de pertencer à subclasse residencial baixa renda, migrando para a classe residencial, devido aos novos critérios (denominados de "Residencial T1" na planilha que consta da resolução);

\footnotetext{
${ }^{100}$ Data da Lei n ${ }^{\circ}$ 10.438/2002 que alterou os critérios de classificação.

101 Os consumidores com atendimento monofásico e consumo até $80 \mathrm{kWh}$ são "automaticamente" classificados como baixa renda, de acordo com a Lei $n^{\circ} 10.438 / 2002$. Para aqueles com consumo entre 80 e 220 kWh é necessário comprovarem o cadastramento nos programas sociais do Governo Federal.
} 
c. dentre os anteriormente classificados (item a), aqueles que também atendem os novos critérios ("Baixa Renda T4");

d. os que passaram a ser classificados como baixa renda, após os novos critérios, segundo a Resolução n 264 (denominados “Baixa Renda T2”) e a Resolução no 485/2002 ("Baixa Renda T3”).

Para a identificação do montante de subsídio decorrente dos novos critérios estabelecidos pela Lei $\mathrm{n}^{\mathrm{o}} 10.438 / 20023$ são efetuados mensalmente os seguintes cálculos:

a. as perdas de receita correspondem ao somatório da energia faturada de cada novo consumidor baixa renda ("Baixa Renda T2" e "Baixa Renda T3") multiplicada pela diferença entre a tarifa "plena" residencial e a tarifa com descontos, respeitadas as faixas de consumo;

b. para os ganhos de receita, o mesmo cálculo considerando cada consumidor que deixou de ser baixa renda ("Residencial T1");

c. caso as perdas sejam maiores do que os ganhos, a distribuidora terá direito ao subsídio.

A regulamentação determina o recálculo dos montantes da subvenção econômica, desde maio de 2002, já homologados pela Aneel. O prazo para envio do recálculo é de 120 dias após a publicação da resolução ${ }^{102}$.

A eventual diferença entre os valores anteriormente homologados e aqueles obtidos por meio dessa nova metodologia deverá ser ajustada pela Eletrobrás, ou seja, a empresa que recebeu a menos será ressarcida, da mesma forma, aquela que recebeu a mais terá a diferença descontada nas parcelas subseqüentes.

Esse critério, apesar da maior complexidade, é mais justo do que o anteriormente adotado pela Aneel, pois o ressarcimento é feito com base nos consumos efetivamente realizados e não no percentual de receita entre consumidores baixa

\footnotetext{
${ }^{102}$ A Resolução no 89 , de 25 de outubro de 2004, foi publicada no Diário Oficial da União em 5 de novembro de 2004.
} 
renda e residenciais que possivelmente se alterou, para mais ou para menos, no período pós-racionamento.

\subsection{CONSIDERAÇÕES}

As definições das metas de universalização pela Aneel, determinada pela Lei $\mathrm{n}^{\circ}$ 10.438/2002, e aquelas do Programa Luz para Todos, lançado no final de 2003 pelo Governo Federal, não estão harmonizadas, sendo desejável uma ação coordenada entre os diversos agentes setoriais e também demais setores do governo ${ }^{103}$.

O Programa Luz para Todos direciona recursos a fundo perdido e financiamento em condições melhores das praticadas pelo mercado visando mitigar eventual impacto tarifário, principalmente nas regiões menos desenvolvidas e pobres onde estão localizadas majoritariamente a população sem acesso ao serviço de energia elétrica.

As ações coordenadas entre o MME e a Aneel facilitariam o cumprimento e o acompanhamento das metas de universalização. Eventuais atrasos na assinatura dos contratos do programa e na liberação dos recursos podem afetar o plano de ação das distribuidoras que contam com os recursos do Programa Luz para Todos para atender as metas de universalização.

Parte dos recursos anuais da CDE (67\%) está comprometida com a compensação das perdas decorrentes da nova classificação dos consumidores baixa renda, no caso dos recursos oriundos da comercialização de energia elétrica pela Eletrobrás nos leilões serem insuficientes.

Dessa forma, a possível competição pelos recursos da CDE entre a universalização do acesso e a do uso (subsídio para tarifa baixa renda) poderá prejudicar os recursos futuros para a continuidade do Programa Luz para Todos. Por outro lado, é importante reconhecer que há saldo referente aos recursos da CDE recolhidos em

103 O Ministério de Minas e Energia assinou com a Agência dos Estados Unidos para Desenvolvimento Internacional (USAID) e o Programa das Nações Unidas para o Desenvolvimento (PNUD), um protocolo de intenções para planejar e executar um programa de difusão do uso de energia elétrica para o desenvolvimento social e econômico. Segundo informações da Radiobrás, o objetivo do convênio é identificar sinergias entre os ministérios e elaborar um plano de combate à pobreza de forma integrada. 
2003 (aproximadamente R \$ 1 bilhão), que garante a fase inicial do programa de universalização.

Por outro lado, mitigando a possível falta de recursos, a Lei $\mathrm{n}^{\circ}$ 10.762/2003 destina também recursos da RGR como subvenção econômica para parcela dos investimentos necessários para a universalização alterando a sistemática de repasse desses recursos, normalmente considerados como empréstimos. Dependendo dessa alocação da RGR, os montantes iniciais planejados para a universalização pelo MME poderão ser parcialmente reconstituídos. A solução encontrada foi questionada quanto à legalidade de se direcionar recursos da RGR, a fundo perdido, para destinações não previstas na sua criação.

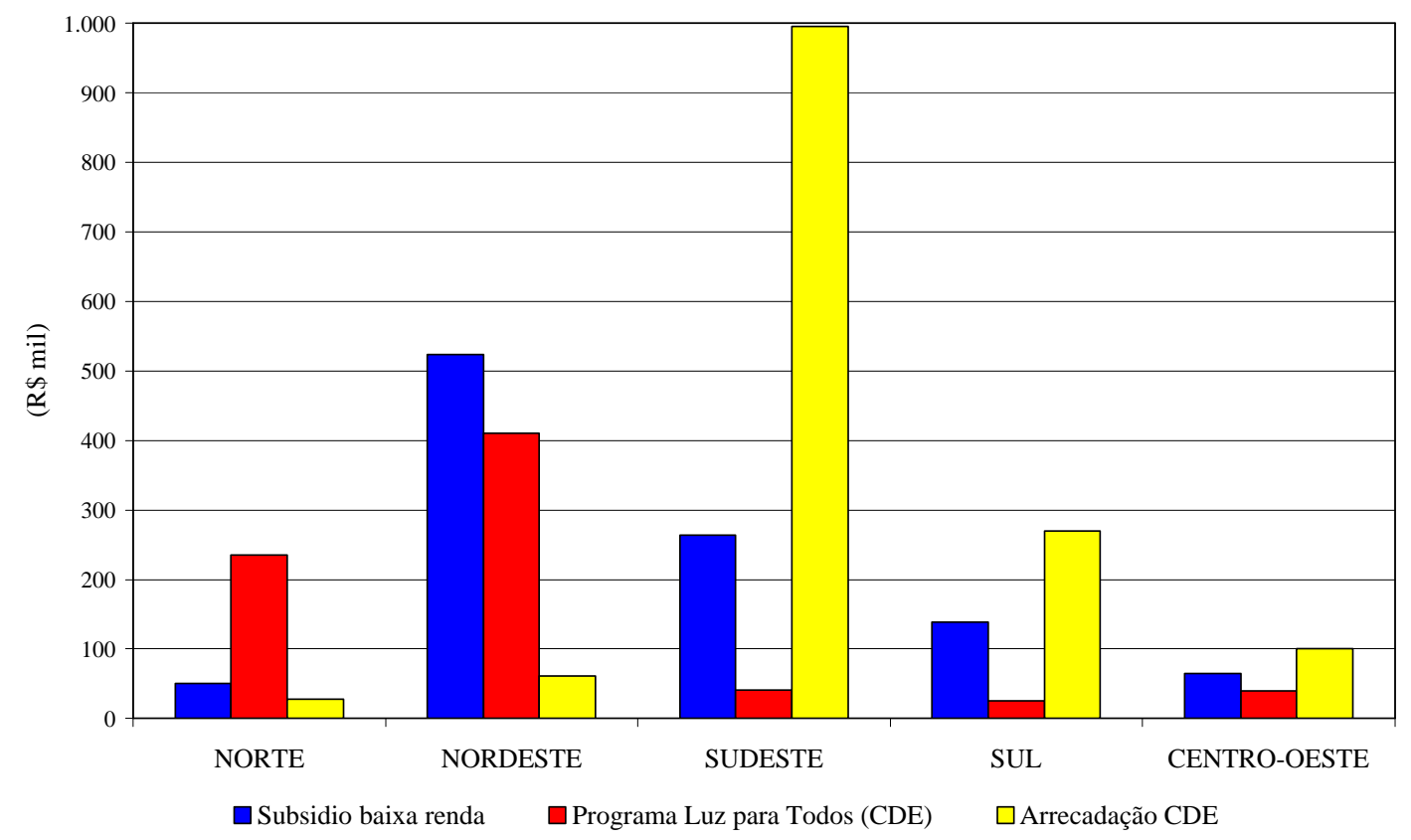

Fonte: Elaborado pelo autor com base em dados da Aneel.

Figura 12 - Arrecadação da CDE e sua alocação por Região

A Figura 12 apresenta uma estimativa dos recursos da CDE de 2004: previsão de arrecadação e sua aplicação no subsídio das perdas de receita das distribuidoras com os novos consumidores baixa renda e no Programa Luz para Todos. Observa-se que, no agregado, o total previsto de arrecadação (cerca de $\mathrm{R} \$ 1$ bilhão) é inferior ao somatório dos gastos previstos com o subsídio baixa renda ( $\mathrm{R} \$ 1$ bilhão) e com o programa de universalização ( $\mathrm{R} \$ 800$ milhões). Os dados demonstram que a maior 
parte da arrecadação provém das regiões Sudeste e Sul enquanto as aplicações destinadas para a universalização dos serviços de energia elétrica, no seu sentido amplo, são direcionadas principalmente para as Regiões Nordeste e Norte.

Com a correção monetária da CDE pela variação do IPCA, as quotas "brutas" previstas para 2005 correspondem a aproximadamente a $\mathrm{R} \$ 2,054$ bilhões. Com a extinção da CCC do sistema interligado a partir de 2006, o valor das quotas "líquidas" é o mesmo das brutas a partir desse ano. A Tabela 39 a seguir apresenta as estimativas de arrecadação da CDE até 2008.

Tabela 39 - Arrecadação anual da CDE (em R\$ bilhões)

\begin{tabular}{c|c|c|c|c|c|c}
\hline Ano & $\begin{array}{c}\text { Multas } \\
\text { da Aneel }\end{array}$ & UBP & $\begin{array}{c}\text { Quotas } \\
\text { brutas }\end{array}$ & $\begin{array}{c}\text { CCC } \\
\text { Sistema } \\
\text { Interligado }\end{array}$ & $\begin{array}{c}\text { Quotas } \\
\text { líquidas }\end{array}$ & $\begin{array}{c}\text { Total } \\
\text { CDE }\end{array}$ \\
\hline 2003 & 0,002 & & 1,592 & 0,516 & 1,076 & 1,078 \\
\hline 2004 & 0,015 & 0,040 & 1,782 & 0,332 & 1,450 & 1,505 \\
\hline 2005 & $*$ & 0,017 & 2,054 & 0,176 & 1,878 & 1,894 \\
\hline 2006 & $*$ & 0,038 & 2,054 & 0,000 & 2,054 & 2,092 \\
\hline 2007 & $*$ & 0,147 & 2,054 & 0,000 & 2,054 & 2,201 \\
\hline 2008 & $*$ & 0,308 & 2,054 & 0,000 & 2,054 & 2,361 \\
\hline
\end{tabular}

* Não estimado.

Fonte: Elaborado pelo autor com base na Resolução Homologatória no 12/2004 e na Resolução Normativa ${ }^{\circ} 144 / 2004$.

A Resolução Normativa $n^{\circ} 129 / 2004$ possibilita o reembolso de até $100 \%$ do combustível das termelétricas que utilizem carvão nacional a partir de 2004, descontados os valores concedidos pela CCC. Com base no Relatório de CCC da Eletrobrás, o valor anual de gastos com combustível foi estimado, em torno de $\mathrm{R} \$$ 400 milhões ${ }^{104}$. A estimativa para a cobertura dos custos das instalações de transporte de gás natural levou em conta que a regulamentação assegura percentuais mínimos da receita anual da CDE e determina que o saldo dos recursos eventualmente não utilizados seja destinado à mesma utilização no ano seguinte. Destaca-se que, a princípio, não haveria recursos suficientes para atender as demandas do Programa Luz para Todos e a cobertura das perdas das distribuidoras devido aos novos

${ }^{104}$ O valor do reembolso da CCC de 2004 para as termelétricas a carvão é R\$ 230 milhões, o que corresponde a $50 \%$ do total, de acordo com o decréscimo previsto. Segundo os dados da Eletrobrás, o reembolso de 2002 para essas usinas seria de R\$ 468 milhões (100\% do total). Dessa forma, conservadoramente, estimou-se o valor da ordem de $\mathrm{R} \$ 400$ milhões para as despesas de combustível. 
consumidores baixa renda, se mantidos nesses níveis, considerando as demais alocações previstas, demonstrados na Tabela 40 a seguir.

Tabela 40 - Destinação anual da CDE (em R\$ bilhões)

\begin{tabular}{c|c|c|c|c|c|c|c}
\hline Ano & $\begin{array}{c}\text { Total } \\
\text { CDE }\end{array}$ & $\begin{array}{c}\text { Luz } \\
\text { para } \\
\text { Todos }\end{array}$ & $\begin{array}{c}\text { Baixa } \\
\text { renda }\end{array}$ & $\begin{array}{c}\text { Térmicas } \\
\text { a carvão }\end{array}$ & $\begin{array}{c}\text { Gás } \\
\text { Natural }\end{array}$ & $\begin{array}{c}\text { Saldo } \\
\text { Anual }\end{array}$ & $\begin{array}{c}\text { Saldo } \\
\text { Acumulado }\end{array}$ \\
\hline 2003 & 1,078 & 0,000 & 0,000 & 0,000 & 0,000 & 1,078 & 1,078 \\
\hline 2004 & 1,505 & 0,800 & 1,000 & 0,230 & 0,226 & $-0,751$ & 0,327 \\
\hline 2005 & 1,894 & 0,800 & 1,000 & 0,300 & 0,322 & $-0,528$ & $-0,200$ \\
\hline 2006 & 2,092 & 0,800 & 1,000 & 0,400 & 0,418 & $-0,527$ & $-0,727$ \\
\hline 2007 & 2,201 & 0,800 & 1,000 & 0,400 & 0,550 & $-0,549$ & $-1,276$ \\
\hline 2008 & 2,361 & 0,800 & 1,000 & 0,400 & 0,708 & $-0,547$ & $-1,823$ \\
\hline
\end{tabular}

Fonte: Elaborado pelo autor.

Finalmente, é importante destacar que a principal discussão envolve, nos dias atuais, os recursos necessários para o processo de universalização. A discussão anterior, sobre a necessidade e o alcance desse processo, está superada, o que coroa os esforços de várias décadas de pioneiros, pesquisadores, engenheiros, distribuidoras e cooperativas, que de algum modo abraçaram essa causa. 


\section{CAPÍTULO 9 - APRIMORAMENTOS DA REGULAMENTAÇÃO E POLÍTICAS}

\subsection{NECESSIDADES DE REGULAMENTAÇÃO}

Além da análise da regulamentação promovida pela Aneel e da necessidade de sua complementação apresentada no capítulo anterior, alguns aspectos que, embora não se refiram à universalização propriamente dita, estão ligados a esse processo e também necessitam de regulamentação. Por isso, a demarcação das áreas atendidas por cooperativas e sua regularização, a incorporação pelas distribuidoras das redes particulares sem ato autorizativo, assim como a aplicação do ICMS sobre o subsídio decorrente dos novos critérios estabelecidos para a classificação dos consumidores baixa renda são discutidos a seguir.

\subsubsection{Regularização de cooperativas}

O Decreto $\mathrm{n}^{\mathrm{o}} 4.855$, de 9 de outubro de 2003, determinou o prazo de um ano para que a Aneel procedesse a avaliação econômico-financeira das cooperativas e definisse seus respectivos enquadramentos jurídicos.

O processo, que inclui a avaliação das instalações, identificação dos cooperados e a delimitação das áreas de atuação, resultará na regularização das cooperativas analisadas, classificadas em 55 permissionárias e 70 autorizadas $^{105}$ (ANEEL, 2004b).

A Lei $n^{\circ} 10.438 / 2002$, com redação dada pela Lei $n^{\circ} 10.762 / 2003$, determina que as cooperativas de eletrificação rural devem cumprir as mesmas metas de universalização atribuída às distribuidoras, nas quais se localizam, quando for o caso.

Esta determinação legal é tecnicamente incoerente, pois a cooperativa regularizada como permissionária já estava contemplada pela Lei e a cooperativa autorizada é consumidor final sem possibilidade de expandir o seu atendimento fora da área delimitada e para consumidores não rurais.

\footnotetext{
${ }^{105}$ De acordo com a Aneel (2004b), cinco processos foram indeferidos, pois não atenderam os prérequisitos.
} 
No entanto, a futura definição de metas de universalização para os municípios atendidos somente por cooperativas, a exemplo de Holambra, no Estado de São Paulo, resolve-se particularmente este problema dessas localidades que estavam à margem da regulamentação, uma vez que a Resolução nº 223/2003 não definiu metas de universalização para as cooperativas que estavam em processo de regularização.

Por outro lado, essa definição poderá, eventualmente, resultar em conflito no caso de cooperativa com previsão para regularização como autorizada. Nessa área, não é obrigatório o atendimento pela concessionária de distribuição de acordo com a Resolução no 223/2003; dessa forma, enquanto perdurar o processo de regularização, um novo domicílio mesmo não sendo associado da cooperativa deveria ser atendido pela cooperativa e não pela concessionária.

\subsubsection{Linhas particulares}

A Lei $\mathrm{n}^{\circ}$ 10.848, de 15 de março de 2004, determina que, de acordo com a regulamentação a ser emitida pela Aneel, as distribuidoras deverão incorporar a seus patrimônios as redes particulares ${ }^{106}$ que não disponham de ato autorizativo do Poder Concedente. Possibilita também a incorporação de redes particulares que, mesmo dispondo de autorização, exista interesse do proprietário e da distribuidora pela transferência.

O Decreto $\mathrm{n}^{\circ}$ 5.163, de 30 de julho de 2004, determina que a Aneel regulamente esse processo até outubro de 2005. A partir de $1^{\circ}$ de janeiro de 2006, as redes particulares que não dispuserem de autorização serão incorporadas ao patrimônio das distribuidoras, observadas a avaliação prévia das instalações, para a fixação do valor a ser indenizado ao titular da rede particular a ser incorporada. Porém, as redes particulares instaladas exclusivamente em imóveis de seus proprietários não serão objeto de ato autorizativo ou de incorporação, conforme determina o regulamento.

De acordo com o referido decreto, os custos decorrentes da incorporação, incluindo a reforma das redes, serão considerados nos processos de revisão tarifária da

\footnotetext{
106 Segundo o Decreto no 5.163/2004, rede particular é aquela utilizada para o fim exclusivo de prover energia elétrica para unidades de consumo de seus proprietários.
} 
concessionária incorporadora implicando a sua recuperação por meio da tarifa paga pelos consumidores.

A existência de linha particular, desprovida de ato autorizativo, decorre da construção da rede de distribuição de energia elétrica pelo próprio solicitante, sem posterior doação à empresa. Esse consumidor, conhecido no jargão do setor elétrico como "pioneiro", mantinha a propriedade da linha na tentativa de obter compensação de outros consumidores que, eventualmente, estivessem aguardando a construção da rede de distribuição para então solicitar a ligação sem a necessidade de pagar pelas obras.

A linha de distribuição para atendimento exclusivo do consumidor poderia continuar como particular, desde que se obtivesse autorização do Poder Concedente. Nesse caso, a distribuidora não poderia utilizá-la para conectar uma nova ligação ao longo do traçado da linha ou expandi-la para atender outro consumidor localizado após a propriedade rural do "pioneiro". Ou seja, para utilizar essa linha particular para atendimento a outros consumidores, a empresa deveria ser a proprietária da rede de distribuição.

Atualmente, há distribuidoras com aproximadamente 50\% de linhas rurais de propriedade de particulares sem ato autorizativo (ANEEL, 2003b). Com a definição das metas de universalização e a necessidade de expansão das redes, possivelmente a incorporação será a solução técnica e econômica adequada em relação à construção de novas redes de distribuição de energia elétrica. Dessa forma, a regulamentação dessa incorporação é necessária e urgente para a avaliação de alternativas para o atendimento pelas distribuidoras nos Planos de Universalização.

\subsubsection{Cobrança de ICMS sobre o subsídio}

Com os novos critérios estabelecidos legalmente em 2002, para a maioria das distribuidoras, houve aumento no número de consumidores baixa renda ocasionando uma perda de receita. Os recursos da CDE, como visto, subsidiam as perdas decorrentes dos novos critérios definidos pela Lei $n^{\circ} 10.438 / 2002$, pois os anteriores são cobertos, na estrutura tarifária da distribuidora, pelos demais consumidores. 
A arrecadação do Imposto sobre Circulação de Mercadorias e Serviços (ICMS) pelos Estados também diminuiu, uma vez que o faturamento menor, decorrente dos descontos concedidos aos novos consumidores baixa renda, é a base de cálculo sobre a qual incidem as alíquotas desse imposto.

Em outubro de 2004, o Conselho Nacional de Política Fazendária (Confaz) concebeu como legítima a cobrança do ICMS sobre o valor do total do fornecimento que inclui a diferença entre esse valor e aquele efetivamente faturado para o consumidor baixa renda, ou seja, o repasse da subvenção da CDE para a distribuidora devido aos novos critérios.

Esta decisão leva o consumidor baixa renda a arcar com o valor de ICMS correspondente à aplicação da tarifa residencial plena, sem incidência dos descontos. Em outras palavras, o consumidor paga pela tarifa de energia com descontos, porém arca com o ICMS sobre a tarifa plena.

Dessa forma, segundo dados da Aneel (2004a), um consumidor baixa renda poderá ter acréscimo de até $49 \%$ na fatura de energia elétrica, para um consumo mensal de 30 kWh. O ICMS cobrado na conta de energia elétrica alcançaria 98\% em relação ao valor da energia efetivamente consumida, apesar da alíquota base ser de $25 \%$ no exemplo calculado pela agência, conforme pode ser observado na Tabela 41 a seguir. 
Tabela 41 - Impacto da incidência de ICMS sobre o subsídio baixa renda

\begin{tabular}{|c|c|c|c|c|c|c|c|c|}
\hline \multirow[b]{2}{*}{ Consumo } & \multicolumn{3}{|c|}{$\begin{array}{l}\text { Condição sem incidência de } \\
\text { ICMS sobre o subsídio }\end{array}$} & \multicolumn{3}{|c|}{$\begin{array}{l}\text { Após decisão do Confaz - } \\
\text { ICMS sobre o subsídio } \\
\text { (diferença entre tarifa } \\
\text { residencial e baixa renda) }\end{array}$} & \multirow{2}{*}{$\begin{array}{l}\text { Aumento } \\
\text { efetivo } \\
\text { da conta } \\
((f / c)-1)\end{array}$} & \multirow{2}{*}{$\begin{array}{c}\text { Relação } \\
\text { ICMS' / } \\
\text { energia } \\
\text { consumida } \\
\text { (e/a) }\end{array}$} \\
\hline & $\begin{array}{c}\text { Valor } \\
\text { energia } \\
\text { consumida } \\
\text { (a) }\end{array}$ & $\begin{array}{l}\text { Valor } \\
\text { ICMS } \\
\text { (b) }\end{array}$ & $\begin{array}{c}\text { Valor } \\
\text { pago } \\
(\mathbf{c}=\mathbf{a}+\mathbf{b}) \\
\end{array}$ & $\begin{array}{l}\text { cálculo } \\
\text { ICMS } \\
\text { (tarifa } \\
\text { sem } \\
\text { descontos) } \\
\text { (d) } \\
\end{array}$ & $\begin{array}{l}\text { Valor } \\
\text { ICMS' } \\
(\mathbf{e}) \\
\end{array}$ & $\begin{array}{c}\text { Total a } \\
\text { ser pago } \\
(\mathbf{f}=\mathbf{a}+\mathbf{e})\end{array}$ & & \\
\hline $30 \mathrm{kWh}$ & 2,83 & 0,94 & 3,77 & 8,31 & 2,77 & 5,60 & $49 \%$ & $98 \%$ \\
\hline $50 \mathrm{kWh}$ & 6,05 & 2,02 & 8,07 & 13,84 & 4,61 & 10,66 & $32 \%$ & $76 \%$ \\
\hline $80 \mathrm{kWh}$ & 10,90 & 3,63 & 14,53 & 22,15 & 7,38 & 18,28 & $26 \%$ & $68 \%$ \\
\hline $100 \mathrm{kWh}$ & 14,13 & 4,71 & 18,84 & 27,69 & 9,23 & 23,36 & $24 \%$ & $65 \%$ \\
\hline $120 \mathrm{kWh}$ & 18,97 & 6,32 & 25,29 & 33,22 & 11,07 & 30,04 & $19 \%$ & $58 \%$ \\
\hline $140 \mathrm{kWh}$ & 23,81 & 7,94 & 31,75 & 38,76 & 12,92 & 36,73 & $16 \%$ & $54 \%$ \\
\hline $160 \mathrm{kWh}$ & 29,19 & 10,80 & 39,99 & 44,30 & 16,38 & 45,57 & $14 \%$ & $56 \%$ \\
\hline $180 \mathrm{kWh}$ & 34,57 & 12,79 & 47,36 & 49,83 & 18,43 & 53,00 & $12 \%$ & $53 \%$ \\
\hline $200 \mathrm{kWh}$ & 39,95 & 14,78 & 54,73 & 55,37 & 20,48 & 60,43 & $10 \%$ & $51 \%$ \\
\hline $220 \mathrm{kWh}$ & 45,34 & 16,77 & 62,11 & 60,91 & 22,53 & 67,87 & $9 \%$ & $50 \%$ \\
\hline
\end{tabular}

Fonte: Adaptado de: Aneel (2004a).

Além do acréscimo na fatura de energia devido a inserção do novo valor de ICMS, muitos desses consumidores poderão arcar com o pagamento do imposto retroativo a abril de 2002 - início da vigência dos novos critérios para classificação dos consumidores baixa renda (abril/2002).

A Aneel (2004a) apresentou para o Confaz e para o Congresso Nacional um parecer no qual afirma que esse procedimento corresponderia a bitributação, pois o recurso para subsidiar as distribuidoras, proveniente da $\mathrm{CDE}$, está incorporado à tarifa dos consumidores de energia elétrica que já é tributada pelo ICMS.

A aplicação dessa decisão provocará possíveis dificuldades operacionais e distorções no tratamento isonômico que deve ser dados aos consumidores baixa renda: os anteriores à Lei 10.438/2002 devem continuar a pagar ICMS sobre o valor com desconto e não sobre o valor decorrente da tarifa plena. A distribuidora não recebe 
subsídio da CDE por esse consumidor; uma vez que essa parcela está incorporada na estrutura tarifária e de mercado da empresa.

\subsection{PROPOSTAS DE REGULAMENTAÇÃO}

As análises feitas no Capítulo 8 demonstram a necessidade de aprimoramentos dos regulamentos e da própria política pública para que o processo de universalização se desenvolva sem impedimentos. Este item tratará das propostas no âmbito da regulamentação que não necessitam de alterações no marco legal da universalização.

\subsection{1 Áreas delimitadas, setor censitário e licitação}

Como visto, a fiscalização do cumprimento das metas de universalização é dificultada pela não existência de áreas geograficamente definidas. A agência não tem instrumentos para aferir se, por exemplo, um consumidor poderá ser atendido num prazo menor do que aquele definido no Plano de Universalização da distribuidora, em função da proximidade da rede elétrica. Em adição, a incorporação do crescimento vegetativo da área de concessão nas metas de universalização poderá mascarar o atendimento das metas constantes no Plano de Universalização, por isso esse crescimento com índice maior do que o estimado possivelmente dificultará a identificação do número real de consumidores atendidos exclusivamente no âmbito da universalização.

Uma solução cabível seria a definição pelas distribuidoras de áreas delimitadas crescentes de universalização, de modo a contemplar, no horizonte definido pelo regulador, toda a área de concessão da empresa. Os limites das áreas poderiam ser determinados em função de uma distância em torno das redes de distribuição ou pela utilização de dados relativos aos setores censitários do Censo $2000^{107}$.

107 O IBGE utiliza a unidade espacial denominada de Setor Censitário na implementação das pesquisas. São classificados em urbanos e rurais, de acordo com a legislação vigente. Um Setor Censitário Urbano engloba cerca de 300 domicílios, enquanto um Setor Censitário Rural compreende cerca de 150 domicílios. O Brasil foi dividido em 218.000 Setores Censitários, estando cada município subdividido em um conjunto de setores em função do total da população e de sua distribuição espacial. 
Dessa forma, a Aneel definiria o horizonte de universalização diferenciado para cada região do Brasil e para cada município da área de concessão, tendo como base critérios técnicos e econômicos da expansão da rede de distribuição da concessionária, além de ser considerada a taxa de atendimento do município, de acordo com o Censo 2000.

Nos planos, as empresas definiriam para cada município ou conjunto de municípios as áreas de universalização, respeitando os limites de expansão da rede de distribuição e, preferencialmente fundamentado nos setores censitários definidos pelo IBGE. O setor censitário poderia ser, portanto, a unidade básica para constituição das áreas de universalização.

Após serem definidas, as áreas de universalização nas distribuidoras seriam divididas em dois grandes grupos. O primeiro, denominado áreas "R", teria como limite, em linhas gerais, o critério técnico e econômico de expansão da rede de distribuição e os aspectos fisiográficos da região. O segundo grupo, áreas "S", distantes das redes de distribuição, poderia ser atendido alternativamente por geração local.

As concessionárias definiriam, tanto para as áreas " $\mathrm{R}$ " como para a " $\mathrm{S}$ ", as prioridades de atendimento, levando em consideração o horizonte estabelecido pela Aneel, tendo como unidade os setores censitários ou o seu agrupamento.

Os parâmetros que poderiam ser considerados na priorização dessas áreas são estes:

- $\quad$ aspectos fisiográficos ${ }^{108}$;

- $\quad$ setores censitários;

- $\quad$ existência de áreas pertencentes unidades de conservação ou áreas indígenas;

- critérios técnicos de expansão da rede de distribuição;

- projeção de crescimento do mercado;

- capacidade de execução do atendimento;

\footnotetext{
${ }^{108}$ Fisiográfico: relativo à fisiografia que significa o estudo das formas físicas da Terra, de suas causas e das relações entre elas. É a caracterização da forma de relevo, declividade hidrografia, localização de mananciais, por exemplo.
} 
- índices de atendimento;

- densidade populacional;

- aspectos sócio-econômicos;

- áreas controladas por cooperativas de eletrificação rural;

- áreas sob litígio judicial que impeça a realização de novas ligações.

Dessa forma, o Plano de Universalização seria constituído por um conjunto de programas anuais de universalização até o horizonte de universalização contendo, no mínimo, as seguintes informações:

- mapas digitais georreferenciados definindo as áreas de atendimento " $\mathrm{R}$ ” $\mathrm{e}$ "S", com base nos limites dos setores censitários ou, alternativamente aos mapas, lista dos setores associados ao ano inicial de universalização;

- formas de atendimento propostas (rede, geração local, fontes alternativas);

- justificativas e critérios utilizados na definição das áreas e formas de atendimento;

- cronogramas físicos e econômico-financeiros para o atendimento das áreas;

- estimativa do número de unidades a serem atendidas por município e separadas em atendimento por meio de extensão de rede ou sistemas alternativos descentralizados;

- valores médios e valor total dos investimentos estimados para o atendimento, especificados por classe de unidade consumidora, por kVA instalado, por km de extensão de rede e por unidade de sistema alternativo descentralizado;

- custo médio por atendimento de unidade urbana e rural;

- formas de divulgação do plano de universalização para a sociedade.

Nessa proposta, as distribuidoras poderiam identificar com maior facilidade as áreas que seriam atendidas com fontes alternativas, desde que representassem menor custo para o atendimento. Isso poderia estimular o atendimento por meio de organizações 
não governamentais ( $\left.\mathrm{ONG}^{\prime} \mathrm{s}\right)$, em parceria com a distribuidora possibilitando o atendimento em um prazo inferior ao previsto no Plano de Universalização. Essas organizações facilitariam a cobrança de tarifa e promoveriam a redução de custos da distribuidora no atendimento em regiões isoladas.

O Plano de Universalização seria previamente apresentado em Audiência Pública em localidades da área de concessão. Essa estratégia visaria maior transparência do processo para a sociedade, pois a definição das áreas prioritárias seria apresentada para os setores organizados da comunidade e para o poder público local.

A principal vantagem da sistemática proposta de balizamento nos setores censitários como unidade mínima de universalização é a de facilitar a divulgação e a fiscalização. A distribuidora poderia definir, para cada setor censitário, seu respectivo horizonte de universalização, respeitando como limite máximo o ano previsto, na regulamentação da Aneel, para a universalização do Município. Qualquer solicitação de ligação posterior ao ano previsto para a universalização poderia ser identificada imediatamente pela Aneel ou pelas agências conveniadas. A seguir são resumidas as principais vantagens adicionais dessa sistemática:

- impõe uma delimitação geográfica reconhecida;

- rápida identificação e delimitação de áreas para as metas de universalização;

- permite, por meio do Censo 2000, a quantificação da população residente no setor e a sua caracterização sócio-econômica, assim como a espacialização dos indicadores sócio-econômicos da região coberta pela concessão;

- não necessita de sistemas sofisticados de geoprocessamento;

- minimiza a possível utilização de critérios políticos;

- assegura a visualização rápida e clara do processo de expansão da rede de distribuição;

- é de fácil implementação (principalmente com a utilização dos códigos dos setores em substituição ao mapeamento);

- facilita a licitação posterior das áreas não atendidas ou atendidas de forma não adequada pela distribuidora prevista no art. 15 da Lei $n^{\circ} 10.438 / 2002$. 


\subsubsection{Participação financeira}

A alteração promovida pela Lei $n^{\circ} 10.762 / 2003$ retomou o conceito de participação financeira para solicitações de ligação de unidade consumidora com carga instalada acima de $50 \mathrm{~kW}$ e de aumento de carga. Sem regulamentação desde novembro de 2003, os custos das obras eventualmente necessárias para o atendimento desses consumidores podem ser repassados aos solicitantes.

Uma alternativa para a regulamentação seria definir um Limite de Investimento Obrigatório (LIO) da distribuidora, o que se associa ao retorno financeiro de parte da tarifa paga pelo novo consumidor, em um determinado período. A parcela da tarifa a ser utilizada no cálculo é o valor correspondente à remuneração dos investimentos incorporada à tarifa da distribuidora.

A Tarifa de Uso do Sistema de Distribuição (TUSD) atualmente é constituída por duas componentes: uma associada à distribuição de energia elétrica - "serviço fio" denominada de "TUSD Fio", e outra que incorpora as perdas comerciais e os encargos como CCC, Proinfa, dentre outros, conhecida como "TUSD Encargo".

A "TUSD Fio" é calculada com base nos custos marginais de expansão, refletindo, portanto, a necessidade de expansão da rede de distribuição para cada nível de tensão. Na avaliação de notas técnicas da Aneel, referentes aos cálculos da TUSD das distribuidoras, observa-se que, em geral, os custos são ajustados, para cobrir a receita requerida do sistema de distribuição ("serviço fio"), transformando-se, então, no custo médio de referência.

A receita requerida do "serviço fio" é composta por várias parcelas: custos operacionais, remuneração dos investimentos, quotas de depreciação, perdas técnicas, encargos de conexão, RGR, CDE, taxa de fiscalização, dentre outras. A partir disso é possível calcular o percentual da remuneração dos investimentos em relação ao montante total da receita requerida da distribuidora.

Esse percentual também corresponde à fração da futura receita anual, decorrente da tarifa ("TUSD Fio") paga pela nova ligação, utilizada para remunerar os 
investimentos da empresa. Considerando essa parcela da receita anual como uma anuidade $^{109}$ pode-se estimar o seu valor presente ${ }^{110}$, conforme a seguinte equação:

$$
V P A=C *\left\{\frac{1-\left[1 /(1+r)^{t}\right]}{r}\right\}
$$

Onde,

VPA = valor presente da anuidade;

$\mathrm{C}=$ anuidade;

$\mathrm{r}=$ taxa de retorno;

$\mathrm{t}=$ período.

O VPA calculado corresponde ao retorno financeiro da parcela da tarifa paga pelo solicitante que remunera os investimentos da distribuidora. Portanto, o VPA é o próprio valor do investimento recuperado na tarifa pela distribuidora, ou seja, o Limite de Investimento Obrigatório (LIO) ${ }^{111}$.

Para facilitar o cálculo, pode-se adequar a equação acima vinculando o VPA com a TUSD e calculando o Fator de Limite de Investimento Obrigatório (Fator LIO). Esse número depende do percentual da parcela da remuneração do capital em relação ao montante da receita requerida da "TUSD Fio", que corresponde à anuidade (C) utilizada no cálculo do VPA.

Considerando VPA $=$ LIO e $\mathrm{C}=p *$ TUSD, onde $p=$ percentual da parcela da remuneração de capital no montante da receita requerida da "TUSD fio", obtém-se:

$$
L I O=p^{*} T U S D *\left\{\frac{1-\left[1 /(1+r)^{t}\right]}{r}\right\}
$$

\footnotetext{
${ }^{109}$ A anuidade é conceituada como uma série de fluxos de caixa constantes ou uniformes por certo número de períodos.

${ }^{110}$ Valor equivalente hoje que reproduz os fluxo futuros a uma dada taxa de descontos.

${ }^{111}$ O cálculo é feito utilizando como parâmetros: período " $t$ " de 25 anos, estimado para a vida útil de uma rede de distribuição; e uma taxa de retorno " $\mathrm{r}$ " correspondente ao custo médio de capital ponderado de $11,26 \%$, utilizado no processo de revisão tarifária.
} 


$$
\text { FatorLIO }=\frac{L I O}{T U S D}=p^{*}\left\{\frac{1-\left[1 /(1+r)^{t}\right]}{r}\right\}
$$

Por exemplo, no caso da Coelba, a parcela da remuneração do capital é $25 \%$ da receita requerida do serviço de distribuição (ANEEL, 2004c). Aplicando-se os parâmetros definidos anteriormente, chega-se a: FatorLIO $=2$.

Assim, um solicitante, do subgrupo tarifário A4, com demanda estimada de $30 \mathrm{~kW}$ e de $100 \mathrm{~kW}$, na ponta e fora de ponta, respectivamente, proporcionaria uma receita anual referente à “TUSD Fio" de R\$ 28.222,80, aplicando-se as tarifas vigentes em outubro de 2004 da Coelba ${ }^{112}$. Para atender esse consumidor, a distribuidora deveria arcar com o custo das obras, eventualmente necessárias, até o limite de $\mathrm{R} \$ 56.445,60$, com base nos critérios de remuneração e vida útil utilizados.

Pode-se comparar esse valor com o limite de investimento da distribuidora, considerando a sistemática extinta pela Portaria $n^{\circ}$ 05/90. Para esse consumidor, a concessionária deveria participar com até $\mathrm{R} \$$ 6.448,00; no caso de atualização da tarifa fiscal, esse valor seria de $\mathrm{R} \$ 17.230,00$.

\subsubsection{Critério monofásico}

O entendimento da Aneel, configurado na regulamentação do sistema monofásico a três fios, para a classificação dos consumidores baixa renda, a princípio, resolve a situação de exclusão que ocorreria nas distribuidoras que utilizam esse sistema na área urbana, caso o pleito das empresas de considerá-lo como bifásico fosse aceito.

No entanto, como as tensões 230/115 V não são mais padronizadas, a expansão da distribuição de energia elétrica é feita, em geral, utilizando-se de transformadores trifásicos que disponibilizam as tensões 127/220 V. Nesse caso, como o critério básico é o atendimento por sistema monofásico, um consumidor seria baixa renda se fosse atendido somente com a tensão monofásica de 127 V. Para efeitos de inclusão, esse consumidor não poderia ser atendido pelas duas tensões $127 / 220 \mathrm{~V}$. 
Na Região Metropolitana de São Paulo, a população está habituada com a disponibilidade de duas tensões $(115 / 230 \mathrm{~V})$, até por uma questão cultural. Não são encontrados, facilmente, produtos como chuveiro elétrico com tensão nominal de $115 \mathrm{~V}$, diferentemente do que ocorre no interior paulista. Com a expansão sistema 127/220V e o atendimento por sistema bifásico, no decorrer do tempo, a utilização do critério de atendimento monofásico para classificação como baixa renda, poderá ocasionar novamente casos de exclusão.

Uma possível solução, no campo da regulamentação seria o consumidor ser informado $^{113}$, no momento do pedido de ligação, da necessidade de atendimento monofásico como critério básico para sua classificação como residencial baixa renda. Assim, ficaria ciente de que o beneficio é concedido somente para o atendimento monofásico $127 \mathrm{~V}$, devendo adquirir equipamentos específicos para essa tensão, como por exemplo, chuveiro elétrico.

Porém, às vezes o consumidor não é informado dessa restrição. O autor observou in loco a regularização da rede de energia elétrica em favelas nas quais a distribuidora estava atendendo em sistema bifásico, apesar da distribuição em tensão monofásica ser possível e comum na região ${ }^{114}$. Naquela época, anterior à Lei n ${ }^{\circ} 10.438 / 2002$, observava-se que um dos critérios específicos para a classificação como baixa renda da concessionária local era o atendimento por circuito monofásico.

Também se faz necessário incluir esse conceito de monofásico a três fios no art. 48 da Resolução $n^{\circ} 456 / 2000$ que regulamenta os valores mínimos faturáveis do Grupo B, referentes ao custo de disponibilidade do sistema elétrico.

A redação atual estabelece três categorias: monofásico e bifásico a dois condutores; bifásico a três condutores; e trifásico. Uma proposta adequada poderia ser a inclusão

\footnotetext{
112 As tarifas para esse consumidor da Coelba, de acordo com o anexo II da Resolução Homologatória $\mathrm{n}^{\circ} 116 / / 2004$, correspondem para de $\mathrm{R} \$ 38,83$ e $\mathrm{R} \$ 11,87$ na ponta e fora da ponta, respectivamente.

113 A Resolução no 456/200 determina que a empresa analise todos os elementos de caracterização da unidade consumidora objetivando a aplicação da tarifa mais vantajosa a que o consumidor tiver direito, em especial, a da Residencial Baixa Renda.

114 Possivelmente os consumidores não foram completamente esclarecidos das vantagens e desvantagens entre o atendimento bifásico e monofásico.
} 
do atendimento monofásico a três fios (ou condutores) na segunda categoria, assumindo que o custo de disponibilidade seria função do número de condutores e mantendo a atual sistemática de cobrança na região metropolitana de São Paulo.

Uma solução alternativa, que depende de alteração na Lei $n^{\circ} 10.438 / 2002$, seria definir um limite de carga calculado em função dos equipamentos elétricos considerados necessários para o bem-estar mínimo de uma família. Dessa forma, a classificação do consumidor não estaria vinculada ao sistema de atendimento adotado pela distribuidora.

\subsubsection{Metodologia de cálculo das perdas e dos ganhos de receitas}

O risco de mercado, entendido neste caso como a variação do número de consumidores bem como do consumo, sempre foi associado à distribuidora. Admitindo-se, para uma rápida análise, que não houve a alteração de critérios para classificação dos consumidores baixa renda em 2002: um eventual aumento desses consumidores, sem a alteração de critérios, seria admitido pela distribuidora como risco de mercado, nos intervalos entre revisões tarifárias.

A Resolução $n^{\circ}$ 89/2004 identifica todos os novos consumidores classificados como baixa renda no cálculo das perdas da distribuidora, incorporando indevidamente, porém, uma pequena parcela de consumidores cuja responsabilidade seria da empresa: aqueles ligados após abril de 2002, que atenderiam tanto os critérios específicos da distribuidora como os definidos pela Lei $n^{\circ} 10.438 / 2002$.

Adicionalmente, a regulamentação não prevê, explicitamente, que os eventuais ganhos da distribuidora com a exclusão dos consumidores classificados pelos antigos critérios sejam revertidos para a modicidade tarifária por ocasião da revisão, diminuindo a receita requerida da empresa.

Dessa forma, é necessário estudar a efetiva responsabilidade pelo aporte de subsídio para as distribuidoras no momento de revisão tarifária, sendo imprescindível a transparência desse processo.

Na estrutura de mercado utilizada pela Aneel, no cálculo das tarifas de fornecimento, é fundamental que cada um desses tipos de consumidores estejam corretamente 
identificados. Por exemplo, os novos consumidores baixa renda (incluídos pela Lei $\mathrm{n}^{\circ} 10.438 / 2002$ ) devem ser considerados como integrante do mercado residencial "normal" e não no mercado residencial baixa renda, na estrutura tarifária para efeitos do processo de revisão, pois a distribuidora já recebe o subsídio da CDE.

\subsubsection{Fator $X$ e investimentos em universalização}

O Fator X é um elemento utilizado no momento do reajuste tarifário para possibilitar o compartilhamento com os consumidores dos ganhos futuros decorrentes das melhorias de produtividade da distribuidora.

É constituído pelas parcelas Xa, Xc e Xe. A primeira se refere ao ajuste do índice que mede a variação dos custos de materiais e mão-de-obra (IPCA) em relação ao utilizado para reajustar as tarifas de energia elétrica (IGP-M). A segunda parcela corresponde ao desempenho em qualidade da distribuidora mensurado pela pesquisa de satisfação do cliente (IASC) promovida pela Aneel.

A componente Xe é calculada no processo de revisão tarifário e tem como objetivo compartilhar os ganhos de eficiência da distribuidora com os seus consumidores, reduzindo, em geral, em conjunto com as demais parcelas do Fator X, o índice de reajuste tarifário.

Essa componente é uma função do fluxo de caixa e dos valores dos ativos remuneráveis, denominado de base de remuneração líquida, nos momentos inicial e final do período entre revisões tarifárias, de acordo com a equação a seguir:

$$
\operatorname{VPL}(\mathrm{FC})=\mathrm{BRRLi}-\mathrm{VPL}(\mathrm{BRRf})
$$

Onde,

VPL $(F C)=$ valor presente líquido do fluxo de caixa da distribuidora;

BRRLi = valor da base de remuneração regulatória inicial; e

BRRLf $=$ valor da base de remuneração regulatória final 
Dessa forma, igualando-se o valor presente do fluxo de caixa do período e o valor presente da base de remuneração líquida final com o valor da base de remuneração inicial é calculada a taxa de retorno que deveria corresponder ao custo médio de capital ponderado $(11,26 \%)$ utilizado no processo de revisão tarifária. Caso a taxa de retorno seja maior, deve ser reduzido o fluxo de caixa da empresa, por meio da componente $\mathrm{Xe}$, de forma a convergir para a taxa de retorno de $11,26 \%$.

O fluxo de caixa é, basicamente, a diferença entre a receita da empresa e os custos operacionais e investimentos. A receita está diretamente relacionada com o mercado de fornecimento. Os custos operacionais, de acordo com a metodologia da Aneel para o cálculo do Fator $\mathrm{X}$, são proporcionais ao número de consumidores e ao mercado da distribuidora.

Os investimentos "regulatórios" "115 são determinados, para o cálculo da componente Xe, pela "Lei de Quantidade de Obras" (LQO) para a expansão do sistema de distribuição; pelo "Fator de Renovação" função da vida útil e da taxa de crescimento médio dos ativos, para a renovação dos ativos; e pela própria distribuidora, para os investimentos no sistema de subtransmissão.

Os investimentos, por outro lado, contribuem para aumentar o valor da base de remuneração regulatória. Essa evolui, ao longo do período, incorporando os investimentos anuais e deduzindo a parcela referente à depreciação.

Observa-se preliminarmente que, mantido os fatores considerados na revisão tarifária, as metas de universalização poderão distorcer o valor do Fator X que não corresponderá à nova realidade de investimentos da distribuidora.

A receita estimada para o cálculo do Fator $X$ não terá, com a universalização, uma variação significativa em relação a estimada, pois os novos consumidores devem, a princípio, ter uma participação menor do que a média da respectiva classe, residencial ou rural.

\footnotetext{
115 Os investimentos "regulatórios" são utilizados somente para o cálculo do Fator X e não correspondem necessariamente aos níveis de investimentos reais da distribuidora para a manutenção e expansão do sistema.
} 
No caso dos custos operacionais, porém, a relação não permanecerá no mesmo nível da situação anterior, pois o crescimento de mercado será proporcionalmente menor do que o crescimento do número de consumidores. Os custos operacionais estimados para o cálculo do Fator X, portanto, têm a tendência de crescimento maior do que o estimado no ambiente sem considerar a universalização.

No caso dos investimentos, é necessário adaptar os parâmetros utilizados pela Lei de Quantidade de Obras (LQO) ao crescimento das obras para o atendimento das metas de universalização. Possivelmente, o crescimento da expansão do sistema de distribuição seria maior do que os níveis históricos adotados pela Aneel ${ }^{116}$.

Dessa forma, os acréscimos estimados decorrentes dos custos operacionais e dos investimentos diminuem o fluxo de caixa da distribuidora, considerado no cálculo do Fator X; o maior investimento em universalização, por outro lado, aumenta a base de remuneração regulatória. A conseqüência é a componente Xe teórica ser maior do que a calculada, sendo a taxa de retorno menor do que o $11,26 \%$ estabelecido pela Aneel.

Assim, o esforço de universalização determinado pelo regulador não está incorporado no cálculo do Fator X, podendo ocasionar perdas para a distribuidora que demandar maior investimento em universalização.

Se essa adequação no cálculo do Fator X não for possível, a Aneel poderia resgatar o Fator K, definido como um

[...] elemento de recuperação de despesas operacionais e de investimentos (ambas estimadas), de caráter extraordinário, a ser aplicado - a critério do regulador - quando houver necessidade de compensação de fatores que extrapolem as obrigações do Contrato de Concessão e afetem o desequilíbrio econômico-financeiro do contrato [...] (ANEEL, 2002b),

incorporando um valor que mitigue o efeito demonstrado anteriormente.

\footnotetext{
116 Interessante notar que os índices adotados pela Aneel, de acordo com "a experiência dos consultores" são os mesmos independentemente da área de concessão da empresa e dos históricos individuais.
} 


\subsection{PROPOSIÇÃO DE NOVAS DIRETRIZES PARA APRIMORAR A POLÍTICA DE UNIVERSALIZAÇÃO}

\subsubsection{Universalização do acesso}

Para entender uma política de universalização, no seu aspecto de acesso, é preciso tecer algumas considerações sobre a abrangência desse processo. $O$ termo universalização, como exposto anteriormente, compreenderia o acesso para todos os consumidores, independentemente das condições sócio-econômicas individuais. No entanto, considerando o nível de recursos envolvidos e a necessidade de se mitigar possível impacto tarifário, a universalização passou, necessariamente, por uma focalização nos consumidores do Grupo B com carga até $50 \mathrm{~kW}$.

Restringir o atendimento no público-alvo, não é, no caso brasileiro, oposto ao conceito de universalizar, pois a maior parcela da população sem acesso não possui renda para arcar com os custos das obras necessárias para o seu atendimento. Dessa forma, a focalização é um meio para conduzir a universalização, em ambos os aspectos acesso e uso, face aos recursos escassos e a necessidade de tarifas módicas.

\subsubsection{Público alvo}

A primeira questão a ser debatida diz respeito à amplitude da universalização do acesso, ou seja, qual o público-alvo a ser atendido. A Lei nº 10.438/2002 assegurou, a princípio, o atendimento sem ônus para todos os consumidores solicitantes, sem analisar previamente a condição social ou atividade econômica. Posteriormente a Lei $\mathrm{n}^{\circ}$ 10.762/2003 restringiu a universalização para consumidores do Grupo B com carga instalada até $50 \mathrm{~kW}$.

Uma alternativa mais restritiva, que unificaria o público-alvo da universalização do acesso e do uso, seria atender somente os consumidores baixa renda, incluindo também os moradores da área rural com a mesma condição econômica. No entanto, essa restrição não seria adequada, pois nas áreas urbanas o acesso às redes de distribuição está praticamente resolvido e nas áreas rurais as dificuldades para se classificar os consumidores baixa renda seriam significativas. 
Assim, a amplitude da universalização do acesso, definida atualmente em função da carga instalada, está parcialmente adequada, considerando também a revogação do inciso III, art. $7^{\circ}$, da Resolução no 456/2000 pela Resolução no 223/2003 que possibilitava o atendimento na área rural em tensão primária de distribuição, independentemente da carga instalada, impondo o custo do transformador para o consumidor.

Por outro lado, o atendimento com base na carga instalada não restringe o atendimento ao público-adequado, abrangendo também consumidores que poderiam arcar com o custo da universalização. Em adição, a restrição ao aumento de carga pode implicar uma condição diferente de atendimento para cargas semelhantes. Por exemplo, um novo consumidor será atendido sem ônus, para uma carga até $50 \mathrm{~kW}$; ao contrário, um consumidor com carga de $20 \mathrm{~kW}$, que solicitar um aumento para 50 kW, deverá arcar com o custo das obras eventualmente necessárias.

\subsubsection{2 Áreas de atendimento}

A Política de Estado da universalização do acesso, em linhas gerais, ao definir a sua amplitude, a responsabilidade da distribuidora e o direcionamento de recursos da RGR e da CDE, está adequada; porém a Política de Governo implementada pelo Programa Luz para Todos e a regulamentação definida na Resolução no 223/2003 da Aneel não assegura a continuidade da universalização do acesso, apesar dos resultados iniciais.

Para entender essa assertiva é necessário retomar o conceito de universalização do acesso. A Lei $n^{\circ}$ 10.438/2002, e, por conseguinte, a Resolução nº 223/2003, garantem o atendimento sem ônus para os consumidores do Grupo B com carga até $50 \mathrm{~kW}$. Nesse contexto, é possível apenas o diferimento das ligações que exigem expansão de rede primária, com a possibilidade de antecipação, mediante aporte de recursos, seguido de posterior ressarcimento pela distribuidora.

Essa sistemática de áreas crescentes, nas quais o atendimento é realizado sem ônus, e de áreas decrescentes, nas quais é possível o adiamento, foi o recurso utilizado pelo 
legislador para promover uma transição entre a obrigação da participação financeira do consumidor e o atendimento sem ônus pela distribuidora.

Portanto, esse mecanismo, proposto no trabalho da Unifacs (CORREIA; VALENTE; PEREIRA, 2002) e incorporado pela Lei $n^{\circ} 10.438 / 2002$, objetiva criar, para a distribuidora, uma trajetória de atendimento a qualquer pedido de ligação (até $50 \mathrm{~kW}$ ), sem ônus para o solicitante, em toda a área de concessão, possível de ser cumprida devido aos recursos e a capacidade técnica.

A Resolução $n^{\circ}$ 223/2003 estabelece o período de transição que vigora, por município, até o ano definido para universalização como, por exemplo, 2004 para 2.370 municípios do Brasil. A partir de 2005 a distribuidora deve atender qualquer pedido de ligação de consumidores do Grupo B com carga até $50 \mathrm{~kW}$ sem ônus para o solicitante nesses municípios. Ou seja, o ano de universalização previsto na regulamentação da Aneel pressupõe a cobertura da área do município ao final desse período.

Nesse sentido, deverão ser atendidos também os consumidores em locais distantes da rede de distribuição ou isolados desses municípios, como uma ilha, por exemplo, mesmo representando custos significativos e sem haver o auxílio do Programa Luz para Todos. De acordo com a Nota Técnica nº 087/2004 - SRC/ANEEL, por exemplo, na área de concessão da CEAM há ilhas marítimas e fluviais que demandam uma infra-estrutura especial de atendimento.

As alternativas possíveis seriam o atendimento por sistemas individuais de geração ou a regulamentação de tratamento diferenciado para esses casos ou ainda a aplicação do disposto no art. 15 da Lei ${ }^{\circ}$ 10.438/2002, que prevê a possibilidade de licitação das áreas que a Aneel entendesse que não fosse contemplada pela universalização.

Os critérios para o fornecimento de energia elétrica por meio de Sistemas Individuais de Geração de Energia Elétrica com Fontes Intermitentes (Sigfi) foram aprovados pela Resolução Normativa $n^{\circ} 83 / 2004$. Os sistemas de geração que utilizam a energia 
solar fotovoltaica e a eólica poderão atender a comunidades isoladas nas quais é inviável a prestação do serviço pelo sistema de distribuição convencional.

O fornecimento da energia elétrica será em corrente alternada, com observância dos níveis de tensão e freqüência predominantes no município onde estiver localizada a unidade consumidora, e deverá atender as características constantes das classes de atendimento com autonomia de dois dias ${ }^{117}$, conforme Tabela 42 a seguir.

Tabela 42 - Sigfi - Classificação e disponibilidade de atendimento

\begin{tabular}{c|c|c|c}
$\begin{array}{c}\text { Classes de } \\
\text { Atendimento }\end{array}$ & $\begin{array}{c}\text { Consumo } \\
\text { Diário de } \\
\text { Referência } \\
(\mathbf{W h} / \text { dia })\end{array}$ & $\begin{array}{c}\text { Potência } \\
\text { Mínima } \\
\text { Disponibilizada } \\
(\mathbf{W})\end{array}$ & $\begin{array}{c}\text { Disponibilidade } \\
\text { Mensal } \\
\text { Garantida } \\
(\mathbf{k W h})\end{array}$ \\
\hline SIGFI13 & 435 & 250 & 13 \\
\hline SIGFI30 & 1000 & 500 & 30 \\
\hline SIGFI45 & 1500 & 700 & 45 \\
\hline SIGFI60 & 2000 & 1000 & 60 \\
\hline SIGFI80 & 2650 & 1250 & 80 \\
\hline
\end{tabular}

Fonte: Resolução Normativa nº 82/2004

Dessa forma, o sistema individual da classe SIGFI13 deverá garantir o fornecimento de, no mínimo, $13 \mathrm{kWh} / \mathrm{mês}$, correspondendo a um consumo diário de referência de $435 \mathrm{Wh} / \mathrm{dia}^{118}$ para uma potência mínima de $250 \mathrm{~W}$.

O regulamento prevê, ainda, a instalação de medidores de energia, em sistemas com capacidade superior a $30 \mathrm{kWh} / \mathrm{mês}$. As unidades consumidoras atendidas por meio de Sigfi serão faturadas pela mesma tarifa da concessionária utilizada para os consumidores atendidos por sistema convencional de distribuição de energia elétrica.

A distribuidora que utilizar esta opção tecnológica deverá apresentar projeto para aprovação da Aneel, contemplando aspectos técnicos dos sistemas, procedimentos para leitura e faturamento, dentre outros. Os consumidores não serão responsáveis

117 Autonomia é a capacidade de fornecimento de energia elétrica do sistema de acumulação (baterias), expressa em dias, necessária para suprir o consumo na completa ausência da fonte primária, tendo como base o consumo diário de referência.

118 Consumo diário de referência é a quantidade de energia que o Sigfi é capaz de fornecer diariamente calculada a partir da Disponibilidade Mensal Garantida. 
pela custódia dos equipamentos, devendo a empresa providenciar apólice de seguros para cobrir, pelo menos, as situações de roubo, furto e vandalismo.

O atendimento por meio do Sigfi pode ser adequado para situação de comunidades isoladas com baixa necessidade consumo, substituindo primariamente a iluminação à vela ou querosene, por exemplo, além de outros equipamentos elétricos como rádio e televisor. O maior sistema previsto na regulamentação disponibiliza no total 80 $\mathrm{kWh} / \mathrm{mês}$, considerando uma potência de $1.250 \mathrm{~W}$ durante algumas horas por dia. Caso o consumidor de uma localidade isolada requeira uma carga maior até $50 \mathrm{~kW}$, a distribuidora deveria atender essa solicitação em consonância com o Plano de Universalização, estendendo a rede de distribuição de energia elétrica ou instalando sistema de geração descentralizado com maior potência.

Além disso, o sistema de geração individual era normalmente tratado como préeletrificação nos programas das distribuidoras, como no caso da Cemig (2001); uma transição para o atendimento posterior de uma carga maior. Porém, como a Lei $n^{\circ}$ 10.438/2002 não classifica o aumento de carga como atendimento sem ônus, o consumidor não poderá exigir, no âmbito da universalização, uma carga maior posteriormente.

Uma segunda modificação seria um atendimento diferenciado do previsto no âmbito da universalização, que necessita alteração na legislação para possibilitar que consumidores com carga até $50 \mathrm{~kW}$ em localidades isoladas e com alto poder aquisitivo não sejam financiados pelos consumidores da distribuidora e nem pelos contribuintes da União, como, por exemplo, ilhas, residências de veraneio.

A terceira sugestão seria possibilitar que determinadas áreas, nas quais a distribuidora não manifestou interesse pelo serviço de energia elétrica ou a Aneel avaliou que as metas estavam inadequadas, fossem licitadas, possibilitando a entrada de novos agentes no mercado para atendimento às unidades consumidoras localizadas em áreas isoladas.

A Lei $n^{\circ} 10.438 / 2002$ permite que a Aneel promova licitações para outorga de permissões em áreas já concedidas cujos contratos de concessão não contenham 
cláusula de exclusividade, visando a universalização do serviço público de energia elétrica. Segundo a referida Lei, o serviço também poderá ser prestado mediante a associação ou contratação com agentes detentores de tecnologia ou titulares de autorização para fontes solar, eólica, biomassa e pequenas centrais hidroelétricas.

\subsubsection{Tarifas}

De acordo com a Resolução $\mathrm{n}^{\circ}$ 83/2004, as tarifas cobradas dos consumidores atendidos por Sigfi devem ser as mesmas praticadas pela distribuidora para consumidores atendidos por sistema convencionais. Por exemplo, na Coelba, o faturamento mínimo, correspondente a $30 \mathrm{kWh} /$ mês para sistemas monofásicos, implicaria o pagamento de $\mathrm{R} \$ 9,14$, para o consumidor residencial, ou $\mathrm{R} \$ 3,11$, para o consumidor baixa renda ou ainda $\mathrm{R} \$ 5,72$, para o consumidor rural ${ }^{119}$.

Com esse nível tarifário, esses investimentos isoladamente não teriam retorno adequado, sendo necessário o subsídio repassado para os demais consumidores da área de concessão.

Como visto no Capítulo 7, na Argentina e no Chile, o valor cobrado corresponde à “propensão a pagar" dos consumidores calculados, com base na substituição de outras fontes de energia. Se essa sistemática fosse adotada no Brasil, a capacidade de pagamento da população ribeirinha da Comunidade Santa Luzia de Jacarequara, Município de Itapiranga, Amazonas, seria cerca de R\$ 19,28 por mês, de acordo com o Núcleo de Eficiência Energética da Universidade da Amazônia (2001) ${ }^{120}$.

É necessário, portanto, avaliar a adequação da política tarifária: todos os consumidores, pertencentes à mesma classe, devem pagar a mesma tarifa ou é possível tarifa diferenciada para as regiões isoladas, considerando a "propensão a pagar", associada à substituição dos gastos com outras fontes de energia.

\footnotetext{
${ }^{119}$ Segundo a Resolução Homologatória n ${ }^{\circ}$ 116/2004, os valores das tarifas da Coelba correspondem a $\mathrm{R} \$ 103,69$ para consumidores residenciais baixa renda com consumo até $30 \mathrm{kWh}, \mathrm{R} \$ 304,77$ para consumidores residenciais e $\mathrm{R} \$ 190,68$ para consumidores rurais.

${ }^{120}$ Nesta comunidade distante cerca de duas horas, por via fluvial, da sede do município, há 14 residências. $\mathrm{O}$ atendimento é feito por um gerador com motor diesel durante três horas (18 às $21 \mathrm{~h}$ ). $\mathrm{O}$ rateio do custo do combustível e o custo médio com energéticos que podem ser substituídos pela eletricidade totalizam, para cada família, aproximadamente $\mathrm{R} \$ 19,28$ por mês.
} 
Em termos lógicos, custos maiores de atendimento corresponderiam a tarifas proporcionalmente maiores; o efeito, porém, é perverso considerando a condição econômica desses consumidores. Assim, haveria uma barreira para a entrada de um novo agente nessas áreas isoladas no caso da política tarifária impor o atendimento nos mesmos níveis tarifários das distribuidoras, que têm cobertura por meio de subsídios cruzados entre classes de consumidores. Por esse motivo, a comparação não poderia ser feita com as tarifas rurais das distribuidoras. Assim, a solução envolve uma avaliação da política tarifária para essas regiões isoladas: definição de subsídios externos à área de atuação da distribuidora (concessionária ou permissionária) ou o incentivo para as ONG's, em conjunto e sob responsabilidade da distribuidora, atuar visando a antecipação das metas de universalização.

De forma similar, a regularização das cooperativas envolve a mesma discussão dos subsídios cruzados entre classes. Conforme exposto na Audiência Pública $n^{\circ}$ 40/2004, a Ceripa (2004) afirma que, para aplicar uma tarifa similar à concessionária de distribuição e manter seu equilíbrio econômico-financeiro, a cooperativa necessitaria "receber toda a energia sem custo e ainda subsídio extra".

\subsubsection{Influência na tarifa dos investimentos para a universalização}

A política de universalização do acesso deve ser elaborada considerando tanto os aspectos técnicos quanto os econômicos. O aumento do nível tarifário devido aos investimentos e o impacto no Fator $\mathrm{X}$ devem ser compatibilizados com a necessidade de tarifa módica para os consumidores da área de concessão a ser universalizada.

Uma possibilidade que visa compatibilizar os investimentos prudentes com tarifas módicas seria a distribuidora firmar um compromisso de metas e áreas de universalização, cujos custos fossem reconhecidos pela Aneel no momento da revisão tarifária. Poderiam ser definidas áreas em função de uma distância que resultasse em custos que não comprometessem a modicidade tarifária, conforme possibilita a Lei $n^{\circ} 10.438 / 2002$.

Por outro lado, é necessário estudar com profundidade os impactos do Programa Luz para Todos. Na revisão tarifária, a incorporação da remuneração dos investimentos 
decorrentes da universalização, bem como o aumento de custos de operação e manutenção dessas redes de distribuição, poderão resultar em tarifas elevadas para algumas regiões, especialmente para as áreas com menor densidade de consumidores e menor consumo médio.

Nesse segundo momento, pós-revisão tarifária, uma parcela da população dessas regiões poderá ter dificuldades para pagar o fornecimento de energia e, conseqüentemente, para manter o acesso ao serviço, embora tenham sido beneficiadas, no primeiro momento, com a chegada da energia elétrica às suas residências.

Para analisar a sensibilidade dos investimentos em universalização nas tarifas residenciais das distribuidoras foi elaborado um estudo pelo autor. A Tabela 43 apresenta dados para distribuidoras escolhidas devido ao possível impacto tarifário significativo.

Os custos da universalização na área rural foram calculados com base no número de domicílios sem acesso estimado pelo Censo 2000 do IBGE e nos custos médios regionais do Programa Luz no Campo. A remuneração dos investimentos em universalização tem duas componentes: cerca de $4 \%$ de depreciação sobre o total dos investimentos e a aplicação da taxa de retorno definida pela Aneel sobre a parcela dos recursos próprios e oriundos de empréstimos. Os recursos da CDE e do Estado são contabilizados como obrigações especiais e não compõem a base de remuneração da empresa, pois são recursos a fundo perdido.

O acréscimo médio na tarifa de cada Estado, que corresponde, neste estudo preliminar, somente a remuneração dos investimentos dividida pelo mercado de energia elétrica, foi calculado a partir dos dados de consumo divulgados pela Eletrobrás (2002b). O impacto sobre a tarifa média residencial, calculado pela relação entre o acréscimo médio na tarifa e o valor da tarifa residencial, foi estimado com base nos dados regionais, uma vez que a tarifa residencial média por Estado não está disponível no site da Aneel. 
Tabela 43 - Impacto dos investimentos em universalização na tarifa

\begin{tabular}{l|r|r|r|r|r|r}
\hline $\begin{array}{c}\text { Grandes regiões } \\
\text { e unidades da } \\
\text { federação }\end{array}$ & $\begin{array}{c}\text { Domicílios } \\
\text { rurais sem } \\
\text { Iluminação } \\
\text { Elétrica }\end{array}$ & $\begin{array}{c}\text { Custo } \\
\text { Estimado } \\
\text { (milhares } \\
\mathbf{R} \mathbf{\text { R) }}\end{array}$ & $\begin{array}{c}\text { Remuneração } \\
\text { dos } \\
\text { investimentos } \\
\text { (milhares R\$) }\end{array}$ & $\begin{array}{c}\text { Consumo } \\
\text { Anual } \\
\text { (MWh) }\end{array}$ & $\begin{array}{c}\text { Acréscimo } \\
\text { na tarifa } \\
\text { (R\$/MWh) }\end{array}$ & $\begin{array}{c}\text { Impacto na } \\
\text { Tarifa Média } \\
\text { Residencial }\end{array}$ \\
\hline Rondônia & 47.804 & 177.687 & 14.958 & 1.620 & 9,23 & $\mathbf{3 , 8 \%}$ \\
\hline Acre & 25.742 & 95.683 & 5.518 & 384 & 14,37 & $\mathbf{6 , 0 \%}$ \\
\hline Roraima & 9.347 & 34.743 & 2.004 & 48 & 41,74 & $\mathbf{1 7 , 3 \%}$ \\
\hline Pará & 250.684 & 931.792 & 78.439 & 4.199 & 18,68 & $\mathbf{7 , 7 \%}$ \\
\hline Tocantins & 50.551 & 187.898 & 15.817 & 862 & 18,35 & $\mathbf{7 , 6 \%}$ \\
\hline Maranhão & 230.605 & 691.815 & 58.238 & 2.556 & 22,78 & $\mathbf{1 0 , 6 \%}$ \\
\hline Piauín & 144.101 & 432.303 & 36.392 & 1.488 & 24,46 & $\mathbf{1 1 , 4 \%}$ \\
\hline Ceará & 162.115 & 486.345 & 40.941 & 5.918 & 6,92 & $\mathbf{3 , 2 \%}$ \\
\hline Alagoas & 50.086 & 150.258 & 13.977 & 1.956 & 7,15 & $\mathbf{3 , 3 \%}$ \\
\hline Bahia & 489.380 & 1.468 .140 & 110.617 & 9.015 & 12,27 & $\mathbf{5 , 7 \%}$ \\
\hline Mato Grosso & 54.473 & 252.156 & 32.367 & 3.457 & 9,36 & $\mathbf{3 , 7 \%}$ \\
\hline Brasil & $\mathbf{2 . 1 1 3 . 2 7 8}$ & $\mathbf{6 . 8 5 1 . 1 4 1}$ & $\mathbf{6 2 0 . 5 8 0}$ & $\mathbf{2 7 6 . 2 1 0}$ & $\mathbf{2 , 2 5}$ & $\mathbf{0 , 9 \%}$ \\
\hline
\end{tabular}

Fonte: Elaborado pelo autor.

Observa-se, a partir desse estudo preliminar, que embora o impacto estimado no País seja pequeno, em 11 Estados da Federação seria superior a 3\% sobre a tarifa residencial, somente em decorrência de investimentos em universalização. Para os Estados de Roraima, Maranhão e Piauí, o impacto estimado é maior do que $10 \%$ sobre as tarifas residenciais médias da região, sinalizando que a alocação de recursos a fundo perdido deveria ser revista para reduzir esse possível impacto tarifário.

Esse estudo preliminar deve ser complementado, uma vez que nele foram utilizados dados de tarifas médias regionais com custos por Estado, além de terem sido utilizadas estimativas de domicílios sem acesso à energia referentes ao ano de 2000. Também se deve incorporar ao impacto tarifário, os custos de operação e manutenção decorrente das novas ligações realizadas no âmbito da universalização.

Em adição seria necessário também analisar o crescimento do mercado estimado para os consumidores atendidos pela universalização. No período entre revisões tarifárias, os impactos não serão reconhecidos na tarifa, pois os custos operacionais e a remuneração do capital (itens que compõem a Parcela B) são corrigidos nos reajustes tarifários pela variação do IGP-M do período. 
A receita reconhecida pela Aneel, no processo de revisão tarifária, dividida pelo mercado de fornecimento da distribuidora, é conhecida como tarifa unitária, sendo que parte da mesma corresponde à remuneração do capital. Dessa forma, há uma relação $\mathrm{R} \$ \mathrm{MWh}$ referente a essa parcela que, mantida constante, corresponderia a um equilíbrio econômico-financeiro do contrato de concessão.

Analisando a universalização, caso os investimentos necessários para o atendimento de um consumidor e o consumo de energia desse consumidor mantivessem a relação anterior, seria garantido o equilíbrio econômico financeiro do contrato.

No entanto, o consumo estimado para o beneficiário pela universalização é menor que a média atual, pois os atualmente conectados são, em geral, médias e grandes propriedades rurais que tiveram condições de arcar com os custos das obras necessárias para o seu atendimento. Além do provável consumo inferior, os investimentos para o atendimento das novas ligações nessas áreas são cada vez maiores.

Adicionalmente, o fator de carga dos consumidores atendidos na universalização deve ser menor, correspondendo a um consumo menor para uma maior necessidade de investimentos. O valor da tarifa unitária de fornecimento já seria insuficiente mesmo que os investimentos necessários para a universalização correspondessem à média histórica da distribuidora.

Pode-se deduzir que no período entre revisões, a tarifa da distribuidora não recupera totalmente os investimentos realizados, agravado pela utilização do Fator X calculado inadequadamente com base em parâmetros que não incorporam a obrigação de universalização.

Isso torna necessário adequar a metodologia de cálculo do Fator X, como comentado na proposta de regulamentação, e definir uma política tarifária que considere e incentive o atendimento nas regiões isoladas. 


\subsubsection{Tarifa social}

\subsubsection{Formatação da política de atendimento}

São três as alternativas para programas de atendimento das necessidades de energia de populações carentes, de acordo com Anuatti (2000), apresentado no Capítulo 2 o realismo tarifário, acompanhado de um programa social, o direito de acesso a uma quantidade mínima de energia para todos, independentemente da classe social, também chamado benefício universal e os descontos para as famílias consideradas pobres.

O realismo tarifário, principalmente para um país onde a desigualdade econômicosocial é imensa, necessita de um programa social complementar que contemple as várias necessidades básicas do ser humano, dentre essas, a energia elétrica. Um programa dessa natureza necessitaria de uma rede de seguridade social bem mais organizada e eficiente.

A filosofia do benefício universal era aplicada, até 1995, à tarifa residencial, com os descontos nas faixas iniciais de consumo para todos, independentemente da classe social. Esta alternativa seria justa desde que as famílias pobres e não-pobres apresentassem perfis de consumo diretamente proporcionais à renda. Algumas distorções na inclusão do público-alvo podem ocorrer devido ao número de pessoas por domicílios pobres ser, em geral, maior do que nos domicílios não-pobres e o aumento do acesso a sistemas de aquecimento de água utilizando gás canalizado para edifícios de médio e alto padrão em alguns centros urbanos. No primeiro caso, os domicílios pobres teriam consumo de energia elétrica maior, o que implicaria sua exclusão do programa; no segundo, os domicílios não-pobres teriam um consumo menor, podendo ser incluídos indevidamente.

Alguns estudos concluem que o consumo de energia elétrica de um domicílio não necessariamente está relacionado com a renda. Segundo Pazelo (2000), a partir das variáveis comuns à Pesquisa Nacional de Amostras de Domicílios (PNAD) e à Pesquisa de Horário de Verão é possível estimar o consumo de energia elétrica das famílias pobres e não-pobres. 
Para a região metropolitana de São Paulo, observou-se que as famílias, independentemente da renda, apresentavam perfis semelhantes: $76 \%$ das famílias pobres e $57 \%$ das famílias não-pobres apresentavam consumo de energia elétrica inferior a $220 \mathrm{kWh} / \mathrm{mês}$. Dessa forma, o consumo familiar médio estimado nesse estudo é similar: 191 e $213 \mathrm{kWh} / \mathrm{mês}$, para as famílias pobres e não-pobres, respectivamente.

Adicionalmente, o Tribunal de Contas da União (2003b) apresenta um estudo semelhante que conclui, com base na Pesquisa sobre Padrões de Vida (PPV) de 1996/1997 do IBGE, que não há correlação ${ }^{121}$ entre as variáveis: consumo de energia elétrica e renda per capita domiciliar; ou seja, baixo consumo não implica baixa renda, e vice-versa. Assim, segundo o TCU, utilizar exclusivamente o consumo domiciliar de energia elétrica como critério para selecionar o consumidor de baixa renda não seria adequado.

A terceira alternativa, descontos tarifários para as famílias pobres, é aplicada desde 1995, com a criação da subclasse residencial baixa renda. A atual sistemática determinada pela Lei $\mathrm{n}^{\mathrm{o}}$ 10.438/2002 emprega essa filosofia de descontos para os domicílios com consumo entre 80 e 220 kWh/mês; mas a norma legal, ao possibilitar o benefício para todos os consumidores com consumo até $80 \mathrm{kWh} / \mathrm{mês,}$ independentemente da condição sócio-econômica, também aplica a filosofia de benefício universal, ainda que restrita aos atendidos por sistema monofásico.

Em tese, esse sistema limitaria o atendimento da carga. Porém, em primeiro lugar, não necessariamente a carga atendida por esse sistema é uma sinalização da condição econômica dos domicílios. Além disso, a carga monofásica máxima não é unificada, sendo definida pela distribuidora com base em critérios técnicos específicos e na cultura local.

Para o autor, a política definida pela Lei $\mathrm{n}^{\circ} 10.438 / 2002$, a filosofia de descontos às famílias pobres, é a mais viável para ser aplicada no País, pelos motivos expostos. O

121 De acordo com o TCU (2003b), o coeficiente Pearson obtido, "além de praticamente igual a zero $(0,015)$ é estatisticamente significativo apenas para $49 \%$ de confiabilidade". 
próximo passo, definida a filosofia a ser empregada, é o estabelecimento do públicoalvo do programa de descontos tarifários.

\subsubsection{Público alvo}

O público-alvo da atual política, definido por regulamento da União, focaliza as famílias beneficiárias pelos programas sociais do Governo Federal. Atualmente, os programas consideram a renda per capita familiar de $\mathrm{R} \$ 100,00$ como valor único da linha de pobreza, optando por tratar o Brasil sem as diferenças regionais, embora, segundo Rocha (2000a), haja diferenças significativas dos valores regionais de pobreza.

É necessário definir claramente o público-alvo do programa de descontos nas tarifas de energia elétrica para, então, definir os critérios de focalização utilizados para identificar as famílias beneficiárias.

Atualmente, os dois tipos de tratamento dado pela Lei ${ }^{\circ} 10.438 / 2002$, na prática, resultam em público-alvo distintos. Para a faixa de consumo entre 80 e $220 \mathrm{kWh} / \mathrm{mês}$, embora coerente com os demais programas sociais do Governo Federal, o público-alvo fica restrito aos consumidores considerados pobres. Para consumo inferior a $80 \mathrm{kWh} / \mathrm{mês}$, devido a não existência de correlação entre consumo e renda, o público-alvo é maior incluindo consumidores não-pobres.

Dessa forma, a proposição de público-alvo adequada, na visão do autor, corresponderia somente às famílias pobres, considerando, porém, as diferenças regionais de renda e de consumo. Os consumidores não-pobres com consumo até 80 kWh/mês, portanto, poderiam ser excluídos do benefício de descontos tarifários.

\subsubsection{Critérios de focalização}

É necessário estudar a adequação da linha de pobreza, adotada nos programas sociais do Governo Federal, aos valores regionais da alimentação, moradia, serviços públicos básicos, transporte. Outro aspecto é o fato de que, admitindo-se um valor para a linha de pobreza, as pessoas com renda per capita um pouco superior não teriam direito aos benefícios do desconto tarifário. 
A dificuldade para estabelecer um limite devido às "nuances" de pobreza implica que o setor elétrico não deveria se responsabilizar por essa definição, repassando-a para os órgãos capacitados e experientes, em geral responsáveis pelos programas sociais. Assim, para os critérios de focalização, a sugestão do autor é, além dos atuais beneficiários dos programas sociais, incorporar com base em critérios préestabelecidos os integrantes de programas destinados às famílias carentes dos Municípios, Estados e Distrito Federal.

Adicionalmente, poder-se-ia utilizar o critério denominado de geographic target no qual uma determinada região seria contemplada com os benefícios do programa de descontos. Alternativamente, a identificação do beneficiário poderia ser a comprovação da dimensão do imóvel, idêntica à utilizada para isenção de impostos municipais, por exemplo. O mecanismo geographic target depende do conhecimento da distribuição geográfica da pobreza, sendo mais eficiente quanto maior for a sua concentração em determinadas localidades.

A atual sistemática definida pela Aneel de utilizar o limite regional somente para a aplicação da tarifa com desconto e não como limite para classificação é um avanço importante que não deve ser desconsiderado. Manter um limite de consumo, atualmente $220 \mathrm{kWh} / \mathrm{mês}$, é importante para sinalizar a necessidade de uso eficiente da energia elétrica. O mais justo para limitação de consumo seria considerar um valor per capita, o que na prática, porém, é inviável. Assim, no contexto dos descontos tarifários para famílias pobres, seria atribuição da Aneel, como reguladora do setor elétrico, a definição técnica adequada dos limites regionais de consumo e do limite para classificação, que corresponderia a uma "cesta básica de energia elétrica".

Definido o publico alvo, os critérios de focalização e os limites de consumo, é necessário analisar a adequação dos percentuais de desconto nas tarifas de fornecimento em relação à renda das famílias pobres.

\subsubsection{Nível de descontos}

Dado um consumo de energia correspondente à "cesta básica" o valor da fatura mensal, aplicada à tarifa com descontos, não poderia comprometer 
significativamente a renda dos consumidores baixa renda. Como discutido anteriormente, os descontos percentuais foram gradativamente diminuindo permanecendo nos níveis atuais desde 1995. O estudo elaborado pelo Dnaee sobre tarifas sociais estimava um comprometimento de $4 \%$ do salário mínimo da época.

Similarmente, o IETS (2001) analisou o consumo de energia elétrica e o seu peso na renda das comunidades de baixa renda do Rio de Janeiro. O estudo estimou o consumo médio, com base em levantamento de eletrodomésticos nas comunidades pesquisadas, em $199 \mathrm{kWh} / \mathrm{mês}^{122}$.

Foram estudados três cenários definidos com base no consumo médio estimado da localidade; no limite regional de consumo de $140 \mathrm{kWh} / \mathrm{mês}$ - considerado na época como critério para classificação como baixa renda; e nas tarifas com os descontos e plena. No primeiro cenário adotou-se o valor pago por um consumidor baixa renda com consumo de $140 \mathrm{kWh} / \mathrm{mês}$. No segundo, o valor pago por um consumidor residencial para um consumo de 199 kWh/mês. Finalmente, para o terceiro cenário, admite-se que a tarifa baixa renda seja aplicada para um consumo de $199 \mathrm{kWh} / \mathrm{mês}$, embora este seja superior ao limite regional.

A Tabela 44 a seguir apresenta o peso dos gastos com energia elétrica na renda média familiar das comunidades baixa renda, segregado por décimo da população estudada. Portanto, os $10 \%$ mais pobres, aqueles que estão no primeiro décimo, gastariam $14 \%$ da sua renda com energia elétrica para um consumo de $140 \mathrm{kWh} / \mathrm{mês}$ se fossem classificados como baixa renda. Porém, um consumo de 199 kWh/mês comprometeria $33 \%$ da renda dessa parcela da população, pois seria excluída, na época, da subclasse renda por não atender ao critério de limite regional de consumo. Caso não fosse aplicado o limite - hipótese sem fundamento regulatório - o gasto com energia seria de $20 \%$.

\footnotetext{
${ }^{122}$ Equipamentos elétricos utilizados: quatro pontos de luz (60 W cada), chuveiro elétrico, geladeira,
} ventilador TV. 
Tabela 44 - Peso da energia elétrica na renda das comunidades baixa renda do Rio de Janeiro

\begin{tabular}{|c|c|c|c|c|}
\hline \multirow{3}{*}{ Décimo } & \multirow{3}{*}{$\begin{array}{l}\text { Renda média } \\
\text { familiar (R\$) }\end{array}$} & $140 \mathrm{kWh}$ & \multicolumn{2}{|c|}{$199 \mathrm{kWh}$} \\
\hline & & $\begin{array}{c}\text { Cenario } 1 \text { - Tarifa } \\
\text { Baixa Renda }\end{array}$ & $\begin{array}{c}\text { Cenário } 2 \text { - Tarifa } \\
\text { Residencial }\end{array}$ & $\begin{array}{l}\text { Cenário } 3 \text { - } \\
\text { Tarifa Baixa } \\
\text { Renda }\end{array}$ \\
\hline & & R\$ 19,99 & $\mathrm{R} \$ 48,00$ & $\mathrm{R} \$ \mathbf{3 0 , 0 0}$ \\
\hline 1 & 147,00 & $14 \%$ & $33 \%$ & $20 \%$ \\
\hline 2 & 240,00 & $8 \%$ & $20 \%$ & $13 \%$ \\
\hline 3 & 314,00 & $6 \%$ & $15 \%$ & $10 \%$ \\
\hline 4 & 391,00 & $5 \%$ & $12 \%$ & $8 \%$ \\
\hline 5 & 472,00 & $4 \%$ & $10 \%$ & $6 \%$ \\
\hline 6 & 572,00 & $3 \%$ & $8 \%$ & $5 \%$ \\
\hline 7 & 681,00 & $3 \%$ & $7 \%$ & $4 \%$ \\
\hline 8 & 828,00 & $2 \%$ & $6 \%$ & $4 \%$ \\
\hline 9 & $2.068,00$ & $1 \%$ & $2 \%$ & $1 \%$ \\
\hline 10 & $2.958,00$ & $1 \%$ & $2 \%$ & $1 \%$ \\
\hline
\end{tabular}

Fonte: Adaptado de: IETS(2001).

Em resumo, a definição do nível dos descontos deve ser feita no âmbito de uma política publica discutida com a sociedade. Essa política para a subclasse residencial baixa renda englobaria também destacar a fonte de origem dos recursos para a implementação de um programa, ou seja, subsídios cruzados das classes mais favorecidas ou um fundo para compensação.

Deve ser estudada uma solução para o equacionamento das perdas e dos ganhos das distribuidoras decorrentes dos novos critérios para classificação dos consumidores baixa renda. A regulamentação atual da Aneel não prevê o fim do subsídio e nem o tratamento da questão no processo de revisão tarifária. A CDE, utilizada para cobrir as perdas das distribuidoras a partir de 2004, será arrecadada até 2027. Embora o prazo seja longo, a CDE atualmente está em grande parte comprometida com essa subvenção.

\subsubsection{Rural baixa renda}

De acordo como o MME (2003a), no que abrange a área rural, cerca de dois milhões de famílias não tem acesso à energia elétrica no Brasil dos quais $90 \%$ possuem renda inferior a três salários mínimos, configurando também a necessidade de avaliação das tarifas praticadas no meio rural. 
Com base nas tarifas de algumas distribuidoras representativas do mercado, foi elaborada o Quadro 7 que compara a relação entre as tarifas de fornecimento rural e residencial bem como a relação entre esta e a TUSD.

\section{Quadro 7 - Comparação das tarifas residencial e rural}

\begin{tabular}{|c|c|c|c|c|c|c|c|}
\hline Região & Distribuidora & $\begin{array}{c}\text { Tarifa } \\
\text { Residencial } \\
\text { (R\$/MWh) }\end{array}$ & $\begin{array}{l}\text { TUSD Res. } \\
\text { (R\$/MWh) }\end{array}$ & $\begin{array}{l}\text { Tarifa Rural } \\
\text { (R\$/MWh) }\end{array}$ & $\begin{array}{l}\text { TUSD Rural } \\
\text { (R\$/MWh) }\end{array}$ & $\begin{array}{c}\text { Relação } \\
\text { TUSD/Tarifa }\end{array}$ & $\begin{array}{c}\text { Relação } \\
\text { Rural/ } \\
\text { Residencial }\end{array}$ \\
\hline \multirow{4}{*}{ Norte } & CEAM & 282,93 & 152,81 & 191,28 & 103,31 & $54 \%$ & $68 \%$ \\
\hline & BOA VISTA & 269,99 & 112,78 & 180,53 & 75,41 & $42 \%$ & $67 \%$ \\
\hline & CELPA & 297,28 & 207,76 & 186,13 & 130,08 & $70 \%$ & $63 \%$ \\
\hline & MANAUS & 278,40 & 145,97 & 186,13 & 97,59 & $52 \%$ & $67 \%$ \\
\hline \multirow{6}{*}{ Nordeste } & CEMAR & 327,55 & 191,72 & 183,10 & 107,17 & $59 \%$ & $56 \%$ \\
\hline & CEPISA & 283,42 & 164,87 & 177,27 & 103,12 & $58 \%$ & $63 \%$ \\
\hline & COELCE & 315,30 & 197,72 & 185,89 & 116,57 & $63 \%$ & $59 \%$ \\
\hline & COSERN & 272,44 & 165,55 & 170,86 & 103,82 & $61 \%$ & $63 \%$ \\
\hline & \begin{tabular}{|l|} 
CELPE \\
\end{tabular} & 266,82 & 178,91 & 162,26 & 108,80 & $67 \%$ & $61 \%$ \\
\hline & COELBA & 304,77 & 195,10 & 190,68 & 122,07 & $64 \%$ & $63 \%$ \\
\hline \multirow{10}{*}{ Sudeste } & CEMIG & 344,18 & 223,17 & 201,42 & 130,60 & $65 \%$ & $59 \%$ \\
\hline & ESCELSA & 302,03 & 184,02 & 173,38 & 105,64 & $61 \%$ & $57 \%$ \\
\hline & \begin{tabular}{|l|} 
SANTA MARIA \\
\end{tabular} & 294,20 & 157,56 & 171,26 & 91,72 & $54 \%$ & $58 \%$ \\
\hline & \begin{tabular}{|l|} 
LIGHT \\
\end{tabular} & 309,37 & 158,97 & 174,86 & 89,85 & $51 \%$ & $57 \%$ \\
\hline & CERJ & 350,33 & 226,22 & 201,43 & 130,07 & $65 \%$ & $57 \%$ \\
\hline & \begin{tabular}{|l|} 
ELEKTRO \\
\end{tabular} & 363,14 & 217,44 & 213,87 & 128,06 & $60 \%$ & $59 \%$ \\
\hline & \begin{tabular}{|l|} 
CPFL \\
\end{tabular} & 331,53 & 176,71 & 179,09 & 95,46 & $53 \%$ & $54 \%$ \\
\hline & ELETROPAULO & 311,51 & 162,05 & 193,89 & 100,86 & $52 \%$ & $62 \%$ \\
\hline & PIRATININGA & 322,99 & 157,00 & 201,07 & 97,74 & $49 \%$ & $62 \%$ \\
\hline & BANDEIRANTE & 332,84 & 194,06 & 207,19 & 120,80 & $58 \%$ & $62 \%$ \\
\hline \multirow{5}{*}{ Sul } & COPEL & 300,44 & 155,82 & 176,12 & 91,34 & $52 \%$ & $59 \%$ \\
\hline & CELESC & 305,36 & 148,62 & 181,44 & 88,31 & $49 \%$ & $59 \%$ \\
\hline & CEEE & 304,36 & 177,19 & 209,10 & 121,73 & $58 \%$ & $69 \%$ \\
\hline & \begin{tabular}{|l|} 
AES-SUL \\
\end{tabular} & 298,19 & 169,57 & 204,85 & 116,49 & $57 \%$ & $69 \%$ \\
\hline & RGE & 320,22 & 153,53 & 220,00 & 105,48 & $48 \%$ & $69 \%$ \\
\hline \multirow{3}{*}{$\begin{array}{l}\text { Centro- } \\
\text { Oeste }\end{array}$} & ENERSUL & 338,29 & 237,37 & 209,70 & 147,14 & $70 \%$ & $62 \%$ \\
\hline & CEMAT & 339,02 & 183,93 & 224,87 & 122,00 & $54 \%$ & $66 \%$ \\
\hline & CEB & 283,68 & 155,30 & 170,88 & 93,55 & $55 \%$ & $60 \%$ \\
\hline
\end{tabular}

Fonte: Aneel (on line, 13 nov. 2004).

Depreende-se da observação dos dados que a tarifa de um consumidor do Grupo B classificado como rural corresponde a pouco menos de $70 \%$ da tarifa de um consumidor residencial. A menor relação, das distribuidoras selecionadas, é da CPFL na qual a tarifa rural corresponde a $54 \%$ da tarifa residencial.

É possível, então, comparar a tarifa residencial baixa renda, que possui descontos escalonados (de acordo com a faixa de consumo) sobre a tarifa residencial, com a tarifa rural. 
Por exemplo, para a CPFL, na qual a tarifa rural corresponde a 54\% da residencial, os consumidores residenciais baixa renda pagam tarifa menor do que os rurais, mesmo que ambos consumam até $105 \mathrm{kWh} / \mathrm{mês}$, devido à aplicação dos descontos escalonados da tarifa baixa renda ${ }^{123}$. Essa situação é invertida se ambos excederem o consumo citado, porque os descontos da tarifa baixa renda não são suficientes para mantê-la menor que a tarifa rural.

Similarmente na AES-Sul, cuja relação entre tarifas é maior, sendo que a tarifa rural chega a $69 \%$ da residencial, o consumidor baixa renda tem a vantagem de obter uma tarifa menor do que a atribuída ao consumidor rural, para um consumo igual ou inferior a $183 \mathrm{kWh} / \mathrm{mês}$.

Observa-se que os descontos concedidos para os pequenos consumidores rurais são similares àqueles concedidos para os consumidores residenciais baixa renda. No entanto, propriedades rurais com consumo superior a esses valores possuem uma tarifa menor do que a aplicada para consumidores residenciais baixa renda.

Uma residência na área rural pode ser classificada como consumidor rural de acordo com o inciso IV, art. 20, da Resolução $n^{\circ}$ 456/2000. O art. 18 determina a analise de todos os elementos de caracterização visando a aplicação da tarifa mais vantajosa para o consumidor, em especial o residencial, “caso em que a classificação será definida considerando as subclasses Residencial, Residencial Baixa Renda ou Rural Agropecuária Residencial”.

Para o consumidor, de uma maneira geral, a melhor classificação seria rural, no que tange às tarifas. Para a distribuidora, considerando também a cobertura das perdas com consumidores baixa renda, a melhor classificação seria nessa subclasse. No entanto, a incidência de alíquotas de ICMS diferenciadas pode alterar essa análise.

Nota-se, porém, que os percentuais de descontos para a tarifa residencial baixa renda bem como a relação entre a tarifa rural e residencial não estão definidos em norma

\footnotetext{
${ }^{123}$ Os descontos escalonados para a tarifa baixa renda, como visto anteriormente, correspondem a $65 \%$ para consumo até $30 \mathrm{kWh} / \mathrm{mês}$, $40 \%$ para a faixa entre 31 e $100 \mathrm{kWh} / \mathrm{mês}$ e $10 \%$ para a faixa entre $101 \mathrm{kWh} /$ mês e o limite regional. A composição desses descontos resulta valores diferenciados em função do consumo. Por exemplo, consumo de $105 \mathrm{kWh} /$ mês corresponde a $46,1 \%$ de desconto ou uma relação entre a tarifa baixa renda e a residencial de 53,9\%.
} 
legal. A Lei $n^{\circ} 8.631 / 93$ possibilita que a concessionária defina os níveis tarifários relativos a cada consumidor final.

\section{Lei $n^{0}$ 8.631, de 4 de março de 1993}

Art. $1^{\circ}$ Os níveis das tarifas de fornecimento de energia elétrica a serem cobradas de consumidores finais serão propostos pelo concessionário, ao Poder Concedente, que os homologará, observado o disposto nesta Lei.

$[\ldots]$

$\S 4^{\circ}$ Respeitado o valor médio das tarifas de fornecimento, devidamente homologado na forma do disposto neste artigo, fica facultado ao concessionário distribuidor promover alterações compensatórias entre os níveis das tarifas de fornecimento relativos a cada classe de consumidor final.

Observa-se, portanto, que parte da política tarifária correspondente a definição dos níveis relativos à cada classe encontra-se sob responsabilidade da distribuidora. Adicionalmente, as tarifas homologadas pela Aneel, mesmo considerando o processo de realinhamento tarifário em curso, mantêm os sinais tarifários existentes desde a década de 90. Dessa forma, é necessária a definição da política tarifária que envolva tanto a tarifa residencial baixa renda quanto à tarifa rural, incluindo os aspectos apresentados nesse item, visando atender as duas vertentes da universalização dos serviços de energia elétrica.

\subsubsection{ICMS}

Os Quadros 8 e 9 apresentam o levantamento das alíquotas do ICMS incidentes sobre o fornecimento de energia elétrica feito pela Abradee (2003b) para os consumidores residenciais e rurais. 


\section{Quadro 8 - Alíquotas de ICMS incidentes sobre o fornecimento de energia elétrica - classe residencial}

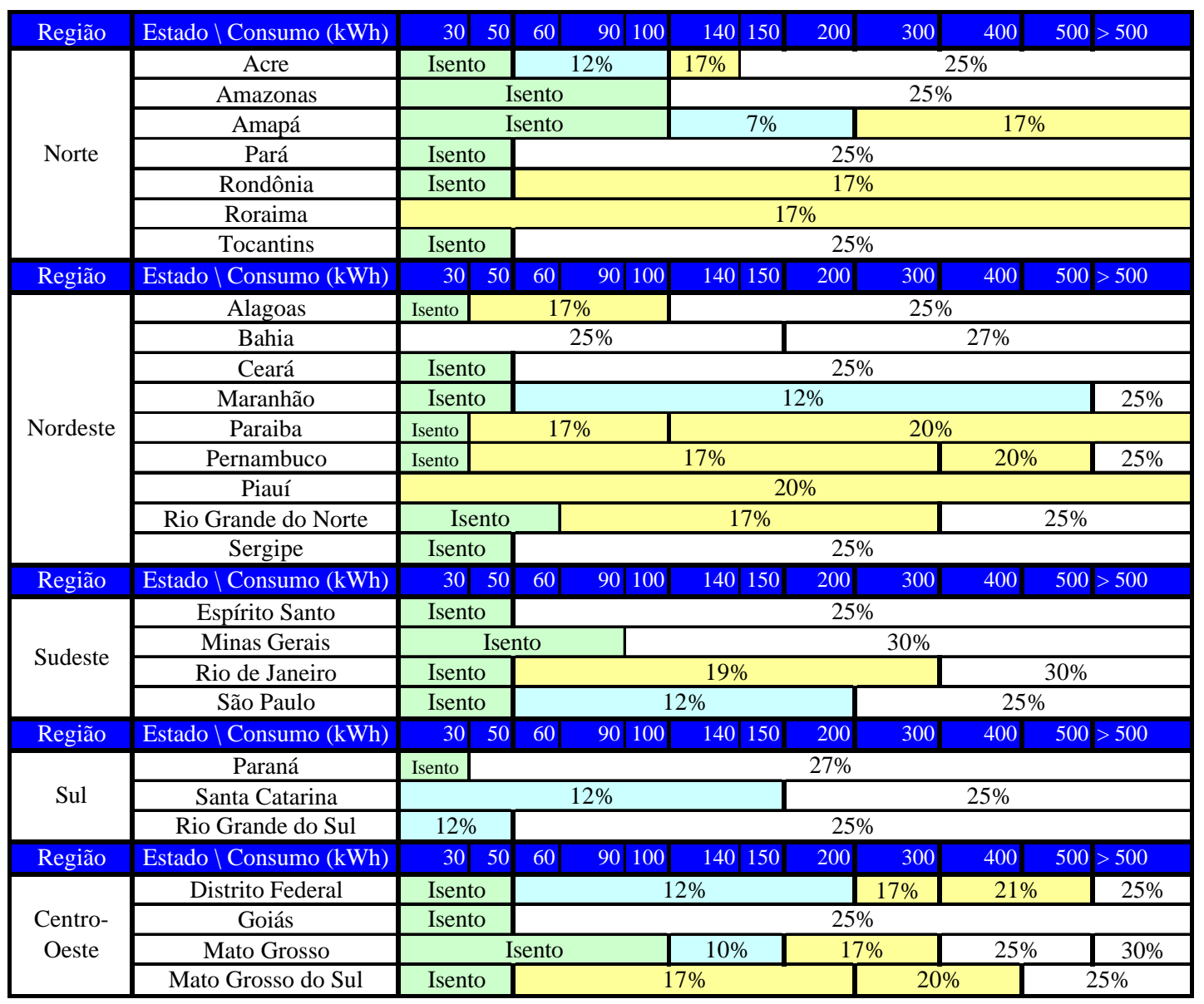

Fonte: Adaptado de: Abradee (2003b).

Atualmente, 22 Estados concedem isenção de ICMS sobre o fornecimento de energia elétrica residencial, em geral, de até $50 \mathrm{kWh} / \mathrm{mês}$, sendo que num deles - o Ceará -, a isenção abrange os consumidores baixa renda. Por outro lado, cinco Estados (BA, PI, RR, RS e SC) não concedem isenção para nenhum valor de consumo residencial.

Segundo a Abradee (informação pessoal) ${ }^{124}$, a arrecadação do ICMS sobre o fornecimento de energia elétrica aos consumidores baixa renda, verificada no exercício de 2002, foi de $\mathrm{R} \$ 265$ milhões, representando apenas 2,4\% da total da arrecadação de ICMS sobre energia elétrica. Se em 2002, esses consumidores

\footnotetext{
${ }^{124}$ ABRADEE. Impactos da reforma tributária. [mensagem pessoal]. Mensagem recebida por <sergiokf@uol.com.br> em 24 nov. 2003.
} 
estivessem sujeitos à alíquota única de 25\%, o montante da arrecadação do ICMS, em vez de $\mathrm{R} \$ 265$ milhões, teria sido de $\mathrm{R} \$ 500$ milhões.

Uma das propostas em discussão no Congresso Nacional em setembro de 2003 estabelecia a aplicação da alíquota mínima de $4 \%$ ao fornecimento de energia elétrica para os consumidores da subclasse residencial baixa renda e a uniformização da alíquota em $25 \%$ para os todos os demais consumidores de energia elétrica. De acordo com a Abradee, essas alíquotas resultariam um aumento da arrecadação de ICMS de aproximadamente $\mathrm{R} \$ 2,8$ bilhões.

Uma proposta adequada, na visão do autor, seria isentar do pagamento de ICMS sobre o fornecimento de energia elétrica os consumidores residências baixa renda ou ter alíquota reduzida. A aplicação da alíquota de $25 \%$, a maior prevista, pode ser considerada inadequada para um serviço essencial. Por isso, deveriam ser aplicadas alíquotas progressivas para o fornecimento de energia elétrica para consumidores residenciais (não baixa renda), considerando que um determinado nível de consumo seja vital para o bem-estar do consumidor.

Essas propostas dependem de ações integradas das áreas do Governo Federal, pois o benefício concedido pelo setor elétrico pode ser muito reduzido pela decisão de outras esferas como o que ocorreu com a aplicação do ICMS sobre a tarifa residencial plena para os consumidores baixa renda, definido em outubro de 2004 pelo Confaz. A perda de arrecadação do ICMS foi analisada somente do ponto de vista econômico pelo Confaz, refletindo, portanto, a falta da política governamental para os consumidores residenciais baixa renda.

Em nenhum Estado, exceto no Ceará, se concede descontos diferenciados ou mesmo isentam os consumidores residenciais baixa renda, tratando-os de maneira idêntica a um consumidor residencial comum. Por exemplo, no Estado de São Paulo um consumidor baixa renda, paga a mesma alíquota de ICMS de um consumidor residencial comum (25\%) referente a um consumo de $220 \mathrm{kWh} / \mathrm{mês}$. Similarmente, um consumidor residencial com consumo inferior a $50 \mathrm{kWh} / \mathrm{mês}$ seria isento independentemente de sua condição sócio-econômica. 
É necessário também ressaltar que a legislação estadual que versa sobre ICMS não utiliza necessariamente os mesmos períodos de leitura previstos na regulamentação da Aneel. Dessa forma, essa diferença de sistemática pode ocasionar a cobrança indevida de ICMS para um consumidor classificado como baixa renda.

\section{Quadro 9 - Alíquotas de ICMS incidentes sobre o fornecimento de energia elétrica - classe rural}

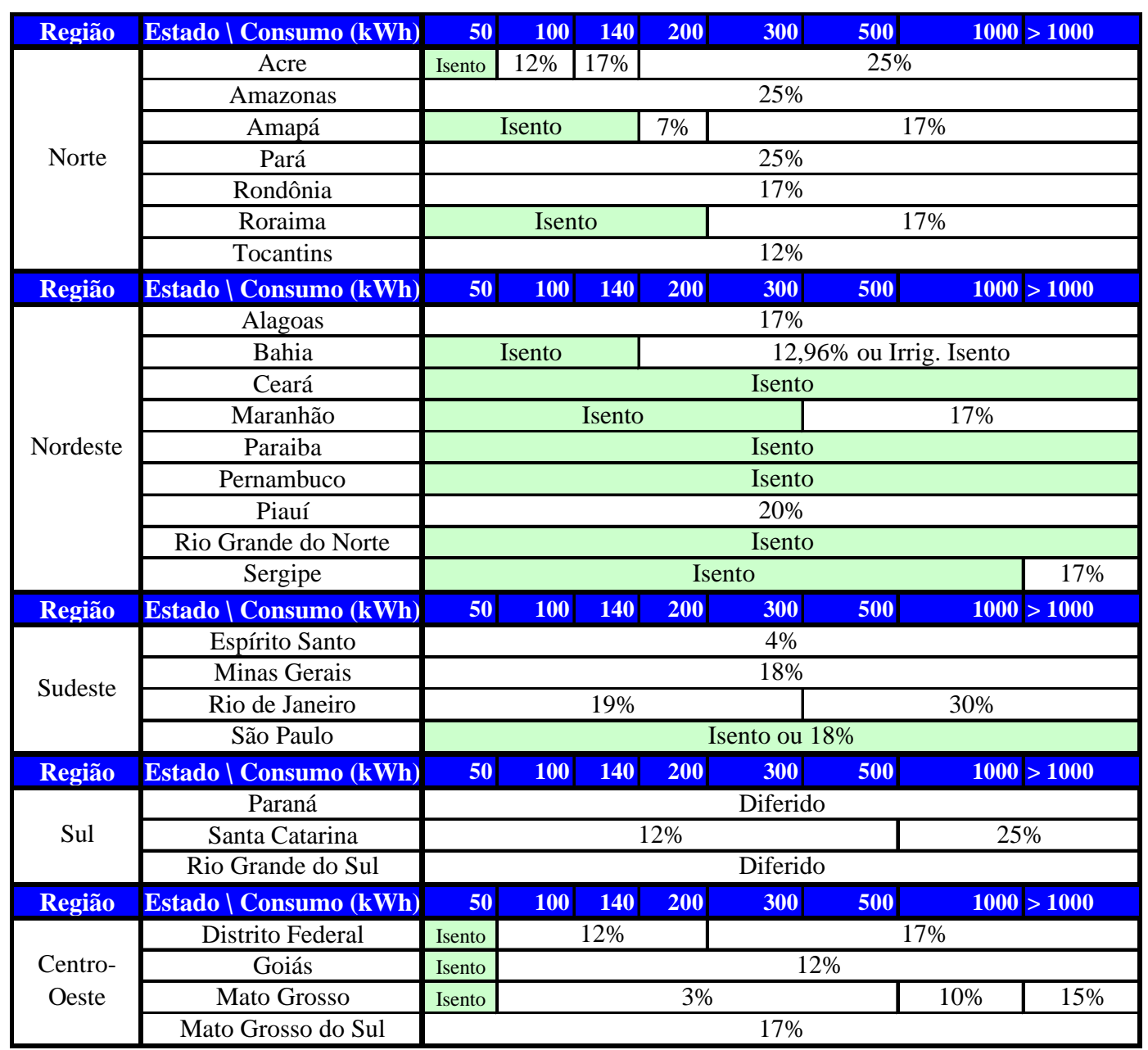

Fonte: Adaptado de: Abradee (2003b).

Para os consumidores rurais, a maioria dos Estados concede isenção de ICMS sobre o fornecimento de energia elétrica. Nesse caso, a proposta é garantir ao consumidor rural baixa renda a mesma isenção que tem o produtor rural em geral. No Estado de São Paulo, a isenção depende de comprovação que caracterize o consumidor como produtor rural. Dessa maneira, um domicílio de um trabalhador rural, apesar de ser classificado como unidade rural conforme Resolução no 456/2000, não teria isenção de ICMS. 


\section{CAPITULO 10 - CONCLUSÕES E COMENTÁRIOS}

\subsection{CONCLUSÕES}

Conceituando-se a universalização dos serviços de energia elétrica com base nos aspectos referentes ao acesso e uso contínuo, este estudo apresentou inicialmente uma análise abrangente dessas vertentes, por meio de uma revisão da literatura que englobou o histórico da legislação brasileira e determinados aspectos de políticas públicas e de pobreza no Brasil, além de experiências internacionais relevantes. O Capítulo 6, que demarca essa seção, apresentou o marco legal da universalização e sua regulamentação, enfocando ambas as vertentes definidas, pela primeira vez, na Lei ${ }^{\circ} 10.438 / 2002$.

A parte final do trabalho contém uma análise da situação atual enfatizando não só os recursos necessários e os alocados, como também questões relevantes para o amplo cumprimento do marco legal.

O Capítulo 8 apresentou uma análise da regulamentação identificando necessidades de seu aprimoramento e de complementação. O Capítulo 9, adicionalmente, identificou a necessidade de solucionar assuntos que, embora não se refiram à universalização propriamente dita, estão ligados a esse processo; propôs alternativas para parte das lacunas da regulamentação identificadas e sugeriu diretrizes para uma política de universalização que engloba também um aprimoramento da política tarifária na qual ressalta-se sua componente fiscal.

A proposição acadêmica da tese da universalização abrangendo o acesso e uso contínuo foi comprovada pelas pesquisas e estudos apresentados, ficando configurada a necessidade de tratamento dessas duas vertentes em conjunto, para conferir sustentabilidade ao processo de universalizar o serviço de energia elétrica no Brasil.

Em relação à universalização do acesso, observa-se incertezas para a continuidade do atendimento após o ano horizonte de universalização previsto na regulamentação da Aneel que pressupõe a cobertura da área do município ao final desse período. 
Portanto, após aquela data deverão ser atendidos também os consumidores com carga até $50 \mathrm{~kW}$ em locais distantes da rede de distribuição ou isolados desses municípios, mesmo representando, para determinadas concessionárias, custos significativos e sem haver o auxílio do Programa Luz para Todos a partir de 2009.

A universalização do uso emprega atualmente a filosofia de descontos para domicílios com consumo entre 80 e $220 \mathrm{kWh} /$ mês, cujos responsáveis estejam cadastrados nos programas sociais do Governo Federal. Ao mesmo tempo, a norma legal possibilita o benefício para todos os domicílios com consumo até $80 \mathrm{kWh} / \mathrm{mês}$, independentemente da condição sócio-econômica dos moradores, aplicando, nesse segmento a filosofia denominada de benefício universal, ainda que restrita aos atendidos por sistema monofásico.

Contudo, percebe-se que o número de consumidores classificados como baixa renda é maior do que o de famílias pobres, o que evidencia que os critérios de focalização utilizados para classificação dos consumidores baixa renda não são ideais. Por outro lado, parte das famílias com condições para inclusão nos programas sociais do Governo Federal ainda não estão cadastradas, o que não as qualifica para receber os descontos restritos para a subclasse residencial baixa renda, no caso de consumos acima de $80 \mathrm{kWh} / \mathrm{mês}$.

Portanto, apesar da Lei $n^{\circ}$ 10.438/2002 ter representado um significante avanço na universalização dos serviços de energia elétrica, o processo não está completamente equacionado, por isso necessita aprimoramentos, tanto na política pública como nos regulamentos. Os principais temas discutidos foram os recursos para a universalização; a concatenação das metas da Aneel, com as do programa do Governo Federal; os possíveis impactos tarifários em médio prazo; a participação financeira do consumidor não alcançado pela universalização; a incidência de ICMS sobre a tarifa plena para consumidores baixa renda; a metodologia para cálculo das perdas das receitas das distribuidoras com os novos critérios de classificação de consumidores. As análises e proposições feitas nos Capítulos 8 e 9 demonstraram a complexidade dos problemas e sua multidisciplinaridade, merecendo que essa problemática seja abordada em novos estudos, de caráter aprofundado. 
Uma perfeita coordenação entre o MME e a Aneel facilitaria o cumprimento e o acompanhamento das metas de universalização, pois eventuais atrasos na assinatura dos contratos e na liberação dos recursos podem afetar a ação das distribuidoras que contam com os recursos do Programa Luz para Todos para atender as metas de universalização. Como exemplo, segundo a Portaria MME no 447/2004, a meta de 2004 do programa do Governo Federal foi alterada, passando de 400 mil para 150 mil, permanecendo, porém, a meta de 2 milhões até 2008.

\subsection{COMENTÁRIOS E FUTUROS ESTUDOS}

Ressalta-se que a universalização dos serviços de energia elétrica é um assunto complexo, o que abre espaço para futuros estudos que aprimorem a análise iniciada neste trabalho. Como temas para futuras pesquisas podem ser nomeados: a análise do impacto tarifário ocasionado pela remuneração dos investimentos e pelo aumento dos custos de operação e manutenção em determinadas regiões do Brasil com maiores demandas relativas de domicílios para universalizar; medidas para incentivar o atendimento nas áreas isoladas; metodologia de cálculo do limite de investimento da distribuidora para consumidores não abrangidos pela universalização; incorporação dos investimentos em universalização e da receita decorrente dos novos consumidores baixa renda nos procedimentos de revisão e de reajuste tarifário.

A incidência de ICMS sobre o fornecimento de energia elétrica para os consumidores residenciais baixa renda deve ser debatida no momento da definição das novas alíquotas. Poderiam ser analisados, por exemplo, valores progressivos para consumidores residenciais com alíquotas unificadas, isenção dos consumidores baixa renda tal como foi realizado recentemente pelo Governo do Mato Grosso ${ }^{125}$, evitando que o beneficio dos descontos tarifários fossem parcialmente perdidos pela cobrança de um imposto maior.

Também é necessário o re-exame dos níveis tarifários residencial baixa renda e rural, uma vez que os valores atualmente homologados pela Aneel mantêm estrutura similar desde as décadas de 80 e 90.

${ }^{125}$ Lei Estadual no 8.233 , de 14 de dezembro de 2004. 
Finalmente, a sistemática de compensação das perdas deveria ser restrita aos casos que comprovadamente necessitam de cobertura com recursos extraconcessão, evitando que a situação se mantenha indefinidamente. Também deveria ser revista a atual aplicação simultânea das duas filosofias hoje existentes: os beneficio universal e os descontos tarifários. A proposição da filosofia de descontos somente para as famílias pobres, considerando, porém, as diferenças regionais de renda e de consumo, e com parâmetros de focalização eficientes poderia ser uma solução adequada. 


\begin{abstract}
ANEXOS
Anexo A - Acesso à energia elétrica - Dados do Censo 2000

Anexo B - Estimativa de custos da universalização

Anexo C - Municípios - Índices máximos e mínimos por Estado

Anexo D - Municípios e domicílios sem acesso à energia elétrica em função do índice de atendimento municipal

Anexo E - Resultados do Programa Luz no Campo - 2003

Anexo F - Estimativa da alocação dos recursos do Programa Luz para Todos

Anexo G - Estimativa preliminar de impacto tarifário decorrente da universalização

Anexo H - Caracterização dos domicílios classificados na subclasse residencial baixa renda - 1998

Anexo I - Cadastro único dos programas sociais - Estimativa de cadastramento

Anexo J - Evolução do número de consumidores baixa renda por distribuidora 1998 a 2002

Anexo K - Perdas de receita da distribuidora devido aos novos consumidores baixa renda -2002

Anexo L - Perdas de receita das distribuidoras decorrentes dos novos consumidores baixa renda -200

Anexo M - Perdas de receita das distribuidoras decorrentes dos novos consumidores baixa renda - $1^{\circ}$ semestre 2004

Anexo N - Leis e regulamentos relevantes
\end{abstract}


Anexo A - Acesso à energia elétrica - Dados do Censo 2000

\begin{tabular}{|c|c|c|c|c|c|c|c|c|}
\hline \multirow[b]{2}{*}{$\begin{array}{c}\text { Grandes regiões e } \\
\text { unidades da federação }\end{array}$} & \multicolumn{4}{|c|}{ POPULAÇÃ̃O } & \multicolumn{4}{|c|}{ DOMICÍLIOS } \\
\hline & $\begin{array}{l}\text { Moradores em } \\
\text { domicílios } \\
\text { particulares } \\
\text { Permanentes } \\
\end{array}$ & Iluminação elétrica & $\begin{array}{l}\text { Sem Iluminação } \\
\text { elétrica }\end{array}$ & $\begin{array}{l}\text { Moradores sem } \\
\text { energia elétrica }\end{array}$ & $\begin{array}{c}\text { Domicílos } \\
\text { particulares } \\
\text { permanentes }\end{array}$ & $\begin{array}{l}\text { Iluminação } \\
\text { Elétrica }\end{array}$ & $\begin{array}{l}\text { Iluminação } \\
\text { Elétrica }\end{array}$ & $\begin{array}{l}\text { Domicílios sem } \\
\text { energia elétrica }\end{array}$ \\
\hline Rondônia & 1.361 .295 & 1.142 .771 & 218.524 & $16,1 \%$ & 347.192 & 294.327 & 52.865 & $15,2 \%$ \\
\hline Acre & 552.016 & 4418.836 & 133.180 & $24,1 \%$ & 129.392 & 102.163 & 27.229 & $21,0 \%$ \\
\hline Amazonas & 2.780 .256 & 2.285 .203 & 495.053 & $17,8 \%$ & 570.562 & 483.378 & 87.184 & $15,3 \%$ \\
\hline Roraima & 317.662 & $\begin{array}{r}273.362 \\
\end{array}$ & 44.300 & $13,9 \%$ & 74.402 & 64.736 & 9.666 & $13,0 \%$ \\
\hline Pará & $\begin{array}{l}6.121 .430 \\
\end{array}$ & $\begin{array}{l}4.700 .1999 \\
\end{array}$ & 1.421 .231 & $23,2 \%$ & 1.308 .511 & 1.034 .076 & 274.435 & $21,0 \%$ \\
\hline Amapá & $\begin{array}{l}471.545 \\
\end{array}$ & $\begin{array}{l}448.452 \\
\end{array}$ & 23.093 & $4,9 \%$ & 98.521 & 93.745 & 4.776 & $4,8 \%$ \\
\hline Tocantins & $\begin{array}{l}1.143 .283 \\
\end{array}$ & 883.779 & 259.504 & $22,7 \%$ & 280.224 & 218.250 & 61.974 & $22,1 \%$ \\
\hline NORTE & 12.747 .487 & 10.152 .602 & 2.594 .885 & $20,4 \%$ & $\begin{array}{l}2.808 .804 \\
\end{array}$ & 2.290 .675 & 518.129 & $18,4 \%$ \\
\hline Maranhão & 5.621 .913 & 4.426 .852 & 1.195.061 & $21,3 \%$ & 1.235 .523 & 985.238 & 250.285 & $20,3 \%$ \\
\hline Piauí & 2.832 .095 & 2.113 .355 & $\begin{array}{l}718.740 \\
\end{array}$ & $25,4 \%$ & 661.105 & 502.106 & 158.999 & $24,1 \%$ \\
\hline Ceará & 7.397 .045 & 6.531 .486 & 865.559 & $11,7 \%$ & 1.757 .249 & 1.568 .648 & 188.601 & $10,7 \%$ \\
\hline Rio Grande do Norte & 2.761 .522 & 2.598 .927 & 162.595 & $5,9 \%$ & $\begin{array}{l}671.581 \\
\end{array}$ & $\begin{array}{r}633.752 \\
\end{array}$ & 37.829 & $5,6 \%$ \\
\hline Paraíba & 3.428 .145 & 3.238 .397 & 189.748 & $5,5 \%$ & 848.972 & 805.558 & 43.414 & $5,1 \%$ \\
\hline Pernambuco & $\begin{array}{l}7.873 .514 \\
\end{array}$ & $\begin{array}{l}7.516 .502 \\
\end{array}$ & 357.012 & $4,5 \%$ & 1.968 .316 & 1.890 .531 & 77.785 & $4,0 \%$ \\
\hline Alagoas & 2.797 .246 & 2.513 .082 & 284.164 & $10,2 \%$ & 649.347 & 590.319 & 59.028 & $9,1 \%$ \\
\hline Sergipe & 1.770 .852 & 1.625 .647 & 145.205 & $8,2 \%$ & 436.717 & 403.652 & 33.065 & $7,6 \%$ \\
\hline Bahia & 12.968 .957 & 10.502 .597 & $\begin{array}{l}2.466 .360 \\
\end{array}$ & $19,0 \%$ & $\begin{array}{l}3.169 .267 \\
\end{array}$ & 2.616 .433 & $\begin{array}{l}552.834 \\
\end{array}$ & $17,4 \%$ \\
\hline NORDESTE & $\begin{array}{l}47.451 .289 \\
\end{array}$ & 41.066.845 & 6.384 .444 & $13,5 \%$ & 11.398.077 & \begin{tabular}{|l|}
9.996 .237 \\
\end{tabular} & \begin{tabular}{|l|l|l}
1.401 .840 \\
\end{tabular} & $12,3 \%$ \\
\hline Minas Gerais & \begin{tabular}{l|}
17.775 .471 \\
\end{tabular} & 17.005 .323 & $\begin{array}{l}770.148 \\
\end{array}$ & $4,3 \%$ & 4.763 .314 & 4.581 .898 & 181.416 & $3,8 \%$ \\
\hline Espírito Santo & 3.077 .469 & 3.036 .410 & 41.059 & $1,3 \%$ & 840.842 & \begin{tabular}{|l}
830.313 \\
\end{tabular} & 10.529 & $1,3 \%$ \\
\hline Rio de Janeiro & 14.298 .735 & 14.233 .119 & 65.616 & $0,5 \%$ & 4.252 .642 & 4.233 .617 & 19.025 & $0,4 \%$ \\
\hline São Paulo & 36.719 .202 & 36.588 .012 & 131.190 & $0,4 \%$ & 10.358 .598 & 10.321 .504 & 37.094 & $0,4 \%$ \\
\hline SUDESTE & 71.870 .877 & $\begin{array}{l}70.862 .864 \\
\end{array}$ & 1.008 .013 & $1,4 \%$ & 20.215 .396 & 19.967 .332 & 248.064 & $1,2 \%$ \\
\hline Paraná & 9.471 .919 & 9.253 .042 & \begin{tabular}{|l|}
218.877 \\
\end{tabular} & $2,3 \%$ & 2.663 .037 & 2.606 .241 & 56.796 & $2,1 \%$ \\
\hline Santa Catarina & 5.319 .120 & 5.243 .848 & 75.272 & $1,4 \%$ & 1.498 .071 & $\begin{array}{ll}1.478 .061 \\
\end{array}$ & 20.010 & $1,3 \%$ \\
\hline Rio Grande do Sul & 10.114 .382 & 9.896 .145 & 218.237 & $2,2 \%$ & 3.040 .070 & $\begin{array}{l}2.972 .897 \\
\end{array}$ & 67.173 & $2,2 \%$ \\
\hline SUL & 24.905 .421 & 24.393 .035 & 512.386 & $2,1 \%$ & \begin{tabular}{|l|l|}
7.201 .178 \\
\end{tabular} & \begin{tabular}{|l|l|}
7.057 .199 \\
\end{tabular} & 143.979 & $2,0 \%$ \\
\hline Mato Grosso do Sul & 2.046 .155 & 1.956 .268 & 89.887 & $4,4 \%$ & $\begin{array}{r}562.769 \\
\end{array}$ & 538.506 & 24.263 & $4,3 \%$ \\
\hline Mato Grosso & 2.439 .861 & 2.183 .199 & 256.662 & $10,5 \%$ & 645.584 & 578.473 & 67.111 & $10,4 \%$ \\
\hline Goiás & 4.953 .940 & $\begin{array}{l}4.817 .749 \\
\end{array}$ & 136.191 & $2,7 \%$ & 1.397 .463 & 1.357 .686 & 39.777 & $2,8 \%$ \\
\hline Distrito Federal & 2.035 .459 & 2.028 .920 & 6.539 & $0,3 \%$ & 547.465 & $\begin{array}{r}545.709 \\
\end{array}$ & 1.756 & $0,3 \%$ \\
\hline CENTRO-OESTE & 11.475 .415 & 10.986 .136 & 489.279 & $4,3 \%$ & \begin{tabular}{|l|}
3.153 .281 \\
\end{tabular} & 3.020 .374 & \begin{tabular}{|l|}
132.907 \\
\end{tabular} & $4,2 \%$ \\
\hline BRASIL & 168.450 .489 & 157.461 .482 & 10.989.007 & $6,5 \%$ & 44.776 .736 & 42.331 .817 & 2.444 .919 & $5,5 \%$ \\
\hline
\end{tabular}




\section{Anexo B - Estimativa de custos da universalização}

\begin{tabular}{|c|c|c|c|c|c|c|c|c|c|c|}
\hline \multirow[b]{2}{*}{$\begin{array}{c}\text { Grandes regiões e } \\
\text { unidades da federação }\end{array}$} & \multicolumn{4}{|c|}{ ÁREA URBANA } & \multicolumn{4}{|c|}{ ÁREA RURAL } & \multicolumn{2}{|c|}{ TOTAL } \\
\hline & Domicílios & $\begin{array}{c}\text { Sem } \\
\text { Iluminação } \\
\text { Elétrica }\end{array}$ & $\%$ & $\begin{array}{c}\text { Custo } \\
\text { Estimado } \\
\text { (milhares R\$) }\end{array}$ & Domicílios & $\begin{array}{c}\text { Sem } \\
\text { Iluminação } \\
\text { Elétrica }\end{array}$ & $\%$ & $\begin{array}{c}\text { Custo } \\
\text { Estimado } \\
\text { (milhares R\$) }\end{array}$ & $\begin{array}{c}\text { Sem } \\
\text { Iluminação } \\
\text { Elétrica }\end{array}$ & $\begin{array}{c}\text { Custo } \\
\text { Estimado } \\
\text { (milhares R\$) }\end{array}$ \\
\hline Rondônia & 228.806 & 5.061 & $2,21 \%$ & 7.592 & 118.386 & 47.804 & $40,4 \%$ & 177.687 & 52.865 & 185.279 \\
\hline Acre & 90.688 & 1.488 & $1,64 \%$ & 2.232 & 38.704 & 25.742 & $66,5 \%$ & 95.683 & 27.230 & 97.915 \\
\hline Amazonas & 452.623 & 7.895 & $1,74 \%$ & 11.843 & 117.940 & 79.290 & $67,2 \%$ & 294.721 & 87.185 & 306.563 \\
\hline Roraima & 58.757 & 319 & $0,54 \%$ & 479 & 15.645 & 9.347 & $59,7 \%$ & 34.743 & 9.666 & 35.221 \\
\hline Pará & 910.694 & 23.750 & $2,61 \%$ & 35.625 & 397.817 & 250.684 & $63,0 \%$ & 931.792 & 274.434 & 967.417 \\
\hline Amapá & 88.876 & 934 & $1,05 \%$ & 1.401 & 9.645 & 3.841 & $39,8 \%$ & 14.277 & 4.775 & 15.678 \\
\hline Tocantins & 211.041 & 11.423 & $5,41 \%$ & 17.135 & 69.183 & 50.551 & $73,1 \%$ & 187.898 & 61.974 & 205.033 \\
\hline Norte & 2.041 .485 & 50.870 & $2,49 \%$ & 76.305 & 767.320 & 467.259 & $60,9 \%$ & 1.736 .802 & 518.129 & 1.813 .107 \\
\hline Maranhão & 757.427 & 19.681 & $2,60 \%$ & 29.522 & 478.096 & 230.605 & $48,2 \%$ & 691.815 & 250.286 & 721.337 \\
\hline Piauí & 429.553 & 14.898 & $3,47 \%$ & 22.347 & 231.552 & 144.101 & $62,2 \%$ & 432.303 & 158.999 & 454.650 \\
\hline Ceará & 1.294 .059 & 26.487 & $2,05 \%$ & 39.731 & 463.191 & 162.115 & $35,0 \%$ & 486.345 & 188.602 & 526.076 \\
\hline Rio Grande do Norte & 505.318 & 6.909 & $1,37 \%$ & 10.364 & 166.263 & 30.920 & $18,6 \%$ & 92.760 & 37.829 & 103.124 \\
\hline Paraíba & 624.656 & 4.502 & $0,72 \%$ & 6.753 & 224.316 & 38.912 & $17,3 \%$ & 116.736 & 43.414 & 123.489 \\
\hline Pernambuco & 1.557 .159 & 10.195 & $0,65 \%$ & 15.293 & 411.157 & 67.591 & $16,4 \%$ & 202.773 & 77.786 & 218.066 \\
\hline Alagoas & 460.931 & 8.942 & $1,94 \%$ & 13.413 & 188.416 & 50.086 & $26,6 \%$ & 150.258 & 59.028 & 163.671 \\
\hline Sergipe & 319.780 & 4.848 & $1,52 \%$ & 7.272 & 116.937 & 28.218 & $24,1 \%$ & 84.654 & 33.066 & 91.926 \\
\hline Bahia & 2.212 .014 & 63.455 & $2,87 \%$ & 95.183 & 957.254 & 489.380 & $51,1 \%$ & 1.468 .140 & 552.835 & 1.563 .323 \\
\hline Nordeste & 8.160 .897 & 159.917 & $1,96 \%$ & 239.876 & 3.237 .182 & 1.241 .928 & $38,4 \%$ & 3.725 .784 & 1.401 .845 & 3.965 .660 \\
\hline Minas Gerais & 3.976 .530 & 30.449 & $0,77 \%$ & 45.674 & 786.785 & 150.968 & $19,2 \%$ & 452.904 & 181.417 & 498.578 \\
\hline Espírito Santo & 683.844 & 3.028 & $0,44 \%$ & 4.542 & 156.998 & 7.501 & $4,8 \%$ & 22.503 & 10.529 & 27.045 \\
\hline Rio de Janeiro & 4.098 .180 & 7.710 & $0,19 \%$ & 11.565 & 154.462 & 11.315 & $7,3 \%$ & 33.945 & 19.025 & 45.510 \\
\hline São Paulo & 9.731 .906 & 17.331 & $0,18 \%$ & 25.997 & 626.693 & 19.764 & $3,2 \%$ & 59.292 & 37.095 & 85.289 \\
\hline Sudeste & 18.490 .460 & 58.518 & $0,32 \%$ & 87.777 & 1.724 .938 & 189.548 & $11,0 \%$ & 568.644 & 248.066 & 656.421 \\
\hline Paraná & 2.212 .607 & 13.568 & $0,61 \%$ & 20.352 & 450.430 & 43.228 & $9,6 \%$ & 129.684 & 56.796 & 150.036 \\
\hline Santa Catarina & 1.204 .034 & 6.469 & $0,54 \%$ & 9.704 & 294.037 & 13.541 & $4,6 \%$ & 40.623 & 20.010 & 50.327 \\
\hline Rio Grande do Sul & 2.511 .114 & 17.614 & $0,70 \%$ & 26.421 & 528.956 & 49.559 & $9,4 \%$ & 148.677 & 67.173 & 175.098 \\
\hline Sul & 5.927 .755 & 37.651 & $0,64 \%$ & 56.477 & 1.273 .423 & 106.328 & $8,3 \%$ & 318.984 & 143.979 & 375.461 \\
\hline Mato Grosso do Sul & 477.739 & 4.097 & $0,86 \%$ & 6.146 & 85.030 & 20.166 & $23,7 \%$ & 93.348 & 24.263 & 99.494 \\
\hline Mato Grosso & 520.620 & 12.638 & $2,43 \%$ & 18.957 & 124.964 & 54.473 & $43,6 \%$ & 252.156 & 67.111 & 271.113 \\
\hline Goiás & 1.226 .372 & 6.903 & $0,56 \%$ & 10.355 & 171.091 & 32.874 & $19,2 \%$ & 152.174 & 39.777 & 162.528 \\
\hline Distrito Federal & 524.625 & 1.055 & $0,20 \%$ & 1.583 & 22.840 & 702 & $3,1 \%$ & 3.250 & 1.757 & 4.832 \\
\hline Centro-oeste & 2.749 .356 & 24.693 & $0,90 \%$ & 37.040 & 403.925 & 108.215 & $26,8 \%$ & 500.927 & 132.908 & 537.967 \\
\hline Brasil & 37.369 .953 & 331.649 & $0,89 \%$ & 497.474 & 7.406.788 & 2.113.278 & $28,5 \%$ & 6.851 .141 & 2.444.927 & 7.348.614 \\
\hline
\end{tabular}

Obs.: Custos adotados RURAL: NE, SE e S - R \$ 3.000,00; CO - R \$ 4.629,00 (Luz no campo); N - R \$ 3.717,00 ( Luz no campo); URBANO: R \$ 1.500,00.

Fonte: Elaborado pelo autor com base em dados do IBGE e do Programa Luz no Campo. 
Anexo C - Municípios - Índices máximos e mínimos por Estado

\begin{tabular}{|c|c|c|c|c|c|c|c|c|c|c|c|}
\hline \multirow[b]{2}{*}{ Região } & \multirow[b]{2}{*}{ Estado } & \multirow[b]{2}{*}{$\begin{array}{c}\mathbf{N}^{\circ} \\
\text { Municípios }\end{array}$} & \multicolumn{5}{|c|}{ Município com Menor Índice de Iluminação Elétrica } & \multicolumn{4}{|c|}{ Município com Maior Índice de Iluminação Elétrica } \\
\hline & & & Município & $\begin{array}{c}\text { Total de } \\
\text { domicílios }\end{array}$ & $\begin{array}{l}\text { Dom. com } \\
\text { Iluminação } \\
\text { elétrica }\end{array}$ & $\begin{array}{c}\text { Dom. sem } \\
\text { iluminação } \\
\text { elétrica }\end{array}$ & Índice & Município & Total de domicílios & $\begin{array}{c}\text { Dom. com Iluminação } \\
\text { elétrica }\end{array}$ & $\begin{array}{c}\text { Dom. sem } \\
\text { iluminação } \\
\text { elétrica }\end{array}$ \\
\hline \multirow{7}{*}{ 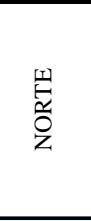 } & Rondônia & 52 & Vale do Anari & 1.938 & 655 & 1.283 & $33,8 \%$ & Porto Velho & 83.744 & 81.222 & 2.522 \\
\hline & Acre & 22 & Jordão & 716 & 127 & 589 & $17,7 \%$ & Rio Branco & 64.010 & 61.254 & 2.756 \\
\hline & Amazonas & 62 & Careiro da Várzea & 3.734 & 1.190 & 2.544 & $31,9 \%$ & Manaus & 326.837 & 323.141 & 3.696 \\
\hline & Roraima & 15 & Uiramutã & 1.024 & 315 & 709 & $30,8 \%$ & Boa Vista & 48.715 & 48.176 & 539 \\
\hline & Pará & 143 & Chaves & 2.945 & 693 & 2.252 & $23,5 \%$ & Ananindeua & 92.519 & 92.022 & 497 \\
\hline & Amapá & 16 & $\begin{array}{l}\text { Mazagão } \\
\end{array}$ & 2.215 & 1.316 & 899 & $59,4 \%$ & Macapá & 60.369 & 59.551 & 818 \\
\hline & Tocantins & 139 & Centenário & $\begin{aligned} 504 \\
\end{aligned}$ & 141 & 363 & $28,0 \%$ & Palmas & 35.097 & 34.434 & 663 \\
\hline \multirow{9}{*}{ 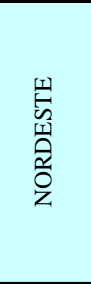 } & Maranhão & 217 & Fernando Falcão & 972 & 158 & 814 & $16,3 \%$ & São Luís & 202.144 & 201.266 & 878 \\
\hline & Piauí & 221 & Novo Santo Antônio & 706 & 57 & 649 & $8,1 \%$ & Teresina & 169.750 & 167.500 & 2.250 \\
\hline & Ceará & 184 & $\begin{array}{l}\text { Salitre } \\
\end{array}$ & 3.056 & 1.157 & 1.899 & $37,9 \%$ & Fortaleza & 525.991 & 523.080 & 2.911 \\
\hline & Rio Grande do Norte & 166 & Venha-Ver & 700 & 369 & 331 & $52,7 \%$ & Natal & 177.665 & 177.083 & 582 \\
\hline & Paraíba & 223 & Santa Inês & 774 & 361 & 413 & $46,6 \%$ & Ouro Velho & 762 & 762 & 0 \\
\hline & $\begin{array}{l}\text { Pernambuco } \\
\end{array}$ & 185 & Santa Cruz & 2.520 & 1.324 & 1.196 & $52,5 \%$ & Toritama & 5.491 & 5.491 & 0 \\
\hline & $\begin{array}{l}\text { Alagoas } \\
\end{array}$ & 101 & $\begin{array}{l}\text { Senador Rui Palmeira } \\
\end{array}$ & 2.515 & 1.184 & 1.331 & $47,1 \%$ & Maceió & 199.708 & 199.054 & 654 \\
\hline & Sergipe & 75 & Gararu & 2.646 & 1.502 & 1.144 & $56,8 \%$ & Aracaju & 116.632 & 116.282 & 350 \\
\hline & Bahia & 415 & Caraíbas & 3.557 & 998 & 2.559 & $28,1 \%$ & Salvador & 651.008 & 649.266 & 1.742 \\
\hline \multirow{4}{*}{ 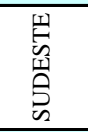 } & Minas Gerais & 853 & Monte Formoso & 903 & 319 & 584 & $35,3 \%$ & Bicas & 3.720 & 3.720 & 0 \\
\hline & Espírito Santo & 77 & Água Doce do Norte & 3.337 & 3.006 & 331 & $90,1 \%$ & Vitória & 85.514 & 85.388 & 126 \\
\hline & Rio de Janeiro & 91 & Trajano de Morais & 2.837 & 2.474 & 363 & $87,2 \%$ & Iguaba Grande & 4.479 & $\begin{array}{ll}4.479 \\
\end{array}$ & 0 \\
\hline & São Paulo & 645 & Barra do Turvo & 1.989 & 1.342 & 647 & $67,5 \%$ & Pedreira & 9.667 & 9.667 & 0 \\
\hline \multirow{3}{*}{ S } & Paraná & 399 & Rio Bonito do Iguaçu & 2.859 & 1.421 & 1.438 & $49,7 \%$ & Cidade Gaúcha & 2.657 & 2.657 & 0 \\
\hline & Santa Catarina & 293 & Entre Rios & 700 & 463 & 237 & $66,1 \%$ & Braço do Norte & 6.669 & 6.669 & 0 \\
\hline & Rio Grande do Sul & 467 & Santana da Boa Vista & 2.682 & 1.666 & 1.016 & $62,1 \%$ & Flores da Cunha & 6.791 & 6.791 & 0 \\
\hline \multirow{4}{*}{ 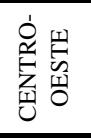 } & Mato Grosso do Sul & 77 & Japorã & 1.370 & 675 & 695 & $49,3 \%$ & Campo Grande & 185.559 & 185.001 & 558 \\
\hline & Mato Grosso & 126 & Nova Bandeirantes & 1.794 & 714 & 1.080 & $39,8 \%$ & Cuiabá & 126.912 & 126.475 & 437 \\
\hline & Goiás & 242 & Cavalcante & 2.214 & 846 & 1.368 & $38,2 \%$ & Nova Veneza & $\begin{array}{ll}1.798 \\
\end{array}$ & 1.798 & 0 \\
\hline & Distrito Federal & 1 & Brasília & 547.465 & 545.709 & 1.756 & $99,7 \%$ & & & & \\
\hline
\end{tabular}

Fonte - CENSO 2000 - IBGE

Quantidade de municípios com 100\% por estado: PE - 2; MG -12; PR -25; SC -37; RS -36 e GO -5.

São Paulo - 107 municípios com 100\% e 465 municípios acima de 99\%. 
Anexo D - Municípios e domicílios sem acesso à energia elétrica em função do índice de atendimento municipal

\begin{tabular}{|c|c|c|c|c|c|c|c|c|c|c|c|c|c|c|}
\hline \multirow{4}{*}{$\begin{array}{c}\text { Grandes regiōes e } \\
\text { unidades da federação }\end{array}$} & \multicolumn{2}{|c|}{2004} & \multicolumn{2}{|c|}{2006} & \multicolumn{2}{|c|}{2008} & \multicolumn{2}{|c|}{2010} & \multicolumn{2}{|c|}{2012} & \multicolumn{2}{|c|}{2014} & \multicolumn{2}{|c|}{2015} \\
\hline & \multicolumn{2}{|c|}{ Índice Atendimento } & \multicolumn{2}{|c|}{ Índice Atendimento } & \multicolumn{2}{|c|}{ Índice Atendimento } & \multicolumn{2}{|c|}{ Índice Atendimento } & \multicolumn{2}{|c|}{ Índice Atendimento } & \multicolumn{2}{|c|}{ Índice Atendimento } & \multicolumn{2}{|c|}{ Índice Atendimento } \\
\hline & $96 \%$ & $100 \%$ & $90 \%$ & $96 \%$ & $83 \%$ & $90 \%$ & $75 \%$ & $83 \%$ & $65 \%$ & $75 \%$ & $53 \%$ & $65 \%$ & $0 \%$ & $53 \%$ \\
\hline & & 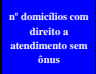 & 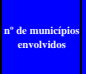 & 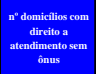 & $\begin{array}{l}\text { n"de mumicipion } \\
\text { envolidas }\end{array}$ & $\begin{array}{c}\mathbf{n}^{\mathbf{n}} \text { domicilios com } \\
\text { direito a } \\
\text { atendiments sem } \\
\text { onmus }\end{array}$ & n'de muncípio & 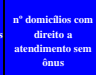 & $\begin{array}{l}\text { n'de municipios } \\
\text { envolidas }\end{array}$ & 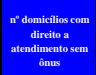 & $\begin{array}{l}\text { n"de municipios } \\
\text { envolididos }\end{array}$ & 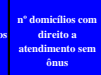 & 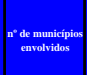 & 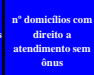 \\
\hline Rondônia & 3 & 4.087 & 6 & 5.352 & 4 & 4.186 & 12 & 6.417 & 10 & 8.734 & 11 & 14.989 & 6 & 9.102 \\
\hline Acre & 0 & 0 & 1 & 2.756 & 0 & 0 & 1 & 2.613 & 3 & 3.087 & 8 & 10.534 & 9 & 8.239 \\
\hline Amazonas & 1 & 3.696 & 0 & 0 & 4 & 3.656 & 12 & 12.813 & 11 & 18.079 & 18 & 20.684 & 16 & 28.256 \\
\hline Roraima & 1 & 539 & 1 & 98 & 1 & 178 & 2 & 817 & 3 & 1.885 & 2 & 2.174 & 5 & 3.976 \\
\hline Pará & 5 & 3.199 & 9 & 5.314 & 17 & 18.361 & 18 & 33.427 & 19 & 32.114 & 22 & 43.207 & 53 & 138.814 \\
\hline Amapá & 2 & 1.117 & 2 & 307 & 4 & 782 & 6 & 1.377 & 0 & 0 & 2 & 1.193 & 0 & \\
\hline Tocantins & 3 & 1.545 & 4 & 2.436 & 16 & 5.197 & 24 & 8.204 & 20 & 6.212 & 32 & 16.176 & 40 & 22.208 \\
\hline R. Norte & 15 & 14.183 & 23 & 16.263 & 46 & 32.360 & 75 & 65.668 & 66 & 70.111 & 95 & 108.957 & 129 & 210.595 \\
\hline Maranhão & 8 & 2.560 & 19 & 9.174 & 35 & 17.851 & 33 & 35.513 & 44 & 66.447 & 37 & 58.863 & 41 & 59.874 \\
\hline Piauí & 4 & 2.437 & 9 & 3.084 & 21 & 12.059 & 23 & 13.020 & 40 & 26.402 & 45 & 35.483 & 79 & 66.517 \\
\hline Ceará & 8 & 6.996 & 40 & 20.197 & 41 & 31.374 & 44 & 44.256 & 36 & 58.772 & 13 & 23.501 & 2 & 3.503 \\
\hline Rio Grande do Norte & 29 & 4.577 & 67 & 11.678 & 47 & 13.291 & 8 & 2.601 & 12 & 4.519 & 2 & 833 & 1 & 331 \\
\hline Paraíba & 61 & 6.200 & 86 & 12.385 & 44 & 10.625 & 22 & 8.911 & 6 & 3.165 & 2 & 984 & 2 & 1.146 \\
\hline Pernambuco & 71 & 14.899 & 73 & 24.581 & 22 & 13.173 & 9 & 10.469 & 6 & 10.363 & 3 & 3.105 & 1 & 1.196 \\
\hline Alagoas & 9 & 2.599 & 28 & 12.248 & 26 & 13.181 & 18 & 11.645 & 13 & 9.810 & 4 & 3.646 & 3 & 5.893 \\
\hline Sergipe & 15 & 2.405 & 30 & 7.214 & 11 & 3.676 & 10 & 8.204 & 6 & 7.324 & 3 & 4.246 & 0 & 0 \\
\hline Bahia & 17 & 12.100 & 39 & 33.028 & 57 & 47.294 & 83 & 90.027 & 64 & 79.479 & 93 & 157.358 & 62 & 133.537 \\
\hline R. Nordeste & 222 & 54.773 & 391 & 133.589 & 304 & 162.524 & 250 & 224.646 & 227 & 266.281 & 202 & 288.019 & 191 & 271.997 \\
\hline Minas Gerais & 444 & 30.282 & 182 & 32.886 & 96 & 30.130 & 58 & 30.731 & 34 & 23.480 & 31 & 26.223 & 8 & 7.697 \\
\hline Espírito Santo & 63 & 7.468 & 14 & 3.066 & 0 & 0 & 0 & 0 & 0 & 0 & 0 & 0 & 0 & 0 \\
\hline Rio de Janeiro & 78 & 14.340 & 10 & 3.185 & 3 & 1.506 & 0 & 0 & 0 & 0 & 0 & 0 & 0 & 0 \\
\hline São Paulo & 603 & 28.036 & 33 & 6.220 & 4 & 1.251 & 3 & 585 & 2 & 1.012 & 0 & 0 & 0 & 0 \\
\hline R. Sudeste & 1.188 & 80.126 & 239 & 45.357 & 103 & 32.887 & 61 & 31.316 & 36 & 24.492 & 31 & 26.223 & 8 & 7.697 \\
\hline Paraná & 282 & 17.135 & 69 & 14.913 & 23 & 8.161 & 14 & 9.081 & 7 & 4.264 & 3 & 1.802 & 1 & 1.438 \\
\hline Santa Catarina & 226 & 10.309 & 50 & 4.517 & 5 & 1.881 & 9 & 2.499 & 3 & 807 & 0 & 0 & 0 & 0 \\
\hline Rio Grande do Sul & 293 & 24.672 & 103 & 18.301 & 50 & 15.067 & 15 & 5.562 & 5 & 2.560 & 1 & 1.016 & 0 & 0 \\
\hline R. Sul & 801 & 52.116 & 222 & 37.731 & 78 & 25.109 & 38 & 17.142 & 15 & 7.631 & 4 & 2.818 & 1 & 1.438 \\
\hline Mato Grosso do Sul & 24 & 4.043 & 26 & 8.417 & 19 & 7.567 & 5 & 2.629 & 2 & 913 & 0 & 0 & 1 & 695 \\
\hline Mato Grosso & 16 & 3.607 & 23 & 5.293 & 27 & 12.627 & 23 & 14.183 & 16 & 10.759 & 17 & 13.237 & 4 & 7.410 \\
\hline Goiás & 130 & 9.944 & 59 & 11.522 & 26 & 7.233 & 13 & 4.661 & 8 & 2.070 & 4 & 2.448 & 2 & 1.899 \\
\hline Distrito Federal & 1 & 1.756 & 0 & 0 & 0 & 0 & 0 & 0 & 0 & 0 & 0 & 0 & 0 & 0 \\
\hline R. Centro-oeste & 171 & 19.350 & 108 & 25.232 & 72 & 27.427 & 41 & 21.473 & 26 & 13.742 & 21 & 15.685 & 7 & 10.004 \\
\hline Brasil & 2.397 & 220.548 & 983 & 258.172 & 603 & 280.307 & 465 & 360.245 & 370 & 382.257 & 353 & 441.702 & 336 & 501.731 \\
\hline
\end{tabular}

Fonte: Elaborado pelo autor com base em dados do Censo do IBGE. 
Anexo E - Resultados do Programa Luz no Campo - 2003

\begin{tabular}{|c|c|c|c|c|c|c|c|c|c|c|c|c|}
\hline \multirow[b]{2}{*}{ Estado } & \multicolumn{7}{|c|}{ Metas físicas } & \multirow[b]{2}{*}{$\begin{array}{l}\text { Famílias } \\
\text { Atendidas }\end{array}$} & \multirow[b]{2}{*}{$\begin{array}{c}\text { km de } \\
\text { rede } \\
\text { instalado }\end{array}$} & \multirow[b]{2}{*}{$\begin{array}{l}\mathbf{N}^{\circ} \text { de } \\
\text { Postes }\end{array}$} & \multirow[b]{2}{*}{$\begin{array}{l}\mathbf{N}^{\circ} \text { de } \\
\text { Trafos }\end{array}$} & \multirow[b]{2}{*}{$\begin{array}{c}\text { Potência } \\
\text { (KVA) } \\
\text { instalado }\end{array}$} \\
\hline & $\begin{array}{l}\text { Familias a } \\
\text { serem } \\
\text { Atendidas }\end{array}$ & $\begin{array}{l}\text { Investimento } \\
\text { Total }\end{array}$ & $\begin{array}{l}\text { Valor Financiado } \\
\text { pela Eletrobrás }\end{array}$ & $\begin{array}{l}\mathbf{k m} \text { de } \\
\text { rede a } \\
\text { instalar }\end{array}$ & $\begin{array}{l}\mathbf{N}^{\circ} \text { de } \\
\text { Postes }\end{array}$ & $\begin{array}{l}\mathrm{N}^{\circ} \text { de } \\
\text { Trafos }\end{array}$ & $\begin{array}{c}\text { Potências } \\
\text { (KVA) a } \\
\text { instalar }\end{array}$ & & & & & \\
\hline Acre & 4.590 & $19.019 .500,00$ & $14.263 .950,00$ & 1.227 & 25.463 & 2.832 & 22.485 & 2.028 & 686 & 6.974 & 1.293 & 10.200 \\
\hline Amazonas & & 0 & 0 & 0 & 0 & 0 & 0 & 0 & 0 & 0 & 0 & \\
\hline Amapá & & & 0 & 0 & 0 & 0 & & & 0 & & & \\
\hline Pará & 51.546 & $126.849 .760,00$ & $95.137 .320,00$ & 15.679 & 121.523 & 14.198 & 197.425 & 24.272 & 4.141 & 44.623 & 1.772 & 37.530 \\
\hline Rondônia & 13.911 & $44.132 .410,00$ & $33.099 .310,00$ & 5.035 & 39.255 & 13.911 & 95.109 & 6.672 & 1.639 & 14.540 & 5.830 & 30.014 \\
\hline Roraima & 4.235 & $24.313 .090,00$ & $17.019 .170,00$ & 3.230 & 26.845 & 4.235 & 42.350 & 945 & 131 & 1.510 & 832 & 8.320 \\
\hline Tocantins & 19.000 & 175.886.490,00 & $46.890 .000,00$ & 38.422 & 198.448 & 20.000 & 326.718 & 16.040 & 18.193 & 166.603 & 9.591 & 155.666 \\
\hline R. Norte & 93.282 & $390.201 .250,00$ & $206.409 .750,00$ & 63.593 & 411.534 & 55.176 & 684.087 & 49.957 & 24.790 & 234.250 & 19.318 & 241.730 \\
\hline Alagoas & 14.000 & $36.000 .000,00$ & $27.250 .000,00$ & 3.595 & 53.072 & 4.136 & 33.685 & 3.193 & 494 & 5.951 & 338 & 3.020 \\
\hline Bahia & 149.000 & $337.000 .000,00$ & $253.250 .000,00$ & 29.289 & 307.547 & $\begin{array}{ll}19.036 \\
\end{array}$ & 252.655 & 129.000 & 14.027 & 217.590 & 12.916 & 156.491 \\
\hline Ceará & 85.000 & $133.412 .050,00$ & $99.342 .420,00$ & 22.963 & 170.142 & 25.757 & 240.250 & 64.416 & 10.343 & 118.215 & 10.592 & 91.990 \\
\hline Maranhão & & & 0 & 0 & 0 & 0 & 0 & 0 & 0 & 0 & 0 & \\
\hline Paraíba & 9.303 & $16.399 .783,00$ & $12.300 .337,00$ & 2.502 & 29.750 & 2.196 & 20.895 & 2.052 & 493 & 5.778 & 438 & 3.660 \\
\hline Pernambuco & 102.600 & $182.167 .790,00$ & $136.625 .840,00$ & $\begin{array}{l}23.269 \\
\end{array}$ & 294.806 & 22.432 & 188.270 & 40.676 & 10.495 & 131.565 & 11.050 & 109.035 \\
\hline Piauí & 13.500 & $30.000 .000,00$ & $22.500 .000,00$ & 6.261 & 28.445 & 3.369 & 31.583 & 7.621 & 1.624 & 15.384 & 924 & 10.678 \\
\hline Rio Grande do Norte & 11.040 & $20.318 .257,00$ & $14.180 .456,00$ & 1.974 & 23.384 & 1.665 & 35.131 & 12.423 & 982 & 13.442 & 1.033 & 23.910 \\
\hline Sergipe & 20.200 & $45.904 .250,00$ & $34.363 .460,00$ & 4.089 & 46.832 & 7.190 & 49.870 & 3.947 & 366 & 7.836 & 585 & 8.145 \\
\hline R. Nordeste & 404.643 & $801.202 .130,00$ & $599.812 .513,00$ & 93.941 & 953.978 & 85.781 & 852.339 & 263.328 & $\begin{array}{ll}38.823 \\
\end{array}$ & 515.761 & 37.876 & 406.928 \\
\hline Espírito Santo & 15.725 & $50.181 .470,00$ & $37.636 .050,00$ & 6.030 & 55.972 & 12.232 & 171.425 & 4.374 & 1.916 & 14.524 & 3.802 & 54.665 \\
\hline Minas Gerais & 117.950 & $324.450 .317,00$ & 176.655.773,00 & 51.140 & 371.217 & 113.353 & 1.116 .663 & 112.827 & 31.778 & 253.722 & 71.114 & 667.210 \\
\hline Rio de Janeiro & 22.449 & $69.363 .020,00$ & $52.022 .266,00$ & 4.444 & 52.585 & 12.742 & 157.145 & 21.249 & $\begin{array}{ll}4.037 \\
\end{array}$ & 45.647 & 12.270 & 156.280 \\
\hline São Paulo & 23.471 & $69.319 .620,00$ & $47.736 .949,00$ & 7.085 & 71.623 & 14.564 & 173.118 & 14.887 & 2.520 & 33.733 & 6.696 & 78.685 \\
\hline R. Sudeste & 179.595 & $513.314 .427,00$ & $314.051 .038,00$ & \begin{tabular}{|c|c|}
68.698 \\
\end{tabular} & 551.397 & 152.891 & 1.618 .350 & 153.337 & 40.252 & 347.626 & 93.882 & 956.840 \\
\hline Paraná & 27.879 & $100.174 .350,00$ & $50.948 .270,00$ & 7.352 & $\begin{array}{l}72.178 \\
\end{array}$ & 19.118 & 222.960 & 27.651 & 6.546 & 66.535 & 18.570 & 214.115 \\
\hline Rio Grande do Sul & 30.534 & $90.802 .474,00$ & $68.101 .850,00$ & 13.254 & 163.069 & 9.041 & 115.910 & 1.716 & 530 & 6.624 & 558 & 7.485 \\
\hline Santa Catarina & 24.000 & $119.690 .790,00$ & $89.768 .100,00$ & 9.712 & 104.282 & 15.621 & 244.108 & 12.012 & 4.540 & 38.744 & 7.508 & 120.798 \\
\hline R. Sul & 82.413 & 310.667.614,00 & $208.818 .220,00$ & $\begin{array}{l}30.318 \\
\end{array}$ & 339.529 & 43.780 & 582.978 & 41.379 & 11.617 & 111.903 & 26.636 & 342.398 \\
\hline Distrito Federal & 2.697 & $8.868 .260,00$ & $6.652 .840,00$ & 346 & 5.366 & 930 & 17.695 & 2.696 & 396 & 5.495 & 881 & 17.115 \\
\hline $\begin{array}{c}\text { Goiás } \\
\end{array}$ & 20.995 & 127.462.837,00 & $76.635 .000,00$ & 14.163 & 113.966 & 20.995 & 209.950 & 16.760 & 12.806 & 94.881 & 16.752 & 167.524 \\
\hline Mato Grosso do Sul & 8.680 & $54.144 .328,00$ & $40.608 .241,00$ & 5.828 & 56.824 & 5.690 & 76.195 & 6.595 & 3.507 & 32.918 & 3.663 & 51.940 \\
\hline Mato Grosso & 44.500 & $186.209 .350,00$ & $139.624 .000,00$ & 24.804 & 161.228 & 28.476 & 231.418 & 36.777 & 10.333 & 87.809 & 13.866 & 102.630 \\
\hline R. Centro-Oeste & 76.872 & $376.684 .775,00$ & $263.520 .081,00$ & 45.140 & 337.384 & 56.091 & 535.258 & 62.828 & 27.042 & 221.103 & 35.162 & 339.209 \\
\hline BRASIL & 836.805 & $2.392 .070 .196,00$ & $1.592 .611 .602,00$ & 301.691 & 2.593 .822 & 393.719 & 4.273 .010 & 570.829 & 142.523 & 1.430 .643 & 212.875 & 2.287 .105 \\
\hline
\end{tabular}

Fonte: elaboração própria a partir de www.eletrobras.gov.br - acessado em 23/01/2004 


\section{Anexo F - Estimativa da alocação dos recursos do Programa Luz para Todos}

\begin{tabular}{|c|c|c|c|c|c|c|c|c|c|c|c|c|c|c|}
\hline \multirow[b]{2}{*}{$\begin{array}{l}\text { Grandes regióes e } \\
\text { unidades da } \\
\text { federação }\end{array}$} & \multicolumn{2}{|c|}{ Domicilios rurais } & \multicolumn{2}{|c|}{ Custos Elet. Rural } & \multicolumn{4}{|c|}{ Alocação de Recursos (\%) } & \multicolumn{4}{|c|}{ Alocação de recursos (milhares $\mathbf{R} \$$ ) } & \multicolumn{2}{|c|}{ Percentual } \\
\hline & $\begin{array}{c}\text { Sem } \\
\text { Iluminação } \\
\text { Elétrica }\end{array}$ & $\%$ & $\begin{array}{c}\text { Custo } \\
\text { Estimado } \\
\text { (milhares } \\
\text { R\$) }\end{array}$ & $\begin{array}{c}\text { Perc. do } \\
\text { custo total }\end{array}$ & CDE & Estado & RGR & $\begin{array}{l}\text { Capital } \\
\text { próprio }\end{array}$ & CDE & Estado & RGR & $\begin{array}{l}\text { Capital } \\
\text { próprio }\end{array}$ & CDE & RGR \\
\hline Rondônia & 47.804 & $40,4 \%$ & 177.687 & $2,6 \%$ & $65 \%$ & $10 \%$ & $10 \%$ & $15 \%$ & 115.497 & 17.769 & 17.769 & 26.653 & $3,1 \%$ & $1,9 \%$ \\
\hline Acre & 25.742 & $66,5 \%$ & 95.683 & $1,4 \%$ & $80 \%$ & $10 \%$ & $0 \%$ & $10 \%$ & 76.546 & 9.568 & 0 & 9.568 & $2,0 \%$ & $0,0 \%$ \\
\hline Amazonas & 79.290 & $67,2 \%$ & 294.721 & $4,3 \%$ & $80 \%$ & $10 \%$ & $0 \%$ & $10 \%$ & 235.777 & 29.472 & 0 & 29.472 & $6,3 \%$ & $0,0 \%$ \\
\hline Roraima & 9.347 & $59,7 \%$ & 34.743 & $0,5 \%$ & $80 \%$ & $10 \%$ & $0 \%$ & $10 \%$ & 27.794 & 3.474 & 0 & 3.474 & $0,7 \%$ & $0,0 \%$ \\
\hline Pará & 250.684 & $63,0 \%$ & 931.792 & $13,6 \%$ & $65 \%$ & $10 \%$ & $10 \%$ & $15 \%$ & 605.665 & 93.179 & 93.179 & 139.769 & $16,1 \%$ & $9,9 \%$ \\
\hline Amapá & 3.841 & $39,8 \%$ & 14.277 & $0,2 \%$ & $65 \%$ & $10 \%$ & $10 \%$ & $15 \%$ & 9.280 & 1.428 & 1.428 & 2.142 & $0,2 \%$ & $0,2 \%$ \\
\hline Tocantins & 50.551 & $73,1 \%$ & 187.898 & $2,7 \%$ & $55 \%$ & $20 \%$ & $10 \%$ & $15 \%$ & 103.344 & 37.580 & 18.790 & 28.185 & $2,8 \%$ & $2,0 \%$ \\
\hline R. Norte & 467.259 & $60,9 \%$ & \begin{tabular}{|l|}
1.736 .802 \\
\end{tabular} & $25,4 \%$ & & & & & 1.173 .903 & 192.470 & 131.165 & 239.263 & $31,2 \%$ & $14,0 \%$ \\
\hline Maranhão & 230.605 & $48,2 \%$ & 691.815 & $10,1 \%$ & $65 \%$ & $10 \%$ & $10 \%$ & $15 \%$ & 449.680 & 69.182 & 69.182 & 103.772 & $12,0 \%$ & $7,4 \%$ \\
\hline Piauí & 144.101 & $62,2 \%$ & 432.303 & $6,3 \%$ & $65 \%$ & $10 \%$ & $10 \%$ & $15 \%$ & 280.997 & 43.230 & 43.230 & 64.845 & $7,5 \%$ & $4,6 \%$ \\
\hline Ceará & 162.115 & $35,0 \%$ & 486.345 & $7,1 \%$ & $50 \%$ & $25 \%$ & $10 \%$ & $15 \%$ & 243.173 & 121.586 & 48.635 & 72.952 & $6,5 \%$ & $5,2 \%$ \\
\hline Rio Grande do Norte & 30.920 & $18,6 \%$ & 92.760 & $1,4 \%$ & $50 \%$ & $20 \%$ & $15 \%$ & $15 \%$ & 46.380 & 18.552 & 13.914 & 13.914 & $1,2 \%$ & $1,5 \%$ \\
\hline Paraíba & 38.912 & $17,3 \%$ & 116.736 & $1,7 \%$ & $55 \%$ & $20 \%$ & $10 \%$ & $15 \%$ & 64.205 & 23.347 & 11.674 & 17.510 & $1,7 \%$ & $1,2 \%$ \\
\hline Pernambuco & 67.591 & $16,4 \%$ & 202.773 & $3,0 \%$ & $50 \%$ & $0 \%$ & $35 \%$ & $15 \%$ & 101.387 & 0 & 70.971 & 30.416 & $2,7 \%$ & $7,6 \%$ \\
\hline \begin{tabular}{|l|} 
Alagoas \\
\end{tabular} & 50.086 & $26,6 \%$ & 150.258 & $2,2 \%$ & $60 \%$ & $10 \%$ & $15 \%$ & $15 \%$ & 90.155 & 15.026 & 22.539 & 22.539 & $2,4 \%$ & $2,4 \%$ \\
\hline Sergipe & 28.218 & $24,1 \%$ & 84.654 & $1,2 \%$ & $50 \%$ & $30 \%$ & $5 \%$ & $15 \%$ & 42.327 & 25.396 & 4.233 & 12.698 & $1,1 \%$ & $0,5 \%$ \\
\hline Bahia & 489.380 & $51,1 \%$ & 1.468 .140 & $21,4 \%$ & $50 \%$ & $30 \%$ & $5 \%$ & $15 \%$ & 734.070 & 440.442 & 73.407 & 220.221 & $19,5 \%$ & $7,8 \%$ \\
\hline R. Nordeste & 1.241 .928 & $38,4 \%$ & \begin{tabular}{|l|}
3.725 .784 \\
\end{tabular} & $54,4 \%$ & & & & & 2.052 .372 & 756.761 & 357.783 & 558.868 & $54,6 \%$ & $38,1 \%$ \\
\hline Minas Gerais & 150.968 & $19,2 \%$ & \begin{tabular}{|l|}
452.904 \\
\end{tabular} & $6,6 \%$ & $40 \%$ & $9,8 \%$ & $34 \%$ & $16,2 \%$ & 181.162 & 44.385 & 153.987 & 73.370 & $4,8 \%$ & $16,4 \%$ \\
\hline Espírito Santo & 7.501 & $4,8 \%$ & 22.503 & $0,3 \%$ & $10 \%$ & $10 \%$ & $65 \%$ & $15 \%$ & 2.250 & 2.250 & 14.627 & 3.375 & $0,1 \%$ & $1,6 \%$ \\
\hline Rio de Janeiro & 11.315 & $7,3 \%$ & 33.945 & $0,5 \%$ & $10 \%$ & $33 \%$ & $42 \%$ & $15 \%$ & 3.395 & 11.202 & 14.257 & 5.092 & $0,1 \%$ & $1,5 \%$ \\
\hline \begin{tabular}{|l} 
São Paulo \\
\end{tabular} & 19.764 & $3,2 \%$ & 59.292 & $0,9 \%$ & $30 \%$ & $10 \%$ & $45 \%$ & $15 \%$ & 17.788 & 5.929 & 26.681 & 8.894 & $0,5 \%$ & $2,8 \%$ \\
\hline R. Sudeste & 189.548 & $11,0 \%$ & 568.644 & $8,3 \%$ & & & & & 204.594 & 63.766 & 209.553 & 90.731 & $5,4 \%$ & $22,3 \%$ \\
\hline Paraná & 43.228 & $9,6 \%$ & 129.684 & $1,9 \%$ & $30 \%$ & $10 \%$ & $40 \%$ & $20 \%$ & 38.905 & 12.968 & 51.874 & 25.937 & $1,0 \%$ & $5,5 \%$ \\
\hline \begin{tabular}{|l|} 
Santa Catarina \\
\end{tabular} & 13.541 & $4,6 \%$ & 40.623 & $0,6 \%$ & $35 \%$ & $30 \%$ & $20 \%$ & $15 \%$ & 14.218 & 12.187 & 8.125 & 6.093 & $0,4 \%$ & $0,9 \%$ \\
\hline \begin{tabular}{|l} 
Rio Grande do Sul \\
\end{tabular} & 49.559 & $9,4 \%$ & 148.677 & $2,2 \%$ & $50 \%$ & $20 \%$ & $15 \%$ & $15 \%$ & 74.339 & 29.735 & 22.302 & 22.302 & $2,0 \%$ & $2,4 \%$ \\
\hline R. Sul & 106.328 & $8,3 \%$ & 318.984 & $4,7 \%$ & & & & & 127.462 & 54.891 & 82.300 & 54.332 & $3,4 \%$ & $8,8 \%$ \\
\hline Mato Grosso do Sul & 20.166 & $23,7 \%$ & 93.348 & $1,4 \%$ & $40 \%$ & $10 \%$ & $35 \%$ & $15 \%$ & 37.339 & 9.335 & 32.672 & 14.002 & $1,0 \%$ & $3,5 \%$ \\
\hline Mato Grosso & 54.473 & $43,6 \%$ & 252.156 & $3,7 \%$ & $40 \%$ & $10 \%$ & $35 \%$ & $15 \%$ & 100.862 & 25.216 & 88.254 & 37.823 & $2,7 \%$ & $9,4 \%$ \\
\hline \begin{tabular}{|l|} 
Goiás \\
\end{tabular} & 32.874 & $19,2 \%$ & 152.174 & $2,2 \%$ & $40 \%$ & $20 \%$ & $25 \%$ & $15 \%$ & 60.869 & 30.435 & 38.043 & 22.826 & $1,6 \%$ & $4,0 \%$ \\
\hline Distrito Federal & 702 & $3,1 \%$ & 3.250 & $0,0 \%$ & $0 \%$ & $0 \%$ & $0 \%$ & $100 \%$ & 0 & 0 & 0 & 3.250 & $0,0 \%$ & $0,0 \%$ \\
\hline R. Centro-oeste & 108.215 & $26,8 \%$ & 500.927 & $7,3 \%$ & & & & & 199.071 & 64.985 & 158.970 & 77.901 & $5,3 \%$ & $16,9 \%$ \\
\hline Brasil & 2.113.278 & $28,5 \%$ & 6.851.141 & $100,0 \%$ & & & & & 3.757 .402 & 1.132 .873 & 939.771 & 1.021 .095 & $100,0 \%$ & $100,0 \%$ \\
\hline
\end{tabular}

Obs.: Custos adotados; NE, SE e S - R \$ 3.000,00; CO - R \$ 4.629,00 (Luz no campo); N - R \$ 3.717,00 ( Luz no campo).

Os percentuais adotados para o Estado de São Paulo foram os da Elektro.

Para as demais concessionárias de São Paulo, os percentuais seriam 10\%,10\%, 65\% e 15\%, para CDE, Estado, RGR e capital próprio respectivamente 


\section{Anexo G - Estimativa preliminar de impacto tarifário decorrente da universalização}

\begin{tabular}{|c|c|c|c|c|c|c|c|c|}
\hline $\begin{array}{l}\text { Grandes regiões e } \\
\text { unidades da } \\
\text { federação }\end{array}$ & $\begin{array}{c}\text { Domicilios } \\
\text { rurais sem } \\
\text { Iluminação } \\
\text { Elétrica }\end{array}$ & $\begin{array}{c}\text { Custo } \\
\text { Estimado } \\
\text { (milhares } \\
\text { R\$) }\end{array}$ & $\begin{array}{c}\text { RGR } \\
\text { (milhares } \\
\mathbf{R} \$ \text { ) }\end{array}$ & $\begin{array}{c}\text { Capital } \\
\text { próprio } \\
\text { (milhares } \\
\text { R\$) }\end{array}$ & $\begin{array}{c}\text { Remuneração dos } \\
\text { investimentos } \\
\text { (milhares R\$) }\end{array}$ & $\begin{array}{c}\text { Consumo } \\
\text { Anual (MWh) }\end{array}$ & $\begin{array}{c}\text { Acréscimo na } \\
\text { tarifa } \\
\text { (R\$/MWh) }\end{array}$ & $\begin{array}{c}\text { Impacto na } \\
\text { Tarifa Média } \\
\text { Residencial }\end{array}$ \\
\hline Rondônia & 47.804 & 177.687 & 17.769 & 26.653 & 14.958 & 1.620 & 9,23 & $3,8 \%$ \\
\hline Acre & 25.742 & 95.683 & 0 & 9.568 & 5.518 & 384 & 14,37 & $6,0 \%$ \\
\hline Amazonas & 79.290 & 294.721 & 0 & 29.472 & 16.997 & 3.408 & 4,99 & $2,1 \%$ \\
\hline Roraima & 9.347 & 34.743 & 0 & 3.474 & 2.004 & 48 & 41,74 & $17,3 \%$ \\
\hline Pará & 250.684 & 931.792 & 93.179 & 139.769 & 78.439 & 4.199 & 18,68 & $7,7 \%$ \\
\hline Amapá & 3.841 & 14.277 & 1.428 & 2.142 & 1.202 & 492 & 2,44 & $1,0 \%$ \\
\hline Tocantins & 50.551 & 187.898 & 18.790 & 28.185 & 15.817 & 862 & 18,35 & $7,6 \%$ \\
\hline R. Norte & 467.259 & 1.736 .802 & 131.165 & 239.263 & 134.936 & 11.013 & 12,25 & $5,1 \%$ \\
\hline Maranhão & 230.605 & 691.815 & 69.182 & 103.772 & 58.238 & 2.556 & 22,78 & $10,6 \%$ \\
\hline Piauí & 144.101 & 432.303 & 43.230 & 64.845 & 36.392 & 1.488 & 24,46 & $11,4 \%$ \\
\hline Ceará & 162.115 & 486.345 & 48.635 & 72.952 & 40.941 & 5.918 & 6,92 & $3,2 \%$ \\
\hline Rio Grande do Norte & 30.920 & 92.760 & 13.914 & 13.914 & 8.628 & 2.939 & 2,94 & $1,4 \%$ \\
\hline Paraíba & 38.912 & 116.736 & 11.674 & 17.510 & 9.827 & 2.820 & 3,48 & $1,6 \%$ \\
\hline Pernambuco & 67.591 & 202.773 & 70.971 & 30.416 & 26.028 & 7.500 & 3,47 & $1,6 \%$ \\
\hline Alagoas & 50.086 & 150.258 & 22.539 & 22.539 & 13.977 & 1.956 & 7,15 & $3,3 \%$ \\
\hline Sergipe & 28.218 & 84.654 & 4.233 & 12.698 & 6.378 & 1.997 & 3,19 & $1,5 \%$ \\
\hline Bahia & 489.380 & 1.468 .140 & 73.407 & 220.221 & 110.617 & 9.015 & 12,27 & $5,7 \%$ \\
\hline R. Nordeste & 1.241 .928 & 3.725 .784 & 357.783 & 558.868 & 311.026 & 40.317 & 7,71 & $3,6 \%$ \\
\hline Minas Gerais & 150.968 & 452.904 & 153.987 & 73.370 & 58.296 & 36.133 & 1,61 & $0,6 \%$ \\
\hline Espírito Santo & 7.501 & 22.503 & 14.627 & 3.375 & 4.082 & 5.906 & 0,69 & $0,2 \%$ \\
\hline Rio de Janeiro & 11.315 & 33.945 & 14.257 & 5.092 & 4.777 & 27.474 & 0,17 & $0,1 \%$ \\
\hline São Paulo & 19.764 & 59.292 & 26.681 & 8.894 & 8.659 & 86.347 & 0,10 & $0,0 \%$ \\
\hline R. Sudeste & 189.548 & 568.644 & 209.553 & 90.731 & 75.813 & 155.860 & 0,49 & $0,2 \%$ \\
\hline Paraná & 43.228 & 129.684 & 51.874 & 25.937 & 18.938 & 18.023 & 1,05 & $0,4 \%$ \\
\hline Santa Catarina & 13.541 & 40.623 & 8.125 & 6.093 & 4.138 & 13.973 & 0,30 & $0,1 \%$ \\
\hline Rio Grande do Sul & 49.559 & 148.677 & 22.302 & 22.302 & 13.830 & 20.082 & 0,69 & $0,3 \%$ \\
\hline R. Sul & 106.328 & 318.984 & 82.300 & 54.332 & 36.906 & 52.078 & 0,71 & $0,3 \%$ \\
\hline Mato Grosso do Sul & 20.166 & 93.348 & 32.672 & 14.002 & 11.982 & 2.800 & 4,28 & $1,7 \%$ \\
\hline Mato Grosso & 54.473 & 252.156 & 88.254 & 37.823 & 32.367 & 3.457 & 9,36 & $3,7 \%$ \\
\hline Goiás & 32.874 & 152.174 & 38.043 & 22.826 & 16.844 & 7.065 & 2,38 & $1,0 \%$ \\
\hline Distrito Federal & 702 & 3.250 & 0 & 3.250 & 704 & 3.620 & 0,19 & $0,1 \%$ \\
\hline R. Centro-oeste & 108.215 & 500.927 & 158.970 & 77.901 & 61.898 & 16.942 & 3,65 & $1,5 \%$ \\
\hline Brasil & 2.113.278 & 6.851 .141 & 939.771 & 1.021 .095 & 620.580 & 276.210 & 2,25 & $0,9 \%$ \\
\hline
\end{tabular}

Obs.: Custos adotados; NE, SE e S - R \$ 3.000,00; CO - R \$ 4.629,00 (Luz no campo); N - R \$ 3.717,00 ( Luz no campo).

Remuneração dos investimentos: taxa WACC sobre investimentos excluindo recursos a fundo perdido e $4 \%$ de depreciação sobre total dos investimentos

Tarifa Média Residencial referentes a jun. 2004 conforme site daAneel 


\section{Anexo H - Caracterização dos domicílios classificados na subclasse residencial}

\section{baixa renda - 1998}

\begin{tabular}{|c|c|c|c|c|c|c|}
\hline REGIÃO & Empresa & $\begin{array}{c}\text { Consumo } \\
\text { (kWh) }\end{array}$ & $\begin{array}{c}\text { Limitação } \\
\text { de carga } \\
\text { (A) }\end{array}$ & $\begin{array}{c}\text { Carga } \\
\text { instalada } \\
(\mathbf{k W})\end{array}$ & Padrão/Localização da Moradia & $\begin{array}{l}\text { Aspecto sócio- } \\
\text { econômico }\end{array}$ \\
\hline \multirow{9}{*}{ NORTE } & CERON & 140 & 30 & 2,5 & $40 \mathrm{~m}^{2}$, periferia & \\
\hline & CEAM & 200 & & & * não aprovado pelo Dnaee & \\
\hline & CER & 140 & & & * não aprovado pelo Dnaee & \\
\hline & CEA & 140 & & & * não aprovado pelo Dnaee & \\
\hline & ELETROACRE & 200 & & & $40 \mathrm{~m}^{2}$, periferia & \\
\hline & BOA VISTA & 220 & 25 & 2,5 & favelas, loteamentos irregulares & \\
\hline & CELPA & 140 & & 1,8 & alvenaria até $30 \mathrm{~m}^{2}$ ou outro tipo de construção sem limite & \\
\hline & CELTINS & 180 & 15 & 3,3 & conj. habitacional poder público e mutirão & 1 salário mínimo \\
\hline & MANAUS & 220 & 20 & 2,5 & periferia, invasões, comunidades carentes & \\
\hline \multirow{11}{*}{ NORDESTE } & CEMAR & 140 & & 2,5 & $40 \mathrm{~m}^{2}$ & \\
\hline & CEPISA & 140 & & 2,5 & $27 \mathrm{~m}^{2}$, baixo padrão, bolsões de pobreza & \\
\hline & COELCE & 140 & & 1,3 & $40 \mathrm{~m}^{2}$, padrão popular & \\
\hline & COSERN & 140 & & 2,5 & $40 \mathrm{~m}^{2}$, padrão popular & sem telefone \\
\hline & SAELPA & 140 & & 2,5 & $45 \mathrm{~m}^{2}$, periferia, favelas & sem telefone \\
\hline & CELB & 140 & & 2,5 & $45 \mathrm{~m}^{2}$, acabamento simples & \\
\hline & CELPE & 140 & & 2,5 & $50 \mathrm{~m}^{2}$, padrão popular, aptos em edifícios até 4 andares & \\
\hline & CEAL & 140 & & & $45 \mathrm{~m}^{2}$, favela, barracos, núcleos habitacionais poder públicos, povoados & 3 salários mínimos \\
\hline & ENERGIPE & 140 & & & $45 \mathrm{~m}^{2}$ & \\
\hline & SULGIPE & 140 & 30 & & $35 \mathrm{~m}^{2}$, padrão popular & \\
\hline & COELBA & 140 & $10(127 \mathrm{~V})$ & $15(220 \mathrm{~V})$ & $45 \mathrm{~m}^{2}$, loteamentos irregulares, conj. populares & \\
\hline \multirow{20}{*}{ SUDESTE } & CEMIG & 180 & 40 & & baixo padrão, favelas, aglomerados & \\
\hline & CAT-LEO & 180 & & 3,3 & $36 \mathrm{~m}^{2}$, barracos, construções alvenaria & \\
\hline & POÇOS DE CALDAS & 180 & 30 & 3,8 & $70 \mathrm{~m}^{2}$, conj. habitacionais populares & \\
\hline & ESCELSA & 180 & $30(127 \mathrm{~V})$ & $15(220 \mathrm{~V})$ & barracos, padrão popular, loteam. Irreg., favelas, núcleos baixa renda & \\
\hline & SANTA MARIA & 180 & 30 & & & \\
\hline & LIGHT & 140 & 40 & 4,4 & residências simples, barracos, cortiços, conj. habitacionais baixa renda & \\
\hline & CERJ & 140 & 30 & & $50 \mathrm{~m}^{2}$, residências simples & 3 salários mínimos \\
\hline & CENF & 140 & 30 & & $50 \mathrm{~m}^{2}$, favelas, moradias populares & \\
\hline & ELEKTRO & 220 & & & monofásico, exceto residências de veraneio & \\
\hline & CPFL & 220 & & & monofásico, $4 \mathrm{~kW}$ & \\
\hline & BRAGANTINA & 220 & 30 & & $70 \mathrm{~m}^{2}$ & \\
\hline & CAIUÁ & 220 & & & $70 \mathrm{~m}^{2}$, conj. habitacionais, mutirão, loteamentos, favelas & \\
\hline & JAGUARI & 220 & & & $70 \mathrm{~m}^{2}$, núcleos habitacionais, favelas, mutirão & \\
\hline & MOCOCA & 220 & & & $70 \mathrm{~m}^{2}$, conj. habitacionais populares, favelas, mutirão & \\
\hline & CPEE & 220 & & & $70 \mathrm{~m}^{2}$, núcleos habitacionais, favelas, mutirão & \\
\hline & \begin{tabular}{|l} 
SANTA CRUZ \\
\end{tabular} & 220 & & & $70 \mathrm{~m}^{2}$, padrão popular & \\
\hline & CSPE & 220 & & & $70 \mathrm{~m}^{2}$, núcleos habitacionais, favelas, mutirão & \\
\hline & V. PARANAPANEMA & 220 & \multicolumn{2}{|c|}{$30(\mathrm{~F}-\mathrm{N}) ; 15$ (F-F) } & $70 \mathrm{~m}^{2}$, loteamentos e conj. habitacionais populares, favelas, mutirão & \\
\hline & NACIONAL & 220 & & 3,3 & $70 \mathrm{~m}^{2}$, loteamentos e conj. habitacionais populares & \\
\hline & ELETROPAULO & 220 & & & * não aprovado pelo Dnaee & \\
\hline \multirow{16}{*}{ SUL } & COPEL & 160 & & & $50 \mathrm{~m}^{2}$, padrão popular & 3 sal. min. ou 0,8 per capita \\
\hline & COCEL & 160 & & 3,3 & $50 \mathrm{~m}^{2}$ & 2 salários mínimos \\
\hline & CORONEL VIVIDA & 160 & & & * não aprovado pelo Dnaee & \\
\hline & CFLO & 160 & 15 & & $70 \mathrm{~m}^{2}$, conj. habitacionais, mutirão, loteamentos, favelas & \\
\hline & CELESC & 160 & & 6 & $70 \mathrm{~m}^{2}$ & \\
\hline & \begin{tabular}{|l} 
URUSSANGA \\
\end{tabular} & 160 & 30 & & padrão habitacional simples, loteamentos irregulares, conj. habitacionais & \\
\hline & IGUACUU ENERGIA & & 30 & & conj. habitacional poder público, mutirão, favelas & \\
\hline & JOÃO CESA & & 30 & & * não aprovado pelo Dnaee & \\
\hline & CEEE & 160 & & & $40 \mathrm{~m}^{2}$ ou características de baixa renda & 3 sal. mín. ou 0,5 per capita \\
\hline & AES-SUL & 160 & & & $40 \mathrm{~m}^{2}$ ou características de baixa renda & \\
\hline & RGE & 160 & & & $40 \mathrm{~m}^{2}$ ou características de baixa renda & \\
\hline & ELETROCAR & 160 & 15 & & $50 \mathrm{~m}^{2}$ & \\
\hline & PANAMBI & & & & $50 \mathrm{~m}^{2}$, habitações populares & \\
\hline & \begin{tabular}{|l|} 
NOVA PALMA \\
\end{tabular} & 160 & 25 & & $50 \mathrm{~m}^{2}$, habitações populares & \\
\hline & DEMEI & 160 & 30 & & periferia & \\
\hline & MUXFELDT & 160 & 15 & & $50 \mathrm{~m}^{2}$, habitações populares & \\
\hline \multirow{5}{*}{$\begin{array}{l}\text { CENTRO- } \\
\text { OESTE }\end{array}$} & ENERSUL & 150 & 30 & 2,5 & barracos, casebres, favelas, núcleos habitacionais baixa renda & \\
\hline & CEMAT & 140 & & 2,5 & & \\
\hline & CELG & & & & padrão habitacional simples & \\
\hline & CHESP & 180 & 20 & 3,3 & $40 \mathrm{~m}^{2}$, padrão popular & \\
\hline & CEB & 180 & & & * não aprovado pelo Dnaee & \\
\hline
\end{tabular}




\section{Anexo I - Cadastro único dos programas sociais - Estimativa de cadastramento}

\begin{tabular}{|c|c|c|c|c|c|c|c|c|c|c|}
\hline UF & $\begin{array}{c}\text { Total de } \\
\text { Municípios } \\
\text { da UF }\end{array}$ & $\begin{array}{c}\text { Total de } \\
\text { Municípios } \\
\text { c/ } \\
\text { cadastros } \\
\text { na base }\end{array}$ & $\%$ & População & $\begin{array}{c}\text { Estimativa } \\
\text { de Famílias } \\
\text { Pobres na } \\
\text { UF }\end{array}$ & $\begin{array}{c}\text { Famílias } \\
\text { Pobres } \\
\text { cadastradas } \\
\text { na UF }\end{array}$ & $\%$ & $\begin{array}{c}\text { Estimativa } \\
\text { de Pessoas } \\
\text { Pobres na } \\
\text { UF }\end{array}$ & $\begin{array}{c}\text { Pessoas } \\
\text { Pobres } \\
\text { cadastradas } \\
\text { na UF }\end{array}$ & $\%$ \\
\hline $\mathrm{AC}$ & 22 & 22 & $100 \%$ & 557.526 & 49.626 & 48.361 & $97 \%$ & 208.429 & 202.862 & $97 \%$ \\
\hline $\mathrm{AL}$ & 102 & 102 & $100 \%$ & 2.822 .621 & 344.428 & 268.003 & $78 \%$ & 1.446 .598 & 1.098 .751 & $76 \%$ \\
\hline$\overline{\mathrm{AM}}$ & 62 & 62 & $100 \%$ & 2.812 .557 & 246.627 & 123.879 & $50 \%$ & 1.035 .833 & 547.219 & $53 \%$ \\
\hline $\mathrm{AP}$ & 16 & 16 & $100 \%$ & 477.032 & 19.300 & 15.598 & $81 \%$ & 81.060 & 69.755 & $86 \%$ \\
\hline $\mathrm{BA}$ & 417 & 417 & $100 \%$ & 13.070 .250 & 1.451 .244 & 1.121 .561 & $77 \%$ & 6.095 .225 & 4.592 .731 & $75 \%$ \\
\hline $\mathrm{CE}$ & 184 & 184 & $100 \%$ & 7.430 .661 & 824.112 & 905.306 & $110 \%$ & 3.461 .270 & 3.627 .673 & $105 \%$ \\
\hline $\mathrm{DF}$ & 1 & 1 & $100 \%$ & 2.051 .146 & 87.407 & 63.942 & $73 \%$ & 367.109 & 241.725 & $66 \%$ \\
\hline ES & 78 & 78 & $100 \%$ & 3.097 .232 & 229.061 & 128.949 & $56 \%$ & 962.056 & 534.011 & $56 \%$ \\
\hline $\mathrm{GO}$ & 246 & 232 & $94 \%$ & 5.003 .228 & 314.876 & 203.783 & $65 \%$ & 1.322 .479 & 790.048 & $60 \%$ \\
\hline MA & 217 & 216 & $100 \%$ & 5.651 .475 & 632.015 & 535.295 & $85 \%$ & 2.654 .463 & 2.305 .384 & $87 \%$ \\
\hline $\mathrm{MG}$ & 853 & 853 & $100 \%$ & 17.891 .494 & 1.109 .730 & 1.169 .202 & $105 \%$ & 4.660 .866 & 4.868 .038 & $104 \%$ \\
\hline MS & 77 & 77 & $100 \%$ & 2.078 .001 & 116.558 & 100.470 & $86 \%$ & 489.544 & 398.472 & $81 \%$ \\
\hline MT & 139 & 137 & $99 \%$ & 2.504 .353 & 149.615 & 117.262 & $78 \%$ & 628.383 & 488.462 & $78 \%$ \\
\hline PA & 143 & 143 & $100 \%$ & 6.192 .307 & 567.810 & 290.578 & $51 \%$ & 2.384 .802 & 1.361 .671 & $57 \%$ \\
\hline PB & 223 & 223 & $100 \%$ & 3.443 .825 & 385.045 & 397.877 & $103 \%$ & 1.617 .189 & 1.596 .393 & $99 \%$ \\
\hline $\mathrm{PE}$ & 185 & 185 & $100 \%$ & 7.918 .344 & 839.295 & 763.067 & $91 \%$ & 3.525 .039 & 2.947 .256 & $84 \%$ \\
\hline PI & 222 & 221 & $100 \%$ & 2.843 .278 & 324.765 & 309.983 & $95 \%$ & 1.364 .013 & 1.247 .464 & $91 \%$ \\
\hline PR & 399 & 397 & $99 \%$ & 9.563 .458 & 503.965 & 503.310 & $100 \%$ & 2.116 .653 & 1.991 .774 & $94 \%$ \\
\hline RJ & 92 & 91 & $99 \%$ & 14.391 .282 & 548.604 & 226.721 & $41 \%$ & 2.304 .137 & 895.232 & $39 \%$ \\
\hline $\mathrm{RN}$ & 167 & 167 & $100 \%$ & 2.776 .782 & 274.274 & 300.643 & $110 \%$ & 1.151 .951 & 1.157 .816 & $101 \%$ \\
\hline RO & 52 & 50 & $96 \%$ & 1.379 .787 & 120.389 & 62.094 & $52 \%$ & 505.634 & 258.493 & $51 \%$ \\
\hline RR & 15 & 15 & $100 \%$ & 324.397 & 28.627 & 29.169 & $102 \%$ & 120.233 & 129.731 & $108 \%$ \\
\hline RS & 497 & 496 & $100 \%$ & 10.187 .798 & 439.313 & 515.704 & $117 \%$ & 1.845 .115 & 1.983 .724 & $108 \%$ \\
\hline $\mathrm{SC}$ & 293 & 293 & $100 \%$ & 5.356 .360 & 155.001 & 192.285 & $124 \%$ & 651.004 & 819.403 & $126 \%$ \\
\hline SE & 75 & 75 & $100 \%$ & 1.784 .475 & 186.156 & 150.038 & $81 \%$ & 781.855 & 615.434 & $79 \%$ \\
\hline SP & 645 & 636 & $99 \%$ & 37.032 .403 & 1.157 .764 & 872.695 & $75 \%$ & 4.862 .609 & 3.408 .767 & $70 \%$ \\
\hline TO & 139 & 133 & $96 \%$ & 1.157 .098 & 102.666 & 84.022 & $82 \%$ & 431.197 & 354.415 & $82 \%$ \\
\hline Total & 5.561 & 5.522 & $99 \%$ & 169.799 .170 & 11.208.273 & 9.499.797 & $85 \%$ & 47.074.747 & 38.532.704 & $82 \%$ \\
\hline
\end{tabular}


Anexo J - Evolução do número de consumidores baixa renda por distribuidora 1998 a 2002

\begin{tabular}{|c|c|c|c|c|c|c|}
\hline \multirow{3}{*}{ Empresa } & \multicolumn{3}{|c|}{ Dados Aneel - 1998} & \multicolumn{3}{|c|}{ Dados Aneel março/2002 } \\
\hline & \multirow{2}{*}{ Residenciais } & \multicolumn{2}{|c|}{ Baixa renda } & \multirow{2}{*}{ Residenciais } & \multicolumn{2}{|c|}{ Baixa Renda } \\
\hline & & Número & Perc. & & Número & Percentual \\
\hline CEA & 192.278 & 96.139 & $50,00 \%$ & 94.587 & 48.691 & $51,5 \%$ \\
\hline CER & & & & 13.988 & 9.815 & $70,2 \%$ \\
\hline CERON & 192.278 & 96.139 & $50,00 \%$ & 237.319 & 42.737 & $18,0 \%$ \\
\hline ELETROACRE & 78.701 & 56.815 & $72,19 \%$ & 79.028 & 16.654 & $21,1 \%$ \\
\hline BOA VISTA & 35.876 & 10.085 & $28,11 \%$ & 45.742 & 15.805 & $34,6 \%$ \\
\hline CELPA & 703.904 & 266.772 & $37,90 \%$ & 938.995 & 241.883 & $25,8 \%$ \\
\hline CELTINS & 166.411 & 3.282 & $1,97 \%$ & 213.625 & 8.812 & $4,1 \%$ \\
\hline CEAM & & & & 107.299 & 95.295 & $88,8 \%$ \\
\hline Manaus & 254.034 & 103.417 & $40,71 \%$ & 308.271 & 124.694 & $40,4 \%$ \\
\hline R. NORTE & 1.431 .204 & $\mathbf{5 3 6 . 5 1 0}$ & $37,49 \%$ & 2.038 .854 & 604.386 & $29,6 \%$ \\
\hline CEMAR & 785.906 & 438.087 & $55,74 \%$ & 915.701 & 321.692 & $35,1 \%$ \\
\hline CEPISA & 419.063 & 528 & $0,13 \%$ & 522.125 & 1.584 & $0,3 \%$ \\
\hline COELCE & 1.553 .757 & 1.187 .888 & $76,45 \%$ & 1.273 .405 & 311.532 & $24,5 \%$ \\
\hline COSERN & 522.911 & 100.862 & $19,29 \%$ & 508.733 & 141.483 & $27,8 \%$ \\
\hline S.AELPA & 601.747 & 264.623 & $43,98 \%$ & 677.597 & 89.939 & $13,3 \%$ \\
\hline CELB & 87.510 & 22.882 & $26,15 \%$ & 103.165 & 12.401 & $12,0 \%$ \\
\hline CELPE & 1.490 .198 & 873.875 & $58,64 \%$ & 1.851 .411 & 396.780 & $21,4 \%$ \\
\hline CE.AL & 458.632 & 8.929 & $1,95 \%$ & 494.202 & 46.586 & $9,4 \%$ \\
\hline ENERGIPE & 319.090 & 24.955 & $7,82 \%$ & 367.991 & 26.110 & $7,1 \%$ \\
\hline SULGIPE & 55.554 & 14.290 & $25,72 \%$ & 70.111 & 7.153 & $10,2 \%$ \\
\hline COELBA & 2.049 .422 & 190.093 & $9,28 \%$ & 2.562 .045 & 83.195 & $3,2 \%$ \\
\hline R. NORDESTE & 8.343 .790 & 3.127 .012 & $37,48 \%$ & 9.346 .486 & 1.438 .455 & $15,4 \%$ \\
\hline CEMIG & 3.700 .582 & 2.982 .391 & $80,59 \%$ & 4.526 .225 & 1.478 .515 & $32,7 \%$ \\
\hline CAT-LEO & & & & 215.867 & 3 & $0,0 \%$ \\
\hline POÇOS DE CALDAS & 37.169 & 68 & $0,18 \%$ & 45.434 & 41 & $0,1 \%$ \\
\hline ESCELSA & 604.369 & 30.019 & $4,97 \%$ & 745.078 & 46.982 & $6,3 \%$ \\
\hline SANTA MARIA & 32.128 & 1.641 & $5,11 \%$ & 40.886 & 1.612 & $3,9 \%$ \\
\hline LIGHT & 2.528 .265 & 152.894 & $6,05 \%$ & 2.954 .049 & 370.007 & $12,5 \%$ \\
\hline AMPLA & 1.193 .108 & 76.690 & $6,43 \%$ & 1.482 .676 & 45.085 & $3,0 \%$ \\
\hline CENF & & & & 67.048 & 7 & $0,0 \%$ \\
\hline ELEKTRO & 1.226 .593 & 586.456 & $47,81 \%$ & 1.490 .860 & 712.550 & $47,8 \%$ \\
\hline CPFL & 2.108 .137 & 1.135 .726 & $53,87 \%$ & 2.529 .664 & 544.147 & $21,5 \%$ \\
\hline BRAGANTINA & 59.735 & 3.172 & $5,31 \%$ & 75.661 & 3.309 & $4,4 \%$ \\
\hline CAIUÁ & 127.577 & 459 & $0,36 \%$ & 147.009 & 422 & $0,3 \%$ \\
\hline JAGUARI & 15.281 & 1.539 & $10,07 \%$ & 19.787 & 2.133 & $10,8 \%$ \\
\hline MOCOCA & 23.906 & 748 & $3,13 \%$ & 27.182 & 1.361 & $5,0 \%$ \\
\hline CPEE & 27.519 & 2.842 & $10,33 \%$ & 32.761 & 3.745 & $11,4 \%$ \\
\hline S.ANTA CRUZ & 102.701 & 41.702 & $40,61 \%$ & 123.288 & 41.456 & $33,6 \%$ \\
\hline CSPE & 37.499 & 2.474 & $6,60 \%$ & 46.551 & 3.135 & $6,7 \%$ \\
\hline V. PARANAPANEMA & 97.548 & 641 & $0,66 \%$ & 111.344 & 82 & $0,1 \%$ \\
\hline NACIONAL & 56.082 & 600 & $1,07 \%$ & 67.535 & 379 & $0,6 \%$ \\
\hline ELETROPAULO & 5.105 .711 & 3.606 .756 & $70,64 \%$ & 4.258 .214 & 485.853 & $11,4 \%$ \\
\hline B.ANDEIRA.NTE & 1.773 .168 & 978.185 & $55,17 \%$ & 1.046 .895 & 680.325 & $65,0 \%$ \\
\hline PIRATININGA & & & & 1.020 .468 & 774.966 & $75,9 \%$ \\
\hline R. SUDESTE & 18.857.078 & 9.605 .003 & $50,94 \%$ & 21.074.482 & 5.196 .115 & $24,7 \%$ \\
\hline COPEL & 2.036 .210 & 334.513 & $16,43 \%$ & 2.317 .426 & 152.590 & $6,6 \%$ \\
\hline COCEL & 19.823 & 818 & $4,13 \%$ & 25.301 & 1.370 & $5,4 \%$ \\
\hline CORONEL VIVIDA & 3.290 & 1.968 & $59,82 \%$ & 3.865 & 869 & $22,5 \%$ \\
\hline CFLO & 29.603 & 2.159 & $7,29 \%$ & 34.014 & 2.118 & $6,2 \%$ \\
\hline CELESC & 1.208 .614 & 25.293 & $2,09 \%$ & 1.427 .744 & 48.803 & $3,4 \%$ \\
\hline URUSSANGA & 2.619 & 329 & $12,56 \%$ & 2.609 & 249 & $9,5 \%$ \\
\hline IGUACCU ENERGLA & 13.409 & 1.237 & $9,23 \%$ & 15.833 & 1.482 & $9,4 \%$ \\
\hline JOÃO CESA & 1.495 & 111 & $7,42 \%$ & 1.715 & 1.715 & $100,0 \%$ \\
\hline COOPERALIANÇA & & & & 19.092 & 13.731 & $71,9 \%$ \\
\hline CEEE & 957.430 & 74.368 & $7,77 \%$ & 1.070 .390 & 88.669 & $8,3 \%$ \\
\hline AES-SUL & 674.860 & 129.647 & $19,21 \%$ & 767.861 & 48.936 & $6,4 \%$ \\
\hline RGE & 6.640 .003 & 53.194 & $0,80 \%$ & 683.596 & 56.923 & $8,3 \%$ \\
\hline ELETROCAR & 18.677 & 515 & $2,76 \%$ & 21.437 & 568 & $2,6 \%$ \\
\hline PANAMBI & 8.102 & 87 & $1,07 \%$ & 9.728 & 82 & $0,8 \%$ \\
\hline NOVA PALMA & 5.361 & 3.330 & $62,12 \%$ & 6.892 & 1.352 & $19,6 \%$ \\
\hline DEMEI & 18.122 & 7.254 & $40,03 \%$ & 19.857 & 1.330 & $6,7 \%$ \\
\hline MUXFELDT & 3.473 & 1.992 & $57,36 \%$ & 4.632 & 3.261 & $70,4 \%$ \\
\hline R. SUL & 11.641 .091 & 636.815 & $5,47 \%$ & 6.431 .992 & 424.048 & $6,6 \%$ \\
\hline ENERSUL & 402.430 & 61.588 & $15,30 \%$ & 478.121 & 51.662 & $10,8 \%$ \\
\hline CEMAT & 413.309 & 114.878 & $27,79 \%$ & 404.872 & 115.999 & $28,7 \%$ \\
\hline CELG & 1.092 .282 & 5.984 & $0,55 \%$ & 1.385 .576 & 3.948 & $0,3 \%$ \\
\hline CHESP & 16.563 & 1.156 & $6,98 \%$ & 18.811 & 451 & $2,4 \%$ \\
\hline CEB & 413886 & 159384 & $38,51 \%$ & 518.278 & 214.416 & $41,4 \%$ \\
\hline R. CENIRO-O & 2.338 .470 & 342.990 & $14,67 \%$ & 2.805 .658 & 386.476 & $13,8 \%$ \\
\hline BRASIL & 42.611 .633 & 14.248 .330 & $33,44 \%$ & 41.697.472 & 8.049 .480 & $19,3 \%$ \\
\hline
\end{tabular}


Anexo J - Evolução do número de consumidores baixa renda por distribuidora 1998 a 2002 (continuação)

\begin{tabular}{|c|c|c|c|c|c|c|c|c|c|}
\hline \multirow{3}{*}{ Empresa } & \multicolumn{3}{|c|}{ Dados Aneel setembro/2002 } & \multicolumn{3}{|c|}{ Dados Aneel julho/2004 } & \multirow{2}{*}{\multicolumn{3}{|c|}{$\begin{array}{c}\text { Dados Aneel julho/2004 } \\
\text { Baixa Renda }\end{array}$}} \\
\hline & \multirow[b]{2}{*}{ Residenciais } & \multicolumn{2}{|c|}{ Baixa Renda } & \multirow[b]{2}{*}{ Residenciais } & \multicolumn{2}{|c|}{ Baixa Renda } & & & \\
\hline & & Número & Percentual & & Número & Percentual & até $80 \mathrm{kWh}$ & 80 a $220 \mathrm{kWh}$ & $\begin{array}{l}\text { Inscritos } \\
\text { programas }\end{array}$ \\
\hline CEA.A & 94.587 & 48.691 & $51,5 \%$ & 103.861 & 28.050 & $27,0 \%$ & 25.127 & 2.923 & $\cdot$ \\
\hline CER & 13.988 & 9.815 & $70,2 \%$ & 14.958 & 12.048 & $80,5 \%$ & 5.204 & 6.844 & \\
\hline CERON & 241.709 & 84.130 & $34,8 \%$ & 264.580 & 76.233 & $28,8 \%$ & 54.517 & 21.716 & 6.704 \\
\hline ELETROACRE & 79.028 & 16.654 & $21,1 \%$ & 106.406 & 38.210 & $35,9 \%$ & 31.233 & 6.977 & 705 \\
\hline BOA VISTA & 46.146 & 14.642 & $31,7 \%$ & 53.159 & 9.110 & $17,1 \%$ & 5.718 & 3.392 & 653 \\
\hline CELPA & 970.846 & 463.445 & $47,7 \%$ & 1.083 .079 & 556.351 & $51,4 \%$ & 407.072 & 149.279 & 76.752 \\
\hline CELTINS & 219.105 & 114.296 & $52,2 \%$ & 238.746 & 122.686 & $51,4 \%$ & 99.016 & 23.670 & 19.674 \\
\hline CEAM & 107.299 & 95.295 & $88,8 \%$ & 140.379 & 70.666 & $50,3 \%$ & 54.608 & 16.058 & $\cdot$ \\
\hline MANAUS & 308.271 & 124.694 & $40,4 \%$ & 347.828 & 116.870 & $33,6 \%$ & 100.139 & 16.731 & - \\
\hline R. NORTE & 2.080 .979 & 971.662 & $46,7 \%$ & 2.352 .996 & 1.030 .224 & $43,8 \%$ & 782.634 & 247.590 & 104.488 \\
\hline CEMAR & 923.586 & 633.831 & $68,6 \%$ & 994.378 & 693.799 & $69,8 \%$ & 581.360 & 112.439 & 108.693 \\
\hline CEPISA & 185.970 & 349.988 & $188,2 \%$ & 590.398 & 400.569 & $67,8 \%$ & 348.606 & 51.963 & 31.195 \\
\hline COELCE & 1.583 .877 & 1.030 .802 & $65,1 \%$ & 1.845 .073 & 1.284 .215 & $69,6 \%$ & \begin{tabular}{|l|l|}
1.021 .819 \\
\end{tabular} & 262.396 & 164.504 \\
\hline COSERN & 641.558 & 384.884 & $60,0 \%$ & 698.115 & 394.847 & $56,6 \%$ & \begin{tabular}{|l|}
317.598 \\
\end{tabular} & 77.249 & 45.664 \\
\hline SAELPA & 684.603 & 477.137 & $69,7 \%$ & 722.186 & 495.306 & $68,6 \%$ & 435.630 & 59.676 & 31.264 \\
\hline CELB & 104.967 & 67.121 & $63,9 \%$ & 110.904 & 69.295 & $62,5 \%$ & 58.685 & 10.610 & 1.929 \\
\hline CELPE & 1.870 .509 & 1.119 .303 & $59,8 \%$ & 1.950 .167 & 1.176 .385 & $60,3 \%$ & 1.040 .163 & 136.222 & 35.105 \\
\hline CEAL & 546.540 & 350.259 & $64,1 \%$ & 583.874 & 354.110 & $60,6 \%$ & 313.219 & 40.891 & 164 \\
\hline ENERGIPE & 379.239 & 242.581 & $64,0 \%$ & 398.235 & 242.658 & $60,9 \%$ & 211.953 & 30.705 & 8.067 \\
\hline SULGIPE & 71.868 & 55.593 & $77,4 \%$ & 77.643 & 58.245 & $75,0 \%$ & 54.877 & 3.368 & 1.802 \\
\hline COELBA & 2.673 .410 & 1.714 .464 & $64,1 \%$ & 2.921 .988 & 1.876 .903 & $64,2 \%$ & 1.629 .819 & 247.084 & 146.035 \\
\hline R. NORDESTE & 9.666 .127 & 6.425 .963 & $66,5 \%$ & 10.892 .961 & 7.046 .332 & $64,7 \%$ & \begin{tabular}{|l|}
6.013 .729 \\
\end{tabular} & 1.032 .603 & 574.422 \\
\hline CEMIG & 4.586 .841 & 2.118 .239 & $46,2 \%$ & 4.793 .771 & 1.974 .805 & $41,2 \%$ & \begin{tabular}{|l|l|}
1.497 .361 \\
\end{tabular} & 477.444 & 273.514 \\
\hline CAT-LEO & 217.880 & 77.374 & $35,5 \%$ & 229.026 & 96.809 & $42,3 \%$ & 74.967 & 21.842 & 9.432 \\
\hline POÇOS DE CALDAS & 45.848 & 8.479 & $18,5 \%$ & 48.115 & 9.547 & $19,8 \%$ & 7.281 & 2.266 & 1.107 \\
\hline ESCELSA & 749.099 & 271.318 & $36,2 \%$ & 772.334 & 275.771 & $35,7 \%$ & 237.236 & 38.535 & 15.487 \\
\hline SANTA MARIA & 41.640 & 1.642 & $3,9 \%$ & 44.368 & 14.121 & $31,8 \%$ & 11.511 & 2.610 & 1.583 \\
\hline LIGHT & 3.011 .973 & 384.562 & $12,8 \%$ & 3.130 .055 & 923.337 & $29,5 \%$ & 703.455 & 219.882 & 2.633 \\
\hline AMPLA & 1.482 .676 & 45.085 & $3,0 \%$ & 1.788 .034 & 862.766 & $48,3 \%$ & 578.993 & 283.773 & 9.961 \\
\hline CENF & 67.751 & 17.431 & $25,7 \%$ & 70.920 & 18.772 & $26,5 \%$ & 15.489 & 3.283 & 330 \\
\hline ELEKTRO & 1.506 .245 & 707.062 & $46,9 \%$ & 1.588 .087 & 745.855 & $47,0 \%$ & 237.123 & 508.732 & 38.706 \\
\hline \begin{tabular}{|l|l|} 
CPFL \\
\end{tabular} & 2.574 .282 & 782.800 & $30,4 \%$ & 2.660 .776 & 783.229 & $29,4 \%$ & 375.001 & 408.228 & 53.453 \\
\hline BRAGANTINA & 77.441 & 12.108 & $15,6 \%$ & 83.070 & 10.299 & $12,4 \%$ & 8.185 & 2.114 & 612 \\
\hline CAIUÁ & 148.404 & 25.521 & $17,2 \%$ & 154.592 & 31.160 & $20,2 \%$ & 21.294 & 9.866 & 7.268 \\
\hline JAGUARI & 20.272 & 2.942 & $14,5 \%$ & 22.381 & 1.418 & $6,3 \%$ & 884 & 534 & 132 \\
\hline MOCOCA & 27.398 & 4.311 & $15,7 \%$ & 28.768 & 4.298 & $14,9 \%$ & 2.542 & 1.756 & 30 \\
\hline CPEE & 33.167 & 5.476 & $16,5 \%$ & 34.908 & 3.890 & $11,1 \%$ & 1.847 & 2.043 & 39 \\
\hline S.ANTA CRUZ & 124.691 & 50.239 & $40,3 \%$ & 130.043 & 32.171 & $24,7 \%$ & 18.802 & 13.369 & 5.942 \\
\hline CSPE & 47.078 & 10.157 & $21,6 \%$ & 50.104 & 9.104 & $18,2 \%$ & 5.506 & 3.598 & 68 \\
\hline PARANAPANEMA & 112.929 & 20.644 & $18,3 \%$ & 116.814 & 25.780 & $22,1 \%$ & 17.518 & 8.262 & 4.443 \\
\hline NACIONAL & 67.535 & 379 & $0,6 \%$ & 71.661 & 5.869 & $8,2 \%$ & 4.194 & 1.675 & 965 \\
\hline ELETROPAULO & 4.488 .191 & 802.372 & $17,9 \%$ & 4.604 .620 & 697.777 & $15,2 \%$ & 408.095 & 289.682 & 6.783 \\
\hline BANDEIRANTE & 1.046 .895 & 680.325 & $65,0 \%$ & 1.131 .719 & 90.564 & $8,0 \%$ & 46.573 & 43.991 & 9.936 \\
\hline PIRATININGA & 1.020 .468 & 774.966 & $75,9 \%$ & 1.083 .600 & 213.398 & $19,7 \%$ & 160.034 & 53.364 & 5.185 \\
\hline R. SUDESTE & 21.498 .704 & 6.803 .432 & $31,6 \%$ & 22.637 .766 & 6.830 .740 & $30,2 \%$ & 4.433.891 & 2.396 .849 & 447.609 \\
\hline COPEL & 2.349 .673 & 557.735 & $23,7 \%$ & 2.455 .485 & 699.113 & $28,5 \%$ & 470.543 & 228.570 & 143.975 \\
\hline COCEL & 25.647 & 5.907 & $23,0 \%$ & 28.273 & 9.183 & $32,5 \%$ & 5.338 & 3.845 & 1.679 \\
\hline CORONEL VIVIDA & 3.435 & 499 & $14,5 \%$ & 4.161 & 1.506 & $36,2 \%$ & 995 & 511 & 627 \\
\hline CFLO & 34.581 & 9.685 & $28,0 \%$ & 36.637 & 10.345 & $28,2 \%$ & 7.593 & 2.752 & 2.173 \\
\hline CELESC & 1.397 .368 & 205.733 & $14,7 \%$ & 1.486 .729 & 236.991 & $15,9 \%$ & 204.439 & 32.552 & 1.073 \\
\hline URUSSANGA & 2.917 & 509 & $17,4 \%$ & 3.096 & 645 & $20,8 \%$ & 333 & 312 & 113 \\
\hline IGUAÇU ENERGIA & 16.135 & 3.463 & $21,5 \%$ & 17.166 & 3.689 & $21,5 \%$ & 2.155 & 1.534 & 792 \\
\hline JOÃO CESA & 1.715 & 1.715 & $100,0 \%$ & 1.827 & 359 & $19,6 \%$ & 216 & 143 & 95 \\
\hline COOPERALIANÇA & 19.092 & 13.731 & $71,9 \%$ & 20.316 & 10.131 & $49,9 \%$ & 5.348 & 4.783 & 816 \\
\hline CEEE & 1.078 .846 & 265.343 & $24,6 \%$ & 1.045 .012 & 247.493 & $23,7 \%$ & 183.038 & 64.455 & 31.443 \\
\hline AES-SUL & $\begin{array}{l}799.309 \\
\end{array}$ & 160.361 & $20,1 \%$ & 824.255 & 183.169 & $22,2 \%$ & 134.044 & 49.125 & 29.638 \\
\hline RGE & 753.820 & 190.423 & $25,3 \%$ & 799.565 & 215.222 & $26,9 \%$ & 150.778 & 64.444 & 31.312 \\
\hline ELETROCAR & 21.664 & 4.092 & $18,9 \%$ & 22.741 & 6.073 & $26,7 \%$ & 3.858 & 2.215 & 2.058 \\
\hline PANAMBI & 9.728 & 82 & $0,8 \%$ & 11.218 & 2.218 & $19,8 \%$ & 1.301 & 917 & 881 \\
\hline NOVA PALMA & 6.892 & 1.352 & $19,6 \%$ & 7.380 & 2.728 & $37,0 \%$ & 1.447 & 1.281 & \\
\hline DEMEI & 20.116 & 4.045 & $20,1 \%$ & 21.646 & 5.099 & $23,6 \%$ & 3.064 & 2.035 & 1.244 \\
\hline MUXFELDT & 4.767 & 3.394 & $71,2 \%$ & 5.302 & 3.742 & $70,6 \%$ & 876 & 2.866 & 449 \\
\hline R. SUL & 6.545 .705 & 1.428 .069 & $21,8 \%$ & 6.790 .809 & 1.637 .706 & $24,1 \%$ & 1.175 .366 & 462.340 & 248.368 \\
\hline ENERSUL & 482.682 & 139.895 & $29,0 \%$ & 514.552 & 151.861 & $29,5 \%$ & 119.214 & 32.647 & 17,792 \\
\hline CEMAT & 538.197 & 150.673 & $28,0 \%$ & 586.969 & 123.924 & $21,1 \%$ & 50.780 & 73.144 & 10.605 \\
\hline CELG & 1.422 .468 & 466.735 & $32,8 \%$ & 1.477 .336 & 519.740 & $35,2 \%$ & 382.153 & 137.587 & 68.329 \\
\hline CHESP & 18.930 & 8.248 & $43,6 \%$ & 20.021 & 9.769 & $48,8 \%$ & 7.428 & 2.341 & 1.891 \\
\hline CEB & 532.805 & 292.700 & $54,9 \%$ & 590.642 & 110.590 & $18,7 \%$ & $\begin{array}{l}63.510 \\
\end{array}$ & 47.080 & 9.281 \\
\hline & 2.995 .082 & 1.058 .251 & $35,3 \%$ & 3.189 .520 & 915.884 & $28,70 \%$ & 623.085 & 292.799 & 107.898 \\
\hline BRASIL & 42.786 .597 & 16.687 .377 & $39,0 \%$ & 45.864 .052 & 17.460 .886 & $38,1 \%$ & 13.028 .705 & 4.432.181 & 1.482 .785 \\
\hline
\end{tabular}




\section{Anexo K - Perdas de receita da distribuidora devido aos novos consumidores}

\section{baixa renda - 2002}

\begin{tabular}{|c|c|c|c|c|c|c|c|c|c|}
\hline DISTI & AIO & INHO & Л兀LНО & AGOSTO & SETEMBRO & OUTUBRO & NOVEMBRO & DEZEMBBRO & TOTAL 2002 \\
\hline ERON & $211.550,42$ & $224.078,60$ & $202.923,77$ & $203.530,90$ & $189.232,27$ & $182.689,26$ & $176.018,29$ & $209.477,59$ & $1.599 .501,10$ \\
\hline ETROACRE & 0,00 & $118.599,54$ & $1.497,89$ & 0,00 & 0,00 & 0,00 & 0,00 & $96.014,65$ & $346.112,08$ \\
\hline BOA VISTA & $22.059,20$ & $17.435,06$ & $16.573,38$ & $10.384,24$ & $5.915,55$ & $4.870,25$ & 0,00 & 494,07 & $77.731,75$ \\
\hline ELPA. & $1.293 .508,69$ & $1.349 .700,05$ & $1.346 .396,68$ & $1.610 .770,91$ & $1.551 .137,21$ & $1.474 .108,09$ & $1.747 .749,17$ & $1.747 .545,39$ & $12.120 .916,19$ \\
\hline ELTINS & $624.012,02$ & $630.279,60$ & $697.505,42$ & $714.772,40$ & $715.476,20$ & $690.106,45$ & $683.556,54$ & $666.786,40$ & $5.422 .495,03$ \\
\hline ANAUS & $137.073,44$ & $136.145,49$ & $104.479,44$ & $56.389,40$ & 0,00 & 0,00 & $131.737,82$ & $129.022,68$ & $694.848,27$ \\
\hline R. NORIE & $2.288 .203,77$ & $2.476 .238,34$ & $2.499 .376,58$ & $2.595 .847,85$ & $2.461 .761,23$ & $2.351 .774,05$ & $2.739 .061,82$ & $2.849 .340,78$ & $20.261 .604,42$ \\
\hline CEMAR & $1.727 .642,24$ & $1.936 .828,87$ & $1.886 .597,06$ & $1.938 .600,07$ & $2.124 .531,60$ & \begin{tabular}{|r}
$2.185 .781,78$ \\
\end{tabular} & $2.444 .656,09$ & $2.471 .653,25$ & $16.716 .290,96$ \\
\hline CEPISA & $1.576 .006,20$ & $\begin{array}{l}1.619 .708,81 \\
\end{array}$ & $1.584 .658,82$ & $\begin{array}{l}1.619 .904,41 \\
\end{array}$ & $1.954 .459,92$ & $1.890 .541,16$ & $1.947 .800,33$ & $1.886 .738,60$ & $14.079 .818,25$ \\
\hline COELCE & $4.155 .687,53$ & $4.722 .333,99$ & $4.660 .227,46$ & 4.697.679,91 & 4.133.512,35 & 4.762.568,96 & $5.114 .461,79$ & $5.072 .411,61$ & $37.318 .883,60$ \\
\hline COSERN & $810.676,72$ & $11.456,60$ & $833.976,39$ & $1.775 .547,08$ & $1.689 .411,75$ & $1.751 .899,92$ & $1.766 .787,09$ & $755.909,28$ & $14.145 .664,83$ \\
\hline SAELPA & $1.917 .757,91$ & $1.882 .648,41$ & $1.865 .719,69$ & $1.871 .268,02$ & $1.987 .007,26$ & $2.152 .856,73$ & $2.154 .778,55$ & $2.142 .449,32$ & $15.974 .485,89$ \\
\hline CELB & $311.177,57$ & $306.399,49$ & $\begin{array}{l}297.070,31 \\
\end{array}$ & $297.434,07$ & $286.539,02$ & $292.667,30$ & $302.824,44$ & $299.860,24$ & $2.392 .972,44$ \\
\hline CELPE & $3.934 .120,34$ & $3.959 .193,29$ & $4.014 .407,87$ & $3.975 .494,03$ & $3.804 .664,51$ & $3.767 .443,95$ & $3.778 .847,23$ & $3.782 .753,26$ & $31.016 .924,48$ \\
\hline CEAL & $543.148,32$ & $1.535 .336,72$ & $1.538 .863,62$ & $1.542 .178,71$ & $1.830 .132,01$ & $1.593 .383,48$ & $1.622 .129,48$ & $1.661 .567,31$ & $12.866 .739,65$ \\
\hline ENERGIPE & $92.139,09$ & $1.227 .207,81$ & $1.218 .681,40$ & $1.179 .437,67$ & $1.201 .510,00$ & $1.217 .804,89$ & $1.234 .277,92$ & $1.215 .657,11$ & $9.686 .715,89$ \\
\hline SULGIPE & $0.955,03$ & $205.566,14$ & $8.166,96$ & $247.307,78$ & $246.449,30$ & $242.760,51$ & $258.516,68$ & $310.190,97$ & $2.029 .913,37$ \\
\hline OELBA & $9.238 .938,46$ & $9.398 .306,98$ & $9.542 .500,59$ & $9.342 .691,62$ & $9.356 .238,66$ & $9.396 .187,59$ & $9.556 .012,77$ & $9.518 .903,11$ & $75.349 .779,78$ \\
\hline R. NORDESTE & $27.688 .249,41$ & $28.604 .987,11$ & $28.630 .870,17$ & $28.487 .543,37$ & $28.614 .456,38$ & $29.253 .896,27$ & $30.181 .092,37$ & \begin{tabular}{|l|}
$30.117 .094,06$ \\
\end{tabular} & 231.578.189,14 \\
\hline CEMIG & $5.503 .351,87$ & \begin{tabular}{|c|}
$6.195 .564,24$ \\
\end{tabular} & 6.551.211,20 & $5.827 .116,99$ & \begin{tabular}{|r}
$5.863 .070,75$ \\
\end{tabular} & $5.466 .031,49$ & \begin{tabular}{|r|}
$5.133 .320,60$ \\
\end{tabular} & \begin{tabular}{|r|}
$6.348 .737,03$ \\
\end{tabular} & $46.888 .404,17$ \\
\hline CAT-LEO & $508.083,18$ & $0.926,00$ & $8.518,47$ & $580.125,82$ & $543.301,69$ & $561.337,92$ & $571.067,96$ & $542.271,09$ & $4.345 .632,13$ \\
\hline POÇOS DE CALDAS & $49.935,66$ & $51.802,33$ & $43.006,57$ & $46.956,95$ & $51.735,07$ & $50.371,51$ & $50.760,29$ & $48.876,89$ & $393.445,27$ \\
\hline ESCELSA & $1.519 .839,58$ & 024,16 & $80.423,55$ & $1.543 .993,88$ & $1.667 .984,08$ & $1.704 .231,72$ & $1.784 .818,91$ & $1.762 .908,45$ & $12.856 .224,33$ \\
\hline SANTA MARIA & $80.914,16$ & 944,18 & $78.149,82$ & $79.840,34$ & $77.546,29$ & $80.325,73$ & $81.829,58$ & $82.256,39$ & $639.806,49$ \\
\hline LIGHT & $344.521,50$ & $512.060,67$ & $578.204,55$ & $502.984,28$ & $565.904,11$ & $3.917 .070,85$ & 4.232.941,81 & $4.103 .533,74$ & $14.757 .221,51$ \\
\hline CERJ & $147.962,14$ & $354.343,62$ & $296.780,49$ & $2.049 .305,75$ & $2.553 .059,28$ & $2.593 .587,70$ & $2.676 .007,25$ & $2.638 .746,37$ & $18.309 .792,60$ \\
\hline CENF & $92.590,98$ & 732,80 & $95.815,66$ & $100.905,91$ & $94.860,82$ & $96.783,49$ & $104.459,07$ & $94.200,88$ & $772.349,61$ \\
\hline ELEKTRO & $384.509,39$ & $602.297,92$ & $8.607,30$ & $320.272,12$ & $406.424,91$ & $459.398,25$ & 0,00 & $255.143,44$ & $2.986 .653,3$ \\
\hline CPFL & $22.143,40$ & $1.788 .665,86$ & $1.828 .274,09$ & $1.865 .391,56$ & $1.769 .375,11$ & $1.568 .308,62$ & $1.787 .346,81$ & $1.926 .207,91$ & $14.125 .713,36$ \\
\hline BRAGAI & $60.447,37$ & 534,03 & $58.309,20$ & $56.276,28$ & $56.421,04$ & $54.971,70$ & $55.059,52$ & $53.798,13$ & $456.817,27$ \\
\hline CAIUÁ & $6.537,06$ & $.793,59$ & $232.039,33$ & $157.458,53$ & $163.718,46$ & $163.131,16$ & $181.277,33$ & $179.299,52$ & $1.423 .254,98$ \\
\hline JAGUARI & 0,00 & 0,00 & $5.342,07$ & $5.363,82$ & 520,51 & $4.327,77$ & $1.960,42$ & $4.660,26$ & $25.174,8$ \\
\hline MOCOCA & 0,00 & 0,00 & $13.894,82$ & $13.105,02$ & $12.817,45$ & $12.011,29$ & $13.022,21$ & $8.473,17$ & $78.323,96$ \\
\hline CPEE & 0,00 & $1.120,48$ & $10.531,32$ & $10.285,10$ & $9.271,07$ & $8.477,52$ & $8.358,43$ & $10.252,59$ & $58.296,5$ \\
\hline SANTA CRT & $47.784,80$ & 993,81 & $.051,54$ & 4,06 & $68.183,49$ & $58.67 \mathrm{z}$ & $9.529,91$ & 572,05 & $526.992,85$ \\
\hline CSPE & 132,35 & 51,92 & 469,92 & .368,93 & $44.044,65$ & $.019,74$ & 499,21 & $.334,39$ & $5.121,11$ \\
\hline V. PARANAP. & $48.944,81$ & $.648,43$ & $7.264,00$ & $124.760,44$ & $135.034,89$ & $132.975,54$ & $142.164,59$ & $146.271,66$ & $1.112 .064,36$ \\
\hline NACIONAL & $31.644,05$ & $31.672,34$ & $30.151,24$ & $30.016,48$ & $29.926,75$ & $30.165,01$ & & $33.100,91$ & $247.636,89$ \\
\hline ELETRO & $3.211 .872,35$ & $2.890 .129,53$ & $2.643 .543,36$ & $2.411 .898,28$ & $2.170 .315,73$ & $2.535 .108,28$ & $2.332 .799,40$ & $2.644 .790,03$ & $0.456,96$ \\
\hline R. SUDESTE & $14.898 .214,65$ & $17.043 .505,91$ & $17.197 .588,50$ & $15.844 .630,54$ & $16.286 .516,15$ & \begin{tabular}{|l}
$19.539 .308,48$ \\
\end{tabular} & $19.287 .183,41$ & \begin{tabular}{|l|}
$21.012 .434,90$ \\
\end{tabular} & $141.109 .382,5$ \\
\hline COPEL & $2.171 .144,99$ & $9.294,96$ & $0.188,22$ & $2.701 .257,16$ & $\begin{array}{r}2.779 .312,68 \\
\end{array}$ & \begin{tabular}{|r}
$2.756 .756,11$ \\
\end{tabular} & \begin{tabular}{|l|}
$3.080 .478,93$ \\
\end{tabular} & \begin{tabular}{|l|}
$3.197 .281,31$ \\
\end{tabular} & $1.765 .714,36$ \\
\hline COCEL & $11.369,80$ & 0,00 & $\begin{array}{r}15.551,29 \\
\end{array}$ & $\begin{array}{r}26.029,25 \\
\end{array}$ & $27.678,99$ & $27.724,28$ & $32.165,55$ & $35.422,37$ & $175.941,53$ \\
\hline CORONEL VIVIDA & 843,58 & 935,04 & 858,35 & $\begin{array}{r}827,36 \\
\end{array}$ & 851,83 & $1.723,42$ & $.545,72$ & $3.734,03$ & $13.319,3$ \\
\hline CFLO & $.214,43$ & 927,78 & $42.667,91$ & $41.315,87$ & $44.531,43$ & $44.683,20$ & $49.909,27$ & $52.043,62$ & $367.293,51$ \\
\hline CELESC & $.224,81$ & $1.259 .994,40$ & $0.677,33$ & $539.947,53$ & $1.729 .313,49$ & $562.852,90$ & $591.057,08$ & $1.693 .940,73$ & $.389 .008,2$ \\
\hline URUSS & 93,46 & 4,40 & $2.030,53$ & 03,31 & $1.896,60$ & $2.125,39$ & $2.014,56$ & $1.890,04$ & $16.408,2$ \\
\hline XANZ & 349,47 & 50,14 & 720,03 & $15.583,71$ & $13.209,02$ & $12.613,20$ & & 1,04 & $102.970,8$ \\
\hline JOÃO CE & 0,00 & 726,77 & 0,00 & 738,54 & $1.327,92$ & 519,12 & $1.184,07$ & & $4.496,4$ \\
\hline COOPEB & $.675,89$ & $53.506,61$ & $52.950,61$ & $45.864,93$ & $56.402,02$ & $8.616,87$ & $11.398,63$ & $16.583,42$ & $293.998,98$ \\
\hline CEEE & & & $1.102 .176,19$ & $1.052 .257,44$ & $1.148 .306,99$ & $1.170 .763,68$ & & $2.104 .131,48$ & $.383 .893,2$ \\
\hline AES-S & $.415,68$ & 906,99 & $.946,23$ & $776.974,35$ & $8.286,13$ & $841.278,49$ & $912.840,62$ & $940.445,49$ & 6.582 .093$, \\
\hline RGE & $7.848,17$ & $802.717,92$ & $0.040,05$ & $\$ 21.077,06$ & $921.367,21$ & $937.368,75$ & $946.146,34$ & $960.385,48$ & $7.026 .950,98$ \\
\hline ELETB & & & & & $18.466,96$ & $18.866,68$ & & & $157.064,5$ \\
\hline PANA & $7.502,40$ & $\begin{array}{ll}7.684,83 \\
\end{array}$ & $7.878,87$ & $8.361,16$ & $7.991,02$ & $11.475,99$ & $14.237,80$ & $11.774,82$ & 76.906 \\
\hline NOVA PALMA & $6.167,65$ & $6.367,34$ & $6.802,76$ & $6.193,36$ & $6.957,25$ & $6.541,73$ & $8.351,41$ & $8.361,77$ & $55.743,27$ \\
\hline DEMEI & $1.120,14$ & $15.632,53$ & $25.576,99$ & $17.156,72$ & $17.512,25$ & $28.411,97$ & $17.975,13$ & $28.307,13$ & $151.692,8$ \\
\hline MUX & $2.188,76$ & 0,00 & 185,51 & $3.862,41$ & 763,34 & 0,00 & 0,00 & 0,00 & 7.000 \\
\hline R. SUL & $5.364 .727,07$ & \begin{tabular}{|l|l}
$6.493 .886,95$ \\
\end{tabular} & $6.058 .658,27$ & $6.078 .247,64$ & $7.594 .175,13$ & 6.432.321,77 & $7.451 .023,32$ & $9.097 .457,23$ & $4.570 .497,38$ \\
\hline ENERS & $681.668,22$ & $2.831,89$ & $1.048,88$ & $696.987,14$ & $3.809,70$ & & & & $5.255 .168,9$ \\
\hline CEMA & 0,00 & 514,55 & $123.940,68$ & $94.947,82$ & $229.650,23$ & $140.912,92$ & $141.107,97$ & $191.559,40$ & $1.275 .633,5$ \\
\hline CELG & $1.612 .954,23$ & $1.680 .265,69$ & $1.639 .718,14$ & $1.738 .469,59$ & $2.141 .352,15$ & $3.090 .270,79$ & $3.290 .579,24$ & $3.202 .167,18$ & $18.395 .777,01$ \\
\hline CHESP & $50.306,06$ & $50.555,74$ & $47.919,05$ & $48.886,60$ & $55.226,98$ & $52.001,67$ & $53.828,06$ & $59.307,25$ & 418.031, \\
\hline R. CENTRO-OESTE & $2.344 .928,51$ & $2.787 .167,87$ & \begin{tabular}{|l|}
$\mathbf{2 . 5 0 8 . 6 2 6 , 7 5}$ \\
\end{tabular} & $2.579 .291,15$ & $3.060 .039,06$ & \begin{tabular}{|l}
$3.874 .702,59$ \\
\end{tabular} & $4.124 .806,87$ & \begin{tabular}{|l|}
$4.065 .048,09$ \\
\end{tabular} & $25.344 .610,8$ \\
\hline RASII & & & & & & & & & \\
\hline
\end{tabular}


Anexo L - Perdas de receita das distribuidoras decorrentes dos novos consumidores baixa renda -2003

\begin{tabular}{|c|c|c|c|c|c|c|}
\hline DISTRIBUIDORA & JANEIRO & FEVEREIRO & MARCCO & ABRIL & MAIO & JUNHO \\
\hline CERON & $229.522,27$ & $254.846,27$ & $265.040,22$ & $216.488,76$ & $263.696,98$ & $269.119,98$ \\
\hline ELETROACRE & $73.624,02$ & $87.764,81$ & $96.030,59$ & $85.300,19$ & $85.245,50$ & $84.858,76$ \\
\hline BOA VISTA & $5.745,66$ & $6.270,96$ & $6.025,87$ & $1.738,70$ & $12.727,39$ & $14.644,30$ \\
\hline CELPA & $1.751 .947,96$ & $1.909 .036,08$ & $1.856 .066,95$ & $2.063 .401,94$ & $1.866 .067,02$ & $1.966 .739,67$ \\
\hline CELTINS & $694.658,58$ & $726.584,38$ & $685.640,07$ & $759.362,58$ & $708.114,89$ & $756.265,09$ \\
\hline MANAUS & $159.864,80$ & $208.526,14$ & $209.385,49$ & $246.543,94$ & $250.345,64$ & $349,438,00$ \\
\hline R. NORIE & $2.915 .363,29$ & $3.193 .028,64$ & $3.118 .189,19$ & $3.372 .836,11$ & $3.186 .197,42$ & $3.441 .065,80$ \\
\hline CEMAR & $2.533 .204,31$ & $2.920 .773,08$ & $2.347 .619,58$ & $2.690 .005,13$ & $2.690 .005,13$ & $2.660 .060,96$ \\
\hline CEPISA & $1.910 .891,89$ & $1.858 .010,37$ & $1.972 .907,31$ & $1.857 .040,63$ & $1.950 .085,41$ & $1.958 .535,06$ \\
\hline COELCE & $5.227 .353,47$ & $5.006 .607,95$ & $5.095 .907,55$ & $6.199 .197,39$ & $6.199 .197,39$ & $8.216 .603,68$ \\
\hline COSERN & $1.789 .996,61$ & $1.785 .234,31$ & $1.788 .200,63$ & $1.770 .006,46$ & $1.948 .546,02$ & $1.970 .936,03$ \\
\hline S.AELPA & $2.255 .231,36$ & $2.350 .489,79$ & $2.165 .956,04$ & $2.171 .237,04$ & $2.274 .053,18$ & $2.197 .231,13$ \\
\hline CELB & $309.165,61$ & $336.616,01$ & $366.338,45$ & $368.980,70$ & $370.225,47$ & $361.892,47$ \\
\hline CELPE & $3.693 .808,28$ & $3.693 .808,28$ & $3.623 .931,46$ & 4.161.122,09 & $4.700 .036,71$ & $4.760 .660,25$ \\
\hline CEAL & $1.660 .763,71$ & $1.685 .825,48$ & $1.649 .549,49$ & $1.631 .161,35$ & $1.640 .578,63$ & $1.618 .515,47$ \\
\hline ENERGIPE & $1.241 .893,14$ & $1.226 .738,00$ & $1.222 .436,90$ & $1.204 .835,65$ & $1.466 .519,98$ & $1.463 .690,42$ \\
\hline SULGIPE & $324.271,61$ & $315.464,45$ & $300.440,22$ & $311.740,26$ & $307.438,94$ & $304.896,04$ \\
\hline COELBA & $10.007 .737,00$ & $9.794 .443,60$ & $9.839 .018,16$ & $9.940 .378,25$ & $11.843 .493,52$ & $12.413 .069,32$ \\
\hline R. NORDESTE & $30.954 .316,99$ & $30.974 .011,32$ & $30.372 .305,79$ & $32.305 .704,95$ & $35.390 .180,38$ & $37.926 .090,83$ \\
\hline CEMIG & $5.518 .594,83$ & $6.321 .642,07$ & $6.652 .906,10$ & $7.618 .360,89$ & $6.838 .358,52$ & $7.853 .146,11$ \\
\hline CAT-LEO & $608.420,51$ & $608.420,51$ & $583.129,91$ & $588.490,97$ & $594.713,11$ & $606.331,03$ \\
\hline POÇOS DE CALDAS & $50.170,48$ & $50.170,48$ & $52.145,37$ & $55.508,07$ & $53.925,06$ & $55.750,05$ \\
\hline ESCELSA & $1.845 .082,07$ & $1.845 .082,07$ & $1.755 .779,21$ & $1.673 .735,59$ & $1.712 .057,31$ & $1.670 .679,99$ \\
\hline S.ANTA MARIA & $83.461,64$ & $104.150,26$ & $96.963,38$ & $93.281,75$ & $91.286,22$ & $90.642,66$ \\
\hline LIGHT & $4.146 .378,42$ & $3.978 .810,29$ & $3.745 .979,83$ & $4.162 .839,37$ & $4.347 .826,19$ & $4.436 .526,12$ \\
\hline CERJ & $3.027 .544,68$ & $3.344 .763,01$ & $3.237 .511,33$ & $3.167 .626,11$ & $3.315 .085,87$ & $3.305 .208,35$ \\
\hline CENF & $99.294,44$ & $96.766,92$ & $96.357,12$ & $103.608,47$ & $103.521,36$ & $102.584,0 \mathrm{~S}$ \\
\hline ELEKTRO & & & & & $217.822,62$ & $294.325,63$ \\
\hline CPFL & $2.045 .514,24$ & $2.199 .963,11$ & $1.489 .454,59$ & $2.424 .474,21$ & $2.188 .140,48$ & $2.576 .056,68$ \\
\hline BRAG.ANTINA & $51.887,36$ & $87.321,38$ & $64.758,18$ & $69.429,52$ & $64.541,08$ & $66.662,17$ \\
\hline CAIUÁ & $188.779,37$ & $268.520,68$ & $232.039,33$ & $249.756,77$ & $233.698,10$ & $247.690,07$ \\
\hline JAGUARI & $1.934,51$ & 0 & $2.997,08$ & $4.454,63$ & $1.732,75$ & $4.318,38$ \\
\hline MOCOCA & $15.135,38$ & $16.159,13$ & $18.871,49$ & $21.407,29$ & $21.612,96$ & $22,182,63$ \\
\hline CPEE & $8.874,92$ & $9.902,07$ & $13.334,10$ & $17.027,76$ & $12.429,00$ & $14.012,00$ \\
\hline SANTA CRUZ & $43.752,39$ & $265.752,86$ & $46.997,09$ & $111.005,46$ & $92.038,90$ & $106.207,34$ \\
\hline CSPE & $45.292,46$ & $50.138,88$ & $55.333,85$ & $55.889,95$ & $54.804,53$ & $55.004,85$ \\
\hline PARANAPANEMA & $156.888,78$ & $225.867,14$ & $195.546,95$ & $217.203,59$ & $207.436,33$ & $215.216,24$ \\
\hline NACIONAL & $34.601,51$ & $48.099,16$ & $42.438,43$ & $45.269,08$ & $42.846,60$ & $43.521,05$ \\
\hline ELETROPAULO & $2.181 .509,13$ & $2.049 .465,57$ & $1.948 .258,48$ & $1.975 .750,19$ & $2.118 .686,04$ & $1.897 .956,40$ \\
\hline R. SUDESTE & $20.153 .117,12$ & $21.570 .995,59$ & $20.330 .801,82$ & $22.655 .119,67$ & $22.312 .563,03$ & $23.664 .021,83$ \\
\hline COPEL & $3.414 .337,54$ & \begin{tabular}{|l|}
$3.414 .337,54$ \\
\end{tabular} & $3.410 .501,25$ & $3.473 .879,69$ & $3.481 .998,39$ & $3.533 .102,71$ \\
\hline COCEL & $36.270,00$ & $40.551,59$ & $43.311,02$ & $72.368,30$ & $58.593,45$ & $57.047,24$ \\
\hline CORONEL VIVIDA & $3.995,71$ & $4.021,64$ & $4.333,84$ & $4.631,80$ & $4.548,19$ & $4,429,36$ \\
\hline CFLO & $54.429,61$ & $77.429,07$ & $64.223,20$ & $69.615,08$ & $69.615,08$ & $69.615,08$ \\
\hline CELESC & $307.670,77$ & $341.886,67$ & $1.168 .812,88$ & $790.537,86$ & $733.837,68$ & $1.881 .434,98$ \\
\hline URUSSANGA & $1.916,58$ & $2.059,64$ & $2.223,16$ & $2.350,56$ & $3.211,75$ & $3.406,66$ \\
\hline XANXERÊ & $12.934,06$ & $14.988,23$ & $15.671,74$ & $14.797,73$ & $16.734,95$ & $16.758,17$ \\
\hline JOÃO CESA & $2.174,69$ & $2.381,37$ & & $1.729,45$ & $1.243,91$ & $1.021,26$ \\
\hline COOPERALIANCCA & & $13.650,53$ & $15.849,62$ & $7.147,19$ & $31.755,99$ & $16.839,68$ \\
\hline CEEE & $2.350 .489,40$ & $2.316 .127,86$ & $2.426 .624,79$ & $2.140 .619,34$ & $1.827 .312,58$ & $1.704 .470,49$ \\
\hline AES-SUL & $973.709,33$ & $973.591,86$ & $947.841,80$ & $984.656,18$ & $1.096 .641,14$ & $1.138 .854,82$ \\
\hline RGE & $956.803,41$ & $993.680,13$ & $1.007 .631,39$ & $1.083 .372,92$ & $1.365 .665,43$ & $1.293 .337,49$ \\
\hline ELETROCAR & $29.779,33$ & $30.251,94$ & $30.268,10$ & $30.086,20$ & $30.500,04$ & $29.525,67$ \\
\hline PANAMBI & $12.245,32$ & $12.725,23$ & $12.066,92$ & $12.962,55$ & $12.718,91$ & $13.311,08$ \\
\hline NOVA PALMA & $9.106,75$ & $8.408,43$ & $9.097,90$ & $10.046,91$ & $10.181,42$ & $10.463,47$ \\
\hline DEMEI & $17.241,10$ & $17.241,10$ & $18.408,12$ & $19.005,64$ & $18.775,91$ & $19.277,50$ \\
\hline MUXFELDT & 343,7 & 0 & 0,00 & $3.140,68$ & 64,54 & $1.924,83$ \\
\hline R. SUL & $8.183 .447,30$ & $8.263 .332,83$ & $9.176 .865,73$ & $8.720 .948,08$ & $8.763 .399,36$ & $9.794 .820,49$ \\
\hline ENERSUL & $583.640,94$ & $609.018,80$ & $609.714,23$ & $700.619,07$ & $\$ 54.370,07$ & $877.159,87$ \\
\hline CEMAT & $230.443,01$ & $312.871,02$ & $274.725,76$ & $664.529,84$ & $777.700,20$ & $50.233,72$ \\
\hline CELG & $3.115 .889,88$ & $3.124 .568,64$ & $3.158 .728,47$ & $2.816 .699,47$ & $3.230 .382,57$ & $4.465 .099,60$ \\
\hline CHESP & $60.019,26$ & $59.245,98$ & $57.002,66$ & $60.641,89$ & $61.296,25$ & $60.710,49$ \\
\hline R. CENTRO-OESII & $3.989 .993,09$ & 4.105.704,44 & $4.100 .171,12$ & 4.242.490,27 & $4.923 .749,09$ & $5.453 .203,68$ \\
\hline BRASIL & s & 7.072,82 & $67.098 .333,65$ & $71.297 .099,08$ & 74.576.089,28 & $80.279 .202,63$ \\
\hline
\end{tabular}


Anexo L - Perdas de receita das distribuidoras decorrentes dos novos consumidores baixa renda - 2003 (continuação)

\begin{tabular}{|c|c|c|c|c|c|c|c|}
\hline DISTRIBUIDORA & ЛULНО & AGOSTO & SETEMBRO & OUTUBRO & NOVEMBRO & DEZEMBRO & TOTAL 2003 \\
\hline CERON & $237.107,96$ & $302.973,06$ & $294.598,53$ & $274.124,08$ & & & $2.607 .518,11$ \\
\hline ELETROACRE & $\$ 4.733,44$ & $88.776,44$ & $96.763,51$ & $89.163,50$ & & & $872.260,76$ \\
\hline BOA VISTA & $19.836,86$ & $3.463 .004,63$ & $5.927,14$ & & & $1.428,59$ & $3.537 .350,10$ \\
\hline CELPA & $1.880 .681,18$ & $3.209 .096,26$ & $2.479 .645,39$ & $2.447 .355,74$ & $2.589 .490,34$ & $2.509 .173,39$ & $26.528 .701,92$ \\
\hline CELTINS & $991.310,64$ & $1.002 .501,37$ & $979.796,40$ & $988.623,72$ & $1.019 .164,08$ & & $9.312 .021,80$ \\
\hline MANAUS & $339.021,26$ & $272.902,13$ & $301.159,69$ & $320.398,53$ & $305.930,19$ & $346.673,83$ & $3.310 .189,64$ \\
\hline R. NORTE & $3.552 .691,34$ & $8.339 .253,89$ & $4.157 .890,66$ & $4.119 .665,57$ & $3.914 .584,61$ & $2.857 .275,81$ & $46.168 .042,33$ \\
\hline CEMAR & $2.608 .813,21$ & $2.717 .516,44$ & $3.171 .660,71$ & $3.539 .488,46$ & $3.560 .438,80$ & $3.719 .010,72$ & $35.158 .596,53$ \\
\hline CEPISA & $1.986 .190,15$ & $365.256,10$ & $2.208 .733,51$ & $2.484 .309,17$ & $2.546 .407,71$ & $2.491 .630,17$ & $23.589 .997,48$ \\
\hline COELCE & $7.014 .617,23$ & $7.020 .809,59$ & $6.995 .971,31$ & $7.425 .045,87$ & $7.435 .513,13$ & $7.616 .442,71$ & $79.453 .267,27$ \\
\hline COSERN & $2.042 .635,69$ & $2.041 .292,03$ & $2.038 .573,01$ & $2.027 .559,86$ & $2.035 .018,31$ & $2.027 .055,19$ & $23.265 .054,15$ \\
\hline S.AELPA & $2.138 .273,12$ & $2.217 .139,06$ & $2.714 .496,64$ & $3.039 .233,91$ & $3.044 .069,03$ & $3.123 .657,17$ & $29.691 .067,47$ \\
\hline CELB & $346.390,63$ & $360.311,43$ & $371.552,77$ & $379.120,61$ & $382.819,55$ & $388.553,96$ & $4.341 .967,66$ \\
\hline CELPE & $4.988 .357,22$ & $5.054 .543,05$ & $5.220 .873,76$ & $5.328 .461,96$ & $5.299 .514,77$ & $5.252 .781,38$ & $55.777 .899,21$ \\
\hline CEAL & $1.597 .742,35$ & $1.694 .154,85$ & $2.294 .508,45$ & $2.012 .481,54$ & $2.028 .051,80$ & $2.039 .745,31$ & $21.553 .078,43$ \\
\hline ENERGIPE & $1.405 .867,48$ & $1.471 .785,58$ & $1.476 .889,25$ & $1.582 .496,54$ & $1.581 .434,62$ & $1.578 .927,54$ & $16.923 .515,10$ \\
\hline SULGIPE & $302.463,71$ & $303.606,79$ & $306.170,72$ & $305.052,22$ & $312.480,49$ & $367.107,57$ & $3.761 .133,02$ \\
\hline COELBA & $12.689 .151,62$ & $12.692 .461,50$ & $12.623 .945,67$ & $13.080 .465,53$ & $13.263 .174,55$ & $13.320 .124,77$ & $141.507 .463,49$ \\
\hline R. NORDESTE & $37.120 .502,41$ & $35.938 .876,42$ & $39.423 .375,80$ & $41.203 .715,67$ & 41.488.922,76 & $41.925 .036,49$ & $435.023 .039,81$ \\
\hline CEMIG & $8.016 .214,18$ & $7.840 .463,05$ & $8.845 .094,76$ & $8.084 .168,12$ & $7.787 .342,79$ & $9.449 .002,62$ & $90.825 .294,04$ \\
\hline CAT-LEO & $743.307,45$ & $759.514,85$ & $800.971,06$ & $870.589,52$ & $858.714,96$ & $877.500,82$ & $8.500 .104,70$ \\
\hline POÇOS DE CALDAS & $59.602,31$ & $65.013,62$ & $67.821,94$ & $73.975,79$ & $78.987,23$ & $79.403,79$ & $742.474,19$ \\
\hline ESCELSA & $1.676 .358,95$ & $1.728 .379,95$ & $1.934 .812,32$ & $1.977 .165,03$ & $1.991 .705,53$ & $2.042 .763,67$ & $21.853 .601,69$ \\
\hline SANTA MARIA & $90.105,46$ & $92.799,28$ & $92.645,15$ & $95.690,84$ & $98.176,16$ & $98.112,32$ & $1.127 .315,12$ \\
\hline LIGHT & $4.671 .887,81$ & $4.690 .212,71$ & $4.720 .055,69$ & $4.836 .726,84$ & $4.767 .191,89$ & $4.672 .027,90$ & $53.176 .463,06$ \\
\hline CERJ & $3.129 .219,46$ & $3.330 .259,56$ & $3.276 .237,79$ & $4.258 .702,68$ & $4.338 .086,26$ & $4.422 .119,27$ & $42.152 .364,37$ \\
\hline CENF & $123.313,72$ & $127.366,29$ & $128.896,29$ & $135.695,86$ & $133.853,87$ & $132.744,96$ & $1.384 .003,38$ \\
\hline ELEKTRO & $323.094,67$ & $175.407,62$ & $537.351,96$ & $297.693,25$ & & $221.748,39$ & $2.067 .444,14$ \\
\hline CPFL & $2.379 .712,95$ & $2.443 .399,36$ & & & & & $17.746 .715,62$ \\
\hline BRAGANTINA & $64.536,43$ & $68.462,68$ & 65962,67 & $67.446,15$ & $71.093,52$ & $71.543,05$ & $813.644,19$ \\
\hline CAIUA & $244.474,38$ & $255.071,88$ & $254.422,12$ & $264.646,37$ & $280.606,45$ & $277.807,00$ & $2.997 .512,52$ \\
\hline JAGUARI & $3.441,08$ & $1.142,08$ & $2.624,05$ & $1.761,09$ & & $2.044,61$ & $26.450,26$ \\
\hline MOCOCA & $23.297,20$ & $22.980,37$ & $24.980,91$ & $32.454,77$ & $32.534,24$ & $33.156,15$ & $284.772,52$ \\
\hline CPEE & $14.415,14$ & $9.187,68$ & $14.268,13$ & $12.345,60$ & $8.966,77$ & $12.890,42$ & $147.653,59$ \\
\hline SANTA CRUZ & $99.621,29$ & $103.062,38$ & $86.912,09$ & $88.071,36$ & $77.572,08$ & $107.405,28$ & $1.228 .398,52$ \\
\hline CSPE & $56.257,92$ & $55.451,08$ & $55.427,97$ & $55.314,51$ & $55.413,08$ & $58.427,14$ & $652.756,22$ \\
\hline V. PARANAPANEMA & $212.005,58$ & $222.415,11$ & $221.789,54$ & $225.388,20$ & $238.033,91$ & $236.227,56$ & $2.574 .018,93$ \\
\hline NACIONAL & $43.622,34$ & $45.367,45$ & $45.818,74$ & $45.839,72$ & $48.866,98$ & $48.649,16$ & $534.940,22$ \\
\hline ELETROPAULO & $2.115 .262,57$ & $2.273 .454,37$ & $2.142 .542,23$ & $2.096 .168,83$ & $2.221 .670,80$ & $2.292 .252,74$ & $25.312 .977,35$ \\
\hline R. SUDESTE & $24.089 .750,89$ & $24.309 .411,37$ & $23.318 .635,41$ & $23.519 .844,53$ & $23.088 .816,52$ & $25.135 .826,85$ & $274.148 .904,63$ \\
\hline COPEL & $6.004 .925,94$ & $6.065 .291,37$ & $5.414 .709,41$ & $5.672 .972,96$ & $6.002 .128,45$ & $6.082 .984,73$ & $55.971 .169,98$ \\
\hline COCEL & $55.843,52$ & $42.386,12$ & $55.074,07$ & $57.243,68$ & $57.853,59$ & $59.950,27$ & $636.492,85$ \\
\hline CORONEL VIVIDA & $4.422,57$ & $4.660,68$ & $5.576,59$ & $6.520,10$ & $8.325,87$ & $9.369,55$ & $64.835,90$ \\
\hline CFLO & $69.615,08$ & $69.615,08$ & $69.615,08$ & $69.555,31$ & $69.615,08$ & $73.548,76$ & $\$ 26.491,51$ \\
\hline CELESC & $842.947,03$ & $901.908,90$ & $2.295 .285,12$ & $977.044,24$ & $950.095,41$ & $2.219 .491,54$ & $13.410 .953,08$ \\
\hline URUSSANGA & $3.563,03$ & $3.516,92$ & $3.507,86$ & $3.719,18$ & $3.652,34$ & $3.842,00$ & $36.969,68$ \\
\hline XANXERE & $17.579,87$ & $30.999,35$ & $23.375,07$ & $23.432,67$ & $24.246,18$ & $24.962,36$ & $236.480,38$ \\
\hline JOÃO CESA & 745,89 & $2.493,62$ & $2.606,49$ & $1.233,65$ & $1.570,61$ & $1.152,88$ & $18.353,82$ \\
\hline COOPERALIANCA & $31.254,42$ & $27.597,24$ & $25.443,14$ & $26.603,52$ & $31.529,40$ & $28.236,39$ & $255.907,12$ \\
\hline CEEE & $1.716 .626,58$ & $1.716 .577,07$ & $1.613 .162,43$ & $1.792 .810,55$ & $2.368 .150,14$ & $2.049 .773,09$ & $24.022 .744,32$ \\
\hline AES-SUL & $1.152 .582,78$ & $1.174 .127,12$ & $1.195 .481,38$ & $1.250 .212,08$ & $1.295 .645,22$ & $1.302 .424,69$ & $13.485 .768,40$ \\
\hline RGE & $1.364 .185,87$ & $1.388 .279,12$ & $1.427 .659,15$ & $1.500 .109,87$ & $1.524 .717,58$ & $1.583 .967,71$ & $15.489 .410,07$ \\
\hline ELETROCAR & $35.162,04$ & $40.747,57$ & $41.635,34$ & $47.746,15$ & $44.635,84$ & $45.380,07$ & $435.718,29$ \\
\hline PANAMBI & $16.675,12$ & $16.675,12$ & $20.901,20$ & $19.688,32$ & $20.105,18$ & $19.637,62$ & $189.712,57$ \\
\hline NOVA PALMA & $10.768,32$ & $11.041,18$ & $10.477,21$ & $10.523,14$ & $9.690,26$ & $12.460,70$ & $122.265,69$ \\
\hline DEMEI & $22.088,63$ & $3.745,94$ & $33.490,48$ & $35.033,45$ & $37.221,50$ & $38.644,85$ & $280.174,22$ \\
\hline MUXFELDT & $6.056,88$ & $4.680,67$ & $2.691,95$ & $5.749,01$ & & $4.961,09$ & $29.613,35$ \\
\hline R. SUL & $11.355 .043,57$ & $11.504 .343,07$ & $12.240 .691,97$ & $11.500 .197,88$ & $12.449 .182,65$ & $13.560 .788,30$ & $125.513 .061,23$ \\
\hline ENERSUL & $910.946,61$ & $918.629,60$ & $936.827,52$ & $957.140,59$ & $959.596,24$ & $970.201,35$ & $9.887 .864,89$ \\
\hline CEMAT & $489.192,62$ & $490.274,85$ & $486.048,65$ & $361.422,96$ & $462.938,79$ & $495.058,28$ & $5.095 .439,70$ \\
\hline CELG & $4.679 .401,65$ & $14.928,89$ & $3.581 .637,00$ & $4.026 .670,37$ & $3.979 .582,24$ & $3.967 .807,23$ & $40.161 .396,01$ \\
\hline CHESP & $58.057,91$ & $62.631,73$ & $80.437,82$ & $84.900,63$ & $\$ 2.040,71$ & $79.567,27$ & $806.552,60$ \\
\hline R.CENTRO-OESTE & $6.137 .598,79$ & $1.486 .465,07$ & $5.084 .950,99$ & $5.430 .134,55$ & $\mathbf{5 . 4 8 4 . 1 5 7 , 9 8}$ & $5.512 .634,13$ & $55.951 .253,20$ \\
\hline BRASL & $82.255 .587,00$ & $81.578 .349,82$ & $84.225 .544,83$ & $85.773 .558,20$ & $86.425 .664,52$ & 88.991.561,58 & $936.804 .301,20$ \\
\hline
\end{tabular}


Anexo M - Perdas de receita das distribuidoras decorrentes dos novos consumidores baixa renda - $\mathbf{1}^{\circ}$ semestre 200404

\begin{tabular}{|c|c|c|c|c|c|c|c|}
\hline DISTRIBUIDORA & JANEIRO & FEVEREIRO & MARÇO & ABRIL & MAIO & JUNHO & $\begin{array}{c}\text { TOTAL } \\
\text { I' }^{\circ} \text { sem. } 2004\end{array}$ \\
\hline CERON & $325.906,24$ & $360.862,73$ & & & & $235.843,15$ & $922.612,12$ \\
\hline ELETROACRE & & $103.636,26$ & $14.167,09$ & $45.304,74$ & & & $163.108,09$ \\
\hline BOA VISTA & & $6.164,84$ & & & $*$ & $*$ & $6.164,84$ \\
\hline CELPA & $2.637 .915,44$ & $2.816 .334,47$ & $2.598 .209,56$ & $3.160 .113,38$ & $2.950 .644,18$ & $3.031 .445,50$ & $17.194 .662,53$ \\
\hline CELTINS & $1.007 .507,02$ & $1.020 .402,02$ & $980.551,66$ & $1.062 .370,34$ & $1.019 .858,68$ & $1.040 .534,19$ & $6.131 .223,91$ \\
\hline MANAUS & $370.810,00$ & $417.336,32$ & $268.210,46$ & * & * & * & $1.056 .356,78$ \\
\hline R. NORTE & $4.342 .138,70$ & $4.724 .736,64$ & $3.861 .138,77$ & $4.267 .788,46$ & $3.970 .502,86$ & $4.307 .822,84$ & $25.474 .128,27$ \\
\hline CEMAR & $3.620 .185,73$ & $3.657 .734,27$ & $3.329 .816,19$ & $3.492 .472,19$ & $3.430 .957,17$ & $3.482 .446,39$ & $21.013 .611,94$ \\
\hline CEPISA & $2.565 .741,36$ & $2.438 .029,64$ & $2.514 .062,70$ & $2.576 .202,70$ & $2.600 .122,33$ & $2.567 .107,09$ & $15.261 .265,82$ \\
\hline COELCE & $8.073 .030,48$ & $7.647 .543,18$ & $8.582 .384,88$ & $8.659 .657,44$ & $8.708 .504,51$ & $8.985 .435,35$ & $50.656 .555,84$ \\
\hline COSERN & $2.047 .011,64$ & $2.034 .465,68$ & $1.700 .331,91$ & $1.711 .098,11$ & $1.894 .977,62$ & $1.985 .509,75$ & $11.373 .394,71$ \\
\hline SAELPA & $3.190 .751,05$ & $3.019 .650,25$ & $3.080 .939,04$ & $3.077 .425,32$ & $2.982 .480,31$ & $2.955 .661,09$ & 18.306.907,06 \\
\hline CELB & $405.533,33$ & $415.220,75$ & $453.262,41$ & $458.555,92$ & $438.784,83$ & $439.718,35$ & $2.611 .075,59$ \\
\hline CELPE & $5.360 .458,72$ & $5.371 .333,92$ & $4.761 .056,69$ & $5.815 .993,79$ & $5.542 .566,72$ & $5.609 .741,55$ & $32.461 .151,39$ \\
\hline CE.AL & $2.107 .786,43$ & $2.081 .135,17$ & $2.061 .437,16$ & $2.261 .489,98$ & $2.247 .835,61$ & $2.255 .635,63$ & $13.015 .319,9 \mathrm{~s}$ \\
\hline ENERGIPE & $1.683 .828,04$ & $1.591 .186,91$ & $1.661 .673,11$ & $1.791 .644,99$ & $1.813 .033,32$ & $1.740 .005,63$ & $10.281 .372,00$ \\
\hline SULGIPE & $327.425,39$ & $401.409,33$ & $382.451,72$ & $394.646,19$ & $390.141,54$ & $392.506,82$ & $2.288 .580,99$ \\
\hline COELBA & $13.939 .483,55$ & $13.370 .917,86$ & $13.455 .533,76$ & $14.000 .397,57$ & $14.713 .561,34$ & $14.749 .891,98$ & $84.229 .786,06$ \\
\hline R. NORDESTE & $43.321 .235,72$ & $42.028 .626,96$ & $41.982 .949,57$ & \begin{tabular}{|l|}
$44.239 .584,20$ \\
\end{tabular} & $44.762 .965,30$ & \begin{tabular}{|l|l|}
$45.163 .659,63$ \\
\end{tabular} & $261.499 .021,38$ \\
\hline CEMIG & $7.704 .154,75$ & $9.692 .249,42$ & $3.858 .555,32$ & $2.470 .975,48$ & $3.328 .018,82$ & $4.130 .803,95$ & $31.184 .757,74$ \\
\hline CAT-LEO & $943.050,39$ & $902.722,97$ & $966.024,52$ & $984.902,74$ & $958.930,50$ & $1.047 .024,34$ & $5.802 .655,46$ \\
\hline POCOOS DE CALDAS & $80.572,45$ & $79.903,27$ & $80.731,60$ & $80.955,70$ & $79.508,76$ & $79.583,16$ & $481.254,94$ \\
\hline ESCELSA & $2.186 .165,19$ & $2.150 .219,03$ & $2.147 .476,69$ & $1.962 .574,80$ & $1.966 .199,30$ & $1.918 .873,97$ & $12.331 .508,98$ \\
\hline SANTA MARIA & $101.698,07$ & $127.025,74$ & $112.738,94$ & $121.929,08$ & $116.121,62$ & $114,635,98$ & $694.149,43$ \\
\hline LIGHT & $4.708 .523,61$ & $4.662 .679,48$ & $4.940 .049,78$ & $5.021 .458,23$ & $5.002 .951,04$ & $5.150 .439,22$ & $29.486 .101,36$ \\
\hline CERJ & & $5.190 .128,86$ & $7.309 .139,12$ & $8.767 .504,42$ & $9.044 .483,08$ & $8.842 .929,67$ & $39.154 .185,15$ \\
\hline CENF & $140.059,35$ & $134.348,13$ & $142.191,15$ & $143.047,94$ & $139.769,61$ & $159.929,72$ & $859.345,90$ \\
\hline ELEKTRO & & & & & * & $*$ & 0,00 \\
\hline CPFL & & & & & & & 0,00 \\
\hline BRAGANTINA & $73.441,09$ & $73.084,01$ & $34.481,65$ & $47.445,36$ & $42.371,10$ & $43.453,38$ & $314.276,59$ \\
\hline CAIUA & $293.512,64$ & $281.990,87$ & $278,609,35$ & $303.864,02$ & $276.811,78$ & $276.667,11$ & $1.711 .455,77$ \\
\hline IAGUARI & 189,2 & $3.387,20$ & & & $*$ & $*$ & $3.576,40$ \\
\hline MOCOCA & $33.300,35$ & $44.434,49$ & $25.534,74$ & $26.513,37$ & $27.338,76$ & $26.778,38$ & $183.900,09$ \\
\hline CPEE & $9.137,76$ & $29.898,50$ & & & $*$ & $*$ & $39.036,26$ \\
\hline SANTA CRUZ & $65.085,90$ & $186.502,90$ & & & $*$ & * & $251.588,80$ \\
\hline CSPE & $56.451,49$ & $77.184,31$ & $39.565,06$ & $43.834,72$ & $47.033,99$ & $47.419,57$ & $311.489,14$ \\
\hline PARANAPANEMA & $252.169,28$ & $272.484,81$ & $255.260,20$ & $275.753,64$ & $256.123,79$ & $262.217,66$ & $1.574 .009,38$ \\
\hline NACIONAL & $51.709,83$ & $47.707,40$ & $45.188,02$ & $50.010,96$ & $45.990,94$ & $45.794,16$ & $286.401,31$ \\
\hline ELETROPAULO & $2.314 .394,28$ & $2.481 .005,74$ & $633.859,19$ & $530.557,60$ & $682.057,71$ & $600.219,24$ & $7.242 .093,76$ \\
\hline R. SUDESTE & $19.013 .615,63$ & $26.436 .957,13$ & $20.869 .405,33$ & \begin{tabular}{|l|}
$20.831 .328,06$ \\
\end{tabular} & 22.013.710,80 & $22.746 .769,51$ & $131.911 .786,46$ \\
\hline COPEL & $5.803 .396,50$ & $5.742 .484,08$ & $5.149 .922,86$ & $5.323 .925,46$ & $5.181 .329,34$ & $5.362 .897,44$ & $32.563 .955,68$ \\
\hline COCEL & $63.066,61$ & $64.201,41$ & $64.713,14$ & $\$ 1.691,72$ & $78.972,78$ & $77.685,63$ & $430.331,29$ \\
\hline CORONEL VIVIDA & $9.834,99$ & $10.235,86$ & $10.743,44$ & $12.695,36$ & $12.182,26$ & $12.204,59$ & $67.896,50$ \\
\hline CFLO & $78.518,81$ & $77.922,56$ & $64.899,93$ & $71.170,82$ & $63.133,72$ & $64.200,85$ & $419.846,69$ \\
\hline CELESC & $973.357,12$ & $1.170 .666,06$ & $2.254 .359,39$ & $932.550,85$ & $1.056 .045,18$ & $2.702 .151,83$ & $9.089 .130,43$ \\
\hline URUSSANGA & $3.744,40$ & $4.126,44$ & $4.194,86$ & $4.127,44$ & $3.740,43$ & $3.842,17$ & $23.775,74$ \\
\hline IGUACCU ENERGIA & $25.994,28$ & $25.851,89$ & $19.440,73$ & $20.434,06$ & $20.058,24$ & $18.975,35$ & $130.754,55$ \\
\hline JOÃO CESA & $3.198,37$ & $2.404,99$ & * & * & * & $*$ & $5.603,36$ \\
\hline COOPERALIANCCA & & & $10.034,17$ & $7.367,81$ & $34.774,61$ & $24.679,82$ & $76.856,41$ \\
\hline CEEE & $2.200 .701,52$ & $2.216 .442,99$ & $1.862 .867,03$ & $1.546 .935,68$ & $1.517 .885,06$ & & $9.344 .832,28$ \\
\hline AES-SUL & $1.355 .950,67$ & $1.357 .982,87$ & $984.656,18$ & $1.413 .892,37$ & $1.237 .505,09$ & $1.268 .575,29$ & $7.618 .562,47$ \\
\hline RGE & $1.605 .543,71$ & $1.635 .996,05$ & $1.395 .065,03$ & $1.487 .325,60$ & $1.494 .197,63$ & $1.473 .417,12$ & $9.091 .545,14$ \\
\hline ELETROCAR & $46.731,59$ & $47.623,95$ & $47.293,66$ & $46.926,00$ & $45.516,62$ & $44.854,06$ & $278.945,88$ \\
\hline PANAMBI & $20.877,80$ & $20.881,97$ & $18.327,65$ & $19.528,78$ & $18.150,35$ & $18.043,37$ & $115.809,92$ \\
\hline NOVA PALMA & $12.917,53$ & $14.966,65$ & $16.186,27$ & $16.213,50$ & $15.596,32$ & $15.707,12$ & $91.587,39$ \\
\hline DEMEI & $38.208,48$ & $41.212,58$ & $42.855,47$ & $33.007,32$ & $33.267,67$ & $33.065,20$ & $221.616,72$ \\
\hline MUXFELDT & 886,48 & 718,19 & & & & & $1.604,67$ \\
\hline R. SUL & $12.242 .928,86$ & $12.433 .718,54$ & $11.945 .559,81$ & \begin{tabular}{|l|}
$11.017 .792,77$ \\
\end{tabular} & $10.812 .355,30$ & $11.120 .299,84$ & $69.572 .655,12$ \\
\hline ENERSUL & $971.126,24$ & $983.756,39$ & $915.606,60$ & $8 S 8.927,43$ & $960.660,26$ & $979.959,66$ & $5.700 .036,58$ \\
\hline CEMAT & $568.081,43$ & $636.226,21$ & $77.768,41$ & & * & & $1.282 .076,05$ \\
\hline CELG & $4.123 .333,61$ & $4.045 .051,13$ & $4.161 .453,17$ & $4.198 .571,26$ & $4.135 .713,60$ & $4.255 .708,43$ & $24.919 .831,20$ \\
\hline CHESP & $85.288,22$ & $\$ 1.752,55$ & $78.976,46$ & $\$ 5.354,78$ & $85.419,82$ & $\$ 3.801,86$ & $500.593,69$ \\
\hline R. CENTRO-OESTE & $5.747 .829,50$ & $5.746 .786,28$ & $5.233 .804,64$ & $5.172 .853,47$ & $5.181 .793,68$ & $5.319 .469,95$ & $32.402 .537,52$ \\
\hline BRASL & $84.667 .748,41$ & 91.370.825,55 & $83.892 .858,12$ & 85.529.346,96 & $86.741 .327,94$ & $88.658 .021,77$ & $520.860 .128,75$ \\
\hline
\end{tabular}




\section{Anexo N - Leis e regulamentos relevantes}

\section{LEIS}

Lei $n^{0}$ 4.504, de 30 de novembro de 1964. Dispõe sobre o Estatuto da Terra, e dá outras providências.

Lei $\mathbf{n}^{0}$ 4.156, de 28 de novembro de 1962. Altera a legislação sobre o Fundo Federal de Eletrificação e dá outras providências.

Lei $n^{0}$ 5.655, de 20 de maio de 1971. Dispõe sobre a Remuneração Legal do Investimento dos concessionários de serviços públicos de energia elétrica e dá outras providências.

Lei $\mathbf{n}^{\mathbf{0}}$ 5.764, de 16 de dezembro de 1971. Define a política nacional de cooperativismo, institui o regime jurídico das sociedades cooperativas e dá outras providências.

Lei $n^{0}$ 6.766, de 19 de dezembro de 1979. Dispõe sobre o Parcelamento do Solo Urbano e dá outras Providências.

Lei $n^{0}$ 8.631, de 04 de março de 1993. Dispõe sobre a fixação dos níveis das tarifas para o Serviço Público de Energia Elétrica, extingue o regime de remuneração garantida e dá outras providências.

Lei $n^{0}$ 8.987, de 13 de fevereiro de 1995. Dispõe sobre o Regime de Concessão e Permissão da Prestação de Serviços Públicos previsto no art. 175 da Constituição Federal e dá outras providências.

Lei $\mathbf{n}^{\mathbf{0}}$ 9.074, de 7 de julho de 1995. Estabelece normas para outorga e prorrogações das concessões e permissões de serviços públicos e dá outras providências.

Lei $\mathbf{n}^{0}$ 9.427, de 26 de dezembro de 1996. Institui a Agência Nacional de Energia Elétrica - Aneel, disciplina o Regime das Concessões de serviços públicos de energia elétrica e dá outras providências.

Lei $\mathbf{n}^{\circ}$ 9.472, de 16 de julho de 1997. Dispõe sobre a organização dos serviços de telecomunicações, a criação e funcionamento de um órgão regulador e outros aspectos institucionais, nos termos da Emenda Constitucional nº 8, de 1995.

Lei $\mathrm{n}^{\circ}$ 9.785, de 29 de janeiro de 1999. Altera o Decreto-Lei $\mathrm{n}^{\circ} 3.365 / 41$ (desapropriação por utilidade pública) e as Leis $n^{\text {os }} 6.015 / 73$ (registros públicos) e 6.766/79 (parcelamento do solo urbano).

Lei $\mathbf{n}^{0}$ 10.219, de 11 de abril de 2001. Cria o Programa Nacional de Renda Mínima vinculada à educação - "Bolsa Escola", e dá outras providências.

Lei $\mathbf{n}^{\mathbf{0}} \mathbf{1 0 . 4 3 8}$, de 26 de abril de 2002. Dispõe sobre a expansão da oferta de energia elétrica emergencial, recomposição tarifária extraordinária e universalização do Serviço Público de Energia Elétrica, cria o Programa de Incentivo às Fontes Alternativas de Energia Elétrica - Proinfa, a Conta de Desenvolvimento Energético $\mathrm{CDE}$, dá nova redação às Leis $\mathrm{n}^{\text {os }}$ 9.427/96, 9.648/98, 3.890-A/61, 5.655/71, 5.899/73, 9.991/2000, prorroga o prazo para entrada em operação das Usinas enquadradas no Programa Prioritário de Termeletricidade e dá outra providências. 
Lei $\mathrm{n}^{\mathbf{0}} \mathbf{1 0 . 6 0 4}$, de 17 de dezembro de 2002. Dispõe sobre recursos para subvenção a consumidores de energia elétrica da Subclasse Residencial Baixa Renda; sobre os contratos de compra e venda, e os de fornecimento de energia elétrica, dá nova redação aos artigos 27 e 28 da Lei 10.438 de 26.04.2002, e dá outras providências.

Lei $n^{0}$ 10.762, de 11 de novembro de 2003. Dispõe sobre a criação do Programa Emergencial e Excepcional de Apoio às Concessionárias de Serviços Públicos de Distribuição de Energia Elétrica, altera os arts. $8^{\circ}$ e 10 da Lei $n^{\circ} 8.631 / 93$, os arts. 17 e 26 da Lei $n^{\circ} 9.427 / 96$, e os arts. $3^{\circ}, 5^{\circ}, 13,14$ e 25 da Lei ${ }^{\circ} 10.438 / 2002$ e acrescenta o inciso III ao parág. $4^{\circ}$ do art. 11 da Lei $n^{\circ} 9.648 / 98$.

Lei $\mathbf{n}^{\mathbf{0}} \mathbf{1 0 . 8 3 5}$, de 8 de janeiro de 2004. Institui a renda básica de cidadania e dá outras providências.

Lei $\mathbf{n}^{\mathbf{0}}$ 10.836, de 9 de janeiro de 2004. Cria o Programa Bolsa Família e dá outras providências.

Lei $\mathbf{n}^{0}$ 10.848, de 15 de março de 2004. Dispõe sobre a comercialização de energia elétrica, altera as Leis ${ }^{\text {os }} 5.655 / 71,8.631 / 93,9.074 / 95,9.427 / 96,9.478 / 97,9.648 / 98$, 9.991/2000, 10.438/2002, e dá outras providências.

\section{MEDIDAS PROVISÓRIAS}

Medida Provisória $n^{0}$ 2.206-1, de 6 de setembro de 2001. Cria o Programa Nacional de Renda Mínima vinculado à saúde: "Bolsa-Alimentação" e dá outras providências.

Medida Provisória no 14, de 21 de dezembro de 2001. Dispõe sobre a expansão da oferta de energia elétrica pela Comercializadora Brasileira de Energia Emergencial - CBEE, bem como os custos relativos à aquisição de energia que serão rateados entre consumidores finais atendidos pelo Sistema Elétrico Nacional Interligado. Convertida na Lei $\mathrm{n}^{\circ}$ 10.438/2002.

Medida Provisória $\mathrm{n}^{\circ}$ 64, de 26 de agosto de 2002. Estabelece exceção ao alcance do artigo $2^{\circ}$ da Lei $\mathrm{n}^{\circ}$ 10.192/2001, que dispõe sobre medidas complementares ao Plano Real, altera a redação dos artigos 27 e 28 da Lei ${ }^{\circ}$ 10.438/2002, e dá outras providências. Convertida na Lei $n^{\circ}$ 10.604/2002.

Medida Provisória no 108, de 27 de fevereiro de 2003. Cria o Programa Nacional de Acesso à Alimentação - PNAA. Convertida na Lei no 10.689/2003.

Medida Provisória n⿳ 127, de 4 de agosto de 2003. Dispõe sobre a criação do Programa Emergencial e Excepcional de Apoio às Concessionárias de Serviços Públicos de Distribuição de Energia Elétrica e dá outras providências. Convertida na Lei $\mathrm{n}^{\circ} 10.762 / 2003$.

Medida Provisória $n^{0}$ 132, de 20 de outubro de 2003. Cria o Programa Bolsa Família e dá outras providências. Convertida na Lei nº 10.836/2004.

\section{DECRETOS}

Decreto $n^{0}$ 41.019, de 26 de fevereiro de 1957. Regulamenta o Código de Águas. 
Decreto $\mathrm{n}^{\mathbf{0}}$ 1.033, de 22 de maio de 1962. Altera o art. 177, do Decreto $\mathrm{n}^{\circ}$ 41.019/57, que passa, a ter a seguinte alínea: XI - cooperativas rurais.

Decreto $n^{0}$ 62.655, de 3 de maio de 1968. Regulamenta a execução de serviços de eletrificação rural mediante autorização para uso privativo e revoga o Decreto $\mathrm{n}^{\circ}$ $1.033 / 62$.

Decreto $n^{0}$ 67.052, de 13 de agosto de 1970. Institui o Fundo de Eletricidade Rural - FUER, e dá outras providências.

Decreto $\mathbf{n}^{\mathbf{0}}$ 73.080, de 5 de novembro de 1973. Altera o artigo 47, do Decreto $\mathrm{n}^{\circ}$ 41.019/57, que regulamenta os serviços de energia elétrica.

Decreto $\mathrm{n}^{\mathbf{0}}$. 79.898, de 30 de junho de 1977. Define o Programa Nacional de Eletrificação Rural.

Decreto $\mathbf{n}^{\mathbf{0}}$ 79.897, de 30 de junho de 1977. Altera o Decreto $\mathrm{n}^{\circ} 67.052 / 70$ e dá outras providências.

Decreto $\mathbf{n}^{\mathbf{0}}$ 83.269, de 12 de março de 1979. Altera os artigos 136 ao 144 do Decreto $n^{\circ} 41.019 / 57$, que regulamenta os serviços de energia elétrica.

Decreto $\mathbf{n}^{\mathbf{0}}$ 98.335, de 26 de outubro de 1989. Altera os arts. 136 a 144 do Decreto $\mathrm{n}^{\circ}$ 41.019/57, que regulamenta os serviços de energia elétrica.

Decreto de 2 de dezembro de 1999. Institui o Programa Nacional de Eletrificação Rural "Luz no Campo" e dá outras providências.

Decreto $\mathbf{n}^{\mathbf{0}}$ 3.877, de 24 de julho de 2001. Institui o Cadastramento Único para Programas Sociais do Governo Federal.

Decreto $n^{\circ}$ 4.102, de 24 de janeiro de 2002. Regulamenta a Medida Provisória $n^{\circ}$ 18, de 28 de dezembro de 2001, relativamente ao "Auxílio-Gás".

Decreto $n^{0}$ 4.336, de 15 de agosto de 2002. Dispõe sobre a utilização de recursos da Reserva Global de Reversão - RGR para o financiamento do atendimento a consumidores de baixa renda, e dá outras providências.

Decreto $\mathrm{n}^{\mathbf{0}}$ 4.538, de 23 de dezembro de 2002. Dispõe sobre a concessão de subvenção econômica com a finalidade de contribuir para a modicidade da tarifa de fornecimento de energia elétrica aos consumidores finais integrantes da Subclasse Residencial Baixa Renda.

Decreto $n^{\circ}$ 4.541, de 23 de dezembro de 2002. Regulamenta os arts. $3^{\circ}, 13,17$ e 23 da Lei $n^{\circ} 10.438 / 2002$, que dispõe sobre a expansão da oferta de energia elétrica emergencial, recomposição tarifária extraordinária, cria Programa de Incentivo às Fontes Alternativas de Energia Elétrica - Proinfa e a Conta de Desenvolvimento Energético - CDE, e dá outras providências.

Decreto $\mathrm{n}^{\mathbf{0}}$ 4.564, de $1^{\circ}$ de janeiro de 2003. Define o órgão gestor do Fundo de Combate e Erradicação da Pobreza e o funcionamento do seu Conselho Consultivo e de Acompanhamento, dispõe sobre doações de pessoas físicas ou jurídicas, nacionais ou estrangeiras, para o Fundo de Combate e Erradicação da Pobreza, e dá outras providências.

Decreto $n^{\circ}$ 4.768, de 27 de junho de 2003. Dá nova redação ao parágrafo $3^{\circ}$, do artigo $1^{\circ}$, do Decreto $\mathrm{n}^{\circ} 4.538 / 2002$, que dispõe sobre a concessão de subvenção 
econômica com a finalidade de contribuir para a modicidade da tarifa de fornecimento de energia elétrica aos consumidores finais integrantes da Subclasse Residencial Baixa Renda.

Decreto $n^{\mathbf{0}}$ 4.855, de 9 de outubro de 2003. Acrescenta parágrafo ao art. $1^{\circ}$ do Decreto $\mathrm{n}^{\mathrm{o}} 4.562 / 2002$, estabelece prazo para o enquadramento jurídico das cooperativas de eletrificação rural e dá outras providências.

Decreto $n^{0}$ 4.873, de 11 de novembro de 2003. Institui o Programa Nacional de Universalização do Acesso e Uso da Energia Elétrica - Luz para Todos, e dá outras providências

Decreto $n^{0}$ 4.970, de 30 de janeiro de 2004. Dá nova redação ao art. $1^{\circ}$ do Decreto $n^{\circ}$ 4.932/2003, que dispõe sobre a delegação de competências à Agência Nacional de Energia Elétrica - ANEEL previstas na Medida Provisória no 144/2003, e define o índice de atualização monetária das quotas de que trata o $\S 1^{\circ}$ do art. 13 da Lei $\mathrm{n}^{\circ}$ $10.438 / 2002$.

Decreto $\mathbf{n}^{\mathbf{0}}$ 5.029, de 31 de março de 2004. Altera os arts. 33, 34 e 43 do Decreto $\mathrm{n}^{\mathbf{0}}$ $4.541 / 2002$, e o art. $1^{\circ}$ do Decreto $n^{\circ} 4.538 / 2002$, e dá outras providências.

Decreto $\mathbf{n}^{\mathbf{0}}$ 5.100, de 3 de junho de 2004. Altera a redação do art. 36 do Decreto $\mathrm{n}^{\circ}$ 4.541/2002.

Decreto $n^{\circ}$ 5.163, de 30 de julho de 2004. Regulamenta a comercialização de energia elétrica, o processo de outorga de concessões e de autorizações de geração de energia elétrica, e dá outras providências.

Decreto Estadual $n^{\circ}$ 41.187, de 25 de setembro de 1996. Institui o Programa de Eletrificação Rural "Luz da Terra", a Comissão de Eletrificação Rural do Estado de São Paulo - CERESP e dá providências correlatas.

\section{PORTARIAS DNAEE}

Portaria $\mathbf{n}^{0}$ 57, de 15 de maio de 1979. Estabelece procedimentos de cálculo do investimento de responsabilidade das concessionárias de distribuição.

Portaria $\mathbf{n}^{\circ}$ 10, de 21 de janeiro de 1980. Ajusta os critérios e valores definidos na Portaria $n^{\circ} 57 / 79$.

Portaria $\mathrm{n}^{\mathbf{0}}$ 116, de 3 de dezembro de 1980. Ajusta os critérios e valores definidos na Portaria $n^{\circ} 10 / 80$.

Portaria $\mathrm{n}^{\circ}$ 93, de 13 de novembro de 1981. Ajusta os critérios e valores definidos na Portaria $n^{\circ} 116 / 80$.

Portaria $\mathbf{n}^{0}$ 78, de 24 de setembro de 1981. Fixa o valor da Tarifa Fiscal e do Imposto Único sobre Energia Elétrica - IUEE, a vigorar a partir do quarto trimestre de 1981.

Portaria $^{0}$ 222, de 22 de dezembro de 1987. Estabelece as disposições relativas às condições gerais de fornecimento a serem observadas na prestação e utilização do Serviço Público de Energia Elétrica.

Portaria $\mathbf{n}^{\circ}$ 5, de 11 de janeiro de 1990. Dispõe sobre os encargos de responsabilidade da concessionária de serviço público de energia elétrica. 
Portaria $n^{0}$ 347, de 20 de dezembro de 1991. Altera os valores referentes aos encargos de responsabilidade da concessionária.

Portaria n⿳ 922, de 28 de julho de 1993. Determina a elaboração de estudos para a definição da política tarifária das concessionárias para o atendimento aos consumidores residenciais baixa renda.

Portaria $n^{0}$ 437, de 3 de novembro de 1993. Cria a subclasse residencial baixa renda.

Portaria $n^{0}$ 2, de 4 de janeiro de 1996. Estabelece o valor da tarifa fiscal em $\mathrm{R} \$ 64,48 / \mathrm{MWh}$.

Portaria $n^{0}$ 145, de 7 de maio de 1996. Aprova a caracterização das unidades consumidoras da subclasse residencial baixa renda, mantidas pela Light, em sua área de concessão.

Portaria $\mathrm{n}^{\circ}$ 261, de 16 de julho de 1996. Aprova a caracterização das unidades consumidoras da subclasse residencial baixa renda, mantidas pela CPFL, em sua área de concessão.

Portaria $\mathbf{n}^{0}$ 39, de 21 de fevereiro de 1997. Extingue o Custo de Capacidade de Fornecimento (CCF).

\section{RESOLUÇÕES ANEEL}

Resolução n' 261, de 13 de agosto de 1998. Estabelece os percentuais de Redução do Reembolso previsto na sistemática da Conta de Consumo de Combustíveis Fósseis - CCC.

Resolução $\mathbf{n}^{\circ}$ 54, de 7 de abril de 1999. Resolve que a expansão dos serviços e instalações de energia elétrica fica condicionada ao estabelecimento de prévio acordo formal entre concessionários e cooperativas.

Resolução no 333, de 2 de dezembro de 1999. Estabelece as condições gerais para a implantação de instalações de energia elétrica de uso privativo, dispõe sobre a permissão de serviços públicos de energia elétrica e fixa regras para regularização de cooperativas de eletrificação rural.

Resolução no 196, de 7 de junho de 2000. Aprova a caracterização das unidades consumidoras enquadradas na subclasse residencial de baixa renda, atendidas pela Companhia Paulista de Força e Luz - CPFL

Resolução n ${ }^{0} \cdot 456$, de 29 de novembro de 2000. Estabelece, de forma atualizada e consolidada, as Condições Gerais de Fornecimento de Energia Elétrica.

Resolução no 467, de 31 de outubro de 2001. Fixa os valores das quotas anuais referentes aos dispêndios com combustíveis para geração de energia elétrica, de janeiro a dezembro de 2001, para crédito na Conta de Consumo de Combustíveis CCC, do Sistema Interligado Sul/Sudeste/Centro-Oeste, Norte/Nordeste e Sistemas Isolados.

Resolução $\mathbf{n}^{\mathbf{0}}$ 12, de 11 de janeiro de 2002. Estabelece as condições gerais para a regularização de cooperativas de eletrificação rural, nos termos do art. 23 da Lei no 9.074/95. 
Resolução $n^{0}$ 246, de 30 de abril de 2002. Estabelece as condições para enquadramento na subclasse residencial baixa renda de unidade consumidora com consumo mensal inferior a $80 \mathrm{kWh}$.

Resolução $\mathbf{n}^{\circ}$ 325, de 18 de junho de 2002. Fixa os valores das quotas anuais referentes aos dispêndios com combustíveis para geração de energia elétrica, de janeiro a dezembro de 2002, para crédito na Conta de Consumo de Combustíveis Fósseis - CCC, do Sistema Interligado Sul/Sudeste/Centro-Oeste, Norte/Nordeste e Sistemas Isolados.

Resolução $n^{\circ}$ 485, de 29 de agosto de 2002. Regulamenta o disposto no Decreto $\mathrm{n}^{\mathbf{o}}$ 4.336/2002, que estabelece as diretrizes para classificação na Subclasse Residencial Baixa Renda de unidade consumidora com consumo mensal entre 80 e 220 kWh e dá outras providências.

Resolução $n^{0}$ 491, de 30 de agosto de 2002. Estabelece os procedimentos, condições e prazos para homologação dos valores que servirão de base à contratação dos financiamentos, com recursos da Reserva Global de Reversão - RGR para atendimento a consumidores de baixa renda, regulamentando o estabelecido no artigo $1^{\circ}$ do Decreto $\mathrm{n}^{\circ} 4.336 / 2002$.

Resolução $\mathbf{n}^{0}$ 514, de 16 de setembro de 2002. Estabelece os procedimentos contábeis e os critérios de compensação nas tarifas de fornecimento de energia elétrica da concessionária e permissionária de distribuição, decorrentes da aplicação da nova classificação de unidades consumidoras na Subclasse Residencial Baixa Renda, em benefício da modicidade tarifária.

Resolução n⿳ 609, de 5 de novembro de 2002. Altera a redação do caput do art. $4^{\circ}$ da Resolução $n^{\circ}$ 485/2002, que regulamentou as diretrizes para classificação na subclasse residencial baixa renda, de unidade consumidora com consumo mensal entre 80 e $220 \mathrm{kWh}$.

Resolução $\mathbf{n}^{\mathbf{0}} \mathbf{7 8 4}$, de 24 de dezembro de 2002. Estabelece as condições e os prazos para a sub-rogação dos benefícios do rateio da Conta de Consumo de Combustíveis CCC, em favor de titulares de concessão ou autorização de empreendimentos para geração, transmissão e distribuição de energia elétrica, que substituam derivados de petróleo ou que permitam a redução do dispêndio da Conta de Consumo de Combustíveis Fósseis - CCC nos sistemas isolados.

Resolução no 39, de 30 de janeiro de 2003. Fixa os valores provisórios das quotas anuais referentes aos dispêndios com combustíveis para geração de energia elétrica, para crédito na Conta de Consumo de Combustíveis - CCC, relativos ao período de janeiro a dezembro de 2003.

Resolução no 42, de 31 de janeiro de 2003. Fixa as quotas da Conta de Desenvolvimento Energético - CDE, para o exercício de 2003, e estabelece os procedimentos operacionais a serem adotados pelos agentes.

Resolução $\mathbf{n}^{\circ}$ 116, de 19 de março de 2003. Estabelece os procedimentos para solicitação e homologação dos recursos para subvenção econômica, com a finalidade de contribuir para a modicidade da tarifa de fornecimento de energia elétrica aos consumidores integrantes da subclasse residencial baixa renda, mediante liberação 
pela Eletrobras, diretamente às concessionárias ou permissionárias de distribuição de energia elétrica.

Resolução $n^{\circ}$ 136, de 28 de março de 2003. Altera a redação do caput do art. $4^{\circ}$ da Resolução $n^{\circ} 485 / 2002$, que regulamentou as diretrizes para a classificação na subclasse residencial baixa renda de unidade consumidora com consumo mensal entre 80 e $220 \mathrm{kWh}$.

Resolução $\mathbf{n}^{\mathbf{0}} \mathbf{2 2 3}$, de 29 de abril de 2003. Estabelece as condições gerais para elaboração dos Planos de Universalização de Energia Elétrica visando ao atendimento de novas unidades consumidoras ou aumento de carga, regulamentando o disposto nos arts. 14 e 15 da Lei $n^{\circ} 10.438 / 2002$, e fixa as responsabilidades das concessionárias e permissionárias de serviço público de distribuição de energia elétrica.

Resolução $n^{0}$ 308, de 30 de junho de 2003. Altera a redação do caput do art. $4^{\circ}$ da Resolução $n^{\circ} 485 / 2002$, que regulamentou as diretrizes para classificação na Subclasse Residencial Baixa Renda de unidade consumidora com consumo mensal entre 80 e $220 \mathrm{kWh}$.

Resolução $\mathbf{n}^{\mathbf{0}} \mathbf{3 2 0}$, de $\mathbf{1}^{\mathbf{0}}$ de julho de 2003 . Altera a redação do caput e inciso IV do art. $1^{\circ}$ da Resolução $n^{\circ} 116 / 2003$, que estabelece os procedimentos para solicitação e homologação dos recursos para subvenção econômica aos consumidores integrantes da subclasse residencial baixa renda, mediante liberação pela Eletrobrás na forma estabelecida, e acrescenta novos procedimentos para homologação da subvenção econômica aos referidos consumidores.

Resolução no 459, de 5 de setembro de 2003. Estabelece a forma de utilização de recursos provenientes dos pagamentos pelo uso de bem público (UBP) e multas aplicadas pela Aneel para fins do programa de universalização do acesso à energia elétrica em áreas rurais.

Resolução n ${ }^{\circ}$ 694, de 24 de dezembro de 2003. Altera a redação dos arts. $2^{\circ}$ e $4^{\circ}$ da Resolução $n^{\circ} 485 / 2002$, que estabelece as diretrizes para a classificação na subclasse residencial baixa renda de unidade consumidora com consumo mensal entre 80 e 220 kWh, bem como adequando a regulamentação ao preceitos da Medida Provisória $\mathrm{n}^{\circ}$ $132 / 2003$.

Resolução Homologatória $n^{0}$ 12, de 2 de fevereiro de 2004. Fixa as quotas da Conta de Desenvolvimento Energético - CDE, para o exercício de 2004, e estabelece os procedimentos operacionais a serem adotados pelos agentes.

Resolução Normativa $n^{0}$ 44, de 26 de fevereiro de 2004. Retifica a Resolução $n^{\circ}$ 694/2003, que deu nova redação aos arts. $2^{\circ}$ e $4^{\circ}$ da Resolução $n^{\circ} 485 / 2002$, visando adequar a regulamentação aos procedimentos de cadastramento vigentes nos programas sociais do Governo Federal.

Resolução Normativa $n^{0}$ 46, de 10 de março de 2004. Altera a Resolução $n^{\circ}$ 459/2003, que trata da utilização de recursos provenientes de uso de bem público (UBP) e multas aplicadas pela Aneel, exclusivamente, para dar suporte à implantação do Programa Nacional de Universalização do Acesso e Uso da Energia Elétrica - Luz para Todos. 
Resolução Normativa $n^{\circ}$ 52, de 25 de março de 2004. Dá nova redação aos arts. $2^{\circ}$, $3^{\circ}, 4^{\circ}, 5^{\circ}, 6^{\circ}, 8^{\circ}, 9^{\circ}, 10$ e 11 , e inclui o art. 18-A, da Resolução $n^{\circ} 223 / 2003$, que trata das condições gerais para elaboração dos Planos de Universalização de Energia Elétrica, bem como determina prazo para republicação atualizada.

Resolução Normativa $\mathbf{n}^{0}$ 57, de 31 de março de 2004. Delega competência ao titular da SRC, da ANEEL, para aprovar os planos de universalização da energia elétrica, determinar as adequações necessárias, ou decidir pela não-conformidade.

Resolução Normativa $\mathbf{n}^{\circ} \mathbf{5 5}$, de 5 de abril de 2004. Estabelece a metodologia de cálculo do Fator $X$, na revisão tarifária periódica da concessionária do serviço público de distribuição de energia elétrica.

Resolução Normativa $\mathbf{n}^{\circ}$ 60, de 27 de abril de 2004. Estabelece que os custos de consumo de combustíveis primário e secundário poderão ser reembolsados por intermédio da Conta de Desenvolvimento Energético - CDE, para empreendimentos termelétricos que utilizem apenas carvão mineral nacional.

Resolução Normativa $\mathbf{n}^{\circ} \mathbf{7 3}$, de 9 de julho de 2004. Altera a redação do art. $1^{\circ}$, do parág. $2^{\circ}$ do art. $6^{\circ}$, e do art. 13 , da Resolução $n^{\circ} 223 / 2003$, alterada pela Resolução Normativa $n^{\circ} 52 / 2004$, que estabelece as condições gerais para elaboração dos Planos de Universalização de Energia Elétrica, bem como altera o art. $3^{\circ}$ da Resolução Normativa $\mathrm{n}^{\circ}$ 052/2004, que determina o prazo para republicação atualizada.

Resolução Normativa $\mathbf{n}^{\mathbf{0}} \mathbf{7 4}$, de 15 de julho de 2004. Estabelece os critérios e procedimentos para que as concessionárias de transmissão que atendam consumidor livre e/ou autoprodutor, com unidade de consumo conectada às respectivas instalações de transmissão integrantes da Rede Básica do Sistema Interligado Nacional, passem a ser quotistas da Conta de Consumo de Combustíveis Fósseis CCC e da Conta de Desenvolvimento Energético - CDE, em atendimento ao art. 13 da Lei $n^{\circ} 5.899 / 73$, e ao art. 13 da Lei ${ }^{\circ} 10.438 / 2002$, com redação dada pela Lei ${ }^{\circ}$ $10.848 / 2004$.

Resolução Normativa $\mathbf{n}^{\circ}$ 76, de 30 de julho de 2004. Altera a redação dos parágs. $4^{\circ}$ e $5^{\circ}$ do art. $2^{\circ}$ e o art. $4^{\circ}$, da Resolução $n^{\circ} 485 / 2002$, que regulamenta as diretrizes para a classificação na subclasse residencial baixa renda de unidade consumidora com consumo mensal entre 80 e $220 \mathrm{kWh}$.

Resolução Normativa $n^{\circ}$ 79, de 30 de agosto de 2004. Altera o inciso II, parág. $2^{\circ}$ do art. $6^{\circ}$, da Resolução ${ }^{\circ} 223 / 2003$, relativo ao prazo das concessionárias, para o envio da $2^{\circ}$ parte dos Planos de Universalização de Energia Elétrica.

Resolução Normativa $n^{\circ} 80$, de $1^{\circ}$ de setembro de 2004. Estabelece os procedimentos para atendimento ao art. $1^{\circ}$ do Decreto $n^{\circ} 4.855 / 2003$, referente a não aplicação do realinhamento tarifário previsto no art. $1^{\circ}$ do Decreto $n^{\circ} 4.667 / 2003$, para as cooperativas de eletrificação rural.

Resolução Normativa $\mathbf{n}^{\circ}$ 82, de 13 de setembro de 2004. Estabelece as condições para atendimento com redes de energia elétrica em loteamentos urbanos, nos parcelamentos situados em zonas habitacionais de interesse social e nos parcelamentos populares, bem como para incorporação dos bens e instalações ao ativo de concessionária ou permissionária de serviço público de distribuição. 
Resolução Normativa $n^{\mathbf{0}}$ 83, de 20 de setembro de 2004. Estabelece os procedimentos e as condições de fornecimento por intermédio de Sistemas Individuais de Geração de Energia Elétrica com Fontes Intermitentes - SIGFI.

Resolução Normativa $\mathbf{n}^{\circ}$ 89, de 25 de outubro de 2004. Estabelece, com a finalidade de contribuir para a modicidade da tarifa de fornecimento de energia elétrica, a metodologia para o cálculo de subvenção econômica a ser concedida à concessionária ou permissionária de distribuição de energia elétrica, ou de montante a ser utilizado para a redução do nível das suas tarifas, de forma a contrabalançar os efeitos de política tarifária aplicável a unidades consumidoras integrantes da Subclasse Residencial Baixa renda. 


\section{REFERÊNCIAS BIBLIOGRÁFICAS}

AGÊNCIA BRASIL. Governo firma acordo para definir conceito de pobreza. Brasília: 2003. Disponível em: < http://www.radiobras.gov.br>. Acesso em: 12 mar. 2003.

AGÊNCIA NACIONAL DE ENERGIA ELÉTRICA (ANEEL). Relatório Preliminar SRC/ANEEL: Consumidor Residencial Baixa Renda - Diagnóstico. Brasília: 1998.

Nota Informativa: Eletropaulo critérios baixa renda. Brasília: 1999.

Nota Técnica no 047/2000 - SRC/ANEEL: Resultados do projeto Metodologia para definir domicílios baixa renda - FIPE. Brasília: 2000a.

. Ata da Audiência Pública no 6/2000. Brasília: 2000b.

Universalização do Acesso aos Serviços de Energia Elétrica. In: Workshop Luz no Campo, 3., 2002a, Rio de Janeiro.

. Nota Técnica no 326/2002 - SRE/ANEEL: Cálculo do Fator X na revisão tarifária periódica das concessionárias de distribuição de energia elétrica - Proposta de Metodologia. Audiência Pública nº 23/2002. Brasília: 2002b.

. Nota Técnica no 040/2003 - SRC/ANEEL: Estabelecimento das condições gerais para a elaboração dos Planos de Universalização de Energia Elétrica visando o atendimento de novas unidades consumidoras ou aumento de carga, regulamentando o disposto nos arts. 14 e 15 da Lei no 10.438 , de 26 de abril de 2002 , e fixa as responsabilidades das concessionárias e permissionárias. Resolução no 223/2003. Brasília: 2003a.

Relatório de voto: Estabelecimento de metas e diretrizes para a elaboração dos Planos de Universalização e responsabilidade das Concessionárias e Permissionárias de Serviços Públicos de Distribuição de Energia Elétrica na execução de pedidos de novas ligações ou aumento de carga. Resolução nº 223/2003. Brasília: 2003b.

Relatório de voto: Alteração da redação do caput do art. $4^{\circ}$ da Resolução $n^{\circ}$ $485 / 2002$, que regulamentou as diretrizes para classificação de unidade consumidora com consumo mensal entre 80 e $220 \mathrm{kWh}$ na Subclasse Residencial Baixa Renda Resolução no 308/2003. Brasília: 2003c.

Relatório de voto em separado: Prorrogação do prazo estabelecido na Resolução $n^{\circ} 485 / 2002$ para término da aplicação dos critérios anteriores à Lei $n^{\circ}$ 10.438/2002 e do Decreto n 4.336/2002. Resolução nº 308/2003. Brasília: 2003d.

Nota Técnica n' 070/2003 - SRC/ANEEL. Loteamentos. Exclusão dos lotes urbanos situados em loteamentos das condições de atendimento estabelecidas 
na Resolução n. ${ }^{\circ}$ 223/2003. Universalização dos Serviços de Energia Elétrica. Brasília: 2003e.

Nota Informativa: Incidência de ICMS sobre a subvenção econômica com impacto para os consumidores de energia elétrica classificados como baixa renda. Brasília: 2004a.

Relatório Audiência Pública $n^{0}$ 40/2004: Estabelecimento de critérios, procedimentos e condições gerais para regularização de cooperativas. Processo $\mathrm{n}^{\circ}$ 48500.002339/04-89. Brasília: 2004b.

Nota Técnica n 079/2004 - SRD/ANEEL: Revisão das tarifas de uso dos sistemas de distribuição da Coelba. Brasília: 2004c.

Nota Técnica no 073/2004 - SRC/ANEEL: Análise da $1^{\text {a }}$ parte do Plano de Universalização de Energia Elétrica da Elektro. Brasília: 2004d.

Nota Técnica no 087/2004 - SRC/ANEEL: Análise da $1^{\text {a }}$ parte do Plano de Universalização de Energia Elétrica da CEAM. Brasília: 2004e.

ÁlVARES, W. T. Curso de direito da energia. 1. ed. Rio de Janeiro: Companhia Editora Forense, 1978. 692 p.

ANUATTI, F. Critério para avaliação de programas. In: FUNDAÇÃO INSTITUTO DE PESQUISAS ECONÔMICAS (FIPE). Metodologia para definição de domicílios de baixa renda. Brasília: 2000 .

ASSOCIAÇÃO BRASILEIRA DOS DISTRIBUIDORES DE ENERGIA ELÉTRICA (ABRADEE). Universalização do Atendimento - A visão das distribuidoras. In: Workshop Luz no Campo, 3., 2002, Rio de Janeiro.

Contribuição para a Audiência Pública n 015/2000: Universalização. Rio de Janeiro: 2003a.

Relatório Alíquotas de ICMS. Rio de Janeiro: 2003b.

BARROS, C. V. M. Reestruturação do setor elétrico e concorrência. 2000. 222 f. Tese (Doutorado) - Faculdade de Direito, Universidade de São Paulo, São Paulo, 2000.

BARROS, R. P.; HENRIQUES R.; MENDONÇA, R. A estabilidade inaceitável: desigualdade e pobreza no Brasil. Rio de Janeiro: IPEA, 2001. (Texto para Discussão $\left.\mathrm{n}^{\circ} 800\right)$.

BERMANN, C. Energia no Brasil: para quê? Para quem? Crise e alternativas para um país sustentável. 2. ed. São Paulo: Editora Livraria da Física, 2003. 139 p.

BÔA NOVA, A.C. Energia e classes sociais no Brasil. São Paulo: Edições Loyola, 1985. 
CÂMARA DE GESTÃO DA CRISE DE ENERGIA ELÉTRICA (GCE). Relatório de Progresso $\mathbf{n}^{\mathbf{0}}$ 2. Brasília, 2002. Disponível em: < http://www.energiabrasil.gov.br>. Acesso em: 10 jan. 2003.

CASTRO, M. A. L; NUNES, H. R. A. Impactos dos novos critérios de classificação de unidades consumidoras de energia elétrica na subclasse residencial baixa renda. In: Congresso Brasileiro de Regulação de Serviços Públicos Concedidos, 3., 2003, Gramado. CD-ROM.

CENTRAIS ELÉTRICAS BRASILEIRAS (ELETROBRAS). Relatório de Administração 2000. Rio de Janeiro: 2001. Disponível em: < http://www.eletrobras.com.br>. Acesso em: 3 mai. 2004.

Relatório de Administração 2001. Rio de Janeiro: 2002a. Disponível em: < http://www.eletrobras.com.br>. Acesso em: 3 mai. 2004.

Sistema de Informações Estatísticas do Setor de Energia Elétrica: Boletim Síntese 2002. Rio de Janeiro: 2002b. Disponível em: <http://www.eletrobras.br>. Acesso em: 11 fev. 2004.

Relatório de Administração 2002. Rio de Janeiro: 2003. Disponível em: < http://www.eletrobras.com.br>. Acesso em: 3 mai. 2004.

Resultados do Programa Luz no Campo. Rio de Janeiro: 2004. Disponível em: <http://www.eletrobras.com.br>. Acesso em: 16 mar. 2004.

CENTRO DA MEMÓRIA DA ELETRICIDADE NO BRASIL (MEMÓRIA DA ELETRICIDADE). Panorama do setor de energia elétrica no Brasil. Rio de Janeiro: 1988. 333p.

COMISSÃO DE ELETRIFICAÇÃO RURAL DO ESTADO DE SÃO PAULO (CERESP). Relatório anual - Programa Luz da Terra. São Paulo: 2000.

COMITÊ DE REVITALIZAÇÃO. Universalização do atendimento - Relatório Final. Brasília: 2002. Disponível em: < http://www.mme.gov.br>. Acesso em: 14 jan. 2004.

COMPANHIA ENERGÉTICA DE BRASÍLIA (CEB). Fornecimento em tensão secundária de distribuição - unidades consumidoras individuais. Brasília: 2003. Disponível em: < http://www.ceb.com.br>. Acesso em: 10 nov. 2004.

COMPANHIA ENERGÉTICA DE MINAS GERAIS (CEMIG). Luz Solar - Préeletrificação rural utilizando sistemas fotovoltaicos. Belo Horizonte: 2001.

COMPANHIA PAULISTA DE FORÇA E LUZ (CPFL). Fornecimento em tensão secundária de distribuição. Campinas: 2004. Disponível em: < http://www.cpfl.com.br>. Acesso em: 10 nov. 2004. 
COOPERATIVA DE ELETRIFICAÇÃO RURAL DE ITAÍ-PARANAPANEMAAVARÉ LTDA (CERIPA). Contribuições para a Audiência Pública no 40/2004: Regulamentação de cooperativas rurais. Brasília: 2004

COOPERS \& LYBRAND. Projeto de reestruturação do setor elétrico brasileiro: cooperativas de eletrificação rural. Brasília: MME/Eletrobrás, 1997a. 76 p. (Relatório VI-2).

. Projeto de reestruturação do setor elétrico brasileiro. Relatório Consolidado Etapa VII. Anexo G - Encargos de Distribuição. Brasília: MME/Eletrobrás, 1997b. 17p.

- Regulamentação das cooperativas de eletrificação rural. Brasília: MME/Eletrobrás, 1998. 37p. (Working Paper 98/4/1-1).

CORRÊA, M. Metropolitana mudará tarifa social. Gazeta Mercantil, São Paulo, 16 jun. 1998. p. A-6

CORREIA, J. S. S. Eletrificação rural de baixo custo: avaliação e prática. 1993. 242 f. Dissertação (Mestrado em Engenharia) - Escola Politécnica, Universidade de São Paulo, São Paulo, 1993.

CORREIA, J.; VALENTE A.; PEREIRA O. S. (Org.). A universalização do serviço de energia elétrica - Aspectos jurídicos tecnológicos e socioeconômicos. Salvador: Unifacs, 2002. 140 p.

COUTINHO, D. R. Privatização, regulação e o desafio da universalização do serviço público no Brasil. In: FARIA, J. E. (Org.). Regulação, direito e democracia. São Paulo: Editora Fundação Perseu Abramo, 2002. p. 67-94.

DEPARTAMENTO INTERSINDICAL DE ESTATÍSTICA E ESTUDOS SÓCIOECONÔMICOS (DIEESE). As tarifas de energia elétrica no Brasil. São Paulo: 1998, 16p. Disponível em: < http://www.dieese.org.br>. Acesso em: 19 maio 2004.

DEPARTAMENTO NACIONAL DE ENERGiA ELÉTRICA (DNAEE). Pontos Básicos para uma política de eletrificação rural. Brasília: Dnaee, 1985. 190 p.

Tarifa Social. Brasília: Dnaee, 1986. 248 p.

ELETROPAULO. Fornecimento de energia elétrica em tensão secundária de distribuição - Instruções Gerais. São Paulo: 2000. Disponível em: < http://www.eletropaulo.com.br>. Acesso em: 15 set. 2004.

ELETROPAULO. Relatório de Administração 2001. São Paulo: 2002. Disponível em: < http://www.eletropaulo.com.br>. Acesso em: 2 out. 2004.

ELEKTRO. Fornecimento em tensão secundária à edificações individuais. Campinas: 2004. Disponível em: < http://www.elektro.com.br>. Acesso em: 10 nov. 2004. 
FERNANDES, R. Critérios de focalização - targeting. In: FUNDAÇÃO INSTITUTO DE PESQUISAS ECONÔMICAS (FIPE). Metodologia para definição de domicílios de baixa renda. Brasília: 2000.

FRANÇA, C. R. A.; BERMANN C. Perspectivas da legislação sobre programas de atendimento social para extensões de redes de distribuição de eletricidade: Considerações a partir do estudo de caso da Eletropaulo S.A. Contribuição na Audiência Pública nº 6/2000. Brasília: 2000.

FRANÇA, C. R. A. Programas sociais em empresa estatal de serviço público: análise dos projetos de eletrificação de áreas residenciais urbanas de baixa renda na Eletropaulo S.A. e de suas perspectivas sob gestão privada. 1999. 143 f. Dissertação (Mestrado em Energia) - Programa Interunidades de Pós-graduação em Energia, Universidade de São Paulo, São Paulo, 1999.

FUNDAÇÃO INSTITUTO DE PESQUISAS ECONÔMICAS (FIPE). Metodologia para definição de domicílios baixa renda. Relatório Final - Regiões Metropolitanas e Regiões Urbanas. São Paulo: 2000.

FUNDACION GRUPO SOPHIA. Pobreza y Servicios Públicos: Análisis y Propuesta de Tarifa Social. Argentina: 2003. 111 p. Disponível em: < http://www.gruposophia.org.ar>. Acesso em: 16 fev. 2004.

GANIM, A. Setor Elétrico Brasileiro: Aspectos regulamentares e tributários. Rio de Janeiro: Editora CanalEnergia, 2003. 255 p.

GOldemberG, J.; VIllanueVA, L.D. Energia, Meio Ambiente e Desenvolvimento. São Paulo: Editora da USP, 2003.

GROTTI, D. A. M. Teoria dos serviços públicos e sua transformação. In: SUNDFELD, C. A. (Coordenador). Direito administrativo e econômico. São Paulo: Malheiros Editores, 2000.

GOUVELLE, C.; MAIGNE, Y. Eletrificação rural descentralizada - uma oportunidade para a humanidade, técnicas para o planeta. Rio de Janeiro: CRESESB-CEPEL, 2003. 456p.

GUARATNE, L. Rural Energy Services - Best Practices. Report prepared by Nexant for USAID-South Asia Regional Iniative for Energy Program. San Francisco (USA): 2002

HAYT JR., W. H.; KEMMERLY J. E. Análise de circuitos em engenharia. São Paulo: McGraw-Hill do Brasil, 1973.

INSTITUTO DE ESTUDOS DO TRABALHO E SOCIEDADE (IETS). Estudo sobre o custo econômico da energia elétrica para as populações de baixa renda do Rio de Janeiro. Rio de Janeiro: 2001. Disponível em: <http://www.iets.inf.br>. Acesso em: 11 jun. 2004. 
JOHNSON, B.B. et al. Serviços públicos no Brasil - mudanças e perspectivas: concessão, regulamentação, privatização e melhoria da gestão pública. São Paulo: Editora Edgard Blucher Ltda, 1996. 153 p.

KARLSON, F. Rural Energy Services - Legal \& Regulatory Review. Report prepared by Nexant for USAID-South Asia Regional Iniative for Energy Program. San Francisco (USA): 2002

LAMOUNIER, B. Utilidades públicas, cidadania e participação. In: A privatização no Brasil - o caso dos serviços de utilidade pública. Rio de Janeiro: Bndes, 2000. Disponível em: <http://www.bndes.gov.br/publica/ocde.htm>. Acesso em: 13 dez. 2000.

LANCEllotTI, J. O menino e o computador. Diário de São Paulo, São Paulo, 12 set. 2002 .

MARQUES NETO, F. A. Agências reguladoras - instrumento de fortalecimento do Estado. São Paulo: ABAR, 2003. 66p.

MINISTÉRIO DO DESENVOLVIMENTO SOCIAL E COMBATE À FOME (MDS). Cadastro Único - Estimativas por unidades da Federação e cadastramentos - 2004. Disponível em: <http://www.assistenciasocial.gov.br>. Acesso em: 19 jul. 2004.

MINISTÉRIO DE MINAS E ENERGIA (MME). Programa nacional de universalização do acesso e do uso da energia elétrica: Versão inicial para discussão. Brasília: 2003a.

Sumário executivo sobre as providências adotadas pelo MME em atendimento ao acórdão TCU 598/2003. Brasília: 2003b. Disponível em: <http://www.mme.gov.br>. Acesso em: 20 ago. 2004.

Programa nacional de universalização do acesso e do uso da energia elétrica - Luz para Todos: Manual de operacionalização. Brasília: 2003c. Disponível em: 〈http://www.mme.gov.br〉. Acesso em: 20 dez. 2003.

- Plano de revitalização e capacitação Prodeem. Brasília: 2004a. Disponível em: <http://www.mme.gov.br〉. Acesso em: 20 ago. 2004.

- Programa nacional de universalização do acesso e uso da energia Elétrica. In: Encontro de Negócios de Energia Elétrica, 5., 2004b, São Paulo. Disponível em: <http://www.mme.gov.br>. Acesso em: 12 out. 2004.

MOITA, R. Resenha da experiência internacional. In: Fundação Instituto de Pesquisas Econômicas (FIPE). Metodologia para definição de domicílios de baixa renda. Brasília: 2000.

NEXANT. Subsizing Rural Electrification in South Asia: An Introductory Guide. Report prepared for USAID-South Asia Regional Iniative for Energy Program. San Francisco (USA): 2004. 
NÚCLEO DE EFICIÊNCIA ENERGÉTICA (NEFEN) - UNIVERSIDADE DO AMAZONAS. Segundo Relatório do Projeto Ribeirinhas: Comunidade Santa Luzia de Jacarequara - Município de Itapiranga, Amazonas. Manaus: 2001. 13p.

OLIVEIRA, L.C. Perspectivas para a eletrificação rural no novo cenário econômico-institucional do setor elétrico brasileiro. 2001. 116 f. Dissertação (Mestrado) - COPPE, Universidade Federal do Rio de Janeiro, Rio de Janeiro, 2001.

PAGLIARDI O.; GEMIGNANI SOBRINHO A.; JULIANI J.A. Os principais programas de investimento na eletrificação rural paulista e seus benefícios. In: Encontro de Energia no Meio Rural, 3., 2000, Campinas. CD-ROM.

PAUL, G. Impasse impede Lightgás de assumir a Metropolitana. O Estado de São Paulo, São Paulo, 6 jun. 1998. p. B-6.

PAZELO, E. T. Domicílios de baixa renda e linha de pobreza. In: FUNDAÇÃO INSTITUTO DE PESQUISAS ECONÔMICAS (FIPE). Metodologia para definição de domicílios de baixa renda. Brasília: 2000.

PAZZINI, L.H. et al. A experiência da eletrificação rural em São Paulo (19971999). In: Encontro de Energia no Meio Rural, 3., 2000, Campinas. CD-ROM.

PELEGRINI, M. A. Prática da eletrificação rural em São Paulo (1995 - 1997). 1998. Dissertação (Mestrado em Engenharia Elétrica) - Escola Politécnica, Universidade de São Paulo, São Paulo, 1998.

PELEGRINI, M. A. A regulação das cooperativas de eletrificação rural. 2003. Tese (Doutorado em Engenharia) - Escola Politécnica, Universidade de São Paulo, São Paulo, 2003.

PELEGRINI, M. A. et al. Análise das diretrizes brasileiras para eletrificação rural e universalização do serviço de energia elétrica. In: Conferência Latinoamericana de Eletrificação Rural, 19., 2003, Havana (Cuba). CD-ROM.

PELEGRINI, M. A.; FUGIMOTO S. K. Permissões e autorizações como instrumentos para a universalização do serviço de energia elétrica. In: Congresso Brasileiro de Regulação de Serviços Públicos Concedidos, 3., 2003, Gramado. CDROM.

PELEGRINI, M. A.; PAZZINI, L. H. A.; FUGIMOTO S. K. Universalização do serviço de energia elétrica: condicionantes e perspectivas. 2001. $146 \mathrm{f}$. Monografia final do curso de especialização CENARIOS - USP/UNICAMP/EFEI, São Paulo, 2001.

PENNSYLVANIA PUBLIC UTILITY COMMISSION. Universal Service Programs Manual. Disponível em: 〈http://www.puc.state.pa.us/>. Acesso em: 11 nov. 2003.

PEREIRA, O. S. O distanciamento dos programas de eletrificação rural das políticas de desenvolvimento rural e a necessidade de uma revisão desses 
programas. In: Seminário Internacional de Energia Elétrica, 1 (I SIDEE). Volume 3 - Comercialização de energia e sistemas de informação. Belo Horizonte: 1990.

PEREIRA, O. S.; MACHADO, M. P. Processo participativo de estabelecimento de uma estratégia nacional de eletrificação rural: Comitê Técnico 7 Universalização no Fornecimento de Energia. In: Congresso Brasileiro de Energia, 10., 2004, Rio de Janeiro.

PERTUSIER, F. Informações atuais sobre o Programa Luz no Campo. In: I Workshop do Programa Luz no Campo, 1., 2000, Rio de Janeiro. CD-ROM.

PINGUELLI ROSA, L.; TOLMASQUIM, M.T.; PIRES, J.C.L. A reforma do setor elétrico no Brasil e no mundo - uma visão crítica. Rio de Janeiro: Ed. Relume Dumará, 1998.

PINOT, L. G. Tarifa Social. In: Reunión anual Iberoamericana de Reguladores de la Energía, Rio de Janeiro, 2004. Disponível em: < http:// www.ariae.orgr>. Acesso em: 13 out. 2004.

POPPE, M. K. (Organizador). Seminário Reestruturação do Prodeem. Brasília: Secretaria de Energia/MME, 2003.

PRADO JR., F. A. A. Reestruturação do Setor Elétrico Brasileiro - A necessidade da componente social no modelo competitivo. 1999. $223 \mathrm{f}$. Tese (Doutorado em Planejamento de Sistemas Energéticos) - Faculdade de Engenharia Mecânica, Universidade Estadual de Campinas, Campinas, 1999.

PROGRAMA DAS NAÇÕES UNIDAS PARA O DESENVOLVIMENTO (PNUD). Relatório de Desenvolvimento Humano 2003. Disponível em: <http://www.pnud.org.br>. Acesso em: 19 maio 2004.

RAMALHO, E. L. Atuação da CSPE na mediação de conflitos entre consumidores residenciais de baixo poder aquisitivo e concessionária de serviços públicos de energia. São Paulo: 2001. (Relatório Técnico).

RAMALHO, E.L.; ANDRADE, M. T. O. A redistribuição de renda através de tarifas sociais no setor elétrico - atuação do órgão regulador. In: Congresso Internacional de Distribucion Electrica - CIDEL, 2002, Argentina.

RIBEIRO, C. M. Universalização do serviço de energia elétrica, eletrificação rural e o papel da energia solar fotovoltaica. In: TOLMASQUIM M. T. (Coordenador). Alternativas energéticas sustentáveis no Brasil. Rio de Janeiro: Relume Dumará, 2004.

RIBEIRO F.S.; PELEGRINI M. A.; UDAETA M. E. M. Planejamento integrado de recursos energéticos na eletrificação rural. In: Encontro de Energia no Meio Rural, 3., 2000, Campinas. CD-ROM.

RIBEIRO F.S. et al. Programa "Luz da Terra" - Modelo de eletrificação rural participativo. In: Encontro de Energia no Meio Rural, 3., 2000, Campinas. CDROM. 
RIBEIRO, F.S. Eletrificação rural de baixo custo. 1993. 157 f. Tese (Livre Docência) - Escola Politécnica, Universidade de São Paulo, São Paulo, 1993.

ROCHA, S. Opções Metodológicas para a estimação de linhas de indigência e de pobreza no Brasil. Rio de Janeiro: IPEA, 2000a. (Texto para Discussão no 720).

ROCHA, S. Pobreza e desigualdade no Brasil: O esgotamento dos efeitos distributivos do Plano Real. Rio de Janeiro: IPEA, 2000b. (Texto para Discussão $n^{\circ}$ 720).

SANCHEZ, S. S. Tarifa social em servicios públicos privatizados. In: Segundo Congreso Argentino de Administración Pública, Sociedad, Estado Y Administración. Córdoba, 2003. Disponível em: < http:// www.aaeap.org.ar>. Acesso em: 11 set. 2004.

SEN, A. K. Desenvolvimento como liberdade. Rio de Janeiro: Ed. Cia das Letras, 2000. 409p.

SOUTO, C. F.; LOUREIRO, G. K. O novo modelo do setor elétrico brasileiro e as cooperativas de eletrificação rural. Porto Alegre: Livraria do Advogado Editora, 1999. 164p.

TAVARES, M. L. Análise e Evolução da Tarifa Social de Energia Elétrica no Brasil, 1985 a 2002. 2003. 135 f. Dissertação (Mestrado) - Escola Superior de Agricultura "Luiz de Queiroz", Universidade de São Paulo, Piracicaba, 2003.

TRIBUNAL DE CONTAS DA UNIÃO (TCU). Relatório de Auditoria: Cadastro Único dos Programas Sociais do Governo Federal. Brasília: TCU, 2003a. Disponível em: < http://www.tcu.gov.br>. Acesso em: 13 fev. 2004

Relatório de Auditoria: Características sócio-econômicas dos potenciais beneficiários da universalização dos serviços de energia elétrica e subsídios a domicílios de baixa renda. Brasília: TCU, 2003b. 57 p. Disponível em: < http://www.tcu.gov.br>. Acesso em: 13 fev. 2004.

Avaliação do TCU sobre o Programa Energia das Pequenas Comunidades. Brasília: TCU, 2003c. Disponível em: < http://www.tcu.gov.br>. Acesso em: 13 fev. 2004.

ZOMERS, A. N. Rural Electrification. 2001. 321 f. Tese (Doutorado) - University of Twente, Euschede, Netherlands, 2001.

WORLD BANK/ESMAP. Brazil - Rural Electrification Strategy. 2002 Background document version II. 


\section{APÊNDICE A - CONTA DE CONSUMO DE COMBUSTÍVEIS (CCC)}

O art.13, inciso III, da Lei $\mathrm{n}^{\circ} 5.899$, de 5 de julho de 1973, dispõe que os ônus e vantagens decorrentes do consumo dos combustíveis fósseis para atender às necessidades do sistema interligado ou por imposição do interesse nacional sejam rateados entre todas as empresas concessionárias, de acordo com critérios estabelecidos pelo Poder Executivo.

A Lei $n^{\circ} 8.631 / 93\left(\right.$ art. $1^{\circ}, \S 3^{\circ}$ ) determina a inclusão dos valores relativos ao rateio do custo de combustíveis na tarifa de fornecimento de energia elétrica. O Decreto $\mathrm{n}^{\circ}$ 774, de 18 de março de 1993, que regulamentou a referida norma legal, segregou a CCC em três sub-contas distintas:

a. CCC do Sistema Interligado Sul/Sudeste/Centro-Oeste (CCCS/SE/CO): Conta Consumo de Combustíveis destinada a cobrir os custos de combustíveis fósseis da geração termelétrica constantes do Plano de Operação do Sistema Interligado do Sul, Sudeste e CentroOeste, tendo como contribuintes todos as concessionárias que atendam consumidores finais cujos sistemas elétricos estejam, no todo ou em parte, conectados a esse sistema interligado;

b. CCC do Sistema Interligado Norte/Nordeste (CCC-N/NE): Destinada a cobrir os custos de combustíveis fósseis da geração termelétrica constantes no Plano de Operação do Sistema Interligado do Norte e Nordeste, contribuindo as concessionárias que atendam consumidores finais conectados a esse sistema;

c. CCC dos Sistemas Isolados (CCC-ISOL): Idem para os custos constantes no Plano de Operação dos Sistemas Isolados ${ }^{1}$, tendo como contribuintes todos as concessionárias do País que atendam a consumidores finais.

\footnotetext{
1 A CCC-ISOL reembolsa somente as despesas com combustíveis que excederem os montantes correspondentes à respectiva Energia Hidráulica Equivalente, excluídos quaisquer tributos estaduais e municipais incidentes sobre o valor base do combustível.
} 
Portanto, a arrecadação CCC é utilizada para cobrir os custos do uso de combustíveis fósseis para geração termelétrica nos sistemas Interligado e Isolado. As distribuidoras de energia são obrigadas a recolher, mensalmente, sua cota proporcional ao mercado atendido por cada empresa.

Com a reestruturação do setor elétrico brasileiro da década de 90, o arcabouço regulatório previa a supressão progressiva do montante dos recursos destinados à geração termelétrica até sua extinção.

Assim, o art. 11 da Lei $\mathrm{n}^{\circ}$ 9.648/98, estabeleceu que as usinas termelétricas situadas nas regiões abrangidas pelo sistema elétrico interligado em operação a partir de 6 de fevereiro de 1998, não mais fariam jus aos benefícios da sistemática de rateio de ônus e vantagens decorrentes do consumo de combustíveis fósseis - CCC.

O mesmo dispositivo manteve, temporariamente, a sistemática de rateio para as termelétricas do sistema interligado, em operação naquela data. A Resolução $n^{\circ}$ 261/98 que regulamenta os prazos e condições de transição, estabelece o reembolso integral dos custos com combustível até 2002, com redução gradual nos três anos subseqüentes: 25\% em 2003, 50\% em 2004 e 75\% em 2005, até a extinção do benefício para o sistema interligado, a partir de 2006 inclusive. Ressalta-se que a manutenção dessa sistemática, no caso de termelétricas a carvão mineral, aplica-se exclusivamente àquelas que utilizam produto de origem nacional.

Com a extinção do Grupo Coordenador para Operação Interligada (GCOI) e do Comitê Coordenador de Operações do Norte/Nordeste (CCON) e a necessidade da adoção de procedimentos uniformes para o processamento da CCC, a Aneel estabeleceu, por meio da Resolução $\mathrm{n}^{\circ}$ 350, de 22 de dezembro de 1999, os procedimentos para composição dessa conta.

O gerenciamento da CCC é de competência legal da Eletrobrás e o rateio dos custos abrange a totalidade das distribuidoras e autorizadas. O valor da CCC é calculado pela Aneel com base numa previsão anual de geração termelétrica feita pelo Operador Nacional do Sistema Elétrico (ONS) e pelo Grupo Técnico Operacional da Região Norte (GTON), podendo ser revisto no fim do período chuvoso. 
A Lei $n^{\circ} 10.438 / 2002$ alterou o art. 11 da Lei $n^{\circ}$ 9.648/1998, que trata da CCC, ampliando o prazo de 15 para 20 anos da aplicação para o sistema isolado e permitindo a sub-rogação da CCC dessa região para termelétrica a gás natural que substitua a geração a partir de derivado de petróleo ou desloque sua operação para atender ao incremento do mercado, além das $\mathrm{PCH}^{\prime}$ s e da geração de energia elétrica a partir de fontes alternativas (fontes eólica, solar, biomassa) originalmente admitidas.

Com o objetivo de demonstrar a dimensão dos recursos envolvidos, a Tabela 1 a seguir apresenta os valores aportados à CCC, nos quatro últimos anos:

Tabela 1 - Previsão de dispêndios da CCC (R\$)

\begin{tabular}{c|c|c|c|c|c|c}
\hline \multirow{2}{*}{ ANO } & $\mathbf{C C C}-\mathbf{S} / \mathbf{S E} / \mathbf{C O}$ & $\mathbf{C C C}-\mathbf{N} / \mathbf{N E}$ & $\mathbf{C C C}-\mathbf{I S O L}$ & TOTAL & $\begin{array}{c}\text { RES. } \\
\text { Aneel }\end{array}$ \\
& & & & & & \\
\hline $\mathbf{2 0 0 0}$ & $1.265 .894 .248,64$ & $76.493 .018,37$ & $653.192 .688,63$ & $1.995 .579 .955,64$ & $274 / 2000$ \\
\hline $\mathbf{2 0 0 1}$ & $1.488 .625 .807,67$ & $81.425 .273,63$ & $1.045 .652 .233,85$ & $2.615 .703 .315,15$ & $467 / 2001$ \\
\hline $\mathbf{2 0 0 2}$ & $651.492 .012,61$ & $36.381 .165,12$ & $1.366 .077 .597,70$ & $2.053 .950 .775,43$ & $325 / 2002$ \\
\hline $\mathbf{2 0 0 3}$ & $159.921 .724,11$ & $24.547 .498,22$ & $1.858 .292 .156,78$ & $2.042 .761 .379,11$ & $39 / 2003$ \\
\hline $\mathbf{2 0 0 4}$ & $184.668 .747,70$ & $5.525 .777,24$ & $2.682 .569 .498,12$ & $2.872 .764 .023,06$ & $03 / 2004$ \\
\hline
\end{tabular}

O total previsto para a CCC de 2004 foi provisoriamente estabelecido em $\mathrm{R} \$ 2,872$ bilhões, com base nos preços dos combustíveis verificados em novembro de 2003 . O valor representa um aumento de $41 \%$ sobre a CCC fixada para 2003, de R 2,042 bilhões. De acordo com a Aneel, o valor global da CCC para 2004 ainda será reajustado devido aos acréscimos de encargos e tributos referentes à compra de combustíveis para geração de energia elétrica nos Sistemas Isolados, como dispõe a Lei n ${ }^{\circ} 10.883 / 03$, que altera a Legislação Tributária Federal.

Segundo a agência, o impacto da CCC nas tarifas de energia elétrica, será, em média, de $1,75 \%$. A variação decorre do saldo negativo de $\mathrm{R} \$ 428,5$ milhões da CCC de 
2003 referente aos Sistemas Isolados, conforme demonstrado na Tabela 2, elaborada a partir dos dados divulgados na Resolução Homologatória nº 3/2004.

Tabela 2 - Cálculo da cota da CCC 2004 (R\$)

\begin{tabular}{c|c|c|c|c}
\hline ANO & CCC - S/SE/CO & CCC - N/NE & CCC - ISOL & TOTAL \\
\hline Saldo 2003 & $133.900 .000,00$ & $8.400 .000,00$ & $-428.500 .000,00$ & $-286.200 .000,00$ \\
& & & & \\
\hline Necessidades 2004 & $318.568 .747,70$ & $13.925 .777,24$ & $2.254 .069 .498,12$ & $2.586 .564 .023,06$ \\
& & & & \\
\hline Cota 2004 & $184.668 .747,70$ & $5.525 .777,24$ & $2.682 .569 .498,12$ & $2.872 .764 .023,06$ \\
& & & & \\
\hline
\end{tabular}

A CCC referente ao sistema interligado foi reduzida em $50 \%$ este ano, de acordo com a Lei 9.648/98 que determina o fim do repasse da CCC na proporção de $25 \%$ ao ano, a partir de 2003 até 2006. Também foi subtraído do montante o saldo financeiro existente na Conta em dezembro de 2003, referente ao Sistema Interligado. 


\section{APÊNDICE B - DEFINIÇÃO DE SETOR CENSITÁRIO - IBGE}

Setor é a unidade territorial de coleta e de controle cadastral, percorrida por um único recenseador, contínua e situada em área urbana ou rural de um mesmo distrito, em função do perímetro urbano (linha divisória dos espaços juridicamente distintos de um distrito, estabelecida por lei municipal).

Classificação quanto à localização do setor.

\section{1 - Área urbanizada de vila ou cidade}

Setor urbano situado em áreas legalmente definidas como urbanas, caracterizadas por construções, arruamentos e intensa ocupação humana; áreas afetadas por transformações decorrentes do desenvolvimento urbano e aquelas reservadas à expansão urbana;

\section{2 - Área não urbanizada de vila ou cidade}

Setor urbano situado em áreas localizadas dentro do perímetro urbano de cidades e vilas reservadas à expansão urbana ou em processo de urbanização; áreas legalmente definidas como urbanas, mas caracterizadas por ocupação predominantemente de caráter rural;

\section{3 - Área urbanizada isolada}

Setor urbano situado em áreas definidas por lei municipal e separadas da sede municipal ou distrital por área rural ou por um outro limite legal;

\section{4 - Rural - extensão urbana}

Setor rural situado em assentamentos situados em área externa ao perímetro urbano legal, mas desenvolvidos a partir de uma cidade ou vila, ou por elas englobados em sua extensão; 


\section{5 - Rural - povoado}

Setor rural situado em aglomerado rural isolado sem caráter privado ou empresarial, ou seja, não vinculado a um único proprietário do solo (empresa agrícola, indústria, usina etc.), cujos moradores exercem atividades econômicas no próprio aglomerado ou fora dele. Caracteriza-se pela existência de um número mínimo de serviços ou equipamentos para atendimento aos moradores do próprio aglomerado ou de áreas rurais próximas;

\section{6 - Rural - núcleo}

Setor rural situado em aglomerado rural isolado, vinculado a um único proprietário do solo (empresa agrícola, indústria, usina etc.), privado ou empresarial, dispondo ou não dos serviços ou equipamentos definidores dos povoados;

\section{7 - Rural - outros aglomerados}

Setor rural situado em outros tipos de aglomerados rurais, que não dispõem, no todo ou em parte, dos serviços ou equipamentos definidores dos povoados, e que não estão vinculados a um único proprietário (empresa agrícola, indústria, usina etc.);

\section{8 - Rural - exclusive os aglomerados rurais}

Setor rural situado em área externa ao perímetro urbano, exclusive as áreas de aglomerado rural. 